\title{
CRISTIANIZAÇÃO DOS ESPAÇOS NA ANTIGUIDADE TARDIA: O CASO DE APOLLONIA-ARSUF
}

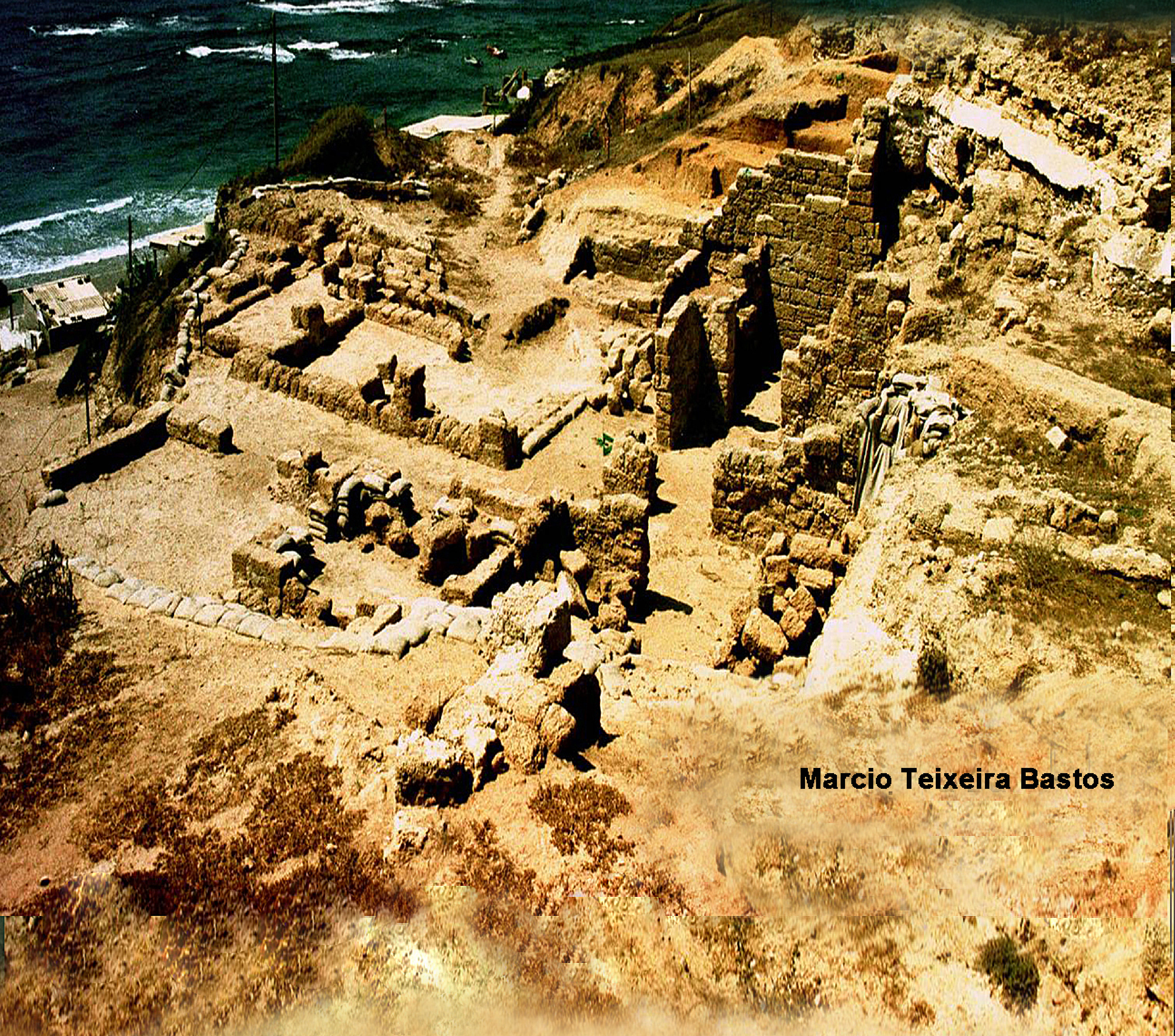

Orientadora: Dra. Maria Isabel D'Agostino Fleming Co-orientador: Dr. Oren Tal 
MUSEU DE ARQUEOLOGIA E ETNOLOGIA PROGRAMA DE PÓS-GRADUAÇÃO EM ARQUEOLOGIA

\title{
CRISTIANIZAÇÃO DOS ESPAÇOS NA ANTIGUIDADE TARDIA: O CASO DE APOLLONIA-ARSUF
}

Marcio Teixeira Bastos

\begin{abstract}
Dissertação apresentada ao Programa de Pós-Graduação em Arqueologia do Museu de Arqueologia e Etnologia da Universidade de São Paulo, para obtenção do título de Mestre em Arqueologia.
\end{abstract}

Orientadora: Profa. Dra. Maria Isabel D'Agostino Fleming

Co-Orientador: Dr. Oren Tal

Linha de Pesquisa: Espaço, Sociedade e Processo de Formação do Registro Arqueológico

São Paulo, Abril de 2011 


\section{Dedicatória}

Dedico essa dissertação a minha mãe, Maria José, meu pai, Paulo Bastos e meu irmão, Daniel Bastos. A vocês todo meu amor e esforço! 


\section{Agradecimentos}

Gostaria de agradecer a todos que contribuíram para que esse trabalho se tornasse uma realidade. $\mathrm{Na}$ verdade foi um trabalho em que muitas pessoas estiveram envolvidas, praticamente todos meus amigos me ouviram pacientemente falar dos pensamentos que estavam em minha mente e muitos deles atuaram de forma direta nessa dissertação. Porém, gostaria de agradecer as pessoas que me deram o primeiro suporte em São Paulo, agradeço a James e Viviane que me acolheram em sua casa enquanto me preparava para o ingresso na pós-graduação. A ajuda de vocês foi imprescindível.

Contudo, nada disso seria possível não fosse uma das pessoas mais competentes, integras e incentivadoras que tomei contato na vida acadêmica. A prof. Dr. Maria Isabel D’Agostino Fleming, longe de ser somente uma orientadora, é um exemplo de profissional para mim, por sua presteza, compreensão e incessante suporte em prover esse trabalho. Mabel a você meu agradecimento!

Agradeço também ao prof. Dr. Francisco Marshall pela oportunidade de ter contato com o projeto Apollonia, gentileza e atenção que sempre dedicou em nossos encontros.

Agradeço ao prof. Dr. Oren Tal, por ter me recebido prontamente na Tel Aviv University provendo todo o suporte necessário a essa pesquisa, pelas trocas de ideias, respeito e profissionalismo com que me tratou. Sem dúvida alguma esse trabalho não seria o mesmo não fosse o tempo que estive em Israel. Obrigado pela Co-orientação desse trabalho.

A Rafael Corteletti, amigo de boas conversas, ideias aguçadas e algumas cervejas. Obrigado pela ajuda com os mapas dessa dissertação. Valeu Corteletti...

As minhas queridas amigas, "irmãzinhas" de São Paulo, Débora e Erêndira. A amizade que construímos nesse tempo, carinho e preocupação com que nos tratamos me ajudaram em muitos momentos desse trabalho. Também agradeço a Erê os desenhos que estão no catálogo dessa dissertação. 
A minha amigona do peito, a pessoa responsável pelos primeiros contatos em São Paulo, meu "amore" Carolina Dias Kesser. Carol obrigada pela ajuda que sempre me deu, os incentivos e também pela acolhida que tua família, que também passou a ser minha, me deu aqui. Zé, Eliana, Camila, Emiliano obrigado pelo carinho!

A Renato Pinto um grande amigo e crítico. Obrigado às observações.

Aos amigos Rafael Milheira, Aluisio Alves, Priscilla Ulguim três sulinos que encontrei por São Paulo. Muitas conversas, risadas e histórias...

A Charles Wise pela assistência, respeito e amizade em todo esse tempo de contato. Sem sua participação certamente essa obra ficaria comprometida.

Gostaria de agradecer muitos outros amigos de maneira particular, mas para não ser extenso, Padu, André, Piruca, amigos de São Paulo; Nardo, Léo, Laurício amigosirmãos que sempre estarão na minha memória. James Gillespie, Camille Collins, Henri Christophe Castare pela ajuda com o inglês. A Hai Ashakenazi amigo de Israel. A Ronen e Michal Chalamish por ter me hospedado em sua casa em Israel durante praticamente todo meu tempo de estudo no país. Um especial agradecimento pelo carinho de toda família de vocês comigo! Todos sabem o quanto contribuíram na minha formação. Aos colegas-amigos do MAE, Irmina, Vagner Porto, Alex, Silvana, e outros que tive a oportunidade de ter contato durante esse tempo. A amizade de Lucia Juliani.

Ao meu amigo-irmão João Anacleto Bitencourt por toda sua amizade e suporte em momentos difíceis. Teu incentivo, longas e boas conversas sempre vêm a minha memória.

Agradeço aos funcionários do MAE, sempre prestativos e eficientes.

Ao Cnpq que financiou essa pesquisa, garantindo as bases matérias para a execução desse projeto.

A minha linda, amada e companheira Aline. Você é um grande presente na minha vida, obrigado pelo apoio, por acreditar em mim, por estar ao meu lado em todos os momentos, até mesmo quando passei uma temporada de "descanso" no hospital das Clínicas. Te amo goy goy.... 
E finalizando, a meu pai Paulo R.S. Bastos, minha mãe, Maria José Bastos e meu irmão Daniel Bastos, vocês são à base da minha vida, sabem as barreiras que tivemos que passar para chegar até aqui, juntos. A vocês que são meu suporte constante, meu mais sincero amor e agradecimento! Espero ter conseguido corresponder a fé que depositam em mim....obrigado minha família! 


\section{SUMÁRIO}

$\begin{array}{ll}\text { Lista de Figuras } & 7\end{array}$

$\begin{array}{ll}\text { Resumo } & 8\end{array}$

$\begin{array}{ll}\text { Abstract } & 9\end{array}$

“Introdução"...as primeiras palavras 10

PARTE I - $\quad 19$

Capítulo 1 - A Província do Oriente: Palaestina e suas tradições culturais 19

1.1 - A Planície do Sharon e sua ocupação $\quad 27$

1.2 -Apollonia no contexto do período romano 38

1.3 - Poder, hegemonia, dominação e resistência 51

Capítulo 2 - "Ab intestato": emergência dos escritos $\quad 61$

2.1 - Os Pais Apostólicos

2.2 - Os Apologistas $\quad \mathbf{8 3}$

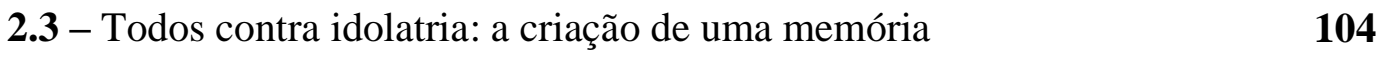

PARTE II -

Capítulo3 - A cerâmica romana: dos aspectos formais às representações $\mathbf{1 1 4}$ iconográficas

3.1 -Cerâmicas de engobe vermelho: a diversidade de terra-sigillatas $\quad \mathbf{1 1 8}$

3.2 - Cerâmicas de iluminação romana: entre morfologias e tipologias 129

3.3 - Lamparinas do período romano em Israel: o estado da questão 142

Capitulo 4 - As lamparinas de Terracota enquanto veículos de iconografia 167 religiosa

4.1 - Entre herodianas, Samaritanas e romanas discus: a associação $\mathbf{1 7 4}$ artefatual e a complicada relação da etnicidade

4.2 - "Quebrando" o habitus: as lamparinas de Apollonia-Arsuf

4.3 - Catálogo 216

PARTE III - Cristianização dos Espaços: o caso de Apollonia-Arsuf 237

Capitulo 5 - "A inclusione unius ad exclusionem alterius": movimento, paisagem, 237 espaço e identidade

Referências Bibliográficas $\quad 276$

$\begin{array}{ll}\text { Anexos } & 295\end{array}$ 


\section{LISTA DE FIGURAS:}

Fig. 1 - Representação dos principais compartimentos geográficos de Israel

Fig. 2 - Costa Mediterrânica com a formação de kurkar

Fig.3 Representação da Vila Maritima de Apollonia

Fig. 4 Exemplo de Vila com peristilo da Península Itálica

Fig 5 Visão Panorâmica das estruturas de período Romana em Apollonia.

Fig. 6 Lamparinas romanas provinciais tipo discus da tumba de Cesareia e em Jaleme 'Atiqot XXI 1992: 59*, Mcdonnell 1988: 132, 340, 343 e 344

Fig. 7 Lamparinas cristãs bizantinas de Tel Mevorakh -'Atiqot 1992. XXI: 65

Fig. 8 Lamparina, sino e anel da caverna de Sajur - 'Atiqot XXV 1994:111

Fig. 9 Lamparinas de Asherat, Sha'ab e Kafr Yasif - ' Atiqot XXXIII: 51; 'Atiqot XXXIII: 80 e 'Atiqot XXXIII: 72.

Fig. 10 Lamparinas Tel Goded - 'Atiqot XXXV: 10*e 17*

Fig. 11 Lamparinas de I 'Billin e MT Gilboa - 'Atiqot XXXVIII:52*; 'Atiqtot XXXVIII: 60*

Fig. 12 Lamparinas de Horbat Rimmon, Horbat Zefiyya e Beit She 'an -; 'Atiqtot :v. 46:108* ‘Atiqot XLIII::60 e Morris-Goring et al. 2002: 18-19

Fig. 13 Lamparinas de 'Ein Ez-Zeituna e Nahalat Ahim - 'Atiqot v.51: 57; 'Atiqot v.54: $75 *-76$

Fig. 14 Lamparinas de Shoran e Horbat Zikhrin - 'Atiqot v.55: 46*.; 'Atiqot v.56: 5051

Fig.15 Lamparinas de Ha-'Emeq - 'Atiqot v.61: 14*-15*

Fig. 16 Lamparinas Ha-Horesh - 'Atiqot v.65: 46*-51*

Fig. 17 Moeda de perutah de origem indefinida com datação entre 67-68 d.C. 
Fig. 18 Estratigrafia do sítio de Apollonia-Arsuf para o período romano

Fig. 19 Planta baixa da estrutura da Villa marittima de Apollonia-Arsuf.

Fig. 20 Cerâmica romana encontrada nos Locus 1937 e 1777

Fig.21 Plano Geral da Villa marittima de Apollonia (visão sul para norte)

Fig. 22 Detalhe do Peristilo central da Villa marittima de Apollonia

Fig. 23 Plano geral da Villa marittima de Apollonia (visão leste para oeste)

Fig.24 Visão do longo corredor Locus Locus1851/1768 (visão de oeste para leste)

Fig. 25 Visão frontal do nicho de maior proporção que representa o Lararium Locus 1768 .

Fig.26 Visão dos dois nichos no Locus 1768

Fig. 27 Visão do colapso em Apollonia no corredor Locus 1761 (visão de oeste para leste)

Fig. 28 Vista do mesmo colapso que se abateu sobre o sítio, parede 1406, Locus 1777 (visão de leste para oeste)

Fig. 29 Detalhe do mapa das áreas de escavação de Apollonia-Arsuf que prioriza a Área E e visão da área $\mathrm{P}$ para a área $\mathrm{E}$.

Fig. 30 Piso de mosaico policromo da igreja de Apolonia

Fig. 31 Charge sobre o estabelecimento de relações

Fig.32 Demonstração do contato de partículas no movimento randômico

Fig. 33 Modelos computacionais de representação do movimento randômico em que a partir do contato de moléculas o movimento acontece

Fig. 34 Mapa dispersão vestígios sítios judaicos na Galileia

Fig. 35 Mapa vestígios cristãos na Galileia

Fig.36 Mapa distribuição vestígios cristãos e judeus na Galileia

Fig. 37 Imagem "b" da prancha 61 
Fig. 38 Lamparinas e Sinos de Ginnegar/Ginosar; Sajur, Shoran e Horbat Zikhrim

Fig. 39 Indicação do desabamento causado pelo terremoto na ala sul da edificação. 


\section{RESUMO}

Nesse projeto apresentamos o desenvolvimento da proposta de estudo sobre o processo de cristianização dos espaços, tendo como objeto central de análise a coleção de lamparinas escavadas no sítio arqueológico de Apollonia-Arsuf, Israel. Constata-se que as lamparinas concernentes ao período de dominação romana na Palestina encontram-se mutiladas na parte relativa às cenas figurativas do paganismo. Artefatos cujo período de atividade estende-se do século I ao século III d.C.. O conhecimento e análise da citada coleção, tanto nos níveis formal quanto imagético, contribui para uma caracterização e maior conhecimento do paradoxo que circunda nosso objeto. A investigação permite questionamentos sobre a construção do orbis romanorum e as relações estabelecidas dentro desse âmbito.

Palavras-chave: Cristianização dos espaços; lamparinas discus; mutiladas; ApolloniaArsuf. 


\begin{abstract}
In this project I present the development of the research about the process of early Christianization in Roman Palestine via the analysis of Roman-period discus lamps retrieved from the archaeological site of Apollonia-Arsuf (Israel). It appears that the discus lamps that came from Roman Apollonia, of the late 1st to 3rd century AD, had the usual pagan and erotic moulded figurative scenes on the upper body intentionally broken away. The knowledge and analysis of this assemblage of hundreds of lamps, both through form and imagery contributes to a better understanding and characterization of the paradox that surrounds our subject of study. The research thus allows questions about the construction of orbis Romanorum and the relations established within this framework.
\end{abstract}

Key-words: early Christianization; discus lamps; intentionally broken; Apollonia-Arsuf 


\section{'Introdução'....as primeiras palavras}

Era uma situação trivial, dessas que ocorrem pelo acaso diário em que estamos constantemente inseridos, uma reunião não formal entre conhecidos, celebrando a amizade e os momentos de vida. As temperaturas da Holanda para um brasileiro são geralmente baixas, sugerindo nessa ocasião umas taças de vinho. $\mathrm{O}$ anfitrião ainda não estava presente, entretanto, como se tratava de amigos, usufruíam a liberdade de ir e vir no ambiente da casa e ali estavam. Como em qualquer encontro, do diálogo emerge uma ideia: ir até a adega, abrir um vinho e degustá-lo. Um dos amigos se disponibiliza e vai até o lugar; lá chegando, defrontou-se com uma satisfatória variedade de vinhos. A tomada de decisão: duas garrafas separadas, simples em aparência. A primeira aberta era de cor verde e formato prismático, no rótulo indicava que era um vinho francês. A França é conhecida pela qualidade de vinhos, motivo de orgulho e reconhecimento. A associação de significado logo foi a de degustar, mesmo não conhecendo perfeitamente a grafia francesa, afinal entre aqueles presentes, o domínio da língua francesa, tanto em termos do fazer diário quanto específicos de comunicação, não se fazia necessário.

Tomando o vinho, não lhes foi aprazível e é importante salientar que estavam acostumados a outro paladar, alguns diriam, menos refinado. Eram oriundos de um lócus social onde o acesso a vinhos de maior valor monetário é privilégio de alguns poucos. A diferente concepção de paladar compartilhado ao longo de suas vidas levou ao descarte imediato dessa garrafa, afinal, a variedade, valor e acesso ao produto, nesse momento não eram mais empecilhos. Jogadores de futebol ganham muito bem em suas carreiras quando atreladas à projeção mundial. Abrindo a segunda garrafa, de forma cúbica e de cor amarelada, o desgosto se repetiu e esta também foi acabar no lixo, ambos os recipientes sendo quebrados enquanto da prática de descarte.

Recebendo a ligação telefônica do anfitrião que tinha por objetivo informar de seu atraso, lhe disseram que haviam aberto duas garrafas de vinho e que não agradados do paladar colocaram fora os recipientes. O anfitrião questiona como eram as formas das garrafas e onde estavam na adega. Dada a resposta, vem a informação: o primeiro 
tratava-se de um vinho recebido como presente do presidente da França, de mesma safra do ano de nascimento do presenteado e o segundo de um Châteauneuf-Du-Pape (safra 1976), recebido de presente do então Papa João Paulo II.

Num primeiro olhar há quem diga que se trata de um completo absurdo! Uma falta de refinamento e bom gosto. Contudo, é nas práticas que se confirmam, se modificam ou se ampliam os saberes.

Atos implicam em decisões simbólicas amparadas na prioridade do indivíduo; já que sua tomada de decisão depara com um número imensurável de alternativas, a prioridade é circunstancial sempre. Desta forma, completamente momentânea. Obviamente, essa momentaneidade não é vazia em si, estando repleta de memórias, portanto, dados e informações, para a tomada de decisão. As pessoas são capazes de interpretar suas realidades sociais, e assim fazendo, atribuem, como diria Weber, um "sentido subjetivo" a determinados aspectos delas, empregando ações independentes.

A análise de como a ação se orienta por valores e a maneira com que as pessoas vivem em diferentes contextos sociais, com o ambiente e a materialidade, é um dos objetivos deste trabalho. Nestes processos cognitivos de contínua interação, as pessoas ampliam seus sentidos a respeito do ambiente, imprescindivelmente, promovendo, muitas vezes de forma não intencional, fortes ligações com o local, ainda que em curtos períodos de tempo (Zedeño 2009; Ingold 1993; Schiffer e Miller 1999; Thomas 2003). Assim sendo, as pessoas criam lugares para suas interações comportamentais, com a natureza, com o metafísico e entre si. Essa não é uma premissa original, Bowser (2004: 1) preconiza que as pessoas desenvolvem suas experiências de forma padronizada, através de referenciais espaciais para suas ações, por meio verbal, metafórico e na modificação de suas interações com o mundo material. Portanto, outro objetivo deste trabalho é aquele que incide sobre a forma direta de como as pessoas dão significado simbólico através das ações em seu meio cultural e físico nas suas múltiplas escalas, pensando também nas formas materiais que esses significados podem assumir (Bowser 2004; Gould 1980; Zedenõ 2009).

Desta forma, analisando o conjunto artefactual de lamparinas romanas discus de todas as campanhas de escavação em Apollonia-Arsuf, Israel, proponho-me a contribuir 
para a discussão sobre a quebra na parte central dos objetos, dedicada às iconografias. Através dos anos algumas hipóteses interpretativas a respeito desse fenômeno foram levantadas. Este trabalho pretende tecer algumas considerações a respeito de tais premissas, bem como apontar para um tipo específico de discursos e práticas emergentes no interior da sociedade romana.

No primeiro capítulo o leitor tomará contato com a diversidade de tradições culturais que estiveram em interação na Palaestina romana. Esse cenário amplo visa despertar no leitor a acuidade em relação à efervecência e dinâmica das interrelações que foram se estabelecendo nessa área do Imperium Romani. Dentro desse capítulo o leitor encontrará a descrição e caracterização da Planície do Sharon, região em que está localizada o sítio de Apollonia-Arsuf, às margens do Mediterrâneo. Tratarei especificamente da ocupação desse espaço em período romano, com a intenção de que a paisagem humana e sua ocupação sejam entendidas como uma combinação de vários tempos presentes, memórias vivas de um passado em constante construção. Na sequência o leitor encontrará o contexto de Apollonia-Arsuf em período romano e perceberá que a cidade nesse tempo intermediava um elevado fluxo de pessoa através de sua proximidade às vias romanas. As estradas, então, são tratadas não como "coisas em si" ou "pontos fixos no espaço", mas como linhas potenciais de movimento e intersecção, lugares significativos para a promoção do contato e estabelecimento de referenciais de coletividade. O capítulo se encerra com as perspectivas temáticas de poder, hegemonia, dominação e resistência. A ideia é que o poder está espalhado por todo o tecido social e que essa "coisa" tão enigmática, visível e invisível, presente e oculta, está investida em toda parte, sendo o poder um exerício. Assim, as interações entre os indivíduos, entre seus signos e termos, estão em constante processo de mudança e negociação. Essa polissemia ou heteroglossia, enfim, a multiplicidade existente, conduz à produção de determinados discursos que são engendrados a partir dos demais, sendo a relação intertextual dos mesmos aquilo que manifesta sistemas classificatórios no interior dos grupos e sociedades.

No segundo capítulo, então, o leitor será convidado a analisar a produção de dois grupos principais de escritos cristãos. Entendendo esses escritos como suportes de 
possíveis informações, mas que não correspondem exatamente ao objeto estudado. Os textos oferecem, independentemente da sua natureza, frações indiretas de informação da realidade que se almeja explicar. O objetivo é atentar para essa determinada produção de discurso que perpassa diretamente a temática da idolatria e a criação e defesa de um novo ideario para o Mundo Antigo. Respectivamente, Pais Apostólicos e Apologistas fornecem os subsídios básicos para tal análise proposta.

Imbuídos do discurso de verdade, o fomento de memórias socias proporciona os contextos em que os fundamentos das memórias individuais são formados. Através do processo de lembrança e esquecimento as formas retóricas e as práticas são organizadas e determinadas versões do passado são omitidas e sancionadas, enquanto outras partes são assumidas e privilegiadas. O processo de definição de certo e errado, incluído e excluído, omitido e assumido, é a base dos processos de memória e atua diretamente nas identidades dos indivíduos. Assim, na relação entre pessoas e artefatos um complexo processo em que cada pessoa constitui e atribui determinada forma e uso a distintos objetos, e esses, por sua vez, agem como concretos veículos, sociais e individuais, de expressões de poder e energia, as competências humanas são personificadas através da produção das coisas e a materialidade é subjetivada nas pessoas. As lamparinas romanas discus participam especialmente dessa questão, sendo um objeto capaz de agência.

Portanto, no terceiro capítulo o leitor será conduzido a uma extensa revisão dos aspectos formais e as representações iconográficas nas cerâmicas de iluminação romanas. Tratarei de toda a produção de conhecimento que vem se produzindo nessa área ao longo dos anos, tecendo alguns posicionamentos meus a respeito. Posso dizer que esse capítulo se divide em duas partes: a primeira, que trata dos estudos gerais sobre as cerâmicas de iluminação e a diversidade de terras-sigillata; e a segunda, em que apresento ao leitor como especificamente a lamparina romana provincial discus, uma produção local de sigillata de forte inspiração na produção Norte-Africana, entre os séculos II e III d.C., foi tratada até o presente momento. Aqui convém salientar uma opção pessoal em apresentar na primeira parte da dissertação as ferramentas teóricometodológicas que julguei necessárias ao leitor para que, a partir disso, a independência 
do leitor o leve a ponderação dos argumentos que proponho para uso destas lamparinas nos capítulos subsequentes.

O quarto capítulo é onde o leitor verá que esse tipo específico de lamparina serve como veículo de iconografia religiosa e participa ativamente da religião tradicional romana, através dos ritos do lararium. Esse altar votivo doméstico foi encontrado em Apollonia próximo à parte central da Villa marittima que caracteriza o sítio e fornece importantes correlatos. O capítulo ainda trata da importante relação entre lamparinas herodianas, lamparinas samaritanas e as romanas provinciais discus no território da Palaestina. É possível a dificuldade da associação artefactual com a etnicidade-religiosa judia ortodoxa para a quebra em questão, e nessa parte discuto as hipóteses levantadas e frequentemente utilizadas nas pesquisas em Israel para explicar o fenômeno. Conforme procuro argumentar, a premissa de que a quebra dessas lamparinas foi feita por judeus ortodoxos encontra uma série de dificuldades quando analisada com mais atenção. O capítulo se encerra com a análise do sítio de Apollonia e o contexto que ele apresenta, bem como o encaminhamento de que a quebra dessas lamparinas é uma ação direta na mudança do habitus. Nesse capítulo o leitor encontrará os argumentos para o que chamo no capítulo final de "cristianização dos espaços".

Dessa maneira, o capítulo final trata de entendimento de espaço, movimento, paisagem e identidade e relaciona esses conceitos com o contexto de Apollonia, inferindo a possibilidade de esse sítio proporcionar novos encaminhamentos interpretativos para a questão da quebra das lamparinas romanas provinciais discus em Israel.

Entretanto, para chegar a tal intento, é necessário fugir de teorias que objetam as sociedades como unidades holísticas praticamente orgânicas e suas partes como elementos que são perfeitamente integrados em um grande 'sistema' de estruturas objetivas. Essas teorias organicistas entendem a coletividade maior em que o indivíduo age, como uma estrutura determinada e a ação e interação social como consequentes expressões particulares dessa totalidade. Isso acarreta a ideia de que a população humana está confinada em um único sistema, quando o oposto vem sendo demonstrado 
nos estudos comparativos das últimas décadas: a multiplicidade coalescente de organizações, coletivos e sistemas.

Posto que um lugar pode assumir significados de forma sucessiva ao longo do tempo, particularmente diante da diversidade cultural entre os atores envolvidos no processo, a manipulação por um único indivíduo, um setor social, ou todo um grupo, fomenta nesse processo um sentimento de continuidade. A construção desse tipo específico de memória leva muitas vezes à identificação coletiva sob uma mesma ordem de ação.

As organizações espaciais estão, portanto, ligadas às relações de identidade. Se entendermos os atores como seres que sofrem condicionamentos, porém, nunca determinismos, a perspectiva é de que a presença das sociedades na paisagem é constantemente tempo de possibilidades e não de determinação.

Ultimamente, o tema das "identidades" tornou-se objeto de muita atenção nas Universidades em todo o mundo. Inúmeras publicações sobre tópicos como raça, sexo, etnicidade, nacionalismos, sociedades pós-coloniais, fronteiras, territórios, entre outros, vêm aumentando em produção. Como aponta Timothy Insoll (2007: 3), a participação de arqueólogos no cenário maior dos debates sociais sobre Identidades é uma perspectiva alternativa e ainda em construção. A maior parte da produção nesse campo teórico-prático dá-se na sociologia ou dentro da antropologia ${ }^{1}$, onde preocupados com grupos de identidade atual, os exemplos são obtidos, onde as abordagens de estudo são formuladas e as teorias se fundamentam. Contudo, como bem aponta o autor, a relação das identidades no passado e suas interações, vistas caso-a-caso na arqueologia, poderiam contribuir muito para a ampliação do debate e dos modelos vigentes.

Parece ser consenso atualmente que as identidades não são termos inatos e/ou raciais em absoluto, antes, em resposta a forças historicamente contingentes, são matizadas, exigindo, muitas vezes, uma metanarrativa. Assim, dois níveis de operação estão presentes nas relações de identidade social: aquele definido como individual ou pessoal, em que uma pessoa experimenta muitos aspectos identitários dentro de sua subjetividade; e aquele mais amplo, no qual as identidades sociais são definidas por

\footnotetext{
${ }^{1}$ Veja Barth 1969; 2000 Gellner 1983; 1987 Jenkins 1994.
} 
associações formais e costumes. O primeiro nível é mais ocasional, contingencial e opera a uma frequência maior, já o segundo, que abarca as categorias de sociedade e restrições, leva mais tempo em sua reformulação (Meskell 2007: 24).

Os mecanismos pelos quais as pessoas analisam situações que envolvem suas realidades sociais são sempre uma amostra relativamente pequena de resultados observados (em alguns casos analisados), a partir dos quais inferem-se informações e fazem-se julgamentos sobre as qualidades que geraram tais resultados. A resposta humana à incerteza é tão complexa e variável que por vezes distintas estruturas cerebrais chegam a conclusões diferentes e aparentemente disputam a prevalência sobre as demais.

Dessa forma, em sua constituição, as identidades - tanto individuais como coletivas - sofrem contestação diária, não só em relações coloquiais como em representações escritas. O processo conhecido como ethonogenesis toma por base que grupos de seres humanos passam a ser compreendidos e/ou compreendem a si mesmos como etnicamente distintos da paisagem social mais ampla, a partir da emergência de seu agrupamento. Isto pode acontecer de forma passiva, no acúmulo de marcadores da identidade do grupo, através da interação com o ambiente físico, divisões culturais, religiosas, migrações e entre as seções de uma sociedade, entre outros. Bem como, ativamente, quando de forma deliberada e direta as identidades são engendradas na preservação e/ou imposição de certos valores culturais, relações de poder e demanda política.

Entendendo que o indivíduo usufrui de uma variedade de 'identidades' face à realidade social em que está inserido - sendo que essas não são mutuamente excludentes - o processo de isolar e analisar as identidades antigas pode ser muito difícil. Dada a evidência sempre fragmentária, muitas vezes contraditória e perpetuamente abstrusa à nossa disposição, somos desafiados a tratar com uma imagem borrada pelos efeitos randomizantes de forças externas imprevisíveis e/ou variáveis. Contudo, a importância das identidades e da organização dos espaços, onde os domínios sociais e econômicos interagem, são significativos em si mesmos. Por isso, o "conhecimento de como as coisas se moveram ou se re-alocaram, trasferindo-se; livres 
para desenvolver-se em um novo ambiente, deverá contribuir para uma melhor compreensão dos processos" de relações identitárias de maneira mais abrangente na sociedade (Shaw 2001: 434) ${ }^{2}$.

Aliança, dominação, concorrência, resistência e celebração estão entre os motivos que podem estar subjacentes à existência de um lugar. Na medida em que essas diferentes motivações participam da constituição de um lugar, as pessoas que ali vivem ou passam, ou ainda, que dele lembram-se, o materializam em seus diferentes e, comumente, contraditórios significados, sendo inscritos na memória social. O desafio, mais uma vez, é discernir o que esses significados são (Zedeño 2009).

Seguindo uma das premissas do pós-colonialismo, é necessário romper com o entendimento de que no processo formativo identitário existe um sujeito e um objeto em relação hierárquica. Em outras palavras, um sujeito a quem me considero objeto, sujeito que me forma, e eu objeto que por ele formado sou. Enquanto uma espécie de recipiente que absorve conteúdos acumulados do sujeito - detentor desse tipo de poder - que transfere 'altruisticamente' ao outro as matérias que lhe aprazem. Essas relações de identidade não condizem com o real entendimento do fazer em sociedade. As relações são mais complexas e, conforme procurarei apresentar nesse texto, mais randômicas.

É nesse sentido que a reflexão crítica sobre quaisquer práticas se torna uma exigência imposta da relação Teoria/Prática, assim é necessário fugir de uma teoria que acabe em discurso sem sentido e também de uma prática que seja mero ativismo. A questão do posicionamento ao longo desse texto não é permeada por uma simples produção com base em um autor, na leitura feita de uma ou outra obra, ou pior, tendo lido apenas a crítica de quem só leu a contracapa de um dos livros; pelo contrário, dentro de meu alcance e do conjunto de objetos de minha curiosidade, na reflexão e troca de ideias, me aplico ao fomento das práticas de construção do conhecimento humano. Assim, uma prática que passa necessariamente o entendimento de que

\footnotetext{
2 "A knowledge of how things moved or relocated 'transferred' but freed to develop in a new environment, should therefore contribute to a better understanding of Mediterranean-wide processes". SHAW, Brent D. Challenging Braudel: A new vision of the Mediterranean. Journal of Roman Archaeology. Vol. 14, 2001. p. 419-453
} 
qualquer outra prática que não prime pela correção ética, respeito ao outro, coerência, capacidade de viver e de aprender com relação ao alteros deve ser combatida no exercício do conhecimento social. É imprescindível o posicionamento de que nosso mal-estar pessoal ou a antipatia em relação ao outro, sua origem geográfica ou condição dita (ou imposta) periférica, não encontre lugar no julgamento penoso e facultativo. Cabe aqui uma posição de humildade para nos dedicarmos ao fomento de espaços de diálogo e saber científico de cunho social humano, nos entendendo, dessa forma, enquanto sujeitos da produção do saber, procurando criar possibilidades para produção e/ou construção de diálogos amplos e não cerceados. Fora dessas premissas, a construção de conhecimento é meramente exclusivista e parcial.

Assim, o que se propõe neste trabalho é, dentro de sua historicidade, procurar "o conhecimento novo", que tende a superar algumas questões assumidas e debatidas, e avançar no debate, tendo em perspectiva ser logo conhecimento assimilado e superado por outros amanhã, buscando aquilo que foi enunciado por Gosden (1994:166), como " $a$ busca arriscada, mas necessária, das coisas que unem e dividem os grupos humanos no nível local e global", dentro da perspectiva de uma arqueologia preocupada com a ontologia social e o pluralismo teórico. 


\section{PARTE I}

\section{CAPÍTULO 1}

\section{A província do Oriente: Palaestina e suas tradições culturais}

A região do Oriente Próximo, durante milhares de anos, foi palco de intenso fluxo de pessoas, passando por diferentes períodos de hegemonia. Durante oito séculos a região se viu dividida entre as influências Grega e Romana, em sua porção ocidental, e as do Império Parta e Persa Arsácida, a leste. Se por um lado, como bem observa Kennedy (1999), é problemático apresentar a denominação de "Oriente Médio" e/ou “Oriente Próximo" para a região, pois além de ser um termo muito amplo, ainda suscita uma série de confusões e ideias pré-concebidas, contudo, por outro lado, o termo é válido na medida em que associa a si: "A Arqueologia Greco-Romana na região da subdisciplina, estabelecida desde muito tempo como Arqueologia do Oriente Médio, apesar do âmbito mais amplo da última" (Kennedy 1999: 78) .

O mar Mediterrâneo, as montanhas curdas do Tauros, a norte, e o deserto da Península Arábica, no sul, seriam os marcos geográficos que compreenderiam aquilo que se entende por Oriente Próximo. Variando em extensão para leste, em nosso caso, conforme a influência e administração de Roma, por vezes tornando-se mais esparsa.

Durante esses processos de expansão, inúmeras cidades foram fundadas, distintas instituições, imigrantes, línguas e culturas estiveram em interação e funcionamento nas diversas comunidades. A importância dessa área para o Império romano se dava em termos econômicos, culturais e estratégicos. O assédio romano à região e a manutenção das áreas sob seu controle necessitarão atenção constante e é nesse sentido que Sergio Tufi (2000), afirma que:

\footnotetext{
1 "Graeco-Roman archaeology in the region to the long-established sub-discipline of Near Eastern archaeoloy, despite the wider geographical scope of the latter"
} 
"A realidade politica mais relevante com que Roma entrou em contato nesta área tão significativa do Oriente Próximo antigo é a grande dinastia helenística dos Selêucidas, que foi fundada por Selêuco Nicator I (301-281 a.C.) em uma área que compreendia também na parte da Ásia Menor. O conflito com o rei Antioco III decidiu-se com a batalha de Magnésia, em 189 a.C.; a conquista se consolidou sucessivamente no quadro das campanhas no Oriente conduzidas por Silla, Lucullo, Pompeu, e é este último quem vai constituir, de maneira definitiva, a província em 62 a.C" (Tufi 2000: 323$)^{2}$

Nesse processo de anexação imperialista, os reinos de Galácia (Commagene), Nabatania, Emesa e Judéia, progressivamente vão desaparecendo. Os governantes adquirem outras funções e poderes, adaptando-se às novas realidades que vão se impondo. A eliminação dos estados clientes do oeste do Eufrates e o reforço do poder imperial nos governos locais é um processo concomitante à presença do próprio imperador na região. Paulatinamente, o Oriente Próximo conceberá a figura do imperador e dos aparatos do governo como uma realidade presente. No século II d.C., Trajano, Adriano, Lúcio, Verus. Marco Aurélio, Septímio Severo, e até os usurpadores Avidius Cassius e Pescinnius Níger, estiveram pessoalmente acompanhando os desdobramentos da região. E assim se sucederá nos séculos seguintes, III e IV d.C..

No entanto, o assédio romano a essa parte do mundo antigo foi crescendo desde o fim da República, na expansão em direção à Mesopotâmia. O que trouxe os imperadores romanos, em período posterior, foi mais a ofensiva do Império Sassânida, que substituiu a Pártia, do que a própria defesa da Mesopotâmia.

A Partia localizava-se ao norte da Pérsia, onde hoje é o nordeste do Irã. Formada de uma dinastia iraniana que houvera se instalado em período helenístico, declararam-se independentes dos selêucidas. Lograram tal êxito somente após a ascensão de Mitríadates I ao trono, em 170 a.C. A partir disso, anexaram várias regiões, chegando à

\footnotetext{
2 "La realtà política più rilevante con cui Roma venne a contatto in quest'area cosi significativa del vicino Oriente antico è la grande dinastia ellenistica dei Seleucidi, che era stata fondata da Seleuco I Nicatore (301-281 a.C.) su um'area che comprendeva anche parte dell'Asia Minore. Il conflitto con il re Antioco III si decide con la Battaglia do Magnésia, nel 189 a.C.; la conquista si consolida successivamente nel quadro delle campagne d'Oriente condotte da Silla, Lucullo, Pompeo, ed è quest'ultimo a constituire definitivamente la provicia nel 62 a.C."
} 
Babilônia e a Média, incorporando finalmente os domínios selêucidas a leste do Eufrates quarenta anos depois.

Os Partos limitavam-se à expansão do Império romano a leste, para além da Anatólia central - Capadócia. Estendendo-se do Eufrates até quase o rio Indo, contavam com numerosos reinos vassalos. Foi o Império mais duradouro do antigo Oriente Médio. Chega a seu fim após a rebelião do rei persa vassalo, Ardacher, que se conclamando descendente dos aquemênidas, derruba o rei parto Artabano IV. Dessa maneira, surge a dinastia dos sassânidas em 224 d.C. Por mais de dois séculos o embate entre romanos e partos foi uma constante. Inicialmente o Império Parto infligiu aos romanos sérias derrotas e estes só conseguiram se recuperar aproveitando-se da instabilidade e desunião políticas posteriores. Foi dessa forma que os romanos chegaram a Ctesifonte - capital do império - com Trajano (115 d.C), e em seguida com Marco Aurélio (165 d.C.), Septímio Severo (198 d.C.) e Caracala.

Sob domínio parto, a Pérsia estava relegada à condição de uma província dentro de um vasto e descentralizado Império. Após a rebelião sassânida e ascensão da dinastia, o novo Império Persa empregou uma forte ação expansionista, recuperando a maior parte dos territórios orientais que haviam sido conquistados dos partos pelos kushanos $^{3}$. A Pérsia sassânida organizou-se como um Estado altamente centralizado, em franca oposição à dinastia anterior. Divididos em castas: sacerdotes, soldados, escribas e plebeus, o zoroastrismo tornou-se a religião oficial do Estado e se estendeu para as províncias. O embate contra os romanos perdurou e os sassânidas chegaram até mesmo a lograr a captura do imperador Valeriano, em 260 d.C.

Durante o século IV d.C., Sapor II ascende ao trono e derrota os árabes ao sul, os hunos a leste e os romanos a oeste, chegando ao seu auge em expansão. Nesse mesmo período, completa-se a compilação de textos do zoroastrismo, o Avesta. Porém, em período Bizantino, a Pérsia sassânida conhecerá sua derrocada após a investida contra Constantinopla. Sofrendo ataques pela retaguarda; enquanto se lançava à conquista, o

\footnotetext{
${ }^{3}$ O Império dos Kushana, criado pela tribo de mesma denominação, estava localizado entre os territórios onde hoje são o Tajiquistão, Mar Cáspio, Afeganistão e o vale do Rio Ganges. Por estar localizado num local de passagem entre o Ocidente e o Oriente, o império estabeleceu relações diplomáticas tanto com Roma, Pérsia Sasssânida, bem como a China.
} 
império viu-se obrigado a abandonar os territórios conquistados e recuar. O resultado subsequente foi a guerra civil e desordem interna.

A dinamicidade da região ainda contava com reinos menores. A Galácia era um pequeno reino limitado a leste pela Capadócia, a norte pela Bitínia e Ponto, e a oeste pela Panfília, num planalto entre os montes da Paflagônia e Tauros. É mencionado como aliado dos Assírios, porém, logo dominado pelo Império Persa e em seguida por Alexandre, o Grande. Entre os anos de 100-69 a.C., buscou a política de aliança no casamento com a princesa Síria Laodice VII, reivindicando, dessa forma, os laços tanto com a cultura helenística quanto com os reis Persas. Após o declínio do império de Alexandre, a Galácia torna-se, então, um estado grego-sírio anexado ao Império Selêucida.

Em seus esforços de expansão, foram derrotados pelo selêucida Antioco I (281 261 a.C.), e posteriormente por Atalo I, de Pérgamo (241-197 a.C.). Procuraram aliança com Antioco IV trinta e quatro anos depois para resistir aos romanos, sendo que um século mais tarde, aliaram-se à campanha de Pompeu contra Mitríades, de Ponto (73-64 a.C.). Pompeu recompensou-lhes com o alargamento de seus territórios e o título de rei da Galácia a Deiotaurs. Após sua morte, Marco Antônio lhes concede alguns territórios na Panfília, Licaónia e Cilícia, zona oriental da Frígia e Isauria. Por volta de 25 a.C. todo o território foi transformado na província da Galácia, sob administração de um propaetor (governador).

A população era, portanto, miscigenada entre imigrantes gauleses (gálatas), anatólios e gregos, preponderantemente.

Nabatania foi outro reino em interação no amálgama cultural da região. A zona a sudoeste do Mar Morto serviu de base para a instalação de um povo voltado ao comércio e transporte de especiarias, incenso, mirra e plantas aromáticas. Situada no cruzamento de grandes estradas entre a Síria e o Mar Vermelho, Arábia e Golfo Pérsico, Índia e Mediterrâneo, a cidade de Petra serviu como entreposto aos Nabateus.

No decorrer dos séculos III e II a.C., os nabateus participam ativamente das relações de todo o Oriente Próximo. Obadas I inflige a Alexandre Janeu, rei judeu, a derrota em Golã que lhe vale os territórios de Gilliad e Moabe. Oito anos mais tarde foi 
a vez do rei sírio Antíoco XII experimentar o revés no Neguev. Dessa maneira, a expansão dos nabateus entre os anos de 84-62 a.C. se estendia desde o norte da Arábia, no Sinai, até Damasco. Durante a campanha de Pompeu, os nabateus foram incorporados à Província da Síria, e em 106 d.C. Trajano dá ordens ao governador romano na região que transforme a Nabatéia em província romana da Arábia. Dessa forma, Petra recebeu a concessão de metrópole e a ação romana se tornou mais centralizada. Posteriormente, durante o século III, Petra é abandonada pelas rotas comercias e entra em declínio.

Emesa, por sua vez, esteve obscura até os tempos do Império Selêucida. Incorporada ao distrito de Apamea, era um centro religioso importante, abrigando a adoração de El-Gabal (Baal, o Deus-sol), de quem Heliogábalo (218 d.C.) foi sacerdote. Após Sampsiceramus matar Antiochus XIII, último rei selêucida, a mando de Pompeu, o controle dessa zona foi exercido pela dinastia local de pastores-reis. Floresceu a cultura helenística, contudo, a língua aramaica preponderou nas regiões orientais como língua dos nativos.

Sob Caracala Emesa foi elevada a capital de uma pequena província, Phoenicia Libanesia ou ad Libanum. Além do local de nascimento do Imperador Heliogábalo, um pastor hereditário, Emesa também serviu de quartel-general do imperador Aureliano durante o conflito contra Palmira.

A eliminação de quatro grandes estados nativos foi significante. É necessário considerar que essa eliminação não foi somente um arranjo para uma "suposta romanização"; antes atendia ao objetivo direto de administração dessa região.

Para o caso da Judéia, possuímos mais detalhes nos relatos de Flávio Josefo do que para as demais regiões mencionadas. Contudo, a disponibilidade de maiores detalhes narrativos não implica em maior complexidade e variações em detrimento daquelas que possam ter existido nos outros casos (Kennedy 1999: 83). Nesse sentido, concordando com Mattingly (1997):

"Se essas experiências forem inteiramente aleatórias e sujeitas a uma variação infinita, então o estudo destas tão divergentes perspectivas seriam um exercício sem sentido na lista de decisões. No entanto, o 
ponto crítico a ser observado é aquele sobre a diversidade do comportamento e entendimento que reflete, em partes, uma série de discursos em sociedade" (Mattingly 1997: 13) ${ }^{4}$.

Nenhum desses estados foi vítima passiva, tampouco participante efusivo das ações empregadas pelo Império romano na região. Todos, em certo grau e medida, estabeleceram processos complexos de negociação com o poder imperial, produzindo uma diversidade de discursos em sociedade.

Na Judéia, a relação com o reino Selêucida da Síria e sua respectiva helenização foi motivo de revolta armada. Em 142 a.C. essa região se torna independente sob a dinastia dos Asmoneus. Contudo, em 63 a.C, Pompeu anexa a área ao Império romano. Hircano II, apoiando Pompeu, recebeu a confirmação como sumo-sacerdote e o título de "etnarca" - líder do povo - dentro da ação romana de divide et impera, o que na verdade não era de fato uma divisão, pois ao mesmo tempo em que nomeou Hircano, César designou Antípater ao cargo de procurator Augusti da Judéia. Pompeu dividiu a região em duas partes: uma que abarcava parte da Judéia, Iduméia, e Pereia; e outra na Galiléia. Dessa forma, acompanhando o mesmo sistema de domínio selêucida, o indivíduo mais próximo da corte, nesse caso do próprio imperador, recebe os maiores benefícios. No regime de patronato, as casas da elite funcionam nos mesmos mecanismos de acesso e lógica, alterando-se somente em seu grau de interação com a casa reinante.

Para a Judéia, o que emerge além dessa relação, é uma situação em que seu governante controla uma pequena área e um grande exército. Na verdade, nesse período inicial, Roma contava mais com o auxílio dos exércitos de seus clientes - em caso de conflito em outras partes do Império -, que propriamente com o usufruto dos territórios conquistados. Nessa acepção:

\footnotetext{
4 "If these experiences were entirely random and subject to infinite variation, then the study of such divergent perspectives would be a rather pointless exercise in list-making. However, the critical point to appreciate is that the diversity of behaviour and understanding reflects in part a series of discourses in society"
} 
"No âmbito da Syria e Palaestina, a Iudaea, ou Palestina, ocupa uma posição bastante singular: encontra-se agregada à província somente bastante tarde (44 d.C.), mas, anteriormente já mantinha estreitas relações com Roma, sobretudo durante a época de Herodes o Grande, filho daquele Antipatro que tinha sido, naquela área atormentada desde sempre, homem de confiança de Pompeu, de Cesar e de Crasso" (Tufi 2000: 339$)^{5}$

Herodes, idumeu e genro de Hircano, aproveitando-se das benesses do Imperador Marco Antonio, após alguns percalços para chegar a Roma, é elevado à condição de rei da Judéia que recebeu o título de estado confederado. Apesar da autonomia nos assuntos internos, Herodes frequentemente buscou conselho com o Imperador enquanto esteve no poder. Como observa Kennedy (1999:80), a participação dos governantes nativos no conselho do imperador não variava somente de dinastia para dinastia, ou de imperador para imperador; antes estava sujeita também à vulnerabilidade defensiva de cada estado e o preço pago em tributos a Roma. A sucessão de Herodes não usufruiu as mesmas benesses.

O sucessor, Arquelau (4-6 d.C.), não repetiu as mesmas escolhas hábeis de Herodes e logo foi substituído pelos procurator Augusti, subordinados ao governador da Síria. Concentrando os poderes civil, militar e jurídico, residiam comumente em Cesareia, mas em épocas de festas religiosas se transferiam para Jerusalém. Até o ano 41 d.C., a Judéia, Samaria e Iduméia foram administradas por distintos procuradores romanos. Herodes Antipas se manteve como soberano da Galileia durante trinta e três anos, sendo que após seu período, a administração foi designada novamente aos procuradores romanos. Ainda no primeiro ano destas mudanças foi estabelecido o censo de Quirino que resultou na imposição de uma taxa per capita sobre a população da Judéia.

As taxações e opressões fiscais teriam sido um dos principais motivos das revoltas judaicas, relegando a maior parte da população à pobreza. Calígula, em seu

\footnotetext{
5 'Nell'ambito della Syria et Palaestina, la Iudaea, o Palaestina, occupa uma posizione alquanto singolare: è aggregata alla provincia solo relativamente tardi (44 d.C.), ma, già in precedenza, mantiene stretti raporti con Roma, soprattutto all'epoca del re Erode il Grande, figlio di quell'Antipatro che era stato - in quest'area da sempre tormentata - uomo di fiducia di Pompeo, di Cesare e di Grasso."
} 
governo (37-41 d.C.), interferiu na região procurando substituir o culto judaico pelo seu próprio culto, instalando uma estátua a sua semelhança e fomentando o culto ao imperador. A combinação de elementos simbólicos, econômicos e culturais alimentou a rejeição ao domínio romano. E é nesses contextos que:

"A tensão no país mantem-se todavia alta, por causa do mau governo dos magistrados romanos e da altivez do povo de Israel na tentativa de defender suas próprias tradições. A primeira guerra judaica terminou com a vitória de Tito, em 70, com a conquista de Jerusalém e a definitiva destruição do Templo; a segunda guerra judaica explode com Adriano, quando este imperador começa a transformação da cidade santa de Jerusalém em Aelia Capitolina. Adriano conseguiu prevalecer, com o extermínio em 135 d.C. e no lugar que tinha sido a esplanada do Templo são colocadas as estátuas de Júpiter e do próprio vencedor, enquanto no Calvário foi erigido um templo a Venus. " (Tufi 2000: 340) ${ }^{6}$

A revolta encabeçada por Simão Bar-Kosba resultará, portanto, numa diminuição demográfica em toda Palestina. Com o passar do tempo, a região vai se recuperando dos efeitos causados por esses acontecimentos. Apesar da violenta repressão, opressão fiscal e choque cultural, é em período romano que as cidades tornaram-se mais numerosas e maiores. Os confrontos nunca foram eliminados por completo, tampouco as revoltas judaicas foram as únicas na região. Entretanto, a ação romana no Oriente Média foi decisiva, tornando as insurreições mais raras.

O desenvolvimento do povoado que se torna uma aldeia e da aldeia que se torna uma cidade, fomenta a crescente complexidade e associa as mudanças organizacionais e sociais, diria Kennedy. Ainda segundo o autor quanto "mais rápido a mudança, menos alcance terá para um fácil acréscimo dos ajustes. Igualmente a identidade social da população de vilarejo, vila, cidade ou região refletirão as origens das pessoas"

\footnotetext{
6 "La tensione nel paese si mantiene tuttavia alta, a causa del malgoverno dei magistrati romani e della fierezza del popolo di Israele nel tentare di difendere le proprie tradizioni. La 'prima guerra giudaica' viene vinta del 70 da Tito, con la presa di Gerusalemme e la definitiva distruzione del Tempio; la 'seconda guerra giudaica' scoppia con Adriano, quando questo imperatore avvia la trasformazione della città santa di Gerusalemme in Aelia Capitolina. Adriano avrà la meglio, con lo sterminio del 135 d.C.: su quella che era stata la spianata del Tempio saranno collocate le statue di Giove e dello stesso vincitore, mentre sul Calvario sara eretto un tempio di Venere"
} 
(Kennedy 1999: 94) ${ }^{7}$. Contudo, numa região com a constelação de padrões comportamentais e étnicos como a dessa efervescente periferia do Império romano, é temerário falar em origem de um povo em termos de identidade social, baseados numa linha direta de ocupação.

\subsection{A Planície do Sharon e sua ocupação}

Entender uma região como a da Planície do Sharon (hebraico: שרון) é mister quando se tem a intenção de abordar as relações que foram estabelecidas nesse âmbito. A paisagem do Sharon serviu de espaço de interação às culturas e povos que nela se instalaram e que por ela passaram. Dessa forma, é produto das inter-relações sociais e materiais, por consequência, participa da dinâmica de tensão entre o ambiente natural e uma imagem socialmente construída da paisagem (Knapp 1999: 230). Ao passo que a Planície foi sendo ocupada e manejada conforme as contingências de ordem social, econômica, cultural e simbólica, os indivíduos foram sendo condicionados, influenciados, adaptados e estimulados pela mesma.

Israel está divido longitudinalmente em três grandes regiões geográficas, sendo elas: a Planície Costeira, a Região das Montanhas e o Vale do Jordão. Formada pela deposição de sedimentos marinhos, a Planície Costeira compreende uma área entre 4-7 $\mathrm{km}$ de largura ao norte, estendendo-se ao sul cerca de $50 \mathrm{~km}$. Delimitada pelo Monte Carmelo (norte), Península do Sinai (sul), montes de Samaria (leste), e pelo Mar Mediterrâneo (oeste); a Planície ainda divide-se em seis áreas: Planície da Galiléia, Planície do Akko, Planície Carmel, Planície Litoral Mediterrânea, Planície Litoral do Sul e Planície do Sharon.

\footnotetext{
7 "more rapid the change, the less scope there will be for easy incremental adjustements. Equally, the social identity of the population of a village, town, city or region will reflect the origins of the people"
} 


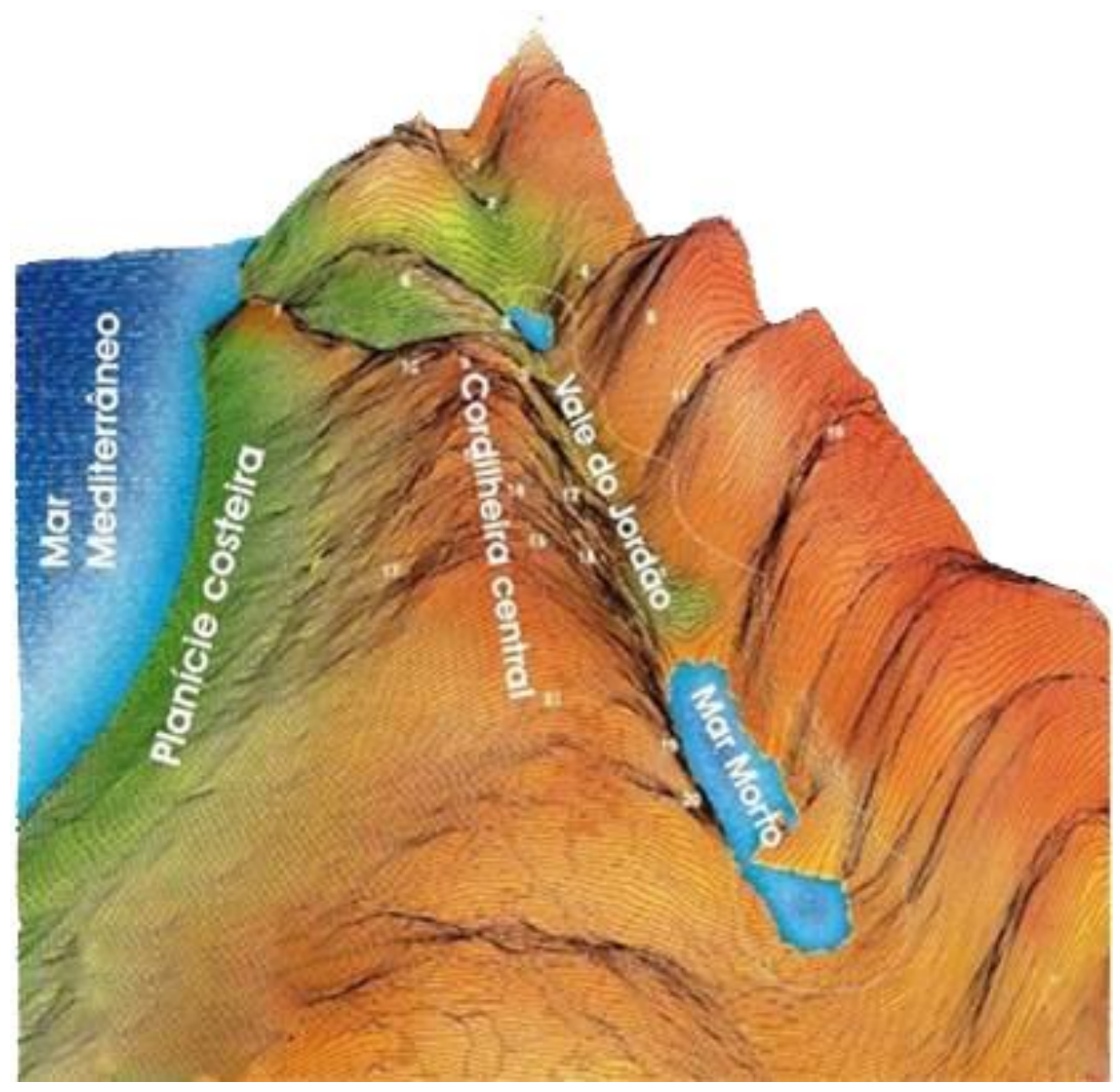

Fig. 1 - Representação dos principais compartimentos geográficos de Israel.

A Escarpa do Sharon, por sua vez, pode ser vista como a linha divisória entre a praia do Mediterrâneo e uma prateleira superior que se ergue a aproximadamente $40 \mathrm{~m}$ do nível do mar. Essa escarpa, se observada panoramicamente, forma quase uma reta, ligeiramente senoidal, constituída de uma crista de arenito longitudinal, formada por grãos fossilizados, com clareiras naturais por onde alguns riachos fluem, sendo esta a parte mais ocidental de uma série de cordões de dunas do Holoceno (Perath e Almagor 2000: 208). Essas dunas quartzosas constituem penhascos ao longo da costa e essa formação de arenito de quartzo carbonatado recebe o nome de Kurkar (Fig. 1). 


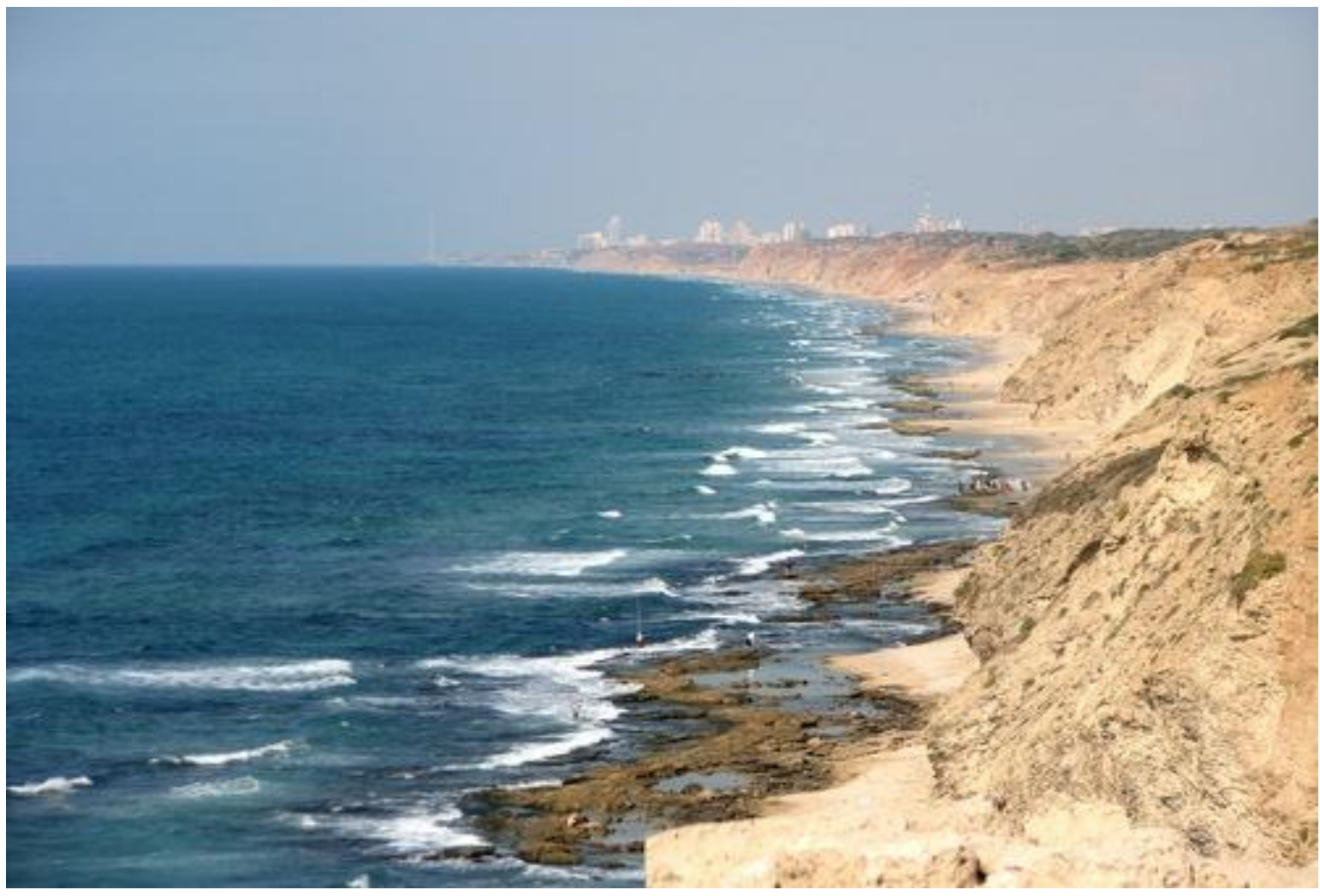

Fig. 2 - Costa Mediterrânica com a formação de kurkar.

Embora num primeiro olhar tenhamos a tendência de identificar a Planície do Sharon de forma homogênea, é importante salientar que sua topografia é marcada por três distintas cadeias de Kurkar, que se estendem a leste até os montes de Samaria. Essas escarpas bloqueiam o escoamento das águas aluvionares formando depressões conhecidas como marzevahs. A percolação da água da chuva dissolve o carbonato e aumenta as fissuras no calcarenito, causando parcial liquefação e formando entalhes. Dessa forma a água que flui através dos sulcos é absorvida rapidamente pelas fissuras devido à porosidade do kurkar, carreando, assim, a densa camada superior de areia vermelha, o hamra. Nos locais onde essas incidências são constantes, as erosões se intensificam e as depressões são maiores (Perath e Almagor 2000: 213).

A dificuldade no escoamento das águas, particularmente nas áreas de marzavah, contribuiu para formação de inúmeros pântanos entre a segunda e a terceira cadeia de 
kurkar. Esse ambiente aliado à floresta de carvalho - que predominava a região ${ }^{8}$ - tornou dispendioso o processo de ocupação da parte costeira da Planície do Sharon (Roll e Ayalon1988; Roll 1989; Florenzano e Galvão Sobrinho 2001).

Essa região pode ser entendida como um abrangente 'nicho geográfico', onde o Rio Taninim (norte), Rio Poleg (centro) e o Rio Yarkon (sul), são considerados delimitadores geo-referenciais atuantes e as ocupações no tempo e na paisagem não são interpretações lineares e progressivas, como se encerrassem um encadeamento previsível de eventos que levam a um fim inexorável. Até mesmo paisagens que eventualmente não sofreram alterações - como sugere Bradley (2000), podem ser entendidas enquanto categorias culturais, pois revelam termos simbólicos do imaginário dos indivíduos que ocuparam esse espaço, atribuindo significados às unidades elementares da paisagem. Nessa acepção, mesmo aquelas paisagens de pouca circulação são compreendidas como apropriações recorrentes da forma imagética, enquanto delimitadores cosmológicos de ação (Bradley 2000).

Tanto o ambiente geográfico como o espaço socialmente construído, não são vivenciados da mesma forma e nem percebidos da mesma maneira pelos grupos que dele participam e nele estão inseridos. Toda percepção de ambiente tem sua base na cultura, é nela e por ela que os indivíduos concebem as experiências que têm com os distintos ambientes, que modelam suas necessidades de compreensão, e onde aprendem a se definir e definir aquilo que os circunda. (Claval 1997: 89).

É dessa forma que a paisagem é um elemento ativo nas ações humanas, como um vestígio material, produto das interações sociais. Sendo o conjunto de formas que, num dado momento, exprimem memórias socialmente construídas ${ }^{9}$, que representam as sucessivas relações localizadas entre o homem e a natureza (Santos 2004: 103). Zedeño expõe uma interessante ideia agregada à definição aqui apresentada: as landmarks. Esse

\footnotetext{
${ }^{8}$ Estrabão. Geographia 16.2.27-28

${ }^{9} \mathrm{Na}$ conceituação de Milton Santos é empregado o termo "herança" o que implicaria numa série de valorações com as quais não estou de acordo. Nesse sentido, ainda usando a estrutura do conceito de Santos, adapto, alargando a matéria às discussões de História e Memória.
} 
conceito baliza que a paisagem é o repositório de sequências de ações que, através do tempo e repleção, passam a fazer parte da memória de um povo. Essas ações podem ser evidenciadas nos tipos de artefatos com características associadas às múltiplas ocupações de uma determinada localidade ou em práticas de uso visivelmente consistentes que modificam um lugar e seu entorno imediato conforme as necessidades do usuário. Se, ao longo do tempo, um lugar continua a ser ocupado, então, os artefatos, recursos e modificações podem se tornar marcos de memórias individuais e de grupo, de conhecimento coletivo sobre a terra e história, e de lições de moral necessárias para manter a coesão social (Zedeño 2000: 107; Zedeño e Bowser 2009: 8).

Como cultura material não pode ser entendida enquanto um dado pronto que reflete literalmente determinada cultura, em que um pequeno número de artefatos serve para diagnosticar relações étnicas de forma funcionalista, sendo os objetos mera confirmação dos dados históricos, Knapp (1999), procurando escapar de tal concepção, alerta para a constante manutenção e significação da paisagem: "Paisagem não está nem completa nem construída ou descontruída, mas é a expressão social eternamente em construção" (Knapp 1999: 230-231). ${ }^{10}$

Essa constante construção da paisagem pode ser notada na parte norte da Planície do Sharon no ínterim do período helenístico ${ }^{11}$ para o período romano. Lugares como Stratonospyrgos, Krokodeilonpolis, Tel Mevorakh, Tel Zeror, Nadiv Valley, Maioumas, Tel Burga, Tel Duda'imn e Tel Esur, constituíram-se como as principais áreas de ocupação dessa porção do Sharon.

A princípio a região parece ter sido uma pacífica e próspera área agrícola, tendo os portos de Krokodeilonpolis, Mulberry e a Torre de Straton ${ }^{12}$ como elo entre a prática

\footnotetext{
10 "Landscape is neither complete, nor is it built or inbuilt: rather it is a social expression perpetually under construction"

${ }^{11}$ A ocupação da Planície do Sharon precede, certamente, o período helenístico, recuando os vestígios à Idade do Bronze e período Calcolítico. Contudo, o recorte espaço-temporal desse trabalho é eminentemente o período romano, assim, recuo até o período helenístico somente com o objetivo de traçar quadros mais amplos dos processos de longa duração presentes em especial nesse recorte.

${ }^{12}$ Para uma ampla discussão sobre o problema da localização da Torre de Straton veja: ROLLER, D.W.; HOHFELDER, R.L. The problem of the location of Straton's Tower. Bulletin of the American Schools of Oriental Research, No. 252 (Autumn, 1983), pp. 61 -68
} 
agrícola e os contatos através do Mediterrâneo. O clima ameno e a presença perene de três importantes rios - Daliyya, Tanninim e Hadera - forneceram subsídios para espraiar por grande parte da Planície propriedades voltadas à agricultura (manor farms). O nome de dois destes córregos é notadamente conhecido: o Daliyya é identificado como Chorseus e o Tanninim como Krokodeilon; já a identificação do Hadera é desconhecida (Avi-Yonah 1936: 151 in Roller e Hohfelder 1982/3). Embora, nenhum desses rios tenha mais que alguns metros de largura a constância de seu suprimento, ao que tudo indica, contribuiu para o desenvolvimento do cultivo de cereais, ervas e vinhas. A exceção não-agrícola fica por conta da caça a crocodilos no rio Tanninim. A associação dessa interpretação se fundamenta no fato de esse ser o único rio na Palestina onde foram encontrados crocodilos. O reporte dessas informações recua ao século XI d.C, onde o córrego é chamado de "Rio dos Crocodilos" - no tempo de Ricardo I (11571199) dois de seus homens foram comidos por crocodilos (Itinerarum Ricardi 4.14 in Roller e Hohfelder 1982/3: 61) e a última referência aos répteis nessa área é de 1906

A Torre de Straton é conhecida apenas pelas suas ruínas, pois, sobre elas Herodes, o Grande, mandou erigir Caesarea Marítima e, por consequência, aquilo que se sabe da cidade de Stratonospyros, provém dessa mesma fonte. Como para o interior a prática agrícola era predominante, é provável que a Torre de Straton tenha servido como um armazém de estocagem (Levine 1975: 7-8).

Esse tipo de torre de pedra foi uma implantação comum na paisagem palestina, principalmente a partir do século III a.C. Posicionadas pelos campos em espaços relativamente regulares, são geralmente associadas a instalações para processamento de produtos agrícolas. Foram registrados aproximadamente 1500 vestígios dessas torres. $\mathrm{O}$ número elevado de vestígios pressupõe a existência de um agente organizador único e uma re-organização do campo em torno de famílias nucleares (e não mais o Beth-av) (Florenzano e Galvão Sobrinho 2001: 10). Com o estabelecimento da província da Judéia e o implemento do domínio herodiano as torres começam a desvanecer-se. A diminuição pode ser um fenômeno ligado ao confisco de terras promovido por Herodes, durante todo o século I d.C, e mais tarde pelos romanos. 
Sabe-se que Dor e a Torre de Straton foram conquistados por Alexandre Janeu, anexadas pelo Reino dos Hasmoneus, sendo posteriormente dominadas pela conquista romana. No ano 30 a.C, Herodes determina a construção de um porto no local e em honra a Gaius Iulius Caesar Octavianus Augustus, a cidade recebe o nome de Caesarea Marítima. Quando Flávio Josefo remete-se a esse entreposto ele diz que Herodes: "escolheu na costa uma cidade abandonada com o nome de torre Straton...que graças a sua localização favorável foi adquada a realização de seus ambiciosos planos. Ele reconstruiu inteiramente de pedra branca e a adornou com um palácio real que exibia um esplendor único...o brilhantismo de sua mente” (Flavio Josefo. Bellum Judaicum I, $21,5)^{13}$

Como efeito da construção do porto, a costa norte da Planície sofreu com o processo erosivo. O constante vento oeste aliado ao desvio de correntes carregadas de sedimentos pela construção do quebra-mar, agravaram as erosões. Dessa forma, as dunas que formam um semicírculo ao redor do porto, parece terem sido menos extensas que as atuais, alcançando no máximo $5 \mathrm{Km}$ para o interior. Os limites territoriais de Caesarea Marítima acabam, portanto, seguindo basicamente os mesmos de seu predecessor helenístico - a Torre de Straton - ou seja, a sul Apollonia e a norte Dor (Avi-Yonah 1936: 150-51; Abel 1938: 414-16)

Dor e Apolônia apresentam semelhanças, ambas cidades litorâneas em uma região de kurkar de difícil acesso ao interior. Dor esteve organizada, ainda durante o século III a.C., em pequenos lotes com fins agrícolas, locais de parada, sem residência fixa no campo. Dessa forma, estava muito mais voltada para o mar.

O acesso ao litoral se dava mais ao sul da Planície, na altura da bacia do Rio Yarkon que juntamente com o Rio Ayalon e com o Wadi Qana formavam um corredor natural entre o Mediterrâneo e o interior. A fronteira leste do Sharon, pelas condições de solo aluvionar favorável e constantes fontes de água, serviu de elo fundamental no entroncamento das rotas que ligavam o norte da Síria ao Egito, bem como à

\footnotetext{
13 "chose on the coast one forsaken town by the name of Straton's tower....which thanks to its favourable location was suitable for carrying out his ambitious plans. He rebuilt it entirely of white stone and adorned it with a royal palace of unique splendor, displaying...the brilliance of his mind"
} 
Mesopotâmia. A cidade de Tel Aphek, que em período romano tem seu nome mudado para Antípatris, floresce nestes contextos, junto à área da nascente do Rio Yarkon.

Não obstante, a porção Sul da Planície do Sharon, aquela sobre a qual incide a maior atenção desse estudo, tem seus primeiros registros de pesquisa no final do século XIX, sob o Protetorado Britânico. Os locais apontados por Clemont-Ganneau, Guérin e o Survey of Western Paletine - obra de C.R. Conder e H.H. Kitchener - publicado pelo Committe of Palestine Exploration Fund (1881-1883), foram as primeiras referências de localização de alguns sítios da região (Roll e Tal 1999: 18-25). Entre os anos de 19771979 a preocupação em entender e localizar os demais sítios da região conduziu a um survey nas áreas entre os Rios Poleg (norte) e Yarkon (sul), a fim de preparar um mapa arqueológico da municipalidade de Herzliyya. Na década seguinte, a busca pelo mapeamento dessa área se intensificou com outros surveys e em 1998, o Map of Herzliyya com o registro de 99 sítios $^{14}$ foi publicado na série "Archaeological Survey of Israel" com o apoio do Israel Antiquites Authority (Gophna e Ayalon 1998)

O exame das formações da área de Sharon Sul permite dividir essa área em três grandes faixas longitudinais no sentido norte-sul: a faixa costeira ocidental com seus três cumes de kurkar e duas planícies estreitas; a área central arborizada formada por suaves colinas de areia vermelha (ramrah) e, por fim, a faixa leste da planície marzeva. No encadeamento que compõe as três cadeias de kurkar da área, a primeira está linhada próxima à costa, formando-se a partir da bacia do Rio Poleg; a segunda segue paralelo em direção leste na área da municipalidade de Herzliya; e a terceira coberta em sua maioria por colinas de ramrah estende-se até o sopé dos montes de Samaria. Como já referido, a dificuldade de drenagem contribuiu à formação de três consideráveis depressões de solo fértil e lodoso, os marzevahs, separando as margens das montanhas de Samaria da segunda cadeia de depressão.

\footnotetext{
14 Florenzano e Galvão Sobrinho apontam para a problemática do que é considerado um sítio arqueológico na formulação do Mapa de Herzliyya, considerando o emprego classificatório como demasiado fluído. Não é meu objetivo essa discussão, para maior aprofundamento dessa perspectiva vide: FLORENZANO, M.B.; GALVÃO SOBRINHO, C.R. Apolonia e seu território: paisagem rural e mudança social na Palestina romana. Universidade de São Paulo: Relatório de Pesquisa, 2000-2001.
} 
Os assentamentos se concentraram em duas faixas distintas: ao longo da linha costeira, a oeste, e ao longo da marzevah, no sopé das montanhas de Samaria, a leste. Os rios Yarkon e Poleg delimitam um nicho geográfico tendo a concentração de ocupação em seu entremeio. Convém observar, entretanto, que a delimitação empregada aqui é essencialmente artificial e, portanto, arbitrária. Pois, no âmbito das discussões sobre a faixa estreita da marzevah que está entre as montanhas de Samaria, a leste, e as colinas de hamra, por conseguinte, a terceira cadeia de kurkar, não se sabe ainda se esta faixa pertencia ao território de Apolônia, de Samaria, ou de Tel Aphek, assim, na zona de influência do vale do Rio Yarkor (Roll e Ayalon 1988:38; Roll 1989: iii; Florenzano e Galvão Sobrinho, 2001:26).

O território de Tel Aphek (Antípatris) e o marzevah oriental se situam na área limítrofe de Samaria e estiveram sob influência cultural samaritana e judaica, provavelmente fora dos limites territoriais legais das cidades litorâneas de influência fenícia e helenística. Applebaum (1986), sugere que existiam relações de venda e transporte dos gêneros agrícolas e cereais das cidades costeiras para a Judéia em período hasmoneu. Dessa forma, mesmo que muitos dos processos culturais, sociais e simbólicos não estivessem tão presentes nas cidades de costa, algumas destas relações através dos contatos de trocas comercias parecem plausíveis.

As cidades litorâneas do Sharon sul estiveram inicialmente mais voltadas para o mar do que para o interior, devido essencialmente à dificuldade topográfica e ausência de maiores necessidades, posto que a insipiência da agricultura nessa porção da Planície é evidenciada somente em Gelilot e no sítio 13/7 - imediações de Tel Michal - no fim do período persa. No andamento da influência helenística nota-se a diminuição de vestígios arqueológicos em Tel Michal e um crescimento de Apolônia, levando a consideração que esses dois centros urbanos estariam em alternância de destaque. (Gophna e Ayalon 1998: 23).

As atividades ligadas ao extrativismo na floresta são atestadas pelas fontes literárias. Contudo, em Apolônia os fragmentos de ânfora provindos de Rodes e presentes nas áreas D e H, como propõem Fischer e Tal (1996), representariam um comércio de longa distância (Fischer e Tal 1996: 221-25). O intercâmbio através do 
Mediterrâneo possibilitou, assim, para Apolônia e as cidades de Dor (Stern 2000: 201), Stratto, Ioppa, a presença em considerável escala de imigrantes gregos, criando um ambiente de cidades helenizadas.

A implementação agrícola experimentou relativo crescimento durante o reinado de Herodes que estaria associado ao esforço antecedente do estado hasmoneu em colonizar e/ou judaizar a Planície litorânea. Apesar de a historiografia aludir a uma regressão significativa da presença judaica nos territórios helenizados em período posterior (63-30 d.C)(Applebaum 1977: 361), as evidências arqueológicas não atestam tal hipótese, corroborando as observações feitas por Estrabão. Desta feita, se houve algum tipo de regressão, como salientam Florenzano e Galvão Sobrinho (2001), ela durou um curto período e se seguiu de rcuperação demográfica e econômica significativa, provavelmente contando com o auxílio do campesinato samaritano e judeu.

Em Apolônia não é possível constatar a presença de judeus antes do período romano tardio e a ausência de assentamentos propriamente agrícolas reforça a ideia. Outra observação nesse momento é interessante: dos oito sítios helenísticos, quatro deles se situam num raio de $5 \mathrm{~km}$ do núcleo de Apolônia ou a menos de $2 \mathrm{~km}$ do litoral. Inclui-se nessa lista Tel Michal (\#44), que servia a propósitos estritamente militares dentro do quadro de dominação dos hasmoneus (Herzog 1989: 165-8; Derfler 1989: 194). Todas as ocupações estão distribuídas numa faixa paralela à escarpa do Sharon, podendo ser facilmente percorrida a pé algumas vezes ao dia e em menos de uma hora. Quanto aos quatro sítios além do perímetro de 5km, a saber: Ramat Aviv (\#91) está a $8 \mathrm{~km}$, e os outros a $2 \mathrm{~km}$ da costa e $4,5 \mathrm{~km}$ ao sul de Tel Michal. Sendo assim, poderiam estar associados, como indicam Fischer e Tal (1999), ao contexto de Ioppa. Nesse momento, Apolônia e Tel Michal estariam dividindo funções: enquanto a primeira projetava-se na liderança administrativa; a segunda teria uma função específica militar (Fischer e Tal 1996: 254-55).

Fato elucidativo é que as comunidades são economicamente tão diversas quanto ideologicamente separadas. O espaço rural descontínuo, o cultivo agrícola dos cereais de Iamnia e Ioppa, as cebolas de Ascalon, o eventual extrativismo das florestas de 
Apolônia, apontam a uma fragmentação onde cada cidade está voltada às suas próprias especificidades, sem um desígnio centralizador.

O quadro esparso de ocupação do Sharon Sul indica um desenvolvimento mais acentuado somente a partir do século II d.C., associado, segundo Roll e Ayalon (1990), à dinamização da economia, principalmente. Em que pese a explicação pautada nos processos econômicos, o posicionamento que procuro traçar nesse estudo não atribui significado maior sobre esse aspecto além daquele necessário. Assim, embora essa área ainda contasse com espaços completamente vazios e estando coberta por uma floresta de carvalhos, as implicações de ocupação na paisagem não se restringem somente à dinamização da economia. O foco nas interações entre a economia e outros domínios societários não deveria ocupar uma posição predominante na cadeia causal. Antes, na busca pela distinção de uma série de domínios sociais, seria possível abandonar a elevação de uma esfera social em particular que usualmente ocupa a posição de prioridade causal geral e abordar as ocupações no tempo e no espaço de forma multicausal. Assim, participando de uma dinâmica mais ampla de paisagem e espaço, entendidos como uma espécie de palimpsestos. Sendo assim, a paisagem humana e sua ocupação seriam uma combinação de vários tempos presentes, a memória viva de um passado em constante construção por meio de acumulações e substituições, ação dos diferentes atores que se superpõem, se complementando ao mesmo tempo em que se distinguem (Reboratti 1993; Santos 2004: 104).

Logo, um dos objetivos do texto produzido aqui nessa dissertação é lançar outros tipos de indagações interpretativas para o Sharon Sul em período romano, especialmente durante o século II e III d.C., onde o foco dessa pesquisa é maior. 


\subsection{Apollonia no contexto do período romano}

Apollonia está situada na costa do Mediterrâneo equidistante $10 \mathrm{~km}$ da foz do rio Yarqon, a sul, e do rio Poleg, a norte. Estabelecida na prateleira mais jovem e elevada de kurkar do Sharon Sul, o solo chega a atingir $36 \mathrm{~m}$ acima do nível do mar na parte sudoeste do sítio. Na formação do quadro de unidades geológicas que compõem a área estão as falésias de Ramat Gan Bed (base da escarpa), a Nahsolim Hamra Bed, o Tel Baruk Hamra Bed (ainda não totalmente identificada), a Dor Kurkar Bed , o Netanya Hamra Bed e o Tel Aviv Bed (Roll e Tal 2007). Sobre a formação do Tel Aviv Bed assentam-se os vestígios do período romano, na direção sul do sítio, variando em altitude cerca de dez metros, portanto, $26 \mathrm{~m}$ acima do nível do mar. Presume-se que todo material usado pelos habitantes para a construção do lugar foi obtido dessa formação geológica, sem a necessidade de traslados.

A cidade foi denominada de Apollonia Palaestinae por Ptolomeu e Plínio. Existiam em torno de 32 a 43 lugares com a designação do deus Apollo (Hirschfeld et al 1995), assim, era importante um epíteto que definisse com maior precisão o lugar. Foi listada entre as cidades da Iudae/Palaestina, entre Jope e Cesaréia na coordenada de $66^{\circ}$ de longitude e $35^{\circ} 15^{\prime}$ de latitude. A localização estava orientada no eixo sudeste/nordeste, o que implicou num erro de identificação, pois o correto seria o alinhamento de eixo norte-sul. Em De Geometria de Martianus Capella, no século V d.C., a cidade parece se confirmar como um ponto de triangulação, sendo usada para calcular as distâncias entre lugares. A distância base seria de $357 \mathrm{~km}$ do ponto de Ostracine na costa do Sinai (De Geometria VI, 679; Ed. Willis 1983:241 in Roll e Tal 2007).

Privilegiada por sua posição natural, a cidade desde muito cedo surge como um porto de ancoragem. A partir disso, é assumida como principal porto do Sharon Sul desde o período helenístico tardio (Roll e Tal 1999; Galor, Roll; Tal 2009). As cidades de Jope e Cesaréia desempenhavam, conjuntamente, importante papel enquanto portos 
de ancoragem no litoral mediterrânico. Apollonia está aproximadamente a $17 \mathrm{Km}$ de Jope e $34 \mathrm{~km}$ de Cesaréia, praticamente no meio do interfluxo dessas localidades. Contando com uma multiplicidade de ocupações no tempo-espaço, que remontam a contextos muito precedentes, Roll e Tal (2007) discorrendo sobre a ocupação romana na área, alertam para tal preâmbulo:

"Foram excavadas em Apollonia-Arsuf camadas esporádicas do período Calcolítico e da Idade do Ferro II, embora a história contínua do local, começando como um assentamento costal e se desenvolvendo em um centro urbano marinho, cobre um período de aproximadamente dezoito séculos, desde o final do século $6^{o}$. a.C., em meados do século 13․ d.C.. (Roll e Tal 2007: 139) ${ }^{15, "}$

Essa ocupação na longa duração não é mero acaso, obviamente. Apollonia é entendida e definida aqui como um persistent place. Em termos diacrônicos como Schalanger (1992) conceitua:

\begin{abstract}
"Lugares de persistência são lugares que foram usados repetidamente durante um longo tempo de ocupação. Eles não são estritamente sítios (isto é, concentrações de cultura material) nem simplesmente características de uma paisagem. Em vez disso, representa a conjunção de um comportamento humano particular ou uma paisagem em particular" (Schalanger 1992: 97) ${ }^{16 \text { ", }}$
\end{abstract}

Dessa forma, em função de certas especificidades, tanto de ordem histórica, social, política, econômica, geográfica, religiosa ou cultural, os espaços topográficos são ocupados em longa duração, consequentemente implicando na formação e distribuição do registro arqueológico (ibdem). Esse é o caso de Apollonia-Arsuf.

\footnotetext{
15 "Excavations at Apollonia-Arsuf unearthed sporadic layers of Calcolithic period and Iron Age II, although the site's continuous history, beginning as a costal settlement and developing into a marine urban center, covers a period of approximately eighteen centuries, from the late 6th century B.C.E through the mid 13 th century C.E"

16 "Persistent places are places that were repeatedly used during long-term occupations of regions. They are neither strictly sites (that is, concentrations of cultural materials) nor simply features of a landscape. Instead, they represent the conjunction of particular human behavior on a particular landscape".
} 
Até o momento, para o período romano, foi identificada e escavada totalmente uma Vila Marítima do tipo peristilo (Roll e Tal 2008; Galor; Roll; Tal 2009; Marshall, 2003; Rech 2003) ${ }^{17}$. Imbricada em uma plataforma entalhada no arenito de quartzo carbonatado natural da encosta, a vila tem o tamanho de 21,50 × $24 \mathrm{~m}$, alinhada perfeitamente com os referenciais dos quatro pontos cardeais. A vila é composta por quinze cômodos, divididos em onze salas, quatro corredores e um peristilo central. $\mathrm{O}$ pátio peristilo é cercado por pilares e quatro corredores em paralelo, ocupando a parte central da edificação. O maior corredor (loc. 1851/1768) está na porção sul do sítio, atravessando toda a construção de oeste para leste. O final desse corredor é uma parede junto da rocha matriz, onde se encontra um nicho entalhado, eivado de cerâmica ao seu redor. Essa é a técnica de opus incertum que consistia na aplicação de fragmentos cerâmicos como forma de reforçar a espessura do reboco e prevenir de rachaduras e infiltrações. Esse nicho foi identificado como sendo a Lararia, elemento típico das habitações italianas. Toda a construção da Vila era formada do kurkar local com o mortaria, reboco que, constituído de cal e pó de mármore, misturado com amurca borra de azeite - sustentava as paredes da edificação.

É possível que as dimensões da cidade de Apollonia em período romano não se restringissem somente a Villa marittima (Fig. 2). O império romano logrou uma série de cidades pelo Oriente Próximo que contavam com uma enorme variação em seus tamanhos. Algumas maiores, como é o caso de Antioquia, Jerusalém e Damasco; outras poucas de porte médio, mas em sua ampla maioria, pequenas vilas (Woolf 1997: 4-8). Antioquia já era uma das maiores cidades do mundo antigo e passou a ser centro administrativo romano na região, sendo mais tarde residência imperial. Jerusalém era o marco religioso e principal cidade para os judeus e Damasco usufruía da fama de uma das cidades mais antigas do mundo. Entretanto, as outras tantas localidades não passavam de pequenos assentamentos.

\footnotetext{
${ }^{17}$ A campanha de escavação foi realizada no ano de 1998 em forma de cooperação científica entre a Tel Aviv University e a Universidade Federal do Rio Grande do Sul, bem como outras Universidade como USP, Unicamp e PUC.
} 


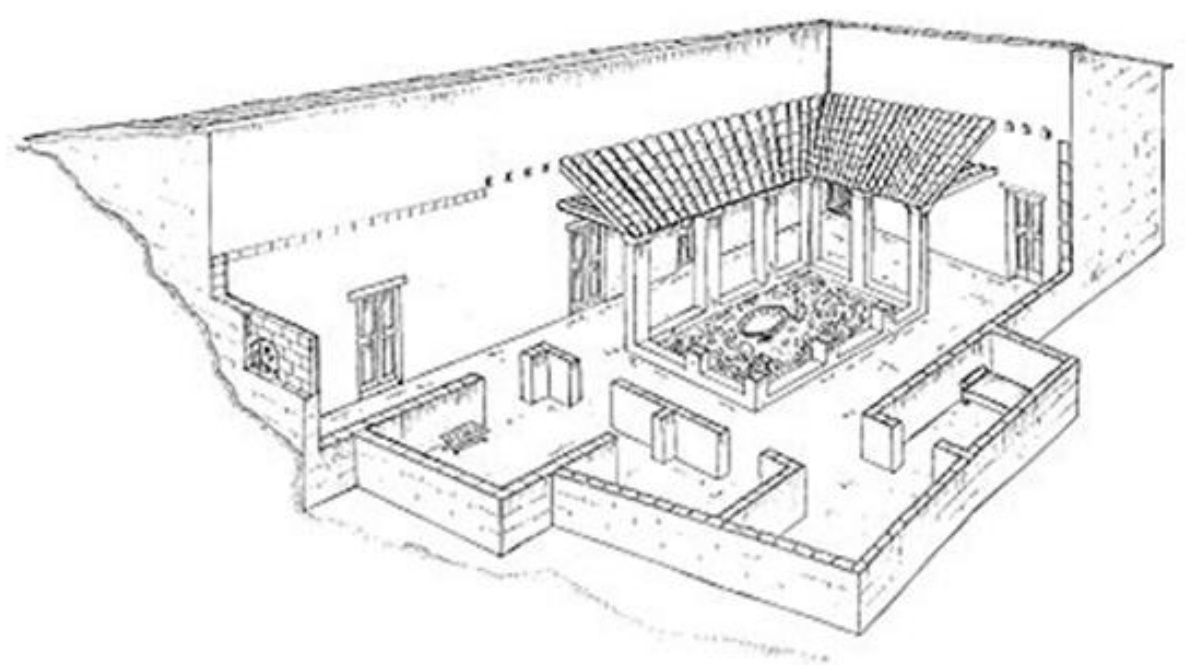

Fig.3 Representação da Vila Maritima de Apollonia.

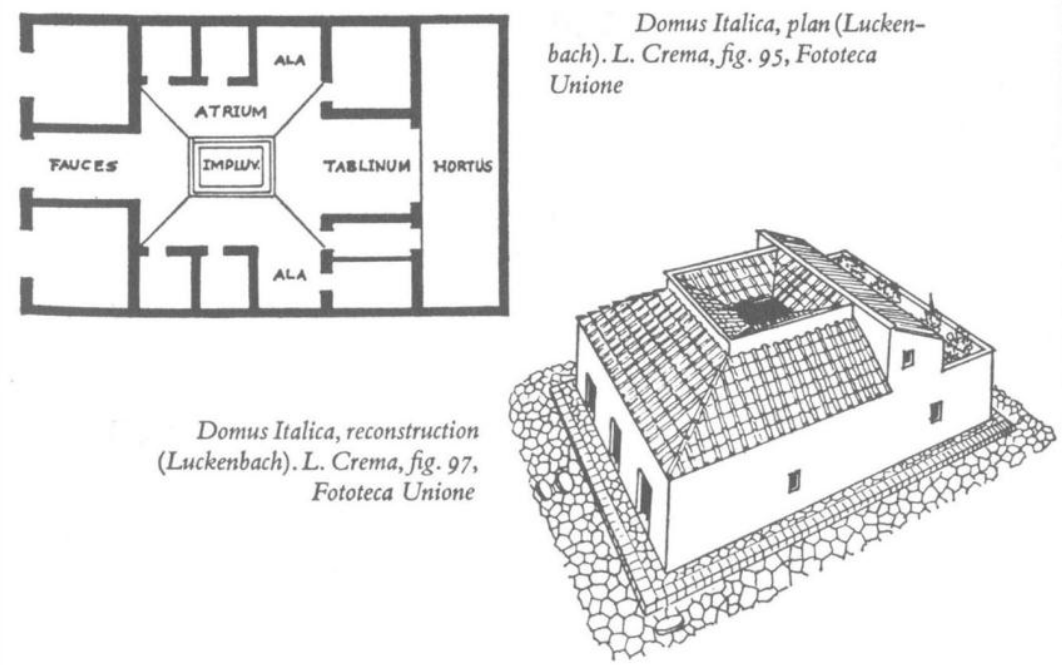

Fig. 4 Exemplo de Vila com peristilo da Península Itálica

A partir da coletânea organizada por Susan Alcook (1997) e dos dados apresentados para a região por G. Woolf (1997), G. Tate (1992; 1997), Y. Hirschfeld (1997), a pergunta síntese de Kennedy (1999) foi se a ocupação da região seria a de "um mundo de cidades ou vilas?"” 
A reposta para essa pergunta ganha contornos quando se constatam mais de 800 pequenos assentamentos para a região no noroeste da Síria e a estimativa de 10.000 ou mais na área da Mesopotâmia, para o Sinai (Kennedy 1999: 94-104). Analisando "The Roman near east" para o período de 31 a.C. - 337 d.C., F. Millar (1993) pondera a respeito da proposição de que pequenas cidades poderiam ter muitas "vilas/aldeias" dependentes, implicando na hierarquia regional ${ }^{18}$. Porém, o próprio autor reconhece que o termo "vila/aldeia" não é muito preciso, generalizando uma variedade de formas, escalas e funções desses assentamentos. A tarefa se torna ainda mais complicada quando se busca a massa de dados coligida e trabalhada pelos arqueólogos ao longo dos anos. Na maior parte das vezes, o foco se ateve à particularidade de algumas cidades, muitas vezes negligenciando a Paisagem como um todo.

É importante salientar que o Império romano não encampou somente antigos assentamentos, mas criou uma série deles. O estímulo nativo à urbanização nos moldes greco-romanos também são bem claros nas ações de Herodes, o Grande. Ele fundou as cidades de Sebaste (Samaria); Cesaréia; construiu a fortaleza de Massada; fomentou a reconstrução do Templo de Jerusalém (que inclusive causou ojeriza aos judeus em colocar um símbolo romano no Templo); os palácios de Herodito, a sul de Jerusalém; Jericó, no vale do Jordão e Maqueronte, nas montanhas, a leste do Mar Morto. Todavia, apesar dos planos e estruturas clássicas, a permanência e concorrência das tradições nativas persistiram nos mais distintos padrões e níveis organizacionais.

Com a anexação romana entre os anos de 60-3 a.C., Pompeu impôs um tributo a toda província e às terras litorâneas de Gaza, Jope, Dora e a Torre de Strato, sendo estas últimas reconstruídas. As cidades que os judeus haviam conquistado na baixa Síria foram perdidas e colocadas como cidades gregas sob jurisdição romana, estabelecendo os limites da Judéia. Após o retorno de Pompeu a Roma, Gabínio é designado ao

\footnotetext{
${ }^{18}$ Esse mesmo modelo organizacional é proposto por Roll e Ayalon (1988: 38-43) para Apollonia em período helenístico. Contudo, como bem apontam Fischer e Tal (1999: 253), essa é uma hipótese difícil de se comprovar dada a escassez de informações.
} 
comando da região. É nesse contexto que se encontra a descrição feita por Flávio Josefo a respeito da reconstrução de Apollonia:

"Gabinio tendo deixado tropas para continuarem o cerco, foi visitar todas as praças da província, restabeleceu a ordem, nas que não tinham sido destruídas e reconstruiu as que tinham sido. Assim Citópolis, Samaria, Antedom, Apolônia, Jamnia, Rafia, Marissa, Dora, Gamala, Azoto e várias outras repovoaram-se, pois seus antigos habitantes voltaram de todas as partes, com grande alegria" (Flavius Josephus. Bellum Judaicum I, 8,4 [166] - Antiquitates Judaicae XIV, 5,3 [88])

A questão da reestruturação de Apollonia ainda é uma questão em aberto. Dois posicionamentos interpretativos são propostos para a reedificação da cidade. Aqueles que sustentam a compatibilidade da reestruturação física em conformidade com o relato de Josefo, a saber: Jones 1971:257-258; Avi-Yonah 1977;79-80; Schürer 1979:92. Por outro lado, existe a sustentação pretendida por Isaac (1992:336-340) que entende a reedificação em termos somente administrativos, não implicando na reconstrução física das localidades. A esse respeito é difícil avançar na discussão.

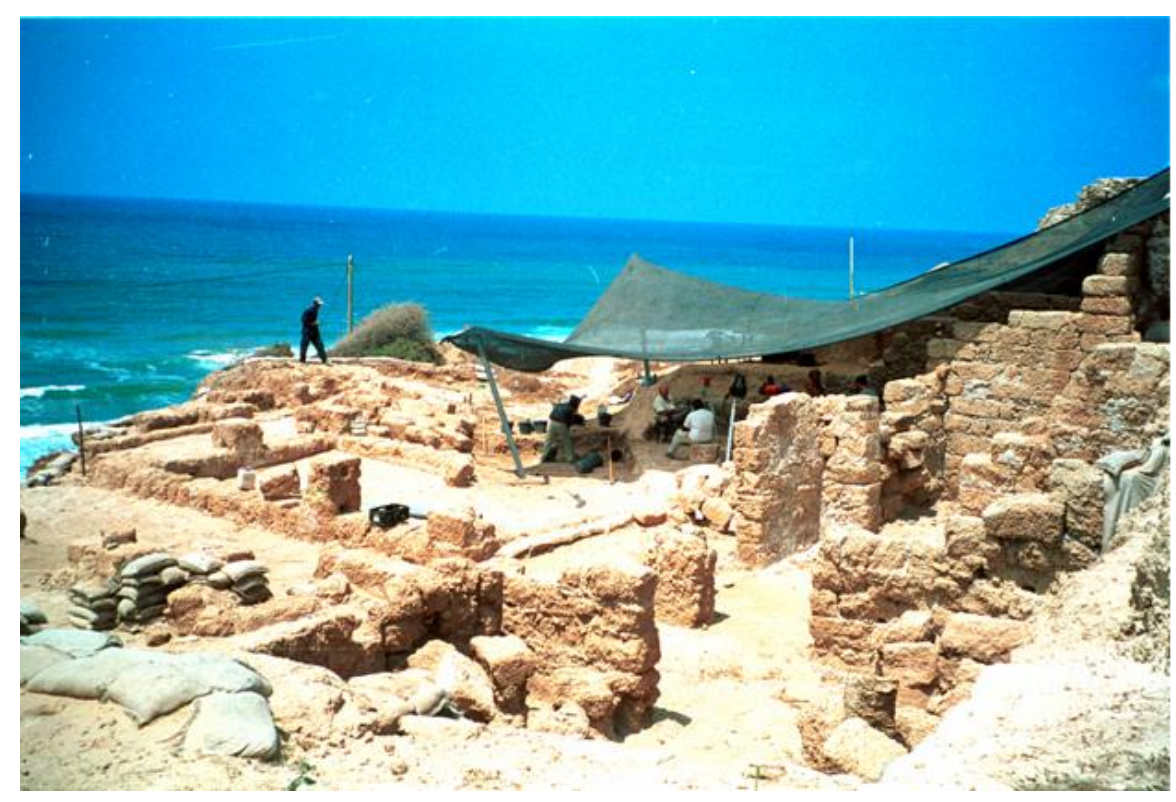

Fig 5 Visão Panorâmica das estruturas do período Romano em Apollonia. 
Sumariamente, a demografia da região foi afetada pelas guerras. Além dos conflitos de anexação, a região foi palco de três outros grandes enfrentamentos entre romanos e judeus. Entre os anos de 66-70 d.C deu-se a Primeira Guerra JudaicoRomana, também conhecida como Grande Revolta Judaica (em hebraico המרד הגדול, ha-Mered Ha-Gadol). Num curto intervalo de tempo, entre os anos de 115-117 d.C., eclode a Segunda Guerra Judaico-Romana (em hebraico מרז הגלויות, mered ha'galoyot ou Rebelião do Exílio), também chamada de "Guerra de Kitos", uma corruptela do nome do General romano Lúsio Quieto ${ }^{19}$. Ainda entre os anos de 132-135 um terceiro conflito é vivenciado. A revolta de Bar Kokhba (recebe esse nome por seu principal expoente Shime'on bar Kokhba, em hebraico כוכבא בר שמעון) é vencida por Severo e no processo - ainda sob as ordens de Adriano - Jerusalém muda seu nome para Aelia Capitolina. A província passa a ser designada Syria Palaestina e os judeus são proibidos de entrar em Jerusalém, bem como expulsos mais uma vez da província.

As estimativas populacionais apresentadas por Josefo por certo são exageradas. Ele aponta que em alguns momentos festivos, somente em Jerusalém, poderiam reunirse um total de 2 milhões e setecentas mil pessoas (7,422-426). E que a perda dos contingentes judaicos chegaram a 1 milhão e 100 mil $(6,420)$ no processo entre guerras. Contudo, segundo as estimativas de Byante (1973: 55), os habitantes de Jerusalém não passariam de 1 milhão, por consequência, as perdas judaicas não chegariam ao valor apontado. $\mathrm{O}$ autor sugere que a Palestina como um todo contava com um índice populacional de 3 milhões de habitantes ${ }^{20}$. Para essa mesma questão, Broshi (1980) se aplica à revisão das estimativas e áreas ocupadas pelas localidades e aponta valores mais modestos.

\footnotetext{
${ }^{19}$ Quintus Lusius Quietus, (70 - 118 d.C.), conhecido como "Príncipe Mouro", de origem berbere, foi nomeado por Trajano para conter os levantes na região. Executado por Adriano temeroso de que Lúsio fosse aclamado pelas tropas como imperador.

${ }^{20}$ Bryant propõe essa estimativa baseando-se nas inferências de Condor, Mazar, Avi-Yonaha, DanielRops,MacCown. BYATT, Anthony. Josephus and population numbers in first century. Palestine, Palestine Exploration Quarterly, p.51-60, 1973
} 
Broshi salienta que os dados populacionais para a "Palestinography" são exagerados por excelência, devido ao fato de tanto os escritos greco-romanos como a Bíblia referirem-se sempre ao coeficiente populacional de forma alegórica e tipológica: “sessenta miríades" ou “quarenta mil”. Há que se dizer também que isso faz parte de um modelo historiográfico helenístico, no qual para mostrar a grandeza de uma vitória, elevam-se as virtudes dos opositores. Dentre essas "virtudes" está, sem dúvida, o contingente das áreas dominadas.

Dessa maneira, calculando o coeficiente baseado na estimativa de 400-500 pessoas por hectare, contudo, relativizando os cálculos com outros fatores, como o suprimento de água, entre outros, Broschi (1980: 1-10), apresenta as seguintes projeções aqui compiladas:

Cidades do Negev.

\begin{tabular}{|l|l|l|}
\hline Cidade & Área & Estimativa de Broschi \\
\hline Kurnub (Mampsis) & 4 hec & 1.500 \\
\hline 'Avdat (Oboda, 'Abdeh) & 8 hec & 3.000 \\
\hline Shivta (Sbeita) & 11.5 hec & 2.000 \\
\hline Rehovot (Ruheibeh) & 12 hec & 4.000 \\
\hline Nissana (Nessana, 'Auja el-Hafir & $15-18$ hec & 4.000 \\
\hline Halusa (Elusa, Halasah) & $\begin{array}{l}35 \text { hec - 25 } \\
\text { hec }\end{array}$ & 10.000 \\
\hline & Total & 24.5000 \\
\hline
\end{tabular}

\begin{tabular}{|l|l|l|l|}
\hline Cidade & Área & $\begin{array}{l}\text { Estimativa } \\
\text { de Broschi }\end{array}$ & Pesquisador da área \\
\hline Aelia Capitolina (Jerusalem) & 120 hec. & 48.000 & M. Broshi (1978) \\
\hline Anthedon & 90 & 36.00 & I. Goldrat \\
\hline Antipatris & 12 & 4.800 & M. Kochavi \\
\hline Apollonia & $9(?)$ & 3.600 & \\
\hline Acalon & 52 & 20.800 & J. Gastang (1922:112) \\
\hline Azotos & $12(?)$ & 4.800 & M. Dothan \\
\hline Azotos Paralius & 40 & 16.00 & R. Gophna \\
\hline Caesarea & 95 & 38.000 & M. Avi-Yonah \\
\hline
\end{tabular}




\begin{tabular}{|l|l|l|l|}
\hline & & & $(1973: 373-74)$ \\
\hline Diocaesarea (Sepphoris) & 60 & 24.000 & A.Siegelmann \\
\hline Diospolis (Lydda) & 10 & 4.000 & R. Gohna \\
\hline Dora & 8 & 3.200 & M. Prausnitz \\
\hline Eleutheropolis (Bet-guvrin) & 30 & 12.000 & A. Kloner \\
\hline Gabaa & $9(?)$ & 3.600 & \\
\hline Gaza & 90 & 36.000 & I. Goldrat \\
\hline Jamnia & 50 & 20.000 & R. Gophna \\
\hline Jamnitarum-Portus & 10 & 4.000 & R.Gophna \\
\hline Jope & 4 & 1.600 & J.Kaplan \\
\hline Legio & 100 & 40.000 & M. Gichon \\
\hline Maiumas Gaza & 30 & 12.000 & Goldrat \\
\hline Neapolis (Shechem) & 30 & 12.000 & Z.Safrai \\
\hline Nicopolis (Emmaus) & 40 & 16.000 & I. Hirschfeld \\
\hline Ptolemais (Acre) & 100 & 40.000 & M. Prausnitz \\
\hline Raphia & 12 & 4.800 & E. Oren \\
\hline Scythopolis (Beith-Shean) & 110 & 44.000 & $\begin{array}{l}\text { C.R. Conder; H.H. } \\
\text { Kitchener } \\
(1882: \text { vol.2:105 }\end{array}$ \\
\hline Sebaste (Samaria) & & & $\begin{array}{l}\text { J.W.Crowfoot et al } \\
\text { (1942: pl. 1) }\end{array}$ \\
\hline Tiberias & & & G. Foerster \\
\hline Total & 77 & 30.800 & \\
\hline
\end{tabular}

Embora eventuais críticas possam ser feitas às projeções elaboradas por Broshi, aquilo que nos serve aqui é que a população em período Romano Tardio em toda a Palestina não deveria ultrapassar 1 milhão de pessoas, como o próprio autor conclui. Evidente que a população não é estática e os índices de picos e depressões são significativos no tamanho da população. As guerras entre judeus e romanos afetaram esses índices, diminuindo a população. Contudo, a reestruturação das cidades com melhorias na captação de água potável, organização e eliminação de resíduos e a estabilidade do período posterior; - devemos crer - propiciaram as condições para o crescimento populacional, ou pelo menos limitaram o déficit. Assim, é justo aceitar que 
as populações urbanas cresceram nos dois primeiros séculos, mesmo com resquícios das situações conturbadas (Kennedy 1999: 92).

Segundo Israel Roll (1996), fazia parte dos elementos básicos de uma adequada administração imperial romana, a organização de uma rede de estradas ordenadas e um sistema de tráfego eficiente. Dessa forma, seriam atendidas tanto as necessidades de mobilidade militar bem como as estratégias de suprimento e comunicação. As rotas recebiam o estatuto jurídico de via publica, servindo ao cursus publicus, atendendo, assim, à administração romana.

A construção de uma estrada romana envolvia desde o processo de traçado, nivelamento e desaterro, até o preenchimento do tálamo, pavimentação e contenção da superfície. Em alguns casos eram construídos diques, muros de contenção e pontes, segundo a necessidade do terreno. Somente após esse processo, a rota poderia receber o estatuto de via publica (Roll 1996: 550). Ao longo das vias, diversos marcos (milestones) eram colocados com o objetivo de informar as distâncias e nome da caput viae, ou seja, uma cidade principal ou acampamento militar, que era o destino final da via. Os marcos eram colocados em grupos de dez ou mais num intervalo de uma milha romana - os mille passus, que seriam mil passos duplos - correspondendo a 1482 metros. Ao que parece, na parte oriental do império foi usada a milha Philetherian, também conhecida como milha egípcia, que correspondia a 1575 metros. Entretanto, as medidas encontradas em Israel, entre a terceira e quarta estação, na via que ligava Eleutheropolis a Hebron, foram de 1635 metros e no caso de Gohna e Jope, chegou a 2100 metros. Portanto, não correspondendo a uma medida estritamente fidedigna para o intervalo dos marcos. Esses eram feitos de pedra calcária e variando entre $150-250 \mathrm{~cm}$, tinham um formato padrão. Sua base quadrada amparava um cilindro - algumas vezes com decoração na borda - onde eram entalhadas as informações e recebiam tinta vermelha sobre os sulcos. As informações contidas eram: primeiro em latim, incluindo o nome e título do governante romano que estava no poder, a época de construção ou reparação; segundo na linguagem nativa, mas no caso de Israel, grego, que continha o nome e distância da maior cidade onde a estrada começava ou para onde ela se direcionava. A rede de marcos constituía uma espécie de grid referencial que cobria 
toda a província, podendo ser usada por civis e militares em suas viagens (Roll 1983: $153)$.

Com o objetivo de orientar os usuários em viagens oficiais, a Tabula Peutingeriana é um dos únicos itens cartográficos, pertencente à classe dos picta itinerária, que mostra a rede de vias oficiais do Império romano na região. Ela descreve as estradas mais utilizadas pelo tráfego oficial nas províncias da Palaestina e Arabia. Obviamente, ela não representa a totalidade de rotas utilizadas na região. Porém, além das vias oficiais, acaba por fornecer - no cruzamento dos nomes das cidades mencionadas - a datação relativa de 135 d.C. ${ }^{21}$ para o mapa. Essa referência e a constatação de um grupo de mais de cinquenta marcos com a datação de 162 d.C., ao longo das principais vias das duas províncias, nos permite inferir que a partir da segunda metade do século II e durante as primeiras décadas do século III d.C., a região atingiu seu maior desenvolvimento no sistema viário, com mais de 2.500 milhas romanas de estradas.

Embora muitos caminhos usados pelos romanos na construção de suas estradas já fossem utilizados desde os períodos bíblicos, a organização de um sistema de vias de tráfego regional projetado em larga escala, é fruto desse período. Orientado pelos quatro pontos cardeais, o sistema contava com um alinhamento longitudinal de vias norte-sul e transversal leste-oeste.

As quatro vias longitudinais norte-sul eram: 1) a da costa do Mediterrâneo: partia de Antioquia-Tiro-Ptloemais-Cesarea-Apollonia-Jope-Iamnia-Ascalon-Gaza, tendo seu final em Alexandria; 2) a da cordilheira ocidental de Samaria e Judeia: partindo de Cesarea-Antipatris-Diospolis-Eleutheropolis, como ramificações para Hebrone Berosaba; 3) a do Vale do Jordão: saindo de Paneas, ao longo da margem oriental do Jordão e mar da Galiléia até Scythopolis; de Scythopolis podendo ramificar para Neapolis ou via Jericó para Jerusalém; 4) a do Planalto oriental além do Rio Jordão: Diocaesarea-Legio-Neapolis-Jerusalém-Hebron, ramificando para Berosaba e Mampsis.

\footnotetext{
${ }^{21}$ A menção das cidades de Luddis, Amavante e Betograbri se dá em período pré-severiano, quando a partir de 135 d.C. as mesmas cidades são renomeadas, respectivamente, como: Diospolis, Nicopolis e Eleutheropolis. Atualmente trata-se de Lydda, Emmaus e Beth Guvrin.
} 
Já as 9 vias transversais de alinhamento leste-oeste eram: 1) Tiro-Paneas-Damascus; 2) Ptolemais-Diocaesarea-Tiberias, e de Tiberias para Gadara e Bostra; 3) Cesaréia-LegioScythopolis, e de lá para Pella e Gerasa; 4) Cesaréia-Sebastes-Neapolis-CoreaFiladélfia; 5) Antipatris-Gofna-Jericó; 6) Jope- Diospolis-Bet Horon- Jerusalém-JericóEsbus; 7) Diospolis-Nicopolis-Jerusalém; 8) Ascalon-Eleutheropolis-Jerusalém; 9) Gaza-Berosaba, ramificando para Malata ou Mampsis.

Nesse contexto de estruturação romana, Cesareia Maritima desempenhou importante papel como caput viae e para ela convergiam nada menos do que sete via publicae. As instalações portuárias sofisticadas e o planejamento da cidade, atendendo às necessidades básicas romanas, fizeram com que a cidade figurasse como quartelgeneral do governador romano e seu executivo. As prioridades de comunicação, transporte e suprimentos entre Cesarea, suas cidades vizinhas - aqui incluo Apollonia e acampamentos militares foram uma contingência que se negligenciou. Desde Jope, Antipatris, Neapolis, Samaria, Ginae, Legio, Gaba e Ptolemais, cada uma dessas cidades contava com uma via publicae que a conectava diretamente com Cesarea, contribuindo no desenvolvimento da localidade e região.

Ao que parece, da metade final do século II d.C. até o século IV d.C. haverá um processo de crescimento dos assentamentos na região. Roll e Ayalon (1990) escrevendo sobre a economia e crescimento do Sharon Sul em período romano inclui entre os referenciais que confirmariam essa mesma hipótese para Apollonia:

"Os ricos achados incluem muitas lamparinas de óleo romanas de tipo redondo, vasos importados do norte da África, jarros com escritos gregos e zoomórficos, vasos com figuras de veado. No centro da cidade existia outro achado de cerâmica e nele cerca de 100 lamparinas de óleo samaritanas do $3^{\circ}$. a $4^{o}$. Século d.C. (Sussman, 1983). Esses achados são um testemunho mas também fragmentário, para dimensionar o assentamento do sítio, que existiu um grande nível de vida” (Roll e Ayalon 1990: 194) $)^{22}$.

\footnotetext{
22 "The rich find includes many Roman oil Lamps of round type, imported vessels from North Africa, jars with Greek writing and Zoomorphic vessels with figures of deer. In the center of the city there was another finding of pottery and in it there about 100 Samaritan oil lamps from the $3^{\text {rd }}$ to $4^{\text {th }}$ century C.E. (Sussman, 1983). This finds is a testament, but also fragmentary, to size of the settlement in the site, that existed a high level of life"
} 
Por similar processo de crescimento teriam passado Tirra, onde num raio de $5 \mathrm{~km}$ constatam-se cinco assentamentos; Kfar Saba onde num raio de 6km notam-se 14 assentamentos; Tel Qasile, onde num raio de 5km estão associados 11 assentamentos (Roll e Ayalon 1988: 34-43). De forma especial, Antipatris teria passado por uma grande reconstrução recebendo edifícios - possivelmente um tetrapilum e decumanus -, fóruns, um pequeno teatro e muitos mosaicos, ainda na metade final do século II d.C.

Para Apollonia está a menção que no raio de $10 \mathrm{~km}$ estariam relacionados 22 assentamentos. A associação de crescimento experimentado é feita em relação à presença de samaritanos na localidade, e Roll e Ayalon (1988) afirma:

"Observando Apollonia e Kfar Saba, existem referências em fontes históricos relacionados aos assentamentos onde os samaritanos viveram. O processo de assentamento dos samaritanos no sul Sharon começou no período romano e alcançou seu ápice no período bizantino. Nós temos a impressão de que os samaritanos foram o principal fator étnico na oscilação de assentamentos que vieram a florescer no sul Sharon no período mencionado" (Roll e Ayalon: 1988: 43) ${ }^{23}$.

$\mathrm{Na}$ interação cumulativa entre os atores envolvidos no processo, cada microrregião em si foi resultado, a longo alcance, de forças externas e, de forma localizada, de forças internas, que nesse interfluxo definiam campos de ação. Como aponta o paradigma kuhniano (Kuhn 1996) ${ }^{24}$ e os enunciados de Foucault (2007), as forças não se concentram num lugar determinado, antes, estão espalhadas em diferentes pontos no tempo e no espaço. A criação de uma rede de comunicação regional

\footnotetext{
23 "Regarding Apollonia and Kfar Saba there are also reference in historical resources that relate them to settlements were the Samarians lived in. The settlement process of the Samarians in Southern Sharon began in the Roman period and reached its peak in the Byzantine period. We get the impression that the Samaritans were the main ethnical factor in the swing of settlements that brought to the flourishing of Southern Sharon in the spoken period"

${ }^{24}$ A contribuição de Tomaz Kuhn (1923-1996), diz respeito à construção do conhecimento considerada como um processo social, sendo caracterizada levando em conta sua complexidade aliada a grande "inventividade" desse tipo de atividade. A existência de mudança conjugada a muitas controvérsias é o indício que define as revoluções científicas. A forma descontínua através da qual acontece a mudança caracteriza a própria ação em si. Assim é que a questão dos paradigmas vem à tona.
} 
integrada, como pode ser definido o plano viário romano, é um dos fatores de peso nesse jogo de relações. Porém, não o único. Outros fatores podem ser mencionados, não somente para a constituição das vias romanas, como propõe Roll (1983), mas como um todo para as ações humanas numa dada paisagem, dentre eles: fatores geográficos naturais (relevo, tipo de solo e rocha, fontes de água, clima, vegetação, entre outros); fatores geográficos humanos (distribuição e densidade da população); fatores econômicos, fatores geo-políticos, média de tráfego e tecnologia, entre outras relações de significado simbólico que tratarei adiante.

É nesse sentido que comunicação envolve conhecimento e conhecimento provoca e sustenta um novo movimento de distintas ideias a respeito dos caminhos aos quais o desenvolvimento pode estar conectado. Algumas vezes, o movimento pode ser estável e pouco móvel. Em outros momentos, intenso e caótico. Entretanto, ele nunca deixa de existir. A mobilidade conectiva faz parte de um mundo de marcos físicos e mentais, orais e textuais, introspectivos e projetivos, analógicos, tipológicos e constantemente em formação. Conforme postulam Horden e Purcell (2000: 90), as estradas não são "coisas em si" ou as vilas e cidades "pontos fixos no espaço"; antes, as estradas, enquanto linhas potenciais de movimento e intersecção, e as vilas e cidades, como lugares significativos para a promoção do contato e estabelecimento de referencias em coletividade, são lugares e espaços onde as relações de troca acontecem, promovendo a oportunidade para uma série de desdobramentos em sociedade.

\subsection{Poder, hegemonia, dominação e resistência}

Tratar dos conceitos de poder, hegemonia, dominação e resistência não é uma tarefa das mais simples, primeiramente porque em diferentes níveis e escalas eles se perpassam e muitas vezes são confundidos dentro de um único pacote de entendimento. 
Em segundo lugar, a dificuldade parte do conceito fundamental de Poder e das relações estabelecidas dentro e a partir de sua mecânica.

Mas o que de fato é poder? Quando esse conceito tange o Império romano cenário amplo dessa dissertação - logo se tem a tendência de formular essa questão de forma vertical: um indivíduo, nesse caso o imperador, que detém o imperium, ou seja, na acepção mais estrita do termo, alguém que detém a supremacia do Estado. Sujeito que personifica nessa magistratura a hegemonia daqueles que investidos dela têm o poder de levantar tropas e comandá-las; tomar auspícios, mesmo fora do pomerium; apresentar propostas aos comícios; deter e punir cidadãos culpados, entre outros poderes. Na qualificação romana estavam os cum imperium e sine imperium. As magistraturas do consulado, da pretura, da ditadura, do tribunato militar e do consulari potestate eram investiduras cum imperium, sendo as demais sine imperium. O grau de exercício do imperium era simbolizado pelo número de lictores, com bastões enfeitados com fasces de cereais, que constituíam a escolta. Contudo, essa alusão vertical que geralmente vem à mente dos mais afoitos passa ao largo da questão central do que é de fato o poder, onde se localiza e qual sua mecânica, seja no âmbito de análise do Império romano ou no de outras organizações societais.

Para um esboço incipiente do que venha a ser definido aqui como poder, penso ser pertinente lançar mão de uma pontuação básica e necessária: poder é uma "coisa"! Embora pareça estranho a alguns e óbvio a outros, é necessário que essa constatação inicial seja feita para não incorrer no erro de muito falar e nada dizer, por fim.

A partir do momento em que Michael Foucault trouxe à voga o tema do poder e de suas relações, tinha em mente as "lutas cotidianas realizadas nas bases com aqueles que tinham que se debater nas malhas mais finas da rede do poder"- como ele mesmo diz. A temática suscitou aos seus olhos a concretude do poder, sua fecundidade enquanto campo de análise, com o objetivo de dar conta das coisas que até então tinham ficado à margem do campo de análise da política (Foucault 2007: 7) ${ }^{25}$. Assim, quando

${ }^{25}$ FOUCAULT, M. Microfísica do poder. São Paulo: Editora Graal, ed. 23, 2007 
Foucault se refere ao poder ele reconhece a dificuldade em "conhecer esta coisa tão enigmática, ao mesmo tempo visível e invisível, presente e oculta, investida em toda parte, que se chama poder" (Foucault 2007: 44).

Seguindo o plano proposto por Foucault, outra constatação pode ser pontuada: poder é um exercício. Ele funciona em cadeia, em rede. Não pode ser localizado aqui ou ali, não se concentra exclusivamente na mão de um só indivíduo ou de alguns, mas está disperso por todo o tecido social. O poder em seu exercício vai além, passa por sutis nuances, de forma mais ambígua, não atende somente à função única de reproduzir relações de produção, como no sentido marxista. Está em distintas redes de dominação que se recobrem, que se amparam e interferem umas nas outras (p.90). Dessa forma não existe poder em si, enquanto propriedade; existem, sim, práticas e relações de poder, onde ele se efetua, onde funciona, onde se exerce. Ninguém é, portanto, titular único e exclusivo do poder, da mesma maneira que não existem aqueles que têm poder e aqueles que não o têm. Logicamente que nesses movimentos de poder ninguém ocupa o mesmo lugar; algumas posições são preponderantes, permitindo produzir efeitos de supremacia e/ou hegemonia. Assegurando uma dominação na medida em que dissociam o poder dos domínios individuas. Entretanto, da maneira como Foucault apresenta:

“(...) o poder não se aplica aos indivíduos, passa por eles. Não se trata de conceber o indivíduo como uma espécie de núcleo elementar, átomo primitivo, matéria múltipla e inerte que o poder golpearia e sobre o qual se aplicaria, submetendo os indivíduos ou estraçalhando-os. Efetivamente, aquilo que faz com que um corpo, gestos, discursos e desejos sejam identificados e constituídos enquanto indivíduos é um dos primeiros efeitos de poder. Ou seja, o indivíduo não é o outro do poder: é um de seus primeiros efeitos. $O$ indivíduo é um efeito do poder e simultaneamente, ou pelo próprio fato de ser um efeito, é seu centro de transmissão. O poder passa através do indivíduo que ele constituiu (...)" (Foucault 2007: 103) 
Assim, tendo como mérito fugir da óbvia relação vertical que se estabelece muitas vezes entre centro e periferia, macro e micro, Foucault aponta os poderes se exercendo em níveis variados e em pontos distintos da rede social. Não que isso exclua a concepção de periferia, pelo contrário, é a observação dos poderes moleculares e periféricos, ou seja, daqueles poderes exercidos pelos indivíduos, grupos alijados, entre outros segmentos que não foram criados pelo Estado, ou confiscados por ele, que o movimento das forças acontece.

O poder, então, não cumpre somente a função de reprimir os indivíduos, a natureza, os instintos ou uma determinada classe. O que faz com que o poder seja aceito, se mantenha, não é sua qualidade de dizer não, mas o fato de que por permear os indivíduos: produz coisas, induz ao prazer, forma saber, fomenta discurso. Deveria, por conseguinte, conforme propõe o autor, ser considerado como uma rede produtiva que atravessa todo o tecido social. Não somente nos termos de instância negativa e repressão, como geralmente é utilizado (ibidem, p.8).

Com esse encaminhamento, o poder é em si ativação e desdobramento de uma relação de força. É sobre essa base que Foucault lança a hipótese das estruturas disciplinadoras, que cumprem a função de gerir a vida dos homens, controlá-los em suas ações, objetivando o aproveitamento elevado de suas potencialidades e utilizando um sistema de aperfeiçoamento contínuo de suas capacidades. Seguindo essas premissas, ele propõe analisar o poder enquanto combate, confronto e guerra e assevera:

"O problema é ao mesmo tempo distinguir os acontecimentos, diferenciar as redes e os niveis a que pertencem e reconstituir os fios que os ligam e que fazem com que se engendrem, uns a partir dos outros. Daí a recusa das análises que se referem ao campo simbólico ou ao campo das estruturas significantes, e o recurso às análises que se fazem em termos de genealogia das relações de força, de desenvolvimentos estratégicos e de táticas. Creio que aquilo que se deve ter como referência não é o grande modelo da língua e dos signos, mas sim da guerra e da batalha. A historicidade que nos domina e nos determina é belicosa e não lingüística. Relação de poder, não relação de sentido. A história não tem "sentido", o que não quer dizer que seja absurda ou 
incoerente. Ao contrário, é inteligível e deve poder ser analisada em seus menores detalhes, mas segundo a inteligibilidade das lutas, das estratégias, das táticas. Nem a dialética (como lógica de contradição), nem a semiótica (como estrutura da comunicação) não poderiam dar conta do que é a inteligibilidade intrínseca dos confrontos. A "dialética" é uma maneira de evitar a realidade aleatória e aberta desta inteligibilidade reduzindo-a ao esqueleto hegeliano; e a "semiologia" é uma maneira de evitar seu caráter violento, sangrento e mortal, reduzindo-a à forma apaziguada e platônica da linguagem e do diálogo". (Foucault 2007: 6)

Se por um lado as observações de Foucault são bem empregadas no sentido das micro-relações de poder e sua disseminação no tecido social; por outro, a crítica que recebe de Tracy L. Sweely (2001) é pertinente quando a autora afirma que tanto nos escritos de Marx, Weber, quanto nos do próprio Foucault, o foco principal está nas formas institucionais, relegando demasiado papel a elas enquanto formadoras da individualidade. Essa conotação cria uma grande diferença entre as estruturas ideológicas - estando inclusas aqui as estruturas sociais, políticas e econômicas - e os indivíduos reais que interagem dentro delas. Nesse sentido, Foucault quando prioriza os sujeitos como produto das instituições culturais incide sobre o mesmo paradigma, ao invés do contrário.

Sweely procura apresentar outro paradigma interpretativo para as relações de poder. Discordando francamente da afirmação de que a linguagem e as estruturas de significado não nos dominam, ela apresenta o referencial de Bakhtin (Bakhtin 1981 apud Sweely 2001) para suporte de suas proposições. Nesse paradigma é a força centrífuga - identificada pela consciência individual - da variação e improvisação em qualquer interação específica que se torna mais importante do que o conjunto de regras - chamadas de forças centrípetas - que lhes empregam sua forma básica (Sweely 2001: 3). Em outras palavras, é a linguagem e, por extensão a cultura, que determinam num dado momento e num contexto particular as relações de poder. Até que ponto as pessoas concordam em compartilhar uma série de condições ideológicas seria a força que cobre e torna as estruturas sociais secundárias aos indivíduos. A belicosidade é o ponto da 
"não negociação", onde outros fatores interferem, mas também estes fatalmente passam pelas relações de sentido e significado.

$\mathrm{Na}$ interação entre os indivíduos, entre seus signos e termos estão sendo continuamente criadas as relações de linguagem e a isso Sweely, parafraseando Bakhtin, acrescenta:

"Discurso internamente persuasivo - oposto ao que é externamente autoritário - como é afirmada através da assimilação, intimamente entrelaçada com a "palavra da própria pessoa." Nos arredores do cotidiano de nossa consciência, a palavra internamente persuasiva é meia nossa e meia de outro. Sua criatividade e prodtividade consiste precisamente no fato de que tal palavra desperta novas e independentes palavras que organiza massas de nossas palavras de dentro e não permanecer em uma condição isolada e estática. Não é tão interpretado por nós como está longe, isto é livremente, desenvolvido, aplicado aos materiais, novas condições; entra numa relação de interanimação com novos contextos." (Bakhtin 1981:346 apud Sweely 2001: 4)

Esse princípio de polissemia ou heteroglossia como o define Bakhtin, contribui para o fomento da multiplicidade de caminhos na coexistência de contradições ideológicas, elas são as forças centrífugas resultantes dessas intercessões.

Apesar de o princípio da particularidade circunstancial de momentos, a relação de significados no contato com o outro e a relação de movimentos de força ${ }^{27}$ serem muito úteis nos enunciados de Bakhtin, as relações estabelecidas para o que chama de força centrífuga e força centrípeta, mesmo em relação analógica, são difíceis de conceber em sociedade. Por força centrífuga entende-se um movimento de rotação em

\footnotetext{
26 "Internally persuasive discourse - as opposed to one that is externally authoritative - is as it is affirmed through assimilation, tightly interwoven with "one's own word." In the everyday rounds of our consciousness, the internally persuasive word is half-ours and half-someone else's. Its creativity and productiveness consist precisely in the fact that such a word awakens new and independent words, that it organizes masses of our words from within, and does not remain in an isolated and static condition. It is not so much interpreted by us as it is farther, that is, freely, developed, applied to new material, new conditions; it enters into interanimating relationships with new contexts."

${ }^{27}$ Discutirei essas relações mais adiante tratando de movimento randômico.
} 
relação a um referencial inercial, ou seja, um referencial sem movimento. Já por força centrípeta concebe-se a resultante que atrai o corpo - nesse caso seria o indivíduo - para o centro da trajetória de, mais uma vez, um movimento circular ou quiçá curvilíneo. Não é mais possível conceber as sociedades e as relações entre os agentes sociais enquanto movimentos circulares ou curvilíneos, mesmo que seja de forma figurada. Nem as sociedades nem os indivíduos se movimentam em círculos, embora muitas vezes no âmbito cotidiano tenha-se essa impressão, isto não passa de um senso comum, tanto para indivíduos como para períodos históricos.

O individuo não é um dado sobre o qual se abate poder, é portador de agência e retém poder, como o poder não é passível de doação ou de troca, só existe em ação e numa relação de contato; aí sim, no movimento, na polissemia, nos desejos e nas forças.

Como já aludi, na medida em que alguns indivíduos estão dispostos em determinadas posições preponderantes nessas relações de contato e quando se utilizam delas dissociando o poder dos domínios individuais, os efeitos de hegemonia se estabelecem e podem ser evidenciados de forma mais clara. É importante salientar que a dominação não existe enquanto forma global, mas nas múltiplas formas presentes no exercício da sociedade. Mesmo o imperador em sua posição central está sujeito às várias sujeições que existem e funcionam nos meandros do tecido social, a essas mesmas sujeições todos nós estamos expostos diariamente.

Portanto, não é uma hegemonia global que se cristaliza, desdobra e repercute até uma suposta base social. Antes, de forma desconjuntada, expandida, modificada, essas relações são investidas desse discurso, que nesse caso visa à legitimação do controle hegemônico. Dessa maneira, as inúmeras relações de poder que nos atravessam e que compõem o social, "não podem se dissociar, se estabelecer nem funcionar sem uma produção, uma acumulação, uma circulação e um funcionamento do discurso. Não há possibilidade de exercício do poder sem uma certa economia dos discursos de verdade que funcione dentro e a partir desta dupla exigência. Somos submetidos pelo poder à produção da verdade e só podemos exercê-lo através da produção da verdade." (Foucault 2007: 101). 
A resultante dessa multidão de produção de "verdades" é a percepção de condições ideológicas distintas e contradições inerentes às interações. Conforme aponta Cohen (1994), as contradições estão consagradas nas interpretações individuais das condições ideológicas e nos termos de tendência à agregação e segmentação. Podendose, geralmente, revela-se sob a forma de distinção social (Cohen 1994).

Essas distinções sociais são apresentadas no conjunto diferenciado de relações que, conjuntamente com a intepretação dos indivíduos sobre as ideologias em questão, fornecem as condições, através das quais é permitido exibir afirmações de poder, sempre numa contínua negociação e reinterpretação de significados específicos (Sweely 2001).

Quando Ruth Trocolli (2001) tenta conceituar a noção de poder, a autora discorre sobre aquilo que chama de um continuum, baseado em circunstâncias. Numa extremidade estaria a capacidade de ação e/ou autodeterminação e na outra ponta estaria a capacidade de controlar os outros, por meio do consentimento sancionado. Nesse processo de continuum, as relações seriam multiescalares, da mesma forma que as hegemonias o são.

Pensar as relações de poder, hegemonia e dominação sem falar em resistência seria uma quimera. De modo geral, "onde existe poder, existe resistência". Não entendida como substância ou anterior ao poder, mas na coexistência. A resistência, assim como o poder, é tão invertida, móvel, produtiva e disseminada. Logo:“ a partir do momento em que há uma relação de poder, há uma possibilidade de resistência. Jamais somos aprisionados pelo poder: podemos sempre modificar sua dominação em condições determinadas e segundo uma estratégia precisa" (Foucault 2007: 136). De modo geral, sempre haverá formas e estratégias de escapar das relações tanto de domínio, quanto da hegemonia, e é nesses - algumas vezes ínfimos - intervalos que se engendram e se consolidam as resistências.

Finalizando, se por um lado Foucault apesenta os argumentos de que os homens dominam outros homens e disto emergem as diferenças de valor; classes dominam 
classes e então nasce a ideia de liberdade; de que cada momento da história a dominação se fixa em determinado ritual, impondo obrigações e direitos, constituindo cuidadosos procedimentos, estabelecendo marcas e, desse jeito, gravando lembranças. Por outro, é na manutenção dos discursos de verdade e a forma textual - assim dos sentidos que se figuram em ações - que o discurso permite o armazenamento físico daquilo que se perderia numa cotidiana fala ou reter-se-ia na memória. O discurso engendrado abriga poderes, direta e indiretamente, em relação a outros discursos, ele é interxtual, por excelência, manifestando os mais diversos sistemas classificatórios societais. Até mesmo na ação beligerante o discurso - novamente, interno ou externo é um dos componentes de tal organização.

Assim, por sistemas classificatórios estão incluídos os traços comuns: a) das noções hierarquizadas dispostas que os grupos mantêm entre si, definidas num conjunto que compõe um todo num dado momento; b) da constituição dos instrumentos de comunicação e conhecimento pelos quais a sociedade confere um sentido à organização social mais ampla em que se insere, ou seja, a forma de se fazer compreender e tornar-se inteligível nas relações existentes entre os agentes; c) das condições sociais das quais ambos dependem, pois as relações sociais entre os agentes servem de base e modelo para as relações lógicas entre as coisas experienciadas (Bourdieu 2002).

Nesse mesmo sentido, Tilley (1995) ressalta a importância dos contextos de produção dos discursos:

“(...) é sublinhado o fato de toda a comunicação ser social. A contextualidade social de ambos os discrsos perite sua construção $e$ simultaneamente coage sua forma de sua aparência. As declarações feitas e os significados das palavras empregadas no contexto (onde) e em relação ao que (outros duscursos, indivíduos ou instituições) elas são relatadas. Discursos são sempre historicamente e socialmente posicionados e constituídos" (Tilley 1995: 40) ${ }^{28}$.

\footnotetext{
28 “ (...) is to underline the fact that all communication is social. The social contextuality of discourse both permits its construction and simultaneously constrains its forms of appearance. The statements made and the meanings of the words employed depend on the context (where) and in relation to what (other discourses, individuals or institutions) they are to relate. Discourses are always historically and socially positioned and constituted"
} 
É desses discursos sobre verdade, das declarações de significado e dos posicionamentos sociais de seus agentes que passo a me ocupar no próximo capítulo, abordando as produções cristãs dos Apologistas e Pais Apostólicos nas suas respectivas construções textuais, sob a ótica de relações de hegemonia, domínio e resistência dentro do contexto da paisagem que até aqui apresentei. 


\section{CAPÍTULO 2}

\section{2. "Ab intestato": a emergência dos escritos cristãos}

O cristianismo surge enquanto movimento social durante o século I d.C.. Entretanto, serão os séculos seguintes aqueles decisivos em seu desenvolvimento e consolidação. Recebendo a designação de espalhar "até os confins do mundo" o propósito da mensagem cristã, os apóstolos empenharam-se ardorosamente em conquistar prosélitos à sua causa. Objetivando as mais diferentes mentes e classes sociais, o cristianismo em seu início não passava de mais um dentre tantos seguimentos religiosos presentes na conturbada e conflitante Palaestina.

Diante da realidade hostil, tornou-se iminente para a existência do cristianismo consolidar seu ideário. Portanto, à medida que ampliava o raio de sua difusão e que pretendia satisfazer às exigências dos espíritos cultivados, o cristianismo necessitava especificar e organizar sua mensagem. Isto é, na prática, engendrá-la para legitimá-la não só aos prosélitos conquistados, como também perante aos opositores que passavam a existir. Afinal, após a morte ${ }^{1}$ de João, o "amado", que seria o mais jovem dos doze escolhidos por Jesus, nenhum outro apóstolo reconhecido ou amplamente aceito sobrepujou sua morte. Dessa forma, para se alcançar reconhecimento de liderança frente à própria comunidade, os candidatos a presbíteros ${ }^{2}$ buscavam amparo numa "linhagem de designação", ou seja, procuravam ligar seu nome, sua história, ou seu discipulado a um dos apóstolos, na busca de legitimidade. Se no interior da comunidade a situação estava difícil; fora dela, então, o cristianismo se encontrava ainda menos organizado e eivado de contradições e dissonâncias.

\footnotetext{
${ }^{1}$ Essa morte teria acontecido por volta do ano 90 d.C., embora essa data não seja uma consonância.

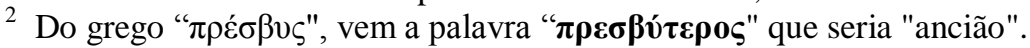


Alguns movimentos marcaram o pensamento cristão de forma decisiva. O gnosticismo foi um dos que cumpriu importante papel no contraste de interpretações. Não chegavam a formar um grupo coeso, contudo, é possível definir, nos diferentes grupos que se identificavam com essas ideias, cinco semelhanças fundamentais: (1) a transcendência total de deus, ente espiritual afastado da criação material, que ele não criou; (2) a essência do homem como centelhas desse deus aprisionadas em matéria corpórea (físico humano) tendo expectativa de volta a sua essência original (deus); (3) o entendimento da "Criação" e da "Queda" humana como a mesma coisa. A "Criação" levou o homem à "Queda" que faz os espíritos permanecerem presos nos corpos físicos e na materialidade, estando sujeitos ao pecado ou erro. Esse aberratio ictus (erro de alvo) é causado pela ignorância da sua verdadeira natureza e habitação. (4) a premissa de que a salvação é escapar da escravidão material, retornando para o lugar de onde os espíritos (caídos) saíram. (5) por fim, a consciência de que Jesus seria o mensageiro celestial, emanação que ensina o caminho a alguns espíritos.

A soteriologia gnóstica enfatizava, portanto, o exercício da gnosis, em outras palavras, o aprendizado do auto-conhecimento e sabedoria - daí a denominação recebida. Foi uma linha interpretativa bastante presente no pensamento cristão, fazendo frente ao que se convencionou chamar, posteriormente, de ortodoxia ${ }^{3}$.

Outro movimento de forte imbricação com o pensamento cristão emergente foi o "Montanismo". Seus partidários o chamavam de Nova Revelação ou Nova Profecia, seus oponentes referenciam-se simplesmente como "montanismo", devido ao nome de seu fundador e principal profeta: Montano. Ele auto-identificava-se como porta-voz incomparável de deus e acusava os demais líderes de prender o Espírito Santo dentro de um livro, ao tentar limitar a inspiração divina aos escritos apostólicos.

Enquanto o gnosticismo e o montanismo representaram enfrentamentos internos à mensagem apostólica, bem como à união e integridade que se propunha o

\footnotetext{
${ }^{3}$ Entende-se por "pensamento ortodoxo" aquele teologicamente definido conforme os escritos apostólicos contidos no cânone hebraico ou Palestino.
} 
cristianismo, o desafio externo ficava por conta de escritores e oradores judeus e pagãos, dentre os quais: Fronto, Tácito, Luciano, Porfírio e Celso.

Por volta de 175-80 d.C. Celso, um cidadão culto romano, lança uma das mais duras contestações iniciais do cristianismo: "A verdadeira doutrina: um discurso contra os cristãos". Nesse livro, ele impõe uma das principais questões da mensagem cristã a serem respondidas: o seu monoteísmo. Segundo Celso, não era lógico os cristãos chamarem-se monoteístas, da mesma forma que judeus, posto que eles tinham Jesus também como deus. A conta não fechava para Celso.

Bem, uma coisa era defender-se de acusações levianas de superstição, libelos de sangue e perjúrios, que cristãos supostamente tinham feito; outra, muito diferente, era articular um discurso que sustentasse argumentos lógicos para o silogismo do qual eram acusados. Essa questão será combatida em Contra Celsum, escrito por Orígenes de Alexandria, que partindo de referenciais clássicos, procurou articular sua reposta nos mesmos quadros de análise de Celso.

A filosofia grega também passou a ser, para alguns pensadores cristãos, uma aliada na explicação dos conceitos imanentes do cristianismo. O império romano estava cheio de religiões de mistério, cultos de iniciação com uma diversidade de mitos sobre deuses que morriam e renasciam, bem como caminhos para a imortalidade mediante cerimônias secretas. Existiam, ainda, as diversas sagrações e templos sobre os panteões grego e romano de deuses e deusas do Olimpo como Zeus, Apolo e Diana.

A essência da filosofia grega, contudo, não concordava com o politeísmo das religiões populares e com as cerimônias de iniciação das religiões de mistério. Na sua extensa maioria, os cidadãos romanos cultos tendiam a considerar essas seitas como organizações fraternais para a diversão e muitas vezes satisfação sexual. A "verdadeira doutrina", na filosofia platonista, pautava-se na crença de uma única divindade cuja identidade exata estava além do entendimento humano, mas que criou o universo e o governa como um déspota benevolente e justo. Aqueles que tendiam mais ao 
estoicismo $^{4}$ do que ao platonismo ${ }^{5}$ viam o divino relacionado com a natureza e com a ordem natural das coisas. Nessa acepção deus era considerado o arché ou a fonte e origem última de todas as coisas. Portanto, de forma oportuna aos cristãos, era muito mais monoteísta do que politeísta, diferenciando-se do deus cristão principalmente pelo fato do creatio ex nihilo (criação do nada), que na acepção filosófica não fora realizado pelo arché. Contudo, afirmava de igual forma a imortalidade da alma/espírito e a importância de se ter uma vida virtuosa e ética que buscasse o equilíbrio entre os extremos e evitasse a pura sensualidade.

Esses particulares princípios da filosofia grega, bem como uma série de outras apropriações de mesmo cunho, foram incorporados ao discurso cristão na tentativa de organizar-se de maneira aceitável e com argumentos mais próximos daqueles presentes no orbis romanorum. Essas questões podem ser vistas como um desvio ou digressão da mensagem embrionária do cristianismo ou como um desdobrar dos significados da mensagem sob novos contextos (Olson 2001).

Fato é que visões cristãs conflitantes passaram a existir durante o século II d.C., mesmo tendo os apóstolos deixado alguns escritos. O próprio João, “o amado", deixou um evangelho, algumas cartas e a visão que recebeu quando estava exilado na Ilha de Patmos. Entretanto, esse e outros escritos, como as cartas de Paulo e Atos dos Apóstolos, não estavam compilados e amplamente difundidos entre todos os convertidos ao pensamento cristão. Na verdade, nenhum núcleo do cristianismo, seja uma igreja ou mesmo regiões onde o cristianismo floresceu - diga-se: Roma, Éfeso, Antioquia $^{6}$ ou Egito - tinha uma coletânea completa dos escritos apostólicos e não havia

\footnotetext{
${ }^{4} \mathrm{Na}$ filosofia antiga, Parmênides discorreu de um Ser totalmente abrangente que ocupa todo o espaço e o pensamento, sendo imutável. Heráclito, contudo, ensinou que a realidade é mudança, um tipo de processo ordenado por um princípio vital, ou logos. Essas ideias constituíam a base do estoicismo que floresceu por séculos no mundo greco-romano. Doutrina que preconizava a indiferença ao prazer e a dor.

5 Platonismo é caracterizado por uma concepção espiritualista da vida e uma alta estima pela capacidade da mente humana no sentido de descobrir a verdade absoluta. A tendência de estruturar o mundo em termos opostos, tais como mente e matéria, bem e mal, realidade e aparência, leva ao dualismo formulado por Platão. E quando se propõe um dualismo cósmico, ele com frequência está subordinado (na ideia de Platão) a alguma realidade abrangente e absoluta como Deus ou a Ideia do Bem.

${ }^{6}$ Havia duas cidades por nome Antioquia na Antiguidade. Uma delas era Antioquia da Pisídia, relacionada entre as 16 cidades fundadas por Seleuco Nicanor e situada na Frígia, quase nos limites da Pisídia. À que nos referimos é Antioquia da Síria, situada na margem do Oronte, 50 quilômetros do mar e
} 
consonância quanto a quais escritos eram de autoridade apostólica e quais não eram. Esse ab intestato (falta de Testamento) instigaria os líderes das congregações locais ao fomento de mais discursos em sociedade, da preservação e perpetuação das doutrinas, bem como o controle das bases de conduta e vivência do que era cristão e do que não era. Assim, o conjunto de escritos conhecido como 'pais apostólicos' centra sua atenção no convívio comunitário, nas primeiras e básicas crenças e nas observâncias comportamentais necessárias aos prosélitos.

No século II d.C. e decorrer do século III d.C., as tensões e transformações tornaram-se mais complexas e abriram precedentes para discussões mais intelectualizantes e abordagens que chegassem a instâncias elevadas dentro do Império romano. Alguns pensadores voltaram sua atenção ao mundo fora do círculo da igreja e das condutas internas. Escrevendo cartas aos críticos pagãos e às autoridades romanas para defender a integridade do cristianismo contra mal-entendidos, acusações e perseguições, procuraram subsidiar explicações à cosmovisão e estilos de vida dos poderosos líderes romanos de maneira inteligível e atraente. Oportuniza-se, então, um novo ambiente a communio sanctorum (comunidade de santos).

Foi inevitável, destarte, que o crescente cristianismo entrasse em embate, não só com o judaísmo, criticado muitas vezes por Paulo, o apóstolo, em algumas de suas cartas; mas também com o paganismo e a filosofia de forma geral. Apesar de certa aproximação, como expus acima, a filosofia da época helenística carregava consigo pretensões de ordem religiosa e moral. Revelava-se como sabedoria de vida e, algumas vezes, como doutrina de salvação.

Os pensadores cristãos dos primeiros séculos estavam entre dois mundos profundamente diferentes: o do judaísmo e o do helenismo. Refletidos também na oposição entre politeísmo e monoteísmo. Como nenhum discurso é em essência uma criação livre, estando situado e posicionado nos grupos de declarações, num controle

500 quilômetros de Jerusalém. Fundada também por Seleuco Nicanor por volta de 300 a.C. e batizada assim em memória de seu pai Antíoco. Foi capital, durante quase 1000 anos, dos governantes gregos e romanos da Síria. Nesta cidade surgiu a primeira igreja gentílica e nela os discípulos foram chamados pela primeira vez de cristãos (At 11.19-26). 
social externo daquilo que é aceito e daquilo que não é, em moldes de proibição e divisões de oposição, torna-se plausível concordar com Tilley (1995) quando evoca as premissas de Foucault, afirma:

"Talvez mais importante seja a estrutura dos discursos em torno dos princípios de oposição, o mais predominante, deles é aquele entre a verdade e a falsidade. A busca pelo conhecimento é uma "vontade de verdade", e então é a parte de um sistema de exclusão. Empirismo constitui um desejo de conhecimento, um desejo que antecipa o seu próprio conteúdo e formula seus objetos no avanço em termos de um esquema de possibilidades: observável, mensurável, objetos classificáveis". (Tilley in Miller; Rowlands e Tilley 1995: 42)

Essa "vontade de verdade", vontade do discurso verdadeiro, aquele que responde ao desejo e que exerce o poder, não é no seu interior provido de tal qualidade. Na partilha entre o que é verdadeiro e falso, estaria outra prerrogativa - que segundo Foucault atravessa os séculos - que é a do sistema de exclusão. Sistema esse, por excelência, modificável e constrangedor.

Em nosso cotidiano estamos constantemente proferindo um número imensurável de discursos que nos atravessam. É possível perceber que certos discursos que "se dizem" no correr dos dias, muitas vezes são esquecidos no mesmo momento da origem deles; outros estão diferenciados em novos atos de fala, atos que os retomam, os transformam ou remetem-se a eles; e aqueles discursos que de alguma forma e por alguma razão são tidos como portadores de algum bem ou valor, necessitando permanecerem "marcados" no âmbito social. Como diria Foucault, esses são os "discursos ditos", ou seja, aqueles que acabam por perdurar na prerrogativa de que ainda têm algo "por dizer" em diferentes contextos (Foucault 2007 138; 1971: 6). É nesse sentido que os discursos não têm um sentido fixo ou estável, mas alteram-se de

\footnotetext{
7 "Perhaps more important is the structuring of discourses around principles of opposition, the most prevalent of which is that between truth and falsity. The search for knowledge is a 'will to truth', and so it is part of a system of exclusion. Empiricism constitutes such a desire for knowledge, a desire which anticipates its own contents and formulates its objects in advance in terms of a scheme of possibilities: observable, measurable, classifiable objects"
} 
acordo com as proposições a que se direcionam. De igual forma, o discurso não é criado, antes participa de eventos, onde em série descontínua, interagem, justapõem-se, excluem-se uns aos outros.

Tendo a palavra interdita, a partilha da loucura e a vontade da verdade, como três grandes sistemas de exclusão, é no discurso como ritual que se torna possível notar como esse sistema de restrição é veemente. O discurso ritual define e qualifica quem possui o privilégio da fala, que lugar ocupa, quais enunciados pertinentes; define gestos, comportamentos, as circunstâncias e os conjuntos de sinas que acompanham o discurso. Desse jeito, o discurso ritual fixa a eficácia - suposta ou imposta - das palavras, bem como seus efeitos sobre aqueles a quem se dirigem, circunscrevendo e atribuindo seu valor de constrangimento, portanto, impondo limites. No interior desse discurso, a doutrina permeia os tipos de enunciação e lhes interdita as demandas. Os mecanismos de exclusão e rejeição servem como manifestação e instrumento de pertencimento prévio ao rito em questão, estando essas prerrogativas presentes no seio de cada discurso (Foucault 1971).

As categorias de heresia e ortodoxia fazem parte dos mecanismos doutrinais, não são uma fanática exageração. Pelo contrário, elas estão inerentes às relações do discurso ritual, pois o "erro"' ou a heresia, não podem surgir e ser avaliados senão no interior de uma prática definida e disciplinada. A proposição passa pelas complexas e pesadas exigências até reportar-se ao conjunto de uma dada disciplina. O princípio das limitações, ou disciplina, se caracteriza num "domínio de objetos, um conjunto de métodos, um corpo de proposições consideradas verdadeiras, um jogo de regras e de definições, de técnicas e de instrumentos: tudo isto constitui uma espécie de sistema anônimo à disposição de quem quer ou pode servir-se dele, sem que o seu sentido ou a sua validade estejam ligados ao seu inventor" (Foucault 1971: 8). Portanto, o que fica claro é que um discurso antes de se propor a ser verdadeiro ou falso, tem de estar no interior da disciplina ou "no verdadeiro". Imbuída dos limites, cada disciplina outorga sentenças falsas e verdadeiras e exclui o restante de saber que não lhe serve de interesse, nessa acepção. 
Atendendo a esses princípios, o cristianismo buscará justamente os discursos em sociedade como forma de sustentação de suas proposições. Tilley (1995) reforça a ideia do discurso enquanto poder a despeito da disputa das estruturas dominantes, da seguinte forma:

"Discurso é também um poder que pode ser tomado para subverter essas divisões. Assim, discursos não são subservientes às estruturas dominantes de poder nem são automaticamente levantadas contra eles. Ao contrário, eles estão indelevelmente situados em relação ao poder. Eles podem formar um ponto de resistência ao poder, e o ponto de partida para uma estratégia de resistência à repressão " (Tilley in Miller; Rowlands e Tilley 1995: 44-45) ${ }^{8}$.

As estratégias de resistência à repressão, a busca de representatividade, as disputas inerentes ao discurso são matrizes presentes no grupo de escritos de 'pais apostólicos' e 'apologistas' do século II e III d.C. Afinal, como Foucault (1971) pertinentemente afirma:

“(...) o discurso - a psicanálise mostrou-o -, não é simplesmente o que manifesta (ou esconde) o desejo; é também aquilo que é objeto do desejo; e porque - $e$ isso a história desde sempre o ensinou - o discurso não é simplesmente aquilo que traduz as lutas ou os sistemas de dominação, mas é aquilo pelo qual e com o qual se luta, é o próprio poder de que procuramos assenhorear-nos" (Foucault 1971:2)

Sob essa égide de pensamento, o cristianismo lança-se sem medidas à luta que ora apresentava-se diante sua emergência.

\footnotetext{
8 "Discourse is also a power which may be seized to subvert these divisions. So discourses are neither necessarily subservient to dominant power structures nor are they automatically raised up against them. Rather, they are indelibly situated in relation to power. They can form a point of resistance to power, and the starting point for a strategy resisting repression"
} 


\subsection{Os Pais Apostólicos}

Os primeiros sistematizadores do pensamento cristão foram os líderes das congregações locais, homens que produziram extensa bibliografia, reconhecidamente alcunhados de "Pais Apostólicos", pois, supostamente, estabeleceram contato com um ou mais apóstolos, sem, contudo, serem discípulos diretos dos mesmos. Ao que tudo indica são tratados pela insígnia de "pais" a partir do século IV quando alguns cristãos procuram fazer menção desses primeiros escritos. Entretanto, a expressão de fato parece ter sido cunhada em definitivo a partir de 1672 por Jean-Baptiste Cotelier, considerando em sua obra - Patres aevi apostolici - os escritos de Clemente de Roma, Ignacio de Antioquia, Policarpo de Esmirna, Barnabé de Alexandria e o Pastor de Hermas, como os "pais da idade apostólica" - daí, então, a expressão. Essa lista de escritos logo foi se ampliando e reduzindo conforme, através dos tempos, o estudo daquilo que passou a ser conhecido como 'Patrística' foi se desdobrando.

Já que de fato é difícil elucidar algum tipo de contato desses possíveis autores com os apóstolos em termos de historicidade, a atribuição dessa suposta relação fica por conta dos elementos literários, dentre eles os principais: o uso do grego, o modo de expressar o conteúdo das proposições e relações de teor com os evangelhos. Essa convenção é uma atribuição feita pela teologia enquanto disciplina. É bem possível que muitos discursos estivessem em circulação durante o século II e III d.C. - e de fato estavam - sem que o seu sentido ou eficácia estivessem ligados em poder a um autor. Palavras do dia-a-dia, decretos ou contratos com necessidade de signatários, mas sem autor, receitas técnicas que se transmitiram no anonimato e, posteriormente, entendidas como um princípio de agrupamento do discurso; ou seja, dentro de uma unidade de origem e significações, num lastro de coerência, foram coligidos sob a designação de uma determinada figura que representasse tais valores. Esse é, por exemplo, o caso do Didaquê que apresentarei na sequência entre os 'pais apostólicos'; mas não seria espantoso que o mesmo princípio fosse empregado em outros escritos aqui 
apresentados, ora historicizados a determinado autor pelo estabelecimento da teologia e da mensagem cristã enquanto disciplina.

Assim, agora passo a apresentar a listagem consensual de 'pais apostólicos', presente na obra de compilação do teólogo suíço Philip Schaff (1819-1893). A obra em questão é composta de um conjunto de dez volumes, editada em série entre os anos de 1867-1873, que teve sua forma reorganizada e impressa em 1885 sob o título de AnteNicene Fathers: The Writings of the Fathers Down to A.D. 325. A versão em inglês dos escritos antinicênicos, ou seja, aqueles anteriores ao Concílio de Niceia (325 d.C.) - o que foi presidido pelo Imperador Constantino -, é bastante fidedigna, além de apresentar uma série de notas de contribuição em grego e latim.

\section{Clemente de Roma}

A figura de Clemente surge como sendo provavelmente um romano, responsável pela comunidade que estaria estabelecida em Roma, entre os anos 30-100 d.C. Especula-se que tenha conhecido e convivido com Paulo e a partir disso tenha imitado o estilo e mensagem desse apóstolo. O suposto contato poderia ter ocorrido em Filipos, por volta de 57 d.C. Já que se tratava de uma colônia romana, não seria improvável que Clemente estivesse por lá devido a alguma incumbência pública, talvez, inclusive, tendo passado em Corinto após sua estada em Filipos.

O primeiro texto atribuído a Clemente é provavelmente também o primeiro escrito cristão preservado, além daqueles contidos no Cânon do Novo Testamento. Denominada de Primeira Epístola de Clemente, o texto estava desconhecido no Ocidente até a descoberta do manuscrito Alexandrino - conhecido e referido usualmente como Codex A - que foi apresentado em 1628 por Cirilo, patriarca de Constantinopla, a Charles I, rei da Grã-Bretanha. Hoje o manuscrito se encontra no Museu Britânico.

A carta está em nome da comunidade estabelecida em Roma, endereçada à comunidade instituída em Corinto. Contudo, apesar de não assinar explicitamente essa epístola, a 
maioria dos teólogos toma como ponto pacífico que Clemente foi mesmo seu autor. A opinião é de que se trata da mesma pessoa referida por Paulo em Filipenses 4:3. Além dessa referência, o conteúdo prefixados para o manuscrito, estilo da mensagem e a menção tardia de Eusébio (Hist. Ecles. Iii. 15), parece corroborar essa assertiva.

Como era conhecedor da Septuaginta e utilizando-se do grego, Clemente provavelmente se dirigiu à comunidade estabelecida em Corinto para adverti-los e instrui-los. A data dessa epístola é objeto de controvérsia, pois embora fique claro em seu início (Cap. I) que ela foi composta durante alguma perseguição sofrida pela comunidade de cristãos em Roma, não fica claro de qual delas se trata. A hipótese gira em torno de Nero e Domiciano. Aceitando o primeiro caso, a data estaria em 68 d.C., assim para a segunda metade do século I d.C. Entretanto, a consonância parece estar sob o regime de Domiciano, de modo que a epístola, poderia ser datada entre os anos de 9597 d.C. com maior segurança.

Essa foi uma epístola amplamente aceita, e Eusébio (Hist. Ecles. III 16) afirma que ela foi lida publicamente em muitas igrejas desde muito cedo até seu tempo. Alguns cristãos no Egito a relacionavam entre os escritos, digamos "testamentários" - assim como outros tantos 'pais apostólicos'. O seu lugar no Manuscrito Alexandrino também parece confirmar essa hipótese: logo na sequência dos livros do cânone nicênico. A diferença de fato não parece tão grande entre as formas de discurso, exceto pelo fato de Clemente usar o mito de fênix como prova cabal da ressureição do corpo. No capítulo vinte e cinco, após discorrer sobre as evidências na natureza que apontam para a ressureição, ele afirma:

"Deixe-nos considerar esse maravilhoso sinal [da ressurreição] que toma lugar em terras orientais, ou seja, na Arábia e nos países ao redor. Existe um certo pássaro chamado de fênix. É o único da sua espécie e vive quinhentos anos. E quando o momento da sua dissolução se aproxima e deve morrer, ele próprio constrói um ninho de olíbano, mirra e outras espciarias, entre outras, quando o tempo está cumprido, ele entra e morre. Mas enquanto sua carne se decompõe um certo tipo de verme é produzido, que, sendo nutrido pelas essências da ave morta, faz

\footnotetext{
${ }^{9}$ Emprego dessa forma, pois a questão de quais escritos pertenciam ao 'Novo Testamento' foi motivo de controvérsia e definida somente no Concílio de Nicea, em 325 d.C., como já mencionei.
} 
nascer penas. Então, quando ele adquire força, se levanta do ninho no qual estão os ossos de seus pais e os enterrando, voa das teras da Arábia até o Egito, para a cidade chamada Heliopólis. E, na abertura do dia, voando à vista de todos os homens, colocando-os sobre o altar do sol, e tendo feito isso, apressa-se em voltar para sua antiga morada. Os padres, então, inspecionam os registros das datas e constata que retorbou exatamente quando quinhentos anos foram completados" (Clement of Rome, vol.1, cap. XXV, p. 22)

Como é possível observar, o autor trata o mito de fênix enquanto uma realidade concreta, em nenhum momento enquanto relação alegórica. Além da óbvia relação que faz com a ordem sacerdotal do rito.

Todavia, parece que o motivo principal de um líder romano ter escrito à comunidade em Corinto, eram de fato as contradições internas que estavam ocorrendo no interior da congregação. A ascensão de uma liderança contestada por alguns membros da comunidade levou um líder constituído e que supostamente teve contato com pelo menos dois apóstolos - Paulo e Pedro - a escrever na tentativa de apaziguar os ânimos. Fica evidente que havia mais de uma comunidade na região e que um único líder havia suscitado a si o poder na área. Clemente acaba por repreender aqueles insurretos a essa liderança, chamando-lhes a atenção e dizendo não encontrar repreensão nem nesse líder nem nas demais lideranças que o cercavam. Dessa forma ele discorre sobre a ordem dos ministérios na igreja:

"Os apóstolos pregaram o Evangelho do Nosso Senhor Jesus Cristo;
Jesus Cristo [o fez também] recebendo-o de Deus. Cristo, por sua vez, o
enviou adiante, recebendo-o de Deus. Ambos os apontamentos, então,
foram feitos de maneira ordenada, de acordo com o desejo de Deus.
Tendo, depois, recebido suas ordens, e estando completamente

10 "Let us consider that wonderful sign [of the resurrection] which takes place in Eastern lands, that is, in Arabia and the countries round about. There is a certain bird which is called a phoenix. This is the only one of its kind, and lives five hundred years. And when the time of its dissolution draws near that it must die, it builds itself a nest of frankincense, and myrrh, and other spices, into which, when the time is fulfilled, it enters and dies. But as the flesh decays a certain kind of worm is produced, which, being nourished by the juices of the dead bird, brings forth feathers. Then, when it has acquired strength, it takes up that nest in which are the bones of its parent, and bearing these it passes from the land of Arabia into Egypt, to the city called Heliopolis. And, in open day, flying in the sight of all men, it places them on the altar of the sun, and having done this, hastens back to its former abode. The priests then inspect the registers of the dates, and find that it has returned exactly as the five hundredth year was completed". 
assegurado pela ressurreição de Nosso Senhor Jesus Cristo, e estabelecida em nome de Deus, com total segurança do Espírito Santo, eles forma adiante proclamando que o reino de Deus estava próximo. E assim, pregando através dos países e cidades, eles apontaram os primeiros frutos [de seu labor], tendo suas primeiras provações do Espírito, para serem bispos e diáconos daqueles em quem posteriormente acreditariam. Não foi aquilo algo novo, de fato, desde muitos anos havia sido escrito a respeito dos bispos e diáconos. Por isso diziam as Escrituras em determinado ponto, "Eu apontarei sues bispos em retidão e seus diáconos na fé" (Clement of Rome, vol.1, cap. XLII, p. 31$)^{11}$

Os termos bispos e diáconos empregados nesse texto podem ser considerados 'supervisores' e 'servos', já que as hierarquias estavam por se definir. Ao reafirmar essas condições, Clemente contribui de forma direta para a mudança sutil e geral rumo ao moralismo cristão, no cristianismo do século II, associando o pertencimento à comunidade a subordinação total aos líderes devidamente nomeados e reconhecidos por outros, bem como a prática de uma vida moralmente adequada que atendesse a um princípio fundamental: a obediência.

\section{Inácio de Antioquia}

Inácio foi o líder da comunidade situada em Antioquia, na província da SíriaPalaestina. Supõe-se que ele e Policarpo de Esmirna tenham sido discípulos diretos do apóstolo João, o 'amado'. Dessa maneira, a figura de Inácio estaria situada entre os anos 30-107/15 d.C. Existe o mito de que ele próprio seria o menino a quem Jesus chamou e colocando no meio dos discípulos os interpelou e aconselhou que fossem

\footnotetext{
11 "The apostles have preached the Gospel to us from the Lord Jesus Christ; Jesus Christ [has done so] from God. Christ therefore was sent forth by God, and the apostles by Christ. Both these appointments, then, were made in an orderly way, according to the will of God. Having therefore received their orders, and being fully assured by the resurrection of our Lord Jesus Christ, and established in the word of God, with full assurance of the Holy Ghost, they went forth proclaiming that the kingdom of God was at hand. And thus preaching through countries and cities, they appointed the first-fruits [of their labours], having first proved them by the Spirit, to be bishops and deacons of those who should afterwards believe. Nor was this any new thing, since indeed many ages before it was written concerning bishops and deacons. For thus saith the Scripture in a certain place, "I will appoint their bishops in righteousness, and their deacons in faith."
} 
como crianças para entrar no reino dos céus (Mt 18:2). O importante é que Inácio gozava da admiração dos cristãos do século II, sendo martirizado em Roma por volta de 110-15 d.C. Sobre seu martírio, ele próprio teria se apresentado a Trajano, em Antioquia, enquanto esse estava em expedição contra os partos e armênios. Professando-se cristão teria sido condenado às feras.

As epístolas de Inácio deram origem a uma série de controvérsias, pois o autor aborda uma grande quantidade de questões eclesiásticas. Por seu prestígio, foram atribuídas a ele cerca de quinze epístolas. Porém, só sete dessas podem ser de sua autoria, já que as outras oito obras são notadamente construções posteriores ao tempo de Inácio. Não existem menções delas nem por parte de Eusébio, tampouco Jeronimo o faz. Assim, são consideradas e entendidas como falsificações.

A controvérsia sobre quais escritos poderiam ser atribuídos a Inácio tomou forma mais concreta por volta do século XVIII, quando uma longa discussão foi imposta sobre traduções gregas, latinas e siríacas, chegando-se as sete epístolas: Epístola a Policarpo de Esmirna, Epístola aos Efésios, Epístola aos Esmirniotas, Epístola aos Filadelfos, Epístola aos Magnésios, Epístola aos Romanos, Epístola aos Tralianos.

Inácio teria escrito essas cartas enquanto estava em viajem, sob escolta, para Roma. Além de suas próprias cartas, Policarpo faz menção a Inácio em sua Epístola aos Filipenses (cap.9), e também Irineu o cita numa passagem de sua Epístola aos Romanos (Adv. Haer, v. 28, Epist ad Romanos, cap iv.), sem, entretanto, nominá-lo. Orígenes se refere a ele duas vezes: primeiro em seu comentário sobre o Cântico de Salomão; e, novamente, em sua homilia sobre Lucas, o apóstolo, onde faz referência à epístola aos Efésios de Inácio.

O autor, seguindo um padrão dos 'pais apóstólicos', enfatiza veementemente a obediência cristã aos bispos:

"Portanto, é apropriado que deveis executar em conformidade com a vontade de seu bispo, coisa que também vós fazeis. Pois seu justos 
renomados presbitérios, merecido de Deus, está exatamente adequado ao bispo como as cordas da harpa o são" (Ignatius, vol.1, cap. IV, p. $84)^{12}$

Nessa afirmação - obviamente acompanhada de outras tantas com mesmo teor é que começa a se articular no cristianismo o "episcopado monárquico", ou seja, a tendência de elevar o episkopos - ou bispo - a uma posição espiritual privilegiada de poder, reverência e autoridade. Inácio também procurou combater o docetismo ${ }^{13}$ e a relação sobre como Jesus era visto por essa vertente de interpretação. Enfatizou como forma de solução - e também enquanto uma maneira de controlar as ideias dissonantes

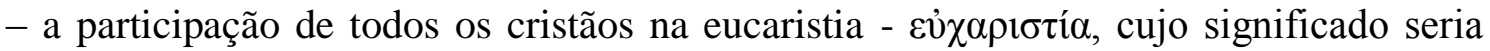
"reconhecimento", termo que ele próprio cunhou. Através desse rito se confirmaria a unidade da igreja e dissipariam-se os outros tipos de comportamentos errôneos:

"Prestai-vos atenção, então, para ter apenas uma Eucaristia. Pois há somente
uma carne de Nosso Senhor Jesus Cristo, e um único cálice para a unidade do
Seu sangue; um altar, assim como há um único bispo, juntamente com o
presbitério e diáconos, meus seguidores-servidores: e assim, tudo quanto
fizerdes, podeis fazê-lo de acordo com [a vontade de] Deus. Eu tenho confiança
em ti no Senhor, que vós sereis de nenhuma outra mente. Por isso eu escrevo
corajosamente ao seu amor, que é digno de Deus, e vos exorto a ter uma só fé e
uma [tipo de] pregação, e uma Eucaristia. Porque existe uma única carne de
Nosso Senhor Cristo; e Seu sangue que foi derramado por nós é único; um pão
também é quebrado para todos [os comungantes], e um cálice é distribuído
entre todos; existe um único altar para toda a Igreja, e um bispo, com seu
presbitério e diáconos, meus seguidores-servidores.
(Ignatius, (...)"

12 "Wherefore it is fitting that ye should run together in accordance with the will of your bishop, which thing also ye do. For your justly renowned presbytery, worthy of God, is fitted as exactly to the bishop as the strings are to the harp"

${ }^{13} \mathrm{O}$ docetismo é um desdobramento da ideia gnóstica de que Jesus é o mensageiro celestial, emanação que ensina o caminho a alguns espíritos. Posto que seria uma emanação, não seria carnalmente um

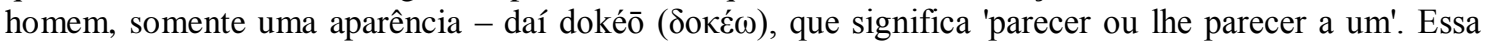
afirmação implicava diretamente na questão da cruxificação.

14 "Take ye heed, then, to have but one Eucharist. For there is one flesh of our Lord Jesus Christ, and one cup to [show forth904] the unity of His blood; one altar; as there is one bishop, along with the presbytery and deacons, my fellow-servants: that so, whatsoever ye do, ye may do it according to [the will of] God. I have confidence of you in the Lord, that ye will be of no other mind. Wherefore I write boldly to your love, which is worthy of God, and exhort you to have but one faith, and one [kind of] preaching, and one Eucharist. For there is one flesh of the Lord Jesus Christ; and His blood which was shed for us is one; one loaf also is broken to all [the communicants], and one cup is distributed among them all: there is but one altar for the whole Church, and one bishop, with the presbytery and deacons, my fellow-servants. (...)" 
Inácio, sem dúvida, desempenhou importante papel na delimitação das ações cristãs durante o segundo século.

\title{
Policarpo de Esmirna
}

A figura de Policarpo surge imediatamente ligada à de Inácio. Apesar de provavelmente ter nascido depois, tudo indica que foram amigos de longa data. É possível situar a figura de Policarpo entre os anos de 65-100 ou 155 d.C. De seus escritos, o único que sobreviveu até nós foi: Carta de Policarpo aos filipenses. Nela, Policarpo exorta os filipenses a uma vida de observâncias, firmeza - até a morte se necessário - e constância. Persuadindo contra a idolatria - assunto bem presente em todos os pais apostólicos - Policarpo encoraja os cristãos à mudança na ordem mundial vindoura:

\begin{abstract}
"Eu estou muito entristecido por Valente, quem uma vez foi presbitero entre vos, porque ele entendeu tão pouco o lugar que lhe foi dado [na Igreja]. Eu vos exorto, portanto, que vos abstenhais da avareza, e sejais castos e verdadeiros. "Abstenhais de toda forma de maldade". Pois se um homem não pode governar a si mesmo tais assuntos, como instruirá os demais? Se um homem não se mantém na avareza, ele será contaminado pela idolatria, e deve ser julgado como um dos pagãos. Mas quem de nós é desconhecedor do julgamento do Senhor? "Não sabemos que os santos julgarão o mundo?" como Paulo ensina" (Polycarp vol.1, cap. XI, pag. 62)
\end{abstract}

Como é possível observar, Policarpo tinha um bom conhecimento dos escritos de Paulo, tanto é que das sessenta citações com relação aos escritos que estão no Novo Testamento, trinta e quatro delas são de autoria de Paulo. O líder de Esmirna, contudo, estava muito mais preocupado com o dia-a-dia da comunidade do que com a ordem eclesiástica - ao contrário de seu amigo Inácio.

\footnotetext{
15 "I am greatly grieved for Valens, who was once a presbyter among you, because he so little understands the place that was given him [in the Church]. I exhort you, therefore, that ye abstain from covetousness, and that ye be chaste and truthful. "Abstain from every form of evil." For if a man cannot govern himself in such matters, how shall he enjoin them on others? If a man does not keep himself from covetousness, he shall be defiled by idolatry, and shall be judged as one of the heathen. But who of us are ignorant of the judgment of the Lord? "Do we not know that the saints shall judge the world?" as Paul teaches".
} 
A autenticidade da epístola de Policarpo é pouco questionável e confirmada pela evidência externa: as menções de Eusébio (Hist. Ecles. III.36 e IV. 14 e) e de Irineu (Adv. Haer. III. 3) servem de base para essa inferência.

Outra obra que faz menção ao líder de Esmirna é: Martírio de Policarpo. Esse escrito surge sob a crescente influência do "culto aos mártires", pelos cristãos do século II. A ideia de venerar aqueles indivíduos que passaram pelo martírio enquanto pessoas especiais, exemplos de virtude, detentores de valores espirituais mais elevados, foi crescendo à medida que se intensificaram as perseguições dentro do orbis romanorum. O documento consiste no testemunho do suposto martírio de Policarpo com suas atitudes de firmeza e coragem frente à desinência proposta pelos romanos ao bispo diante de sua idade avançada - especula-se que Policarpo tinha por volta de 86 anos de idade nesse momento. A negativa de Policarpo se confirmou e o cristianismo ganhava mais um mártir.

\section{O Didaquê}

Esse escrito não possui um autor especificado, apesar de ser mencionado por Eusébio, o manuscrito só veio a público através de um códice do século XI - de 1056 encontrado num mosteiro em Constantinopla no ano de 1873. A princípio estimava-se que o texto, que está na íntegra em grego, oscilava entre as datas de 60-70 d.C. Entretanto, essa perspectiva mudou e parece ser consenso de que se trata de um texto produzido na Síria ou Palestina entre os anos de 70-90 d.C., remontando, portanto, ao final do primeiro século, quiçá início do segundo, se flexionarmos essa datação.

O texto é também conhecido por: $O$ ensino dos doze apóstolos. Na realidade, didache, do grego $\Delta 1 \delta \alpha \chi n$, significa "instrução" ou "doutrina" e o manuscrito parece ter sido mesmo escrito com o intuito de reforçar a moralidade cristã. Além de cumprir a função de alertar sobre o tratamento que deveriam receber eventuais profetas que os procurassem. 
Acredita-se que o texto tenha sido escrito por um só autor na forma de compilação de fontes orais. O manuscrito contém conselhos, instruções detalhadas para a espiritualidade, vida e adoração diárias dos cristãos. Inicia fazendo a distinção dicotômica entre o caminho da vida e o caminho da morte, perpassando na continuação o detalhamento do batismo e a prática da 'ceia do senhor' dentro da comunidade. Com base na evidência interna, o encaminhamento proposto é o de que o escrito consistia em uma carta circular às comunidades cristãs da província romana Siria-Palaestina, com o objetivo de orientar os prosélitos em suas ações comunais. Nele está a perspectiva de que os acontecimentos sucessivos estão sob os domínios de Deus, devendo os cristãos aceitar aquilo que se passa, buscando a cada dia estar mais próximos de seus pares:

"2.E tu deves buscar a cada dia as faces dos santos para que possas descansar em cima de suas palavras." (The Teaching of the Twelve Apostles, vol.7, cap. IV, pag. 561) ${ }^{16}$

Contudo, esse viver em comunidade merece atenção e ressalvas são feitas a respeito do tempo de estada e forma de viver:

"1. Mas deixe cada um que vem em nome do Senhor ser recebido, e depois, vós o provareis e o conhecereis; vós tereis o conhecimento do que é direita e esquerda. 2. Se ele que vem for um viajante, assista-o tanto quando fordes capazes; mas ele não deve permanecer com você, exceto dois ou três dias, se necessário for. 3. Mas se ele quiser permanecer com você, sendo um artesão, deixa-o trabalhar e comer, mas se ele não tiver comércio, 4. De acordo com seu entendimento ver se, como cristão, não viverá contigo sendo ocioso. 5. Mas se ele não o quiser fazer, ele é um caluniador de Cristo. Cuidado e manteis distante." (The Teaching of the Twelve Apostles, vol.7, cap. XII, pag. 568) ${ }^{17}$

\footnotetext{
16 " 2 . And thou shalt seek out day by day the faces of the saints, in order that thou mayest rest upon their words."

17 " 1 . But let every one that cometh in the name of the Lord be received, and afterward ye shall prove and know him; for ye shall have understanding right and left. 2 . If he who cometh is a wayfarer, assist him as far as ye are able; but he shall not remain with you, except for two or three days, if need be. 3 . But if he willeth to abide with you, being an artisan, let him work and eat; but if he hath no trade, 4 . According to your understanding see to it that, as a Christian, he shall not live with you idle. 5. But if he willeth not to do, he is a Christ-monger. Watch that ye keep aloof from such."
} 
Sem dúvida alguma se esperava a mudança da ordem mundial, afinal, tratava-se de comunidades messiânicas. O esforço para a unidade, disciplina e uma moralidade própria, dentro de um legalismo de conduta, eram elementos necessários à distinção social pretendida por aqueles que eram os "chamados para fora ${ }^{18 "}$. No objetivo de manter-se sempre alerta à vinda do messias e a constituição dessa nova ordem, um importante fator necessitava ser observado - que ora apresento aqui e se repetirá constantemente como demonstrarei com mais riqueza adiante: as lamparinas acesas!

Dessa forma, o didaquê em seu capitulo final admoesta:

"Cuide da segurança de tua vida. Não deixe suas lamparinas serem apagadas, nem seus lombos perdidos; mas estejais prontos, pois não sabeis a hora em que nosso Senhor virá. 2. Mas, frequentemente, vós deveis unir-vos, buscando as coisas que são condizentes com vossas almas: para que o tempo todo de vossa fé não não seja aproveitado em vão, se vós não tiverdes sido aperfeiçoados nos últimos tempos." (The Teaching of the Twelve Aposles, vol.7, cap. XVI, pag. 570) ${ }^{19}$

\section{Epístola de Barnabé}

Essa epístola é frequentemente atribuída à figura do apóstolo Barnabé. Os escritos posteriores da igreja unanimemente atribuíram ao judeu levita de Chipre a realização desse manuscrito. Clemente de Alexandria, Orígenes e outros acreditavam tratar-se de uma produção autêntica, sem outro nome surgir para essa designação. Contudo, essa pré-figuração é de difícil aceitação e a evidência interna parece contrapor essa ideia.

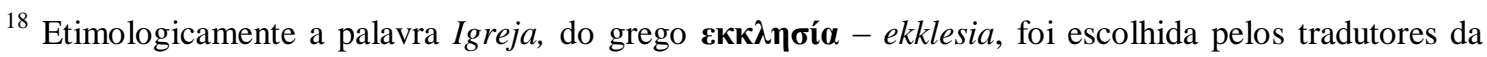
Septuaginta para designar o termo hebraico q(e)hal Yahveh - que referia a reunião geral do "povo do deserto". No grego o significado ficou $e k$ - para fora e klesia - chamados, assim: "chamados para fora". 19 "1. Watch for your life's sake. Let not your lamps be quenched, nor your loins unloosed; but be ye ready, for ye know not the hour in which our Lord cometh.2. But often shall ye come together, seeking the things which are befitting to your souls: for the whole time of your faith will not profit you, if ye be not made perfect in the last time."
} 
A epístola pode ser situada entre os anos de 30-135 d.C., sendo provavelmente a última data a mais verossímil. Foi claramente escrita após a destruição de Jerusalém, quando o autor menciona:

"Além disso, Ele novamente diz: "Eis que os que destruíram este templo, até mesmo eles devem construí-lo novamente." Tem acontecido isso. Para que através deles, indo para a guerra, tendo sido destruídos por seus inimigos, e agora: eles, como servos de seus inimigos, devem reconstruí-lo. Novamente, foi revelado que a cidade e o templo e as pessoas de Israel fossem cedidos. Pois a escritura diz: "E virá para passar nos últimos dias, em que o Senhor entregará as ovelhas do Seu pasto, e seu rebanho e torre, para a destruição" (The Epistle of Barnabas, vol.1, cap. XVI; p. 232) ${ }^{20}$

O escritor dessa epístola tem sido identificado como um suposto judeu Alexandrino dos tempos de Trajano e/ou Adriano, tendo possivelmente o mesmo nome: "Barnabé". A forma como o autor se apresenta é o que gerou a dificuldade de identificálo. O escritor por momentos apresenta-se como um gentio, já em outros momentos se identifica como um judeu. Esse tipo de associação também fora feita pelo Apóstolo Paulo muitas vezes em seus escritos: ora apresentando-se como fariseu, ora como romano. As relações de identidade por si sós são múltiplas e randômicas e os cristãos dos primeiros séculos não fugiram a essa prerrogativa.

A recorrência às figuras de linguagem é também uma marca muito presente dessa epístola. Algo que não seria uma inovação dado que o judeu Filo, justamente de Alexandria, contemporâneo de Jesus, procurou demonstrar a harmonia dos textos do Pentateuco com questões alegóricas da filosofia grega. A busca dos significados simbólicos recebia atenção em determinados contextos e os cristãos desse período tinham a sua mercê tanto significações literais e legalistas de "certo" e "errado" quanto acepções alusivas e figurativas. A epístola de Barnabé exemplifica bem essa assertiva.

\footnotetext{
20 "Moreover, He again says, "Behold, they who have cast down this temple, even they shall build it up again." It has so happened. For through their going to war, it was destroyed by their enemies; and now: they, as the servants of their enemies, shall rebuild it. Again, it was revealed that the city and the temple and the people of Israel were to be given up. For the Scripture saith, "And it shall come to pass in the last days, that the Lord will deliver up the sheep of His pasture, and their sheep-fold and tower, to destruction."
} 


\section{O pastor de Hermas}

O pastor de Hermas foi um dos livros mais populares dentro da comunidade cristã das décadas iniciais, se estendendo desde o século II até o século IV d.C., entre aquele grupo de escritos que entraram no cânone do Novo Testamento. O texto estava anexado ao NT dentro do Codex Sinaiticus ${ }^{21}$. Dois pareceres prevaleceram em relação a sua autoria no âmbito dos primeiros cristãos: o de maior ramificação foi a indicação de Orígenes de que o autor dos escritos era a figura apostólica de Hermas, aquele mencionado na Epístola aos Romanos (Rm 16:14). A outra, que hoje se tem em maior conta é a de que o Hermas mencionado se tratava do irmão de Pio I, um líder da comunidade cristã romana do final do primeiro século. Dessa maneira, o referencial temporal para esse manuscrito estaria entre os anos de 140-145 d.C.

O livro contém cinco visões, entregues por um anjo a Hermas, um escravo liberto. Seguem-se logo em seguida a revelação de doze mandamentos e dez parábolas. $\mathrm{O}$ anjo aparece na figura de um pastor e apresenta uma série de mensagens crivadas de linguagem figurada, nos mesmos moldes dos referenciais de simbolismo encontrados no livro do Apocalipse no NT. A maioria dos mandamentos que são entregues a Hermas dizem respeito ao desenvolvimento da ética cristã e em especial a uma questão legalista: o perdão do pecado.

Nesse livro, a misericórdia de Deus é bastante limitada e o perdão não é oferecido abundantemente. Estando condicionado ao respeito e observância dos mandamentos de Deus, o perdão dos pecados estaria diretamente ligado à pureza de conduta após o batismo:

"E eu lhe disse, "Eu devo continuar com minhas perguntas." "Fale", disse ele. E eu disse, "Eu ouvi, senhor, alguns professores mantendo a afirmação de que não há outro arrependimento que aquele que se assume. Quando nos declinamos até a água e recebemos a remissão de nossos pecados anteriores." Ele disse a mim, "Essa foi a sã doutrina que

\footnotetext{
${ }^{21}$ O Codex Sinaiticus, também denominado Manuscrito 'Aleph', é um dos mais antigos manuscritos gregos descobertos - século IV - e único códex que contém o NT inteiro. Está atualmente no Museu Britânico.
} 
você ouviu, por que é realmente esse o caso. Para quem recebeu a remissão de seus pecados não deveria voltar a pecar, mas viver na pureza". (The Pastor, vol.2,cap. III, p. 33) ${ }^{22}$

É bem possível que deste princípio decorra a crença entre os primeiros cristãos de que poderia haver somente um perdão pelos pecados após o batismo, daí então a prática de esperar para ser batizado apenas quando a morte estivesse próxima. Constantino parece ser um bom exemplo dessa alusão. Obviamente essa não era uma prática unitária tampouco incentivada pelos líderes da cristandade, mas esteve presente no imaginário de muitos durante os séculos II e III d.C.

$\mathrm{Na}$ realidade, o livro de Hermas é bastante austero, inclusive sugerindo que todos os cristãos - assim como Paulo o faz - abstenham-se de sexo. O ascetismo e o puritanismo estão, portanto, presentes nos escritos que caracterizam esse livro. Hermas também acaba por contribuir para os primeiros passos do entendimento sobre a natureza de Jesus. Indicando aquilo que ficou convencionado como a "cristologia do Espírito", o pastor explica que Deus fez com que o Espírito Santo preexistente - presente na criação - habitasse na carne determinada de Jesus e esta lhe servindo em pureza e castidade cooperou com o Espirito Santo, ajudando-o em tudo. Embora atraente essa ideia, ela implica em duas naturezas distintas e separadas em Jesus. Essa foi uma questão bastante delicada para a cristandade durante muito tempo, sendo somente encaminhada no século IV com uma série de Concílios sobre o tema.

O interessante dos escritos de Hermas são justamente as prerrogativas sínteses dos 'pais apostólicos': a afirmação da moralidade e ética cristãs e a esperança da iminente mudança na ordem mundial.

\footnotetext{
22 "And I said to him, "I should like to continue my questions." "Speak on," said he. And I said, "I heard, sir, some teachers maintain that there is no other repentance than that which takes place, when we descended into the water and received remission of our former sins." He said to me, "That was sound doctrine which you heard; for that is really the case. For he who has received remission of his sins ought not to sin any more, but to live in purity."
} 


\subsection{Os Apologistas}

O grupo de escritos denominados como 'Apologistas' eram em sua maioria contemporâneos aos 'pais apostólicos' e cristãos gnósticos. A diferença desse seguimento em relação aos outros dois é de que os 'apologistas', ao contrário dos 'pais apostólicos', estavam preocupados em defender o cristianismo perante as classes mais elevadas do orbis. Em lugar do espiritualismo esotérico - presente nos cristãos gnósticos -, os escritos apologéticos frequentemente lançam mão da razão filosófica para construir seus encadeamentos propositivos. A contradição desses escritos é justamente essa, embora atacassem os filósofos é neles que buscam seus subsídios para suas explicações.

Dispostos, na maioria das ocasiões, a serem suas Apologeticus Archeteles (primeira e última defesa), os 'apologistas' escreveram cartas abertas no intuito de que o cristianismo deixasse de ser visto como uma superstição de iletrados e/ou uma seita dentro do Judaísmo. Imbuídos do conceito de 'verdade', o discurso que emerge desses escritos é veemente e muitas vezes levado às últimas consequências, conforme o caso. Não é incomum encontrar afirmações como as de Atenágoras de Atena quando escreve sua 'A plea for the christians'(Petição em favor dos cristãos), ele emprega exatamente essa convicção: "Para que nós os conquistemos, sem hesitação, entregando, como nós fazemos agora, a nossa própria vida por amor à verdade" (A plea for the christians. vol. 2 ; cap. III, p. 203) ${ }^{23}$.

A lista dos escritos classificados como 'apologistas' não é de consenso amplo e da mesma forma que fiz tratando dos 'pais apostólicos', no corpo desse texto estão somente aqueles escritos que de forma mais direta contribuem ao objeto dessa dissertação. Seguem abaixo os referidos textos e seus argumentos.

\footnotetext{
23 "For we shall then conquer them, unhesitatingly surrendering, as we now do, our very lives for the truth's sake"
} 


\section{A Epístola a Diogneto}

O nome apropriado dessa epístola seria: Epistola de Mathetés a Diogneto (do grego

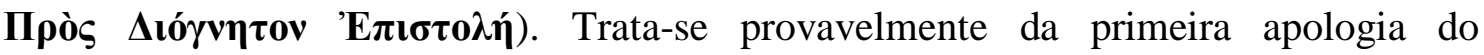
cristianismo, estando situada entre os anos de 130-200 d.C. Os escritos sobreviveram em dois manuscritos e um terceiro veio a público em 1870 na forma de um códex do século XIII, incluindo algumas obras de Justino Mártir anexadas a esse códex. Os dois manuscritos foram provavelmente copiados desse terceiro, segundo nos aponta a crítica.

Sobre o autor dessa eloquente epístola não se têm muitos indícios. Por um período considerável de tempo acreditava-se que seu autor era Justino Mártir, justamente pelo fato de no códex do século XIII os escritos estarem compilados próximos ao desse autor. Contudo, ao lidar com essa questão, as evidências internas e a crítica geral apontaram para outro escritor, que provavelmente viveu em uma data anterior à de Justino. Quem escreveu essa epístola somente apresenta-se como Mathetés, que em seu significado original quer dizer simplesmente 'discípulo'. O apóstolo Mateus em seu evangelho é quem mais se apropria desse termo como um substantivo, usando-o por volta de setenta e três vezes. É ele também que flexiona o termo e usa o verbo "fazer discípulo, ou "fazer-se discípulo" (Mt 13:52; Mt 27:57; Mt 28:19). Entretanto, o 'discípulo', como assim se denomina o autor, provavelmente teve mais contato com os escritos do Apóstolo João, senão com o próprio, isto porque na epístola utiliza-se exclusivamente o termo 'o verbo' para as referências feitas a Jesus ao invés de Cristo ou do próprio nome Jesus. Essa é uma notável característica dos escritos chamados 'joaninos'.

Outro argumento que pode reforçar essa ideia para situar o indefinido autor no período proposto é a referência que está no capítulo XI. Supondo que esse capítulo seja fidedigno, o escritor se apresenta como um "discípulo dos apóstolos":

"Eu não falo de coisas que desconheço, nem devo recorrer a nada inconsistente de maneira racional, mas tendo sido discípulo dos 
Apóstolos, eu me torno um mestre entre os gentios." (Mathetes, vol.1, cap. XI, p.53) ${ }^{24}$

Sobre o Diogneto, a quem é endereçada a epístola, ainda menos se sabe. Especula-se que possa se tratar do tutor do imperador Marcus Aurelius, porém, também se aventou a possibilidade de se tratar de um procurador de Alexandria do II/III século d.C. Como nenhuma palavra pode ser dita com segurança a esse respeito, é prudente deixar os autores em sua obscuridade e atentar àquilo que ela oferece de interessante: o cristianismo como algo novo, não dado a ídolos e possuidor da verdade que transformaria o mundo eminentemente. A expressão inicial é bastante oportuna na consolidação da afirmação que acabo de fazer:

"Desde que o vi, caro Diogneto, extremamente desejoso de aprender o modo de adorar a Deus, prevalente entre os cristãos, e indagando com muito cuidado e seriedade em relação aos mesmos, em que Deus eles confiam, e qual a forma de religião que eles observam, assim como todos a olhar para nosso próprio mundo, e desprezar a morte, enquanto eles nem estimam aqueles que são deuses considerados pelos gregos, nem se agarram à superstição dos judeus; e qual a afeição com a qual amam uns aos outros; e porque, afinal, esse novo tipo de prática [de piedade] somente agora entrou no mundo e não tempos atrás; Eu conrdialmente saúdo esse teu desejo, e eu imploro a Deus, que nos torna capazes de falar e ouvir, por concender a mim falar, que, acima de todos, eu poder te ouvir tem sido edificante e para você, ouvir, assim, eu que falo posso não ter nenhum motivo de arrependimento por ter feito isso". (Mathetes, vol.1, cap. I, p. 44) ${ }^{25}$

É possível perceber o tipo de construção que esses escritores apologistas tomarão por base. Trata-se do desejo de uma nova memória histórica para o mundo em

\footnotetext{
24 "I do not speak of things strange to me, nor do I aim at anything inconsistent with right reason; but having been a disciple of the Apostles, I am become a teacher of the Gentiles."

25 "Since I see thee, most excellent Diognetus, exceedingly desirous to learn the mode of worshipping God prevalent among the Christians, and inquiring very carefully and earnestly concerning them, what God they trust in, and what form of religion they observe, so as all to look down upon the world itself, and despise death, while they neither esteem those to be gods that are reckoned such by the Greeks, nor hold to the superstition of the Jews; and what is the affection which they cherish among themselves; and why, in fine, this new kind or practice [of piety] has only now entered into the world, and not long ago; I cordially welcome this thy desire, and I implore God, who enables us both to speak and to hear, to grant to me so to speak, that, above all, I may hear you have been edified, and to you so to hear, that I who speak may have no cause of regret for having done so."
} 
questão. E na busca por essa nova ordem eminentemente vigente, a oposição aos ídolos será tão necessária quanto a procura por legitimidade e o convite à aceitação. $\mathrm{Na}$ realidade, desconstruir o discurso de verdade do outro, embasado em seu campo de argumento, foi a medida estratégica que os 'apologistas' usaram com a maior frequência. Dessa forma, as outras formulações do divino, a percepção de divindades políadas e distintas morfologias do sagrado foram francamente combatidas nesse cristianismo emergente.

"Venha, pois, depois de ter se libertado de todos os preconceitos que possuíam tua mente, deixe de lado tudo ao que você estava acostumado, como algo suscetível e te enganar, e sendo feito, como se desde o início, um novo homem porquanto, de acordo com sua própria confissão, você está para ser o ouvinte de uma nova [sistema de] doutrina, venha e, contemple, não somente com seus olhos, mas com sua compreensão, aqueles que vos declaram e consideram ser deuses. Não é, em primeiro lugar, um deles uma pedra semelhante àquela em que pisamos? Não é, em segundo, um metal ruim, de modo algum superiores aos vasos que são construídos para o nosso uso comum? Não é, em terceiro, uma madeira que já está podre? Não é, em quarto, prata, que precisa de um homem para assisti-la, sob pena de ser roubada? Não é, em quinto, ferro, consumido pela ferrugem? Não é, em sexto, cerâmica, em nenhum grau mais valiosa do que aquela que é formada pelo mais humilde propósitos? Não é tudo isso de materiais passíveis de corrupção? Não são feitos por meio de aço e fogo? Não era cada um deles, antes que eles fossem formados pelas artes destes [operários] na forma destes [deuses], cada um a sua maneira, sujeios à mudanças? Não seriam aquelas coisas, agora, vasos, formados pelos mesmos materiais, tornariam-se vasos caso eles fossem reunidos pelos mesmos artesãos? Pode não estes, que são adorados por vós, voltar a sererem vasos semelhantes a outros, feitos por homens? Não são todos surdos? Não são todos cegos? Não são todos sem vida? Não são destituídos de sentimentos? Não são todos incapazes de movimentos? Não são todos eles sujeitos a podridão? Não são todos corruptíveis? Essas coisas que vós chamais de Deuses; vos serve, esses que vós adorais; e vos tornais completamente como eles. Por essa razão odiais os cristãos. Porque eles não consideram esses como deuses. Certamente vós não mostrais [por vossa conduta] que ele [vosso deus] é possuidor de senso. E o fato de os cristão não terem por costume servirem a esses deuses, eu posso, facilmente, encontrar muitas outras coisas para dizer; mas mesmo que o que eu disse possa parecer a todos 
insuficiente, eu julgo não ser produtivo dizer algo mais”.(Mathetes, vol.1, cap. II, p. 45) $)^{26}$

Sobre as morfologias do sagrado, Mircea Eliade (1998) apresenta a interessante ideia das hierofanias e cratofanias. Por hierofania, o autor entende a manifestação de uma dada modalidade do sagrado, um momento de sua história, uma experiência que vem a tona entre inumeráveis existentes. A hierofania realiza uma dupla ação: ela revela uma modalidade do sagrado, enquanto momento histórico, ao mesmo tempo em que desnuda uma situação do homem em relação a esse mesmo sagrado. Ela é sempre histórica na medida em que é produzida em situações determinadas, o que não quer dizer que seja determinada em si. Se entendermos a hierofania enquanto um sistema de afirmações coerentes, ela pode ser considerada uma manifestação do sagrado no universo mental daqueles que a recebem e partilham dessa 'teoria' da sacralidade. Já as cratofanias seriam as manifestações de força, em lato sensu, que devido às suas irrupções fazem com que sejam temidas e veneradas. Como campo complementar, então, as epifanias indicam aquilo que é insólito e extraordinário, algo diferente do natural; ou seja, a presença, o apelo, ou o sentimento predestinado desse algo que se faz presente como realidade aos que experimentam essa modalidade (Eliade 1998 p. 7-38).

\footnotetext{
26 "Come, then, after you have freed yourself from all prejudices possessing your mind, and laid aside what you have been accustomed to, as something apt to deceive you, and being made, as if from the beginning, a new man, inasmuch as, according to your own confession, you are to be the hearer of a new [system of] doctrine; come and contemplate, not with your eyes only, but with your understanding, the substance and the form of those whom ye declare and deem to be gods. Is not one of them a stone similar to that on which we tread? Is not a second brass, in no way superior to those vessels which are constructed for our ordinary use? Is not a third wood, and that already rotten? Is not a fourth silver, which needs a man to watch it, lest it be stolen? Is not a fifth iron, consumed by rust? Is not a sixth earthenware, in no degree more valuable than that which is formed for the humblest purposes? Are not all these of corruptible matter? Are they not fabricated by means of iron and fire? Did not the sculptor fashion one of them, the brazier a second, the silversmith a third, and the potter a fourth? Was not every one of them, before they were formed by the arts of these [workmen] into the shape of these [gods], each in its own way subject to change? Would not those things which are now vessels, formed of the same materials, become like to such, if they met with the same artificers? Might not these, which are now worshipped by you, again be made by men vessels similar to others? Are they not all deaf? Are they not blind? Are they not without life? Are they not destitute of feeling? Are they not incapable of motion? Are they not all liable to rot? Are they not all corruptible? These things ye call gods; these ye serve; these ye worship; and ye become altogether like to them. For this reason ye hate the Christians, because they do not deem these to be gods.(...) Certainly you do not show [by your conduct] that he [your God] is possessed of sense. And as to the fact that Christians are not accustomed to serve such gods, I might easily find many other things to say; but if even what has been said does not seem to any one sufficient, I deem it idle to say anything further."
} 
Nas bases mais elementares do sagrado estariam, portanto, as hierofanias e as cratofanias. Essas modalidades revelam sempre uma escolha implicitamente forte, eficaz, temida ou fértil, ainda que a escolha se faça pela singularização do insólito, do novo ou do extraordinário. Aquilo que foi escolhido e revelado como tal, por intermédio de uma hierofania ou de uma cratofania, acaba por se tornar em muitos casos, motivo de temor, justamente pelo fato de conter em si o elemento daquilo que não é conhecido ou apreendido por completo no âmbito da vivência cotidiana. Consequentemente, como Eliade de maneira aguçada refere, a concepção de força ou de eficácia é frequentemente encontrada associada a estas noções.

Entretanto, nenhuma religião se reduz a um nível meramente elementar de hierofanias e cratofanias. Caminhando com esses conceitos estão uma série de experiências e teorias que em nenhum momento são monovalentes, apesar de se encontrarem vestígios mais gerais e fixos desses entendimentos, em alguns casos. Se por vezes essas modalidades não aumentam seu conteúdo religioso, ao menos se alargam as formas. E é nesse caso que em determinados momentos uma ideia ou objeto pode manifestar uma específica modalidade do sagrado; e se esse(a) acaba por revelar algo diferente do meio cósmico circundante ao qual está inserido - uma hierofania, portanto -, então é também plausível considerar que esse mesmo objeto ou ideia pode eventualmente modificar sua forma ao sabor da momentaneidade histórica. É por esta qualidade que, tanto um objeto como uma ideia, pode ser usado em outro momento já não mais a partir daquilo que manifesta imediatamente - enquanto hierofania elementar e primordial -; mas por outra associação, inserida em outra dimensão, que pode ser desde um espaço sagrado até à associação de epifania a um deus, variando conforme a contingência do momento. Independentemente de onde irá se realocar essa ideia ou objeto, continuará a ser algo diferente do meio circundante, a ser sagrado a partir da hierofania primordial que o escolheu. Assim sendo, embora o valor que lhe foi atribuído mude segundo a teoria religiosa em que esta hierofania venha a se integrar, são justamente essas revalorizações e desvalorizações que caracterizam o próprio processo de manifestação do sagrado. 
Nesse sentido, a idolatria e iconoclastia são atitudes naturais dos agentes mediante o fenômeno das hierofanias (p. 30). As duas posições são justificáveis, pois para aqueles que se acreditam de posse de uma nova irrupção do sagrado, as antigas hierofanias e cratofanias perdem o valor e sentido originais, passando - como é o caso apresentado aqui - a ser entendidas como obstáculos à "perfeição da nova experiência religiosa".

Eliade (1998), portanto, afirma que os iconoclastas de qualquer tipo de religião justificam-se tanto por sua própria existência quanto pelo momento histórico em que a experiência se realiza. Igualmente, a idolatria enquanto qualidade de conservar e revalorizar permanentemente as 'antigas' hierofanias, valida a manifestação do sagrado através de alguma coisa. Essa alguma coisa, que como já disse acima, pode ser tanto um objeto do mundo imediato ou um objeto da imensidão cósmica, um símbolo, uma figura divina, lei moral, ou mesmo uma ideia, que continua atuando em essência da mesma maneira: revela o sagrado através de uma coisa fora de si, independente da categoria que assuma.

De qualquer forma, mesmo que essa relação apareça nos objetos, nos símbolos, nos mitos, ela nunca é integralmente e totalmente clarificada. Em todos os casos, ao manifestar-se, o sagrado limita-se, ao incorporar-se, encerram-se desde as formas mais elementares até as mais cosmológicas, como por exemplo, a encarnação do Logos em Jesus - formulação de Justino Mártir que apresento abaixo. Esse processo do sagrado é imanente ao espirito humano e suas limitações, disputas e concessões são constantes motivos do fomento de discursos em sociedade.

\section{Justino Mártir}

A Justino são atribuídas três obras: A Primeira Apologia de Justino; A Segunda Apologia e o Diálogo com o judeu Trifão. O autor teria nascido em Flávia Neápolis, em Samaria, e teria sido instruído desde sua infância em retórica, poesia e história. Já adulto encaminhou-se como filósofo, voltando-se ao platonismo. O próprio autor faz menção 
de como aderiu ao cristianismo através de uma conversa com um ancião. Este o teria persuadido, expondo-lhe o cristianismo em meio a um debate de questões filosóficas. Realmente isso parece ter agradado Justino e ele assumiu para si o papel de 'filósofo de cristo'. A tradição faz a referência de que mesmo após ter aderido ao cristianismo Justino continuou a usar sua toga ou túnica filosófica. Sem dúvida alguma, Justino foi quem gozou da reputação de o apologista mais importante do século II. Assim, é possível situar a figura de Justino, bem como seus escritos, entre os anos de 114-165 d.C.

Consta que por volta de 150 d.C., Justino estabeleceu-se em Roma com o firme propósito de advogar o cristianismo. Cinco anos após seu estabelecimento, escreve sua Primeira Apologia, dirigida ao imperador Antonio Pio, com o intuito de lograr melhor tratamento aos cristãos. De forma audaciosa chega a exclamar:

"Pois nós viemos, não para vos lisonjear através dessa escritura, nem vos agradar através de nosso discurso, mas imploro que me julgais, depois de uma investigação precisa, não lisonjeado por preconceito ou por um desejo de agradar aos homens supersticiosos, nem induzido por impulso irracional ou maus rumores que sempre foram predominantes, para dar uma decisão que venha a ser contra vós mesmos. Assim como para nós, consideramos que o mal não nos pode ser feito, a menos que sejamos convictos como portadores do mal ou provados sermos homen fracos; e vós, podeis matar, mas não nos machucar. "(The First Apology of Justin, vol.1, cap. II, p. 247) ${ }^{27}$

A petição de Justino parece não ter encontrado o final esperado, mesmo quando procurou correlacionar a imagem de Moisés e seus argumentos com a figura de Platão, o filósofo preferido do imperador. Justino intentou explicar a adoração cristã e seus fundamentos de maneira atraente e na linguagem que o aproximasse dos referenciais clássicos. Inevitavelmente o autor acaba incidindo sobre a questão dos ídolos e procura,

\footnotetext{
27 "For we have come, not to flatter you by this writing, nor please you by our address, but to beg that you pass judgment, after an accurate and searching investigation, not flattered by prejudice or by a desire of pleasing superstitious men, nor induced by irrational impulse or evil rumours which have long been prevalent, to give a decision which will prove to be against yourselves. For as for us, we reckon that no evil can be done us, unless we be convicted as evil-doers or be proved to be wicked men; and you, you can kill, but not hurt us."
} 
então, desconstruir esse tema. Argumentando que a adoração aos ídolos não passa de tolice e alegando que não seria necessário dizer que são os artesãos, segundo a moda vigente, que dão forma às matérias às quais prestam reverência, sendo esse tipo de adoração irracional. $\mathrm{O}$ autor procura enfatizar que os cristãos têm uma conduta em sociedade irrepreensível e que adoram Deus - uma divindade que não se enquadra nesse plano material - com discrição, e mesmo que ocasionalmente se encontrem praticando desobediência, na negativa de adorar o imperador em seu culto, não chegam a ter a conduta que os 'idólatras' apresentam. Justino refere:

"Pois porque necessitamos dizer-vos que já sabeis, em quais formas o artesãos cortando, esculpindo e martelando, modelam os materiais? E frequentemente, fora dos vasos da desonra, simplesmente alterando a forma e fazendo a imagem da forma requisitada, eles fazem o que chamam de deus; o que consideramos não somente irracional, mas também insultando a Deus, que, tendo forma e glória indescritíveis, ainda assim tomaram Seu nome e atribuíram a coisas corruptíveis e necessitam de serviços constantes. E que esses artesãos são imoderados, $e$, para não entrar em pormenores, praticam todos os vícios, como é sabido, até mesmo suas próprias meninas que trabalham junto com eles são corrompidas. "'(The First Apology of Justin, vol.1, cap. IX, p. 251$52)^{28}$

O autor, portanto, procura colocar a crença cristã como uma atitude racional. Alegando que os homens sóbrios reconhecem que os cristãos não são ateus nem idólatras e que em seus ritos não é necessário 'rios de sangue', incensos ou libações; mas somente orações e reverencias a Deus. Ao apresentar esses argumentos em seu texto, Justino nos fornece, então, um vívido quadro de quando e como se processava um culto cristão no século II:

\footnotetext{
28 "For why need we tell you who already know, into what forms the craftsmen carving and cutting, casting and hammering, fashion the materials? And often out of vessels of dishonour, by merely changing the form, and making an image of the requisite shape, they make what they call a god; which we consider not only senseless, but to be even insulting to God, who, having ineffable glory and form, thus gets His name attached to things that are corruptible, and require constant service. And that the artificers of these are both intemperate, and, not to enter into particulars, are practiced in every vice, you very well know; even their own girls who work along with them they corrupt."
} 
"E depois nós, continuamente nos recordamos dessas coisas. E o rico entre nós socorre o necessitado; e nós sempre os mantemos unidos; pois todas as coisas com as quais nós somos supridos, nós abençoamos o Feitor de tudo através de Seu Filho Jesus Cristo, e através do Espírito Santo. E no dia chamado de Domingo (Dia do Sol), todos nós que vivemos nas cidades ou em outros países nos reunimos em um único lugar, e as memórias dos apóstolos ou das escrituras dos profetas são lidas tanto quanto permite o tempo; então, quando a leitura finda, o presbitero instrui verbalmente e nos exorta à reprodução daqueles bons feitos. Então nós todos nos levantamos e rezamos juntos, e, como antes nos foi dito, quando nossas orações findam-se, pão e vinho e água são trazidos, e o presbítero, de maneira sutil oferece orações e graças, segundo sua habilidade, e as pessoas sentam-se dizendo Amém; E há a distribuição a todos, e uma participação de tudo sobre o que graças são dadas, e àqueles que não estão presentes, uma porção é enviada pelos diáconos. E aqueles que estão bem e desejosos em fazê-lo, doam o que cabe a cada um; e o que é coletado é depositado junto do presbítero, que socorre aos órfãos e viúvas e àqueles que, através da enfermidade ou qualquer coisa, estão necessitados, e àqueles que estão encarcerados $e$ os estranhos que estão tão somente, em jornada entre nós, e, em suma, toma conta de todos nós que estamos com algum tipo de necessidade. Mas domingo é o dia em que todos nós nos unimos em nossa assembleia comum, pois esse é o primeiro dia em que Deus, tendo transformado a escuridão e a matéria, fez o mundo; e Jesus Cristo nosso Salvador, no mesmo dia, ressuscitou dos mortos. Pois ele foi crucificado no dia anterior ao dia de Saturno (Sábado); e no dia seguinte, que é o dia do Sol, tendo aparecido aos Seus apóstolos e discípulos, Ele os ensinou essas coisas, que nós permitimos a vós saberem também vossa consideração. "(The First Apology of Justin, vol.1, cap. LXVII, p. 290$291)^{29}$

\footnotetext{
29 "And we afterwards continually remind each other of these things. And the wealthy among us help the needy; and we always keep together; and for all things wherewith we are supplied, we bless the Maker of all through His Son Jesus Christ, and through the Holy Ghost. And on the day called Sunday,all who live in cities or in the country gather together to one place, and the memoirs of the apostles or the writings of the prophets are read, as long as time permits; then, when the reader has ceased, the president verbally instructs, and exhorts to the imitation of these good things. Then we all rise together and pray, and, as we before said, when our prayer is ended, bread and wine and water are brought, and the president in like manner offers prayers and thanksgivings, according to his ability, and the people assent, saying Amen; and there is a distribution to each, and a participation of that over which thanks have been given, and to those who are absent a portion is sent by the deacons. And they who are well to do, and willing, give what each thinks fit; and what is collected is deposited with the president, who succours the orphans and widows and those who, through sickness or any other cause, are in want, and those who are in bonds and the strangers sojourning among us, and in a word takes care of all who are in need. But Sunday is the day on which we all hold our common assembly, because it is the first day on which God, having wrought a change in the darkness and matter, made the world; and Jesus Christ our Saviour on the same day rose from the dead. For He was crucified on the day before that of Saturn (Saturday); and on the day after that
} 
O primeiro dia da semana era denominado de dia do Sol dentro do orbis romanorum até o século IV. Reunindo-se, portanto, pelo menos uma vez na semana, os cristãos em assembleia recebiam suas instruções e exortações. Os víveres eram partilhados e as relações de comunidade certamente se fortaleciam. Como pode ser observado era práxis desse culto a leitura dos escritos produzidos. As ideias, conceitos e doutrinas que surgiam circulavam pela comunidade de adeptos. Assim, é possível considerar que as práticas cristãs desse período inicial estavam amplamente amparadas naqueles escritos disponíveis à comunidade. Certo é que não havia uma consonância hegemônica sobre a unidade dos escritos com autoridade canônica, porém, como venho referenciando até o presente momento alguns pontos estavam abertamente definidos e um deles - pode-se asseverar com clareza - era a adoração a ídolos.

Justino ainda procurou na Segunda Apologia, dirigida ao senado romano, o apelo que se atenuasse o peso da mão romana sobre os cristãos. Através de sua retórica e argumentação filosófica afirmou que o tratamento dispensado pelos romanos aos cristãos era fruto da ignorância e do preconceito, sendo que Deus somente não os havia destruído por amor dos próprios cristãos a quem se voltavam. Nessa apologia comparou Cristo a Sócrates e conclui dizendo que as doutrinas cristãs não eram vergonhosas, mas sim superiores a todas as filosofias humanas, convidando que os leitores colocassem a crivo suas palavras.

A terceira obra de Justino que chegou até nós - Diálogo com o Judeu Trifão contém reflexões autobiográficas de suas jornadas filosóficas e o reforço da ideia do 'Logos cósmico'. Essa é uma marcante característica que pode ser vista nessas três construções do autor: Jesus como a encarnação do 'Logos cósmico' de Deus. O Logos em grego $\lambda o ́ \gamma o \varsigma$ - no seu significado lato tinha somente a conotação de "palavra escrita ou falada'. Entretanto, em Heráclito a palavra agregou a referência de universalidade e passou a ser entendida também enquanto razão, tanto para a capacidade de racionalização individual como para um príncipio cósmico de Ordem e Beleza. No estoicismo, estava a afirmação de que todo o universo é corpóreo, assim, o Logos these things, which we have submitted to you also for your consideration." 
passou a desempenhar a qualidade de governo, um Logos dito divino. Nessa acepção, a alma estaria identificada com o princípio extracorpóreo do Logos - ou a razão universal - que ordenaria todas as coisas, surgindo a partir dele e de acordo com ele. Nessa acepção, é atraves da ação do Logos que o mundo tem sua harmonia, e, então é percebido como 'kosmos'.

De posse desse mesmo princípio filosófico grego, Filo de Alexandria - a quem já me referi nesse texto como aquele Judeu-helenista que procurou a aproximação do Pentateuco com a Filosofia grega - buscou a relação do Logos como Hipóstase, ou Pessoa Divina. Filo afirmaria, dessa forma, que a sombra de Deus é o seu Logos e servindo-lhe como instrumento, o serviu na criação do mundo. Portanto, como é pertinente observar, esse era um conceito que estava amplamente difundido no imaginário greco-romano.

Justino se esforçará, então, para demonstrar como Jesus é precisamente esse Logos do qual os filósofos fizeram menção. Reforçando a premissa de que todos já possuíam certa familiaridade com o conceito, só não estavam atentos à sua síntese, por desconhecimento, enfatizará que toda pessoa foi criada enquanto um ser racional e dessa forma participa do Logos, mesmo parcialmente, quando em seus atos expressa verdade. Assim, aquilo que Justino chamou de Logos spermatikos, ou a 'semente do Logos', estaria presente desde os profetas judeus até os filósofos gregos; enfim, em cada ser humano, como a fonte disseminada da totalidade da verdade, sendo sumarizada na pessoa de Jesus. Nas palavras de Justino:

“(...) Eu me orgulho e com toda minha força tento arduamente ser considerado como um cristão; não porque os ensinamentos de Platão são diferentes daqueles de Cristo, mas porque eles não são em todos os aspectos similares, assim como não o são os de outros, estoicos, e poetas, e historiadores. $O$ que cada homem falou bem em proporçãoao para dividir, ele a palavra espermática, observando o que foi relatado. Mas, aqueles que se contradizem na questão mais importante parecem não possuir a sabedoria celeste e o conhecimento que não se pode ir contra. $O$ que quer que se tenha dito diretamente entre todos os homens, é propriedade de nós cristãos. Pois, próximos de Deus, nós adoramos e amamos a Palavra inata e inefável que vem de Deus, desde que Ele tornou-se homem por nossa salvação, tornando-se cúmplice de nosso 
sofrimento, Ele pode também nos trazer a cura. Pois todos os escritores foram capazes de ver sombrias realidades através da semeadura da palavra que foi implantada neles. (...) (The Second Apology of Justin for the Christians Addressed to the Roman Senate, vol.1, cap. XIII, p. 303) ${ }^{30}$

Justino ainda encontra no 'amor ao Logos' ou no amor a essa 'verdade racional', o motivo de os cristãos sofrerem perseguição. Assim como aconteceu a outros grupos, a falta do entendimento pleno desse conceito acarreta o obscurantismo e ações não racionalizadas. $\mathrm{O}$ autor pontua:

"E aqueles da escola estoica - desde que na medida em que a doutrina moral era ensinada, eram admiráveis, como foram também os poetas em algumas particularidades, por causa da semente da razão [Logos], implantada em todas as raças de homens - foram, nós sabemos, odiados e punidos até a morte, - Heraclito, por exemplo, e, entre aqueles de seu tempo, Musonius e outros. Pois, como nos intimidamos, os demônios sempre agem para que todos aqueles que de qualquer modo vivem uma vida séria e razoável e evitam o vício serem odiados. E isso não é nada maravilhoso; se os demônios são provados a fazer com que aqueles sejam ainda mais odiados, aqueles que não vivem de acordo com uma única parte da palavra difusa [dentre os homens] mas através do conhecimento e contemplação de toda a Palavra, que é Cristo." (The Second Apology of Justin for the Christians Addressed to the Roman Senate, vol.1, cap. VIII, p. 299 $)^{31}$

\footnotetext{
${ }^{30}$ (..) I both boast and with all my strength strive to be found a Christian; not because the teachings of Plato are different from those of Christ, but because they are not in all respects similar, as neither are those of the others, Stoics, and poets, and historians. For each man spoke well in proportion to the share he had of the spermatic word, seeing what was related to it. But they who contradict themselves on the more important points appear not to have possessed the heavenly wisdom, and the knowledge which cannot be spoken against. Whatever things were rightly said among all men, are the property of us Christians. For next to God, we worship and love the Word who is from the unbegotten and ineffable God, since also He became man for our sakes, that becoming a partaker of our sufferings, He might also bring us healing. For all the writers were able to see realities darkly through the sowing of the implanted word that was in them (...)

31 "And those of the Stoic school—since, so far as their moral teaching went, they were admirable, as were also the poets in some particulars, on account of the seed of reason [the Logos] implanted in every race of men - were, we know, hated and put to death,- - Heraclitus for instance, and, among those of our own time, Musonius and others. For, as we intimated, the devils have always effected, that all those who anyhow live a reasonable and earnest life, and shun vice, be hated. And it is nothing wonderful; if the devils are proved to cause those to be much worse hated who live not according to a part only of the word diffused [among men] but by the knowledge and contemplation of the whole Word, which is Christ".
} 
O apologista estava convencido de que a filosofia grega fornecia todos os subsídios racionais para o entendimento do cristianismo. Dessa forma, traçando uma crítica contundente e implacável sobre a religião políada, seus mitos e ritos, bem como se amparando no conceito do Logos cósmico, Justino acreditou encontrar e fornecer ao cristianismo o complemento pleno da verdade de Deus. É, portanto, somente na manutenção do discurso de verdade que os caminhos erráticos e maléficos seriam expurgados.

\section{Ireneu de Esmirna}

Se Atenágoras de Atenas (177 d.C.) ajudou a distanciar ainda mais Deus do plano de entendimento físico, postulando-o em seus atributos negativos, ou seja, em tudo aquilo que ele não poderia ser - a chamada 'teologia apofática' -; definindo, dessa maneira, sua existência na origem transcendente e fundamental de todas as coisas, o arché da filosofia grega e, ainda, Teófilo de Antioquia (115 -168/181 d.C.) asseverou que toda a criação aconteceu do nada - o creatio ex nihilo, será em Irineu de Esmirna que o combate discursivo às distintas categorias do divino se intensificará de maneira coesa. Com seu Adversus haerese ${ }^{32}$, procurará combater o gnosticismo sistematicamente e no ímpeto de suas sustentações será o responsável por uma definição formal de um paradigma que estava distribuído em todos os escritos cristãos, mas que ainda não havia sido apresentado de maneira tão aberta. Pela primeira vez de modo ordenado num compêndio de ideias, tem-se a oportunidade de observar um encadeamento propositivo formal de nova memória histórica para o Mundo Antigo - a chamada teoria da Recapitulação.

Ireneu teria nascido em Esmirna ou nos arredores - na Ásia Menor - por volta de 120-d.C. Ainda em sua juventude teria sido instruído ao episcopado por Policarpo, sendo em seguida realocado para ser o responsável da comunidade estabelecida em

\footnotetext{
32 O mais longo de Contra Heresias é: Refutação e destruição do que é falsamente chamado conhecimento.
} 
Lião, ao sul da Gália. Por ter sido instruído por Policarpo, gozava do prestígio de ser um 'herdeiro' Joanino, já que a tradição atribuía o discipulado de Policarpo a João, o Apóstolo. Contudo, Ireneu não deteve seu prestígio somente sob esta base. Devido a suas frequentes viagens a Roma, adquiriu também a reputação de homem versado na diplomacia e mediação. Foi graças a uma dessas viagens que escapou das perseguições e execuções a cristãos na região do Rio Rodes, por volta de 177 d.C. Aproveitando-se do prestígio que lhe fora conferido, escreveu cinco volumes nos quais aborda o gnosticismo a partir de três críticas básicas: 1) Alega que a cosmovisão gnóstica é em boa parte uma mitologia sem qualquer fundamento; 2) Procura desconstruir o suposto legado que Jesus houvera deixado a uns poucos cristãos 'mais espiritualizados', sendo um deles João, o apóstolo. Recorrendo à sua ligação com João, através de Policarpo, o autor assevera que se tal legado secreto fosse verdade, Policarpo saberia, e por consequência ele; 3) Combate a interpretação gnóstica dos escritos cristãos na essência da interpretação, aludindo que tais conclusões não seriam nem racionais, muito menos plausíveis.

Ireneu passou alguns anos estudando cerca de vinte mestres gnósticos e suas escolas de pensamento, identificando dessa maneira que a mais difundida dentre todas era a corrente de pensamento valentiniana. À frente dessa linha de pensamento estava um líder estabelecido em Roma chamado Ptolomeu. Quando o autor passa a descrever algumas das ideias que suportadas pelos escritos cristãos estavam presentes entre as pessoas, acaba fornecendo-nos, mais uma vez, um panorama de quão difuso e multifacetado eram os entendimentos sobre o cristianismo nesse período:

"1. Tal, então, é o relato dado a respeito do que aconteceu dentro do Pleroma; tais calamidades que fluíram da paixão que se agarrou com Eon, que foi nomeado, e que estava dentro de um pouco de perecimento por ter sido absorvido na substância universal, através de sua inquisidora busca do Pai; assim, a consolidação [daquele AEon], a partir de sua condição de agonia por Horos, Stauros, Lytrotes, Carpistes, Horothetes, Metagoges. Tal era também o relato da geração posterior a Aon, especificamente do primeiro Cristo e Espírito Santo, ambos de quem foram feitos pelo Pai depois do arrependimento [de Sophia], e do segundo Cristo (ao modo do Salvador), que deve a sua existência às 
contribuições conjuntas [de AEons].Eles nos disseram, de qualquer forma, que esse conhecimento não foi abertamente divulgado, porque nem todos são capazes de recebê-lo, mas foi misticamente revelado pelo Salvador através de parábolas àqueles qualificados para entendê-las. Esses foram feitos de seguidores. Os trinta Aon foram indicados (como nós já comentamos) durante os trinta anos enquanto se diziam Salvadores, sem atuarem publicamente, e através da parábola dos trabalhadores na vinha. Paulo também, eles afirmam, muito clara e frequentemente nomes desses AEn, e vão o mais longe possível para preservar sua ordem, quando dizem, "Para todas as gerações de Fon de AEon." Não, nós próprios, quando na ação de graças pronunciamos as palavras: "Para AEons de Aons" (para todo o sempre) realmente estabelecemos esses Aons.E, finalmente, quaisquer palavras de Aon ou Aons que ocorram, eles, ao menos, se rferem a eles como aqueles seres." (Against Heresies: Book I, vol.1, cap. III, p. 520-521) ${ }^{33}$

É exatamente devido a essas múltiplas intepretações e ramificações presentes no cristianismo durante toda a Antiguidade Tardia, que Peter Brown, ao tratar da ascensão do movimento cristão no Ocidente, deixa evidente a sentença do desenvolvimento de muitos 'cristianismos regionais'. Assim, aquilo que procuro deixar cada vez mais claro nesse texto é que para o período em questão, assim como Brown (1999) pontuou, as atitudes estavam comprometidas com o amálgama de outras ações em relação ao sagrado. Nesse sentido, a ascensão "da igreja cristã, enquanto uma sociedade dentro de uma sociedade e uma cultura dentro de uma cultura", não pode ser reduzida somente às suas posições na sociedade e na cultura, mas a própria "re-distribuição e re-definição

\footnotetext{
33 "1. Such, then, is the account they give of what took place within the Pleroma; such the calamities that flowed from the passion which seized upon the Æon who has been named, and who was within a little of perishing by being absorbed in the universal substance, through her inquisitive searching after the Father; such the consolidation [of that Æon] from her condition of agony by Horos, and Stauros, and Lytrotes, and Carpistes, and Horothetes, and Metagoges. Such also is the account of the generation of the later Æons, namely of the first Christ and of the Holy Spirit, both of whom were produced by the Father after the repentance [of Sophia], and of the second Christ (whom they also style Saviour), who owed his being to the joint contributions [of the Æons]. They tell us, however, that this knowledge has not been openly divulged, because all are not capable of receiving it, but has been mystically revealed by the Saviour through means of parables to those qualified for understanding it. This has been done as follows. The thirty Æons are indicated (as we have already remarked) by the thirty years during which they say the Saviour performed no public act, and by the parable of the labourers in the vineyard. Paul also, they affirm, very clearly and frequently names these Æons, and even goes so far as to preserve their order, when he says, "To all the generations of the Æons of the Æon." Nay, we ourselves, when at the giving2686 of thanks we pronounce the words, "To Æons of Æons" (for ever and ever), do set forth these Æons. And, in fine, wherever the words Æon or Æons occur, they at once refer them to these beings"
} 
desses pontos, nos quais o sagrado se encontrava dentre os negócios humanos" (Brown 1999: 175-176) ${ }^{34}$.

Sob essa afirmação é importante expor a aclamação de Ireneu pela unidade da igreja, a busca pelas 'práticas imaculadas', e a formulação de uma nova capitulação para o mundo. Tanto em Contra Heresias, como na obra Demonstração de pregação apostólica, o autor irá exibir aquilo que a Teologia convencionou chamar de "Teoria da Recapitulação".

Como é possível compreender da citação acima, os gnósticos entendiam Jesus como um redentor espiritual que teria vindo através dos níveis dos Æons (éons) e arcontes, aparecendo em forma, sem, contudo, assumir uma natureza física. Portanto seria algo como uma holografia com o objetivo de revelar a mensagem aos espíritos preparados. As dimensões material e física não estavam presentes na interpretação gnóstica. Para combater essa ideia, Ireneu enfatizará justamente a dimensão material e física de Jesus, em contraponto. Argumentando que o Logos havia encarnado em Cristo a fim de operar a transformação da humanidade, que estava caída, pecaminosa e morta. O autor usa o termo grego Anakephalaiosis, da raiz kephalé, com o direto significado de 're-encabeçar', para explicar a encarnação do Logos em Jesus. Essa ação por si só seria a fonte que transforma a raça humana inteira, fazendo-a 'nascer de novo' sob uma nova 'cabeça' - daí em latim o termo ser capitus. Diante de uma nova origem e base, agora saudável, vitoriosa, imortal e plena, a fusão com a humanidade na encarnação de Jesus cumpriria o papel do segundo Adão.

A teoria da Recapitulação de Ireneu é uma extensa e sistemática interpretação do capítulo cinco dos escritos de Paulo aos romanos. Explicando melhor, se por um lado, através do 'protoplasma' - ou a fonte física - da humanidade em Adão, o mundo conheceu a morte, corrupção e a desgraça. Pelo mesmo protoplasma, o Logos de Deus, a humanidade e sua posteridade foi recapitulada à sua antiga condição, antes da Queda. Pela participação dos seres humanos na natureza divina do Logos, esses foram

\footnotetext{
${ }^{34}$ BROWN, P. A ascensão do Cristianismo no Ocidente. Tradução de Eduardo Nogueira. Lisboa: Editorial Presença, 1999. (Coleção Construir a Europa)
} 
redimidos de sua condição e uma nova ordem ou uma nova história da humanidade começa a se processar depois da morte em obediência de Jesus. Esse processo ficou conhecido posteriormente entre os cristãos como 'divinização' ou 'deificação'(theosis).

Segundo Ireneu:

"1. Como ficou claramente demonstrado que a Palavra, que existe desde o início com Deus, por quem todas as coisas foram criadas, de acordo com a época apontada pelo Pai, unido a sua própria obra, na medida em que Ele se tornou um homem capaz de sofrer, [segue-se] que toda objeção é posta de lado por aqueles que dizem: "Se nosso Senhor nasceu naquela época, Cristo não tinha, portanto, nenhuma existência anterior." Pois eu mostrei que o Filho de Deus não começa a existir, estando com o Pai desde o início, mas quando Ele torna-se encarnado e é feito homem, Ele começou novamente a longa linha de seres humanos, e forneceu-nos, de forma breve e abrangente, a salvação; de modo que aquilo que havíamos perdido em Adão, ou seja, para ser conforme à imagem e semelhança de Deus, para que possamos recuperar em Cristo Jesus. " (Against Heresies: Book III, vol.1, cap. XVIII, p. 741) ${ }^{35}$

“(...) ele demonstra que ele mesmo, que esteve na ignorância em tempos passados, isto é, na ignorância de Deus, é renovado pelo conhecimento a respeito Dele. Pois o conhecimento em Deus renova o homem. E quando ele diz, "depois da imagem do Criador", ele estabelece a recapitulação do mesmo homem, que foi feito, no início, segundo à semelhança de Deus." (Against Heresies: Book V, vol.1, cap. XII, p. 904) ${ }^{36}$

O esforço de coesão sob essa nova memória histórica para o Mundo Antigo ou em outras palavras, essa cristianização do espaço intelectual, foi o empenho não só desses pensadores do segundo e terceiro século d.C., mas de outros tantos cristãos

\footnotetext{
35 " 1 . As it has been clearly demonstrated that the Word, who existed in the beginning with God, by whom all things were made, who was also always present with mankind, was in these last days, according to the time appointed by the Father, united to His own workmanship, inasmuch as He became a man liable to suffering, [it follows] that every objection is set aside of those who say, "If our Lord was born at that time, Christ had therefore no previous existence." For I have shown that the Son of God did not then begin to exist, being with the Father from the beginning; but when He became incarnate, and was made man, He commenced afresh the long line of human beings, and furnished us, in a brief, comprehensive manner, with salvation; so that what we had lost in Adam-namely, to be according to the image and likeness of God-that we might recover in Christ Jesus."

36 " (...) he demonstrates that he, the selfsame man who was in ignorance in times past, that is, in ignorance of God, is renewed by that knowledge which has respect to Him. For the knowledge of God renews man. And when he says, "after the image of the Creator," he sets forth the recapitulation of the same man, who was at the beginning made after the likeness of God"
} 
imbuídos do mesmo espírito. Tertuliano (200-250 d.C.) intensificará ainda mais a exegese cristã e outras correntes de pensamento serão relegadas à categoria de heresia; Cipriano (200-258 d.C.) empregará seu labor à consolidação de uma eclesiologia doutrina e vida da igreja - voltada à centralização na figura dos bispos; Orígenes (185 230/254 d.C.) formulará conceitos sobre razão e fé, abrigando alguns precedentes para outras interpretações alegóricas. Será nesse processo de tensões e transformações que o cristianismo atravessará não só o século II d.C. e III d.C., mas também boa parte de sua história. Contudo, é sobre essas bases que os referenciais subsequentes são formulados.

\section{Hipólito de Roma}

A figura de Hipólito surge como uma das mais importantes do século III d.C. Algumas histórias sobre sua figura surgiram posteriormente durante os séculos VII e VIII d.C. Ele foi associado a um soldado que teria se convertido, recusando ser questor na cidade de Óstia, edil em Prato, preferindo a carreira das armas. Sua simpatia pelo cristianismo teria provindo do contato com seus pares no exército, onde a religião cristã crescia. Outra associação foi feita com um mártir homônimo da cidade Portus, na região do Lácio. Contudo, a identificação que parece ter maior credibilidade é aquela que afirma tratar-se mesmo de um bispo nascido em Roma e atuante entre os anos de 170236 d.C.

Sendo um presbítero em Roma, Hipólito parece ter influenciado o pensamento de Orígenes, que o ouvira pregar em certa ocasião. Por sua eloquência e erudição entrou em choque com outro epíscopo da cidade. E por esse enfrentamento contra Zeferino ficaria conhecido nos séculos seguinte como um antipapista - obviamente depois que a primazia de Roma foi alcançada, estabeleceu-se uma linhagem de homens considerados papas. Para o momento em questão, Hipólito estava somente em combate de ideias com outros da mesma classe.

Escrevendo em grego, as obras que chegaram até nós foram: Refutação de todas as heresias - Philosophumena - em 10 volumes; Comentarios sobre o profeta Daniel e 
Comentários sobre o Cântico dos Cânticos, bem como alguns apêndices atribuídos à sua figura. Muito de suas obras se perdeu quando a igreja se latinizou, a partir do século IV d.C.

Hipólito trata dos temas mais variados que vão desde a exegese, homilética, apologética, polêmica, cronologia, chegando até as questões de direito canônico. Daquilo que é pertinente a esse trabalho, o autor, ao escrever Comentário sobre o Cântico dos Cânticos, utiliza-se da alegoria de relação entre Israel, Jesus e os gentios. Apresentando referências do Logos nas mais diferentes acepções, fornece consideráveis subsídios para essa interpretação: como figura feminina de Sophia, agente de Deus na criação que posteriormente teria estado com Salomão, inspirado os profetas, chegando a ser enquadrada como a genitora do vinho, este o nutriente da igreja - uma referência ao vinho que era partilhado na ceia e que também representaria o sangue de Jesus dado na cruz. Ainda lança mão da figura de Hélio que atravessa os céus e agrega as nações para fazer a mesma associação.

Escrito em forma de mistagogia ${ }^{37}$, uma instrução aos novos cristãos, objetivava o entendimento dos princípios fundamentais que compunham o cristianismo e as práticas necessárias em seu meio. É interessante observar que existe uma frequente apropriação de referenciais clássicos. Utilizando-se do recurso de retórica chamado exphrasis, uma forma de persuasão que se apelava a temas bem conhecidos oriundos de representações populares, contidas geralmente em paredes ou em mosaicos, nos pisos, conduzia os leitores dentro de suas familiaridades, aproximando o discurso, para os persuadirem ao cristianismo. Ainda utilizava o schema isagogicum, técnica de introdução das convenções retóricas, demonstrando seus conhecimentos sobre obras clássicas e fornecendo bases para as eventuais complicações de entendimento que seus argumentos pudessem apresentar no decorrer do texto.

A ideia tipificada da igreja da circuncisão como sendo de Israel substituída pela igreja composta tanto por judeus convertidos quantos gentios, estará presente nos

\footnotetext{
${ }^{37}$ Mistagogia era um pequeno compêndio para instruir os novos prosélitos nos princípios cristãos. Palavra provinda do grego que significa "conduzir, guiar ao mistério".
} 
escritos de Hipólito. Assim, a preocupação de que os cristãos possuíssem subsídios ao discurso e debate também marcou esses compêndios, nesse sentido o autor afirma:

"Para que nós observemos que nosso discurso foi útil não somente para a refutação das heresias, mas também àqueles que acolhiam essas opiniões. Agora esses, quando encontram o extremo cuidado evidenciado por nós, serão golpeados com admiração da nossa seriedade, e não vão desprezar a nossa indústria e condenar os cristãos como loucos quando eles discernem as opiniões com as quais eles próprios, estupidamente, consentem sua crença. E, além disso, aqueles que desejosos de aprendizado, devotados à verdade, serão assistidos pelo nosso discurso, quando aprenderem sobre os princípios fundamentais das heresias, para tornarem-se mais inteligentes, não somente para a fácil refutação daqueles que tentaram enganá-los, mas também quando verificaram as declarações confessas dos homens sábios e trem sido feitos familiares com eles; que eles não devem ser confundidos por eles como pessoas ignorantes nem como descuidados de certos atos individuais, agindo como se por algum certo tipo de autoridade; não, mais do que isso, eles devem permanecer alerta contra aqueles que estão permitindo que eles mesmos tornem-se vitimas desses enganos"(The Refutation of All Heresies: Book IV, vol.5, cap. XII, p. 74-75) ${ }^{38}$

Com base em todas essas referências, os cristãos foram sendo ensinados e doutrinados. A manutenção dos discursos de verdade, apontando o que seriam erros de comportamento e interpretação; a consolidação de um número cada vez maior de limites e restrições e a constituição de uma nova memória histórica para o mundo vigente, propiciaram os fundamentos de conduta e ação, apontando para uma redimensão daquilo que se poderia chamar de Centro, em seu sentido mais lato. O Centro enquanto simbolismo da procura imemorial do eixo-centralizador, aquela categoria geral que

\footnotetext{
38 "For we observe that our discourse has been serviceable not only for a refutation of heresies, but also in reference to those who entertain these opinions. Now these, when they encounter the extreme care evinced by us, will even be struck with admiration of our earnestness, and will not despise our industry and condemn Christians as fools when they discern the opinions to which they themselves have stupidly accorded their belief. And furthermore, those who, desirous of learning, addict themselves to the truth, will be assisted by our discourse to become, when they have learned the fundamental principles of the heresies, more intelligent not only for the easy refutation of those who have attempted to deceive them, but that also, when they have ascertained the avowed opinions of the wise men, and have been made acquainted with them, that they shall neither be confused by them as ignorant persons would, nor become the dupes of certain individuals acting as if from some authority; nay, more than this, they shall be on their guard against those that are allowing themselves to become victims to these delusions."
} 
remete à experiência do transcendente e permite ao indivíduo - nesse caso todos os cristãos - encontrar um lugar de aporte idealizado, lugar onde a tensão que obriga a uma escolha tende à rejeição de um estado de apatia e infertilidade espiritual para um ordenamento de cosmovisão que pretende a estabilidade vindoura e a segurança eterna. De fato, essas escolhas no cotidiano muitas vezes se mesclam e ora são conjugadas ora dissociadas. Nesse aspecto, não deve causar estranheza alguma quando se encontra em certos casos um amálgama de elementos clássicos e cristãos. Esta conjugação pode ser percebida não somente nos compêndios, mas também nas práticas diárias das comunidades cristãs que foram aparecendo. Contudo, é exatamente nesse processo que o esforço empreendido tanto por 'pais apostólicos' como dos 'apologistas' ${ }^{39}$, incidirá. Ambos os grupos empenharam seu labor na cristianização desse Centro, procurando colocar Jesus Cristo, o Logos de Deus e o cristianismo, consequentemente, nesse espaço em detrimento de outras concepções religiosas.

\subsection{Todos contra idolatria: a criação de uma memória.}

Até o presente momento o leitor recebeu os subsídios que considerei básicos para avançar em algumas questões que tangem a memória social que o cristianismo procurou construir em seus séculos iniciais. Agora quero examinar melhor os conceitos de memória, suas implicações e como essa relação afeta os artefatos e vice-versa.

$\mathrm{O}$ entendimento da memória enquanto um banco de dados fidedigno sobre o passado, ao qual temos pleno acesso em qualquer momento e onde encontramos

\footnotetext{
${ }^{39}$ Alguns dos autores que apresentei nesse texto também são qualificados como Polemissistas, é o caso de Ireneu, Tertuliano, Cipriano, Orígenes e mesmo Hipólito. Contudo, preferi colocá-los como 'apologistas' de maneira geral, justamente por encontrar em seus textos o mesmo ideal de defesa e construção de memória histórica que é possível notar naqueles que são convencionados na Teologia como 'apologistas'.
} 
respostas concretas sobre os mais variados eventos que estamos a escrutinar, não passa de mera ilusão. Por abrigar em si as categorias conjuntas da lembrança e do esquecimento como mecanismos de funcionamento, conceber o conceito de memória como algo fixo e estático seria um grave erro. As memórias, tanto coletiva como individual, estão distribuídas em milhares de fragmentos por todo o tecido social. As pessoas recorrerem à lembrança e ao esquecimento do passado, conforme a necessidade do presente em que se encontram e é justamente por causa desse mecanismo que, acima de tudo, a memória é sempre um processo ativo e em construção. Ela não reside somente na mente humana, como haveria de se supor, mas conforme bem observa Andrew Jones (2007), também emerge através das experiências intersubjetivas que as pessoas têm com o mundo material. No partilhar de memórias sobre eventos e objetos, os atores sociais projetam para além de si mesmos as lembranças que, então, deixam de ser simplesmente compartilhadas e passam a participar ativamente de um processo de criação, interpretação, modificação e ressignificação através das lembranças e dos esquecimentos coletivos (Jones 2007:41). É por isso que memórias não são transmitidas sem contínua revisão e modificação, atendendo a novos significados conforme a ocasião. O ditado popular de quem conta um conto aumenta (ou suprime) um ponto, não está de todo errado.

Se Rosemary Joyce (2003) está correta, é possível estabelecer uma diferenciação mínima entre a memória implícita e explícita, estando a memória explícita relacionada aos usos da memória que são acompanhados pela experiência subjetiva da lembrança. Uma memória consciente. (Kelley, Lindsay 1996: 54 apud Joyce 2003: 106). A memória está imbuída de um processo de reconhecimento que alcançamos através de algo que já conhecemos ou nos é familiar. A habilidade de reconhecer algo previamente registrado por nós é o que nos torna capazes de submeter determinadas coisas ao crivo da memória, orientando na maior parte das vezes nosso campo de ação. Agimos segundo nossas lembranças. Parte importante também nesse processo é aquela que através da seleção intuitiva opera-se o esquecimento. Sem a capacidade de esquecer, de esvanecer as informações obsoletas, não seríamos capazes de suportar o acúmulo de informações que dada realidade comporta. Não é possível agir sem o 
esquecimento. Essencialmente devido a estas questões é que a memória é tanto cognitiva quanto social.

Embora não seja possível estabelecer um único locus para a memória, até porque no nível cognitivo, diferentes estruturas cerebrais estão envolvidas na aquisição, evocação e armazenamento das diversas informações adquiridas, hoje em dia é razoável entender que a memória pode ser divida em dois tipos principais: a memória declarativa, ou explícita, que comporta a capacidade de externar, sejam fatos, nomes, acontecimentos, estando associada com o nível consciente; e a memória não-declarativa, esta por sua vez também chamada de implícita ou procedural, que comporta os procedimentos motores. Essa memória depende dos gânglios basais e não atinge o nível de consciência. Através dela andamos, executamos movimentos com precisão e ela é a responsável pelas ações que muitas vezes nos referimos como 'automáticas', ou seja, aquelas que na mesma relação, chamamos de 'costumeiras'. Em geral esse tipo de memória nãodeclarativa requer mais tempo para ser adquirida, contudo, é mais duradoura.

Dessa forma, grosso modo a memória declarativa seria armazenar o saber que algo se deu enquanto a memória não-declarativa seria o como isto se deu.

Ainda sobre a memória declarativa ou explícita uma divisão é possível, entre a memória episódica e a memória semântica. A primeira ligada à lembrança de acontecimentos específicos, seria uma memória imediata que dura de frações a poucos segundos. Instigada por distintas e variadas informações que estariam em processamento num período inicial de 'pré-atenção", esse tipo de memória, através dos estímulos sensoriais, necessitaria ser incentivada ativamente para que a diminuição da frequência dos mesmos estímulos não opere - a curto termo - o esquecimento. Já a memória semântica estaria responsável pela lembrança de aspectos gerais, e tendo duração de alguns segundos ou minutos, participaria ativamente no processo de formação dos traços de memórias mais longos. O intervalo desses traços de formação é chamado de Período de consolidação, sendo ele o responsável pela nossa capacidade de lembrança dos acontecimentos recentes. Estas seriam todas memórias de curto prazo. Ambas sendo constantemente usadas enquanto dada a prática de determinada ação, 
servindo quase como uma conversa interna codificada, que independe do estímulo visual ou auditivo (ibidem).

Para que uma memória de curta duração passe a ser uma memória de longo prazo é necessário um processo elaborativo que contemple a construção inter-relacionada de imagens, associações de lugares e espaços, narrativas e uma série de atribuições de significados que a tornem distinta das demais lembranças que estão operando concomitantemente (Nairne 1996:109; Kelley e Lindsay 1996:33-4; Pashler e Carrier 1996:18; Belleza 1996:349-50, 356-9, apud Joyce 2003: 107).

No processo de fomento das memórias sociais são proporcionados os contextos e fundamentos das memorias individuais. Através do processo de lembrança e esquecimento, as formas retóricas são organizadas e, desta maneira, determinadas versões do passado são omitidas e sancionadas, enquanto outras partes são privilegiadas e assumidas. Esse processo de definição de certo e errado, incluído e excluído, omitidos e assumidos, são as bases do processo da memória. Assim, na continuidade da vida social - como um componente das práticas em sociedade e contribuindo na definição das identidades dos indivíduos - a preservação e continuação de práticas de lembrança e esquecimento são fatores preponderantes do viver social (Middleton, Edwards 1997).

O estabelecimento da memória de longa duração é auxiliado na medida em que informações são submetidas sob novas formas, as novas informações são mapeadas em termos semânticos de relação, segundo aquilo que já possuímos de conhecimento, promovendo, assim, uma rede de relações de memória (Baddeley 1990: 120-3; 2358;252-4). Se conscientemente os estímulos sensoriais são realocados articuladamente, tendo em conta as relações implícitas - aquelas não declaradas - e as explícitas - as dispostas pela lembrança social no âmbito do convívio - sobre os determinados eventos; então se cria a possibilidade de mentalmente voltar ao passado e tornar o agrupamento variado e multivalente de informações em uma memória concatenada e assimilável. Essa matriz representativa, tal qual Geertz (1989) a definiria, fomentará a inteligibilidade associativa dessa rede de memórias, estando inerentemente personalizada e unicamente diferenciada pela experiência em sociedade. Dessa maneira, 
portanto, é que uma memória subsistiria por longos períodos de tempo, alcançando a abrangência na longa duração.

Em minha opinião, aquilo que o cristianismo procurará fazer é exatamente atuar nessa relação de memória. De forma sistemática, todos os pensadores cristãos dos primeiros séculos de existência, empreenderão esforços na substituição da matriz representativa políada, procurando outra forma de associação semântica e o suprimento de um aparato informativo em que encontrasse lugar a mudança almejada. Percebem-se ao longo dos textos, destarte, em torno de $293^{40}$ referências opositivas à idolatria, afora as questões colocadas no item 2.2 desse capítulo. Assim, um tema mais que recorrente num intervalo de tempo de no mínimo duzentos anos.

O teor das assertivas é sempre contundente e impositivo, como já referido outrora, e para exemplificar a linha discursiva contida nesses textos, seguem abaixo três referências, a fim de que o leitor tenha uma base da forma como as outras 290 são expressas:

"Para tais expressões são usados, não como se eles realmente fossem deuses, mas porque as Escrituras estão nos ensinando que o verdadeiro Deus, que criou todas as coisas, é Senhor único daqueles que são reputados como deuses e senhores. E para que o Espírito Santo pudesse nos convencer disso, Ele afirmou através do santo David, 'Os deuses das nações, reputados como tal, são idolos dos demônios, e não deuses'; e Ele denuncia uma maldição àqueles que os adoram. "E eu respondi", "Eu não apresentaria essas provas, Trypho, pelo que estou ciente daqueles que adoram estes [ídolos], e tal como são condenados, mas tais [provas] como ninguém poderia encontrar qualquer objecção. Eles irão parecer estranhos para você, embora leia-os todos os dias, de modo que mesmo a partir deste fato, entendemos que, por causa de sua maldade, Deus tem retido sua capacidade de discernir a sabedoria de Suas Escrituras; ainda [há] algumas exceções, a quem, segundo a graça de Seu grande sofrimento, como disse Isaías: Ele deixou a semente da salvação, afim de que sua raça não fosse totalmente destruída, assim como Sodoma e Gomorra. Preste atenção, portanto, no que vou relatar

\footnotetext{
${ }^{40}$ Vide tabela de referências à idolatria nos escritos cristãos em anexo 1
} 
das Sagradas Escrituras, que não precisam de ser expostos, mas apenas ouvidas. "(Dialogue with Trypho, vol.1, cap. LV, p. 355) $)^{41}$

Nessa citação, Justino alerta que o caminho daqueles que se voltam a outros deuses não é outro senão a maldição e a mesma destruição que sofrera Sodoma e Gomorra. Vejamos agora uma passagem de Irineu, discorrendo sobre o mesmo tema:

"Quando, porém, na Escritura contém o termo [deuses], os quais não são deuses, e não o são, como eu já afirmei, declara-os como deuses em todos os sentidos, mas com uma certa adição e significado, pelo que evidencia-se que nação são deuses, de modo algum. Como com David: "Os deuses dos gentios são ídolos dos demônios;" e, "Não deveis seguir outros deuses." Pois, no que ele diz "os deuses dos gentios" - mas os gentios são desconhecedores do verdadeiro Deus - e os chamam de "outros deuses", ele exclui suas reivindicações [para serem encarados] como deuses, de fato. Mas assim como o que eles mesmos são, ele falam em relação a eles; "pois eles são", ele diz, "os ídolos dos demônios." E Isaías: "Deixem-os ser confundidos, todos que blasfemam contra Deus, $e$ esculpem coisas inúteis; mesmo Eu sendo testemunha, disse Deus. "Ele os remove da [categoria de] deuses, mas faz uso da palavra isolada, para esse [propósito], para que possamos saber de quem ele fala. Jeremias também diz o mesmo: "Os deuses não criam o céu e a terra, deixem nos perecer da terra que está abaixo do céu." Pois, a partir do fato de ter acrescentado a sua destruição, ele nos mostra não serem deuses, em absoluto. Elias, também, quando Israel subiu ao Monte Carmelo, desejando desfazerem-se da idolatria, os disse, "Por quanto tempo vos detenhais entre duas opiniões?, Se o SENHOR é Deus, sigamNo." E, novamente, a oferta queimada, ele assim oferece aos padres idólatras: "Vós deveis invocar o nome de vossos deuses, e eu invocarei em nome do SENHOR meu Deus; e o Senhor que ouvirá pelo fogo, Ele é

\footnotetext{
41 "For such expressions are used, not as if they really were gods, but because the Scripture is teaching us that the true God, who made all things, is Lord alone of those who are reputed gods and lords. And in order that the Holy Spirit may convince [us] of this, He said by the holy David, 'The gods of the nations, reputed gods, are idols of demons, and not gods;' and He denounces a curse on those who worship them."And I replied, "I would not bring forward these proofs, Trypho, by which I am aware those who worship these [idols] and such like are condemned, but such [proofs] as no one could find any objection to. They will appear strange to you, although you read them every day; so that even from this fact we understand that, because of your wickedness, God has withheld from you the ability to discern the wisdom of His Scriptures; yet [there are] some exceptions, to whom, according to the grace of His longsuffering, as Isaiah said, He has left a seed of salvation, lest your race be utterly destroyed, like Sodom and Gomorrah. Pay attention, therefore, to what I shall record out of the holy Scriptures, which do not need to be expounded, but only listened to".
} 
Deus." Agora, a partir do fato de o profeta continuar dizendo essas palavras, ele prova que esses deuses que eram considerados assim entre os homens, não são deuses, em absoluto. Ele os dirigiu para aquele Deus em quem ele acreditava e que era o verdadeiro Deus, a quem invocando, ele exclamou, SENHOR Deus de Abraão, Deus de Isaac, e Deus de Jacó, ouça-me hoje e deixe que todo esse povo saiba que Tu és o Deus de Israel. "(Against Heresies, Book III, vol.1, cap. VI, p. 693) ${ }^{42}$

Como é possível perceber o autor se utiliza das referências à monolatria presentes no Pentateuco, condenando veementemente "os ídolos dos demônios" e o ato de esculpir tais representações como uma blasfêmia contra Deus.

Completando esta breve ilustração, é pertinente a interpelação de Teófilo de Antioquia. O autor remete-se diretamente a uma sorte de representações imagéticas comuns no Mundo Antigo, bem como a específicas divindades do panteão grecoromano, vejamos:

\begin{abstract}
"Porque eu deveria recontar a multidão de animais adorados pelos egípcios, não só répteis, mas também bovinos, feras, aves e peixes de rio e ainda, bacias e ruídos desgraçados? Mas se citarem os gregos e oitras nações, eles adoram pedras e madeira, e outros tipos de substâncias materiais, - as imagens, assim como temos dito, de homens mortos. Pois
\end{abstract}

\footnotetext{
42 "When, however, the Scripture terms them [gods] which are no gods, it does not, as I have already remarked, declare them as gods in every sense, but with a certain addition and signification, by which they are shown to be no gods at all. As with David: "The gods of the heathen are idols of demons;" and, "Ye shall not follow other gods." For in that he says "the gods of the heathen"-but the heathen are ignorant of the true God - and calls them "other gods," he bars their claim [to be looked upon] as gods at all. But as to what they are in their own person, he speaks concerning them; "for they are," he says, "the idols of demons." And Esaias: "Let them be confounded, all who blaspheme God, and carve useless things; even I am witness, saith God." He removes them from [the category of] gods, but he makes use of the word alone, for this [purpose], that we may know of whom he speaks. Jeremiah also says the same: "The gods that have not made the heavens and earth, let them perish from the earth which is under the heaven." For, from the fact of his having subjoined their destruction, he shows them to be no gods at all. Elias, too, when all Israel was assembled at Mount Carmel, wishing to turn them from idolatry, says to them, "How long halt ye between two opinions? If the LORD be God, follow Him." And again, at theburnt-offering, he thus addresses the idolatrous priests: "Ye shall call upon the name of your gods, and I will call on the name of the LORD my God; and the Lord that will hearken by fire, He is God." Now, from the fact of the prophet having said these words, he proves that these gods which were reputed so among those men, are no gods at all. He directed them to that God upon whom he believed, and who was truly God; whom invoking, he exclaimed, "LORD God of Abraham, God of Isaac, and God of Jacob, hear me to-day, and let all this people know that Thou art the God of Israel."
} 
Phidias é encontrado em Pisa, fazendo para os Eleios, Júpiter do Olimpo, em Atenas, Minerva da Acrópolis. E eu pergunto a ti, meu amigo, quantos Júpiters existem. Pois existe, primeiramente, Júpiter, cujo de Olimpo, Júpiter Propator, Júpiter Pannychius, Júpiter Poliuchus, Júpiter Capitolinus; e aquele Júpiter, filho de Saturno, que é rei dos cretas, tem um túmulo em Creta, mas o restante não foi considerado dignos de túmulos. E quando se fala a respeito da mãe de todos aqueles chamados de deuses, longe de mim pronunciar com meu lábios seus feitos, ou os feitos daqueles por quem ela é adorada (pois é ilícito a nós assim como o nome de tais coisas), e quais vastos impostos $e$ rendimentos ela e seus filhos fornecem ao rei. Pois esses não são deuses, mas sim ídolos, como já afirmamos, trabalhos de mãos de homens e impuros demônios. E tal podem tornar-se todos aqueles que as fazem e depositam sua confiança nelas!'”(Theophilus to Autolycus, Book I, vol.2, cap.X, p. 140$)^{43}$

Seria ingenuidade pensar que esse montante de referenciais, bem como o tema da idolatria de forma abrangente, restringissem-se somente ao âmbito formal dos escritos. Se tomarmos por base a pertinente ideia de Andy Clark (1997) a respeito das redes neurais, talvez possamos agregar uma interessante perspectiva a este texto. $\mathrm{O}$ autor procura situar a ação cognitiva de forma que essa presença seja atuante na manipulação dos objetos e no fomento das diretrizes para ação futura. A associação da presença cognitiva com os objetos seria, então, fundamental no modo de pensar em sociedade. Essa interessante ideia colocaria em questão a percepção do mundo como um potencial para as atuações e os objetos podendo ser tratados como portadores de

\footnotetext{
43 "Why should I further recount the multitude of animals worshipped by the Egyptians, both reptiles, and cattle, and wild beasts, and birds, and river-fishes; and even wash-pots and disgraceful noises? But if you cite the Greeks and the other nations, they worship stones and wood, and other kinds of material substances, - - the images, as we have just been saying, of dead men. For Phidias is found in Pisa making for the Eleians the Olympian Jupiter, and at Athens the Minerva of the Acropolis. And I will inquire of you, my friend, how many Jupiters exist. For there is, firstly, Jupiter surnamed Olympian, then Jupiter Latiaris, and Jupiter Cassius, and Jupiter Tonans, and Jupiter Propator, and Jupiter Pannychius, and Jupiter Poliuchus, and Jupiter Capitolinus; and that Jupiter, the son of Saturn, who is king of the Cretans, has a tomb in Crete, but the rest, possibly, were not thought worthy of tombs. And if you speak of the mother of those who are called gods, far be it from me to utter with my lips her deeds, or the deeds of those by whom she is worshipped (for it is unlawful for us so much as to name such things), and what vast taxes and revenues she and her sons furnish to the king. For these are not gods, but idols, as we have already said, the works of men's hands and unclean demons. And such may all those become who make them and put their trust in them!"
} 
agência $^{44}$, como o autor propõe (Clark 1997: 46-47, apud Jones 2007: 38). Obviamente não se trata da afirmação de que as coisas refletem intenções humana por si só, mas sim a de que objetos concentram as crenças e experiências humanas de forma diferenciada.

Cris Gosden (1994) ao analisar a relação entre o mundo material e a ações humanas considera que o mundo criado pelos grupos sociais passados serve de base à socialização dos grupos futuros. O mundo não é somente algo que se conhece, mas algo em que se está; e isto é um componente ativo das relações estabelecidas em sociedade (Gosden 1994: 77). A constituição de pessoas e objetos caminha junto das funções de ação. De maneira não isolada, forma e matéria são resultados das redes de relação em sociedade. A materialidade enquanto qualidade de relacionamento, mais do que qualidade de matéria, é o que faz com que pessoas usem determinadas coisas e que essas mesmas coisas sejam capazes de agência entre as pessoas.

A relação entre pessoas e artefatos faz parte de um complexo processo, em que cada pessoa constitui e atribui determinada forma e uso a distintos objetos, e esses, por sua vez, agem como concretos veículos, sociais e individuais, de expressões de poder e energia. As competências humanas são personificadas através da produção das coisas e a materialidade é subjetivada nas pessoas (Miller 1987, apud Jones 2007: 35). Entretanto, as relações estabelecidas com os objetos e deles para conosco nunca são as mesmas, e nesse sentido, reafirmando a ideia de agência da cultura material, Jones aponta:

"Coisas são essenciais e intersticiais para ações humanas eficazes. A ideia de agência nos ajuda a perceber que nem todos os objetos são tratados da mesma maneira; alguns são abstraídos das profundezas do meio ambiente e é concedida a eles especial atenção por sua capacidade de agenciamento de ações. " (Jones 2007: 39) ${ }^{45}$

Notadamente a relação sobre a agência da cultura material merece maior atenção e discussão mais pormenorizada, dela me ocuparei nos capítulos seguintes. Por hora é

\footnotetext{
${ }^{44} \mathrm{O}$ autor usa o termo affording.

45 "Things are essential and interstitial for efficacious human action. The idea of affordances helps us to realize that not all objects are treated in the same way; some are abstracted from the background of the environment and are accorded special attention because of their capacities for affording action."
} 
suficiente que nos contentemos com a assertiva de que parte fundamental das memórias coletivas está na relação com a materialidade e na percepção espacial que os atores sociais têm dela. Como salientado, alguns artefatos têm a "capacidade" de agregar a si mais agência, e este parece ser o caso das lamparinas que foram escavadas em Apollonia-Arsuf.

Passemos agora à análise dessas lamparinas e sua eventual ligação com o contexto até aqui apresentado. 


\section{PARTE II}

\section{CAPÍTULO 3}

3. A cerâmica romana: dos aspectos formais às representações iconográficas

As mãos do oleiro dão forma à argila disforme, embora sua pequena olaria conte com um moderno torno que é acionado por impulso e mantido em rotação regular por meio de uma pesada pedra volante, ele ainda prefere usar somente suas mãos. Pensa que apesar da regularidade nas bordas e perfis dos vasos feitos no torno, ainda são frequentes as linhas horizontais e/ou arestas deixadas pelos dedos de um oleiro durante a rotação do vaso, e já que isso acontece, mesmo usando esse instrumento, não o utiliza e deixa impressas as digitais que lhe se escapam enquanto confecciona seu vaso.

A demanda por suas peças é grande e ele sabe que a distribuição atinge lugares que jamais terá oportunidade de ver. Isso o consola e o motiva nas minúcias. Porém, antes de mais nada, ele sabe que o primeiro passo é encontrar um lugar de argila de boa qualidade, afinal, não são todos os lugares que reservam à produção um bom material para confecção e um oleiro experiente sabe disso. Ainda que não domine o conhecimento de que a argila se origina da degradação de rochas base do tipo cristalina e eruptiva como os feldspatos, granitos e basalto, sendo dessa forma, um silicato de alumínio hidratado composto por óxido de alumínio, óxido de silício e água; e que pelo processo depositório aluvial as partículas menores e mais leves são levadas pela corrente d'água, depositando-se em lugares onde a força hidrodinâmica já não é mais suficiente para mantê-las em suspensão, criando assim, os depósitos argilíticos, como um bom oleiro ele sabe onde encontrá-las. 
As argilas primárias, de difícil acesso, são formadas no mesmo lugar da rocha matriz, onde sofrem menos ataque dos agentes atmosféricos, possuindo partículas mais grossas e coloração mais clara, pouca plasticidade, contudo, grande pureza e alto nível de fusão. Entretanto, ele procura sua matéria-prima nas argilas secundárias, aquelas que sofrem com a ação das intempéries e colúvio, sendo assim mais finas e plásticas, podendo, entretanto, conter algumas impurezas ao se misturarem com outras matérias orgânicas, mas isto não lhe importa. Trabalhando a argila lhe confere a forma desejada e em sua oficina produz vasos a uma demanda específica, que assim como as demais demandas acabam por dispersarem-se e dissiparem-se pelos mais distintos espaçostempo.

Com o decorrer das muitas centúrias é natural não restarem mais tantos exemplares desse oleiro, pois como diria certo pensador ${ }^{1}$, o mundo não muda apenas em suas formas, mas também em seus sentimentos e essas dimensões estão sempre conjugadas.

É dessa forma que numa bucólica manhã dominical londrina, após enfadonhas horas sentado no banco de uma catedral, ouvindo sermões e cânticos, um arqueólogo cumprindo o termo social, espera pacientemente seu fim. Encerrado o evento, levanta-se e dirige-se à saída. A princípio, por estar sobressaltado pelo iminente atraso e chuva, que incidiam na sua agenda, não notou um velho vaso que lhe servira de recipiente ao guarda-chuva, tanto seu quanto dos demais presentes. Depositando-o ali logo procurou acento. Contudo, já em sua saída quando leva a mão para pegar novamente seu guardachuva, mal pode acreditar no que seus olhos - agora mais atentos - estavam a ver. A identificação foi imediata: tratava-se de uma cerâmica "Black Burnished ware". Questionando os presentes sobre como e quem houvera trazido e colocado aquele vaso ali, ninguém soube responder. Na verdade muitos não entenderam as perguntas, pois afinal tratava-se daquele velho vaso que "desde sempre esteve ali". Após explicar a importância do vaso em questão e com as devidas concessões dos eclesiásticos, a cerâmica passou a compor o acervo do museu ao qual o arqueólogo estava ligado.

\footnotetext{
${ }^{1}$ Gosden 2005
} 
Apesar disso, entre os frequentadores do recinto religioso há quem diga que ainda o prefira como suporte para os guarda-chuvas.

Se por um lado as decisões tomadas quando os objetos são feitos podem ocorrer sem deliberada reflexão sobre seu significado, por outro elas nunca acontecem sem um conhecimento geral prevalente do contexto social e das formas materiais existentes. Assim é que um dos mistérios dos objetos é que eles podem tomar uma infinidade de formas em tensão de semelhanças e diferenças, com a capacidade de ordenar e reordenar seus efeitos e finalidades conforme os contextos existentes (Gosden 2005: 193-209).

A cerâmica, assim como os demais artefatos, atua enquanto meio de comunicação e expressão social, veiculando "mensagens" que por vezes podem condicionar e até controlar determinadas ações. Em outros casos, os artefatos podem simplesmente passar "despercebidos", mas ainda assim acabam por transmitir referenciais dos mais variados. Nessa relação os seres humanos desempenham um ativo papel de fomento dos significados e modelagem do mundo que os cerca, interagindo com o ambiente e não meramente reagindo a ele (Beaudry, Cook, Mrozowski 2007: 77). Somos educados pelos objetos ao nosso redor, conferindo-lhes posturas e pressupostos, retificando e ratificando através dos interstícios ocupados pelos objetos, nossas sensações e impressões a respeito dos mesmos. Os objetos, por sua vez, obedecem a seu contexto essencial, que dentro da coletânea de outros objetos, gera o princípio dos estilos. Um dado objeto está associado, ao mesmo tempo, a outro objeto de mesmo estilo e, consequentemente, dissociado de objetos de estilos diferenciados. A questão é perceber no amálgama de associações e dissociações, suas inter-relações. O domínio "inter-artefatual" e os estilos dos objetos fornecem um meio de compreender a lógica interna da materialidade e do ambiente construído (Gosden 2005: 209), como no exemplo do vaso e do guarda-chuva que expus acima.

Nas últimas décadas, os estudos que tangem a relação do estilo e dos sistemas tecnológicos, segundo Dias e Silva (2001), podem ser divididos em dois enfoques principais: o primeiro como resultado das estratégias adaptativas, inter-relacionadas 
com os limites se possibilidades do meio natural e demandas de organização socioeconômica; e o segundo tendo os sistemas tecnológicos como construção social e resultado de escolhas tecnológicas culturalmente circunstanciadas. Nesse sentido um determinado sistema tecnológico é concomitantemente um produto e recurso de criaçãomanutenção de um ambiente natural e construído simbólica e socialmente. Em outras palavras, "a tecnologia é entendida como signo e, portanto, carregada de significados e pode ser definida como corpus de artefatos, comportamentos e conhecimentos transmitidos de geração em geração e utilizado nos processos de transformação e utilização do mundo material" (Dias e Silva 2001: 97). É exatamente dessa maneira que os sistemas tecnológicos, ou seja, os "modos de fazer" estão relacionados aos sistemas de representação e, nesse sentindo, local de manifestação estilística.

Nos aspectos formais é importante o perscrutar dos efeitos da materialidade e como esses efeitos implicam no desenvolvimento dos mais variados estilos, bem como o tempo que se mantém vigente. A categoria de estilo, então, abrigaria três aspectos fundamentais: 1) um determinado modo de fazer algo ou alguma coisa; 2) que este modo de fazer implica em escolhas dentre possibilidades alternativas; e 3) que é próprio de um determinado tempo e lugar (Dias e Silva 2001: 97). Já nas representações simbólicas o acesso ao particular, ao cognitivo no que tange ao questionamento dos significados no registro arqueológico, oferece muitas vezes - através das variadas perspectivas teóricas empregadas, entre elas o estruturalismo, a semiótica cognitiva, a teoria econômica, o marxismo ou mesmo teoria crítica -, possibilidades interpretativas e explanações sobre a diferença social e o problema das representações ${ }^{2}$.

Porém, ainda é presente a ideia de que a noção do simbólico se opõe ao real, assim como o alegórico ao sóbrio, o figurativo ao literal, o obscuro ao claro, o estético ao prático, o místico ao mundano e o decorativo ao substancial. (Geertz 1989: 135). Essas premissas ainda presentes em nosso meio são resquícios provenientes da intelectualidade do século XIX. No desenvolvimento dessas ideias emergiu uma associação entre a fixação dos significados e o referencial espacial, que logo foi tomado

\footnotetext{
${ }^{2}$ Sobre essa temática me ocupo especificamente no capitulo 5.
} 
como "status de panaceia indiscutível", nas palavras de Doreen Massey. Foi assim que a representação, enquanto conceito, foi administrada como espacialização e as características daí derivadas foram também atribuídas ao próprio espaço, entre elas a ação material. Assim, subjugou-se o espaço ao textual, e o conceitual à representação, quando o argumento teria de ser o oposto: o espaço subjuga o temporal e, através da representação, espacializamos o tempo (Massey 2009: 43). Afinal, a cultura é significativamente construída com uma infinidade de eventos sujeitos a interpretações múltiplas.

A cerâmica romana oferece amplas possibilidades de aplicação das premissas ora expostas, em especial as cerâmicas de iluminação. Essas que em inúmeros casos servem de matrizes diretoras na cronologia de muitos sítios e estiveram sujeitas a grande circulação e transformação morfológica em curtos períodos temporais, além de contarem com vasto repertório iconográfico, aludindo a distintos contextos e representações sociais.

\subsection{Cerâmicas de engobo vermelho: a diversidade de terras-sigillatas}

As cerâmicas de engobo vermelho de imediato suscitam questões que ainda não foram respondidas, sendo uma delas a transição das produções de engobos negros e influência helenística para as de engobos vermelhos. A questão que permeia esse debate é se a origem das cerâmicas de engobos vermelhos está na Itália ou na parte oriental do império romano. Certo é que, além de procurar uma relação de causa-efeito para os fabricos orientais e itálicos, o debate atual sugere o questionamento das mútuas influências, das relações de troca entre artesãos e da forma como estas duas regiões estiveram em atividade nesse tipo específico de produção. 
Apesar do argumento de Hayes (1972), de que as produções itálicas teriam influenciado a produção de sigillata oriental, o contrário parece mais verossímil. Ainda que a presença das marcas de oficinas itálicas - C.SENT, de Arezzo, SERENI, provavelmente de Pozzuoli, e ARRE/TINA - apareçam em cerâmicas de sigillata oriental, é mais provável que a produção de cerâmicas cobertas por engobos vermelhos tenha recebido inspiração da sigillata oriental tipo A, importações que chegaram à Itália ainda no I século a.C. A exportação desse tipo cerâmico para diferentes partes do império acontece durante um período em que a sigillata arretina ainda não tinha se espalhado e alcançado proeminência nas relações mediterrânicas. Talvez por isso a sigillata itálica assemelha-se mais com as campânicas do que propriamente com a sigillata Oriental em seu período inicial de fabrico (Viegas 2003: 30).

Nesse sentido, embora a área de difusão da sigillata oriental tenha sido majoritariamente a metade oriental do Mediterrâneo, sua produção se estende e abrange porções da parte ocidental, como por exemplo, as áreas de Pompéia, Tripolitânia e Santarém, onde esse tipo cerâmico pode ser atestado.

Para não criar a falsa impressão que cerâmica terra-sigillata é tratada aqui como um bloco monolítico, ou ainda, está dividida entre a produção itálica e a produção oriental, é pertinente apresentar os diferentes tipos existentes, com o propósito de nuançar suas diferenças e semelhanças, dadas as variações existentes.

\section{a) Terra sigillata itálica}

A menção de Plínio sobre Arezzo (Arretium) como centro produtor de cerâmica acarretou a ilação de que esse seria o único local - ou o mais importante - onde esse tipo cerâmico era produzido. Os autores do final do século XIX e inícios do XX buscaram uma maior sistematização nesse estudo e Dragendorff (1985) designou muitas das formas que são identificadas até hoje, sobretudo na Gália; seguido cronologicamente pelos estudos de Loeschcke (1909), que, baseado no estudo da sigillata presente na base militar de Haltern, apregoou a hipótese da existência de um único centro produtor. 
Embora as atribuições de Haltern possam ser questionadas, seu enquadramento cronológico, salvo alguns exemplares, se mantém correto e somente em análises químicas - e daí seu extenso valor - foi possível perceber que apenas $10 \%$ das pastas eram originárias da localidade de Arezzo, sendo o restante proveniente de Pisa e Lyon (do sítio de La Muette) (Lesfargues e Vertet: 1976; Viegas 2003).

Além das questões relacionadas à origem e formas, discute-se atualmente o papel das pequenas oficinas no fornecimento e abastecimento dos mercados consumidores, tendo inerente algumas ideias como a de Pucci (1985), que sugere que essas pequenas oficinas formavam verdadeiras redes direcionadas a demandas distintas, o que parece ser de fato, uma interessante hipótese (p.369). Analisando as marcas de oleiros e compilando os dados existentes sobre sigillata arretina, Fulle observa o caráter não-urbano dessa produção, na mesma tendência das ânforas e cerâmicas de construção (Fulle 1997: 111-155). Essa afirmação acaba contrariando, portanto, a ideia das oficinas cerâmicas como "empresas" destinadas à produção, com elevada subdivisão e especialização do trabalho, na incidência de grandes centros urbanos.

Assim, as terra-sigillata de tipo itálico tem sua produção identificada para a região da Etrúria, por volta de 45 a.C., coincidindo com as datações para as produções da cerâmica campânica. A fabricação do conjunto cerâmico itálico é caracterizada em linhas gerais por uma pasta dura, de fratura linear com pequenos vácuos, alongados ou arrendados, pouca quantidade de enp e de pequenas dimensões, brancos ou brancoamarelados. O engobo contém brilho e geralmente de espessura média (Quaresma 2009: 13). Os fabricos iniciais desse tipo cerâmico demonstram o escasso domínio da oxidação e é possível notar nos engobos vermelhos algumas manchas acastanhadas, fruto do processo de cozedura (Veigas 2003: 43).

Parece existir algum tipo de consenso quanto à falta de conhecimento integral das áreas que comporiam esse centro produtor, e até o momento têm-se identificado os seguintes centros de produção: região de Nápoles, Arezzo, Pisa e Pádua (SchindlerKaudelka; Schneider; Zabehlichy 1997: 481). As diferenças químicas entre os grupos de referência dessa terra-sigillata são pequenas, estando as maiores nuances na região de 
Arezzo, Pisa e Lyon. Porém, conforme alerta José Carlos Quaresma (2009) até o momento a amostra das análises químicas ainda é escassa, o que torna a relação estatística dos dados complicada para maiores afirmações além das já referidas. Na opinião de Schneider e Daszkiewicz (2006: 538-542), corroborada por Quaresma, existe uma incapacidade na atribuição de centros aos grupos químicos de Roma, igual realidade se apresenta para a região de Nápoles e mesmo em Lyon, onde a amostragem é mais segura, permanecem muitas dúvidas, pois os vasos importados pela área setentrional do Império não condizem com os grupos de referência do referido centro.

\section{b) Terra sigillata sudgálica (La Graufesenque e Montans) e centro-gálica}

Localizada numa posição favorável, às margens de um rio e junto a vias de comunicação, as oficinas da região dos Rutenos, no limite sul da Aquitânia, contavam com abundante matéria-prima. Ainda no século XIX foi possível a identificação desse centro produtor e logo veio à percepção que existiram diversos centros cerâmicos na Gália, tendo os mesmos crescido em importância durante o I século a.C. e I século d.C., após uma aparente queda das produções itálicas (Vernhet 1986:. 96).

Atualmente para esse tipo de sigillata distinguem-se dois grupos geoquímicos: a La Graufesenque e a Montans, de fácil distinção entre suas pastas. A maior aproximação nessa acepção é notada quando os produtos de Montans não apresentam sua comum coloração clara, tendo pastas mais avermelhadas (Dejoie; Relaix; Sciou, 2005: 10-13; Quaresma 2009: 18).

A pasta da La Graufesenque se caracteriza pela sua espessura fina, dura e de coloração castanho-rosada, tendo pequenas partículas de calcário branco, engobo vermelho, semi-vitrificado e muito aderente. (Vernhet 1986b; Quaresma 2009). A fratura da pasta é nítida, de um rosa-castanho pálido (Munsell 10R 6/8, por vezes $6 / 6$ ou 5/8), com teor elevado de cal, em partículas inferiores a $0,1 \mathrm{~mm}$ de dimensão e vácuos alongados de 2,0 mm. O engobo vermelho-castanho (10R 5/8) conta com um verniz bem lustrado. Já as pastas Montans são geralmente claras, bege-rosado ou vermelho- 
castanho pálido (10R 6/8 ou 8/8), fina, tendo uma pasta mais mole e de fraturas pouco nítidas. Encontram-se nas amostras minúsculas partículas de cal (Martin 1986b; Quaresma 2009) contendo maior índice de calcite em comparação com a La Graufesenque. As partículas podem ter de 0,1m de dimensão até 0,4 mm, com presença de mica branca ou grãos de ferro, com aproximadamente $0,3 \mathrm{~mm}$ de dimensão e vácuos de 1,0mm. O engobo de um verniz lustrado com coloração vermelho-castanho (10R 5/8 ou 4/8) mais pálido do que a La Graufesenque coloca seu fabrico mais próximo dos produtos centro-gálicos de Lezoux.

Tecnicamente a produção do século II e III d.C. dos produtos centro-gálicos apresenta uma melhora substancial, com novas formas que aparecendo no início do século II (Vertet 1986: 124). Até o momento a área de Lezoux é identificada como a principal região dessa produção que tem uma pasta amarelada, rosa, salmão ou vermelho-tijolo, com engobo vermelho, vermelho-laranja e vermelho-escuro, brilhante e/ou muito brilhante (Bet e Vertet 1986: 139).

\section{c) Terra sigillata hispânica}

Não é totalmente segura a localização ou localizações das áreas produtoras desse tipo cerâmico, sendo que distintos autores denominam essa cerâmica de diferentes formas. Quatro designações assumem preponderância no atual contexto dos estudos desse tipo de sigillata: Martinez Rodríguez (1989) define-a como "cerâmica bética de imitação tipo Peñaflor", Serrano Ramos (1999a) chama de "produções hispânicas precoces"; Amores e Keay (1999) utilizam o termo "sigillatas de imitação tipo Peñaflor”; e; segundo Keay, Creighton e Remesal Rodríguez (2001) elas são as "sigillata itálica local". Questão de nomenclatura a parte, esse tipo cerâmico, que foi caracterizado pela primeira vez em 1967 por C. Domergue como "cerâmica de verniz vermelho tardio" (Martínez Rodriguez 1989: 61; Quaresma 2009: 71), tem na área de Peñaflor, nas imediações da antiga Celti, seus dados mais substanciais.

Os resultados dos trabalhos em Peñaflor demonstram que esse tipo de produção se estendeu desde época tardo-republicana até o século V d.C., procurando reproduzir, com as mesmas características, as formas tecnológicas itálicas, gálicas e africanas. 
(Quaresma 2009: 72; Amores e Keay 1999: 240). No primeiro momento essa produção se assemelha à terra-sigillata itálica, com paredes finas, engobo vermelho pompeiano; e num segundo momento aproxima-se mais das sigillatas gálicas. Posteriormente a produção inspira-se na sigillata africada, em suas distintas variantes, a saber: A. C e D (Amores e Keay 1999: 240-241). Parece ser consenso atualmente que é durante meados do século I d.C. que esse tipo de produção atinge seu auge, dando lugar em seguida à terra-sigillata de Andújar

A região de Tricio - atinga Tritium Magalum - também figura como um destacado centro produtor desse tipo cerâmico, tendo em áreas como Bezares, Arenzana de Arriba e Nájera, excelentes condições geográficas à obtenção de matéria-prima (Mezquíriz 1985: 114). O centro produtor de La Rioja e/ou as oficinas do Vale do Ebro beneficiaram-se da existência de uma intensa rede viária, tanto terrestre como fluvial - o próprio rio Ebro - e distribuíram seus produtos via cidades como Caesaragusta e Mérida, chegando a áreas como Tarraconese e Lusitania (Sáenz; Sáen 1999: 70).

A evolução das formas de sigillata hispânica está amplamente baseada na estratigrafia de Pamplona, na região de Navarra, indo de meados do século I d.C. a inícios do século V d.C. Entretanto, como reconhece C. Viegas (2003: 139) corroborando a prerrogativa C. Saénz (1999: 65), ainda é necessário estabelecer estudos apoiados em estratigrafias mais seguras, sem ter em mente os estudos tipológicos dos trabalhos clássicos como dogmas de fé - o que muitas vezes implica na ausência de questionamentos e defrontações. Antes, é preciso estabelecer um refinamento cronológico e identificação dos centros produtores com maior acuidade.

A difusão desse tipo cerâmico é mais conhecida, portanto, na região de Andújar e oficinas béticas, situadas junto ao Guadalquivir, que possui tradição oleira de produção desde a cerâmica ibérica pintada até cerâmicas de iluminação (Sottomayor, Roca, Fernández 1999: 21). Porém, a caracterização tanto para os produtos de Tricio quanto para os de Andújar é complicada; bem como as relações de mercado estabelecidas para os produtos hispânicos, de forma geral. A emergência substancial de oficinas de pequena escala, para esse caso, sobretudo em finais do século I d.C., tem sido interpretada sob a ótica do aumento na produção diante da procura exacerbada de 
cerâmicas de mesa (Saénz; Saénz 1999: 74-77). Seria dessa forma que esse tipo cerâmico - através de muitas oficinas de pequena escala - lançaria sua produção sobre a região.

Quanto ao fabrico, o grupo cerâmico apresenta distinta fratura, com arestas retilíneas, tendo uma pasta dura, embora se desfaça facilmente pela ação mecânica. $O$ engobo é fino, estaladiço e pouco homogêneo, produzindo um efeito de mancha. (Quaresma 2009: 96). É característico nessa cerâmica um tipo de decoração roletada (guihoché) nas paredes exteriores dos vasos, sendo uma influência de vasos de paredes finas (Roca 1976: 77), as marcas de oleiro também são frequentes nas formas lisas e abundantes nas cerâmicas de mesa, como os pratos. É dessa maneira que se podem diferenciar os oleiros que produziram sigillata hispânica em Tricio e Andújar (vide Roca e Fernández 1999: 291-296).

\section{d) Terra sigillata africana}

A terra-sigillata africana foi caracterizada pela primeira vez por Hayes (1972), sendo retrabalhada por Carandini (1981), quando o mesmo propôs maior divisão no tipo cerâmico apresentado pelo primeiro autor. A princípio Hayes nomeou a fase inicial das produções norte-africanas de sigillata clara A, tendo como referencial peças de cor laranja-avermelhado, pasta esponjosa, com pequenas partículas de quartzo, micas e calcário. Os engobos de boa qualidade, algumas vezes lustrosos, da mesma coloração da pasta, tendendo a cobrir a superfície interna e externa das peças era outra característica marcante (Hayes 1972: 289; Veigas 2003: 165). Essa cerâmica teria seu início no final do século I a.C. e início do século II d.C., sendo que semelhanças entre as peças de produção sudgálicas pode ser evidenciadas em seu momento inicial.

No interior da produção A, Carandini (1981) identificou três fabricos com base no engobo das peças, distinguido três cronologias com a nomenclatura: A1, A1/2 e A2. O tipo cerâmico A1 seria de fins do século I a.C. a meados do século II d.C., com engobo fino e brilhante, sendo a produção A1/2, da segunda metade do século II d.C. com um engobo menos fino e brilhante. A pasta A1 é dura, compacta, granulosa, tem 
vácuos alongados e/ou raramente os possui, tem cozedura forte, fratura irregular e engobo medianamente fino.

A pasta A2 apresenta-se mais dura, pouco compacta, granulosa, com vácuos alongados e/ou raramente os possuindo, quartzo de médias dimensões, por vezes com alguma mica ou minerais de coloração negra. O engobo parece ser mais fino que na A1, com início redutor e fim oxidante, o que faz com que seu núcleo seja cinzento.

A sigillata clara $\mathrm{C}$ apresenta uma qualidade muito depurada em seus engobos e pastas, essas mais macias e finas que a sigillata clara A. Essa produção inicia no começo do século III d.C. - sigillata clara C1 - e irá dominar os mercados do Mediterrâneo oriental durante o decorrer desse século com sua variante (C2). Carandini ainda apresenta os tipos C3 e C4, que em sua descrição apresentam engobo mais espesso, cobrindo a superfície interna e a parte superior da borda das peças. A cronologia mais avançada para essa variação é a da C4 que atinge todo o século IV d.C. e primeira metade do século V d.C. (Carandini 1981: 15).

Ainda é distinta a sigillata clara D que recupera o fabrico da tipo A, mas se caracteriza por pastas de textura granular fina e engobo de pouca espessura, pouco lustroso e, por vezes, rugoso. Esse fabrico tem duração de inícios do século IV a meados do século VII d.C., com diversas fases estipuladas por Hayes (1972), tendo como característica principal o engobo não cobrir toda a superfície externa. O fabrico D1 (IV e V d.C.) distingue-se do fabrico D2 (IV e VI d.C.), sendo que o último apresenta engobo mais espesso e brilhante pelo acentuado polimento que recebe.

A terra-sigillata africana remete sua origem à região de Cartago; muito embora não sejam amplamente conhecidos esses centros produtores, escavações italianas, inglesas e alemãs aplicaram-se ao escrutínio das áreas (Hayes 1972: 298; 1980: 518; Bonifay 2004: 45). O surgimento desse tipo cerâmico foi denominado como "proto african red slip ware', com datações de inícios do século I e principio do século II a.C. (Hayes 1978: 36). Essa produção proto terra sigillata africana é também conhecida como cerâmica Utica, destinando-se a um mercado somente local. As escavações 
italianas e inglesas (Tortorella 1982, Fulford; Peacock 1984), assim como as alemãs (Mackensen 2004: 153; Rakob 1999), demonstraram em níveis tardo-romanos que o contexto é do segundo terço do século I d.C., sem a presença de terra-sigillata africana propriamente dita (Martin-Kilcher 1999).

Baseado em alguns vestígios em depósitos fluviais foi proposta a região do vale médio do rio Mejerda como local do fabrico da cerâmica africana tipo A, entre Bulla Regia e Simitthus ou entre Dougga e Uchi Majus (apud Bonifay 2004:.45). Nos trabalhos realizados ente os anos de 1987 e 1997 foram identificados 38 sítios no litoral tunisino, espalhados de Sul a Norte, com a presença da sigillata africana A e formas A1 - aparecendo em três sítios - e formas A2 associados ao material do século III d.C.. As análises químicas de porosidade e ativação de nêutrons sobre uma amostra de 194 fragmentos de sigilata africana provenientes de San Sisto Vecchio, Roma, produziram diferenças no interior de uma mesma amostra. Quando Schuring (1988) relacionou os tipos A, A/D e D entre si, notou que o tipo cerâmico A1 apresentou três fabricos distintos e o tipo $\mathrm{A} 2$ outros três fabricos, relacionados à mesma área dos tipos A, A/D e D, sendo somente a cerâmica de cozinha polida de uma produção distinta. Assim, fica evidente a grande variedade de fabricos e necessidade de mais pesquisas nesse sentido.

A terra-sigillata africana A ainda não possui uma cronologia segura e a mais verossímil é aquela dada pelos centros de consumo italianos. Contudo, em Ostia, Roma e Pompéia, os dados passam somente a ser mais seguros a partir do período Flaviano (Carandini e Panella 1977: 331). Diante dos dados de Ostia, Hayes (1980) estabelece novas cronologias, sugerindo que as datações do século II d.C. em seu livro Late Roman Pottery, estavam vinte anos recuadas. Esse problema é creditado às cronologias que foram estabelecidas por Lamboglia (1958) e seriam demasiado prolongadas.

Segundo Quaresma, se analisarmos os dados de Ostia e a camada XXV das Termas do Nadador, é possível perceber no strato V (80-90 d.C.) que apenas nove exemplares são importados; já no strato IV (90-140 d.C.) são quatorze exemplares, e após um hiato estratigráfico de cinquenta anos, no strato III (190- 220/225 d.C.), aparece aquilo que poderia ser um implemento e diversificação do comércio local com a 
presença mais intensa das formas africanas tipo A, tanto a antiga (A1) como tardia (A1/2 e A2), num total acumulado de 123 exemplares. Isso demonstra a capacidade de expansão e variação das produções africanas (Quaresma 2009: 164-5).

Nos últimos anos M. Mackensen e G. Schneider (2002 e 2006) vêm se dedicando ao mapeamento das áreas produtoras de cerâmica norte-africana. Através de análises químicas $\left(\mathrm{WD}_{\mathrm{XRF}}{ }^{3}\right.$ ) nas áreas de Sidi Marzouk Tounsi, el-Mahrine, Henchir el-Biar, Henchir el Guellal (Djilma) e Henchir es-Srira., os autores têm refinado e precisado melhor a origem dos fabricos. Discorrendo sobre o centro produtor de Djilma e Henchir es-Srira refinam a cronologia dessas áreas e tecem interessante observação sobre as decorações em relevo:

"Em Henchir el-Guellal (Djilma), na outra mão, um plano de produção a.C., formas $C^{l}$ e $C^{2}$ foram discernidas assim como as lamparinas red-slipped com dcoração em relevo, embora não haja evidência de produção de vasos com decoração aplicada. Em Henchir es-Srira, juntamente com o tipo ARS é produção $C^{2}$, a produção de relevos decorados, vasos red-slipped das oficinas de Navigius é atualmente confirmada pertencer ao $3^{\circ}$. Século d.C.(...) Os exemplos dos vasos $A^{1}$ e $A^{2}$, surpreendentemente formam um grupo de referência homogênea, pontuando sua produção em um único, mas ainda deslocado centro no nordeste da Tunísia, onde, do tardio $1^{o}$. ao início do $3^{\circ}$. ou ainda, no médio $4^{o}$. D.C., plano e decoração aplicada $A^{1} e^{e} A^{2}$ sigillata são produzidos." Mackensen e Schneider 2002: 179) ${ }^{4}$

De forma geral, a decoração das sigillatas africanas permite um recorte cronológico mais seguro nas decorações aplicadas. As decorações em relevo teriam sido produzidas com molde de meados/finais do século IV e início do V d.C., em menor escala que outros estilos. A decoração aplicada teve maior vigência durante os séculos

\footnotetext{
${ }^{3}$ Wavelength-Dispersive X-Ray Fluorescence

${ }^{4}$ At Henchir el-Guellal (Djilma), on the other hand, a production of plain $\mathrm{A} / \mathrm{D}, \mathrm{C}^{1}$ and $\mathrm{C}^{2}$ forms was discerned, as well as of red-slipped lamps with relief-decoration, although there was no evidence of a production of appliqué-decorated vessels. At Henchir es-Srira, in addition to ARS ware is fabric $\mathrm{C}^{2}$, the production of relief-decorated, red-slipped vessels from workshop of Navigius is now confirmed for $3^{\text {rd }}$ c.(...) The samples of the $\mathrm{A}^{1}$ e $\mathrm{A}^{2}$ vessels surprisingly form a homogeneous reference group pointing to their production in a single, as yet unlocated centre in N(E) Tunisia, where, from the late $1^{\text {st }}$ until the early $3^{\text {rd }}$ or even the mid- $3^{\text {rd }} c$., plain and appliqué-decorated $\mathrm{A}^{1}$ and $\mathrm{A}^{2}$ sigillata had produced".
} 
III e IV e inícios do século V d.C. As temáticas do século III d.C. caracterizam-se pela dispersão de motivos relacionados a espetáculos com feras e cenas de caça ("venationes"), no corpo e/ou fundo dos vasos (Viegas 2003: 166). Distinguem-se ainda as variantes: A (i), A (ii) e A (iii), com cronologias das primeiras décadas do século IV e último quartel do século V d.C., nas decorações com motivos florais e geométricos e composições radiais. O tipo B de meados do século IV ao primeiro quartel do século $\mathrm{V}$ d.C. e o tipo $\mathrm{C}$ de finais do século IV e meados do V d.C., contam com incipiência de figuras com animais - principalmente pássaros. Posteriormente, símbolos cristãos especialmente o monograma da cruz - foram incorporados em seu repertório, correspondendo ao tipo D. No tipo E as figuras humanas e outras espécies de animais se tornaram presentes, tendo cronologia do primeiro quartel do século $\mathrm{V}$ e início do século VII d.C. (Hayes 1972: 217-220).

Além das decorações com relevo, estampa e aplique, a sigillata clara africana ainda conheceu técnicas como as caneluras, o guilhoche, barbotina, os gomos, entalhes, orifícios e padrões brunidos e enegrecidos. O que dá uma dimensão da vivacidade e dinâmica dos produtos dessa parte do Império. Mackensen e Schneider ressaltando o valor dessa prerrogativa postulam que:

“(...) O relevo ou decoração estampada do tipo ARS permite uma avaliação da habilidade dos artesãos individualnte, oficinas ou de todos os centros de produção. Além disso, permite uma dedução dentro da compreensão do repertório de imagens alegóricas, mitológicas, profanas e cristãs e sua dependência de outras artes e habilidades, tais como touretics (vasos de bronze e prata), objetos de mármore ou vasos de vidro." (Mackensen e Schneider 2002: 163$)^{5}$

A produção da África Proconsular, Bizacena e Tripolitana obteve ampla aceitação no mercado mediterrânico, sendo largamente comercializada, sobretudo no

\footnotetext{
5 "The relief or stamped decoration of ARS ware allows an assesment of the craftwork of individual potters and workshops or of whole production centres. Moreover, it provides an insight into the comprehensive repertoire of allegorical, mythological, profane and Christian imagery and its dependency on other arts and crafts such as toreutics (bronze and silver vessels), ivory objects or glass vessels"
} 
século II d.C, momento que parece ser o auge desses produtos (Viegas 2003: 167). A demanda contemplava desde as cerâmicas de cozinha até as cerâmicas de iluminação, com a exportação de lamparinas, e outros produtos alimentícios, como o azeite e o garum $^{6}$, participando, dessa forma, de todo o interfluxo, tanto comercial como imagético, das rotas culturais que influenciavam o Mediterrâneo.

\subsection{Cerâmicas romanas de iluminação: entre morfologias e tipologias.}

O termo grego $\lambda \boldsymbol{v} \chi \boldsymbol{v}$ ópııv significa lucerna, lucernetta ou para o português no Brasil, simplesmente lamparina, trata-se, na verdade, de um substantivo feminino da palavra $\lambda \boldsymbol{v} \chi v i ́ \alpha$. Pelo menos desde o fim do século XIX as lamparinas como área dos estudos cerâmicos de iluminação recebem atenção por parte de uma gama de intelectuais. Entretanto, apesar da sumarização dos dados obtidos nos mais distintos catálogos e do conhecimento de alguns centros produtores, ainda hoje não se tem a mesma relação estabelecida para as características gerais das lamparinas que foram produzidas nestes mesmos centros produtores.

Nos últimos quarenta anos o conhecimento sobre as cerâmicas de iluminação avançou de forma significativa e assinalando essa premissa Ángel Cerdan (1990) aponta que "La mayor parte de las Memorias de Excavación recogen este material. La publicación de catálogos de colecciones y museos más importantes se halla en una fase muy avanzada. Los análisis químicos de pastas así como los estudios iconográficos, de producción y comercialización abren nuevas vias de aproximación al tema con prometedores resultados.." (p. 143). É assim que, apesar dos desdobramentos mencionados, a elaboração das tipologias ainda figura como um ponto sensível que

\footnotetext{
${ }^{6} \mathrm{O}$ garum ou liquamen era um género de condimento feito de sangue, vísceras e de outras partes seleccionadas do atum ou da cavala misturadas com peixes pequenos, crustáceos e moluscos esmagados; deixado em salmoura e ao sol durante cerca de dois meses ou então aquecido artificialmente.
} 
carece da integração sistemática dos dados dispersos entre os autores e suas tipologias próprias. Existe um acentuado número de classificações advindas dos mais variados pontos do império romano, sendo que algumas dessas classificações - na verdade boa parte delas - foram realizadas sobre coleções contidas nos museus, o que implica muitas vezes na falta do controle estratigráfico e comprometimento das cronologias propostas. Portanto, para levar a cabo um estudo sobre as cerâmicas de iluminação no contexto atual, como bem observa Cerdan (1990), é necessário enfrentar um acúmulo de classificações morfológicas de origem, estrutura e terminologia muito variada, necessitando um labor prévio de revisão de cada uma delas. A partir desse primeiro passo, então, é possível buscar as equivalências e similaridades, procurando alinhar o conjunto de peças selecionadas ao contexto amplo dos estudos cerâmicos. Essa relação torna-se um árduo, complicado e pouco gratificante trabalho (Cerdan 1990: 144). Por não haver um "Corpus", como acontece em outras produções cerâmicas, que sirva de guia-base, é comum deparar com muitas formas que coincidem em aparência, porém têm nomenclaturas diferenciadas. Além de que, em outros casos, a presença ou ausência de decoração implica na indecisão a respeito de a qual grupo pode a peça pertencer. Essa variabilidade tipológica obedece diametralmente aos critérios de classificação e seleção que cada investigador postulou e empregou como premissa a seguir em seu trabalho. Algumas vezes priorizam-se os aspectos tecnológicos e/ou decorativos e em outros casos a relação da morfologia, cronologia ou a conjugação de ambos que fica em evidência, sendo os catálogos anteriores à década de setenta do século passado ${ }^{7}$ aqueles que mais se utilizam da prerrogativa da morfologia, considerando-a a mais útil.

O primeiro a propor uma sistematização tipológica baseado nas formas para as cerâmicas de iluminação foi Dressel (1889), seguido por um intervalo de dez anos por Besnier e Blanchet (1900), que estudando a Coleção Forges adotaram como critério tipológico a presença ou ausência da alça nas lamparinas. Dando preferência ao bico e diferenciando quatro formas, Walters (1914) estudou os exemplares do British Museum. Ainda pesquisando as lamparinas do British Museum, Bailey (1980 e 1988) publicou quatro volumes, priorizando a forma e evolução do bico. Os catálogos de Loeshchcke

\footnotetext{
${ }^{7}$ Para citar alguns: Dressel, 1889; Walters, 1914; De Brun y Cagniere, 1937; Lerat, 1954
} 
(1919) e Broneer (1930) - além do de Dressel (1889) - foram os primeiros a elaborar suas tipologias com base em sítios arqueológicos e escavações com controle estratigráfico, respectivamente Vindonissa e Corinto. Dessa forma, a região centro europeia é mais bem conhecida do que os grandes centros italianos de produção, e suas cronologias melhor ajustadas. O mesmo pode-se dizer em relação ao Norte da África e em algumas cidades como Corinto, Tarso, Olímpia e Atenas, onde se encontram dados seguros.

O que parece ser consensual entre os autores é que as lamparinas romanas derivam de protótipos helenísticos, sendo explicadas as afinidades estilísticas através das relações comerciais entre as cidades helênicas da Campânia e o Lácio (Broneer 1930). Os modelos helênicos ${ }^{8}$ serviram, portanto, de base para as produções romanas até o período de Augusto, em que um vasto número de produtos gregos foi importado. A partir desse período o indicativo é de que a Península Itálica passou a figurar como principal centro produtor e exportador no Mediterrâneo e outras relações se estabelecem.

Assim, passemos à lista sumária das principais produções do estudo de cerâmicas de iluminação romana:

\section{H. Dressel (1899)}

Publicado na secção Instrumentum Domesticum do CIL XV o catálogo é baseado na análise de lamparinas itálicas, este é o primeiro trabalho de sistematização de cerâmicas de iluminação mediante metodologia científica. Dressel classifica trinta e um tipos, aplicando excessiva diversificação e sutis diferenças entre grupos, o que em alguns casos torna difícil sua aplicação. Conforme observa Cerdan (1990), existe um ordenamento cronológico em dissintonia com as formas, sendo que algumas cronologias

\footnotetext{
${ }^{8}$ Vide o trabalho de M.Ricci (1974)
} 
estão erradas, especialmente as relativas às lamparinas de canal (p.145). Entretanto, é um dos mais completos em relação às formas.

\section{H.B. Walter (1914)}

Estudo e classificação das lamparinas romanas do British Museum e considerado um dos melhores. É o primeiro trabalho que atribui cronologias gerais para os grandes grupos, apesar de que alguns desenhos não correspondem exatamente às fotografias das peças. $\mathrm{O}$ autor busca salientar as características comuns dos conjuntos e dá prioridade à análise dos bicos caracterizando quatro formas principais e dividindo-as em outras categorizações.

\section{S. Loeschcke (1919)}

É o primeiro trabalho baseado em uma estratigrafia de sítio, constituindo-se em modelos para os trabalhos posteriores. O catálogo apresenta uma das mais completas e organizadas tipologias válidas atualmente. O estudo parte da análise das lamparinas imperiais, ficando a parte as do período republicano. Apesar da ausência, o autor propõe a duração temporal das lamparinas com volutas de bico triangular e suas subdivisões, sendo amplamente aceitas suas indicações.

\section{O. Broneer (1930)}

Broneer analisou as lamparinas de Corinto, seguindo em certo sentido os critérios estabelecidos por Loeschcke para Vindonissa, entretanto, incorporando produções características do mundo Grego e diferenciando as formas do Mediterrâneo Oriental das importações do Ocidente (Caetano 2001: 43; Pereira 2008). Apresenta uma tipologia muito bem organizada, porém sem a representação gráfica de algumas formas e com muitos subtipos. É o primeiro estudo que particulariza independentemente as lamparinas com volutas e alça plástica, determinando os exemplares constituintes dos séculos II e III d.C. Existe uma pequena diferença de cronologia entre algumas formas 
similares a Loeschcke, e se atribui essa relação a motivos geográficos (Cerdan 1990: 146).

\section{F. Doumergue (1932)}

Catálogo que analisa o material do Museu de Oran, atual Argélia, separando as cerâmicas de iluminação em sete grandes grupos cronológicos e culturais, com breve descrição das mesmas. Não pode ser considerada uma inovação na tipologia, embora em alguns casos seja citada como tal. Contém imprecisões cronológicas, sendo a mais evidente aquela em relação às lamparinas com bico redondo sem volutas, que no catálogo datam do século I d.C.

\section{Ivanyi (1935)}

Adotando o critério da decoração e marcas de assinatura, procura individualizar as formas inspirado principalmente em Loeschke e Broneer. Trata-se, na verdade, da análise de mais de 5.000 fundos de lamparinas romanas advindas da Panonia, atual Hungria, com explicações breves e concisas, e um apurado rigor cronológico.

\section{P. de Brun e S. Cagniere (1937)}

Estudando a coleção do Museu Calvet de Avignon, França, apresenta uma cronologia muito sumária, com tipologia simplificada ao extremo e ausência de lamparinas do período republicano. Segundo Cerdan (1990: 147), é um trabalho que fica aquém das pesquisas anteriores.

\section{F. Alvarez-Ossorio (1942)}

Primeira tipologia realizada na Espanha é baseada no conjunto de peças do Museu Arqueológico Nacional. A ausência de boas fotografias das peças, bem como sua terminologia arcaica e cronologia contraditória, dificulta a utilização desse catálogo. O 
catálogo tem em consideração somente alguns tipos de peças organizados sob um critério muito heterogêneo.

\section{P. de Palol (1948-9)}

Considerado até hoje um dos melhores trabalhos espanhóis, o autor apresenta uma tipologia completa e organizada agregando praticamente todas as variantes existentes no Mediterâneo Ocidental (Cerdan 1990: 147). Traça paralelo com as peças apresentadas por Loeschcke, Walters e Ivanyi; sendo a primeira vez que as peças do período republicado recebem um indicativo cronológico mais atento.

\section{H. Goldman (1950)}

Goldman estuda as lamparinas do Mediterrâneo Oriental, amplamente baseado no trabalho de Broneer, do qual referencia tanto as formas quanto a tipologia. De forma esquemática e simplificada, facilita a compreensão, apresentando as lamparinas de Tarso. A crítica fica na ausência dos tipos republicanos, da mesma forma que ocorre em Corinto.

\section{N. Lamboglia e A. Beltran ou Dressel-Lamboglia (1952)}

Lamboglia mantém a classificação apregoada por Dressel, daí ser também conhecida por Dressel-Lamboglia, porém, acrescenta cronologias mais bem estruturadas para cada forma. O avanço no conhecimento das datações sobre sigillatas foi o que possibilitou tal ajuste, o que Dressel em seu período não tinha como conhecer. Acrescenta um novo grupo de lamparinas de canal largo e fechado e propõe cronologias de peças republicanas no século II-I a.C.

\section{Fernández Chicarro (1952)}

Baseado somente na tipologia formal prioriza essencialmente os atributos cronológicos para a distinção de cinco grandes grupos das peças contidas no Museu de Sevilha. Trata-se de um estudo muito restrito. 


\section{Lerat (1954)}

Carente em relação à cronologia, ainda assim, trata-se de um exemplo de trabalho amparado exclusivamente na relação formal. Classifica os grupos com nomenclatura mista de letras e números, o que por vezes torna complicada a associação quando referenciado por outros autores. Baseada em uma coleção pública conta com demasiadas categorias e subgrupos, comparando as peças com o material publicado por Loeschcke,Walters e Broneer.

\section{Menzel (1954)}

Análise do material do Museu de Maguncia, Alemanha, é apresentada com pouca sistemática, seguindo um critério cronológico que, ao contrário, está bem ajustado. $\mathrm{Na}$ verdade somente os pesquisadores centroeuropeus o levam em maior conta.

\section{Ponsich(1961)}

Trabalho sistemático sobre peças provenientes do Marrocos, conta com um resumo das tipologias anteriores e comparação destas com as morfologias e cronologias dos outros trabalhos. Foi a primeira vez que se realizou tal medida, o que contribui em muito nos estudos subsequentes. Com a combinação de critérios formais e cronológicos apresenta um número restrito de grupos individualizados, com variantes e tabela ilustrativa. Amparado pela estratigrafia das escavações conduzidas até o período em questão, Ponsich influencia diretamente nas tipologias atuais e na relação estabelecida entre o norte da África e a parte Ocidental do Império romano.

\section{J. Perlzweig (1961)}

Catálogo das lamparinas escavadas na Ágora de Atenas, apresenta uma clara divisão interna. A cronologia proposta é bem ajustada e configura-se como um referencial para as lamparinas romanas nessa parte do Império. 


\section{J. Deneauve (1969)}

Baseado nas lamparinas romanas da região de Cartago analisa um grande conjunto de peças e ainda hoje é um referencial. Nota-se a influência dos trabalhos de Loeschcke e Lerat, com uma cronologia mais complicada que a de Ponisch, contudo, com algumas precisões mais acuradas em determinados conjuntos. Devido a posição singular de Cartago e suas relações comerciais, sobretudo, a partir do século III d.C., o catálogo de Deneauve torna-se de muita importância para conhecer a produção das cerâmicas de iluminação na parte oriental do Império.

\section{Th. Szentleleky (1969)}

Catálogo elaborado a partir das lamparinas advindas da Hungria, o autor adota a organização sem os critérios de grupos e subgrupos e opta por uma classificação ordinal, dando ênfase na forma e região geográfica de procedência, o que facilita sua consulta. A cronologia proposta é bem ajustada, tendo algumas datas em dissintonia que são atribuídas à perspectiva regional.

\section{G. Heres (1972)}

Trata-se de um catálogo com tipologia bastante completa e estruturada, tendo muitas peças oriundas do Museu de Berlin. O autor faz a divisão de cinco grupos, com subgrupos, ambos baseados em atributos morfológicos e cronológicos. A cronologia para as lamparinas dos séculos II-III d.C. está muito bem documentada e o autor oferece paralelos com os trabalhos de Loeschcke, Broneer, Ivanyi e outros autores.

\section{Ricci (1974)}

Revisão das lamparinas da época republicana e protoaugusta, a autora introduz algumas variantes até então desconhecidas na classificação de Dressel. Amparada por controle estratigráfico, o que tornas as cronologias mais seguras e Ricci estabeleceu os 
parâmetros temporais para as peças republicanas, mantendo a terminologia criada por Dressel.

\section{A.M. Alarcão e S. de Ponte (1976)}

Utilizando de critério misto de cronologia e morfologia os autores procuram comparações nas tipologias dos materiais de Conimbriga e trabalhos de Deneauve, Dressel-Lamboglia, Ponsich, Ivanyi, Loeschckey e Palol, conforme aponta Cerdan (1990: 150) existem alguns erros de identificação. Poucas lamparinas se encontram completas e faltam alguns tipos.

\section{A. Provoost (1976)}

$\mathrm{O}$ autor procurou uma tipologia geral para todas as lamparinas romanas, com numerosas variantes e subgrupos. Pela primeira vez estipula os critérios para agrupamento morfológico, seguindo uma sequência evolutiva bem determinada, com evidencia para as características de depósito. Provoost é um dos poucos autores que volta sua atenção para as formas do baixo império, sendo esse um fator válido em seu trabalho.

\section{A. Leibunndgut (1977)}

Trabalhando com as lamparinas advindas do território suíço, o catálogo conta com um elevado rigor científico e metodológico. Busca padrões comparativos com o material publicado de Loeschcke, sendo que apresenta o contexto estratigráfico para cada peça. Como característica geral das tipologias centroeurpoeias a cronologia tem maior significado que a forma.

\section{A. M. Bisi Ingrassia (1977)}

Catálogo organizado em torno das escavações de Herculano consta de um elevado número de peças, divididas em onze formas com numerosas variantes, dentre as quais três são de tradição helenística, uma de transição e sete de período imperial. A cronologia amparada pelo contexto estratigráfico é bastante segura e a existência da 
inquestionável data de abandono do local (79 d.C.), demonstra que as maioria das lamparinas de disco já estava presente (Cerdan 1990:150).

\section{R. Rosenthal e R. Sivan (1978)}

O mais completo e bem articulado catálogo sobre lamparinas da parte oriental do Império, especificamente relativo ao território de Israel. É baseado em sua ampla maioria da coleção de Schloessinger o que tem torna a cronologia por estimativa e amparada na relação formal. É o catálogo referencial em Israel apresentando lamparinas romanas em comparação com o material publicado por Broneer, bem como outros tipos de lamparinas como helenísticas, egípcias, norte-africanas, palestinas, bizantinas e islâmicas. Trata-se, acima de tudo, de um catálogo que apresenta as principais formas que circularam na região.

\section{M. Bailey(1980)}

Catálogo que abriga os exemplares que estão no British Museum, muito usado atualmente por sua qualidade e volume de trabalho. Trata-se de um estudo minucioso e sistemático que inclui formas já estabelecidas e um vasto repertório de cenas decorativas em comparação com as tipologias anteriores. Publicado em quatro volumes, baseando-se essencialmente na evolução do bico. O segundo volume (1980) é dedicado às produções itálicas e o terceiro volume (1988) procura dar conta da produção provincial. A classificação valendo-se de letras alfabéticas ao invés de números para a nomenclatura dificulta sua utilização comparativa.

\section{Pavolini (1981)}

Tendo como principal valor sua cronologia e os mapas de difusão, o estudo de Pavolini não procura a inovação tipológica. Analisando a produção de lamparina itálicas entre o século III a.C. e II d.C. o autor estabelece os tipos a partir da forma e da área de produção, com pequenas resenhas bibliográficas, o que torna esse estudo muito interessante. 


\section{M.T. Amare (1988)}

Seguindo o modelo de Provoost, a autora procura sistematizar a tipologia das lamparinas espanholas. Baseada exclusivamente no critério morfológico inclui todos os tipos existentes e conhecidos. Segundo Cerdan (1990:151) o inconveniente fica por conta de algumas imprecisões cronológicas e alguns materiais descontextualizados.

\section{M.G.P. Maia e M. Maia (1997)}

Catálogo das lamparinas encontradas em Santa Bárbara de Padrões, em Castro Verde, Portugal. A publicação merece menção, pois trata das centenas de lamparinas escavadas na "Vala das Lucernas". O trabalho tem um grande controle estratigráfico e procura uma divisão que além da Tipologia abrange a iconografia das lamparinas encontradas. Sem dúvida alguma é um catálogo muito bem estruturado, com excelentes representações das lamparinas, oferecendo parâmetros comparativos com outros autores: Dressel, Deneauve, Loeschcke, Ponsich e outros.

As tipologias e morfologias apresentadas dão uma amostra da dificuldade de se lidar com as distintas categorizações e denominações que cada autor, no correr dos anos, reempregou em seu trabalho. As tipologias são as mais variadas e abundantes, sendo, conforme propõe Cerdan (1990), imprescindível ter uma denominação unitária ou a utilização das três classificações mais completas e conhecidas atualmente, a saber: Dressel, Loeschcke e Deneauve. Baseado na proposta de Cerdan, apresento na tabela abaixo a sistematização comparativa das principais tipologias de cerâmicas romanas de iluminação, a fim de que se tenha elucidativamente essa relação em mente: 


\begin{tabular}{|c|c|c|c|}
\hline LAMPARINAS REPUBLICANAS & LAMPARINAS DE VOLUTAS & LAMPARINAS DE DISCO & LAMPARINAS DE CANAL "FIRMALAMPEN" \\
\hline $\begin{array}{l}\text { Tipo Dressel } 2 \\
\text { (Walters, 49-51; Palol, 1; Dessel-Lamb., 2; } \\
\text { Lerat, IIC; Ponsich, IB; Deneauve I; } \\
\text { Szentleleky b-1; Alarcão-Ponte, Al; } \\
\text { Provoost, III-I, 3; Amare 1-2, Ba) }\end{array}$ & 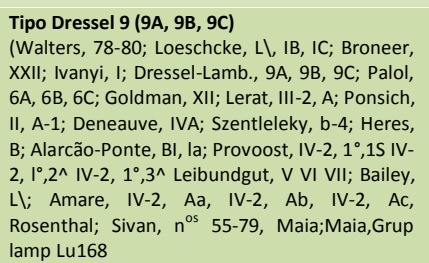 & $\begin{array}{l}\text { Tipo Dressel } 17 \\
\text { (Loeschcke, VIIIK; Broneer, XXV-1; Ivanyil, VII; } \\
\text { Goldman, XVI; Dressel-Lamb., 17; Lerat, III-3, C- } \\
\text { 1; Deneauve, VIID; Heres, Ed; Alarcão-Ponte, B- } \\
\text { II, 4; Provoost, IV-3, 4», 2^; Leibundgut, XX; } \\
\text { Bailey, O; Amare, IV-3, C, Rosenthal; Sivan, }{ }^{\text {os }} \\
\text { 136-174 e 347-367, Maia;Maia,Grup lamp } \\
\text { Lu228 and Lu209) }\end{array}$ & $\begin{array}{l}\text { Tipo Dressel } 5 \\
\text { (Walters, 90-92; Loeschcke, X; Ivanyi, XVI; Palol, } \\
\text { 13; Dressel-Lamb., 5C Y 5D; Lerat, 111-5, A; } \\
\text { Ponsich, VA; Deneauve, IXA; Szendeleky, b-10; } \\
\text { Alarcão-Ponte, B-IV, 1; Provoost, IV-5, 2^, 1^; } \\
\text { Leibundgut, XXVI y XXX; Bailey, N-3; Amare, IV-4, } \\
\text { Aa) }\end{array}$ \\
\hline $\begin{array}{l}\text { Tipo Dressel } 3 \\
\text { (Walters, 73-74; Palol 2a; Dressel-Lamb., } \\
\text { 3; Lerat III-I; Ponsich IC; Deneauve III; } \\
\text { Alarcão-Ponte A-2; Provoost IV-1, } 2^{\wedge}, 1^{\wedge} \text {; } \\
\text { Leibungut II), Maia;Maia,Grup Iamp } \\
\text { Lu391 } \quad\end{array}$ & $\begin{array}{l}\text { Tipo Dressel } 11 \\
\text { (Walters, 81; Loeschcke, IV; Broneer, XXIII; } \\
\text { Ivanyi, II; Dressel-Lamb., 11; Palol, 8; Goldman, } \\
\text { XIII; Lerat, III-2, B-2; Ponsich, 11, B-1; } \\
\text { Deneauve, VA; Szentleleky, b-7; Heres C; } \\
\text { Alarcão-Ponte, B-I, 2a; Provoost, IV-2, } 2 \text { ^ }^{\wedge} \text {; } \\
\text { Leibudgut, XII; Bailey IB; Amare, rV-2, Ba, } \\
\text { Rosenthal; Sivan, }{ }^{\text {os }} \text { 118-134, Maia;Maia,Grup } \\
\text { lamp Lu524 }\end{array}$ & $\begin{array}{l}\text { Tipo Dressel 18 } \\
\text { (Walters, 96; Loeschcke, VIIIK; Ivanyi, VII; } \\
\text { Dressel-Lamb., 18; Lerat, III-3, C-1; Ponsich, III- } \\
\text { B, 1; Deneauve, VIIA; Szentleleky, b-11; Heres, } \\
\text { Ea; Alarcão-Ponte, B-II, 4; Provoost, IV-3, 2S 1^ } \\
\text { Leibundgut, XX; Bailey O), }\end{array}$ & $\begin{array}{l}\text { TipoDressel } 6 \\
\text { (Loeschcke, XK; Ivanyi, XVII; Palol, 13; Dressel- } \\
\text { Lamb., 6; Ponschich, VB; Szentleleky, b- 10; } \\
\text { Provoost, IV-5, } 2^{\wedge} 2^{\wedge} \text {; Leibundgut, XXXII; Bailey, N- } \\
\text { 4; Amare, IV-4, Ab) }\end{array}$ \\
\hline \multirow[t]{8}{*}{$\begin{array}{l}\text { Tipo Dressel } 4 \\
\text { (Palol, 3; Dressel-Lamb., 4; Lerat, III-I; } \\
\text { Ponsich, IC; Deneauve, II; Szendeleky b-2; } \\
\text { Provoost, IV-1,1'- 2"; Leibundgut, I; } \\
\text { Amare III-I). }\end{array}$} & $\begin{array}{l}\text { Tipo Dressel 12-13 } \\
\text { (Walters, 86-89; Loeschcke, III; Broneer, XXI-2; } \\
\text { Ivanyi, III; Dressel-Lamb., 12-13; Palo!, 7; } \\
\text { Goldman, XI; Lerat, III-2, B-1; Ponsich, II, B-1; } \\
\text { Deneauve, VB; Szentleleky, b-3; Heres, Aa, Ab y } \\
\text { Ac; Alarcão-Ponte, B-I, 2c; Leibundgut, X y XI; } \\
\text { Bailey, ID; Amare, IV-2, Bai) }\end{array}$ & $\begin{array}{l}\text { Tipo Dressel } 19 \\
\text { (Loeschcke, VIIIR; Broneer, XXV-4; Ivanyi, VII; } \\
\text { Palol, II C; Goldman, XVI; Dressel- Lamb., 19; } \\
\text { Lerat, III-3, C-1; Ponsich, III-B, 1; Deneauve, } \\
\text { VIIA; Szentleleky, b-11; Heres, Ea; Alarcão- } \\
\text { Ponte, B-III, 5; Provoost, IV-3, 2^, 3*; Bailey, O; } \\
\text { Amare, IV-3, A , Rosenthal; Sivan, nos 136-174 e } \\
\text { 347-367) }\end{array}$ & $\begin{array}{l}\text { Tipo Loeschcke IX } \\
\text { (Walters, 93-94; Broneer, XXVI; Ivanyi, XV; Palol, } \\
\text { 13; Dressel-Lamb., 5A Y 5B; Lerat, III- 5, B; Ponsich, } \\
\text { VC; Deneauve, IXA; Alarcão-Ponte, B-IV, I; } \\
\text { Provoost, IV-5, 1^; Leibundgut, XXIII; Bailey, N-1 y } \\
\text { N-2; Amare, IV-4) }\end{array}$ \\
\hline & $\begin{array}{l}\text { Tipo Dressel 14-16 } \\
\text { Maia;Maia,Grup lamp Lu4 and } 514\end{array}$ & $\begin{array}{l}\text { Tipo Dressel } 20 \\
\text { (Walters, } 95 ; \text { Broneer, XXV-3; Ivanyil, VII; Palol, } \\
1 \text { IA; Goldman, XVI; Dressel-Lamb., 20; Lerat, III- } \\
\text { 3, B; Ponsich, III-B, 1; Deneauve, VIIA; } \\
\text { Szentleleky b-11; Heres, Eb; Alarcão-Ponte, B-II, } \\
\text { 3; Provoost, IV-3, } 3^{\wedge} 1^{\wedge} \text { Leibundgut, XXI-XXII; } \\
\text { Bailey, P; Amare, IV-3, Ba, Rosenthal; Sivan, }{ }^{\circ} \text { s } \\
\text { 136-174 e 347-367,Maia;Maia,Grup lamp } \\
\text { Lu574 and Lu538, Lu580) }\end{array}$ & $\begin{array}{l}\text { TipoWalter } 68 \\
\text { (Ivanyi, VI; Palol, 14; Lerat, III-4; Ponsich, II-B, 3; } \\
\text { Deneauve, XII; Szentleleky, b-8 Y b-13; Provoost, } \\
\text { IV-5, } 3^{\wedge} \text { ) }\end{array}$ \\
\hline & $\begin{array}{l}\text { Tipo Dressel } 14 \\
\text { (Walters, } 83 \text { y } 85 \text {; Loeschcke, V; Broneer, XXIV; } \\
\text { Ivanyi, VI; Dressel-Lamb., 14; Palol, 9; Goldman, } \\
\text { XIV; Lerat, III-2, C; Ponsich, II, B-2; Deneauve, } \\
\text { VD; Szentlelek)', b-8; Heres, D; Alarcão-Ponte, } \\
\text { B-I, 2b; Provoost, IV-3, 1»; Leibundgut, XIV-XV; } \\
\text { Bailey, IC), Rosenthal; Sivan, nos 109-118 }\end{array}$ & $\begin{array}{l}\text { Tipo Loeschcke VIIIL } \\
\text { (Broneer, XXV-2; Ivanyi VII; Goldman, XVI; } \\
\text { Lerat, III-3, B; Ponsich, III-B, 1; Deneauve, VIIA; } \\
\text { Szentleleky, b-11; Heres, Ec; Alarcão-Ponte, B- } \\
\text { II, 3; Provoost IV-3, 3", 2^; Leibundgut, XX; } \\
\text { Bailey, O; Amare, IV-3, Ba), Rosenthal; Sivan, nos } \\
\text { 136-174 e 347-367 }\end{array}$ & \\
\hline & $\begin{array}{l}\text { Tipo Dressel } 15 \\
\text { (Walters, 84; Broneer, XXIV; Palol, 9; Goldman, } \\
\text { XIV; Dressel-Lamb., 15; Ponsich, II, B-2; } \\
\text { Deneauve, VD; Szentleleky, b-8; Heres, D; } \\
\text { Alarcão-Ponte, B-I, 2b; Bailey, IC) Rosenthal; } \\
\text { Sivan, } \mathrm{n}^{\text {os }} \text { 109-118 }\end{array}$ & $\begin{array}{l}\text { Tipo Dressel 21 } \\
\text { (Dressel-Lamb, 21; Provoost, IV-3, } 3^{\wedge} 3^{\wedge} \text { ) }\end{array}$ & \\
\hline & $\begin{array}{l}\text { Tipo Dressel } 16 \\
\text { (Walters, } 83 \text { y } 85 \text {; Loeschcke, V; Broneer, XXIV; } \\
\text { Ivanyi, VI; Palol, 9; Goldman, XIV; Dressel-Lamb. } \\
\text { 16; Lerat, III-2, C; Ponsich, III-A, } 1 \text { y 2; } \\
\text { Deneauve, VD; Szentleleky, b-8; Heres, D; } \\
\text { Provoost, IV-3, I ^ Leibundgut, XIV-XV, Bailey, } \\
\text { IC), Rosenthal; Sivan, } \mathrm{n}^{\circ \mathrm{s}} \text { 109-118 }\end{array}$ & $\begin{array}{l}\text { Tipo Dressel 24 } \\
\text { (Broneer, XXVII; Ivanyi, X; Palol, IIC; Goldman, } \\
\text { XVIII; Dressel-Lamb., 24; Lerat, III-3, C-2; } \\
\text { Ponsich, III-B, 2; Deneauve, VIIB; Szendeleky, b- } \\
\text { 12; Heres, Ei; Alarcão-Ponte, B-II, 5; Provoost, } \\
\text { IV-3, 2^, } 3^{\wedge} \text {; Bailey, O, Maia; Maia,Grup lamp } \\
\text { Lu543 and Lu548, Lu553) }\end{array}$ & \\
\hline & $\begin{array}{l}\text { Tipo Loeschcke VI } \\
\text { (Lerat, III-2, D) }\end{array}$ & $\begin{array}{l}\text { Tipo Dressel 25 } \\
\text { (Walters, 102; Broneer, XXVII; Ivanyi, X; } \\
\text { Goldman, XVIII; Dressel-Lamb., 25; Lerat, III- } \\
\text { 3,C-2; Ponsich, III-B, 2; Szentleleky, b-12; Heres, } \\
\text { Ei; Provoost, IV-3, 2^ } 3^{\wedge} \text { Bailey O) }\end{array}$ & \\
\hline & $\begin{array}{l}\text { Tipo Loeschcke II } \\
\text { (Ivanyi, V; Palol, 10; Deneauve, IVD; } \\
\text { Szentleleky, b-6; Alar^ao-Ponte, B-II, 1; } \\
\text { Provoost, IV-2, } 1^{\wedge} 4^{\wedge} \text { ) }\end{array}$ & $\begin{array}{l}\text { Tipo Dressel } 27 \\
\text { (Walters, 100; Loeschcke, VIIIH; Broneer, XXV- } \\
\text { 1; Ivanyi, VII; Palol, IIB; Goldman, XVI; Dressel- } \\
\text { Lamb., 27; Lerat, III-3, C; Ponsich, III-C; } \\
\text { Deneauve, VIIIA; Szentleleky, b-11; Heres Ee; } \\
\text { Alarcão-Ponte, B-II, 6; Provoost, IV-3, 5^; } \\
\text { Leibundgut, XX; Bailey, Q; Amare, IV-3, D), } \\
\text { Rosenthal; Sivan, } \mathrm{n}^{\text {os }} 136-174 \text { e } 347-367\end{array}$ & \\
\hline & & $\begin{array}{l}\text { Tipo Dressel } 28 \\
\text { (Walters, 101; Loeschcke, VIIIH; Broneer, XXV- } \\
\text { 1; Ivanyi, VII; Palol, IIB; Dreseel-Lamb., 28; } \\
\text { Goldman, XVI; Lerat, III-3, D; Ponsich, III-C; } \\
\text { Deneauve, VIIIB; Szentleleky, b-11; Heres, Ef; }\end{array}$ & \\
\hline
\end{tabular}


É possível extrair destas mais variadas tipologias, além das questões de estilo, que dois foram os métodos essenciais para elaboração e fabrico das lamparinas romanas: moldadas ou torneadas. As lamparinas moldadas eram trabalhadas em moldes previamente tratados, de argila ou gesso, e a decoração feita no protótipo, aplicada ou desenhada na argila ainda úmida, ou ainda de forma simplificada, no próprio molde antes do cozimento. As lamparinas fabricadas através do molde de gesso podem ser identificadas pelas pequenas bolhas deixadas pelo molde na peça. Já as lamparinas feitas no torno eram produzidas como um pequeno pote cujas bordas eram introvertidas em direção ao centro do objeto. O bico - maciço - era posteriormente aplicado e o orifício interno para o pavio era aberto posteriormente.

A técnica por molde parece ter iniciado no primeiro quartel do século III a.C., ampliando-se no século seguinte e atingindo seu auge em época imperial (Amare Tafalla 1987: 22). Durante o período de Augusto a qualidade e acabamento dessa produção se eleva significativamente e a partir do século I d.C. as oficinas locais passam a produzir o mesmo tipo de material, seguindo as inspirações dos maiores centros, criando suas imitações, quebrando a exclusividade dos centros itálicos. É dessa forma, conforme aponta Tafalla (1987: 23), evidente a distinção entre os moldes de várias fases.

O comércio de cópias indica sua generalização no início do império e com as lamparinas de disco atinge patamares de larga escala. Entretanto, é possível a diferenciação entre cópias e peças originais. $\mathrm{O}$ engobo geralmente apresenta-se bastante esbatido sendo mais aguado do que o normal. Na decoração é possível observar os relevos muito empastados, com nitidez comprometida e, em certos casos, não identificável. As peças sobremoldadas são, regra geral, de reduzidas dimensões em comparação com as originais, devido ao processo de secagem (Caetano 2001: 24) e 
imperfeições nos acabamentos pode ser notadas - no momento de juntar as duas partes da peça, por exemplo, a sobreposição muitas vezes não é bem executada dando um aspecto irregular à lamparina, em outros casos, as arestas de argila forma saliências na junção.

O conhecimento sobre os centros produtores e as relações de sobremoldagem ainda são enevoados. Alguns avanços foram obtidos especialmente no Norte da África por Mackensen e Schneider (2002; 2006) de que fiz menção anteriormente. Entretanto, pelo fato de as lamparinas constituírem-se como carga parasitária nas embarcações marítimas e sua fabricação muita vezes ser realizada de maneira marginal é necessário maior atenção com o potencial informativo que as peças podem fornecer além dos dados referidos pela conceituação tipológica e cronológica das peças. Para tal, conforme observa Cerdan, "Na atualidade qualquer classificação válida deve combinar, em maior ou menor grau, as características formais e a cronologia derivada, com certa hierarquização, mas não deixa de ser um modelo explicativo. Nunca pode considerar-se um feito absoluto e imutável." (Cerdan 1990: 162) ${ }^{9}$

\subsection{Lamparinas do período romano em Israel: o estado da questão}

Se por um lado a sobremoldagem é um dos fatores imperativos para o entendimento das produções de cerâmicas de iluminação e suas relações, por outro, não é possível empreender o estudo das lamparinas sem levar em conta alguns aspectos que penso ser imprescindíveis. Assim, é conveniente esboçar algumas considerações sobre a relação das "cópias" e como elas são tratadas, antes de prosseguir. Conceitualmente quando se fala das sobremoldagens - ou das cópias - implícita fica a ideia de que na

\footnotetext{
9 "En la actualidad cualquier clasificación válida debe combinar en mayor o menor porcentaje las características formales y la cronología derivada, com cierta jerarquización, pero no deja de ser un modelo explicativo. Nunca puede considerarse um hecho absoluto e inamovible"
} 
produção desses artefatos está também uma "cópia mental" do mundo em contato, ou seja, das relações culturais que o "original" representa. A ideia central é que se fabrica uma cópia mental e física do objeto e essa cópia ficando armazenada na memória é usada como rememoração.

Essa concepção permite que o indivíduo só possa ser entendido de forma dicotômica: como um sujeito - a mesma relação vale para um centro produtor - que percebe, captura e toma posse de uma dada realidade circundante, mas que não a acessa diretamente, sendo esse um processo psicofísico; ou como um sujeito - ou, novamente, na exemplificação, um centro produtor - que recebe as percepções, tendo um papel mais passivo, em que os estímulos do ambiente passam a existir independentemente do indivíduo que o percebe, em uma relação meramente de estímulo-resposta. O ponto é que uma separação a priori do estímulo e da resposta não é possível, tampouco existente, visto que são categorias indissociáveis: não há resposta sem estímulo e muito menos estímulo sem resposta. Até mesmo a suposta "ausência de resposta" a determinado estímulo, deve ser entendida, no fim das contas, como uma resposta. É dessa forma que essas relações são sempre contingenciais - que é o dado inicial das ações, sejam societais ou individuais. Assim, os comportamentos e as variáveis decorrentes deles são "administradas" pelos inúmeros estímulos aos quais o(s) indivíduo(s) está(ão) sendo exposto(s). Nesse sentido, uma "cópia" não é a autoreflexão de um dado estado "original", mas sim da concepção de realidade local e das múltiplas influências que derivam na similaridade dos aspectos e formas, porém, na mesma proporção, no emprego diferenciado e na distinta leitura contingencial, sendo dessa forma, tão inovador e original quanto o dito "original". Tanto o objeto quanto as relação não são iguais, antes, transformam-se de maneira multifacetada, e dessa maneira, estritamente, não se trata de meras "cópias" num sentido ipsis litteris.

Portanto, a questão aqui não é o emprego da palavra "cópias" e sim o conceito envolto e muitas vezes a-reflexivo que se tem do termo quando em uso. É necessário ter clara em mente a distinção feita quando se trata desse tipo de produção para não incorrer na simplificação demasiada das relações que regem essa atividade. 
O estudo das lamparinas, como já foi dito, não é tarefa das mais simples uma vez que, além da questão das sobremoldagens, a maior parte das publicações é baseada em coleções, públicas ou privadas, muitas vezes sem definição da proveniência do material. Esse statu quo é comum aos estudos empreendidos em Israel e mesmo as peças que provêm de escavações são enevoadas em suas cronologias, pois a maioria é proveniente dos trabalhos realizados em cavernas que serviram como tumbas durante séculos seguidos e muitas vezes encontram-se parcialmente saqueadas, tornando ambígua a interpretação dos dados em determinados casos. Conforme apontou Anna Macdonnell nos idos de 1988, um estudo das lamparinas na Palestina com contextos estratigráficos seguros de todos os períodos ainda espera por ser escrito e parece que essa prerrogativa se mantém até hoje, podendo-se alagar o tema para os estudos de cerâmica de iluminação de maneira geral.

Uma das primeiras publicações a respeito do assunto que contribuiu para a associação dos contextos materiais encontrados em Israel é a de Samuel E. Bassett e C. Weller, de 1903, em que o autor reporta a constatação de lamparinas de terracota na tumba de Vari, em Anayrus, na Ática. A caverna situa-se a quase trezentos metros acima do nível do mar, na alta vertente sul do Monte Hymettus. Nessa tumba foram encontradas cerca de mil lamparinas, sendo a ampla maioria do tipo romana discus.

Se atentarmos para os três principais periódicos arqueológicos do país, a saber: 'ATIQOT, Hadashot Arkheologiyot (HA): Excavations and Surveys in Israel (ESI) e o Journal of Tel Aviv University, é possível traçar as principais influências no pensamento arqueológico israelense no que concerne ao estudo das cerâmicas de iluminação, tendo como referência cronológica para o início a publicação de Basset (1903). É interessante a observação de que a publicação de Dressel (1899), primeira e mais conhecida tipologia, passa praticamente despercebida nas referências entre os autores que publicaram sobre o tema.

Tanto Walters (1914) quanto Loeschcke (1919) aparecem em uma ou outra referência, contudo, é o catálogo de Broneer (1930) aquele que recebe maior atenção e serve de base comparativa para as pesquisas até pelo menos a metade da década de 
setenta. É dessa maneira que as lamparinas tipo discus em Israel são caracterizadas, em sua ampla maioria, como sendo uma produção provincial de variação local do tipo XXV apresentado no catálogo de Broneer ${ }^{10}$. Quatro anos após o referido autor, J.H. Ilife (1934) publica o resultado de sua pesquisa na Tumba de El Bassa. Na caverna localizada próximo a Ras en Naqura, no extremo noroeste de Israel, foram encontradas cinquenta e cinco moedas, o que permitiu a fixação da datação relativa para o ano de 396 d.C. Além do material numismático, a presença de vidro e de quinze lamparinas de terracota contribuíram para a atribuição da cronologia. As lamparinas enquadram-se nos tipos recorrentes do quinto e sexto séculos d.C., portanto, período Bizantino. É pertinente considerar esse um dos estudos inaugurais para a região em questão, nele as lamparinas de terracota figuram como um dos principais materiais na interpretação dos contextos arqueológicos, assumindo a partir de então, um papel recorrentemente relevante nas pesquisas desenvolvidas posteriormente. Seguindo esse paradigma a publicação de F.E. Day (1942) procurou elucidar melhor esse tipo material, focando-se na caracterização e descrição das lamparinas cristãs e islâmicas. Os anos cinquenta seguem a tendência de identificação dos artefatos a etinicidade e Y. Brand (1953) publica Klei Haheres Besifrut Hatalmud, um compêndio que visava dar conta da associação cerâmica com a literatura Talmudica. Nesse estudo Brand foi o primeiro a evidenciar a quebra na parte central do discus, referente à iconografia nesse tipo cerâmico, e asseverou que se tratava de um costume judaico, um ritual de purificação da peça. As lamparinas chegariam fechadas nas tumbas e seriam abertas - ou purificadas, se o leitor preferir - momentos antes da utilização das mesmas em ritos funerários. Essa é uma premissa que será amplamente utilizada e considerada nos estudos consequentes. Na mesma década A. Kindler (1958) divulga o estudo de uma lamparina do século VII d.C. em associação com material numismático.

As décadas de sessenta e setenta testemunharam um progresso nas pesquisas relacionadas ao tema e no mesmo ano em que J. Perlzeweig (1961) publica o catálogo das lamparinas do período romano na Agora de Atenas, R. H. Smith (1961) classifica

\footnotetext{
${ }^{10}$ Para uma visão comparativa com os outros catálogos publicados vide a tabela do item 3.2
} 
lamparinas torneadas (wheel-made) do tipo "knife-pared" definindo-as como "herodianas". O autor classifica as lamparinas herodianas quanto a sua forma em dois tipos, atribuindo sua cronologia para 70 d.C. e sugerindo que os dois tipos foram sequenciais, tendo um período de transição tipológica entre eles. As pesquisas atuais (Adan-Bayewitz, Asaro, Wieder, Giauque 2008) tendem a confirmar essa assertiva. Ainda no mesmo ano P.P. Kahane (1961) noticia as lamparinas encontradas na tumba de Huqoq e fornece mais dados sobre o tema. Localizada na Galiléia, Huqoq trata-se de um complexo de tumbas que atesta a diversidade de sepultamentos realizados em era comum. Referente às lamparinas, Kahane as definie como sendo um tipo local variante das lamparinas redondas discus, atribuindo sua cronologia ao II e III séculos d.C. e estendendo a perspectiva ao século IV d.C. Essas lamparinas são o mesmo tipo que se encontra em Apollonia e o objeto material de análise desta pesquisa. A elas venho pontualmente me referindo ao longo do trabalho. Além da menção às lamparinas discus, é nessa publicação que o autor sugere que as lamparinas herodianas derivam do Tipo XVII de Broneer e, assim, também discute esse tipo cerâmico e define as cronologias para as variantes torneadas (wheel-made) e moldadas (mold-made), entre o I-II séculos d.C. Em 1963 C.A. Kennedy procura traçar o panorama de desenvolvimento das lamparinas na Palestina e acaba por se tornar uma das principais referências pelo ineditismo e qualidade do trabalho. Em 1969 J. Brand publica Indications of Jewish Vessels in the Mishnaic Period e argumenta que a quebra na parte central do discus não se referiam somente a representações humanas, mas estendem-se também as representações com motivos florais. Para o autor isto seria o atestado de que a quebra acontecia não por motivos iconofóbicos, mas - reforçando sua tese de 1953 - seriam o resultado das leis de purificação judaica. Brand argumenta que a lamparina enquanto não fora usada não transfere a "impureza" para a pessoa e assim, podem ser trazidas e "abertas" nas casas e tumbas. O autor ainda refere que as leis de pureza do judaísmo permitiram aos judeus realizar tal ato sobre qualquer representação, inclusive cristãs. Por outro lado, os cristãos, segundo o autor, não poderiam fazer o mesmo se as lamparinas tivessem cruzes, por exemplo. Parece-me um tanto contraditório o argumento, contudo, discutirei essas questões adiante. 
Durante os anos setenta, além da publicação do volume I do catálogo de D.M.B Bailey (1975) sobre as lamparinas gregas, helenísticas e do início do período romano, do British Museum, R. Gophna e V. Sussman (1974) apresentam os resultados da pesquisa em Tel Halif. As autoras caracterizam o sepultamento como judaico e descrevem as lamparinas encontradas no local. Dois anos mais tarde, Sussman (1976) publica a pesquisa sobre a caverna de Kefar 'Ara, servindo de parâmetro comparativo para muitas pesquisas subsequentes. Nesse sepultamento a autora pontua os diferentes tipos encontrados e os refere como pertencentes à tradição caracterizada por desenhos geométricos em relevo linear, composta por linhas radiais, desenhos escalonados, círculos e pontos em várias combinações. As lamparinas são apresentadas em quatro grandes grupos, sendo cronologicamente situadas em período Bizantino. A autora observa que: "a caverna em 'Ara foi primeiramente usada no período Romano. A princípio, os mortos foram sepultados em kokhim ${ }^{11}$, em outros casos em grandes sarcófagos. Outro sarcófago foi colocado no centro da câmara. As poucas ofertas do primeiro estágio de sepultamento são atribuídas ao tardio segundo e terceiro séculos d.C. A última fase do sepultamento é rica em achados e dados do tardio terceiro ao sexto séculos d.C. (...)"12 (p. 100). Apesar da utilização da caverna em período Bizantino a conclusão é que possivelmente trata-se de Samaritanos. Na acepção da autora, como não foram encontrados objetos com simbologia cristã e esse tipo de lamparina foi encontrado nas regiões de Samaria, Beth She'an, Efrain, Hadera, Cesareia, Natania, Kefar Saba, Tel Barukh e Tel Qasile, sendo estas áreas consideradas de assentamentos samaritanos, a atribuição parece conclusiva: "Assim, acreditamos que essas lamparinas pertençam a um tipo que pode, estimativamente, ser chamado de

\footnotetext{
${ }^{11}$ Kokh - no plural Kokhim (hebraico: פּּ⿴囗十) - é um tipo de complexo tumular caracterizado por uma secção central de onde irradiam longos e estreitos eixos, como "corredores", onde os sepultamentos eram realizados. O complexo tumular era geralmente esculpido na rocha e fechados com uma rocha que selava a caverna. Possuia canais de corte para o centro do eixo a fim de drenar toda a água que era escoada através da rocha.

12 "the cave in 'Ara was first used in the Roman period. At first, the dead were buried in the kokhim, sometimes in large stone sarcophagi. Another sarcophagus was placed in the centre of the chamber. The few offerings of the first burial phase are attributed to the late second and third centuries CE. The later burial phase is rich in finds and dates from the late third to the sixth centuries CE (...)".
} 
"Samaritanas", por terem sido manufaturadas para o uso dessas comunidades" $"$.(p.101)

Em 1976, L.Y. Rahmani reporta a pesquisa na tumba de Nahal Raqafot, em Jerusalém, e menciona uma lamparina ovoide com largo orifício de alimentação central, ele atribuiu sua cronologia para o III século d.C., enquanto um terminus post quem para o uso do sítio. Algum tempo depois surge o estudo mais utilizado até hoje em Israel, trata-se do catálogo de R. Rosenthal e R. Sivan (1978), este muito bem estruturado, porém com algumas questões que já foram apontadas no item 3.2 deste estudo. Ainda no mesmo ano L.A. Shier, publica as lamparinas de terracota provenientes da escavação em Karnis, Egito. Essa publicação recebe notoriedade como material comparativo e contribui à percepção das relações comerciais estabelecidas entre as duas regiões.

Os anos oitenta testemunharam a maior densidade de publicações sobre o assunto e foi no início da década que J.W. Hayes (1980) apresentou seu catálogo, tendo como objeto central de análise as lamparinas do Royal Ontario Museum. No mesmo ano V. Sussman (1980) publica dois outros estudos: o primeiro dos moldes de produção cerâmica provenientes de Cesareia; e o segundo, a constatação de cinco lamparinas cristãs provenientes da mesma área. J. Zias (1980) reporta o trabalho realizado na tumba $\mathrm{de}$ 'Ar 'Ara, na caverna foram encontradas duas lamparinas - diferentes tipos - datadas entre os séculos I-II d.C. No ano seguinte E.M. Meyes, J.F. Strange e C.L. Meyes (1981) apresentam os resultados das escavações conduzidas em Meiron, alta Galiléia, e esse estudo passa a compor a lista dos mais referidos na bibliografia comparativa. Contudo, a publicação de W. Neidinger (1982), no Journal of Tel Aviv University, parece ter logrado maior notoriedade que a anterior, principalmente no que diz respeito à hipótese explicativa da quebra nas lamparinas romanas discus encontradas na quadra do mercado de Antipatris. Embora a seção que discute essa ideia não ultrapasse meia página, uma parte de sua hipótese interpretativa foi assimilada e utilizada como

\footnotetext{
13 Thus we believe that these lamps belong to a type which can tentatively be called "Samaritan", as they were manufactured for the use of the Samaritan communities"
} 
diagnóstico étnico de determinadas tumbas, em alguns casos sem maior reflexão a respeito do tema.

V. Sussman no ano seguinte (1982) publica sobre uma ornamentada lamparina de atribuição judaica e em 1983, estudando cerca de noventa e três lamparinas provenientes de Apollonia usa a atribuição cunhada em 1978 e caracteriza-as como lamparinas samaritanas, assim o corpo de dados dessa conceituação se fortalece e tornase referencial. Referente à forma, as lamparinas são arredondas e piriforme alongadas, com decorações variadas e comumente seladas em sua parte central. Tendo por base esse estudo a autora coloca a produção da indústria local para a metade do século II d.C. e/ou século III d.C. Entretanto, os tipos 1 e 2 têm cronologia referida para o III-IV séculos d.C. e os tipos 3 e 4 cronologia entre o V-VII séculos d.C.

J.W. Hayes (1985) finaliza seu estudo e "sigillate Orientali Encicpledia Dell'Arte Antica" emerge como sustentação ao entendimento cerâmico romano e menções a sua obra são feitas nas pesquisas. No mesmo ano V. Sussman (1985) seguindo seu aprofundamento no tema das lamparinas samaritanas publica "Ornamental figures on "Beit Nattif" Type Oil Lamps from Northern and Southern Workshops". Sem dúvida alguma, como o leitor já pode ter notado, Varda Sussman é a principal pesquisadora no que tange às cerâmicas de iluminação no país, especialmente sobre a produção local das lamparinas samaritanas. O ano de 1988 é de especial papel no pensamento arqueológico israelense na temática. D.M.B. Bailey (1988) lança o segundo volume de seu catálogo, com foco nas lamparinas romanas produzidas na Itália. Essa influência externa coincide com duas publicações que tiveram como eixo central Israel. O estudo de A. Macdonnell (1988) procurou dar conta das lamparinas de terracota das escavações conduzidas em Jalame, norte do país. Esta também é uma das obras que receberam bastante atenção por parte dos pesquisadores, passando a ser referida pela qualidade e estruturação do trabalho. Y. Israeli e U. Avida (1988) encerram o profícuo ano, publicando “Oil Lamps from Eretz Israel”. A obra é o esforço de definição e caracterização da coleção de Louis e Carmen Warschaw presente no Museu de Israel, 
Jerusalém. Finalizando a década, mais uma publicação de V. Sussman (1989): "Northern Stamped Oil Lamps and their Typology".

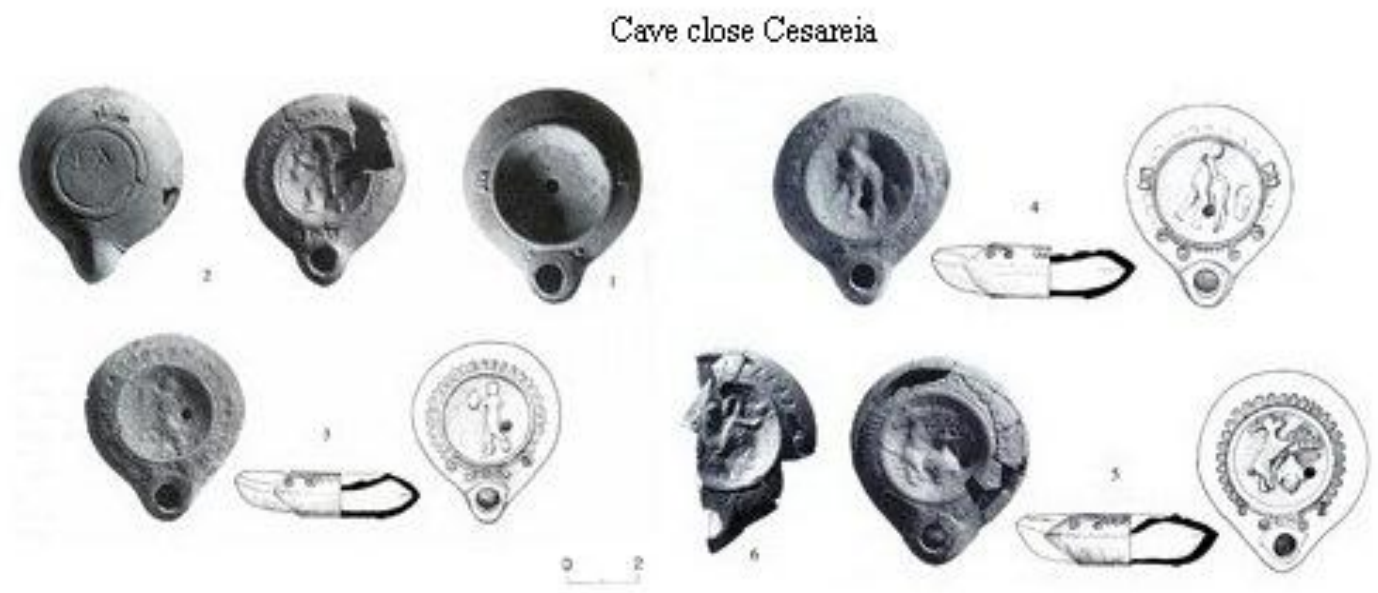

Jalame
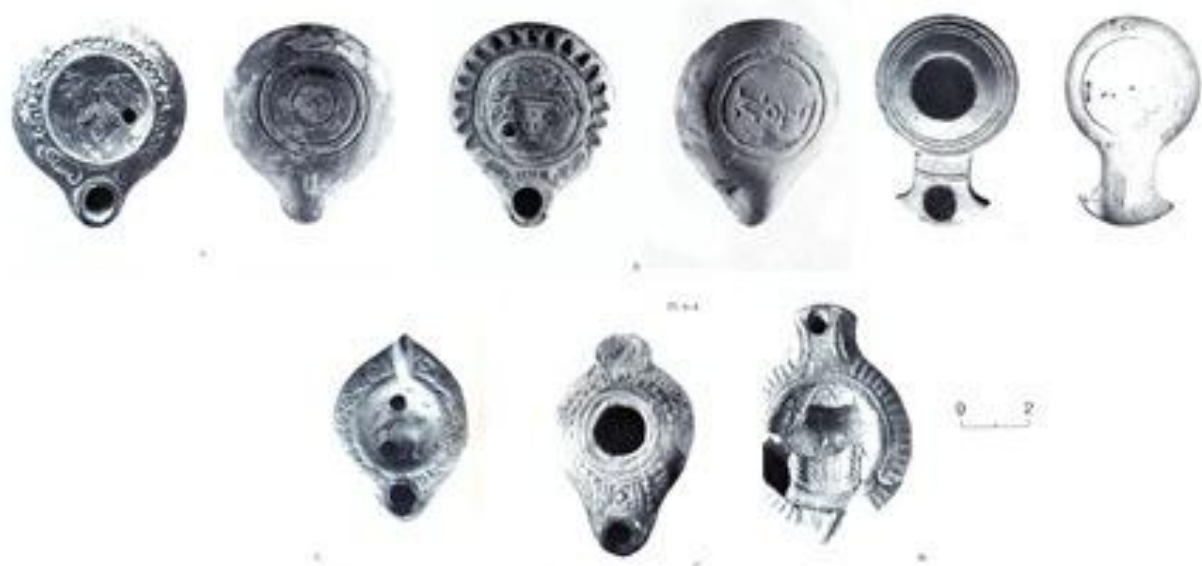

Fig. 6 Lamparinas romanas provinciais tipo discus da tumba de Cesareia e em Jaleme - 'Atiqot XXI 1992: 59*, Mcdonnell 1988: 132, 340, 343 e 344

Os anos noventa foram ainda mais densos que os oitenta em relação às publicações, entretanto, marcados por muitas publicações breves de relatório dos trabalhos - na maioria de salvamento arqueológico - desenvolvidos em cavernas de sepultamentos. Sussman (1992) reporta a análise das lamparinas de uma tumba no Monte Scopus e no mesmo ano A. Siegelmann publica dois outros relatórios. O 
primeiro, em conjunto com A. Ne'eman (1992), refere-se a uma tumba pintada próximo a Cesareia. As pinturas incluem palmeiras, galos, flores e fitas e os autores atribuem os símbolos às relações post mortem e à sacralidade. A palmeira é associada à sinagoga judaica e as flores comparadas às igrejas cristãs. Entretanto, a procedência dessas associações não fica muito clara e resta a dúvida do por quê cada símbolo corresponde à associação feita. As lamparinas, todas do tipo romana provincial discus, apresentam-se intactas - inclusive na iconografia em relevo - com figuras humanas e animais, cenas atribuídas à mitologia Greco-Romana. As lamparinas apresentam sinais de uso - com marcas da queima - e a cronologia estipulada para o I-III séculos d.C. O que condiz com a arquitetura da caverna, datada para o II século d.C. Os autores argumentam que em Cesareia a população incluía judeus, cristãos, samaritanos e pagãos, e atribuem a tumba a judeus, porém, não as lamparinas, considerando tratar-se da influência helenística e romana.

O segundo relatório de A. Siegelmann (1992) diz respeito a quatro distintas tumbas: a) uma tumba e columbário ${ }^{14}$ próximo a Tel Hadarim; b) a tumba no noroeste de Tel Mevorakh; c) a tumba em Or 'Aqiva e d) a tumba em HaMa 'apil. Essas cavernas de sepultamento estiveram em uso durante o período romano e bizantino, algumas abrangendo períodos posteriores, como é o caso de Tel Hadarim. De especial menção é a tumba de Tel Mevorakh que consistindo em uma plataforma com base de cantaria, contava com um nicho retangular onde foram encontrados - no norte da plataforma - o sarcófago e quatro lamparinas redondas moldadas do período bizantino. Similares moldes foram encontrados em Cesareia e noticiados por Sussman (1980). A iconografia em relevo das lamparinas bizantinas consiste em representações de um santuário, um forte, estrela, cruz e roseta. O material foi encontrado coberto por uma espessa camada de sedimento argiloso, rico em material orgânico, o que denotou a conclusão do desmoronamento do túmulo causado por inundação, quando a construção da barragem próxima em Nahal Tanninim foi realizada.

\footnotetext{
${ }^{14}$ A columbário é um local para o armazenamento, geralmente compartilhado, de urnas funerárias. O termo vem do latim columba (pomba) e originalmente se referia à habitação compartimentada das pombas.
} 


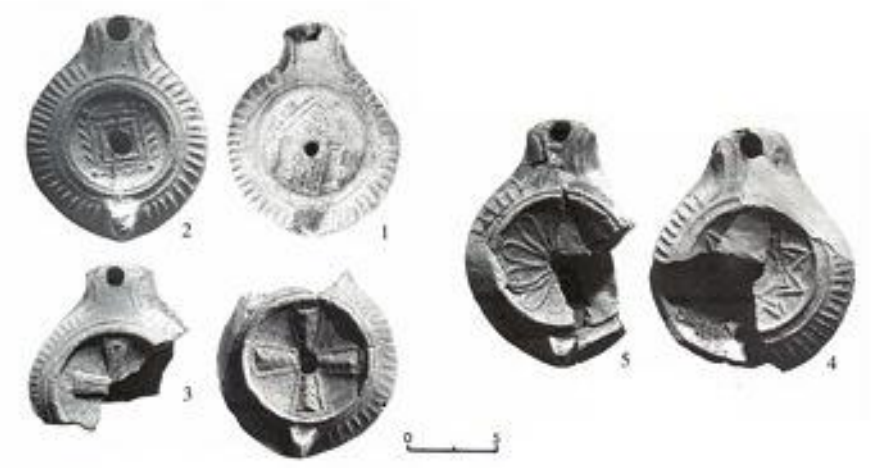

Fig. 7 Lamparinas cristãs bizantinas de Tel Mevorakh -'Atiqot 1992. XXI: 65

Duas publicações sobre Sagalassos, Turquia, no ano de 1993 serviram de material comparativo a respeito das Lamparinas de Terracota. I. Roovers (1993) publicou os resultados das análises da prospecção de 1986-1989 e da escavação de 1990-1991, e E. Scheltens (1993) no segundo relatório da campanha de escavações de 1992 publicou sobre outras lamparinas encontradas. Ainda em 1993, sete nichos foram

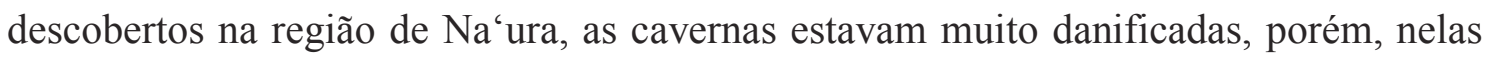
foi encontrada uma lamparina romana provincial discus (fig.30), uma lamparina do período bizantino tardio (fig.31c) e vestígios de fuligem numa tampa cerâmica. Pesos de tear e um anel de bronze também estavam entre os objetos, além de um conjunto de instrumentos para cosméticos.

Em 1994 sete publicações forneceram maiores esclarecimentos sobre as cerâmicas de iluminação e seus respectivos contextos no país. E. Mazar (1994) noticia o trabalho numa tumba de período romano em Gesher Haziv e D.M.B. Bailey (1994) volta à cena discutindo as lamparinas importadas e as cópias locais; D. Barag e M. Hershkovitz (1994) publicam as lamparinas das escavações de Massada, e pela importância desse sítio, especial atenção é dedicada às lamparinas provenientes dessa escavação. Os autores classificam um grande grupo de bicos isolados de lamparinas herodianas quanto a suas formas e tipos, refinando a caracterização dessa cerâmica. 
E. Aylon (1994) reporta o trabalho realizado numa tumba em Khirbet Sabiya, localizada na parte ocidental da moderna Kefar Sava, na Planície do Sharon, perto da estrada que passava por Apollonia. Na tumba foram encontrados, além do material ósseo - que após a decomposição foi transferido para os potes cerâmicos - lamparinas, enfeites de metal e material vítreo. Todas as lamparinas eram do tipo samaritano, sugerindo que a caverna foi usada por samaritanos, sendo abandonada por volta do século V-VI d.C. quando rebeliões samaritanas teriam ocorrido contra as autoridades bizantinas. No mesmo ano, A. Onn (1994) notifica o trabalho em Kafr Misr e a evidência de lamparina Bow-Shaped Nozzle (Kennedy 1963:80-81, Pls. 24:623; 25:624; Rosenthal; Sivan 1978:106-107, Nos. 423-432) de período bizantino.

Referente às lamparinas romanas discus, a publicação de E. Braun, C. Dauphin e G. Hadas (1994) sobre a tumba de Sajur assumiu um interessante papel, o que lhe conferiu referências comparativas nos estudos subsequentes de mesma caracterização. Especial nota para este estudo é a lamparina romana discus (fig.4:10) associada ao anel com símbolo de um leão e à presença de sinos no sepultamento. $\mathrm{O}$ autor esclarece sobre as relações existentes entre pagãos, judeus e cristãos na área em questão e prudentemente não atribui a nenhum desses o pertencimento da tumba.

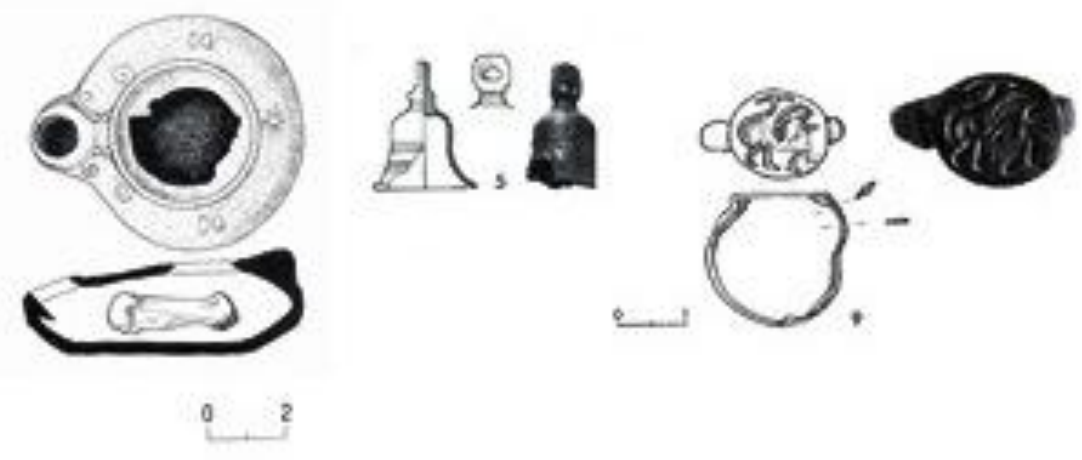

Fig. 8 Lamparina, sino e anel da caverna de Sajur - 'Atiqot XXV 1994:111 
Entre 1995 e 1996 mais três obras - uma de influência externa e duas internas contribuíram para a consolidação dos dados de pesquisa em cerâmicas de iluminação na região. Trata-se da publicação de J. Mlynarczyk (1995), New data on the Chronology of Late Roman Lamps in Alexandria, e a publicação de V. Sussman (1996), Caesarea Illuminated by Its Lamps.

L.Wexler e G. Gilboa (1996) apresentaram no Journal of Tel Aviv University seu estudo sobre as lamparinas do período romano provenientes de Apollonia. Nesse estudo as autoras apresentaram uma proposição classificatória para esse tipo cerâmico no tangente às decorações e formas. A obra passou a receber constantes referências dos estudos que depararam com lamparinas romanas provinciais tipo discus em outros contextos. As autoras opinando sobre a quebra da parte central em relevo, referente à iconografia - o discus - asseveraram que a ausência decorria do processo pósdeposicional sobre as peças, em outros termos, a pressão do acúmulo das camadas estratigráficas nos objetos.

No ano seguinte, mais uma vez uma enorme densidade de relatórios contendo a temática das lamparinas fica em evidência. H. Hizmi (1997) publica os trabalhos realizados na caverna de Itamar e na caverna de Rafidya (Shechem); Y Baruch (1997) reporta o estudo da tumba de período romano em El-Kirmil; M. Avian e Y Rosen-Gorin noticiam três tumbas de período romano em Hurfeish. O complexo na Alta Galiléia apresenta duas lamparinas romanas provinciais discus com quebra na parte central do objeto que os autores atribuem a uma questão prática: o alargamento do orifício de alimentação. H. Smithline (1997) reporta o resultado das pesquisas de mais três tumbas de período romano em Asherat. Na localidade foram encontradas duas lamparinas romanas provinciais discus com a quebra na parte da iconografia e também um anel com a figura de câncer, bem como alguns braceletes. M. Avian (1997) em A burial cave at Kafr Yasif faz menção a outra lamparina de mesmo tipo com decoração vegetal na parte central e quebra. Em A Rock-cut Tomb at Sha 'Ab - outro trabalho do autor - mais uma vez a constatação é realizada. Em ambos os trabalhos somente o apontamento da quebra é notado e a referência com o mesmo fenômeno pode ser encontrada na 
publicação sobre a caverna da Sajur. No mesmo ano, o autor ainda apresenta o resultado do estudo da tumba de H. Sugar em que se constata lamparinas do período bizantino. Na Hadashot Arkheologiyot (HA) três relatórios fizeram breve menção sobre lamparinas provinciais discus nesse ano. No complexo funerário em Kafr Kanna, as cavernas A e C apresentaram o tipo cerâmico e os trabalhos foram conduzidos por $\mathrm{H}$. Abu 'Uqsa e N. Najjar (1997). Em outro trabalho na tumba de Ginnegar ou Ginosar, Aviram Oshri acompanhado de N. Najjar (1997) publicam outro breve relatório e constata-se mais uma vez a associação de uma lamparina discus junto de um sino. Encerrando o ano produtivo E.J. Stern (1997) noticia a análise da caverna de Kisra, em que foram encontradas lamparinas de período bizantino, associadas a um pingente de osso no formato de cruz (IV d.C) e dois sinos, o primeiro situado entre o IV-VI séculos d.C. e o segundo entre os séculos III-VI d.C.
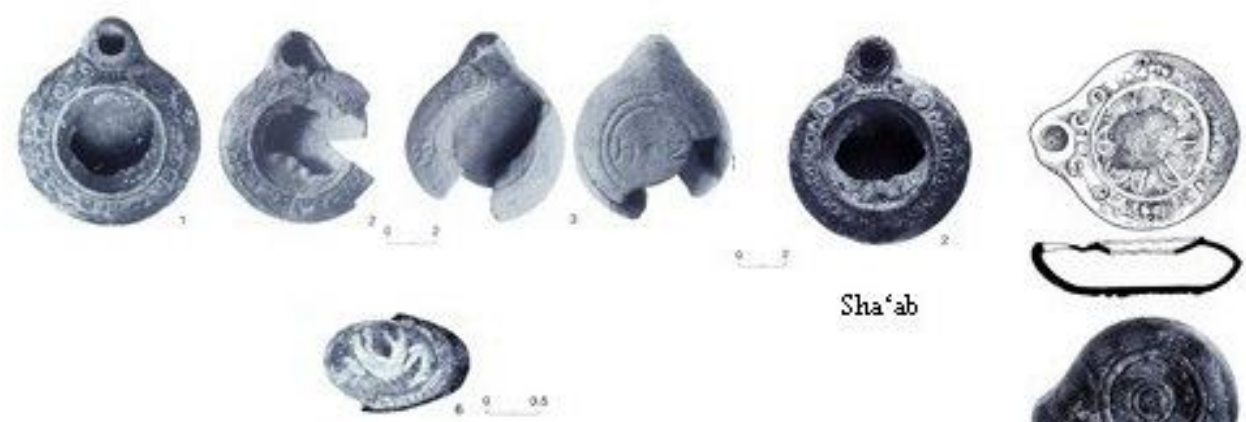

Sha'ab

Asherat
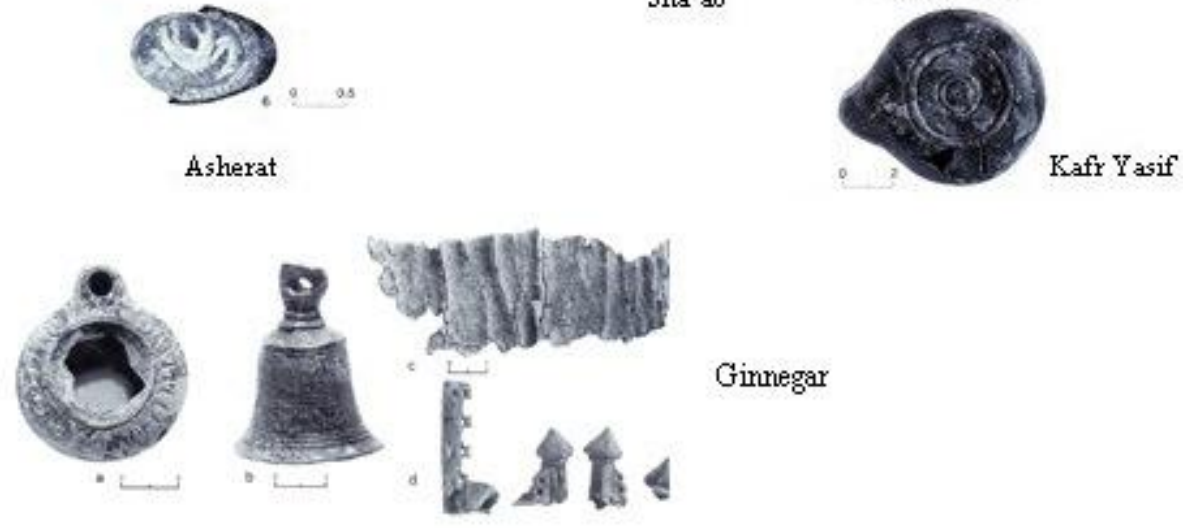

Fig. 9 Lamparinas de Asherat, Sha'ab e Kafr Yasif - 'Atiqot XXXIII: 51; 'Atiqot XXXIII: 80 e 'Atiqot XXXIII: 72. 
Em 1998, três obras sobre o assunto. Mlynarczyk (1998) publica as lamparinas de terracotta moldadas (mould-made) de Alexandria e a obra é incorporada como referência comparativa. N. Sagiv, B. Zissu e G. Avini (1998) publicam a pesquisa nas tumbas de Tel Goded, na Judeia. Nas cavernas I e IV aparecem lamparinas romanas provinciais discus com quebra, porém os autores nada mencionam a respeito. A Caverna I tem design bizantino, fato inusitado para a cronologia que foi situada entre I-II séculos d.C. e nela encontra-se uma lamparina discus com quebra (fig.4: 10 p.10). Na Caverna IV o quadro é o mesmo, mais lamparinas aparecem, as primeiras são lamparinas do IV século d.C. (Rosenthal e Sivan 1978: 103-107) e a última é uma lamparina discus também com quebra (fig. 12: 7 p.17). R. Kletter e Y Rapauano (1998) expõem a pesquisa em Khirbet Ibreiktas onde duas lamparinas são apresentadas. A primeira uma lamparina discus fragmentada e junto dela um tipo datado do III-IV século d.C., forma similar pode ser encontrada em Tel Halif (Rosenthal, Sivan 1978: 99-103; Gophna; Sussman 1974: fig.4:9), e em boa parte da Alta Galiléia.

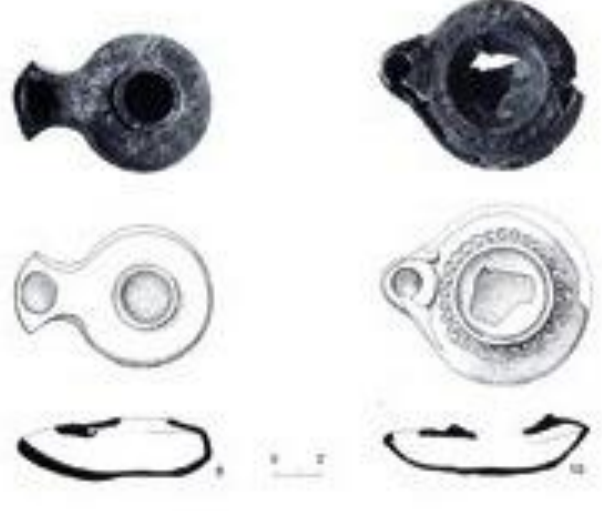

Cave I
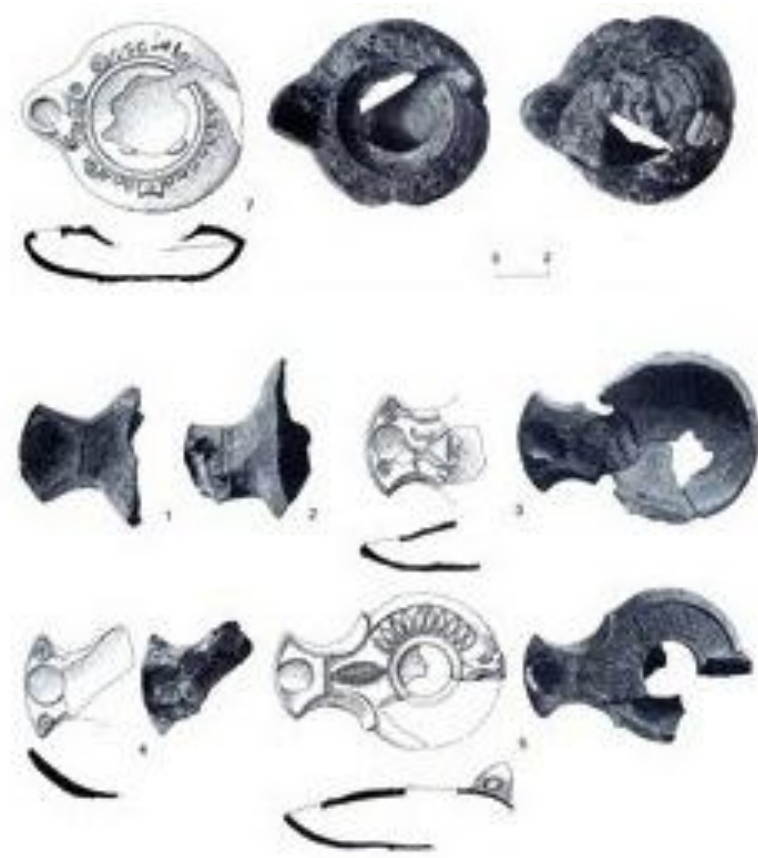

\section{Cave IV}

Fig. 10 Lamparinas Tel Goded - 'Atiqot XXXV: 10*e 17* 
Os anos noventa encerram-se com a publicação de N. Feig (1999) sobre a tumba de I'Bilin e o relatório de D. Syon sobre uma tumba no Monte Gilboa. Na pesquisa em I'Bilin o autor limita-se a afirmar que a quebra é intencional, sem maior discussão sobre o tema e referencia a publicação de Wexler e Gilboa (1996); já na segunda pesquisa no Monte Gilboa a tumba fazia parte de um extenso cemitério que conjugava distintos períodos e grupos étnicos. Na caverna - parte do cemitério - foram encontradas doze lamparinas bizantinas (Rosenthal e Sivan 1978: 103-107), três lamparinas ovoides com "large filling-Hole" - provenientes do III-IV século (Rosenthal e Sivan 1978: 100-103), e uma lamparina discus com quebra na parte central. Durante o século II d.C. a caverna foi ampliada pela adição de uma câmara, alargando-se a abertura da tumba e o material associado confirma a cronologia. A respeito da população esta é uma área considerada de convivência entre samaritanos e cristãos, o autor atribui o pertencimento da caverna à comunidade samaritana.
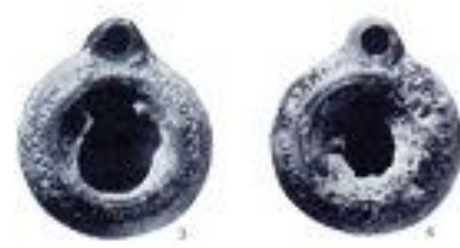

I'Billin
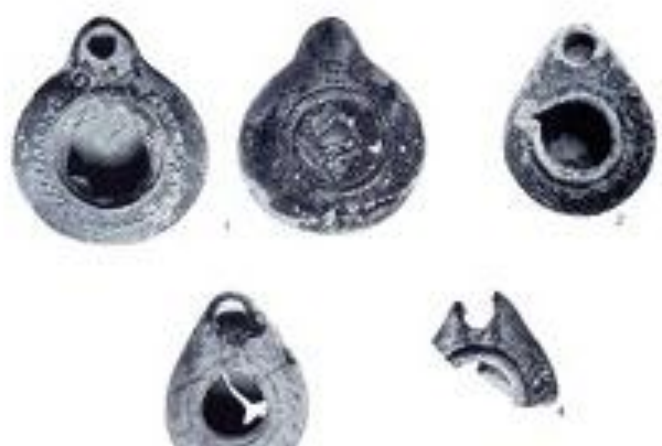

Fig. 11 Lamparinas de I 'Billin e MT Gilboa - 'Atiqot XXXVIII:52*; 'Atiqtot XXXVIII: 60*

D. Gorni-Avshalon publica a última pesquisa sobre o assunto no século XX, e tratando de uma tumba de período bizantino em Bet She'an apresenta quatorze lamparinas do mesmo período. Em 2002 V.Sussman procura a reflexão sobre a importação e produção das cerâmicas de iluminação entre Eretz-Israel e o Egito e no mesmo ano S. Hadad (2002) apresenta as lamparinas das escavações de Bet She'an. 
Seguindo as premissas teóricas de Brand (1953), Smith (1961) e Neidinger (1982), P. Nahshoni et al. (2002) publicam o relatório do trabalho realizado numa tumba em Horbat Zefiyya, na Judeia. Na localidade foram encontradas setenta e nove lamparinas, dentre as quais constavam muitas moldadas (wheel-made) Knife-Pared e Judean 'Darom', em outros termos, lamparinas herodianas, bem como algumas lamparinas romanas provinciais discus. Ao atribuir a ocupação do sítio à comunidade de judeus fica implícito que a quebra na parte central das lamparinas discus tenha sido realizada pelos mesmos, em conformidade com a hipótese dos autores ora referidos. É interessante a observação dos autores notando que tal tipo de lamparina não se evidencia em Massada e, portanto, em conformidade com a premissa de Barag e Hershkovitz (1994:127), postulam que a circulação das lamparinas romanas provinciais tipo discus é posterior a 115 d.C. Não é possível também deixar de mencionar o Qedem Reports 4, editado por N. Goring-Morris, L.I. Levine e A. Mazar, que procura a compilação da produção local de lamparinas encontradas em Beit She'an. No capítulo publicado encontram-se tanto lamparinas discus com quebra quanto com iconografia intacta. Sem dúvida alguma, é um referencial comparativo que fornece dados para a discussão mais aprofundada da temática.

V. Sussman (2004) publica as lamparinas e pequenos achados de Horbat Rimon. Num complexo tumular de seis cavernas e diferentes contextos, a autora mostra que na caverna 5 são constatadas lamparinas romanas provinciais com quebra. A autora não discorre muito a respeito do fenômeno e ao final do texto cogita como possibilidade aceita a ideia preconizada por Brand (1953). Assim escreve a autora:

"Quem foram as pessoas enterradas nas covas? O hábito de quebrar o discus em todas as lamparinas torneadas, importantes ao uso, é frequente em covas. Se esse hábito, de fato, é judeu, como sugerem vários especialistas (Brand 1953:353), pode-se assumir que o cemitério serviu à população judia. Isso está em conformidade com o uso de ossuários, onde se enterravam os hebreus, a planta das covas como 
descrito no artigo, e a localização do cemitério, na proximidade do grande centro judeu de Horbat Tilla." 15 (Sussman 2004:110*-111*)

No mesmo ano, D. Barshad (2004) com seu trabalho em Horbat Indur, no sopé de Giv 'at Há-Moré, o autor apresenta uma lamparina romana provincial (Fig.3:6) e aventa a possibilidade que a quebra aconteça: a) pela preferência em Israel por um bocal mais largo do que o pequeno orifício de alimentação, característico desse tipo de cerâmica - premissa enunciada por M. Avian e Y Rosen-Gorin (1997) a respeito das tumbas de Hurfeish. - b) o desejo de destruir a imagem contida no discus. A respeito da segunda afirmação, o autor embora não explicite isso no texto faz referência à ideia de Brand sobre o assunto. O. Shurkin (2004) estudando um complexo funerário com cronologia que começa no II século d.C. e estende-se até o período bizantino em Wadi El-Halaf, próximo a Khirbat Ras Abu Ma 'Aruf, reporta o aparecimento de lamparinas do mesmo tipo. No artigo são referidas duas lamparinas romanas provinciais discus (Fig. 15:10 p.39* e Fig. 21:2 p.47*). Ambas as lamparinas apresentam a quebra da representação em relevo do discus e o autor, mencionando somente a primeira - a segunda peça passa sem a menção -, cogita que o fenômeno seja resultado da necessidade de tornar o objeto "kosher"16 para uso judaico, referencia a hipótese de Brand.

\footnotetext{
15 "Who were buried in the caves? The habit of breaking the discus in all mold-made lamps, prior to use, is frequent in the caves. If this habit is indeed Jewish, as suggested by many scholars (Brand 1953: 353), it may be assumed that the cemetery served a Jewish population. This conforms to the use of ossuaries, one of which bears a Hebrew name, the plan of the caves as described in the article, and the proximity of the cemetery to the nearby large Jewish center at Horbat Tilla."

${ }^{16}$ Cashrut ou kashrut - em hebraico: כַשְׁרוּת -, é o termo que se refere às leis alimentares do judaísmo. De acordo com a halachá (lei judaica) é chamada de kosher, do termo hebraico כשר (kashér), aquilo que não se tem "contaminado" e significa "próprio" para o comsumo. Os judeus que seguem o kashrut não podem consumir comida não-kosher. É a separação entre o puro, portanto, kosher e o impuro, não-kosher.
} 


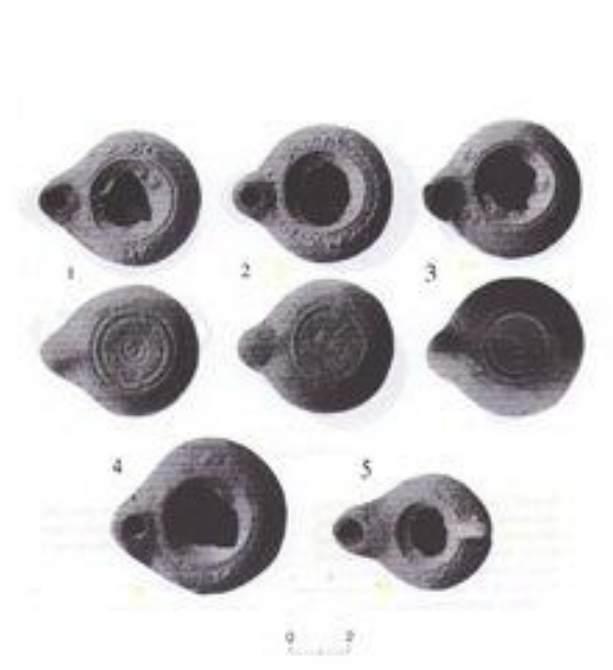

Horbat Rimmon

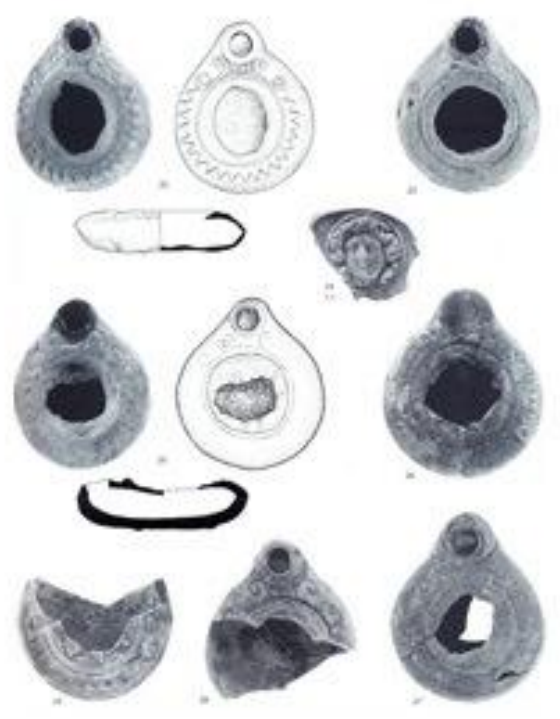

Beit She an

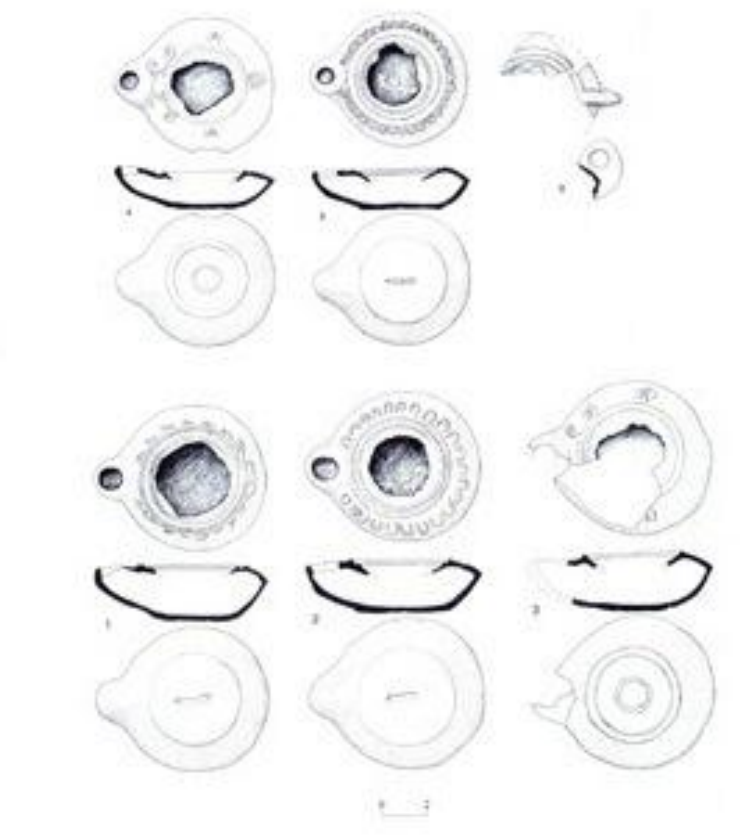

Horbat Zefiyya
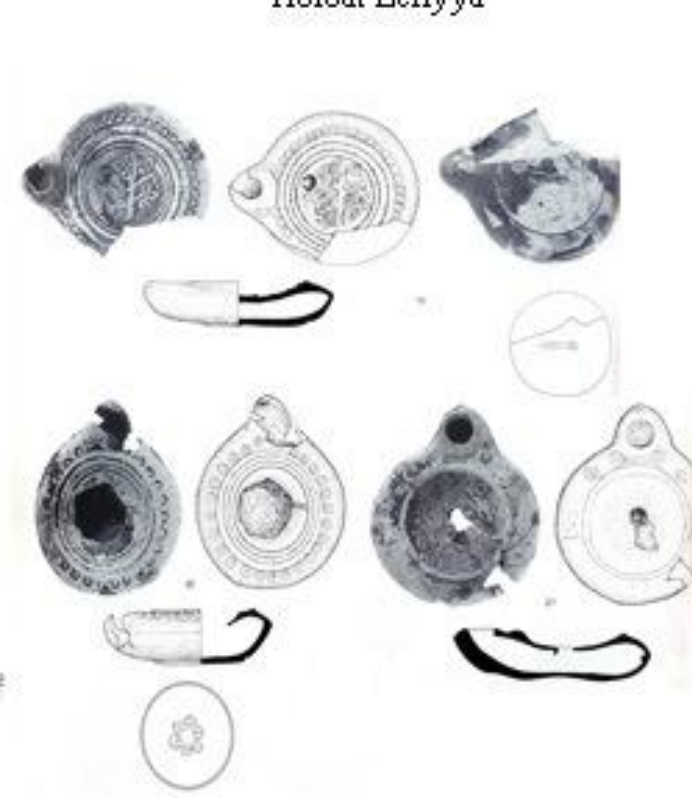

Fig. 12 Lamparinas de Horbat Rimmon, Horbat Zefiyya e Beit She 'an -; 'Atiqtot :v. 46:108* 'Atiqot XLIII::60 e Goring-Morris et al. 2002: 18-19

Especialmente interessante é a escavação que foi conduzida por D. Glick (2006) em 'Ein Ez-Zeituna em Nahal 'Iron. O sítio conta com muitas características 
semelhantes a Apollonia, tratando-se também de um edifício com peristilo, e fíca próximo a Cesareia. Esse edifício medindo 15×20m é caracterizado como sendo uma mansio e possui um único período de ocupação que é o final do século I e II século d.C. O edifício, segundo o autor, parece ter sido abandonado voluntariamente, não sendo possível verificar qualquer sinal de destruição ou conflagração. Entretanto, há sinais de colapsos na cantaria resultado provável dos terremotos que a região da baixa Galiléia constantemente sofreu no período. Em 'Ein Ez-Zeituna o fenômeno da quebra das lamparinas romanas provinciais tipo discus também pode ser evidenciado, mas o autor não atribui qualquer relação para o fato. Ainda em 2006 E. Zehavi-Kogan estudando uma tumba de período bizantino em Nahalat Ahim, Jerusalém, publica um grande número de lamparinas do III-IV d.C.séculos que são muito interessantes em relação a forma e design. As lamparinas desse tipo podem ser encontradas como referncia no catálogo de Rosenthal e Sivan (1978) entre as páginas 103-107. Contudo, os anos e as pesquisas demonstram uma diversidade muito maior da contida no catálogo o que muitas vezes dificulta uma atribuição sob esse parâmetro e acaba-se incorrendo na simplificação e generalização. A publicação de S.L. Ofm (1989) Lucerne Bizantine in Terra Santa com iscrizioni in Greco, fornece alguns dados elucidativos. Contudo, ainda assim não é suficiente e como o próprio título explicita cuida somente daquelas que possuem inscrição em Grego. Um trabalho específico e de maior envergadura sobre esse tipo cerâmico ainda carece ser feito. 

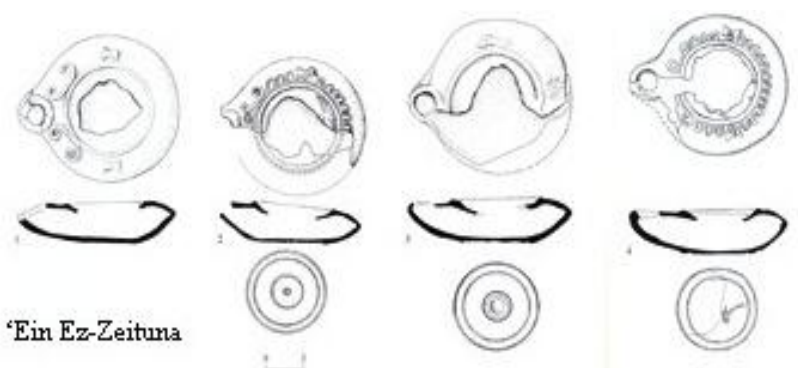

'Ein Ez-Zeitura
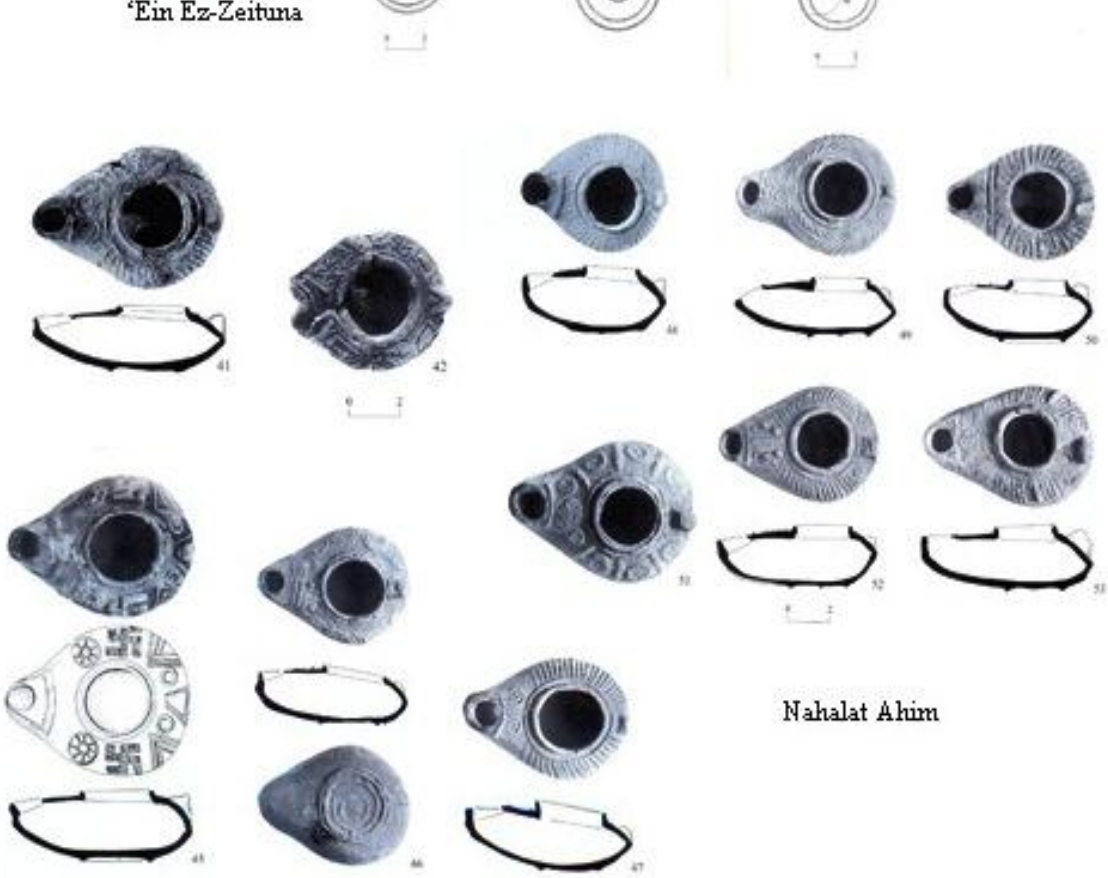

Wahalat Ahim

Fig. 13 Lamparinas de ‘Ein Ez-Zeituna e Nahalat Ahim - 'Atiqot v.51: 57; ‘Atiqot v.54: 75*-76

Nesse sentido, V. Sussman (2007) dá também sua contribuição imprescindível publicando "The Clay Oil Lamps from Khirbat El-Ni 'Ana”. Nesse artigo a autora dá conta, além das variantes do tipo Bet Nattif, de uma série de outros tipos cerâmicos, passando ainda pelos tipos Gezer e contemplando as lamparinas samaritanas. No mesmo ano mais três publicações sobre o tema recebem evidência. A primeira de A. Nagorski (2007) diz respeito a uma tumba em Shoham, onde é possível observar na caverna T4 - do I-II séculos d.C. - a constatação de três lamparinas romanas provinciais tipo discus: duas delas apresentam a fratura que o leitor já deve ter notado ser recorrente nesse tipo cerâmico. O interessante no caso de Shoham é mais uma vez a associação de dois sinos de bronze ao contexto do sepultamento. A segunda publicação do ano é a de 
E. Haddad (2007) sobre uma caverna de sepultamento do IV-V séculos d.C. em Horbat Zikhrin. Nela novamente a associação de um sino de bronze com uma lamparina romana provincial tipo discus quebrada em sua parte central acontece. $\mathrm{O}$ autor constata a quebra intencional, mas não desenvolve a discussão e argumenta que o plano geral da tumba, bem como sua arquitetura estão "de acordo com o padrão aceito e desenho das tumbas judias dos primeiro e segundo séculos d.C."(Kloner 1980: 218-19, 231"17)" (p.48). Por último, o relatório de Y. Porath sobre sepultamentos do período romano e bizantino em Cesareia traz a lume um belo candelabro imperial com a iconografia intacta. Em outra caverna do mesmo complexo funerário foram encontradas diversas lamparinas samaritanas, algumas delas ainda seladas.

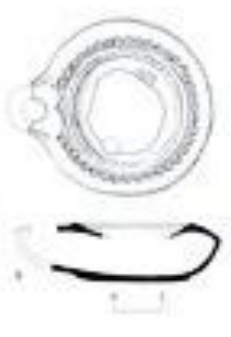

Shoran
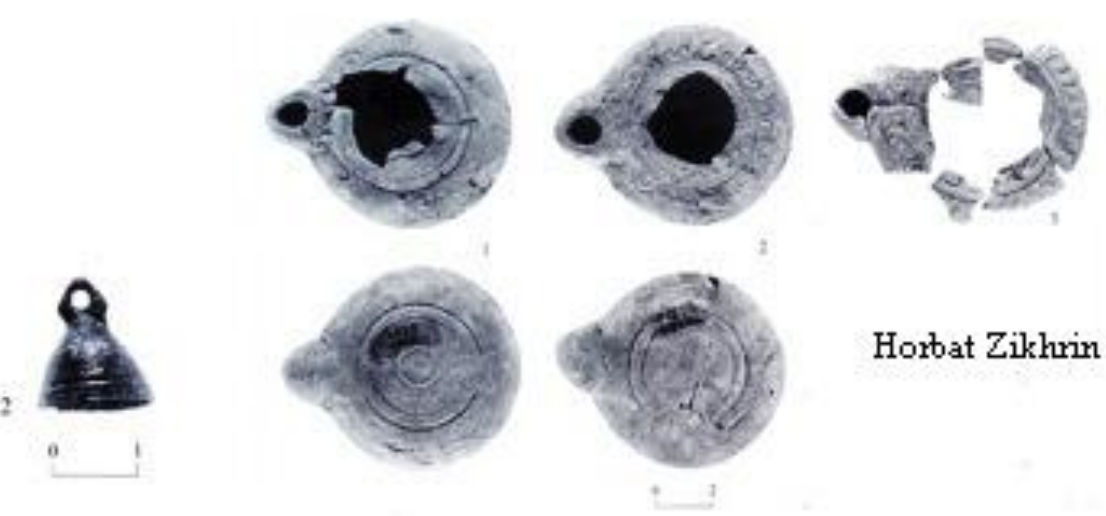

Horbat Zikhrin

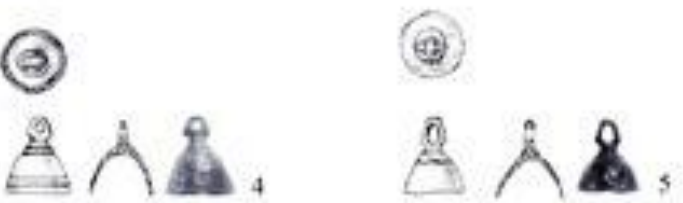

Fig. 14 Lamparinas de Shoran e Horbat Zikhrin - 'Atiqot v.55: 46*.; 'Atiqot v.56: 50-51

Em 2008 B. Zissu publica as escavações conduzidas em Horbat Burgin, na Judeia. Dentre as várias instalações escavadas, muitas lamparinas do período bizantino foram encontradas, enriquecendo os dados sobre a temática. B. Zissu juntamente com Amir Ganor publicaram em 1997uma breve nota na Hadashot Arkheologiyot (HA), noticiando que na caverna A, o material era relativo ao século I-II d.C. e na caverna B, o

\footnotetext{
17 "conform to the accepted standards and layout of Jewish tombs of the first and second centuries CE".
} 
material referia-se ao período Bizantino, sendo uma tumba com cruzes e influência helenística.

A. Tatcher e Z. Gal, ainda em 2008, reportam o trabalho realizado no Cemitério de Migdal Ha-'Emeq (El-Mujeidil), no extremo oeste de Nazaré. O cemitério inclui tumbas escavadas na rocha que foram utilizadas durante os períodos helenístico, romano, bizantino, chegando até o período inicial islâmico. A maioria das tumbas foi usada no período romano e bizantino e o segundo uso remete aos períodos mameluco e otomano. A população da região era mista nos períodos romano e bizantino, e vestígios de igrejas são encontrados em Ramat Yishai e Belém, bem como a presença de sinagogas em Ginegar Otrebnat. No sítio constata-se a presença de lamparinas romanas provinciais tipo discus nas tumbas $\mathrm{AD}$ e $\mathrm{Y}$. Na Tumba $\mathrm{AD}$ foram encontradas duas moedas, respectivamente dos anos de 192 d.C. e 156 d.C., situando a cronologia no II século d.C. Na tumba L foi encontrado um pequeno sino de bronze datado entre os séculos VI-VII d.C., período bizantino. Embora o autor mencione que a população era mista, a atribuição final do cemitério é baseada na planta das tumbas, no material ósseo e na urna funerária (pottery coffins) - encontrada na tumba $\mathrm{AD}$-, a presença de uma lamparina com o símbolo da menorah, tumba U. O autor afirma que 'amparado' pelas lamparinas quebradas - adotando assim a premissa de Brand - e pelas outras evidências referidas de que o pertencimento de todo o cemitério pode ser atribuído ao assentamento judaico, tanto para o período Romano quanto para o Bizantino.

No ano de 2009 publicando no Journal of Tel Aviv University, R. Porat, H. e A. Frumkin noticiam o trabalho realizado nas cavernas no norte de 'En-Gedi, junto ao mar Morto. As cavernas teriam servido de refúgio para os judeus após a Revolta de BarKokhba. Na área $\mathrm{C}$, caverna $84 \mathrm{~b}$, foi encontrado o fragmento da parte superior de uma lamparina romana provincial tipo discus. A lamparina indica ter a quebra da parte central e os autores relacionam a peça em similaridade com as lamparinas tipo Darom. Certamente essa quebra foi realizada pelos judeus que ali se refugiavam. 


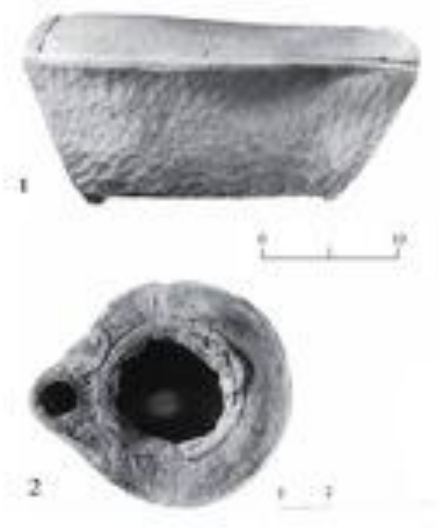

Cave AD

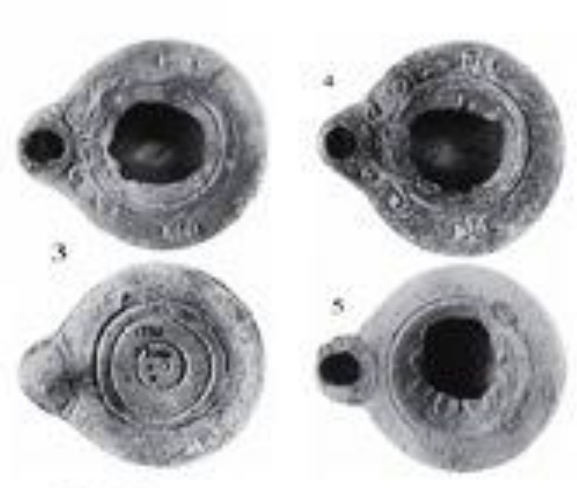

Cave $Y$

Fig.15 Lamparinas de Ha-'Emeq -- 'Atiqot v.61: 14*-15*

A última, e mais recente menção sobre lamparinas, especialmente as romanas provinciais tipo discus, é feita por F. Vitto (2011) publicando: A Roman-Period Burial Cave on Ha-Horesh Street, Qiryat Tiv. A maioria do material refere-se ao último quarto do I século d.C. e metade do II século d.C., sendo exceção uma urna funerária e uma lamparina do III-IV séculos d.C. A parte central da tumba (Câmara A) tem 2-2,3m de largura, $3 \mathrm{~m}$ de comprimento e 1,25 $\mathrm{m}$ de altura e nela foram encontradas mais de trinta lamparinas, sendo aproximadamente 26 delas do tipo romana provincial discus, todas quebradas na parte central. O autor faz uma ótima e bem argumentada discussão sobre esse tipo específico de cerâmica e parece concordar com a tese de que a quebra era feita por judeus. A conclusão final é que a sepultura foi usada primeiramente por uma família judaica, provavelmente vinda de Jerusalém após 70 d.C., trazendo consigo a prática de sepultamento secundário em ossuário de calcário. $\mathrm{O}$ autor aponta que a forma bruta do ossuário e a ausência decorativa denotam que o material foi feito localmente, enquadrando-se no Grupo Galileu B5A enunciado por Rahmani (1994:22-24), com cronologia entre 70-135 d.C., podendo ser uma ou duas décadas posterior. Assim, a caverna indica ter sido usada no final do I e meados do II séculos d.C., tendo um lapso temporal de ausência e retomada a utilização no meio III ou IV d.C. 


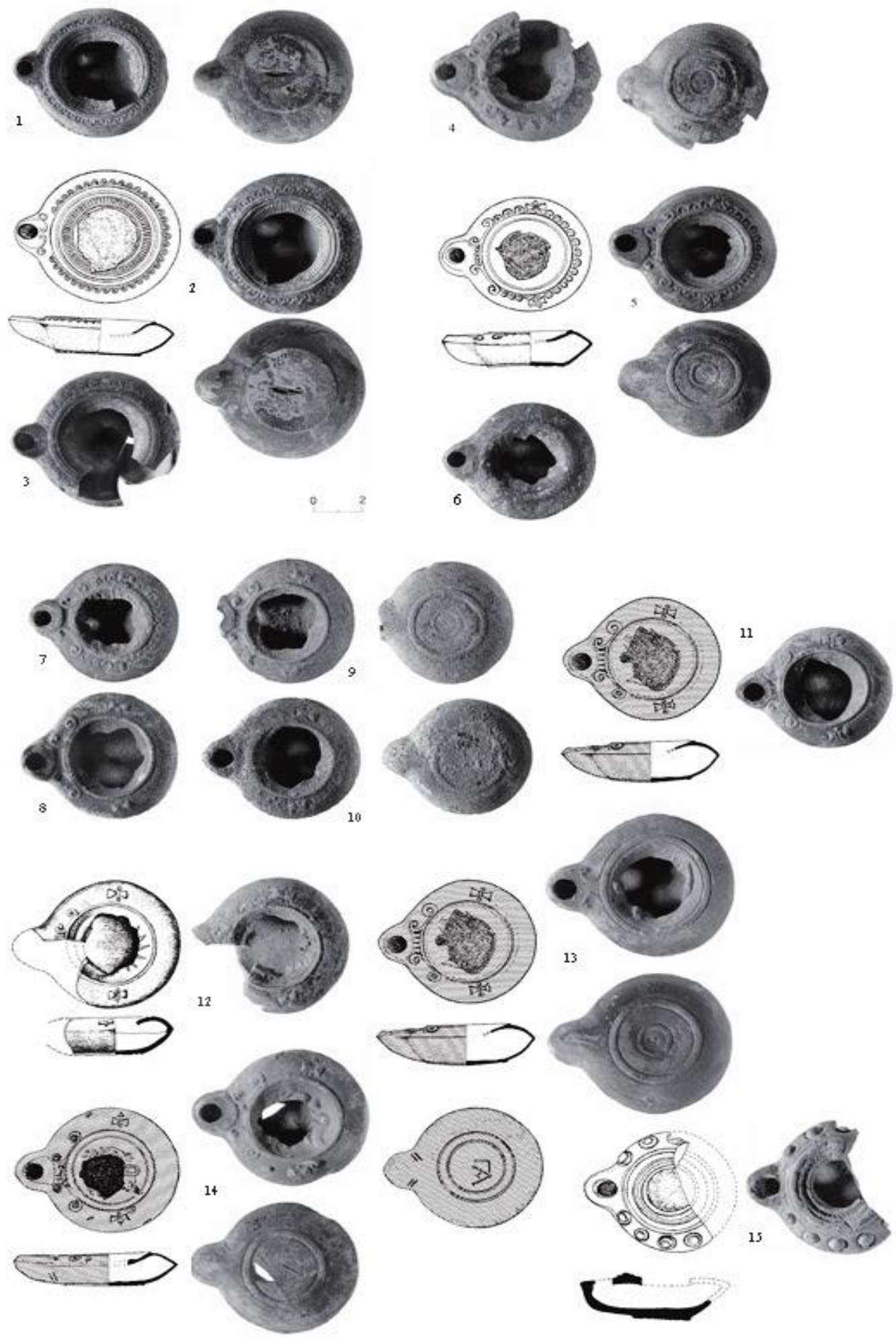

Fig. 16 Lamparinas Ha-Horesh - 'Atiqot v.65: 46*-51* 


\section{CAPÍTULO 4}

\section{Lamparinas de Terracota enquanto veículos de iconografia religiosa}

As lamparinas de terracota são encontradas nas mais distintas conjunturas, desempenhando variadas funções e participando ativamente nos espaços. No período romano dois modelos foram aqueles que predominantemente estiveram em circulação durante o I século a.C. até o final III d.C., são eles: as lamparinas de volutas e as lamparinas circulares com bicos redondos, respectivamente. Embora tenha referido no capítulo anterior como elas foram tratadas e seus respectivos estudos, dando ênfase como o leitor deve ter notado as últimas, não defini em pormenores seus atributos e características prevalecentes, com o objetivo de fazê-lo de maneira especial ao longo deste capítulo.

As lamparinas de volutas têm sua produção referenciada para o período de Augusto estendendo-se a meados do século II d.C. Essa cerâmica de iluminação deixa transparecer uma mudança significativa em comparação às tardo-republicanas: a utilização do molde. Essa prática permitiu ampliar o diâmetro do disco e, assim, suas dimensões aumentaram sensivelmente. Possuindo uma forma côncava e um variado repertório representativo na parte central do objeto, esse tipo de lamparina geralmente apresenta representações que vão dos motivos vegetais aos geométricos, passando pelas figurações animais e humanas. O bico varia entre o triangular e o redondo. Baseando-se nesse atributo Dressel (1899) estabeleceu cinco variações para a forma de bico (Dressel 9 a 16), sendo seguido quanto a este padrão por Loeschke(1919) - nas variantes I, II, III, IV, V - (Cerdán, 1999: 67). A respeito da borda, ela encontra-se separada do disco por duas ou mais molduras e são as volutas que margeiam o rostrum a característica mais marcante dessas peças.

O outro tipo recorrente para o período apresentado é a lamparina de disco, ou a chamada discus, que marcou uma nova maneira de fabrico das cerâmicas de iluminação quanto a sua morfologia. Ao que tudo indica essa produção parecer ter seu início nas mesmas oficinas itálicas que fabricavam as lamparinas de volutas. Contudo, apesar de 
eventualmente a produção itálica ser reconhecida como a principal área de produção dessa cerâmica de iluminação em seu período inicial, é nas pequenas oficinas do Norte da África, em modelos imitados a princípio, que num curto período de tempo a África Proconsular amplia sua produção e estrutura, empreendendo seus próprios modelos e repertórios - tanto formal quanto decorativo. Essa conjuntura fomenta, então, uma nova agenda de produção amplamente aceita no orbis e repleta de peculiaridades (Deneauve, 1969). A preponderância que essa região do Império Romano parece assumir nesse tipo de produção pode ser cronologicamente situada a partir de meados do século II d.C. e abrange todo o século seguinte com grande vigor. Enquanto as produções africanas espalharam-se por praticamente todas as províncias do império, o comércio itálico, ao que tudo indica, restringiu-se à área tirrênica e algumas regiões da Hispânia e Gália.

Segundo Morillo Cerdán (1999: 107) é muito complicado tratar com o conjunto cerâmico das lamparinas tipo discus, tanto em suas tipologias quanto na própria relação cronológica, pois existe uma grande variedade de exemplares individualizados e tipos de diferentes proveniências que escapam aos padrões conhecidos. Portanto, esse tipo de lamparina, de maneira geral, apresenta um corpo circular com uma borda mais larga convexa inclinada para seu interior, o disco tem reduzidas dimensões em relação ao protótipo das de volutas, e seu bico é curto e arredondado. Em alguns casos a borda apresenta-se lisa, em outros se mostra decorada, geralmente com elementos vegetais e/ou geométricos. O aumento do corpo é acompanhado pela crescente verticalidade da alça - naquelas variantes que possuem essa característica - e assume ares de um apêndice maciço em período tardio (Pereira 2008: 42-43). 


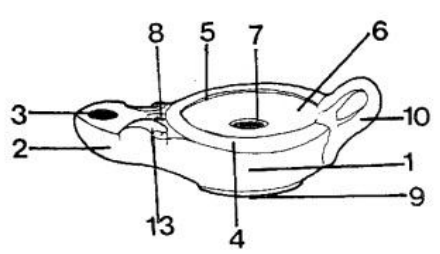

Partes constituintes de uma lamparina (In Amaré

Tafalla 1987 apud Pereira 2008):

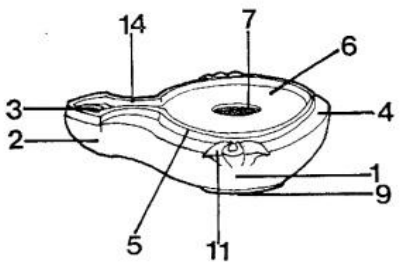

2- Rostrum ou bico

3- Orifício para o pavio

4- Borda ou Orla

5- Moldura

6- Discus ou disco

7- Orifício de alimentação

8- Orifício de ventilação

9- Base ou fundo

10- Ansa ou alça

11- Aletas

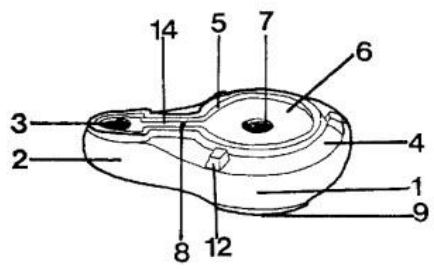

12- Apêndices

13- Volutas

14- Canal

Como já mencionei, a sobremoldagem de uma lamparina não é um processo de extrema dificuldade, reproduzindo-se os modelos almejados de maneira simples. Assim, é nos processos de sobremoldagem que um pequeno proprietário de uma olaria familiar, ou mesmo oleiros de centros produtores maiores, aparentemente buscaram seu know how (Caetano 2001: 22). Os repertórios iconográficos, por sua vez, ficaram por conta de algumas representações amplamente aceitas no orbis e diretamente ligadas às manifestações de gosto das sociedades locais a que se destinavam. Procurando atender às demandas existentes, num cenário que tendia ao crescimento, diversificação e procura. Assim, uma extensa rede de oficinae passa a existir nos contextos apresentados (Cerdán 1999: 163).

A iconografia em lamparinas, bem como seus desdobramentos de forma, é, portanto, fruto dos processos de transformação que em período romano atingem seu destaque maior. Se no período Grego Clássico as lamparinas eram objetos eminentemente funcionais, sem qualquer tipo de ornamentação, no período romano esse quadro passou por mudanças alcantiladas. É bem verdade que a manifestação do gosto 
artístico nesses objetos não é exclusividade do período romano, podendo-se retroceder ao período helenístico em seus primórdios, contudo, a conjugação de funcionalidade e estética ornamental parece mesmo estar situada no período em questão. No período helenístico se desenvolveu a técnica de molde bivalve e a redução do orifício de alimentação, bem como o estreitamente e/ou alargamento da orla e a ampliação dos discos, que passaram a ser praticamente todo coberto em período imperial, quando o estilo foi criado. A cobertura praticamente total do disco das lamparinas é sem dúvida alguma um avanço tecnológico e funcional, pois o controle de oxigênio na combustão ocasiona maior tempo de queima. Quanto mais ar alimentando a combustão, mais rápido a chama se consome, por consequência menos tempo de iluminação. Embora em período helenístico note-se que nas lamparinas moldadas a decoração em relevo apresenta alguns motivos vegetais ou pequenas aplicações de máscaras sobre o bico e borda, é nas lamparinas romanas que um novo estilo decorativo facilitado pela mudança da forma do recipiente desenvolve-se em sua plenitude (Fleming 1989: 174). .

No processo das representações é possível notar, portanto, que os repertórios iconográficos das cerâmicas de iluminação e sigillatas romanas têm algumas temáticas em comum, dentre elas a fauna, a flora, cenas mitológicas e eróticas (Cerdán 1999: 164). Além dessa constatação empírica básica que todo o pesquisador que depara com nesse tipo cerâmico faz, M. Amaré Tafalla (1986: 851) argumenta que existe a evidência representativa de temas comuns entre lamparinas e moedas. A autora afirma que as representações iconográficas das lamparinas romanas são acompanhadas, em certa medida, também dentro do campo numismático. Tafalla afirma que a técnica de ornamentação em baixo relevo é comum a ambas e apresenta as semelhanças que considera relevantes nas duas categorias materiais. Entretanto, essa correlação necessita ainda uma maior perscrutação e pode ser interessante associação a ser feita em estudos alhures. Outra interessante ideia aventada a esse respeito é a de que tenham existido "cadernos" que constituíam as cenas destinadas a figurar nas lamparinas, sendo que os mesmos circulariam entre os artesãos que, então, escolheriam as cenas que pretendiam colocar em suas peças. Essa é uma proposta de C. S. Pires Pereira (2008), que complementa a hipotética ideia dizendo que dentro dessa mesma circulação de "cadernos iconográficos", seriam repassados também os moldes, permitindo dessa 
forma as sobremoldagens concomitantemente ao tema que ora seria representado (Pereira 2008: 80).

Com efeito, aquilo que a princípio é plausível afirmar em relação à circulação das representações iconográficas com certo grau de segurança, é que dentre todos os temas representativos, são as decorações geométricas aquelas que perduram mais tempo em circulação, e talvez isso seja devido à possibilidade de nelas não se encontrar aparentemente maiores associações com a realidade concreta, como acontece com as temáticas que perpassam a vida cotidiana, fauna, flora, signos celestes, animais e figurações humanas, por exemplo.

Na observação de M. I. D’A. Fleming (1989) que procurou notar a articulação das representações iconográficas da religião oficial romana com o domínio da religião popular, caminhando ao lado da seleção de temas:

“(...) entrevê-se uma modificação de forma na representação na medida em que o pequeno artesão de lamparinas responsável por uma produção de âmbito familiar poderia satisfazer sua clientela não só pela escolha de certos temas iconográficos religiosos, mas eventualmente, acrescentando àquilo que, num primeiro momento, era uma representação do mundo religioso oficial, algo que a enquadrasse no código da religião popular” (Fleming 1989: 179).

Em termos práticos as lamparinas serviam habitualmente para prover a iluminação, seja dos locais públicos ou dos domínios domésticos. Em Pompéia tem-se a constatação de que essa forma cerâmica está presente nos edifícios públicos e ruas, junto às tabernae (Amaré Tafalla 1987: 20-21). Além da iluminação, as lamparinas serviam como marcadores de tempo, sendo referência não somente no contexto diário doméstico, mas principalmente nas galerias de extração de minério romano. Entretanto, nesse cenário as dimensões das lamparinas tendiam a mudar, sendo que as peças apresentam um rostrum alongado - para maior iluminação - e o recipiente de depósito com maior capacidade.

Um dos mais interessantes aspectos em relação à funcionalidade das lamparinas de terracota é aquele que concerne à vida religiosa. As lamparinas participam 
ativamente dos locais de culto, seja iluminando um determinado local ou, particularmente, desempenhando um importante papel nas atividades votivas. Em certo sentido, para além das práticas públicas de adoração nos templos, a religiosidade romana expressava-se de maneira mais cotidiana na presença do lararium contido nos domicílios romanos. $\mathrm{O}$ ato das ofertas votivas aos deuses, convidando-os à intimidade da casa, refletia na verdade a concepção primordial do Pax Deorum, em que partilhar a coexistência entre os seres humanos e deuses é a premissa essencial. Portanto, o empenho básico da adoração diária em casa consistia na separação de um "lugar sagrado", um altar, ou seja, o lararium. Nesse altar tanto os Lares Familiares divindades protetoras - como as divindades do paterfamilias são honradas em dois ritos diários junto ao lararium, um pela manhã e outro à noite. Durante esses ritos os deuses são adulados e pedidos de proteção, atenção e prosperidade são feitos. O lararium era naturalmente também um lugar onde os indivíduos poderiam adorar os deuses confidencialmente, e render pequenas oferendas. Essencialmente o lararium é o "coração sagrado" da casa, o lugar onde as forças positivas dos deuses podem ser trazidas à existência saecularis diária.

A forma dos lararia é muito variada, podendo em residências de ricas famílias encontrarem-se situados no atrium, feitos de mármore e reproduzindo esteticamente um templo, tal qual uma cópia em miniatura. Em outros casos, em residências menos abastadas, poderia ser somente uma prateleira de madeira simples na parede. De todos os modos, grande ou pequeno, o importante sobre um altar de lararium é que ele esteja colocado num lugar não remoto da casa, para não ficar ignorado ou esquecido, tampouco em um lugar que obstrua a circulação. A questão principal, portanto, é que constitua um lugar especial para as divindades no âmbito doméstico e diário.

A composição do altar de lararium é feita por sete elementos: a pátera, o salinum, o turibulum, o acerra, o incensum, o gutus, e a lucerna.

A pátera era um prato, geralmente raso, em que se oferecia uma porção do alimento da casa como forma de compartilhamento das benesses providas em relação aos víveres cotidianos. O salinum, por sua vez, era um recipiente para sal que cumpria o objetivo de purificação dos espíritos negativos. O turibulum nada mais era do que um 
incensário usado para criar os aromas sagrados que satisfariam as divindades e poderiam mudar as coisas do formulário contínuo para um formulário etéreo, consumindo-as com fogo. Este recipiente continha em seu interior, carvões quentes e o incenso pulverizado ou a resina aromática que produziam o aroma e a fumaça votiva. Os carvões também eram usados para queimar pequenas oferendas como porções alimentares, flores ou plantas. O accerra era um recipiente especial para o incensum sagrado e uma variedade de incensos era utilizada para queima na sociedade romana. Geralmente eram resinas, substâncias ou ervas pulverizada, ou ainda uma mistura das três. As resinas assim como os incensos e mirras eram muito populares, sendo comum a presença desses tipos de incesum no lararium. Já o gutus consistia em um recipiente para o leite e/ou o vinho ofertado. Da mesma maneira que o accera e o salinum, o gutus era usado para manter uma substância oferecida limpa e protegida. Enquanto praticamente todos os recipientes anteriores eram feitos geralmente de argila - e em alguns casos de metal, dependendo da preferência e posição social dos indivíduos -, o gutus poderia estar presente sob a forma vítrea. O líquido do gutus seria derramado na pátera quando este fosse ser ofertado. É importante dizer que todos esses alimentos não poderiam de forma alguma ficar um longo período de tempo expostos, pois certamente viriam a decompor-se. Então, seria imperioso manter as oferendas frescas, o que implica na renovação constante das mesmas.

De maneira particular os dois outros elementos presentes nos ritos junto ao altar do lararium estão interligados e têm especial atenção aqui, são eles: o fogo sagrado e a lucerna. É através da lucerna, a lâmpada de óleo, que aparece a representação da fonte de flama sagrada no altar do lararium. Uma lamparina deveria sempre estar no lararium e geralmente seria acesa no momento de execução dos ritos, ou seja, uma vez pela manhã e outra à noite, salvo libações particulares. A lamparina nesse contexto cumpre três papeis essenciais: o primeiro como a representação da chama sagrada, abriria o precedente para a interpretação da flama que ela produz, sendo que a direção e oscilação do lume poderiam ser interpretadas como bom ou mau augúrio. O segundo aspecto é o da representação da imagem que estaria no disco da lamparina e poderia associar-se a determinado propósito votivo e/ou a uma divindade específica. O terceiro então, decorrente tanto do primeiro como do segundo aspecto - ou mesmo da conjugação de 
ambos - é aquele em que a lamparina implicitamente representa a figuração material da comunicação entre mundos. Enquanto os outros materiais representariam as ofertas, podendo ser considerados como a "voz ofertante" - a exceção do salinum que tem papel purificador -, a lucerna expressa tanto a "voz ofertante" como fornece os sinais daquilo que chamaria aqui de "voz do ofertado". Portanto, dos materiais presentes nos ritos do lararium é aquele que melhor expressa a dualidade vocal.

No contexto religioso as lamparinas ainda aparecem como um especial elemento no mundo funerário. Segundo Walters (1914: xv) a presença de lamparinas no mundo funerário tem larga influência helenística e podem cumprir um papel de simples oferendas ou ainda abrigar outros significados mais profundos. Se por um lado, como indiquei acima, elas cumprem uma função específica no contexto do lararium, por outro lado, também estão presentes em templos associados às divindades cultuadas publicamente, e ainda, são depositadas nos contextos de sepultamento como uma "necessidade" para a vida post mortem (Almeida 1952: 90). Essa multivalência de ação das lamparinas tanto nos contextos religiosos domésticos e públicos, como também nos funerários é o que lhe confere um papel importantíssimo na mudança social e influência comportamental.

Entretanto, antes de avançar nessa discussão é importante salientar mais uma vez ao leitor que eminentemente as lamparinas cumprem um papel de veículo de mensagens religiosas, seja com a iconografia presente, seja nos contextos em que se apresentam cumprindo funções especificamente determinadas. 


\subsection{Entre herodianas, samaritanas e romanas discus: a associação artefactual e a complicada relação da etnicidade}

As lamparinas herodianas - conhecidas como "torneadas e aparadas por facas" (wheel-made and knife-pared, referência provável à espátula que tem função de desbastar e à forma do bico desse tipo de lamparina) - compartilham algumas características gerais, dentre elas estão o fato de terem uma abertura média na parte superior diferentemente das romanas do mesmo período. $\mathrm{O}$ bocal geralmente curto tem a forma espatulada e é feito separado da peça, sendo conectado ao reservatório por meio de um eixo colocado junto ao corpo do objeto. Esse tipo de bico é a característica marcante dessa cerâmica de iluminação e através dessa parte do objeto podem-se diferenciar dois tipos, segundo Smith (1961). O tipo 1 não apresenta decoração e possui a moldura em relevo sendo a borda relativamente larga em torno do amplo orifício de alimentação. O bico espatulado apresenta-se alongado e grande. Já o tipo 2 tem a moldura ao redor do orifício de alimentação menor do que no tipo 1 e a borda mais estreita. O bico frequentemente apresenta decoração, é menos espatulado que o tipo anterior. As decorações geralmente são círculos estampados e/ou uma ou duas linhas horizontais incisas ou ainda linhas roletadas (Smith 1961; Adan-Bayewitz et al. 2008: 40).

Essa cerâmica de iluminação começa a aparecer no final do século I a.C. ou talvez início do I século d.C. Seus exemplares aparecem no palácio de Herodes em Jericó em cronologias que se situam entre 15 a.C. e 6 d.C. (Bar-Nathan 2002: 112-113), e podem ser também verificados posteriormente, em suas tardias aparições nos contextos do século II d.C. (Loffreda 1996: 112). De maneira particular são constatados em Masada, onde variantes foram atribuídas aos dois tipos enunciados por Smith. Segundo Adan-Bayewitz et al. (2008: 40), as variantes apresentadas nos estudos de Barag e Hershkovitz (1994) - respectivamente tipos CI, CII, CIII - são correspondentes 
aos tipos 1 e 2 de Smith, sendo a variante CIII o momento de transição entre ambas. (Adan-Bayewitz et al. 2008: 40).

Adan-Bayewitz et al. (2008), analisando uma amostra de cento e setenta e seis lamparinas herodianas provenientes de cinco sítios do norte de Israel - Gamala, Iotapa, Sepphoris, Dor e Scythopolis - e dois na área de Jerusalém - a própria cidade e Horvat Ha-Motza - chegaram a interessantes inferências sobre esse tipo cerâmico e sua distribuição no país. A comparação das análises feitas demonstrou que a ampla maioria das lamparinas herodianas de Gamala, Iotapata e Sepphoris, não tem distinção química na composição de suas argilas daquelas usadas em Jerusalém e arredores no período que se estende até o II século d.C. Portanto, permitindo a segura inferência de que as comunidades judaicas que utilizaram essas lamparinas as traziam diretamente da localidade, demonstrando, assim, uma preferência estrita em relação a esse tipo de produção cerâmica. Em contraste, a maioria das lamparinas herodianas encontradas e analisadas tanto em Dor como Scythopolis apresentam uma composição diferente na argila (p. 58). A composição química das lamparinas dessas áreas - elas também foram encontradas em menor quantidade nos sítios de Iotapata e Sepphoris - foi identificada como pertencendo à formação geológica Ein Haqore, planície central costeira, solos da formação Brown Rendzinic, Baixa Galiléia, e dos sopés do Monte Carmelo. Isso permite dizer que os exemplares que não foram trazidos diretamente de Jerusalém, foram feitos provavelmente por artesãos familiares que obtiveram a matéria-prima nas imediações da Galiléia e reproduziram esse tipo cerâmico, demonstrando sua predileção pelo modelo específico.

Os autores levantaram três possibilidades explicativas para essa predileção: 1) a qualidade, 2) as fronteiras administrativas e 3) a identidade da população. Ponderando sobre a qualidade notaram que lamparinas herodianas vindas das imediações de Jerusalém estavam presentes, em maior ou menor quantidade, em todos os cinco sítios do norte do país. Assim, observam:

"Ao invés de produzirem localmente lamparinas Herodianas ou obterem-nas de algum produtor de localidades próximas do norte, no entanto, um esforço foi feito, mesmo em Dora e Scuthopilis, para se ter, 
ao menos, algumas dessas lamparinas de uma área relativamente distante de Jerusalém" (Adan-Bayewitz et al. 2008: 72). ${ }^{1}$

Portanto, apesar de as lamparinas herodianas serem feitas em outros centros de produção, a Galiléia surge como um deles, usando diferentes matérias-primas, parece existir uma preocupação em obter exemplares vindos de Jerusalém, possivelmente considerados de melhor qualidade.

Essa relação conduz à próxima análise feita pelos autores: as fronteiras administrativas. Ao contrário de Sepphoris, Iotapata e Gamala, as localidades de Dor e Scythopolis não estiveram sob o domínio de Herodes ou seus sucessores, desta forma, não seriam lugares de ocupação predominantemente judaica. A questão colocada na argumentação é que, se costumes fossem uma barreira para o acesso aos materiais, então por que um número considerável de lamparinas herodianas seria encontrado tanto em Dor quanto em Scythopolis? Um encaminhamento que colocaria por terra a questão das fronteiras administrativas como entrave aos contatos, relações de troca e comércio, é que no mesmo período em questão a fronteira oriental da Judeia não significava um impedimento para as cerâmicas comuns que eram produzidas no centro de Kefar Hananya que chegaram a distintas partes do país. Esse centro produtor na Galiléia era o principal fornecedor de cerâmicas de mesa do período (Adan-Bayewitz 1993; 2003 in Adan-Bayewitz et al. 2008: 73). Por último, a evidência numismática parece corroborar a afirmativa dos autores, pois a proporção de moedas “judaicas” em Dor e Scythopolis cerca de $60 \%$ do total encontrado nos sítios - é similar à das localidades de Gamala, Iotapata e Sepphoris. Assim, a questão administrativa não parece mesmo ter sido empecilho algum nos contatos e relações comerciais na área (ibidem).

Dessa forma, a questão síntese apresentada é a da identidade da população que usava as lamparinas herodianas nos lugares apresentados. Considerando que Gamala está $132 \mathrm{~km}$ de Jerusalém, e Iotapata e Sepphoris, a $116 \mathrm{~km}$ e $107 \mathrm{~km}$, respectivamente, o questionamento imposto é por que durante um longo período de tempo parece ter havido um esforço para obter as lamparinas diretamente dessa região, e concomitantemente e/ou

\footnotetext{
1 "Rather than making Herodian lamps locally or obtaining them from a nearby northern producer, therefore, an effort was made, even at Dora and Scuthopolis, to obtain at least some of these lamps from the relatively distant Jerusalem area".
} 
em período posterior, o mesmo esforço teria sido feito para reproduzir as mesmas peças na área próxima dos assentamentos? A resposta à questão parece levar à preferência identitária da população judaica estabelecida nesses lugares. Segundo os autores, peregrinos da Galiléia são mencionados explicitamente em um grande número de fontes literárias $^{2}$, dessa maneira um determinado grupo de devotos que estivesse retornando de Jerusalém poderia trazer facilmente as lamparinas consigo. Essa, então, poderia ser uma prática recorrente entre as comunidades estabelecidas na região. Além disso, a lamparina herodiana cumpriria um importante papel religioso e talvez ritualístico aos judeus de forma geral. Nas palavras de Adan-Bayewitz et al. (2008):

"A origem da área relativamente uniforme de Jerusalém, durante um longo período, a presença de lamparinas Herodianas ao norte de sítios judeus sugere que tais lâmpadas tenham tido alguma significância de ordem sócio-religiosa ou ritualística. Um dos importantes usos de lamparinas por judeus nesse período eram os de iluminação da casa e participação nas refeições nas sextasfeiras, especificamente, nas noites. A iluminação de uma lamparina entorno do por-do-sol nas noites das sextas-feiras era o ato mais definitivo, significando o início do Sabbath. (Mishna Shabbat, 2, 67) $O$ ato de acender as lamparinas como característca notável do Sabbath judeu é descrito a partir dos escritos pérsios pagãos do primeiro século (34-62 d.C.; Satires 5:180-84; M. Stern 1974: 43537) e Sêneca (morto em 65 d.C.; Moral Letters 95.47; M. Stern 1974: 429-30, 432-33) e também é mencionado por Josefo (AgAp 2.282). Para alguns, acender uma lamparina de Jerusalém, especialmente nas noites de sexta-feira, poderia ter significado especial" (Adan-Bayewitz et al. 2008: 75).

\footnotetext{
${ }^{2}$ Sobre o contato entre o norte da Judeia e Jerusalém na discussão das fontes literárias do período veja: Safrai 1965: 43-54, 1974: 191-204, 1976: 898-904; Goodman 1999; Levine 2002, para a relação dos peregrinos; e Leibner 2004: 63-352; Rappaport 2006: 42-125; Goodman 1983; Oppenheimer 1991 sobre a discussão do ethos galileu.

3 "The relatively uniform Jerusalem area origin, over a long period, of the Herodian lamps at northern Jewish sites suggest that these lamps may had some socio-religious or ritualistic significance. One important use of lamps by Jews in this period was for lighting the house and partaking of a meal on Friday, specifically at night. The lighting of a lamp around sunset on Friday evening was the most, definitive act signifying the onset of the Sabbath (e.g Mishna Shabbat, 2, 6-7). The kindling of lamps as a striking feature of the Jewish Sabbath is described by the first-century pagan writens Persius (34-62 C.E.; Satires 5:180-84; M. Stern 1974: 435-37) and Seneca (died 65 C.E.; Moral Letters 95.47; M. Stern 1974: 429-30, 432-33) and is also mentioned by Josephus (AgAp 2.282). For some, lighting a lamp from the Jerusalem area, on Friday evenings in particular, may have had special meaning".
} 
Nessa acepção, as lamparinas herodianas estão desempenhando importante papel no rito do Sabbat e corroborando a identidade da comunidade judaica, tanto que são trazidas de Jerusalém e quando isto não é possível, reproduzidas localmente. A esse respeito, a evidência de que em Shikhin - outro produtor local de cerâmica na Galiléia a prática de reproduzir lamparinas herodianas era técnica rotineira, sendo que dois exemplares com similar composição química são encontrados em Iotapata, apoia a assertiva proposta pelos autores (Adan-Bayewitz et al. 2008: 74).

Portanto, como é pertinentemente ressaltado pelos autores, a constatação de um ou mais exemplares de lamparinas herodianas num determinado sítio por si só não representa que no lugar tenha havido Judeus, da mesma forma que amparar-se somente na evidência numismática é demasiado perigoso, posto que a circulação de moedas não implica em relações étnicas, e sim comerciais. Contudo, a conjugação dos elementos apresentados permite afirmar que as populações judaicas tinham uma predileção por este tipo de lamparina, estando essas ligadas a sentimentos identitários das comunidades.

As lamparinas samaritanas, por sua vez, foram amplamente estudadas por V. Sussman, como discorri no capítulo anterior. Esse tipo cerâmico é caracterizado pela coloração de sua argila variando entre o vermelho-rosado e o cinza acastanhado, sendo facilmente distinguido entre as outras produções do período pela ausência do acabamento brilhante. Embora em alguns casos apareça o engobo de argila diluída, geralmente poucos exemplares indicam característica de banho ou pintados, o que torna a argila mais áspera ao toque (Sussman 1983: 73). O grupo de lamparinas samaritanas apresenta certa homogeneidade de maneira abrangente, podendo ser dividido em dois tipos básicos: as redondas e as alongadas. Algumas alterações nas alongadas é o que provê os parâmetros comparativos para os outros dois tipos derivantes - tipo 3 e 4 - e todos os tipos podem ser associados com a evidência clara dos assentamentos samaritanos.

O tipo 1 das lamparinas samaritanas é caracterizado por um corpo redondo, bico côncavo e largo. A base conta com dois ou três anéis concêntricos de larguras diferenciadas, embora em alguns casos possa aparecer somente um anel mais espesso. $\mathrm{O}$ lado inferior e superior do bico côncavo é acompanhado por duas linhas curvas 
paralelas e no seu interior um dos lados é maior, terminando na voluta que caracteriza tipicamente essas lamparinas. Já o tipo 2 tem a forma e dimensões semelhantes ao tipo 1, porém, o bico é mais alongado e menos côncavo. A forma nesse tipo cerâmico é semelhante a uma pera e como característica peculiar a lamparina possui um canal estreito e reto na frente/verso do bocal, entre o buraco do bico e a abertura de alimentação. Isso dá a impressão do aumento do comprimento da peça. As alças têm as mesmas variações do tipo 1 com formato piramidal de cume aplainado, sendo em alguns casos mais pontiagudo. O tipo 3 é caracterizado por seu formato ovoide e sem curvatura no bico. O bico reto e estreito apresenta um canal de ligação entre o orifício do bico e a abertura de alimentação do corpo da lamparina, ligeiramente trapezoidal. Esse tipo de lamparina se caracteriza por uma mudança significativa no estilo decorativo, que consiste principalmente em linhas horizontais/oblíquas ao redor da abertura de alimentação em seu corpo. Assim como nos tipos anteriores a alça em formato piramidal é predominante e tal qual o tipos antecedentes, a abertura de alimentação consiste em uma quebra intencional, pois as lamparinas samaritanas eram produzidas seladas. No momento em que o indivíduo as fosse usar era necessário abri-la quebrando a parte central, que não apresentava qualquer tipo de representação. A exceção desse tipo de abertura são alguns modelos do tipo 4 em que certos exemplares parecem terem sido projetados já com o orifício de alimentação aberto, sem a necessidade de abertura do mesmo como nas anteriores. Os exemplares do tipo 4 são aqueles que têm o corpo mais amplo dentre todos os outros citados e seu bico é largo com um canal que se nivela à superfície da peça, sendo essa sua característica marcante (Sussman 1983: 72-74).

Esse tipo de cerâmica tem uma rica variação de decoração que geralmente consiste em linhas alongadas, motivos florais, geométricos, círculos, semicírculos e linhas concêntricas, bem como variantes conjugadas de ambos os temas. A distribuição dessas lamparinas pelo território de Israel está bem conhecida e é possível referenciar pelo menos trinta e dois sítios onde as lamparinas samaritanas aparecem, com suas respectivas variações (vide mapa de distribuição no final do capítulo 5). Um grande número dessas lamparinas foi encontrado na capital Samaritana, a saber, a própria Samaria, e em cidades onde são evidentes os assentamentos dessa comunidade. De 
maneira particular, muitos exemplares desse tipo de lamparina também apareceram em Apollonia, porém, isso discutirei no próximo item desse capítulo.

As lamparinas romanas discus podem, então, ser apresentadas em três tipos principais quanto a sua forma mais geral, tendo correlações nos catálogos de estudos mais conhecidos. A primeira forma associada às formas Dressel 17/Loescke VIIIA/Deneauve VIID/ Rosenthal; Sivan, $\mathrm{n}^{\text {os }}$ 140, 141, 151 tem um corpo perfeitamente circular, a borda larga e convexa. Geralmente essa forma não apresenta qualquer tipo de decoração, nem na borda nem no disco. O disco côncavo é separado da borda por uma ou duas molduras, sendo o bico curto e redondo, separado do corpo da lamparina por uma pequena linha curva incisa. Esse tipo possui uma alça elevada o que muitas vezes dificulta um melhor enquadramento cronológico das peças por suas inúmeras variações. A segunda forma pode ser referida nos modelos Dressel 19/Loeschcke VIIIR/Ponsich III - B1/Deneauve VIIA/ Rosenthal; Sivan, $\mathrm{n}^{\text {os }} 180$, 181, e tem corpo circular, a borda ampla, larga e convexa, porém com o diferencial de na borda apresentar decoração. Os temas mais frequentes são motivos vegetais e geométricos. O disco é côncavo tendo também o orifício de alimentação separado da borda por uma ou duas molduras. O bico curto e redondo é destacado do corpo da lamparina por uma pequena linha reta, fruto da diferença de orientação entre o bico e a borda do objeto. Essa característica permitiu alguns autores diferenciar essa forma da Dressel 20 em que a linha é incisa. Já a terceira forma se enquadra nos paralelos de Dressel 27/Loeschcke VIIIH/Ponsich III C/Deneauve VIIIA/Rosenthal; Sivan, $\mathrm{n}^{\text {os }}$ 186-191, e tem o corpo perfeitamente circular, a borda larga e convexa contendo decorações variadas. $\mathrm{O}$ disco é côncavo e mantém o padrão de separação da borda por uma ou duas molduras, que reduzem o seu tamanho. A característica mais peculiar dessa forma é a separação entre o bico e o corpo da peça mediante duas linhas curvas, o que lhe confere a forma de um pequeno coração. Nas lamparinas com essas características ainda existem duas variantes, a forma Dressel 28, que se diferenciam das anteriores pela presença de decoração na borda.

Em Israel, a ampla maioria das lamparinas de tipo romana discus é comumente caracterizada como a variante do tipo XXV de Bronner, respectivamente Dressel 27 e 28/Loeschcke VIIIH/Ponsich III-C/Deneauve VIIIA/ Rosenthal; Sivan, $n^{\text {os }} 347-367$. Sua caracterização geral é de corpo circular sem a presença de alça, o bico curto e 
redondo separado do disco por linhas paralelas incisas ou pequenas circunferências. $\mathrm{O}$ bico separado do corpo por um par de volutas - as pequenas volutas que adornam o interstício do bico e do disco é uma das mais marcantes características dessa lamparina. Em certos casos as volutas podem não ocorrer, porém, isto não é usual. A base tem um ou mais círculos concêntricos, sendo identificados como "falsos anéis". A borda convexa apresenta decoração variada que vai desde cachos de uva estilizados, círculos e semicírculos (óvulos), corações e os machados duplos, outra característica que aliada às volutas marca representativamente essas peças. O disco é côncavo com um pequeno orifício de alimentação - cerca de $6 \mathrm{~mm}$ de diâmetro em média - e apresenta decoração em relevo com um vasto repertório iconográfico. Contudo, são comuns por vezes alguns modelos que não apresentam decoração no disco. A argila tem diferentes colorações e a variação das peças passa pelo vermelho-rosado (pinkish-reddish - Munsell 5YR 7/6; 10R 5/10 e 2.5YR 6/12), verde-amarelado ou alaranjado (yellowish green - Munsell 5Y 8/3-6, 5YR 7/8 e 10YR 8/6) e marron-escuro (buff and dark brown slip - Munsell 10YR 3/2 e 10YR 4/4).

As lamparinas romanas provinciais tipo discus aparecem em dois tamanhos diferenciados. Fanny Vitto recentemente as chamou de variante 1 e variante 2. As lamparinas da variante 1 apresentadas pelo autor (2011: 46*, Fig.23) têm paralelo direto com a que foi anteriormente descrita por Wexler e Gilboa (1996: 118, Fig.2) e está presente no catálogo dessa dissertação na prancha $\mathrm{n}^{\circ} 19$. Esse tipo de lamparina tem em média $10 \mathrm{~cm}$ de comprimento, entre 8,8 e $8,9 \mathrm{~cm}$ de largura e de 2,5 a 2,8 $\mathrm{cm}$ de altura. O bico e o corpo da lamparina são separados por duas linhas curvas no formato de um pequeno coração, ou não apresentam essa característica. A decoração da borda geralmente é composta por semicírculos (também conhecido como óvulos), ou tendo cachos de uvas estilizados, como no caso da Fig.23: 3 apresentado por Vitto. O disco é côncavo tendo o orifício de alimentação separado da borda por uma ou duas molduras e linhas incisas paralelas, com decoração em relevo - ausente pela questão da quebra. As variantes 2 são as mais encontradas por todo o território de Israel e é possível referir sua presença com quebra em pelo menos vinte e três sítios ao longo do país (vide mapa de distribuição de sítios no final do capítulo 5). Elas são lamparinas de pequeno porte medindo entre $8,7 \mathrm{~cm}$ de comprimento, $7 \mathrm{~cm}$ de largura e $2,2 \mathrm{~cm}$ de altura em média 
geral, apresentam a caracterizam geral das lamparinas romanas provinciais tipo discus acima descritas e o leitor pode ter a referência ilustrativa no catálogo dessa dissertação (item 4.3).

A problemática da quebra desse tipo de cerâmica de iluminação foi tangencialmente tratada através dos anos como discuti no capítulo anterior. A ideia é que se trata de uma produção do Mediterrâneo Oriental ou talvez da Fenícia, especialmente pela presença dos machados duplos na borda das peças. Como já referido elas estão em circulação a partir do último quartel do II século d.C. (provavelmente a partir de 135 d.C.) e seguem em durante o século III d.C. Portanto, esteve em circulação tanto com modelos herodianos - que entram em circulação antes e que certamente não desapareceram da noite para o dia - como com os modelos samaritanos - que perduram mais tempo em circulação do que elas. No contexto da tumba III de Maresha é encontrada junto do modelo Darom $^{4}$, uma produção local com representações muito semelhantes à produção samaritana (Sussman 1983: 75), que, no entanto, não ultrapassou a incipiência do II século d.C. (Oren e Rappaport 1974: 121-125).

V. Sussman (2003) sugere que as lamparinas que têm o bico liso (prancha 16, 17) seriam anteriores às que apresentam volutas. Por outro lado, a opinião externada por Wexler e Gilboa (1996) é de que existiu um processo de degeneração da forma, e a ausência das volutas acontece no decorrer do II e III séculos d.C. Fanny Vitto (2011) aponta que acontece uma perda na qualidade e estilização da decoração, especialmente nas bordas e ombros, durante esse período. Porém, nenhum dos autores parece fornecer maiores subsídios a suas inferências e seria necessário um estudo mais aprofundado sobre a temática para dirimir a questão.

Essa cerâmica de iluminação tem frequentemente recebido atribuição geral de uso dentro de uma relação étnica que é expressa da seguinte forma: aquelas que têm a parte da iconografia intacta são atribuídas ao uso dos gentios; e aquelas que apresentam quebra na parte central do objeto são atribuídas à prática judaica religiosa. $\mathrm{O}$ argumento inicial foi apresentado por Brand em 1953 e depois em 1969. Recentemente Fanny Vitto (2011) os sintetizou de maneira perspicaz, sendo esta a última publicação que tratou do

\footnotetext{
${ }^{4}$ O termo é adaptado de "Daroma” que é o nome na Mishná para a parte sul da Judeia.
} 
tema até aqui. Além do texto de Êxodo 20:4-5 sobre a adoração de imagens, nesses trabalhos é mencionado o texto da Mishná Avodah-Zarah que diz na integra: "Aquele que encontrar um vaso com a figura do sol, a figura da lua, ou a figura de um dragão, deve jogá-los no Mar Morto. Rabino Shimon ben Gamliel diz: aqueles valiosos são proibidos, aqueles sobre os simples são permitidos. R. Yose diz: ele deve triturar e espalhá-lo ao vento ou o jogar no mar. Eles lhe disseram: mesmo que se torne adubo, $e$ é dito (Det. 13:18): "E não se deve pegar nada devotado com a tua mão" (Avodah Zarah 3:3 $)^{5}$. O argumento de Brand ainda procura agregar a passagem de outra Mishná que afirma: "Não se deve esculpir uma lamparina, porque se forma um novo recipiente, e não se pode fazer um alimentador de fogo em Yom Tov, e não se pode cortar um pavio em dois. R. Yehudah diz: Pode-se cortá-lo com a chama em duas luzes" (Betzah 4:4) ${ }^{6}$.

A interpretação desta passagem é proposta no sentido de que os judeus ortodoxos comprariam as lamparinas discus fechadas dos oleiros - consideradas "impuras" - e quebrariam a parte central do objeto para torná-las "limpas" e, assim, poderiam trazer a seus domicílios para utilização (Brand 1953, 1969; Smith 1961; Neidinger 1982; S. Hadad 2002; Nahshoni et al. 2002; V. Sussman 2004; D. Barshad 2004; O. Shurkin 2004; A. Tatcher, Z. Gal 2008; F. Vitto 2011).

A afirmativa é ainda endossada por outras duas passagens da Mishná Kelim contemporâneas à circulação das lamparinas romanas discus. A primeira é a referência que afirma em sua íntegra: "o lugar onde a lamparina é depositada [torch] é suscetível a impureza e seu reservatório contrai imundícia através do espaço-ar. A decoração da borda, segundo R. Eliezer, não é suscetível a impureza, mas os sábios concordaram que é suscetível"8 (Kelim 2:8). Já segunda afirmação diz, em sua totalidade, o seguinte: "quanto a um jarro o tamanho do buraco deve ser tal qual um figo seco (para cair

\footnotetext{
5 "One who finds vessels on which is the figure of the sun, the figure of the moon, or the figure of a dragon, shall take them to the Salt Sea. Rabban Shimon ben Gamliel says: those on valuable ones are forbidden, those on plain ones are permitted. R. Yose says: he grinds it and scatters it to the wind or throws it into the sea. They said to him: even that becomes fertilizer, and it is said" (Deut. 13:18): "And there shall cleave nought of the devoted thing to your hand".

6 "One may not hollow out a lamp, because one makes a vessel; and one may not make charcoal on Yom Tov; and one may not cut a wick into two. R. Yehudah says, One may cut it with a flame into two lights". ${ }^{7}$ A "tocha" consistia no pedestal ou lugar onde estava fixa a lamparina para a iluminação do ambiente.

8 "A torch is susceptible to uncleanness and the reservoir of a lamp contracts uncleanness through its airspace. The comb of a cooler, R. Eliezer ruled, is not susceptible to uncleanness, but the sages ruled that it was susceptible".
} 
através dele); disse o R. Simeão. R. Judah fala em uma noz. R. Meir diz azeitona. $O$ tamanho do buraco em um pote de guisado deve ser o de uma azeitona (para cair através dele); numa botija, como o de um óleo (para penetrar através dele); e no jarro como um filete de água (para penetrar através dele). Segundo R. Simeão: o tamanho do buraco em todos os três casos deve ser tal qual o de uma semente. Na lamparina o tamanho do buraco deve ser o de um fio óleo (para penetrar através dele). R. Eliezer disse: tal qual um pequeno perutah (que possa cair através dele). Uma lamparina que tem o bico [pavio ${ }^{9}$ ] removido é limpa, e uma feita de terra que o bico tenha sido queimado pelo pavio também é limpa" ${ }^{\prime 10}$ (Kelim 3:2).

A associação dos argumentos com a relação artefactual é um tanto complicada e gostaria de pensar melhor a respeito de alguns pontos dessa questão. A passagem da Mishná Avodah-Zarah parece ser muito clara quanto a seu objetivo. Na passagem que antecede a citada anteriormente (Avodah-Zarah 3:3), suporte da ideia de Brand, a Mishná orienta o procedimento para quando fossem encontrados imagens, e assim afirma: "se alguém encontra fragmentos de imagem, isso é permitido. Se ele encontra a forma de uma mão ou forma de um pé, isso é proibido, já que esses itens são de adoração" (Avodah-Zarah 3:2). ${ }^{11}$ Portanto, se alguém encontrar fragmentos de imagens, estes são permitidos, pois há uma dupla incerteza sobre eles: se as imagens, ao todo, eram adoradas ou se foram gentios que a quebraram, assim, anulando o efeito dela. Dessa forma, os rabinos estão sendo indulgentes em relação a esses fragmentos e um judeu os poderia usar. Lembrando que os rabinos estão discorrendo de maneira geral. A Gemara ${ }^{12}$ dessa Mishná explica que a referência a fragmentos de imagens é

\footnotetext{
${ }^{9}$ Nota do autor; vide discussão abaixo.

10 "A jar the size of the hole must be such that a dried fig (will fall through): so R. Simeon. R. Judah said walnuts. R. Meir said: olives. The size of a hole in a stew-pot or a cooking pot must be such that olives (will fall through); in a cruse and a pitcher, such that oil (will penetrate through it) and in a cooler, such that water (will penetrate through it). R. Simeon ruled: the size of the hole in the case of all three groups must be such that seed (will fall through it). In a lamp the size of the hole must be such that oil (will penetrate through it). R. Eliezer said: such that a small perutah (will drop out through it). A lamp whose nozzle has been removed is clean and one made of earth whose nozzle has been burnt by the wick is also clean".

11 "If one finds fragments of images, these are permitted. If he found the form of a hand or the form of a foot, these are forbidden, since similar items are worshipped".

12 A Guemara também transliterada Gemora ou, menos frequentemente, Gemorra - do aramaico gamar - גמרא -, literalmente, "para estudar "ou "aprender por tradição" é a parte do Talmude que contém comentários e análises rabínicas da Mishná. A Guemara e a Mishná juntas compõem o Talmud. O
} 
permitida, pois se supõe que o gentio a quebrou e, portanto, a anulou. Entretanto, se o seguidor das observações identificar a forma de pés e mãos (veja prancha $\mathrm{n}^{0} 32$ do catálogo) não é permitido o uso desse objeto, pois a conclusão é que desde sua origem na confecção da peça - ela se destinava à adoração. Aqui residem dois pontos interessantes: o primeiro é que a passagem não se refere somente a "mãos e pés", obviamente, mas a todo o conjunto de imagens e objetos em que for identificado o objetivo da adoração. Dessa maneira poucas lamparinas romanas discus escapariam dessa classificação, pois a maioria delas tem clara referência a elementos de adoração greco-romanos, mesmo aquelas com motivos vegetais.

A afirmação sobre o objetivo votivo implica em outras passagens instigadoras que remetem ao segundo ponto dessa observação. Na Mishná Kelim 3:3 é dito que: "Se um jarro [vaso/lamparina] que tinha um buraco foi remendado com resina [pitch] $e$ quebrado novamente, e se o fragmento que foi remendado com a resina contiver um quarto de matéria vegetal $[\log =$ caule lenhoso de árvore] isso o torna impuro, pois desde sua confecção deixou de ser usado para outra coisa, que não sua função. Se um jarro tinha um buraco e foi remendado com resina, trata-se de um vaso limpo, pois embora possa conter um quarto de matéria vegetal, deixou de ser usado para seu fim". 13

Se o leitor não deixar sua atenção ser levada pela frase "um quarto de matéria vegetal" (a quarter of a log), que poderia confundi-lo sobre o objetivo da frase, o que esta sendo dito é que quando acontece um remendo num vaso ele deve ser usado em outra função, pois a quebra o inutiliza em sua função original, tornando-o outra coisa, ou seja, impuro para sua função primordial. A questão não é o remendo em si, mas sua função. Todo vaso tem sua designação original, para a qual foi projetado, e se sofrer dano, pode até ser consertado, conforme indica a passagem, contanto que seja utilizado em outro contexto, para o que se torna "limpo". O mesmo argumento é indicado para lamparinas quando a Mishná Betzah 4:4 diz: "Não se deve esculpir uma lamparina,

Talmud, assim, compreende duas componentes: a Mishná, o texto principal, e da Guemará, a análise e o comentário que "completam" o Talmud.

13 "If a jar that had a hole was mended with pitch and then was broken again, if the fragment that was mended with the pitch can contain a quarter of a log it is unclean, since the designation of vessel has never ceased to be applied to it. If a potsherd had a hole that was mended with pitch, it is clean though it can contain a quarter of a log, because the designation of vessel has ceased to be applied to it". 
porque se forma um novo recipiente”. A Mishná afirma que não é licito a um judeu ortodoxo fazer uma lamparina quebrando-a ou cavando um orifício em outra forma cerâmica - a palavra no hebraico numa das versões é pothim e em outra versão é pohatim e tem o sentido de diminuir o tamanho da argila. Essa proibição, aliada à constatação das funções dos objetos, leva à conclusão de que um judeu seguidor da religião não poderia ele próprio realizar a quebra de uma peça cerâmica como as lamparinas romanas discus, sendo esse o segundo ponto dessa observação.

O desenvolvimento da premissa de Brand sugeria, então, que os judeus compravam as lamparinas e que: a) eles as quebravam ou b) pediam ao oleiro para fazêlo, dada a restrição imposta. Em todos os casos, o objetivo final seria um só: "limpar" as peças. Embora seja possível pensar no argumento de que os judeus estariam entendendo que a função e designação primordial estavam sendo "mudadas" de um plano que atendia à religiosidade gentia em sepultamentos, ritos domésticos e iluminação cotidiana $^{14}$, para outro plano, "outra função", portanto, que atenderia à demanda da religiosidade judaica. Entretanto, se analisarmos esse argumento encontraremos algumas dificuldades. Vejamos: em primeiro lugar implicaria que todos os oleiros que tratavam com esse tipo cerâmico teriam de ser gentios, o que de imediato acarretaria numa especificação do ofício: os oleiros que trabalham com lamparinas romanas discus e os oleiros que não trabalham com lamparinas romanas discus, e, portanto, forneciam outro tipo de cerâmica, tal como as lamparinas herodianas e samaritanas, por exemplo. Embora seja pouco provável essa primeira consequência, o argumento ainda conduz a um segundo empecilho prático mais delicado: no momento da compra e do pedido de quebra um judeu ortodoxo estaria ciente de que: 1) está obtendo uma peça de um gentio que fornece um tipo específico de lamparina, quando supostamente existem em circulação outras lamparinas a optar e outros oleiros a fornecer; e 2) estar consciente de que a iconografia da peça que ele está adquirindo é pagã e devido a isso solicitaria ao oleiro - detalhe: gentio - que quebrasse a peça para que ele possa levar o objeto a sua casa. Porém, isso seria um confronto direto com Avodah-Zarah 3:2 que afirma que se existe a identificação do propósito para qual a peça foi designada e esse propósito é

\footnotetext{
${ }^{14}$ Ashqelon (Stager 1991:43); Caesarea Maritima (Siegelman; Ne'eman 1992); Jalame (Macdonnell 1988); Dor (Stern 1994:308-309); Qeren Naftali - Kh.Hurrawi- (Avian 2004:82, 83, 8); Jerusalém (Magness 2005).
} 
votivo, então: "é proibido, já que esses itens são de adoração". Dessa forma, a orientação não é um impulso à quebra como sugere a ideia de Brand e sim uma restrição a ela, em termos práticos, vejamos por que.

A Mishná em questão discute duas questões: 1) a suspeita do uso dos recipientes para idolatria; 2) como proceder se houver essa constatação. Como um judeu ortodoxo certamente saberia que a peça que estava adquirindo acarretava elementos votivos, sua conduta não poderia ser outra senão cumprir o que estava orientado para esse caso: "triturar e espalhar ao vento ou jogar no mar" o objeto. Note-se que não se fala de uma alteração na função do objeto, ou na mudança do plano idólatra para o não-idólatra, ou do impuro para o puro, mas sim da estrita ordem de inutilização completa da peça, ou seja, destruição total do objeto. Não há acordo quanto a essa afirmação no âmbito do judaísmo ortodoxo, conforme indica a própria Mishná.

Assim, chega-se a um impasse: ou os judeus ortodoxos fizeram vista grossa ao ícone presente nas lamparinas e solicitaram sua quebra ao oleiro no ato da aquisição, o que os colocaria em confrontação direta com a observação das imagens; ou os judeus que praticaram tal ato ignoraram a orientação dos rabinos, quebrando eles próprios a lamparina somente na parte do ícone, não sendo tão ortodoxos como convencionalmente se pretende na acepção de Brand (1953), Smith (1961) e Neidinger (1981) - este último somente no que se refere à parte inicial de sua tese.

Em ambos os casos a ortodoxia certamente seria posta de lado, convido o leitor à análise: o rabino Shimon ben Gamliel diz que: "aqueles valiosos são proibidos, aqueles sobre os simples são permitidos" e é completado pelo R. Yose que afirma: "E não se deve pegar nada devotado com a tua mão". Em outro sentido é empregado "e não pegará nada do anátema na tua mão". Note que o rabino Shimon ben Gamliel está diferenciando os vasos de maior e de menor valor. Aqueles com muitos adornos seriam entendidos como proibidos, pois a conclusão é que teriam o fỉm da adoração; já os mais simples, ou seja, sem representações e adornos estariam lícitos ao uso, provavelmente se referindo às cerâmcias de mesa que tinham pouca ou nenhuma decoração, lembrando que a Mishná está tratando dos objetos de maneira geral e não especificamente de lamparinas. O rabino R. Yose completa dizendo para não tocar nas peças que são 
devotadas, portanto, criando mais um impedimento para que judeus ortodoxos executem a quebra, conforme frequentemente lhes é atribuída. Embora o R. Eliezer entenda que a decoração da borda não é suscetivel a impureza, o complemento da ideia no parágrafo sobre o procedimento que deveria ser adotado em observância à Mishná Kelim 2:8 não deixa dúvida a respeito: "mas os sábios concordaram que é suscetível”, ou seja, embora um rabino pense o contrário, o consenso dos demais rabinos é de que os objetos são, sim, suscetíveis a impureza e colocam isso publicamente na Mishná para que se tenha claro qual opinião prevalece nesse sentido.

Soa estranho, então, que se tenha uma grande restrição e cuidade nos termos alimentares e dos víveres, como indicam os texots, e justamente no momento dos sepultamentos - contexto em que aparece a maioria das lamparinas romanas quebradas - essas restrições se flexionassem e objetos suscetíveis a impureza estivessem presentes no rito de judeus ortodoxos que em tese deverim ser muito bem instruído quanto a isso. Os contextos domésticos de Apollonia e 'Ein Ez-Zeituna que poderiam contribuir apoiando a ideia da quebra por observância de judeus ortodoxos, não suportam tal explicação como veremos. Afinal, se essa prática se estende aos sepultamentos, em tese, novamente, deveria estar também presente nas habitações domésticas.

Convém salientar que as lamparinas de barro, contanto que não tivessem iconografia gentia e fossem abertas desde sua confecção original, não eram consideradas impuras, a Mishná Kelim 2:3 fala a respeito e diz: “Os seguintes não são suscetíveis à impureza entre vasos de barro: uma bandeja sem borda, panela de cozinha com lados quebrados, tubo para assar milho, calhas, mesmo que sejam dobradas e com alguma forma de receptáculo, uma tampa de cesta que foi transformada em cesta de pão, um jarro que foi adaptado como tampa para uvas, um jarro para nadadores [swimmers], um pequeno jarro fixado como se fosse uma concha, uma cama, um pequeno banco, um banco, uma mesa, um barco [a ship] e uma lamparina de barro, eis que estes são insuscetíveis à impureza. A seguinte regra geral: qualquer vaso de barro que não tem parte interna não é suscetível à impureza em suas partes externas." 15 Talvez isso explique o esforço no translado das lamparinas

\footnotetext{
15 "The following are not susceptible to uncleanness among earthen vessels: a tray without a rim, a firepan with broken sides, a tube for coasting corn, gutters even if they are bent and even if they have some
} 
herodianas para a Galiléia vindas diretamente de Jerusalém, no mesmo período em questão, como afirmam Adan-Bayewitz et al. (2008).

Embora a lamparina não seja impura, o lugar onde ela é colocada é suscetível à impureza como é afirmado na Mishná Kelim 2:8 e é nessa mesma Mishná - Kelim 3:2 que se discute o tamanho que deve ter o buraco dos recipientes para que não se tornem impuros. Em todos os casos ele deve ser muito pequeno, do tamanho de uma semente. Especificamente para as lamparinas a referência imediata é a de um fio de óleo, sendo que na sequência o rabino Eliezer diz que deve ter o tamanho de uma moeda de perutah (vide imagem abaixo) para que através desse tamanho de orifício ela possa cair. F. Vitto (2011) pondera que a moeda de perutah tem, em média, $15 \mathrm{~mm}$ de diâmetro, enquanto o orifício de alimentação das lamparinas romanas provinciais discus tem $6 \mathrm{~mm}$ em média (Brand 1969: Pl. 7: 2). O autor cogita que para o cumprimento da observância orientada pelos rabinos - de um perutah - os judeus ortodoxos teriam alargado o orifício (Vitto 2011: 52*). Entretanto, além da questão de que se fossem judeus ortodoxos não lhes era lícito fazer isso, o diâmetro de quebra dos discos de Apollonia, por exemplo, tem a média de $30 \mathrm{~mm}$ (vide catálogo item 4.3.) e parece ser esse padrão existente nos vinte e três sítios passíveis de referência em que aparecem lamparinas romanas discus com essa quebra (vide mapa de distribuição no final do capítulo 5). Num buraco desse tamanho, portanto, podem passar duas perutah, descaracterizando a relação de ser um pequeno orifício, como indica o texto dos rabinos. Mais uma vez a Mishná Kelim 3:1 reforça: “ $O$ tamanho do buraco de um vaso que o representa limpo deve seguir: se o vaso for usado para gêneros alimentícios o buraco deve ser grande o suficiente para azeitonas (para caírem através dele), se o vaso for usado para líquidos basta que o tamanho seja grande o suficiente para os líquidos (para serem introduzidos por ele), e se for usado para ambos ele é submetido a uma restrição maior, que o buraco seja grande o suficiente para uma azeitona (para cair através dele). "l6 Além dessa explicitação é

form of receptacle, a basket-cover that was turned into a bread-basket, a pitcher that has been adapted as a cover for grapes, a jar for swimmers, a small jar fixed to the sides of a ladle, a bed, a stool, a bench, a table, a ship, and an earthen lamp, behold these are insusceptible to uncleanness. The following is general rule: any among earthen vessel that has no inner part is not susceptible to uncleanness on it outer sides."

16 "The size of a hole that renders an earthen vessel clean is the following: if the vessel was used for foodstuffs the hole must be big enough for olives (to fall through), if it was used for liquids it suffices for the hole to be big enough for liquids (to be admitted through it), and if it was used for both it is subjected to the greater restriction, that the hole must be big enough for olives (to fall through)" 
possível constatar formas padronizadas de quebra que ultrapassam a largo essa orientação, tal qual apresento na sequência desse capítulo.

Com relação ao complemento final do segundo parágrafo dessa Mishná, que diz: "Uma lamparina que tem o bico [pavio] removido é limpa, e uma feita de terra que o bico tenha sido queimado pelo pavio também é limpa" (Kelim 3:2), é possível que a primeira parte da frase que diz: "uma lamparina que tem o bico removido é limpa" tenha sido entendida como a justificação de que foram os judeus ortodoxos que praticavam a quebra das lamparinas. Em português, tal qual traduzi do inglês, "A lamp whose nozzle has been removed is clean and one made of earth whose nozzle has been burnt by the wick is also clean", pode-se pensar que a remoção do bico/nozzle é a quebra que se nota nas lamparinas em discussão, mesmo que fique claro no texto que bico/nozzle não é o disco de uma lamparina e sim a extremidade do objeto. Mesmo assim, é esclarecedor quando se recorre ao hebraico para o entendimento dessa passagem, a fim de não cometer algum tipo de confusão Vejamos que a orientação é: "טהור ,פתילהב פיו שהוסק אדמה ושל ;טהור ,פיו שניטל פר" (da esquerda pra direita). A sentença diz que a lamparina é שהור - tahor - limpa, pura - quando פיור - zarbuvit - o bocal, que no português ficou como bico e no inglês nozzle - tiver o פתילה-ptila - que é o pavio - removido - שניטל - shenital - ou na tradução mais ao pé da letra: tomado ou tirado. Veja o leitor, então, que a orientação, mesmo no hebraico, não muda seu sentido, mas amplia o entendimento. Ela trata do uso que deve ser feito de uma lamparina em relação ao pavio que está no bocal e não do orifício de alimentação, que nas frases anteriores da mesma Mishná foi orientado que fosse pequeno. Seria uma contradição, portanto, se na frase seguinte da Mishná a orientação fosse o contrário, ou seja, "quebrar e alargar o orifício de alimentação". A orientação se refere, dessa forma, ao ptila-pavio- que sendo removido, tomado, tirado, como o leitor preferir, do bocal פarbuvit - torna a peça limpa. É por este motivo que a segunda parte da frase complementa a ideia do que está sendo dito e afirma que se um bocal פיפ-zarbuvit - já tiver sido queimado pelo פתילה - ptila-pavio - é limpo da mesma maneira. Assim, na ideia completa: se o pavio foi removido do bocal a peça é limpa, da mesma forma que acontece com o bocal que já sofreu queima, pois o pavio não está mais ali, e, portanto, é limpo também. Assim, a questão é sobre a utilização do pavio, que não poderia estar 
presente na lamparina quando um judeu ortodoxo fosse usar o objeto. Isso tornava a peça "impura" e para manter a "pureza" dela, portanto, era necessário que se tirasse o pavio do bocal ou o bocal só apresentasse a queima. A primeira parte da frase se complementa na segunda parte dela, se tomada isoladamente pode incorrer em outra interpretação. Recorde o leitor que a preocupação com a utilização do pavio já fora externada na Mishná Avodah Zarah 3:3 quando ela refere que o pavio das lamparinas não poderia ser dividido, somente o fogo.

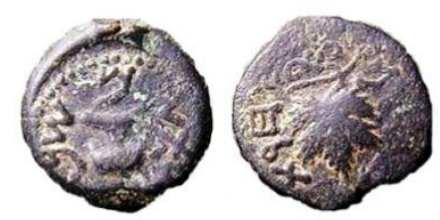

Fig. 17 Moeda de perutah de origem indefinida com datação entre 67-68 d.C.

Assim, a associação da quebra intencional por judeus ortodoxos é um paralelo muito complicado de ser feito com as relações artefactuais e mesmo com os textos de sustentação da ideia, diante das questões expostas. Assim, é na análise de um específico contexto doméstico - o de Apollonia - que meus argumentos caminharão a partir daqui.

\section{3. "Quebrando" o habitus: as lamparinas de Apollonia-Arsuf}

Ao tratar da prática simbólica em grupos sociais, inerente muitas vezes está uma visão equivocada da hierarquização daquilo que se chama frequentemente de tradição. A maneira como é tratada essa mecânica social acarreta em outra ideia que é a do acúmulo de conhecimentos, práticas e símbolos de maneira estanque e monolítica. Ao contrário, a tradição deveria ser vista como um processo simbólico em que os atores, em interação com fragmentos do passado, interpretam e reinterpretam essas memórias, de 
maneira que em contato constante com demais grupos sociais, desempenham determinados papeis e através das associações que fazem nesse processo surgem as questões de "quem somos", "de onde viemos" ou ainda, a mais interessante para essa análise, “o que nós podemos ser” (Hall 1997: 4). Na dimensão cognitiva desse processo está, principalmente, a reificação e maximização da distinção, intrínseca à definição do "eu" e do "outro" (Jenkins 1994; Levine 1999). Nas acepções recentes sobre identidade essa dinâmica cognitiva é uma característica permanente das relações entre os grupos sociais, sendo que os atores inferem a disjunção da identidade objetiva e subjetiva com significado simbólico e continuamente a ajustam e transformam, ocasionando em certo sentido o conflito simbólico entre os grupos sobre o significado, propriedade e valor dos aparatos presentes em determinada(as) tradição(ões) - ou seja, conhecimentos, nomes, práticas, símbolos - pela busca da legitimidade face às hegemonias.

Tal qual tratei no final do primeiro capítulo dessa dissertação, a hegemonia pode ser entendida como uma "consciência predominante" em constante negociação e mudança entre os grupos de interesses, transcendendo o que é comumente definido como ideologia por incluir nessa relação a experiência, sendo, dessa forma, internalizada ou aceita em diferentes níveis pelos membros desses grupos. A hegemonia como um conjunto de expectativas e práticas sobre o viver, que inclui os sentimentos, destinação de energia e as perscepções que moldam o nosso redor e a nós mesmos, nada mais é que um sistema vívido de significados - constitutivos e constituintes - que quando experimentados como práticas se confirmam na reciprocidade (Boggs 1976; Williams 1977; Breudry et al. 2007). Essa apreensão fornece um senso de realidade para a maioria das pessoas da sociedade, e este senso de absoluto fruto das realidades experimentadas - em diferentes níveis - fomenta a ideia de que é dificil se movimentar para além do conjunto que se impõe aos membros do grupo. Equivaleria dizer que se trata de uma "cultura", com o porém de ser uma cultura vista como dominação, subordinação e resistências que são experimentadas por diferentes grupos específicos no ambito social.

Desse modo, o mundo material participa dessa relação na medida em que conduz ao discurso social e constrói/reconstrói a existência do poder dos "textos sem palavras". Nessa leitura dos artefatos como portadores de mensagens estão expressas as acepções 
dos atores sociais em suas relações com os outros, e acima de tudo, com eles mesmos (Hall 1997: 14). Portanto, quando o mundo material e as ações daqueles que o criam entram em contato, sendo usados para determinada finalidade, essas afirmações são exatamente relações de discurso. Os grupos sociais tornam públicas suas diferenças centrando-se, sobretudo, no que percebem como sendo seu próprio interesse. Essa premissa está em Gramsci quando se refere à ideologia, afirmando que as relações estabelecidas ente distintos grupos concorrem na arena cultural e os símbolos podem ser adotados e manuseados por diferentes grupos em um processo que busca a negociação desses pontos para uma posição de liderança (Gramsci 1977, apud Benett 1986: xv). Contudo, ao tratar dessa questão ao invés de usar "ideologia dominante", minha preferência caminha para os mesmos argumentos de Breudry et al. 2007, em que o conceito de hegemonia cultural é priveligiado. Em primeiro lugar, porque discordo veementemente da ideia de que dominação política e/ou econômica é a mesma coisa que dominação social e/ou cultural. Embora, como afirmei anteriormente os indivíduos não estejam distribuídos pelo tecido social igualitariamente e determinados grupos ou indivíduos estejam colocados em posições preponderantes nas relações de contato, dissociando o poder dos domínios individuais, essas relações estão espalhadas pelos mais variados níveis da rede social. Por este fato não são incomuns as rebeliões, revoluções e movimentos de embates de força, afinal, o poder nada mais é que a ativação e desdobramento dessa relação, como diria Foucault. Segundo, na hegemnia cultural o controle é visto através do consenso, e não somente no sentido da coerção. Assim, quando não há mais negociação nesses termos e os fatores de significado e sentido são colocados acima das negociações, a belicosidade tende a sua manifestação maior. Esse fenômeno é cotidiano em minha opinião. $O$ terceiro ponto, sendo a decorrência dos outros dois, é que as iniciativas e contribuições alternativas demonstram opções às hegemonias, muito embora, na maior parte das vezes sejam estruturadas nos mesmos termos do discurso hegemônico quando chegam às disputas pelos recursos societais (Boggs 1976: 40; Williams 1977: 114).

Dessa forma, a importância da cultura material em comunicar é o que a distingue na negociação cotidiana das hegemonias, tal qual uma "resistência cotidiana", a ambiguidade coalecente dos múltiplos significados que a cultura material pode assumir 
perfaz o sentido da polissemina, em outras palavas, os artefatos como parte integrante das afirmações de sentido, criam e recriam seus significados na mesma medida em que contribuem para a própria criação do discurso que cria e recria o "outro" (Hall 1997: 26). É, portanto, por isso que os comportamentos simbólicos efêmeros tornam seus traços materias ainda mais importantes (Breudry et al. 2007). Assim, a prática simbólica tem sua caracterização também no conhecimento socializado e na contínua transformação reflexiva dos conhecimentos tradicionais, das redes de contatos sociais e dos simbolismos entre grupos.

Na percepção de Bourdieu nós somos capazes de compreender que "os pontos de vista" são uma posição assumida a partir de um ponto, isto é, a partir de uma posição fixa no espaço. $\mathrm{O}$ indivíduo tem um ativo recrutamento no mundo que está sob o regime de determinadas limitações conceituais. Dessa maneira, o mundo social, em sua opinião, tende a ser percebido como uma modalidade dóxica ${ }^{17}$ devido às disposições dos atores seu habitus ou estruturas mentais - a partir da apreensão do mundo social como produto da interiorização das estruturas desse mundo (Bourdieu 1990). As ações dos indivíduos, então, variam de acordo com sua posição tanto quanto de seu habtitus, este entendido como os padrões de percepção e apreciação das estruturas cognitivas e avaliativas. $\mathrm{O}$ habitus é, portanto, simultaneamente um sistema padrão de práticas e a avaliação dessas práticas. Em ambos os casos, é na ação e na posição social que o habitus se constrói (Bourdieu 1991). Essa teoria da prática preconiza que os objetos de conhecimento são construídos e não passivamente registrado, como haveria de se supor. O princípio da sua construção é amparado nas provisões feitas, na ação que orienta para a função do sentido prático. Assim, seriam as condições associadas a determinado grupo que produziriam o habitus tal qual o sistema de disposições, duráveis e efêmeras, dos princípios gerais de organização das práticas e representações que podem ser objetivamente adaptadas para assumir um fim. O habitus expressa o domínio das operações necessárias para atingir as regularidades, sem estar necessariamente vinculado à obediência de regras, da mesma maneira que está coletivamente organizado, sem obrigatoriedade de estar vinculado a uma determinada ação organizadora, como a de um maestro, por exemplo (Bourdieu 1991: 92).

\footnotetext{
${ }^{17}$ Doxa ( $\left.\boldsymbol{\delta} \boldsymbol{o}_{\boldsymbol{~}} \boldsymbol{\alpha}\right)$ é uma palavra grega que significa crença comum ou opinião popular.
} 
O habitus ajusta uma relação entre as probabilidades objetivas e subjetivas das expectativas, muito mais pela realidade das disposições de possibilidades e impossibilidades, liberdades e proibições, vantagens e desvantagens que estão associadas a um determinado fim, do que propriamente ao ajuste consciente do que se espera pela prática. O habitus seria, então, naturalmente a categoria do impensável, resultado das práticas individuais e de grupo em coerência com a historicidade do período. Através das experiências passadas e internalizadas pelos atores, sob a forma do pensar, as percepções e ações engendram um princípio de continuidade e regularidade das práticas sociais que é princípio desse habitus. Destarte, é a partir do interior que se constituem as relações inconscientes de significado, necessidades e gostos, sendo um reflexo e coerência das escolhas que geram o habitus, amparado na distinção e que confere significado aos atos.

A articulação entre significante e significado é o que conhecemos por signo e um símbolo na realidade nada mais é que um signo arbitrário, inconsciente ou consciente. A função do símbolo é, portanto, ser uma das ligações no processo do comunicar que envolve o desconhecido através do conhecido, que passa a ser o próprio símbolo. As qualidades que um dado símbolo recebe pelo consenso que se estabelece podem ser transferidas pelo observador a uma situação na qual o símbolo possa ser empregado. $\mathrm{O}$ símbolo e o simbolizado se relacionam de forma dinâmica e em mudança (Tuner 1974: 25-30). É na interação que estabelecemos determinadas categorias de objetos que passam a ser entendidos como entidades materiais, inseparáveis da situação relacional que as defini como símbolos, elas fixam em quem as usam certos atributos culturais específicos (Breudry et al. 2007: 79). Através de uma ampla variedade de signos, gestos e posturas, nos comunicamos com aqueles que interagimos ao longo dos contatos na vida dizendo-lhes quem somos e o que estamos fazendo. Os usos materias permitem as relações de julgamento, classificação e auto-expressão que perfazem a construção da identidade cultural. Segundo Lofland (1973: 22) a vida na cidade só tornou-se possível através de uma "ordenação" da população amparada na aparência e localização espacial, pois aqueles que viviam na cidade poderiam saber algo em relação ao outro apenas pelo olhar, é o que Breudry et al. (2007) chamou de "problemático mundo dos estranhos". Note-se que essa codificação, baseada na localização e aparência, não passa do 
desdobramento da interpretação dos símbolos visíveis que se decodificam de maneira muita difusa e variada em cada contexto. Aqui se chega a um ponto basilar: é no contexto que o significado está localizado e constituído. A existência de um contexto incorre na presença de significados funcionando dentro e através dele, sendo que não é possível haver significados sem a presença dele. O entendimento e recuperação do significado são baseados no entendimento e recuperação do contexto, pois este não somente estrutura significados através da trama de situações e eventos presentes, como também se liga a ele pelos entendimentos e práticas em jogo. Nesse sentido, não é incomum que em contextos diferenciados e não usuais o significado seja renegociado e redefinido. Nessa relação "extra contexto", ou seja, nas distintas conjunturas utilizadas à parte das hegemonias, a força dos símbolos materiais em comunicar aparece, ao mesmo tempo, agregando e distinguindo. Não é questão de igualar o poder dos artefatos ao poder de seus usuários, pois em realidade eles não atendem nunca a uma única função símbólica, antes mediam uma miríade delas simultaneamente (Breudry et al. 2007: 83).

O contexto de Apollonia é essa "contra-ordem" ou "extra contexto" na questão interpretativa da quebra das lamparinas romanas provinciais discus. A ocupação do sítio em período romano contempla dois momentos diferenciados e um colapso que foi entendido como o final do período de ocupação da edificação. Como anteriormente mencionado o sítio de Apollonia para esse período consiste numa Villa marittima (21,50 x $24 \mathrm{~m}$ ) com três pequenos corredores em torno de um peristilo e um quarto corredor alongado que atravessa toda a estrutura do edifício. Em seu conjunto a edificação foi construída conforme o padrão de pes latinos que marca cerca de 0,3 metros. A espessura das paredes internas - com exceção das do peristilo - varia em 0,4 e $0,45 \mathrm{~m}$ e o pátio central tem as dimensões interiores de 6,45 x 3,85 m, correspondendo a 22 x 13 pedes. Os corredores têm a medida de $2,4 \mathrm{~m}$ em média -8 pedes na medida latina. É conveniente reafirmar que esse tipo de edifício, uma Villa marittima na costa do Mediterrâneo, era até então desconhecido na Judeia, portanto, sua importância tanto como contexto doméstico quanto arquitetônico é singular (Galor, Roll, Tal 2009: 9). 


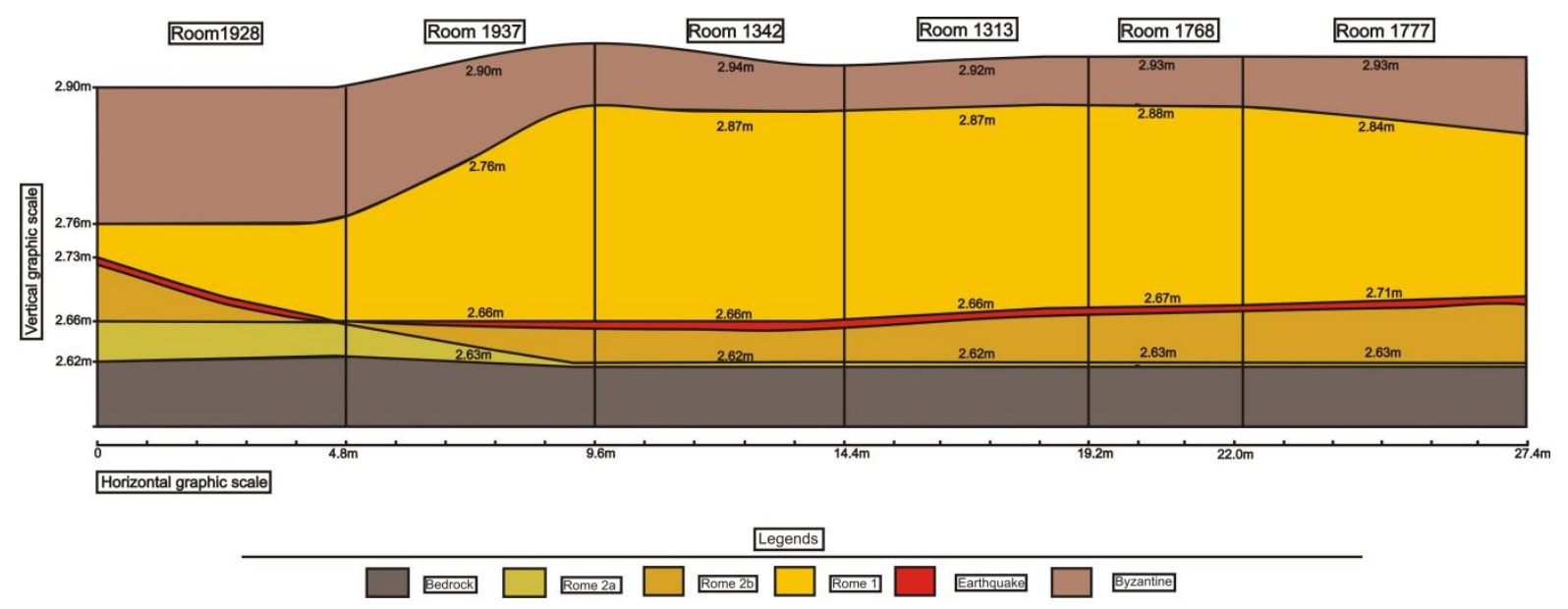

Fig. 18 Estratigrafia do sítio de Apollonia-Arsuf para o período romano.

A escavação inicial (1980) dos dois recintos ligados por um pórtico na parte sul do sítio (Locus 1928 e 1937, veja abaixo) permitiu a primeira constatação: que o edifício foi construído sendo escavado na rocha matriz - kurkar - e aproveitando esse material a edificação foi erguida. No Locus 1928 duas camadas sobrepostas foram encontradas: a camada romana $2 \mathrm{~A}$ e $2 \mathrm{~B}$, ambas contendo material do final do I século d.C. e II século d.C. Esses recintos aparentemente foram atingidos por um terremoto e a escavação de uma trincheira demonstrou que a área havia sido nivelada posteriormente, sendo uma prensa de vinho construída no lugar em período Bizantino. (Roll, Tal 2008: 136). Em outro momento (1990-1993), três recintos adicionais foram escavados (Locus 1342, 1313 e 1768) estendendo-se a sul das edificações anteriores. Um corredor (Locus 1859) foi também identificado, ligando-se ao Locus 1937 e provendo o acesso através dele a todo o complexo da villa. Em todos os recintos a estratigrafia se manteve a mesma, apenas com um piso apoiado diretamente sobre a rocha com dois períodos distintos de ocupação (camada romana 2A e 2B), assim, ficou evidente que o piso original esteve em uso contínuo e os achados pertenciam principalmente à segunda fase de ocupação. No Locus 1342 o recinto apresentava os sinais de um terremoto e as pedras de arenito de quartzo carbonatado que compunham a parede dessa sala estavam desmoronadas. O mesmo quadro se apresentou para o Locus 1313 que fica próximo. Nos recintos havia uma espessa camada de terra marrom (que foi identificada como camada romana 1), contendo grande quantidade de frascos de armazenamento e potes de cozinha, bem como algumas peças finas de mercadorias importadas. Nesse Locus 
(1313) os autores observam: “a camada também incluía um número substancial de lamparinas romanas discus, tipo característico do final do I século d.C. até o III século d.C., com usuais cenas pagãs e eróticas figurativas que foram intencionalmente quebradas" 18 (Roll, Tal 2008: 137).

O peristilo central do edifício (Locus 1844) estava bem abaixo da concentração de vestígios do período Bizantino em sua camada correspondente. Nessa ocasião (1998) grande parte da estrutura restante do prédio veio a lume com a contribuição da equipe brasileira liderada por F. Marshall no âmbito do "Projeto Apollonia: Arqueologia e História da Cidade Antiga", um projeto de cooperação científica entre a Tel Aviv University na figura de I. Roll e a Universidade Federal do Rio Grande do Sul (UFRGS). Outras universidades brasileiras, como a USP e Unicamp, também estiveram ligadas ao projeto por um período.

A variedade dos achados - cerâmicas de mesa, cozinha, jarros de estocagem e lamparinas - confirmara que se tratava de um contexto doméstico com grande segurança para a segunda fase da ocupação - camada romana $2 \mathrm{~B}$ - onde os materiais foram mais bem associados.

O longo corredor (Locus 1851/1768) que atravessa toda a edificação provavelmente serviu como entrada para a Villa no extremo oeste do prédio, porém essa parte não se preservou devido à erosão da cadeia de kurkar que forma a costa mediterrânica. No fim desse corredor em sua parte oriental, encontram-se dois nichos um maior na parede limite e outro menor na parede lateral (parede 1319) que delimita a sala do Locus 1313 - a uma altura de 2,35 m (8 pedes). Os nichos estão próximos aos acessos dos recintos Locus 1777 e Locus 1313 (veja planta da edificação abaixo). Os nichos foram escavados diretamente no kurkar, nele se evidencia a técnica de opus incertum e lembra um tipo comum de lararia das residências romanas da região central e sul da Itália (Boyce 1937: 10-12; Orr 1978: 1575-1587; Bakker 1994: 8-20 in Roll, Tal 2008: 140). O nicho do final do longo corredor indica que o recinto servia mesmo como lararium. Esse longo corredor se conecta com outro menor, na parte leste do sítio

\footnotetext{
18 "The fill also included a substantial number of round (discus) Roman lamps of the type characteristic of the late first to third centuries $\mathrm{CE}$, from which the usual pagan and erotic figurative scenes were intentionally broken away."
} 
(Locus 1859), que desemboca na sala onde um forno de barro cortado na rocha matriz indica que o recinto serviu como culina (Locus 1937). O peristilo ainda é cercado por três corredores menores (Locus 1859, 1902 e 1761), sendo fácil o acesso ao prédio. Os quatro corredores certamente eram cobertos e a entrada para os recintos possuem a média de 1,35 m de largura. As partes mais baixas das paredes leste e sul foram cortadas na rocha e preenchidas com os mortaria e a sobreposição das camadas superiores estava solidamente construída. A solidez estrutural das paredes, bem como sua altura preservada, a leste e sul, parece remeter à provável existência de um segundo andar, pelo menos nessa parte da edificação, já que o mesmo não é crível de verificação na outra extremidade devido ao fato de as paredes oeste da Villa terem colapsado pelos processos erosivos da escarpa do Sharon. De maneira geral, as salas localizadas ao sul do longo corredor (Locus 1777, 1817, 1830 e 1831) são mais bem planejadas e construídas que os demais recintos da edificação - com maior cuidado na aplicação dos mortaria. Os autores então supõem, com certo grau de probabilidade, que a parte sul da edificação que contempla essas salas possivelmente serviu de quartos ao proprietário da Villa, sua família e convidados, enquanto as unidades da parte norte seriam utilizadas principalmente como alas de serviço (ibidem, p. 140-141).

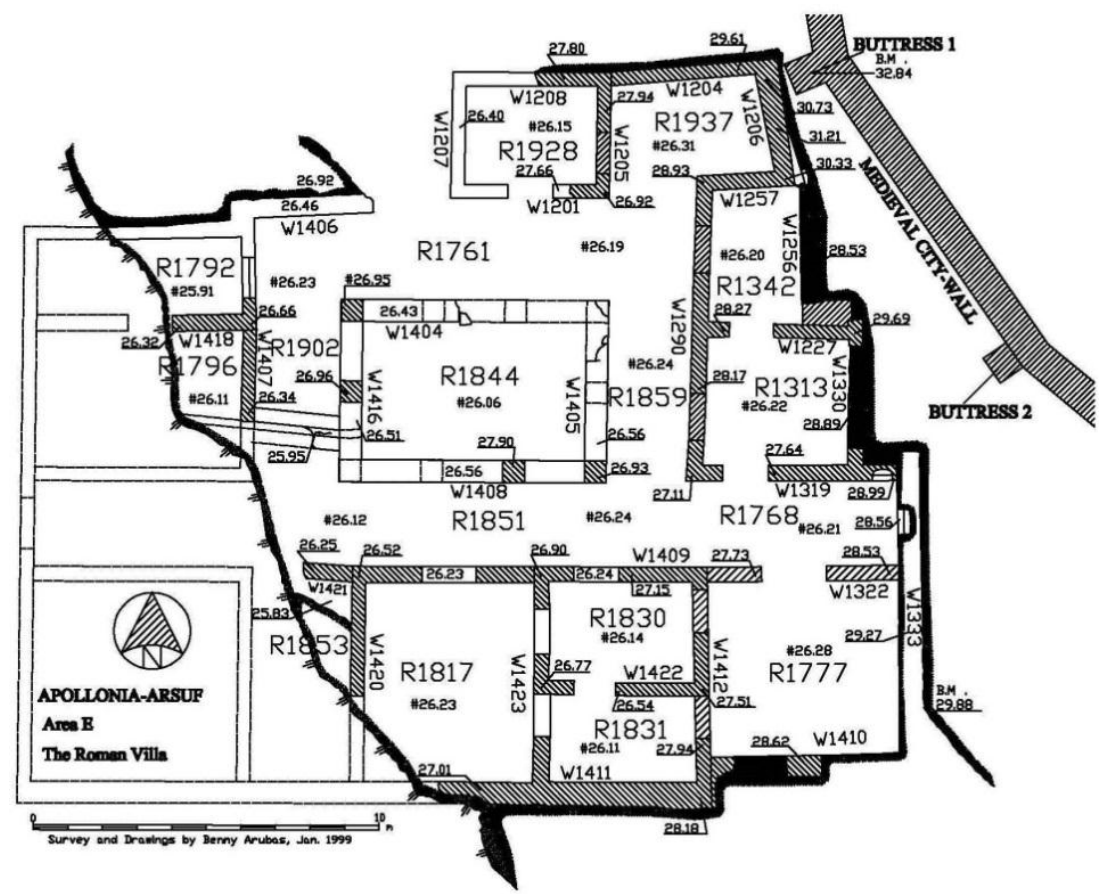

Fig. 19 Planta baixa da estrutura da Villa marittima de Apollonia-Arsuf. 
Portanto, a Villa de Apollonia poderia ter pertencido em sua fase inicial a um rico comerciante ou algum abastado local, contudo, apenas alguns achados se relacionam à camada romana $2 \mathrm{~A}$ estando dispersos entre os recintos do Locus 1313, 1342, 1928 corredor (Locus 1761) e peristilo (Locus 1844). Parece mesmo que a maior área de atividade, tanto nesse período quanto nos demais, foi a porção nordeste do sítio. Entretanto, a condição fragmentada dos objetos sugere que eles foram incorporados à fundação da camada romana $2 \mathrm{~B}$, servindo como um terminus ante quem para a datação da camada romana 2A. Dessa maneira, a camada 2B consistia principalmente de terra batida e muitos fragmentos que provavelmente foram colocados de forma intrusiva no contexto desse alicerce. Isso explicaria a moeda com datação de 159/60 d.C. no contexto da camada 2A (ibidem, p.142).

Na segunda fase de ocupação da edificação - camada romana 2B - a Villa sofreu alterações em sua forma interna: as entradas de algumas salas foram descuidadamente bloqueadas, tornando-se acomodações independentes A criação de salas adjacentes onde antes estavam salas conectadas e a constatação da incorporação de um alicerce de terra batida com fragmentos cerâmicos e entulho triturado sobre uma fina camada de solo marrom dá a entender que nesse período a Villa contou com um número maior de pessoas e proprietários. A maioria dos achados nessa camada inclui cerâmicas de mesa, inclusive a romana Terra Sigillata A; jarros; potes de cozinha, vasos de armazenamento, ânforas importadas de centros da região do Mediterrâneo e lamparinas romanas importadas e locais. Como mencionado, a sala do Locus 1937 parece ter servido como culina, além do forno (tabun), muitos vasos de estocagem e potes de cozinha foram encontrados. Nessa camada ainda duas moedas com datas do período do Imperador Vespasiano - 71 e 79 d.C - foram encontradas nos Locus 1937 e 1777 (ibidem, p. 144). 


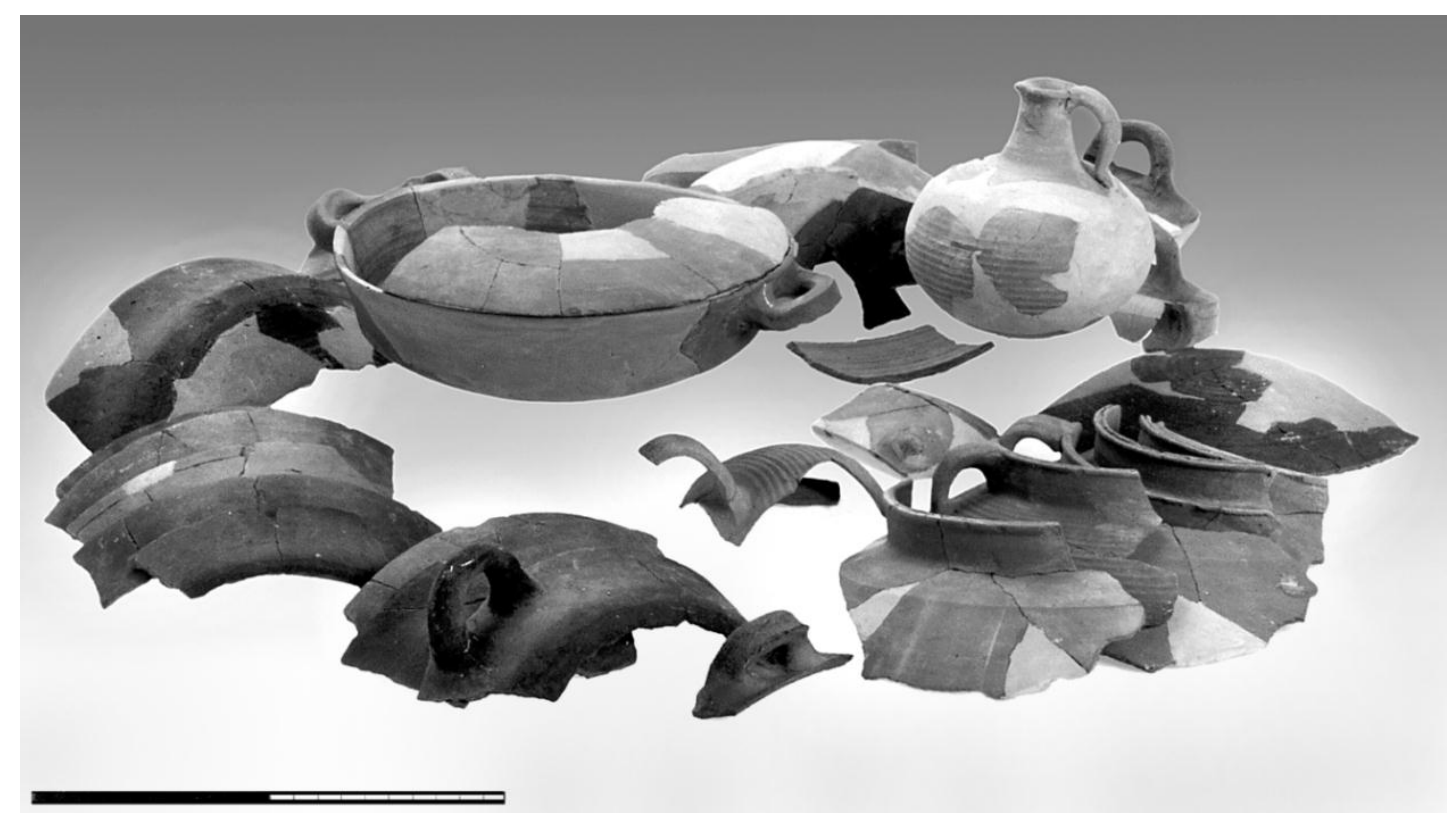

Fig. 20 Cerâmica romana encontrada nos Locus 1937 e 1777.

Como alguns dos achados da ocupação que aparecem na camada $2 \mathrm{~B}$ estão praticamente integrais e são de período similar, a inferência dos autores é de que a camada anterior - romana $2 \mathrm{~A}$ - teve um breve período de ocupação. O desabamento da metade sul da edificação preservou as pedras em suas posições. Nas salas Locus 1313, 1342 e 1777, bem como nas salas laterais Locus 1928 e 1830 o desabamento foi particularmente grave, sendo que foram encontrados vasos esmagados pela queda das pedras. 


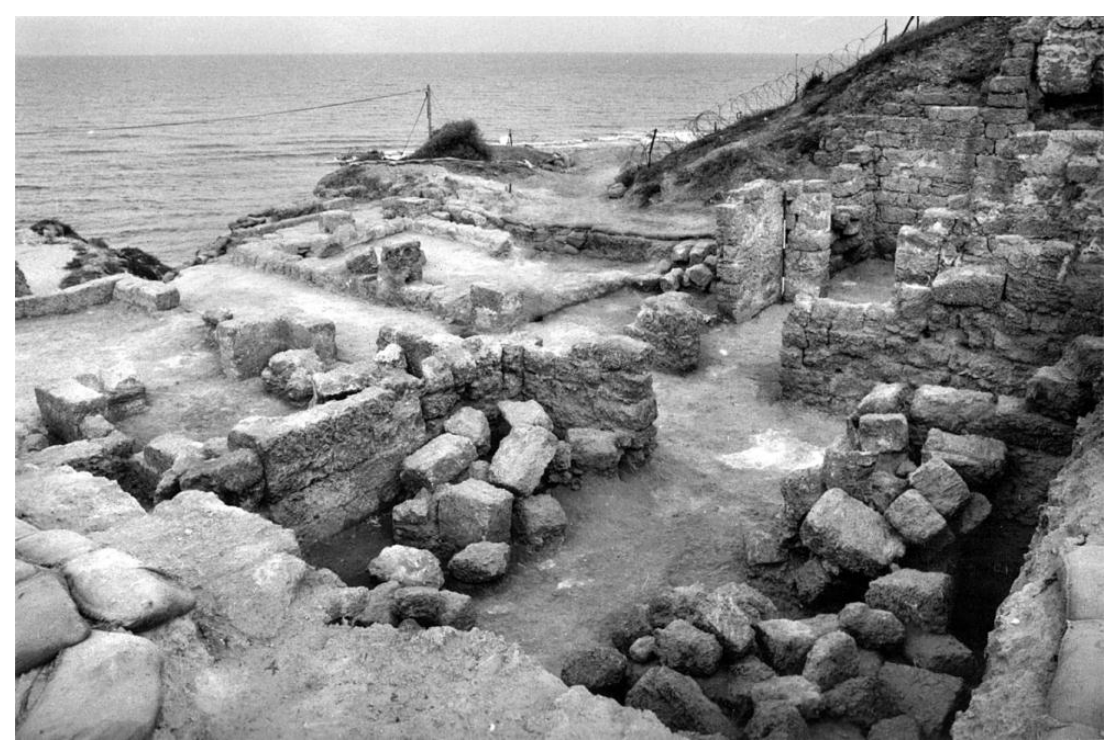

Fig.21 Plano geral da Villa marittima de Apollonia (visão sul para norte).

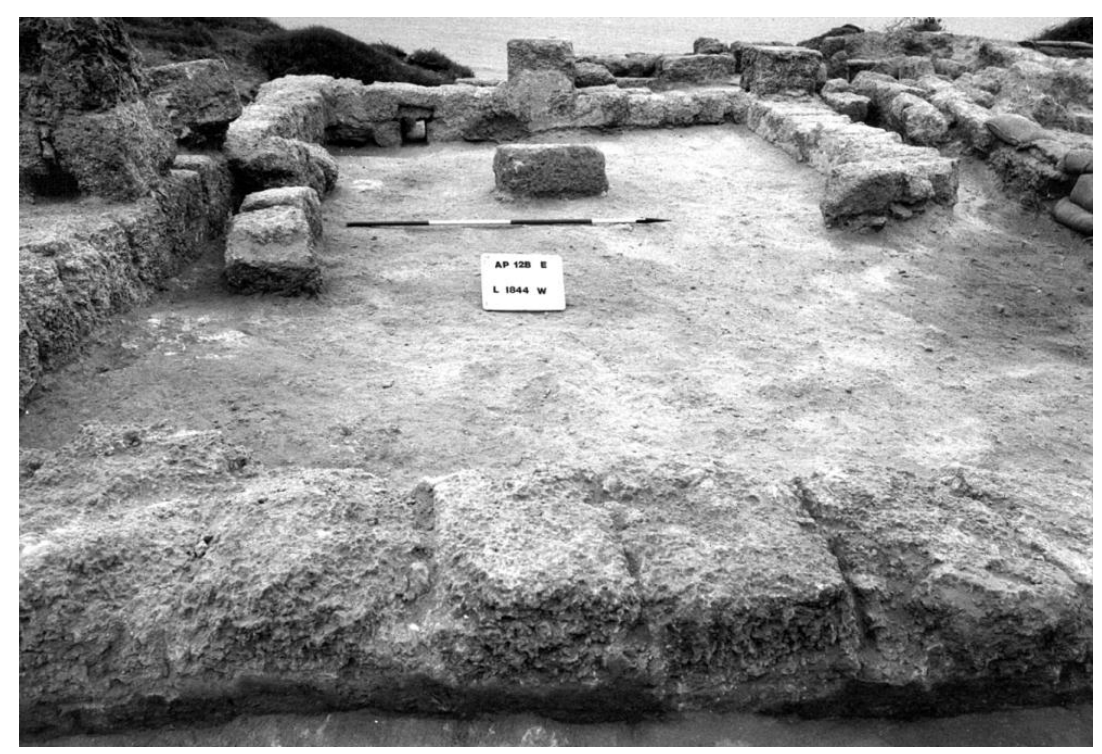

Fig. 22 Detalhe do Peristilo central da Villa marittima de Apollonia.

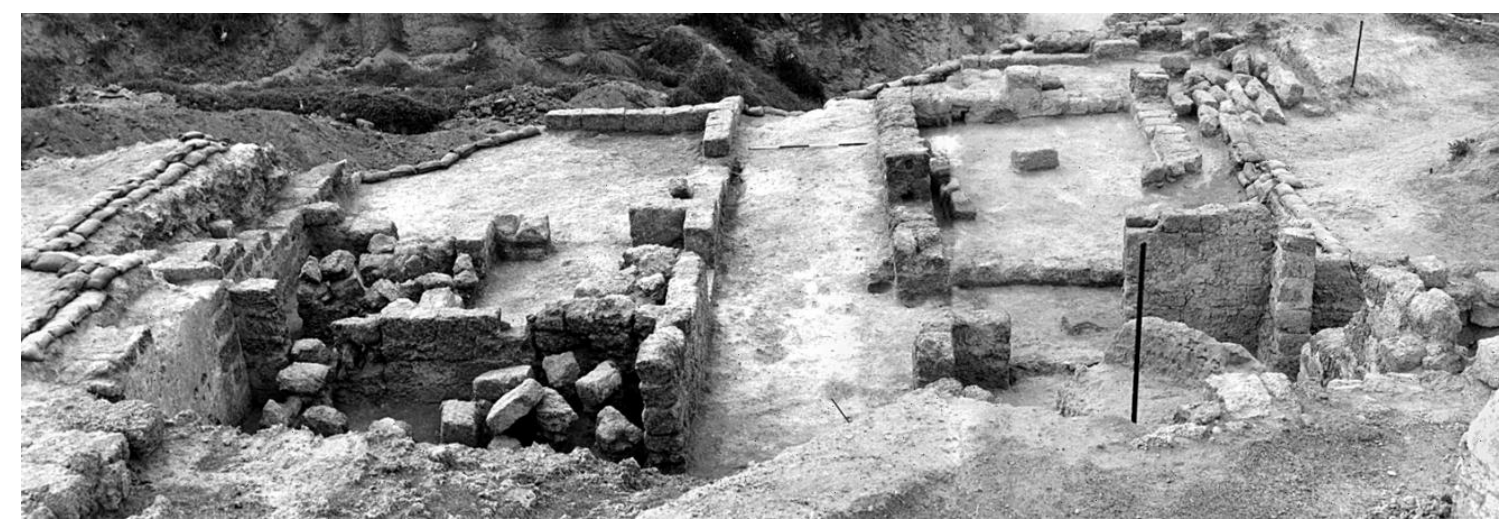

Fig. 23 Plano geral da Villa marittima de Apollonia (visão leste para oeste). 


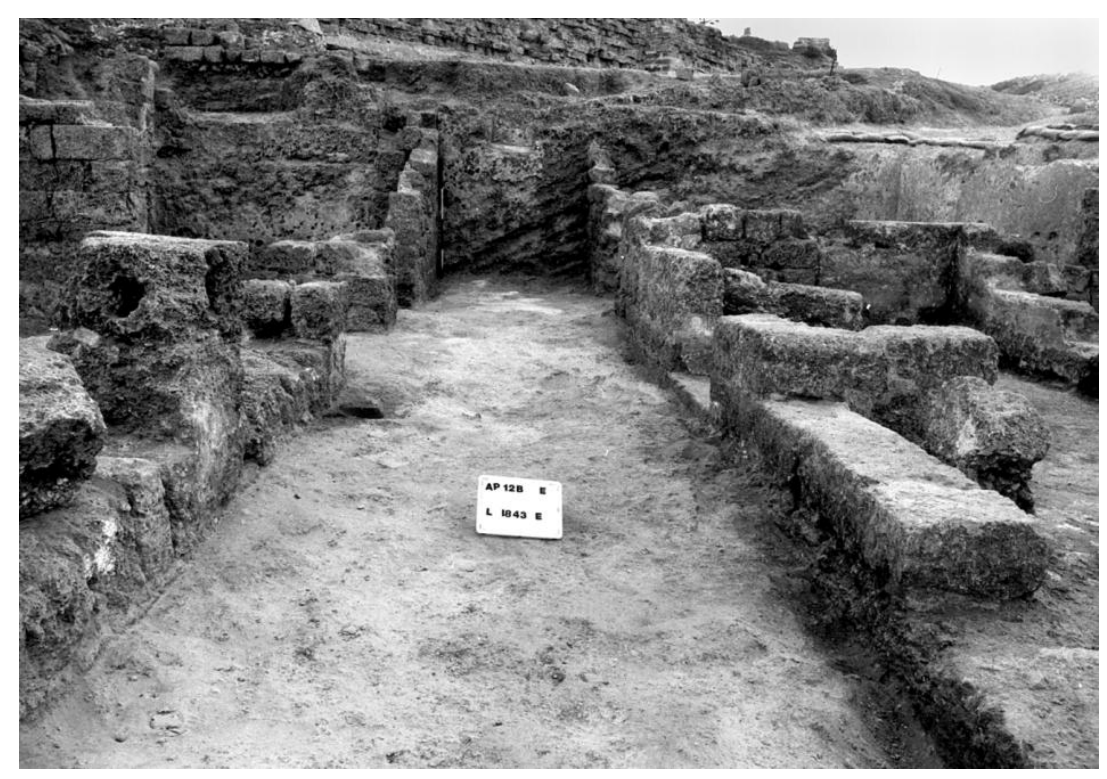

Fig.24 Visão do longo corredor Locus Locus1851/1768 (visão de oeste para leste).

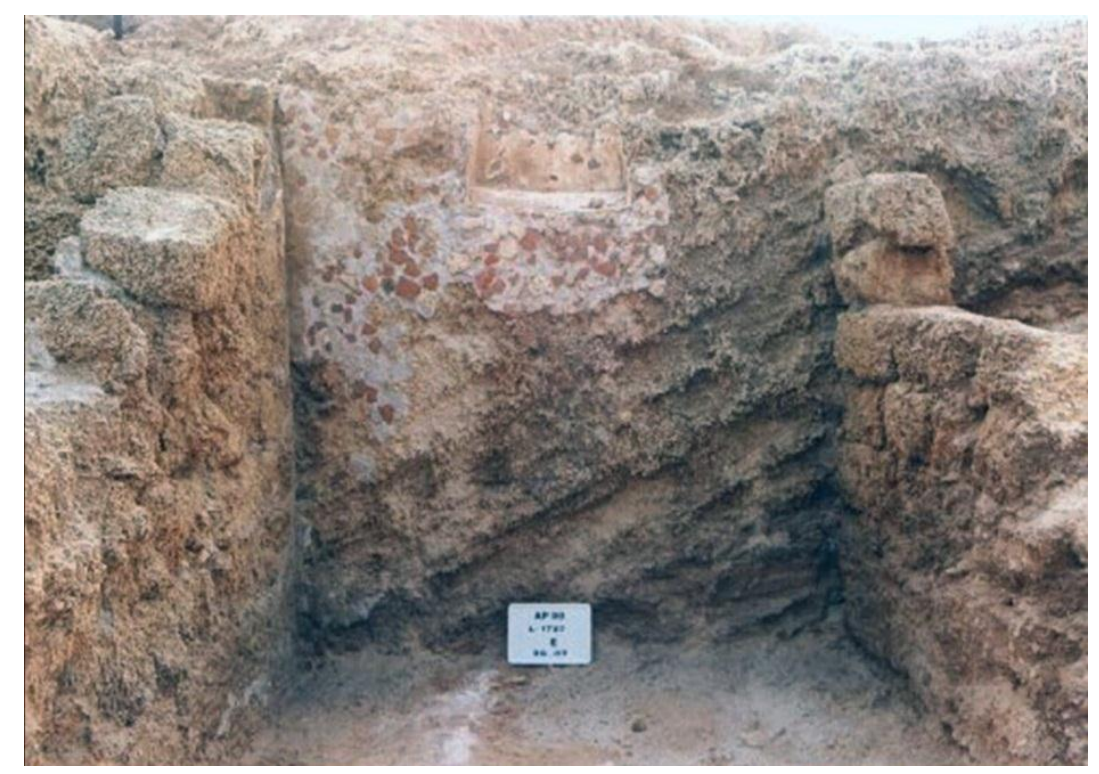

Fig. 25 Visão frontal do nicho de maior proporção que representa o Lararium Locus 1768. 


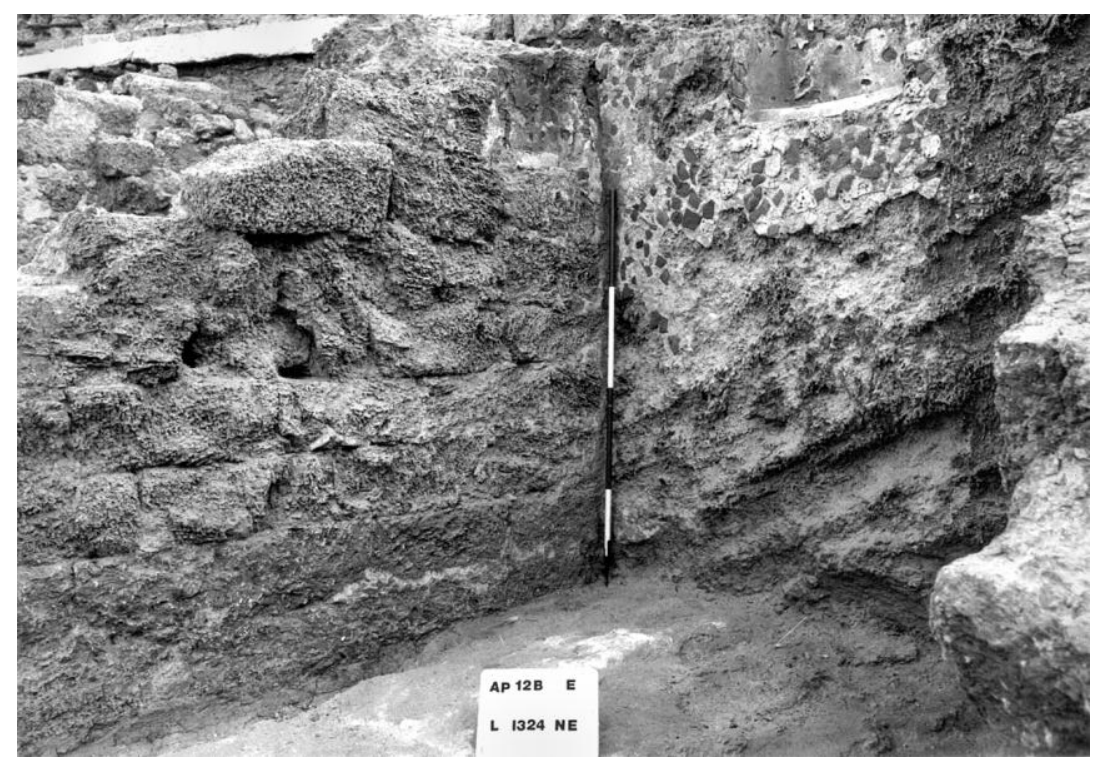

Fig.26 Visão dos dois nichos no Locus 1768.

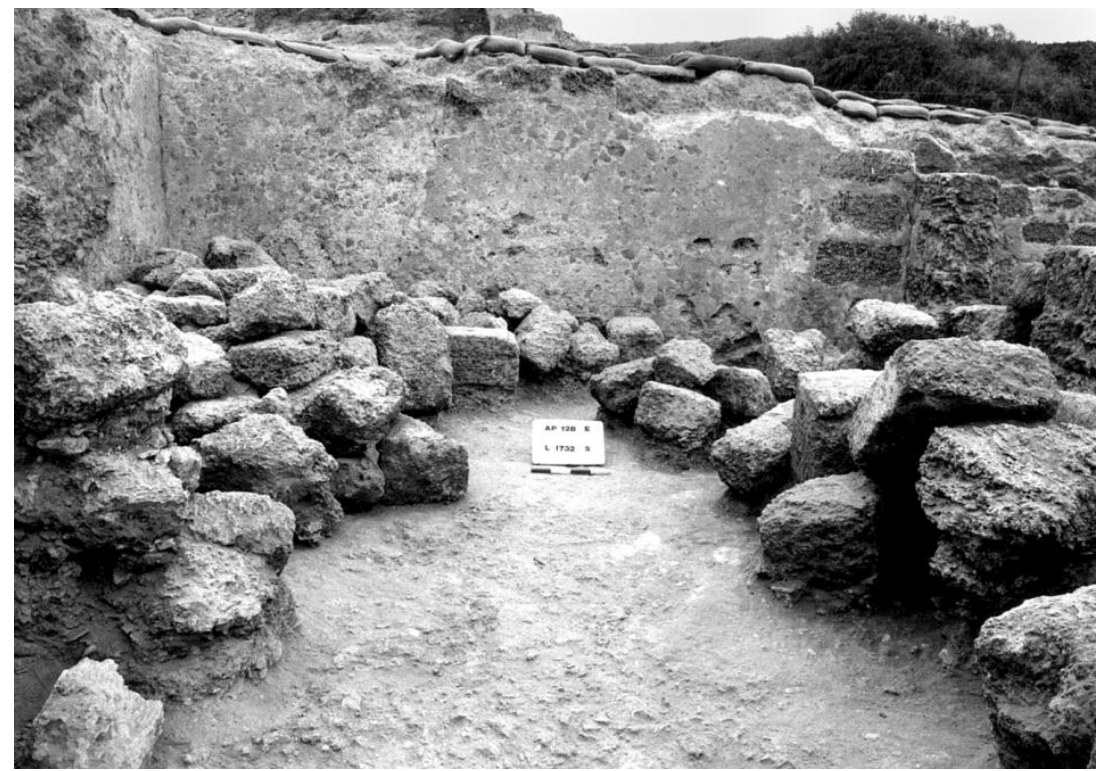

Fig. 27 Visão do colapso em Apollonia no corredor Locus 1761 (visão de oeste para leste). 


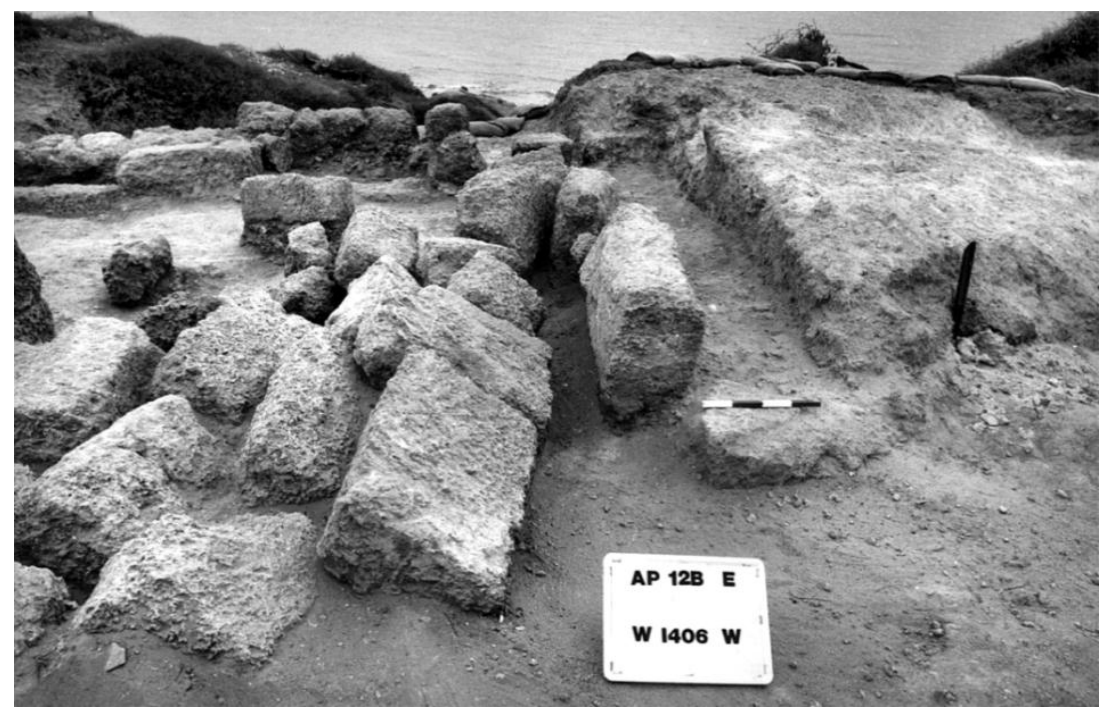

Fig. 28 Vista do mesmo colapso que se abateu sobre o sítio, parede 1406, Locus 1777 (visão de leste para oeste).

Os estudos sobre os abalos sísmicos na região para o período indicam que um terremoto de grandes proporções foi registrado em 113/114 d.C., segundo Russell (1985: 40-41 in Roll, Tal 2008: 146), ou em 126/127 d.C., segundo Gidoboni (1994: 234 in Roll, Tal 2008: 146). Esse impacto teria afetado toda a Planície do Sharon, estendendo-se de Cesareia a Nicópolis. Contudo, no princípio do II século d.C., a destruição do porto de Cesareia parece ter sido causada por um tsunami em dezembro de 115 d.C., resultado desse mesmo terremoto (Reinhardt et al. 2006 in Roll, Tal 2008: 146). Dessa maneira, os autores presumem que um destes abalos tenha afetado Apollonia e comprometido a longevidade da ocupação.

Após um desses abalos (115 d.C. ou 127 d.C.), a edificação não teria sido novamente reconstruída e este fato associado à Villa estar situada numa parte mais baixa da área fez Roll (2003: 167) presumir que a camada romana 1 e a camada bizantina foram formadas pela prática de descarte, servindo a área como depósito de lixo das edificações ao redor. Segundo o autor, numerosas cerâmicas parecem ter vindo de edificações que estavam mais acima no terreno, sendo jogadas deste ponto (Área P) para a Villa (Área E), então destruída e abandonada. Tudo o que pode ser afirmado sobre a área $\mathrm{P}$ é que se trata de habitações do período Bizantino e ainda espera por ser escavada (Roll, Tal 2008: 146). 


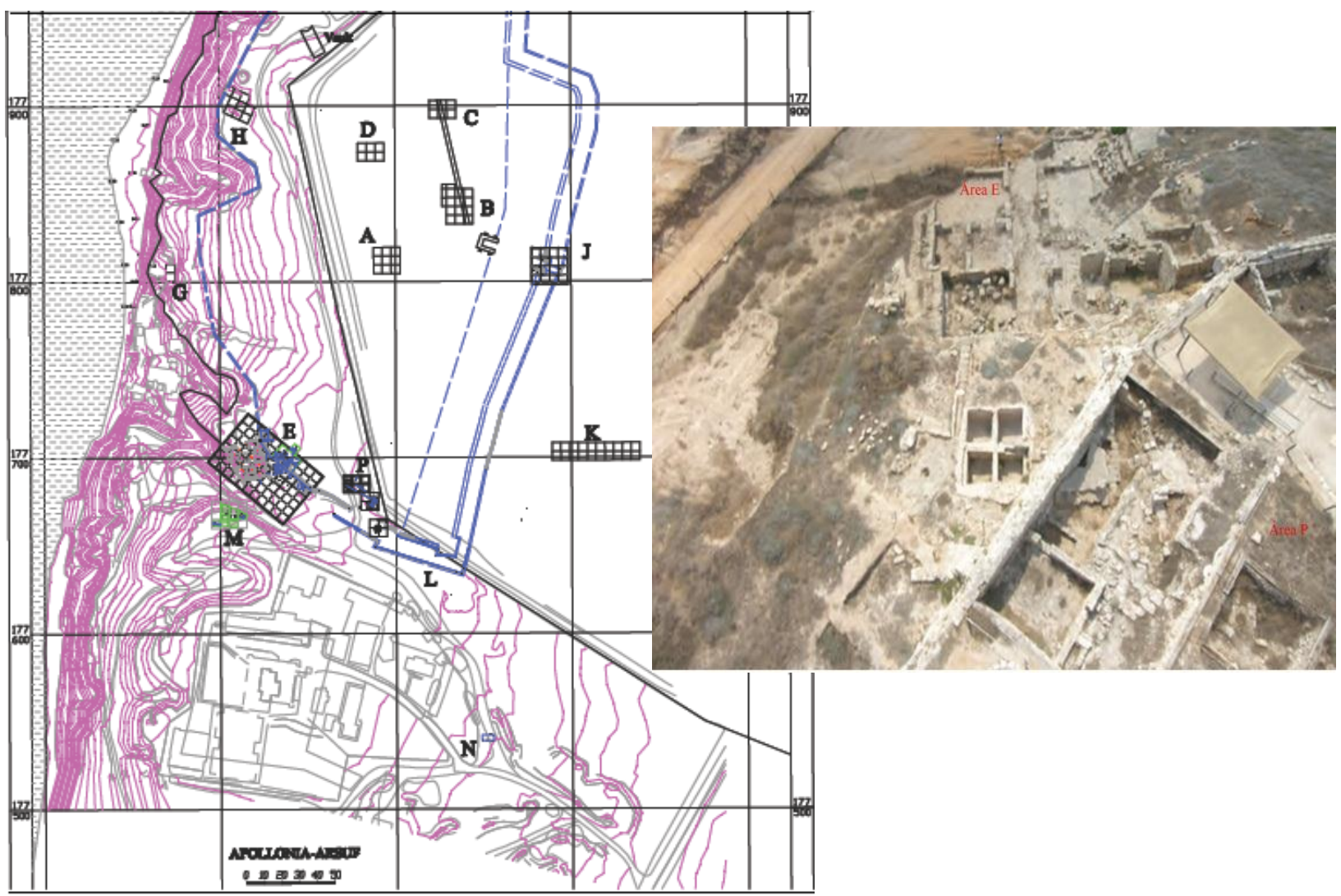

Fig. 29 Detalhe do mapa das áreas de escavação de Apollonia-Arsuf que prioriza a Área E e visão da área $\mathrm{P}$ para a área $\mathrm{E}$.

Os vestígios cerâmicos de lamparinas romanas tipo discus de todos os períodos de escavação em Apollonia, até o momento, somam 566 amostras, sendo dessas 33 objetos íntegros ou passíveis de restauro. A distribuição das lamparinas nas camadas estratigráficas, por período, corresponde a: camada romana $2 \mathrm{~A}, 0,35 \%$ do total das peças; camada romana $2 \mathrm{~B}, 5,30 \%$; camada romana $1,54,9 \%$ e camada bizantina $8,83 \%$ do total das peças. As lamparinas romanas discus estão distribuídas intra-sítio por toda a parte leste do sítio, nas salas que correspondem aos Locus: 1928; 1937; 1342; 1313; 1777, 1817 e no longo corredor que atravessa a edificação em sua porção inicial, Locus 1851, e em sua porção final próximo ao Lararium, Locus 1768. É interessante observar aqui a ausência de lamparinas no peristilo central, Locus 1944. Em Apollonia se evidencia a presença de samaritanos, reforçando-se a ideia de que não se tratava de um lugar de judeus, pelo menos não os ortodoxos, afinal, nesse período não era lícito nem dirigir a palavra a um samaritano; já os cristãos - sendo eles judeus ou não-judeus -, 
não teriam esse problema (sobre a relação de cristãos e samaritanos, vide João 4: 4-30, Lucas 10:25-37 como exemplo). ${ }^{19}$

É pertinente afirmar que em Apollonia foi encontrado um piso de mosaico policromo e muitas bases de coluna colocadas ao longo de uma linha leste-oeste, correspondendo à Área K. Os elementos pertenciam a uma igreja Bizantina, de cujos vestígios somente a nave restou. O mosaico é decorado com padrões geométricos e florais estilizados, adornado por entrelaces e aves em seu interior. A parte que mais chama a atenção nesse mosaico são as três linhas em grego enquadradas em tabula ansata. Ela estava disposta voltada para leste, que era a habitual direção das orações nas igrejas. Apesar de a inscrição estar parcialmente danificada, Birnanbaum e Ovadiah (1990: 190) propuseram a seguinte tradução:

"Eu sou uma igreja melhor que ambrosia e néctar, e Marinos me erigiu exaltando o Deus-celebrado-por-sua-sabedoria e sempre dirigindo seu espírito puro e místico."

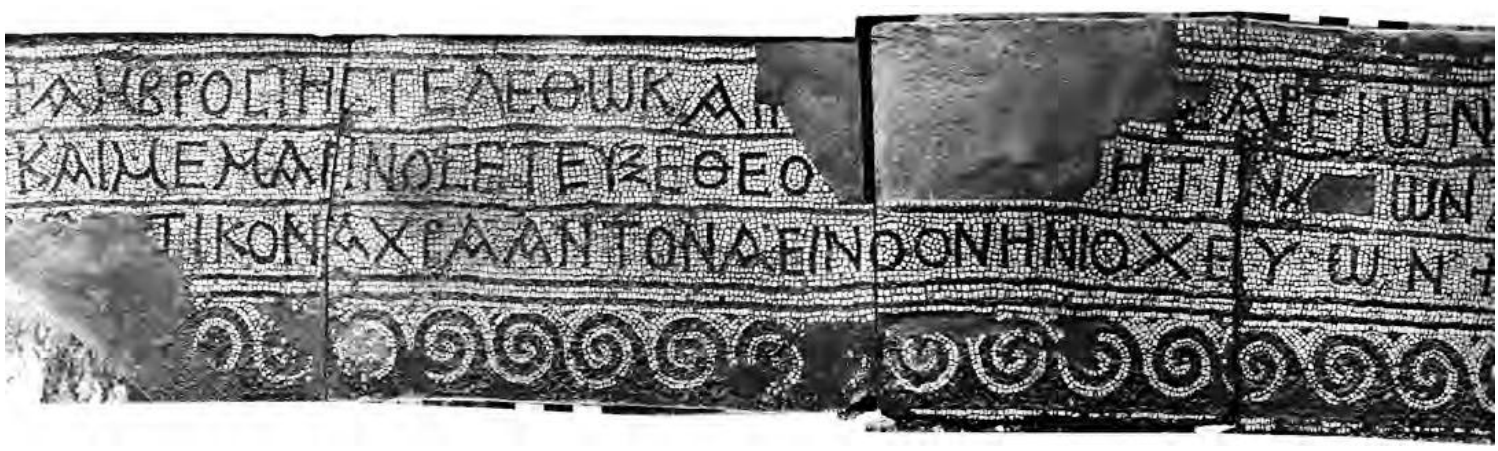

Fig. 30 Piso de mosaico policromo da igreja de Apollonia.

A inscrição é formulada em hexâmetro dactílico e sua linguagem é alusiva, porém nela é possível ver o tom empregado: triunfalista e hegemônica. Note o leitor que o formulário grego é apropriado num sentido de autopromoção e diminuição do "outro", criando um novo sentido discursivo, amparado em um novo status e autonomia, que

\footnotetext{
${ }^{19}$ A primeira referencia diz respeito à mulher samaritana com quem Jesus conversa, ela explicita: "como tu sendo judeu diriges a palavra a mim que sou mulher samaritana?"; a segunda passagem é o ensinamento do bom samaritano, portanto, criando uma nova relação de discurso a respeito dessa identidade.
} 
buscou a primazia sobre as tradições conflitantes existentes - lembro o leitor aqui das formulações cristãs dos escritos dos pais apostólicos e apologistas que apresentei no capítulo 2.

Ao empregar as palavras "ambrosia" e "néctar" o(s) autor(res) da inscrição estava(m) usando o formulário da literatura Grega no épico de Homero e em Ovídio ${ }^{20}$

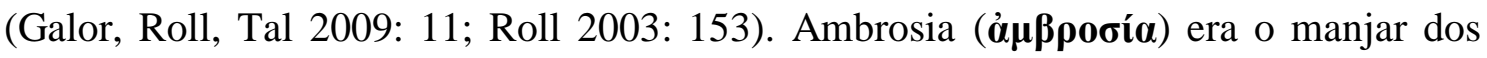
deuses do Olimpo, uma iguaria de divinal sabor que, dentro do aspecto mitológico, era vetado aos mortais. Caso fosse oferecido, era tão poderoso que conferia a quem o provasse a imortalidade e quando os deuses ofereciam a um humano, ao experimentá-lo,

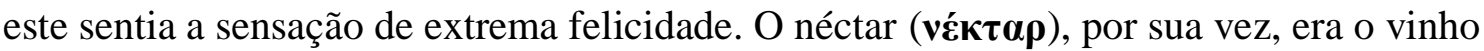
ou a bebida dos deuses que era servida por Hebe, a deusa da juventude e copeira dos deuses, sendo descrito como um líquido vermelho. Hebe foi substituída por Ganímedes, príncipe troiano, em uma das versões por ter sofrido uma queda enquanto atendia aos deuses, ou em outra versão, livremente renunciando para se unir a Héracles. Como fica explícito na inscrição do mosaico, o cristianismo é "superior" a esses deleites de eternidade, pois a eternidade cristã teria o "espírito puro" e "místico". Portanto, tal qual referido por Eliade (1998) nesse trabalho, esse "espírito puro e místico" nada mais é do que a irrupção da hierofania da modalidade do sagrado, que se opõe àquilo que é profano.

A igreja pode ter servido como sede para os bispos de Sozousa, nome da cidade de Apollonia em período Bizantino. (Roll, Tal 1999: 682-85; Roll 2003). Para esse período em Apollonia encontram-se prensas de óleo e vinho, fornos para confecção de vidro, cisternas - provavelmente para o processamento de garum e salsamenta e outras instalações que não tiveram sua função identificada.

O centro cristão parece ter tido influência na região dentro do cristianismo sendo que seu líder é citado nominalmente nos escritos Hipólito de Roma (ainda no século III d.C.), no mesmo conjunto onde outros vultos cristãos são colocados:

\footnotetext{
${ }^{20}$ Homero, Ilíada IV.3; Odisseia V:93-195; Ovídio, As Metamorfoses X: 161.
} 


\section{THE SAME HIPPOLYTUS ON THE SEVENTY APOSTLES}

1. James the Lord's brother, bishop of Jerusalem.

2. Cleopas, bishop of Jerusalem

3. Matthias, who supplied the vacant place in the number of the twelve apostles.

4. Thaddeus, who conveyed the epistle to Augarus.

5. Ananias, who baptized Paul, and was bishop of Damascus.

6. Stephen, the first martyr.

7. Philip, who baptized the eunuch.

8. Prochorus, bishop of Nicomedia, who also was the first that departed, believing together with his daughters.

9. Nicanor died when Stephen was martyred.

10. Timon, bishop of Bostra.

11. Parmenas, bishop of Soli.

12. Nicolaus, bishop of Samaria.

13. Barnabas, bishop of Milan.

14. Mark the evangelist, bishop of Alexandria.

15. Luke the evangelist

(...)

50. Apollo, bishop of Casarea.

51. Cephas.

52. Sosthenes, bishop of Colophonia.

53. Tychicus, bishop of Colophonia.

54. Epaphroditus, bishop of Andriace.

55. Casar, bishop of Dyrrachium.

56. Mark, cousin to Barnabas, bishop of Apollonia.

57. Justus, bishop of Eleutheropolis.

58. Artemas, bishop of Lystra.(...)

(Hippolytus: Appendix to the Works of Hippolytus. Vol.5, The same Hippolytus on the Seventy Apostles, p.464).

*Grifo meu

Esse mesmo centro cristão recebe uma série de menções em período tardio e alguns pontos merecem atenção nesse texto. Ele aparece duas vezes na anônima Cosmografia de Ravenna; uma vez numa lista de centros urbanos da Iudaea-Palaestina, entre Cesareia e Joppe (Cosmography of Ravenna II 14,2; Ed. Schnetz 1940: 25), tal qual acontece na referência em Hipólito de Roma e novamente entre ambas na lista de cidades costeiras do Sinai, Palaestine e Phoenicia (ibid.: v. 7,2; Ed. Schnetz 1940: 90 in Roll, Tall 1999; Roll 2003). É mencionada também numa lista normal das cidades da província, feito com base num mapa das estradas no mesmo período (Dilleman 1997: 156 in Roll, Tall 1999; Roll 2003). Ela é também lembrada numa lista paralela de cidades costeiras do Mediterrâneo Oriental. A localidade também é mencionada na compilação do geógrafo Guido (ibid.; Ed. Schnetz 1940: 133 in Roll, Tall 1999; Roll 
2003), e na lista de 25 cidades enumeradas por Stephanus Byzantius figurando no $13^{\circ}$ lugar, próximo a Jope (kata Iophn).

Apollonia em período Bizantino também está Tabula Peutingeriana, sendo esta uma cópia medieval de um mapa de estradas romanas de 435 d.C. A representação de Apollonia indica que ela estava na rede de estradas imperiais da região. As 22 milhas indicadas no mapa correspondem à verdadeira distância entre Cesarea e Arsuf, tal qual é tratada no período medieval. Note o leitor que a reprodução do mapa de 435 d.C. serve como um parâmetro cronológico da Apollonia cristã.

Stark (1825: 452, nota 5 in Roll, Tall 1999; Roll 2003), e depois ClermontGanneau (1896: 337-339 in Roll, Tall 1999; Roll 2003) explicaram que a ausência do nome de Apollonia nos primeiros Concílios Ecumênicos se deveu a um processo de mudança de nome, ou seja, uma outra identidade assumida em época Bizantina. O nome foi mudado para Sozousa no sentido da associação simbólica com Apollo Soter, ou Apolo "Salvador", figura que dentro do cristianismo foi apropriada e relacionada à figura de Jesus. O processo de mudança de nome também aconteceu em Apollonia da Cirenaica, igualmente denominada Souzousa, e Apollonia da Trácia, chamada Sozopolis. Os seguintes autores concordam com essa afirmação: Benzinger 1895: coluna 117; Thomsen 1907: 109; Honigman 1927: coluna 1257; Abel 1938: 247,472; Schürer 1979: 114-115; Jones 1971: 230,280; Avi-Yonah 1977: 145; Bagatti 1979: 182-183; Tsafrir et al. 1994: 65; Dauphin 1998, Vol. III: 799; e Conder (1881: 248) identificou Souzousa com Deir Serur, entre Cesareia e Sebaste (in Roll, Tall 1999; Roll 2003).

As edições críticas de textos georgianos e árabes posteriores confirmam a ideia (Expugnations Hierosolymae,. 614 d.C.) e nesses textos estão documentadas as ações do patriarca Modestus, bem como sua morte a caminho de Jerusalém em 630-631 d.C. Este evento teria ocorrido numa cidade chamada Sozos (ou Sozosi, isto é, Souzousa) segundo os textos georgianos (Conybeare 1910: 517; Garitte 1960: 55 in Roll, Tall 1999; Roll 2003), e Arsuf, nos textos árabes (Peeters 1923-24: 41; Garitte 1953: 38, 70; 1974: 131 in Roll, Tall 1999; Roll 2003). Este testemunho dá prova clara que Sozousa e Arsuf são lugares idênticos e, consequentemente, que Sozousa e Apollonia eram nomes de uma única cidade, bem como salienta sua atividade dentro do cristianismo. $\mathrm{O}$ fato de 
que Stephanus Byzantius menciona ambos os nomes, Apollonia (n13) e Sozousa (n1), teria sido porque provavelmente ele usou fontes de diferentes períodos. Ele parece ter utilizado uma fonte de época romana quando listou Apollonia, e outra fonte de período bizantino quando mencionou Souzousa (Roll, Tall 1999; Roll 2003).

De acordo com as listas eclesiásticas dos séculos V e VI, Souzousa era uma Sé episcopal e a assinatura de um bispo chamado Baruchius (ou Barachius) de Sozousa aparece em muitos documentos oficiais do Sínodo de Éfeso, que ocorreu em 449 d.C. Dois destes documentos, com um parágrafo cada, sumarizam a participação de Baruchius durante o sínodo, e coloca a localização administrativa oficial e o status de Souzousa. Um deles começa com a frase "Baruchuis episcopus Sozusae Palaestinae provinciae" (Schwartz 1935, Bol. II/3: 183). Já a outra tem a frase "Baruchius episcopus Sozusenae civitatis" (ibid: 245). Em ambos os casos, na metade do século V d.C., Souzousa/Apollonia era uma cidade da província bizantina da Palaestina prima que tinha o status oficial de civitas, e que sua comunidade cristã estava organizada em uma comunidade oficial liderada por um bispo que certamente tanto podia atrelar sua legitimação, bem como a legitimidade da localidade, ao nome de "Marcus, primo de Barnabé", o bispo de Apollonia. ${ }^{21}$ Note que na citação não resta dúvida que se trata de Apollonia-Arsuf, pois na menção a cidade aparece entre Cesareia e Eleutheropolis, em consonância com a localização intermediária que o sítio ocupa na costa do Mediterrâneo. Baruch de Sozusa na Palaestina é também mencionado em uma versão siríaca dos atos do sínodo (Fleming 1917: 9, Vol. II: 555-621; Abel 1952: 322-343; Honigmann 1944: 28-41 in Roll, Tall 1999; Roll 2003). Por fim, o status da cidade parece ter sido desfeito com a oposição crescente à política religiosa do Sínodo de Éfeso, rotulado “o sínodo dos ladrões” (latrocinium) por seus opositores. No concilio ecumênico ocorrido em Calcedônia, em 451 d.C., esta política foi totalmente revertida e muitos dos seus participantes foram postos de lado em nome da "Ortodoxia". Aparentemente, a consequência para Sozousa foi que Baruchius estava relacionado entre os signatários que foram enquadrados nessa perspectiva e tanto ele quanto sua Sé foram aparentemente excluídos das discussões que se sucederam dentro do cristianismo. Nenhum bispo de Sozousa é mencionado nas listas posteriores por quase um século, ou

${ }^{21}$ Sobre o bispo Marcos, vide capítulo 5. 
seja, aconteceu algo muito forte em relação à opinião e posicionamento sobre a doutrina da Igreja. Contudo, isso mostra que a comunidade era ativa nas questões eclesiásticas em período tardio e para tal, como indiquei no capítulo 2 dessa dissertação, era necessária a busca da legitimidade interna ligada aos primórdios do movimento cristão.

Os representantes de Sozousa só voltaram a aparecer em listas oficiais em três encontros eclesiásticos do século VI d.C. O bispo Leontius de Sozousa é citado em duas das listas de sínodos que ocorreram em Jerusalém - o primeiro em 518 d.C. e o segundo em 536 d.C. - e Damianus episcopus Sozytanae civitatis, que também serviu como vice-regente do patriarca de Jerusalém, é mencionado nessas listas (Schwartz 1940, Vol. III: 80, 188 e Straub 1971: 221 in Roll, Tall 1999; Roll 2003). Ainda outro bispo, Eustochius, é listado em uma série de documentos no Quinto Concílio Ecumênico, ocorrido em Constantinopla em 553 d.C.

Dessa forma, o que fica evidente mais uma vez é a importância de Sozousa na Palestina Bizantina Tardia que certamente é aumentada pela presença de uma grande comunidade samaritana, que, de acordo com os Annales Samaritani (p.179 in Roll, Tall 1999: 179; Roll 2003) de Abulfathi (Abu al-fath), residia em Arsuf até a conquista árabe.

As transformações, portanto, muitas vezes ocorrem de forma não intencional quando contradições entre circunstâncias históricas e relações de tradição acabam implicando em crises de identidade (Sahlins 1981) ou quando existe a politização do conhecimento prático e a disjunção gradual das práticas tradicionais de suas origens, como quando os atores perpetuam certas relações e práticas a princípio sem compreender o significado final das mesmas e no contato com os demais do grupo passam a atribuir particulares significados a suas práticas (Pauketat 2001: 77). É possível que a mesma relação tenha sido estabelecida para a prática da quebra das lamparinas. O entendimento de Bourdieu (1994: 170-177) sobre a forma como os indivíduos interiorizam condições sociais como disposições práticas, sendo este o habitus, sobre o que discorri acima, implica na aceitação do legítimo, gerando um conhecimento que se estabelece como inquestionável ou a “doxa". Entretanto, o conhecimento é relacional e participa das associações de poder na aquisição deste mesmo habitus e por este fato os indivíduos não interiorizam todo conhecimento, mas, 
sim, as diferenças de posição, poder e identidade em relação aos "outros". Nessas divisões arbitrárias entre os grupos estão dispostas as delimitações dos significados simbólicos que impõem os princípios de construção das realidades, dentro de relações de prática, que obedecem a seus esquemas próprios.

Portanto, as tradições e discursos são construídos nas relações entre grupos dentro de seus campos de ação, e assim determinadas construções são privilegiadas em detrimento de outras, construindo novas formas discursivas num incessante processo de "vir-a-ser" através da simultaneidade de estórias-até-agora, tal qual preconiza Massey (2009). Como afirmei no capítulo 2 deste estudo, a especial atenção que o cristianismo dispensou a essa parte teve um claro objeto de construção de memória e fomento da identidade na diferença. Harrison (2001: 259) avalia que três categorias que permeiam o conflito simbólico entre grupos: a primeira diz respeito à avaliação, que envolve justamente a luta pelo posto das tradições, através da autopromoção e desintegração dos outros; a segunda se refere à inovação, que envolve os esforços do grupo recémformados ou emergentes para anunciar sua distinção, status e autonomia, através de registros existentes tradicionais, emulando os outros ou inventando novos formulários; e a terceira, por sua vez, é concernente à propriedade, que implica no conflito sobre a primazia da tradição, que pode ser apropriada ou destruída, seja no decurso da disputa, num combate ritualizado ou mesmo no conflito bélico aberto.

Portanto, a conclusão é que os grupos criam conhecimento "novo" a partir do "velho" objetivando a distribuição e redistribuição do poder simbólico, simultaneamente criando significados e poder através dos registros tradicionais, nomes, símbolos e práticas (Chamberlin 2006: 42). Nesse sentido, a quebra da parte central das lamparinas discus em Israel em primeira instância é uma transformação do habitus que objetivamente leva em conta as relações com outros grupos e indivíduos, sendo que o fluxo de conhecimento entre doxa e discurso simbólico acaba por definir a espacialidade de cada grupo. Um habitus não se modifica a não ser que se mude o tipo de ação, pois todas as práticas de mesma espécie pertencem ao mesmo habitus, a espécie de ação deriva do princípio de escolhas paradoxalmente condicionadas e livres do grupo e dos indivíduos. Contudo, ao reconhecer semelhanças e diferenças de maneira acentuada, os indivíduos, e por consequência os grupos, adquirem a capacidade de criar novas 
divisões localizadas entre o que consideram ser o "eu" e os "outros", ajustando dessa forma tanto sua(s) prática(s) - o habitus - como seu(s) discurso(s), que implica(m) diretamente na relação de tradições e hegemonias. Esse tal "ajuste" da prática, no caso desse estudo, é diretamente relacionado ao rompimento da parte referente à iconografia das lamparinas romanas discus que, consequentemente, pode ser entendido como a "quebra" do habitus políade.

Passemos agora ao catálogo das lamparinas romanas discus de Apollonia. 


\subsection{Catálogo}

O catálogo que vem a seguir é o esforço de levantamento e sistematização de dados das lamparinas romanas discus que foram encontradas em todas as campanhas de escavação de Apollonia-Arsuf. As primeiras escavações na área $\mathrm{E}$ foram conduzidas durante a segunda e terceira campanhas de escavação nessa localidade, em 1980 e 1981, respectivamente. Foi durante essas primeiras etapas de intervenção que se constatou a presença de vestígios romanos no sítio com a exposição de parte da edificação peristilo (Locus 1928 e 1937) que caracteriza o lugar nesse período.

As escavações nessa área só foram retomadas cerca de uma década depois, quando quatro campanhas de escavação foram conduzidas entre os anos de 1990 a 1993. Durante essas intervenções o conhecimento a respeito da edificação aumentou significativamente, sendo que outros três recintos foram escavados (Locus 1342, 1313 e 1768), além dos situados a norte, anteriormente trabalhados.

Após um intervalo de cinco anos, em 1998/99, novamente a área E sofreu processo interventivo. Na ocasião uma equipe brasileira associou-se aos trabalhos em Apollonia. Os trabalhos concentraram-se na exposição total da estrutura da edificação. Dessa forma, foi possível a compreensão da planta baixa da Villa marittima de Apollonia-Arsuf.

O catálogo foi organizado com o objetivo de ser um corpus em que as imagens das lamparinas e a sistematização das informações, ora publicadas e dispersas, bem como algumas que ainda não foram publicadas, pudessem ser percebidas material e visualmente, enquanto uma ferramenta expressiva de delimitação e orientação dessa pesquisa. Seguindo alguns dos atributos de análise tipológica empregados por Wexler e Gilboa (1996) que publicaram determinado número de lamparinas também presentes nesse catálogo, adaptei e criei novas categorias de análise, especialmente referente à forma como as lamparinas foram quebradas. Desta maneira, o leitor encontrará nas páginas que se seguem a análise tipológica organizada em três grandes divisões relativas 
ao motivo de decoração, são elas: A) Motivos decorativos da borda; B) Motivo decorativo do disco; c) Motivos decorativos da base. Cada item desses tem seus atributos classificatórios internos, a saber:

\section{A) Motivos decorativos da borda:}

1 - Volutas:

a - voluta dupla para cima

b - voluta dupla para baixo

c - voluta simples junto do bico

d - voluta simples afastada do bico

e - uma pequena circunferência

2- Linhas entre volutas:

a - pequenas circunferências

$\mathrm{b}$ - filetes

c - linha curva incisa

d - linha reta

e - duas linhas curvas - "pequeno coração"

3 - Adornos da orla:

a - ovais ou ovoli

b - folha e cacho de uva estilizado

c - corações

d - círculo de dardos

e - linhas curtas

$\mathrm{h}$ - triângulos

4 - Machado duplo

5 - Sem decoração

B) Motivo decorativo do disco:

1 - Em relevo/ tridimensional

2 - Sem decoração

C) Motivos decorativos da base:

1 - Circunferência simples

2 - Anel em relevo

3 - Dois anéis em relevo

4 - Dois anéis em relevo com circunferência no centro

5 - Aplainada

6 - Incisão abaixo do bico = V-signs

7 - Marcas de produção: ГА

Para os tipos de quebra, três formais intencionais de quebra foram identificadas e, assim, são caracterizadas: 


\section{D) Tipo de Quebra na Iconografia:}

1 - Quebra percussiva direta: Provavelmente realizada de uma só vez, sendo uma quebra de pequena proporção e com fratura geralmente regular.

2 - Quebra percussiva facetada: Seria realizada através de sucessivos impactos para a remoção da parte central do objeto. Esse "aperfeiçoamento" poderia ter sido feito com algum tipo de instrumento que facilitasse o afeite. A fratura é irregular, com um facetado que forma um aspecto craquelado junto das molduras que separam a borda do disco.

3 - Quebra percussiva em esquadro: Muito provavelmente realizado com um tipo específico de instrumento, talvez uma espátula. Apresenta uma fratura regular com quatro arestas identificáveis.

4 - Quebra natural ou pós-deposicional: Quebra pela fragilidade da parte central do objeto através do acúmulo das camadas estratigráficas no processo pós-deposicional.

Os atributos ora expostos estão localizados ao lado das imagens das lamparinas para rápida associação com os dados a respeito da peça. Abaixo das imagens o leitor encontrará esses dados, tal como se fosse sua "identidade". Os campos do ano da escavação, número da peça, localização interna da peça no sítio (Locus), proveniência da cesta na estratigrafia da escavação, estado físico, diâmetro da borda, diâmetro do discus, diâmetro da quebra, espessura do corpo, espessura da borda, comprimento, altura, tipo classificatório da cerâmica, coloração da argila (baseado em Munsell), decoração da base, decoração da borda, iconografia do discus, local de produção, período, comparanda, são apresentados. É importante observar ao leitor que nem sempre todos esses campos estarão completos, devido a questões que se impõem a toda e qualquer pesquisa. Entretanto, essas eventuais ausências em nada comprometem o trabalho ou as conclusões do mesmo. 


\begin{tabular}{|c|c|c|c|c|}
\hline $\begin{array}{l}\text { Sessão/ Ano } \\
\text { escavação }\end{array}$ & Número da peça & $\begin{array}{l}\text { Localização } \\
\text { (Locus/camada) }\end{array}$ & $\begin{array}{l}\text { Localização } \\
\text { (Locus/recinto) }\end{array}$ & Estado físico \\
\hline Diam. da base & Diam. da borda & Diam. do disco & Diam. da quebra & Esp. do corpo \\
\hline Esp. da borda & Comprimento & Altura & Tipo & $\begin{array}{l}\text { Coloração } \\
\text { (Munsell)/tipo de argila }\end{array}$ \\
\hline $\begin{array}{l}\text { Decoração da } \\
\text { base }\end{array}$ & $\begin{array}{l}\text { Decoração da } \\
\text { borda }\end{array}$ & \multicolumn{2}{|c|}{ Iconografia do disco } & Local de produção \\
\hline Período: & Comparanda & \multicolumn{3}{|l|}{ Obs: } \\
\hline
\end{tabular}

Exemplo dos campos de identificação e análise nas pranchas do catálogo.

Portanto, é entendendo o catálogo deste trabalho como uma ferramenta teóricometodológica de grande potencial informativo e que suscita indagações ao debate, não simplesmente como meras representações ilustrativas, que são apresentados os dados a seguir. 


\section{CATÁlOGO}




\begin{tabular}{|c|c|c|c|c|c|}
\hline $\begin{array}{l}\text { Sessão/ Ano } \\
\text { escavação }\end{array}$ & Número da peça & $\begin{array}{l}\text { Localização } \\
\text { (Locus/camada) }\end{array}$ & $\begin{array}{l}\text { Localização } \\
\text { (Locus/recinto) }\end{array}$ & Estado físico & 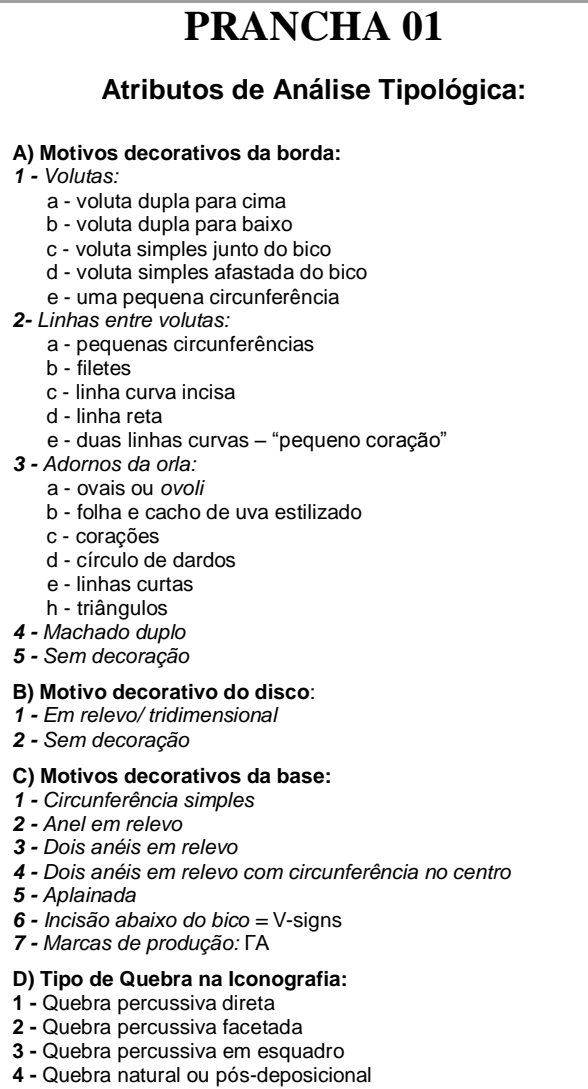 \\
\hline APII6/92 & HM.2031 & 815 - Bizantino & 1859 - corredor leste & Integro & \multirow{6}{*}{$\begin{array}{c}\text { Cristianização dos espaços na } \\
\text { Antiguidade Tardia: o caso de } \\
\text { Apollonia-Arsuf }\end{array}$} \\
\hline Diam. da base & Diam. da borda & Diam. do disco & Diam. da quebra & Esp. do corpo & \\
\hline $41,47 \mathrm{~mm}$ & $71,01 \mathrm{~mm}$ & $43,25 \mathrm{~mm}$ & $28,04 \mathrm{~mm}$ & $x$ & \\
\hline Esp. da borda & Comprimento & Altura & Tipo & $\begin{array}{l}\text { Coloração (Munsell)/tipo } \\
\text { de argila }\end{array}$ & \\
\hline $2,19 \mathrm{~mm}$ & $84,96 \mathrm{~mm}$ & $17,84 \mathrm{~mm}$ & $\begin{array}{l}\text { Produção Local: Costa } \\
\text { Fenícia? }\end{array}$ & $\begin{array}{l}\text { 10YR - 4/2 - Buff clay/dark } \\
\text { brown slip }\end{array}$ & \\
\hline $\begin{array}{l}\text { Decoração da } \\
\text { base }\end{array}$ & Decoração da borda & \multicolumn{2}{|c|}{ Iconografia do disco } & Local de produção & \\
\hline C) 2 & A)1.a; 2.b, c; $3 . b$ & \multicolumn{2}{|c|}{$\begin{array}{l}\text { B)1; D) } 1 \text { - Porém ainda é possível ver algo como a } \\
\text { cauda de um animal }\end{array}$} & Não identificada & $\begin{array}{l}\text { Fotógrafo: Pavel Shrago } \\
\text { Desenho: Erêndira Oliveira }\end{array}$ \\
\hline Período: & Comparanda & \multicolumn{3}{|l|}{ Obs: } & \\
\hline 2nd-3th & $\begin{array}{l}\text { Wexler e Gilboa, } \\
1996 .\end{array}$ & & & & 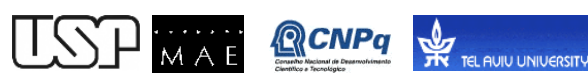 \\
\hline
\end{tabular}




\begin{tabular}{|c|c|c|c|c|c|}
\hline $\begin{array}{l}\text { Sessão/ Ano } \\
\text { escavação }\end{array}$ & Número da peça & $\begin{array}{l}\text { Localização } \\
\text { (Locus/camada) }\end{array}$ & $\begin{array}{l}\text { Localização } \\
\text { (Locus/recinto) }\end{array}$ & Estado físico & 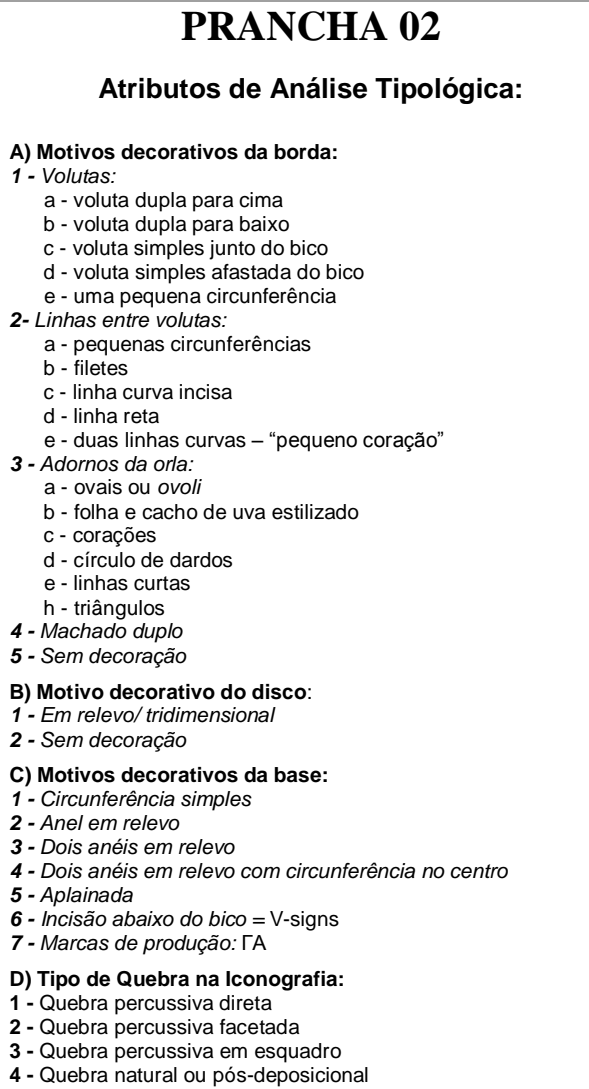 \\
\hline APII & HM. 2037 & 806 - Bizantino & 1937 - culina & Integro & \multirow{6}{*}{$\begin{array}{c}\text { Cristianização dos espaços na } \\
\text { Antiguidade Tardia: o caso de } \\
\text { Apollonia-Arsuf }\end{array}$} \\
\hline Diam. da base & Diam. da borda & Diam. do disco & Diam. da quebra & Esp. do corpo & \\
\hline $41,29 \mathrm{~mm}$ & $73,11 \mathrm{~mm}$ & $44,31 \mathrm{~mm}$ & $25,77 \mathrm{~mm}$ & $x$ & \\
\hline Esp. da borda & Comprimento & Altura & Tipo & $\begin{array}{l}\text { Coloração (Munsell)/tipo } \\
\text { de argila }\end{array}$ & \\
\hline $2,73 \mathrm{~mm}$ & $87,12 \mathrm{~mm}$ & $20,86 \mathrm{~mm}$ & $\begin{array}{l}\text { Produção Local: Costa } \\
\text { Fenícia? }\end{array}$ & $\begin{array}{l}\text { 10YR - 4/2 - Buff clay/dark } \\
\text { brown slip }\end{array}$ & \\
\hline $\begin{array}{l}\text { Decoração da } \\
\text { base }\end{array}$ & Decoração da borda & \multicolumn{2}{|c|}{ Iconografia do disco } & Local de produção & \\
\hline C)2 & A)1.a; 2.b,c;3.b & B)1; D)1 & & Não identificada & $\begin{array}{l}\text { Fotógrafo: Pavel Shrago } \\
\text { Desenho: Erêndira Oliveira }\end{array}$ \\
\hline Período: & Comparanda & \multicolumn{3}{|l|}{ Obs: } & \\
\hline 2nd-3th & $\begin{array}{l}\text { Wexler e Gilboa, } \\
1996 .\end{array}$ & & & & TS」 MA E \\
\hline
\end{tabular}




\begin{tabular}{|c|c|c|c|c|c|}
\hline $\begin{array}{l}\text { Sessão/ Ano } \\
\text { escavação }\end{array}$ & Número da peça & $\begin{array}{l}\text { Localização } \\
\text { (Locus/camada) }\end{array}$ & $\begin{array}{l}\text { Localização } \\
\text { (Locus/recinto) }\end{array}$ & Estado físico & 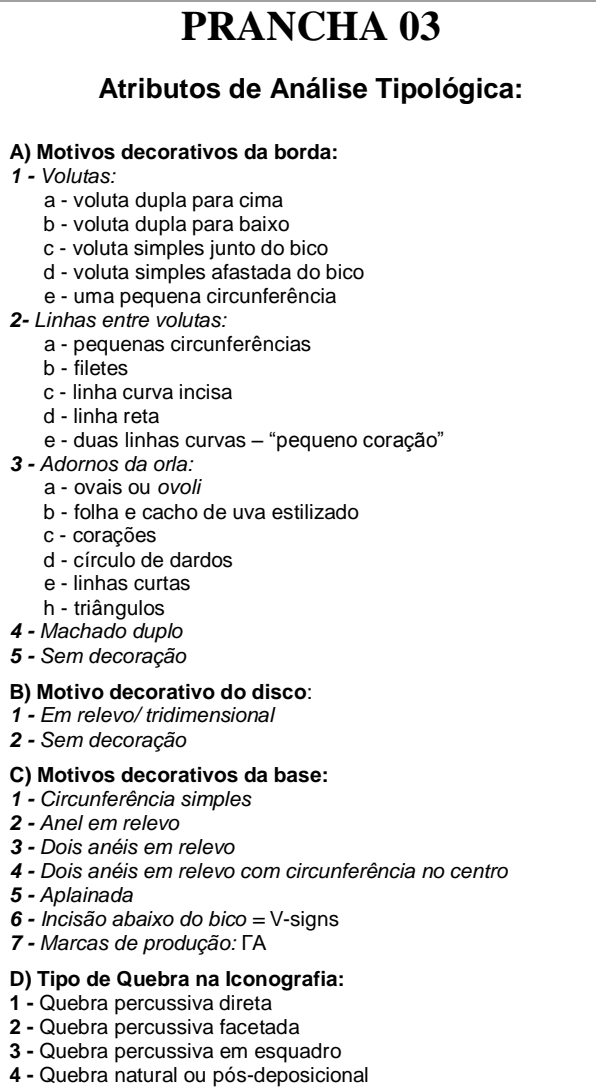 \\
\hline APII & HM.2039 & 806 - Bizantino & 1937 - culina & Integro & \multirow{6}{*}{$\begin{array}{c}\text { Cristianização dos espaços na } \\
\text { Antiguidade Tardia: o caso de } \\
\text { Apollonia }\end{array}$} \\
\hline Diam. da base & Diam. da borda & Diam. do disco & Diam. da quebra & Esp. do corpo & \\
\hline $41,29 \mathrm{~mm}$ & $72,71 \mathrm{~mm}$ & $44,80 \mathrm{~mm}$ & $29,69 \mathrm{~mm}$ & $x$ & \\
\hline Esp. da borda & Comprimento & Altura & Tipo & $\begin{array}{l}\text { Coloração (Munsell)/tipo } \\
\text { de argila }\end{array}$ & \\
\hline $1,87 \mathrm{~mm}$ & $84,97 \mathrm{~mm}$ & $20,02 \mathrm{~mm}$ & $\begin{array}{l}\text { Produção Local: Costa } \\
\text { Fenícia? }\end{array}$ & $\begin{array}{l}\text { 10YR - 4/2 - Buff clay/dark } \\
\text { brown slip }\end{array}$ & \\
\hline $\begin{array}{l}\text { Decoração da } \\
\text { base }\end{array}$ & Decoração da borda & \multicolumn{2}{|c|}{ Iconografia do disco } & Local de produção & \\
\hline C)2; 6 & A)1.a; 2.a, c; 4 & \multicolumn{2}{|l|}{ B)1; D)1 } & Não identificada & $\begin{array}{l}\text { Fotógrafo: Pavel Shrago } \\
\text { Desenho: Erêndira Oliveira }\end{array}$ \\
\hline Período: & Comparanda & \multicolumn{3}{|l|}{ Obs: } & \multirow[b]{2}{*}{ 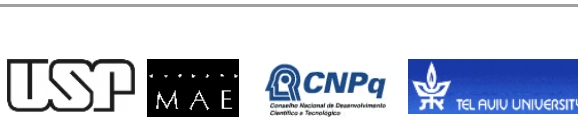 } \\
\hline 2nd-3th & $\begin{array}{l}\text { Wexler e Gilboa, } \\
1996 .\end{array}$ & \multicolumn{3}{|l|}{ 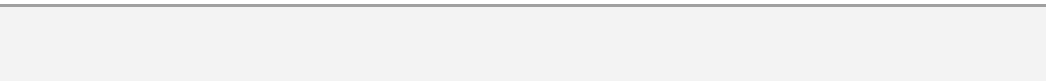 } & \\
\hline
\end{tabular}




\begin{tabular}{|c|c|c|c|c|c|}
\hline $\begin{array}{l}\text { Sessão/ Ano } \\
\text { escavação }\end{array}$ & Número da peça & $\begin{array}{l}\text { Localização } \\
\text { (Locus/camada) }\end{array}$ & $\begin{array}{l}\text { Localização } \\
\text { (Locus/recinto) }\end{array}$ & Estado físico & 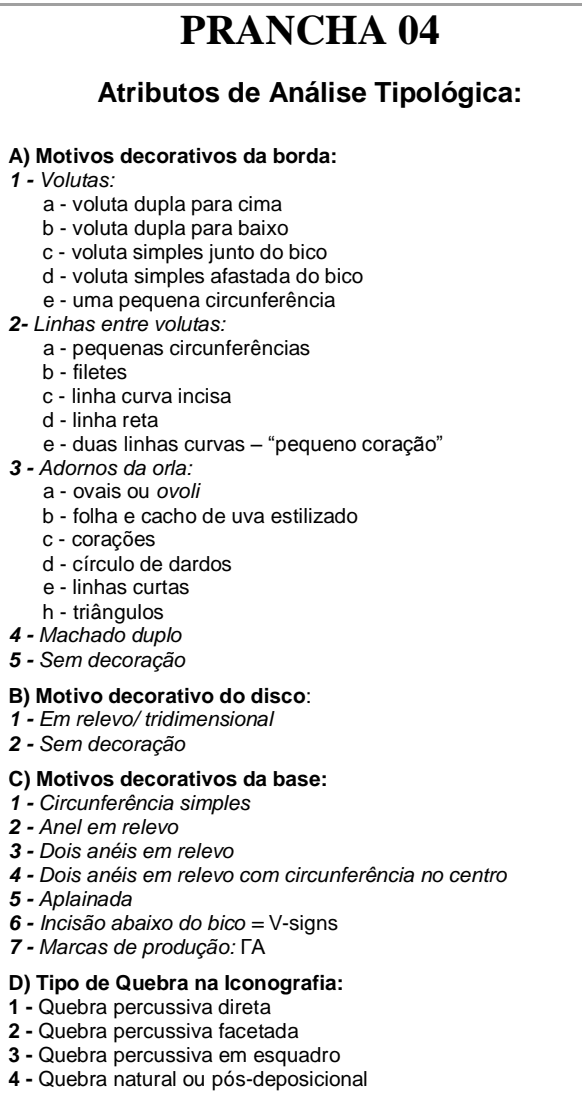 \\
\hline APII & HM.2040 & 824 - Bizantino & 1937 - culina & Integro & \multirow{6}{*}{$\begin{array}{c}\text { Cristianização dos espaços na } \\
\text { Antiguidade Tardia: o caso de } \\
\text { Apollonia }\end{array}$} \\
\hline Diam. da base & Diam. da borda & Diam. do disco & Diam. da quebra & Esp. do corpo & \\
\hline $39,93 \mathrm{~mm}$ & $75,72 \mathrm{~mm}$ & $44,40 \mathrm{~mm}$ & $29,72 \mathrm{~mm}$ & $x$ & \\
\hline Esp. da borda & Comprimento & Altura & Tipo & $\begin{array}{l}\text { Coloração (Munsell)/tipo } \\
\text { de argila }\end{array}$ & \\
\hline $2,29 \mathrm{~mm}$ & $88,89 \mathrm{~mm}$ & $24,03 \mathrm{~mm}$ & $\begin{array}{l}\text { Produção Local: Costa } \\
\text { Fenícia? }\end{array}$ & $\begin{array}{l}2.5 Y R-3 / 2 \text { - Buff } \\
\text { clay/brown slip }\end{array}$ & \\
\hline $\begin{array}{l}\text { Decoração da } \\
\text { base }\end{array}$ & Decoração da borda & \multicolumn{2}{|c|}{ Iconografia do discus } & Local de produção & \\
\hline C) 5 & A)2.c; 4 & B)2 ; D)1 & & Não identificada & $\begin{array}{l}\text { Fotógrafo: Pavel Shrago } \\
\text { Desenho: Erêndira Oliveira }\end{array}$ \\
\hline Período: & Comparanda & \multicolumn{3}{|l|}{ Obs: } & \\
\hline 2nd-3th & $\begin{array}{l}\text { Wexler e Gilboa, } \\
1996 .\end{array}$ & & & & 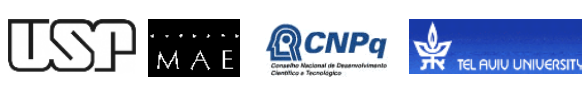 \\
\hline
\end{tabular}




\begin{tabular}{|c|c|c|c|c|c|}
\hline $\begin{array}{l}\text { Sessão/ Ano } \\
\text { escavação }\end{array}$ & Número da peça & $\begin{array}{l}\text { Localização } \\
\text { (Locus/camada) }\end{array}$ & $\begin{array}{l}\text { Localização } \\
\text { (Locus/recinto) }\end{array}$ & Estado físico & 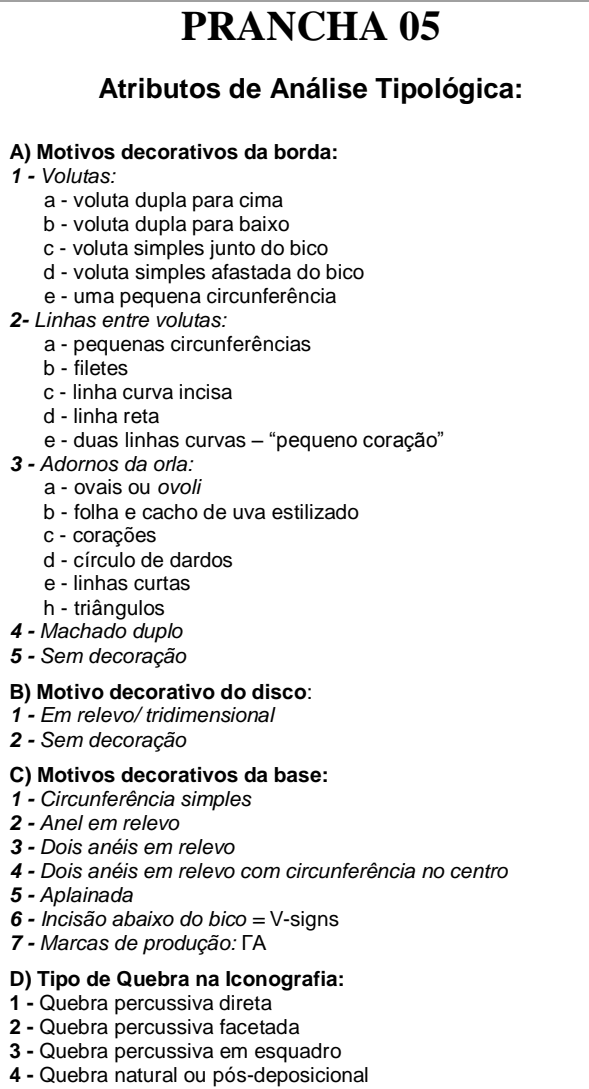 \\
\hline APII & HM.2041 & 806 - Bizantino & 1937 - culina & Integro & \multirow{6}{*}{$\begin{array}{c}\text { Cristianização dos espaços na } \\
\text { Antiguidade Tardia: o caso de } \\
\text { Apollonia }\end{array}$} \\
\hline Diam. da base & Diam. da borda & Diam. do disco & Diam. da quebra & Esp. do corpo & \\
\hline $38,89 \mathrm{~mm}$ & $74,91 \mathrm{~mm}$ & $47,27 \mathrm{~mm}$ & $25,76 \mathrm{~mm}$ & $x$ & \\
\hline Esp. da borda & Comprimento & Altura & Tipo & $\begin{array}{l}\text { Coloração (Munsell)/tipo } \\
\text { de argila }\end{array}$ & \\
\hline $2,41 \mathrm{~mm}$ & $86,82 \mathrm{~mm}$ & $19,82 \mathrm{~mm}$ & $\begin{array}{l}\text { Produção Local: Costa } \\
\text { Fenícia? }\end{array}$ & $\begin{array}{l}2.5 Y R-3 / 2 \text { - Buff } \\
\text { clay/brown slip }\end{array}$ & \\
\hline $\begin{array}{l}\text { Decoração da } \\
\text { base }\end{array}$ & Decoração da borda & \multicolumn{2}{|c|}{ Iconografia do disco } & Local de produção & \\
\hline C) 1 & A)1.a; 2.c; 3.a; 4 & \multicolumn{2}{|c|}{$\begin{array}{l}\text { B) 1; D)1 - Porém é possível ver a iconografia de } \\
\text { uma flor em relevo. }\end{array}$} & Não identificada & $\begin{array}{l}\text { Fotógrafo: Pavel Shrago } \\
\text { Desenho: Erêndira Oliveira }\end{array}$ \\
\hline Período: & Comparanda & \multicolumn{3}{|l|}{ Obs: } & \\
\hline 2nd-3th & $\begin{array}{l}\text { Wexler e Gilboa, } \\
1996 .\end{array}$ & \multicolumn{3}{|l|}{ 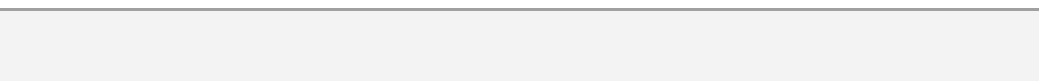 } & 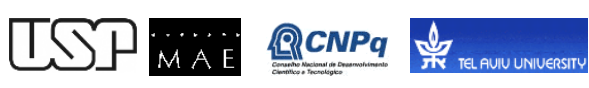 \\
\hline
\end{tabular}




\begin{tabular}{|c|c|c|c|c|c|}
\hline $\begin{array}{l}\text { Sessão/ Ano } \\
\text { escavação }\end{array}$ & Número da peça & $\begin{array}{l}\text { Localização } \\
\text { (Locus/camada) }\end{array}$ & $\begin{array}{l}\text { Localização } \\
\text { (Locus/recinto) }\end{array}$ & Estado físico & 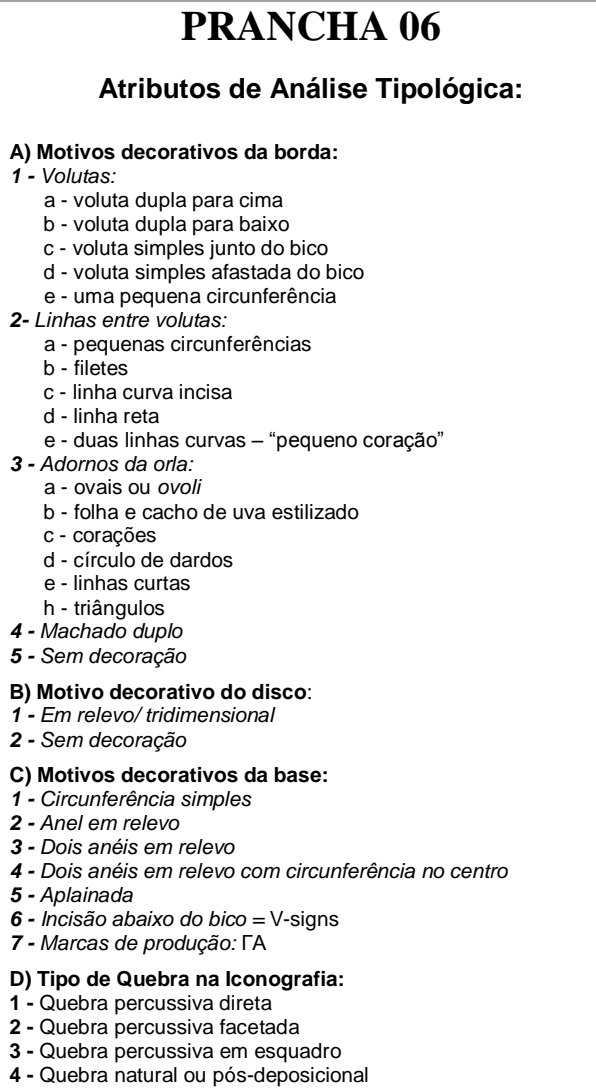 \\
\hline APII & HM.2043 & 806 - Bizantino & 1937 - culina & Integro & \multirow{6}{*}{$\begin{array}{c}\text { Cristianização dos espaços na } \\
\text { Antiguidade Tardia: o caso de } \\
\text { Apollonia }\end{array}$} \\
\hline Diam. da base & Diam. da borda & Diam. do disco & Diam. da quebra & Esp. do corpo & \\
\hline $42,75 \mathrm{~mm}$ & $72,32 \mathrm{~mm}$ & $50,72 \mathrm{~mm}$ & $38,32 \mathrm{~mm}$ & $x$ & \\
\hline Esp. da borda & Comprimento & Altura & Tipo & $\begin{array}{l}\text { Coloração (Munsell)/tipo } \\
\text { de argila }\end{array}$ & \\
\hline $2,38 \mathrm{~mm}$ & $86,04 \mathrm{~mm}$ & $21,14 \mathrm{~mm}$ & $\begin{array}{l}\text { Produção Local: Costa } \\
\text { Fenícia? }\end{array}$ & $\begin{array}{l}\text { 5YR - 3/1 - Ginger clay/ } \\
\text { brown slip }\end{array}$ & \\
\hline $\begin{array}{l}\text { Decoração da } \\
\text { base }\end{array}$ & Decoração da borda & \multicolumn{2}{|c|}{ Iconografia do disco } & Local de produção & \\
\hline C)4 & A)1.c; $2 . b ; 3 . a$ & D)2 & & Não identificada & $\begin{array}{l}\text { Fotógrafo: Pavel Shrago } \\
\text { Desenho: Erêndira Oliveira }\end{array}$ \\
\hline Período: & Comparanda & \multicolumn{3}{|l|}{ Obs: } & \\
\hline 2nd-3th & $\begin{array}{l}\text { Wexler e Gilboa, } \\
1996 .\end{array}$ & & & & 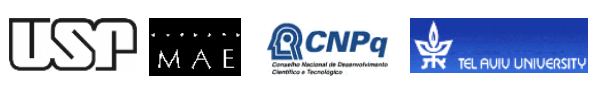 \\
\hline
\end{tabular}




\begin{tabular}{|c|c|c|c|c|c|}
\hline $\begin{array}{l}\text { Sessão/ Ano } \\
\text { escavação }\end{array}$ & Número da peça & $\begin{array}{l}\text { Localização } \\
\text { (Locus/camada) }\end{array}$ & $\begin{array}{l}\text { Localização } \\
\text { (Locus/recinto) }\end{array}$ & Estado físico & 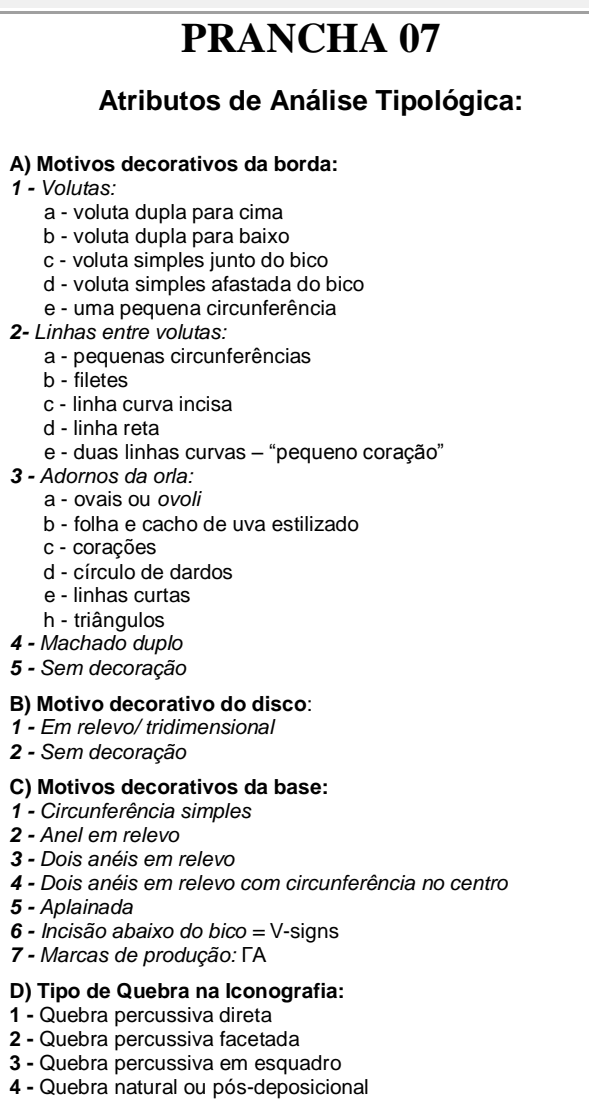 \\
\hline AP IX/92 & HM 2046 & $1250-$ Rom.2b & 1937 - culina & Integro & \multirow{6}{*}{$\begin{array}{c}\text { Cristianização dos espaços na } \\
\text { Antiguidade Tardia: o caso de } \\
\text { Apollonia }\end{array}$} \\
\hline Diam. da base & Diam. da borda & Diam. do disco & Diam. da quebra & Esp. do corpo & \\
\hline $42,04 \mathrm{~mm}$ & $75,34 \mathrm{~mm}$ & $45,12 \mathrm{~mm}$ & $33,83 \mathrm{~mm}$ & $x$ & \\
\hline Esp. da borda & Comprimento & Altura & Tipo & $\begin{array}{l}\text { Coloração (Munsell)/tipo } \\
\text { de argila }\end{array}$ & \\
\hline $1,55 \mathrm{~mm}$ & $88,70 \mathrm{~mm}$ & $20,15 \mathrm{~mm}$ & $\begin{array}{l}\text { Produção Local: Costa } \\
\text { Fenícia? }\end{array}$ & $\begin{array}{l}\text { 5YR - 2.5/2 -Ginger } \\
\text { clay/dark brown slip }\end{array}$ & \\
\hline $\begin{array}{l}\text { Decoração da } \\
\text { base }\end{array}$ & Decoração da borda & \multicolumn{2}{|c|}{ Iconografia do disco } & Local de produção & \\
\hline C) 4 & A)1.a & \multicolumn{2}{|l|}{ D)2 } & Não identificada & $\begin{array}{l}\text { Fotógrafo: Pavel Shrago } \\
\text { Desenho: Erêndira Oliveira }\end{array}$ \\
\hline Período: & Comparanda & \multicolumn{3}{|l|}{ Obs: } & \\
\hline 2nd-3th & $\begin{array}{l}\text { Wexler e Gilboa, } \\
1996 .\end{array}$ & & & & TS」 M A E \\
\hline
\end{tabular}




\begin{tabular}{|c|c|c|c|c|c|}
\hline $\begin{array}{l}\text { Sessão/ Ano } \\
\text { escavação }\end{array}$ & Número da peça & $\begin{array}{l}\text { Localização } \\
\text { (Locus/camada) }\end{array}$ & $\begin{array}{l}\text { Localização } \\
\text { (Locus/recinto) }\end{array}$ & Estado físico & 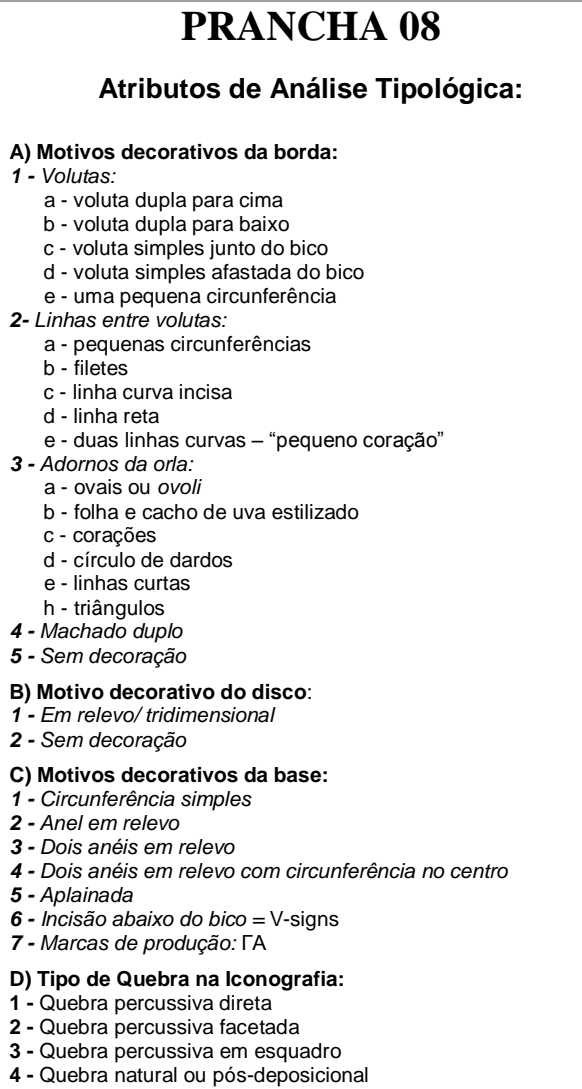 \\
\hline AP IX/92 & HM.2047 & 1218 - Bizantino & $1313-1^{a}$ sala nordeste & Integro & \multirow{6}{*}{$\begin{array}{c}\text { Cristianização dos espaços na } \\
\text { Antiguidade Tardia: o caso de } \\
\text { Apollonia }\end{array}$} \\
\hline Diam. da base & Diam. da borda & Diam. do disco & Diam. da quebra & Esp. do corpo & \\
\hline $41,97 \mathrm{~mm}$ & $71,39 \mathrm{~mm}$ & $44,25 \mathrm{~mm}$ & $33,36 \mathrm{~mm}$ & $x$ & \\
\hline Esp. da borda & Comprimento & Altura & Tipo & $\begin{array}{l}\text { Coloração (Munsell)/tipo } \\
\text { de argila }\end{array}$ & \\
\hline $2,74 \mathrm{~mm}$ & $83,96 \mathrm{~mm}$ & $22,79 \mathrm{~mm}$ & $\begin{array}{l}\text { Produção Local: Costa } \\
\text { Fenícia? }\end{array}$ & $\begin{array}{l}\text { 10YR - 4/2 - Buff clay/dark } \\
\text { brown slip }\end{array}$ & \\
\hline $\begin{array}{l}\text { Decoração da } \\
\text { base }\end{array}$ & Decoração da borda & \multicolumn{2}{|c|}{ Iconografia do disco } & Local de produção & \\
\hline C)2 & A)1.a; $2 . b ; 4$ & D) 1 & & Não identificada & $\begin{array}{l}\text { Fotógrafo: Pavel Shrago } \\
\text { Desenho: Erêndira Oliveira }\end{array}$ \\
\hline Período: & Comparanda & \multicolumn{3}{|l|}{ Obs: } & \\
\hline 2nd-3th & $\begin{array}{l}\text { Wexler e Gilboa, } \\
1996 .\end{array}$ & & & & TSP MAE 国CNPq 䛇 \\
\hline
\end{tabular}




\begin{tabular}{|c|c|c|c|c|c|}
\hline $\begin{array}{l}\text { Sessão/ Ano } \\
\text { escavação }\end{array}$ & Número da peça & $\begin{array}{l}\text { Localização } \\
\text { (Locus/camada) }\end{array}$ & $\begin{array}{l}\text { Localização } \\
\text { (Locus/recinto) }\end{array}$ & Estado físico & 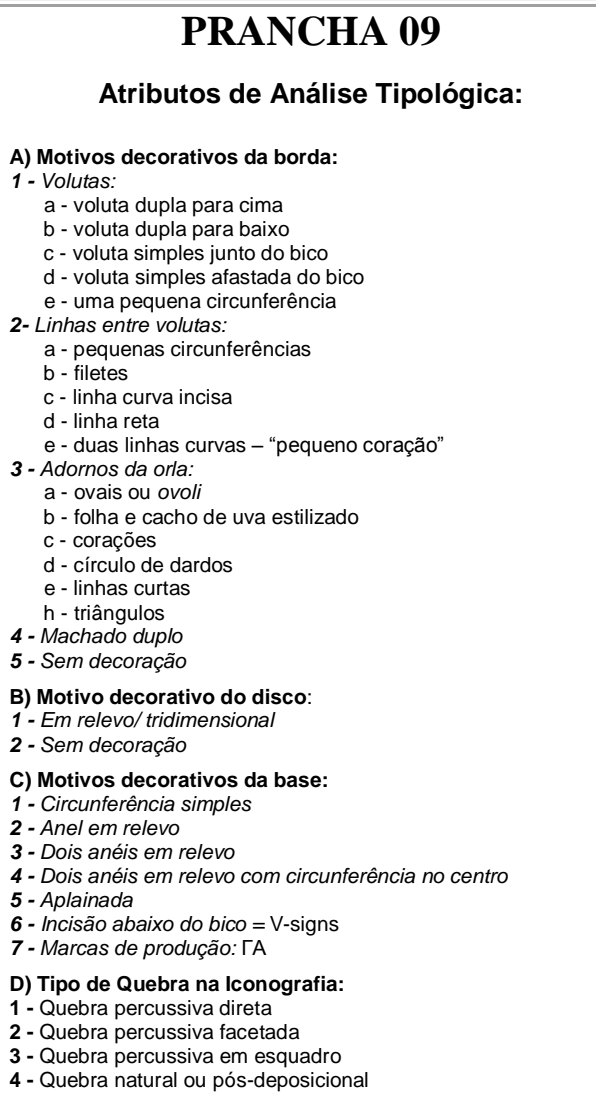 \\
\hline APII6/92 & HM.2017 & Dump/ Lixeira & & Integro & \multirow{6}{*}{$\begin{array}{c}\text { Cristianização dos espaços na } \\
\text { Antiguidade Tardia: o caso de } \\
\text { Apollonia }\end{array}$} \\
\hline Diam. da base & Diam. da borda & Diam. do disco & Diam. da quebra & Esp. do corpo & \\
\hline $39,86 \mathrm{~mm}$ & $69,63 \mathrm{~mm}$ & $45,04 \mathrm{~mm}$ & $35,81 \mathrm{~mm}$ & $\mathrm{x}$ & \\
\hline Esp. da borda & Comprimento & Altura & Тіро & $\begin{array}{l}\text { Coloração (Munsell)/tipo } \\
\text { de argila }\end{array}$ & \\
\hline $2,98 \mathrm{~mm}$ & $83,71 \mathrm{~mm}$ & $22,77 \mathrm{~mm}$ & $\begin{array}{l}\text { Produção Local: Costa } \\
\text { Fenícia? }\end{array}$ & $\begin{array}{l}\text { 10R - 4/6 - reddish } \\
\text { clay/reddish-brown slip }\end{array}$ & \\
\hline $\begin{array}{l}\text { Decoração da } \\
\text { base }\end{array}$ & Decoração da borda & \multicolumn{2}{|c|}{ Iconografia do disco } & Local de produção & \\
\hline C) $3 ; 6$ & A)1.a;2.c; 3.a;4 & \multicolumn{2}{|l|}{ D) 2,3} & Não identificada & $\begin{array}{l}\text { Fotógrafo: Pavel Shrago } \\
\text { Desenho: Erêndira Oliveira }\end{array}$ \\
\hline Período: & Comparanda & \multicolumn{3}{|l|}{ Obs: } & \\
\hline 2nd-3th & $\begin{array}{l}\text { Wexler e Gilboa, } \\
1996 .\end{array}$ & & & & TS」 MA.... Q \\
\hline
\end{tabular}




\begin{tabular}{|c|c|c|c|c|c|}
\hline $\begin{array}{l}\text { Sessão/ Ano } \\
\text { escavação }\end{array}$ & Número da peça & $\begin{array}{l}\text { Localização } \\
\text { (Locus/camada) }\end{array}$ & $\begin{array}{l}\text { Localização } \\
\text { (Locus/recinto) }\end{array}$ & Estado físico & 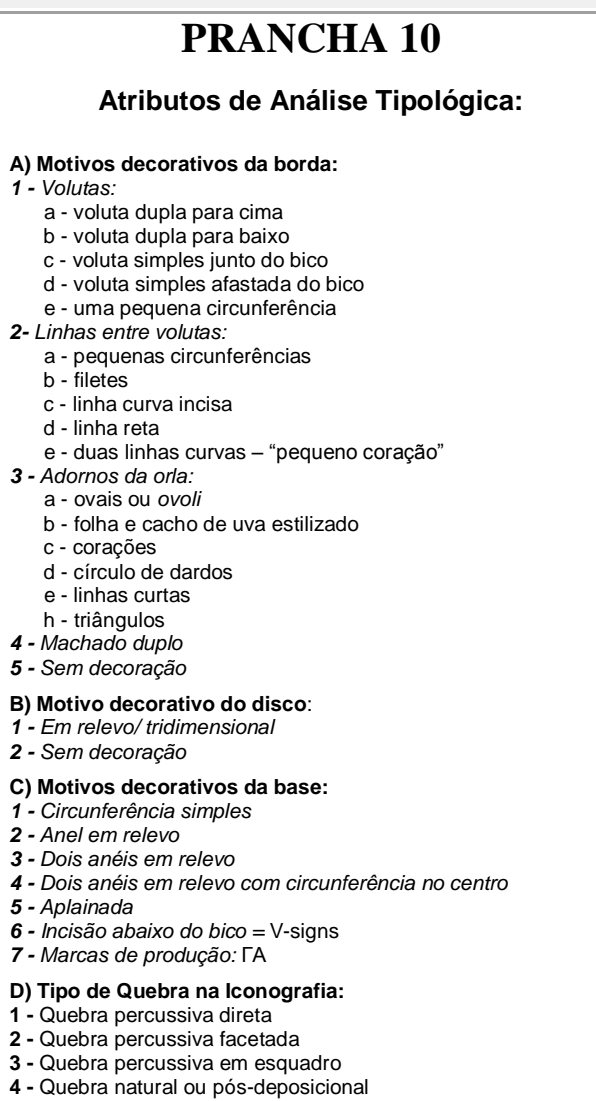 \\
\hline AP II & HM.2117 & 838 - Bizantino & 1928 - sala norte & Integro & \multirow{6}{*}{$\begin{array}{c}\text { Cristianização dos espaços na } \\
\text { Antiguidade Tardia: o caso de } \\
\text { Apollonia }\end{array}$} \\
\hline Diam. da base & Diam. da borda & Diam. do disco & Diam. da quebra & Esp. do corpo & \\
\hline $43,29 \mathrm{~mm}$ & $73,48 \mathrm{~mm}$ & $44,33 \mathrm{~mm}$ & $26,19 \mathrm{~mm}$ & $x$ & \\
\hline Esp. da borda & Comprimento & Altura & Tipo & $\begin{array}{l}\text { Coloração (Munsell)/tipo } \\
\text { de argila }\end{array}$ & \\
\hline $2,06 \mathrm{~mm}$ & $85,43 \mathrm{~mm}$ & $22,64 \mathrm{~mm}$ & $\begin{array}{l}\text { Produção Local: Costa } \\
\text { Fenícia? }\end{array}$ & $\begin{array}{l}2.5 Y R-3 / 2 \text { - Buff } \\
\text { clay/brown slip }\end{array}$ & \\
\hline $\begin{array}{l}\text { Decoração da } \\
\text { base }\end{array}$ & Decoração da borda & \multicolumn{2}{|c|}{ Iconografia do disco } & Local de produção & \\
\hline C) 1 & A)1.e; 2.c & \multicolumn{2}{|l|}{ D)2 } & Não identificada & $\begin{array}{l}\text { Fotógrafo: Pavel Shrago } \\
\text { Desenho: Erêndira Oliveira }\end{array}$ \\
\hline Período: & Comparanda & \multicolumn{3}{|l|}{ Obs: } & \\
\hline 2nd-3th & $\begin{array}{l}\text { Wexler e Gilboa, } \\
1996 .\end{array}$ & \multicolumn{3}{|l|}{ 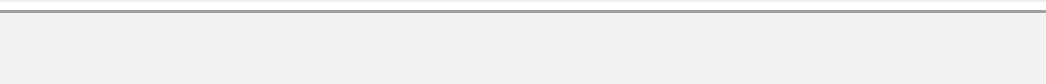 } & TSP M A E E \\
\hline
\end{tabular}




\begin{tabular}{|c|c|c|c|c|c|}
\hline $\begin{array}{l}\text { Sessão/ Ano } \\
\text { escavação }\end{array}$ & Número da peça & $\begin{array}{l}\text { Localização } \\
\text { (Locus/camada) }\end{array}$ & $\begin{array}{l}\text { Localização } \\
\text { (Locus/recinto) }\end{array}$ & Estado físico & 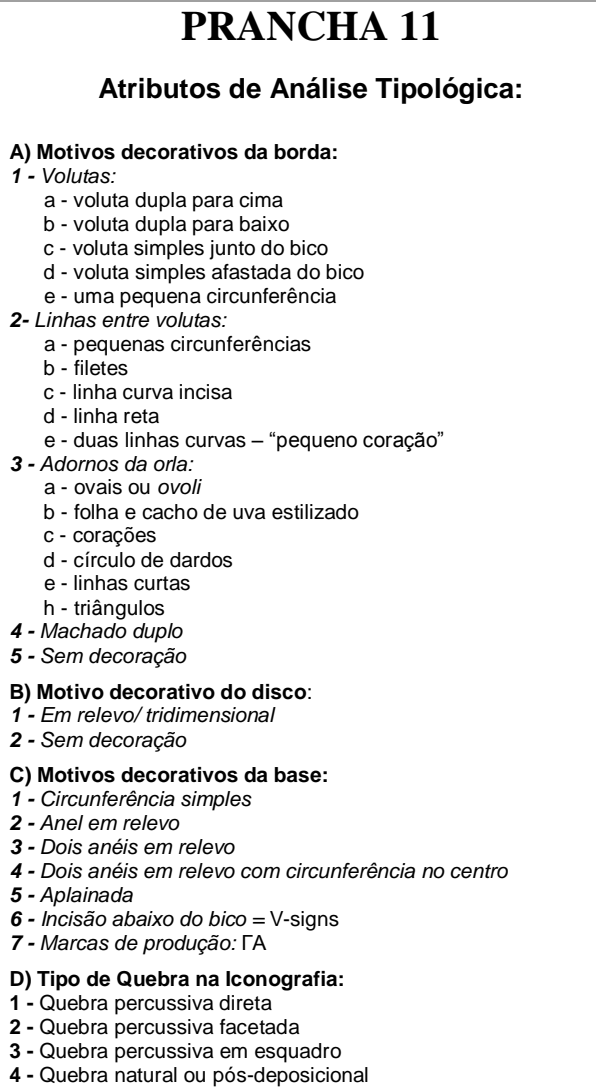 \\
\hline APII6/92 & HM.2148 & 1297 - Rom. 1 & $1342-2^{a}$ sala nordeste & Integro & \multirow{6}{*}{$\begin{array}{c}\text { Cristianização dos espaços na } \\
\text { Antiguidade Tardia: o caso de } \\
\text { Apollonia }\end{array}$} \\
\hline Diam. da base & Diam. da borda & Diam. do disco & Diam. da quebra & Esp. do corpo & \\
\hline $1,80 \mathrm{~mm}$ & $76,85 \mathrm{~mm}$ & $44,23 \mathrm{~mm}$ & $19,55 \mathrm{~mm}$ & $x$ & \\
\hline Esp. da borda & Comprimento & Altura & Tipo & $\begin{array}{l}\text { Coloração (Munsell)/tipo } \\
\text { de argila }\end{array}$ & \\
\hline $1,80 \mathrm{~mm}$ & $87,85 \mathrm{~mm}$ & $21,78 \mathrm{~mm}$ & $\begin{array}{l}\text { Produção Local: Costa } \\
\text { Fenícia? }\end{array}$ & $\begin{array}{l}\text { 10YR - } 4 / 2 \text { - Buff clay/dark } \\
\text { brown slip }\end{array}$ & \\
\hline $\begin{array}{l}\text { Decoração da } \\
\text { base }\end{array}$ & Decoração da borda & \multicolumn{2}{|c|}{ Iconografia do disco } & Local de produção & \\
\hline C) 1 & A)1.a; 2.c; 4 & D) 1 & & Não identificada & $\begin{array}{l}\text { Fotógrafo: Pavel Shrago } \\
\text { Desenho: Erêndira Oliveira }\end{array}$ \\
\hline Período: & Comparanda & \multicolumn{3}{|l|}{ Obs: } & \\
\hline 2nd-3th & $\begin{array}{l}\text { Wexler e Gilboa, } \\
1996 .\end{array}$ & & & & 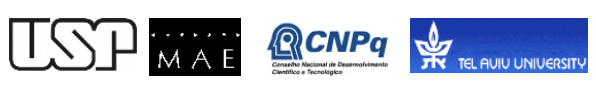 \\
\hline
\end{tabular}




\begin{tabular}{|c|c|c|c|c|c|}
\hline $\begin{array}{l}\text { Sessão/Ano } \\
\text { escavação }\end{array}$ & Número da peça & $\begin{array}{l}\text { Localização } \\
\text { (Locus/camada) }\end{array}$ & $\begin{array}{l}\text { Localização } \\
\text { (Locus/recinto) }\end{array}$ & Estado físico & 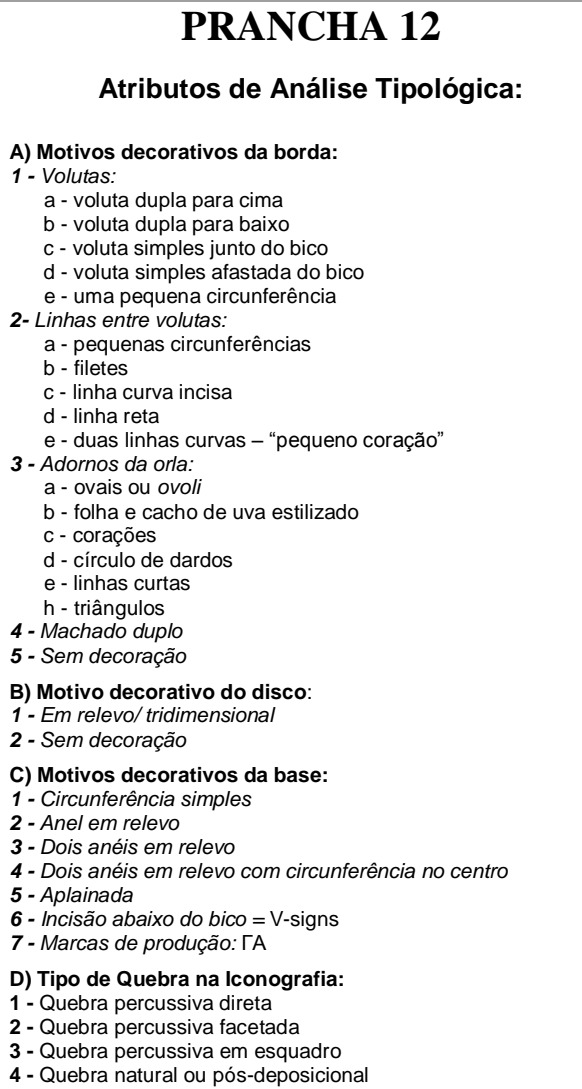 \\
\hline APII6/92 & HM.2149 & 1320 - Rom.1 & $\begin{array}{l}1851 \text { - inicio corredor } \\
\text { longo }\end{array}$ & Integro & \multirow{6}{*}{$\begin{array}{c}\text { Cristianização dos espaços na } \\
\text { Antiguidade Tardia: o caso de } \\
\text { Apollonia }\end{array}$} \\
\hline Diam. da base & Diam. da borda & Diam. do disco & Diam. da quebra & Esp. do corpo & \\
\hline $39,31 \mathrm{~mm}$ & $70,18 \mathrm{~mm}$ & $46,22 \mathrm{~mm}$ & $36,47 \mathrm{~mm}$ & $x$ & \\
\hline Esp. da borda & Comprimento & Altura & Tipo & $\begin{array}{l}\text { Coloração (Munsell)/tipo } \\
\text { de argila }\end{array}$ & \\
\hline $2,25 \mathrm{~mm}$ & $80,11 \mathrm{~mm}$ & $18,54 \mathrm{~mm}$ & $\begin{array}{l}\text { Produção Local: Costa } \\
\text { Fenícia? }\end{array}$ & $\begin{array}{l}2.5 Y R-3 / 2-4 \text { - Buff } \\
\text { clay/brown slip }\end{array}$ & \\
\hline $\begin{array}{l}\text { Decoração da } \\
\text { base }\end{array}$ & Decoração da borda & \multicolumn{2}{|c|}{ Iconografia do disco } & Local de produção & \\
\hline C) 1 & A)1.a; 2.a, c; $3 . a$ & \multicolumn{2}{|l|}{ D) 2} & Não identificada & $\begin{array}{l}\text { Fotógrafo: Pavel Shrago } \\
\text { Desenho: Erêndira Oliveira }\end{array}$ \\
\hline Período: & Comparanda & \multicolumn{3}{|l|}{ Obs: } & \\
\hline 2nd-3th & $\begin{array}{l}\text { Wexler e Gilboa, } \\
1996 .\end{array}$ & & & & 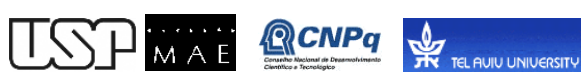 \\
\hline
\end{tabular}




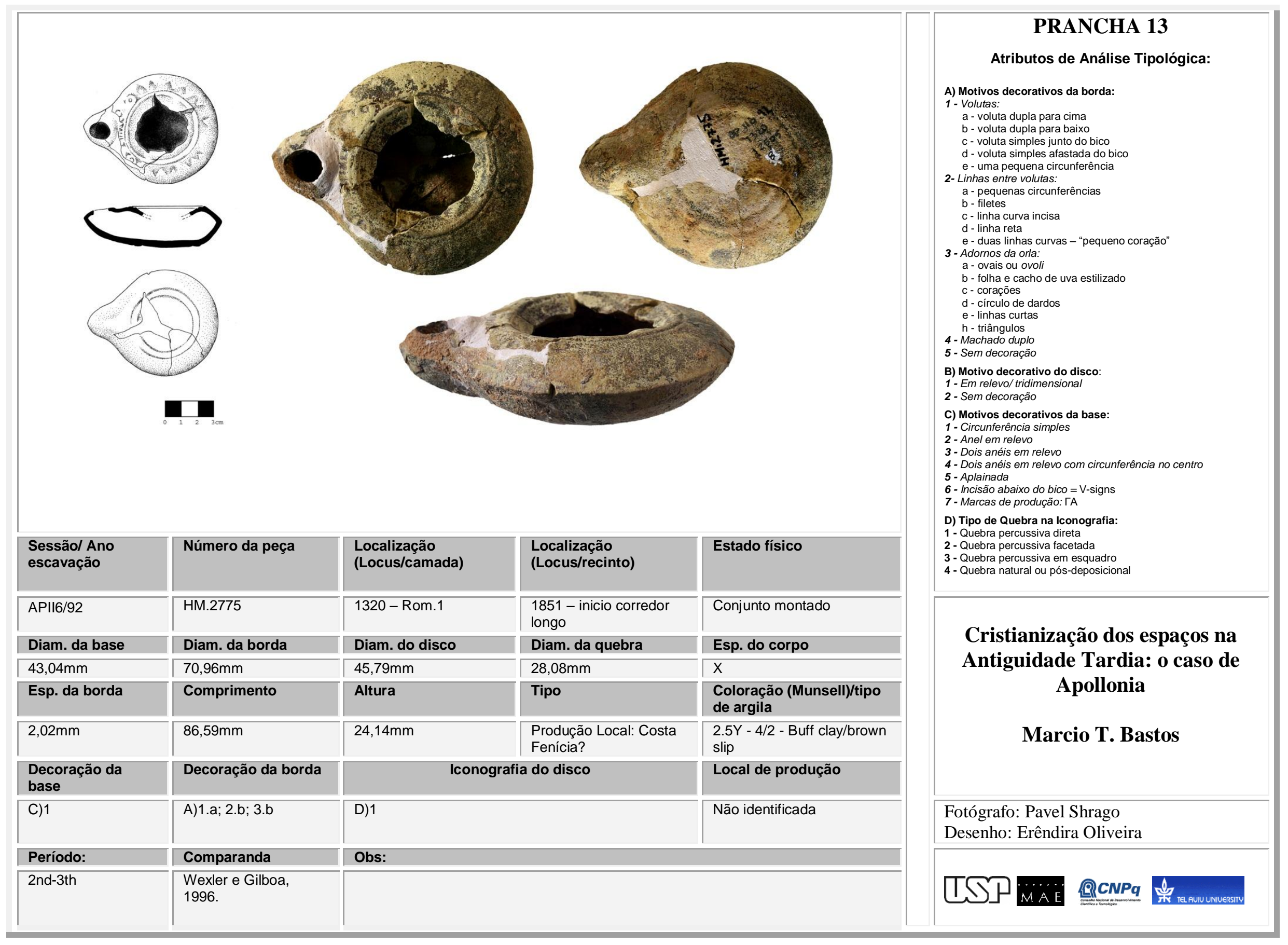




\begin{tabular}{|c|c|c|c|c|c|}
\hline $\begin{array}{l}\text { Sessão/ Ano } \\
\text { escavação }\end{array}$ & Número da peça & $\begin{array}{l}\text { Localização } \\
\text { (Locus/camada) }\end{array}$ & $\begin{array}{l}\text { Localização } \\
\text { (Locus/recinto) }\end{array}$ & Estado físico & 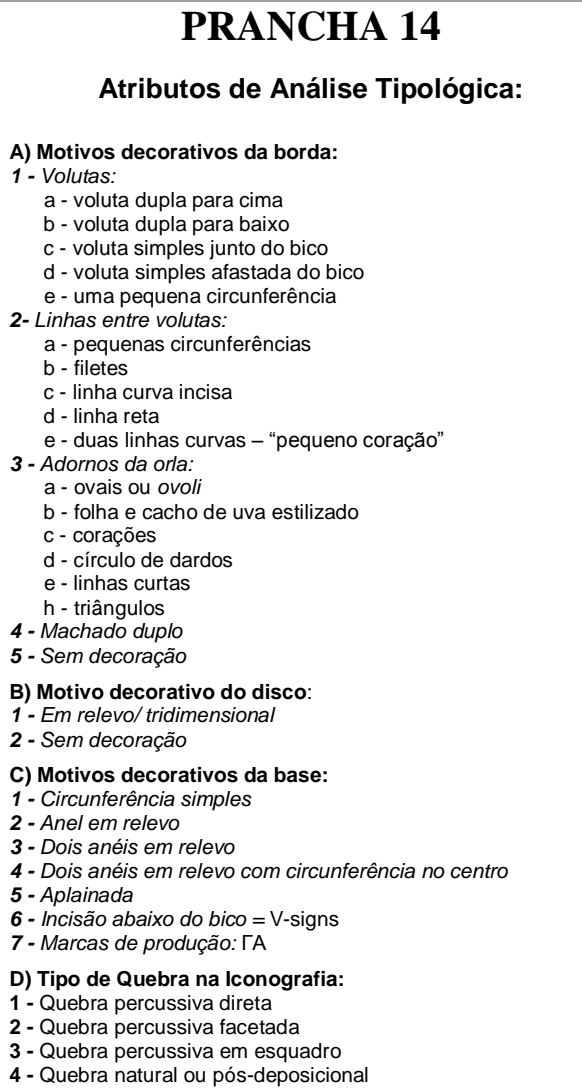 \\
\hline APII6/92 & HM.2227 & 1297 - Rom. 1 & $1342-2^{\mathrm{a}}$ sala nordeste & Integro & \multirow{6}{*}{$\begin{array}{c}\text { Cristianização dos espaços na } \\
\text { Antiguidade Tardia: o caso de } \\
\text { Apollonia }\end{array}$} \\
\hline Diam. da base & Diam. da borda & Diam. do disco & Diam. da quebra & Esp. do corpo & \\
\hline $42,14 \mathrm{~mm}$ & $70,58 \mathrm{~mm}$ & $44,85 \mathrm{~mm}$ & $27,07 \mathrm{~mm}$ & $x$ & \\
\hline Esp. da borda & Comprimento & Altura & Tipo & $\begin{array}{l}\text { Coloração (Munsell)/tipo } \\
\text { de argila }\end{array}$ & \\
\hline $2,44 \mathrm{~mm}$ & $85,14 \mathrm{~mm}$ & $18,31 \mathrm{~mm}$ & $\begin{array}{l}\text { Produção Local: Costa } \\
\text { Fenícia? }\end{array}$ & $\begin{array}{l}5 \text { YR - 4/2 - Ginger clay/ } \\
\text { brown slip }\end{array}$ & \\
\hline $\begin{array}{l}\text { Decoração da } \\
\text { base }\end{array}$ & Decoração da borda & \multicolumn{2}{|c|}{ Iconografia do disco } & Local de produção & \\
\hline C)2 & A)1.a; 2.c & \multicolumn{2}{|c|}{$\begin{array}{l}\text { B)1; D)1 - Possivelmente a iconografia de uma } \\
\text { estrela ou flor estilizada }\end{array}$} & Não identificada & $\begin{array}{l}\text { Fotógrafo: Pavel Shrago } \\
\text { Desenho: Erêndira Oliveira }\end{array}$ \\
\hline Período: & Comparanda & \multicolumn{3}{|l|}{ Obs: } & \multirow[b]{2}{*}{ TSP MAE 道CNPq } \\
\hline 2nd-3th & $\begin{array}{l}\text { Wexler e Gilboa, } \\
1996 .\end{array}$ & \multicolumn{3}{|l|}{ 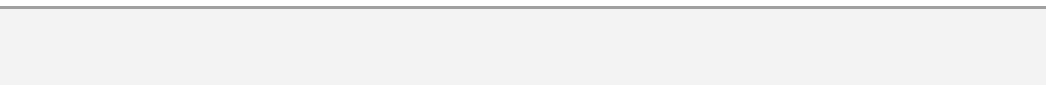 } & \\
\hline
\end{tabular}




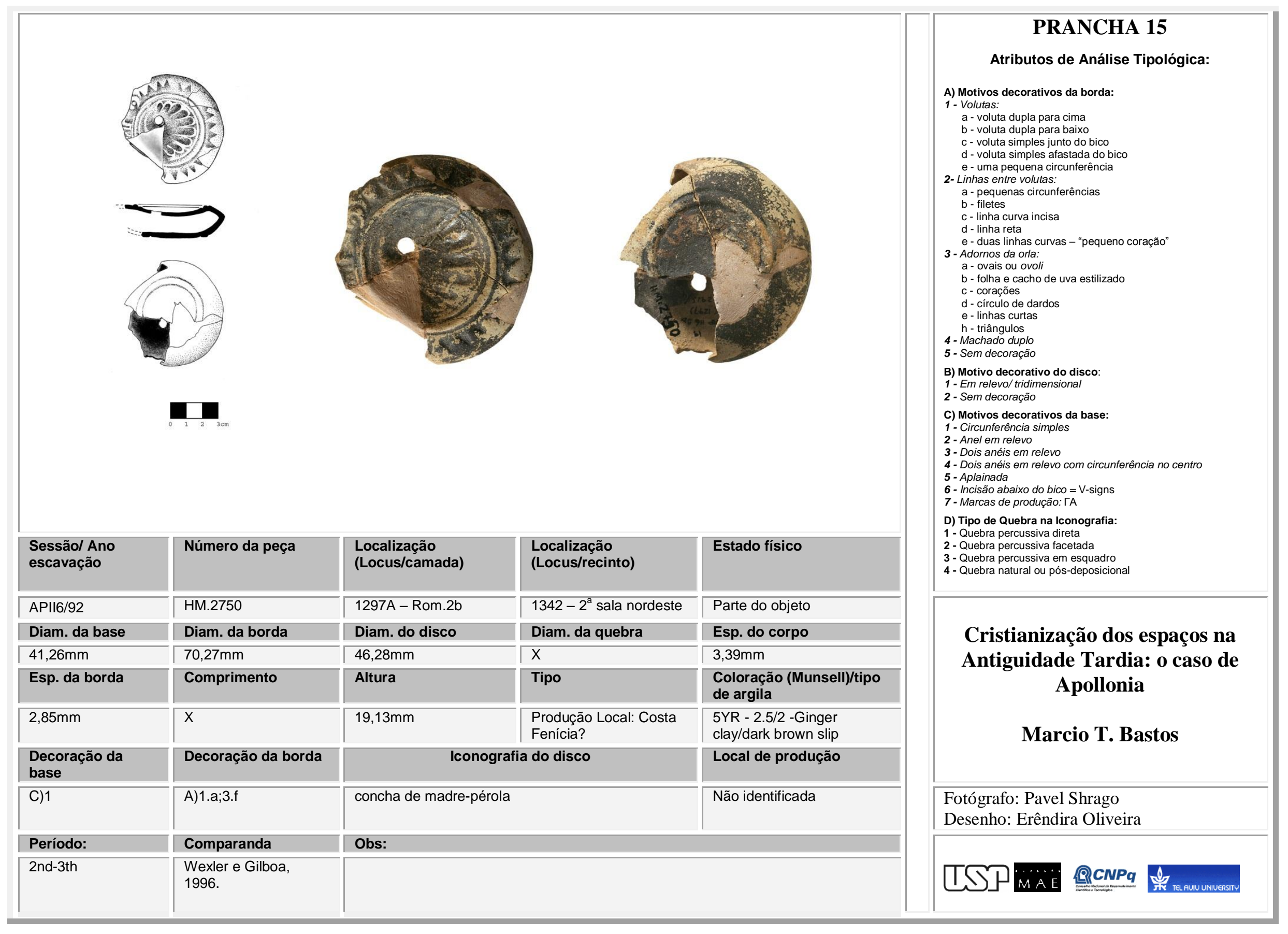




\begin{tabular}{|c|c|c|c|c|c|}
\hline $\begin{array}{l}\text { Sessão/ Ano } \\
\text { escavação }\end{array}$ & Número da peça & $\begin{array}{l}\text { Localização } \\
\text { (Locus/camada) }\end{array}$ & $\begin{array}{l}\text { Localização } \\
\text { (Locus/recinto) }\end{array}$ & Estado físico & 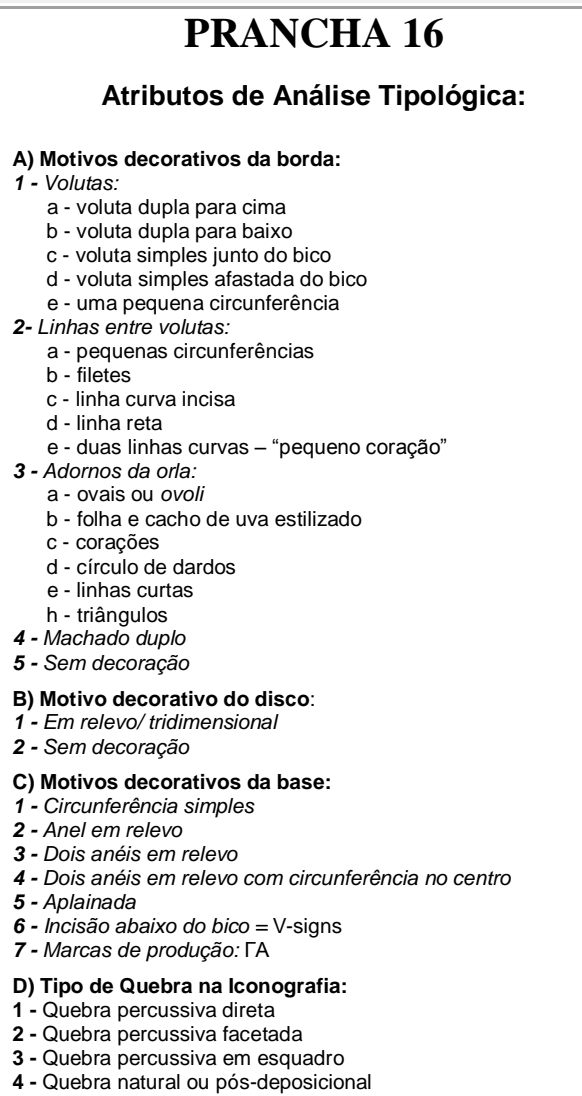 \\
\hline APIII & HM. 2032 & 878 - Bizantino & 1937 - culina & Integro & \multirow{6}{*}{$\begin{array}{c}\text { Cristianização dos espaços na } \\
\text { Antiguidade Tardia: o caso de } \\
\text { Apollonia }\end{array}$} \\
\hline Diam. da base & Diam. da borda & Diam. do disco & Diam. da quebra & Esp. do corpo & \\
\hline $42,11 \mathrm{~mm}$ & $73,05 \mathrm{~mm}$ & $44,68 \mathrm{~mm}$ & $30,25 \mathrm{~mm}$ & $x$ & \\
\hline Esp. da borda & Comprimento & Altura & Tipo & $\begin{array}{l}\text { Coloração (Munsell)/tipo } \\
\text { de argila }\end{array}$ & \\
\hline $2,57 \mathrm{~mm}$ & $84,51 \mathrm{~mm}$ & $21,78 \mathrm{~mm}$ & $\begin{array}{l}\text { Produção Local: Costa } \\
\text { Fenícia? }\end{array}$ & $\begin{array}{l}\text { 10R - } 4 / 8 \text { - reddish } \\
\text { clay/reddish-brown slip }\end{array}$ & \\
\hline $\begin{array}{l}\text { Decoração da } \\
\text { base }\end{array}$ & Decoração da borda & \multicolumn{2}{|c|}{ Iconografia do disco } & Local de produção & \\
\hline C) 1 & A)1.a; $2 . a, c ; 3 . a ; 4$ & \multicolumn{2}{|l|}{ D)2 } & Não identificada & $\begin{array}{l}\text { Fotógrafo: Pavel Shrago } \\
\text { Desenho: Erêndira Oliveira }\end{array}$ \\
\hline Período: & Comparanda & \multicolumn{3}{|l|}{ Obs: } & \\
\hline 2nd-3th & $\begin{array}{l}\text { Wexler e Gilboa, } \\
1996 .\end{array}$ & & & & TSP MAE 道CNPq of ranuunuesin \\
\hline
\end{tabular}




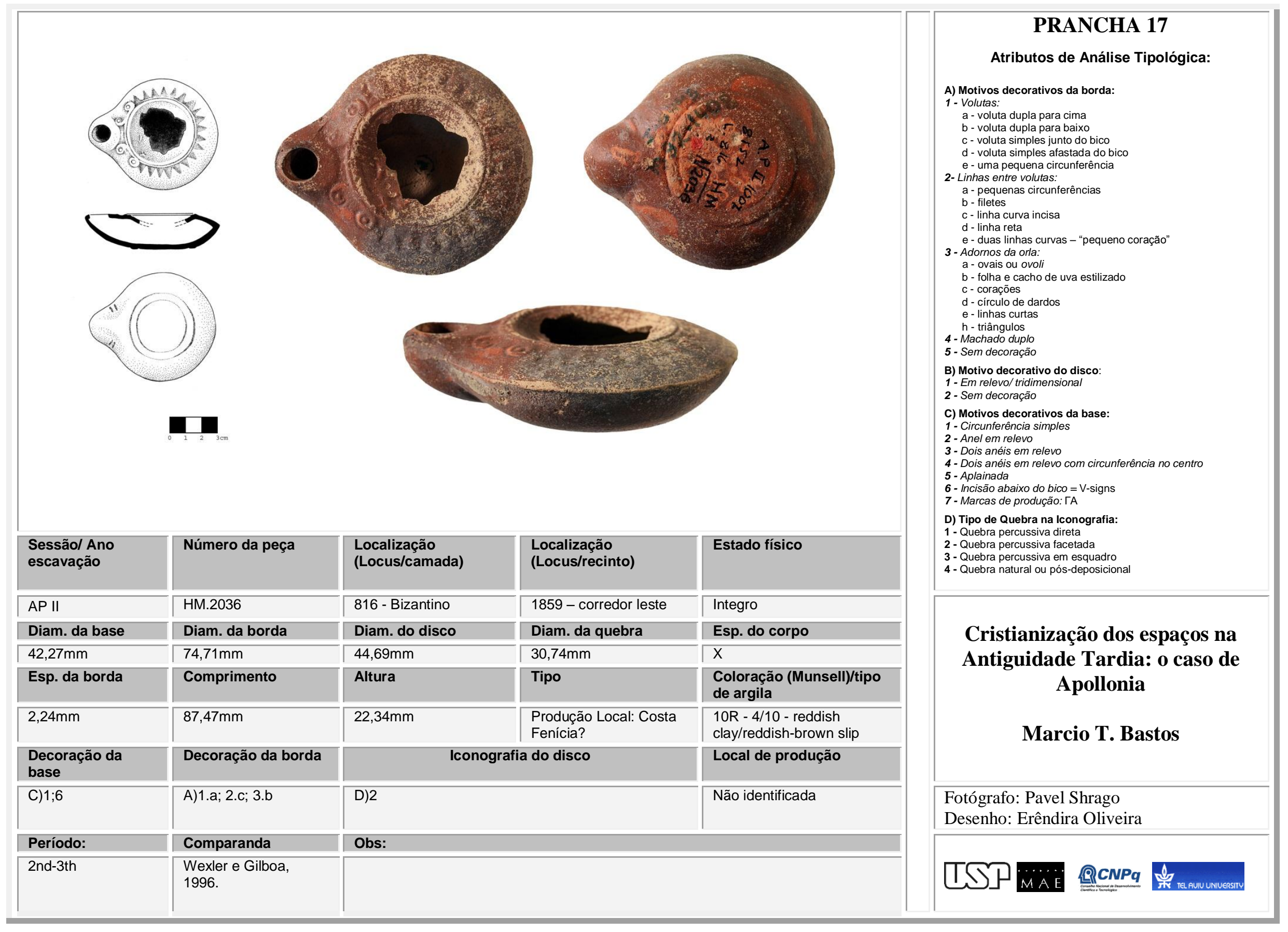




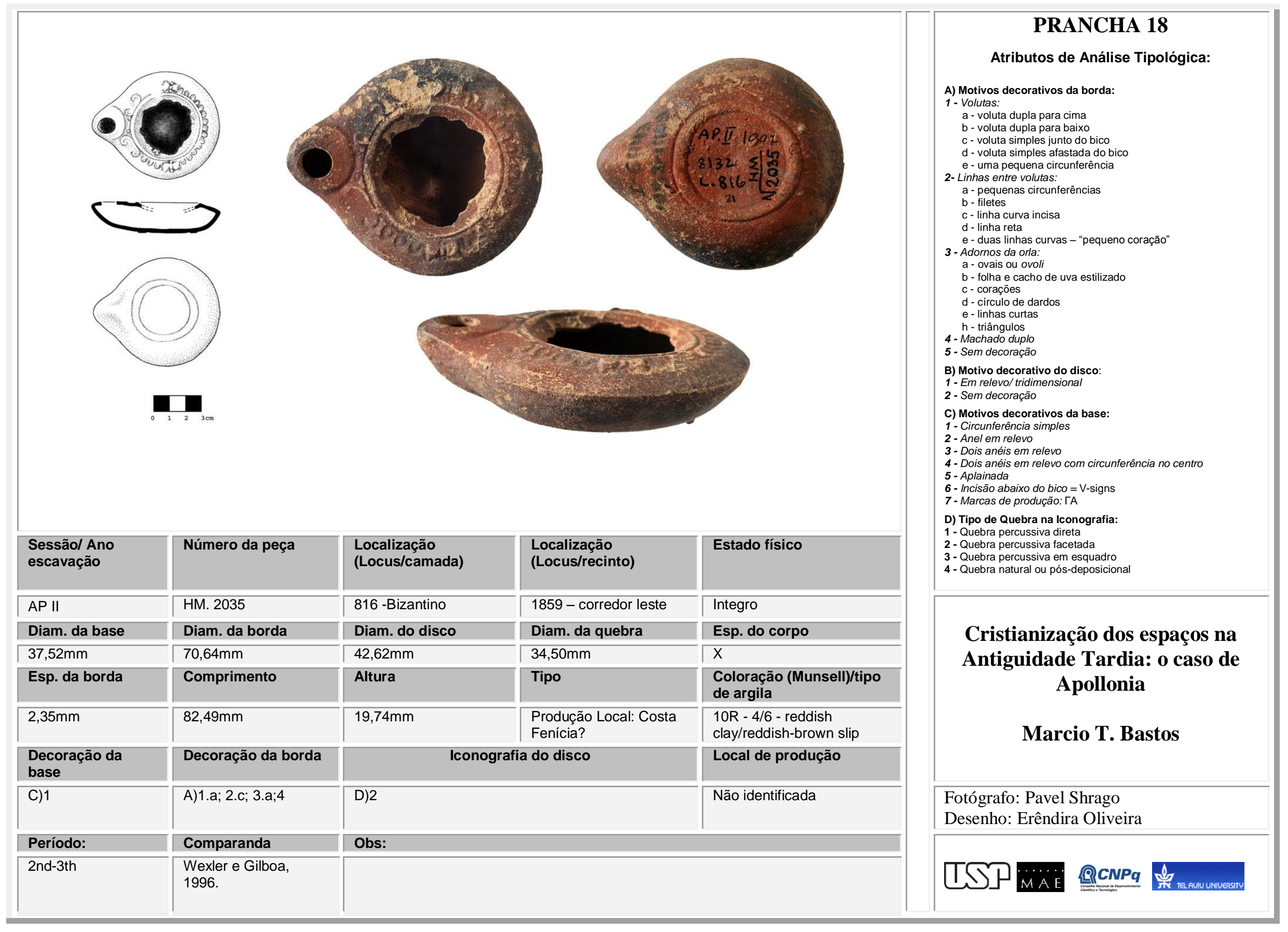




\begin{tabular}{|c|c|c|c|c|c|}
\hline $\begin{array}{l}\text { Sessão/ Ano } \\
\text { escavação }\end{array}$ & Número da peça & $\begin{array}{l}\text { Localização } \\
\text { (Locus/camada) }\end{array}$ & $\begin{array}{l}\text { Localização } \\
\text { (Locus/recinto) }\end{array}$ & Estado físico & 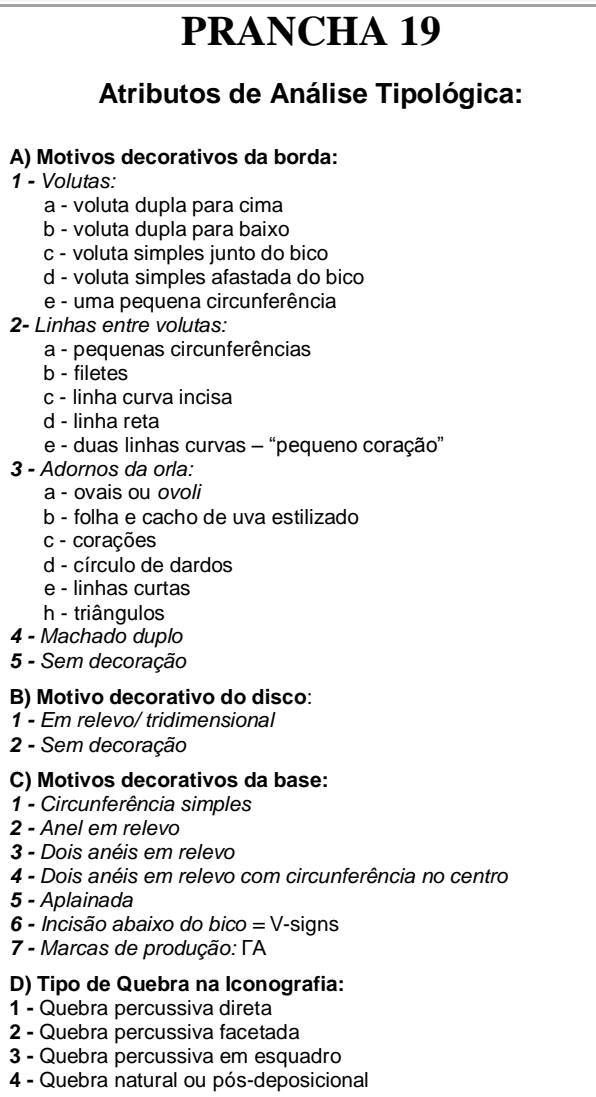 \\
\hline AP II & HM. 2038 & 815 - Bizantino & 1859 - corredor leste & Integro & \\
\hline Diam. da base & Diam. da borda & Diam. do disco & Diam. da quebra & Esp. do corpo & Cristianização dos espaços na \\
\hline $42,16 \mathrm{~mm}$ & $72,80 \mathrm{~mm}$ & $45,20 \mathrm{~mm}$ & $29,49 \mathrm{~mm}$ & $\mathrm{X}$ & Antiguidade Tardia: o caso de \\
\hline Esp. da borda & Comprimento & Altura & Tipo & $\begin{array}{l}\text { Coloração (Munsell)/tipo } \\
\text { de argila }\end{array}$ & Apollonia \\
\hline $2,52 \mathrm{~mm}$ & $84,29 \mathrm{~mm}$ & $21,98 \mathrm{~mm}$ & $\begin{array}{l}\text { Produção Local: Costa } \\
\text { Fenícia? }\end{array}$ & $\begin{array}{l}\text { 10R - 4/6 - reddish } \\
\text { clay/reddish-brown slip }\end{array}$ & \multirow[t]{2}{*}{ Marcio T. Bastos } \\
\hline $\begin{array}{l}\text { Decoração da } \\
\text { base }\end{array}$ & Decoração da borda & \multicolumn{2}{|c|}{ Iconografia do disco } & Local de produção & \\
\hline C) 1 & A)1.a;2.b, c; 4 & \multicolumn{2}{|c|}{$\begin{array}{l}\text { D) } 1 \text { - Porém é possível ver uma flor ou folha } \\
\text { estilizada. }\end{array}$} & Não identificada & $\begin{array}{l}\text { Fotógrafo: Pavel Shrago } \\
\text { Desenho: Erêndira Oliveira }\end{array}$ \\
\hline Período: & Comparanda & \multicolumn{3}{|c|}{ Obs: } & \\
\hline 2nd-3th & $\begin{array}{l}\text { Wexler e Gilboa, } \\
1996 .\end{array}$ & & & & 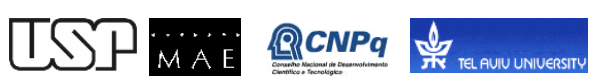 \\
\hline
\end{tabular}




\begin{tabular}{|c|c|c|c|c|c|}
\hline $\begin{array}{l}\text { Sessão/ Ano } \\
\text { escavação }\end{array}$ & Número da peça & $\begin{array}{l}\text { Localização } \\
\text { (Locus)/camada) }\end{array}$ & $\begin{array}{l}\text { Localização } \\
\text { (Locus/recinto) }\end{array}$ & Estado físico & 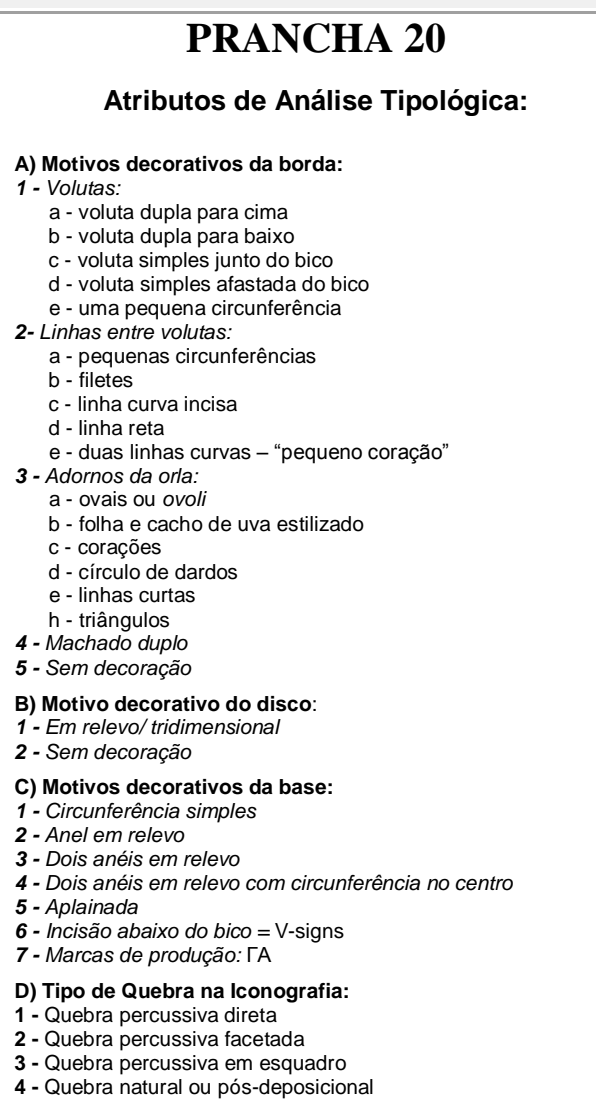 \\
\hline AP II & HM. 2042 & $\mathrm{X}$ & 8002 & Conjunto Montado & \multirow{6}{*}{$\begin{array}{c}\text { Cristianização dos espaços na } \\
\text { Antiguidade Tardia: o caso de } \\
\text { Apollonia }\end{array}$} \\
\hline Diam. dab & Diam. da borda & Diam. do disco & Diam. da quebra & Esp. do corpo & \\
\hline $50,87 \mathrm{~mm}$ & $89,23 \mathrm{~mm}$ & $66,20 \mathrm{~mm}$ & $43,20 \mathrm{~mm}$ & $x$ & \\
\hline Esp. da borda & Comprimento & Altura & Tipo & $\begin{array}{l}\text { Coloração (Munsell)/tipo } \\
\text { de argila }\end{array}$ & \\
\hline $3,21 \mathrm{~mm}$ & $104,04 \mathrm{~mm}$ & $25,58 \mathrm{~mm}$ & $\begin{array}{l}\text { Produção Local: Costa } \\
\text { Fenícia? }\end{array}$ & $\begin{array}{l}\text { 10R - 4/10 - reddish } \\
\text { clay/reddish-brown slip }\end{array}$ & \\
\hline $\begin{array}{l}\text { Decoração da } \\
\text { base }\end{array}$ & Decoração da borda & \multicolumn{2}{|c|}{ Iconografia do disco } & Local de produção & \\
\hline C) 4 & A)2.e; 3.a & D) 1 & & Não identificada & $\begin{array}{l}\text { Fotógrafo: Pavel Shrago } \\
\text { Desenho: Erêndira Oliveira }\end{array}$ \\
\hline Período: & Comparanda & \multicolumn{3}{|l|}{ Obs: } & \\
\hline 2nd-3th & $\begin{array}{l}\text { Wexler e Gilboa, } \\
1996 .\end{array}$ & & & & 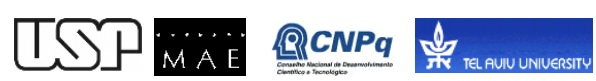 \\
\hline
\end{tabular}




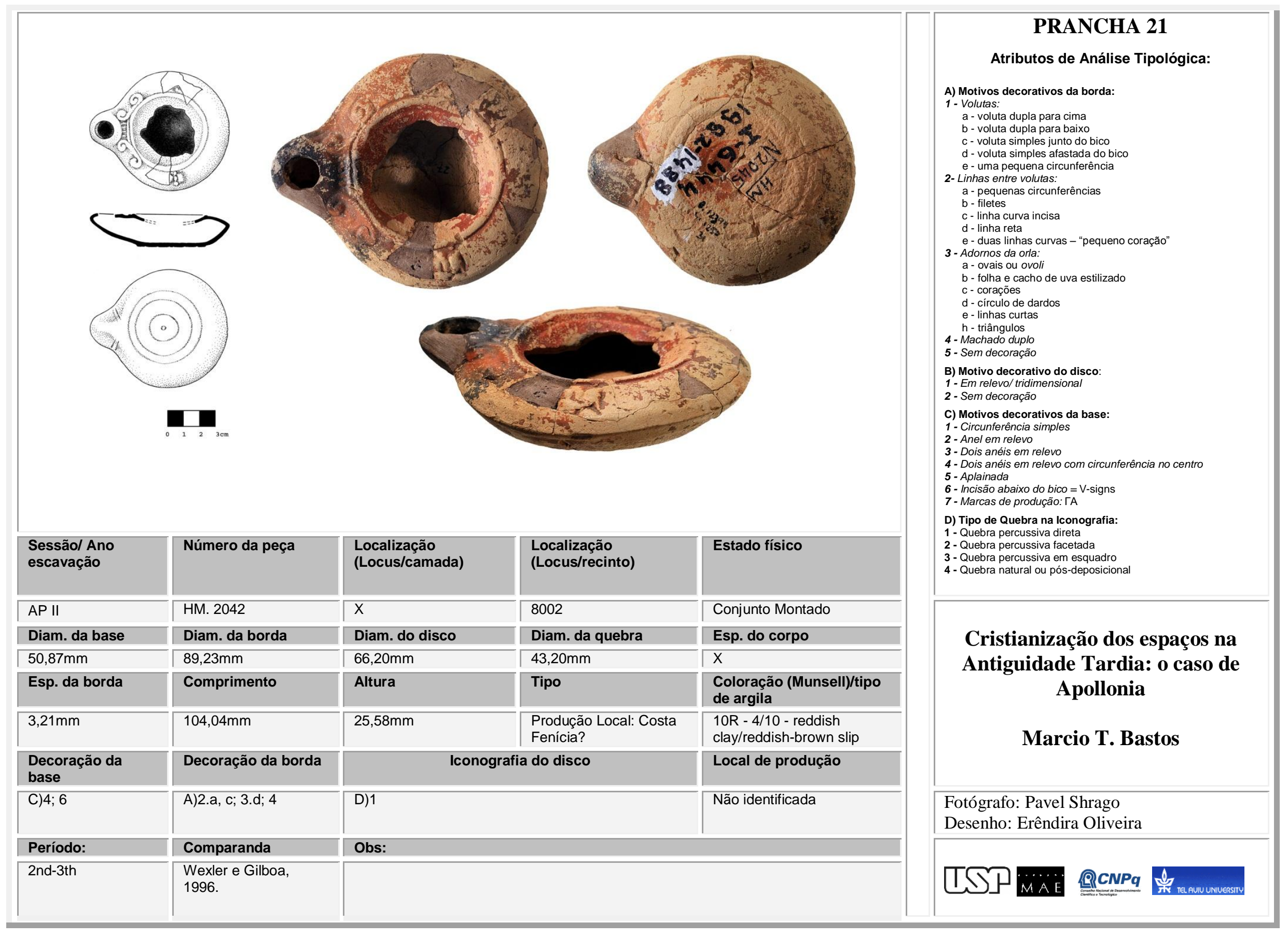



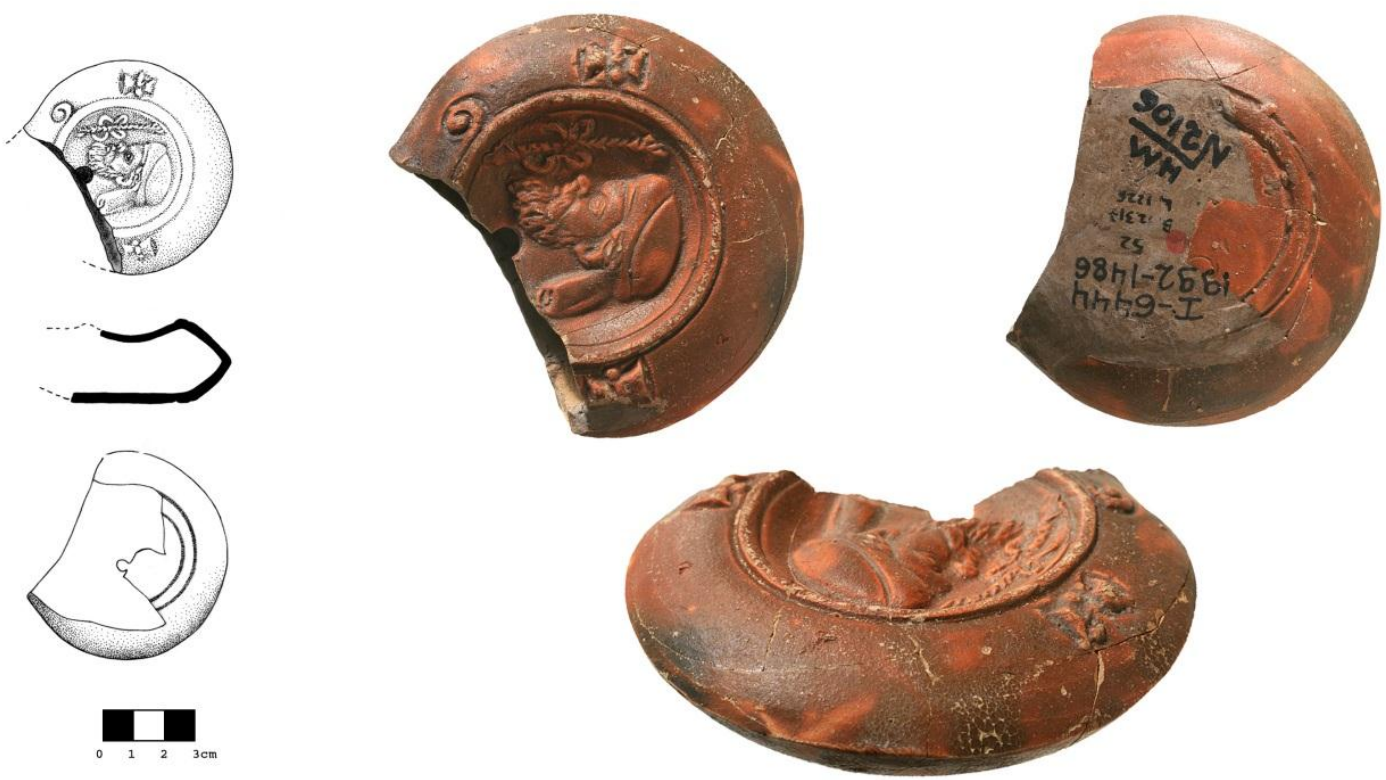

\begin{tabular}{|c|c|c|c|c|}
\hline $\begin{array}{l}\text { Sessão/ Ano } \\
\text { escavação }\end{array}$ & Número da peça & $\begin{array}{l}\text { Localização } \\
\text { (Locus/camada) }\end{array}$ & $\begin{array}{l}\text { Localização } \\
\text { (Locus/recinto) }\end{array}$ & Estado físico \\
\hline AP IX/92 & HM.2106 & 1225 - Rom. 1 & 1937 - culina & Integro \\
\hline Diam. da base & Diam. da borda & Diam. do discus & Diam. da quebra & Esp. do corpo \\
\hline $41,44 \mathrm{~mm}$ & $71,06 \mathrm{~mm}$ & $44,35 \mathrm{~mm}$ & $x$ & $3,02 \mathrm{~mm}$ \\
\hline Esp. da borda & Comprimento & Altura & Tipo & $\begin{array}{l}\text { Coloração (Munsell)/tipo } \\
\text { de argila }\end{array}$ \\
\hline $2,77 \mathrm{~mm}$ & $\mathrm{X}$ & $20,67 \mathrm{~mm}$ & $\begin{array}{l}\text { Produção Local: Costa } \\
\text { Fenícia? }\end{array}$ & $\begin{array}{l}10 R-5 / 10 \text { - reddish clay/ } \\
\text { reddish slip }\end{array}$ \\
\hline $\begin{array}{l}\text { Decoração da } \\
\text { base }\end{array}$ & Decoração da borda & \multicolumn{2}{|c|}{ Iconografia do disco } & Local de produção \\
\hline C) 1 & A)1.a; 4 & \multicolumn{2}{|c|}{$\begin{array}{l}\text { Perfil esquerdo em relevo de um homem com barba e } \\
\text { turbante, em sua frente uma corda traçada estilizada.. }\end{array}$} & Não identificada \\
\hline Período: & Comparanda & \multicolumn{3}{|l|}{ Obs: } \\
\hline 2nd-3th & $\begin{array}{l}\text { Wexler e Gilboa, } \\
1996 .\end{array}$ & & & \\
\hline
\end{tabular}

\section{PRANCHA 22}

Atributos de Análise Tipológica:

A) Motivos decorativos da borda

1-Volutas:

a - voluta dupla para cima

b - voluta dupla para baixo
c - voluta simples junto do bico

d - voluta simples afastada do bico

$\mathrm{e}$ - uma pequena circunferência

2- Linhas entre volutas.

a - pequenas circunferências

c - linha curva incis
d - linha reta

- duas linhas curvas - "pequeno coração"

3 - Adornos da orla:

a - ovais ou ovoli

to estilizado

- corações

- círculo de dardos

$\mathrm{h}$ - triângulos

4 - Machado duplo

5 - Sem decoração

B) Motivo decorativo do disco

1 - Em relevo/ tridimensional

2 - Sem decoração

C) Motivos decorativos da base:

1 - Circunferência simples

2 - Anel em relevo

4 - Dois anéis em relevo com circunferência no centro

5 - Aplainada

6 - Incisão abaixo do bico = V-sign

7 - Marcas de produção: ГA

D) Tipo de Quebra na Iconografia:

1. - Quebra percussiva direta

2 - Quebra percussiva facetada

3 - Quebra percussiva em esquadro

4 - Quebra natural ou pós-deposicion

Cristianização dos espaços na Antiguidade Tardia: o caso de Apollonia

\section{Marcio T. Bastos}

Fotógrafo: Pavel Shrago

Desenho: Erêndira Oliveira

TSP諅CNPq 


\begin{tabular}{|c|c|c|c|c|c|}
\hline $\begin{array}{l}\text { Sessão/ Ano } \\
\text { escavação }\end{array}$ & Número da peça & $\begin{array}{l}\text { Localização } \\
\text { (Locus/camada) }\end{array}$ & $\begin{array}{l}\text { Localização } \\
\text { (Locus/recinto) }\end{array}$ & Estado físico & 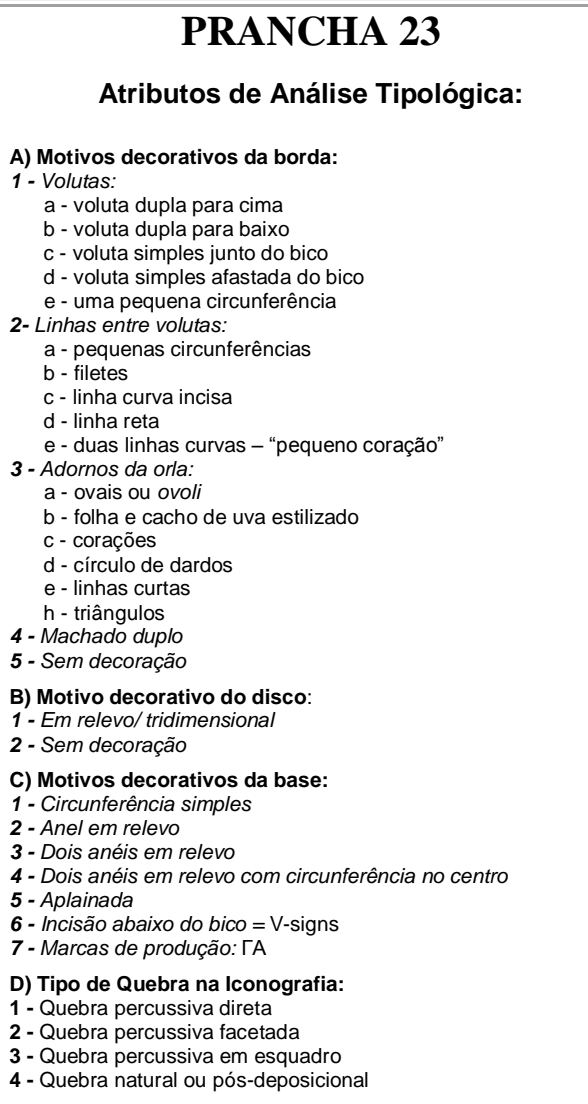 \\
\hline AP IX/92 & HM.2150 & 1309 - Bizantino & $\begin{array}{l}1768-\text { final corredor } \\
\text { longo }\end{array}$ & Integro & \multirow{6}{*}{$\begin{array}{c}\text { Cristianização dos espaços na } \\
\text { Antiguidade Tardia: o caso de } \\
\text { Apollonia }\end{array}$} \\
\hline Diam. da base & Diam. da borda & Diam. do disco & Diam. da quebra & Esp. do corpo & \\
\hline $42,90 \mathrm{~mm}$ & $76,95 \mathrm{~mm}$ & $54,65 \mathrm{~mm}$ & $35,14 \mathrm{~mm}$ & $\mathrm{x}$ & \\
\hline Esp. da borda & Comprimento & Altura & Tipo & $\begin{array}{l}\text { Coloração (Munsell)/tipo } \\
\text { de argila }\end{array}$ & \\
\hline $2,52 \mathrm{~mm}$ & $85,43 \mathrm{~mm}$ & $18,43 \mathrm{~mm}$ & $\begin{array}{l}\text { Produção Local: Costa } \\
\text { Fenícia? }\end{array}$ & $\begin{array}{l}10 R-4 / 4 \text {-reddish clay/ } \\
\text { reddish-brown slip }\end{array}$ & \\
\hline $\begin{array}{l}\text { Decoração da } \\
\text { base }\end{array}$ & Decoração da borda & \multicolumn{2}{|c|}{ Iconografia do disco } & Local de produção & \\
\hline C) 4 & A)1.e; 3.a & \multicolumn{2}{|c|}{$\begin{array}{l}\text { D)1 Porém é possível ver a ponta do que parece ser uma } \\
\text { folha ou flor. }\end{array}$} & Não identificada & $\begin{array}{l}\text { Fotógrafo: Pavel Shrago } \\
\text { Desenho: Erêndira Oliveira }\end{array}$ \\
\hline Período: & Comparanda & \multicolumn{3}{|l|}{ Obs: } & \\
\hline 2nd-3th & $\begin{array}{l}\text { Wexler e Gilboa, } \\
1996 .\end{array}$ & & & & 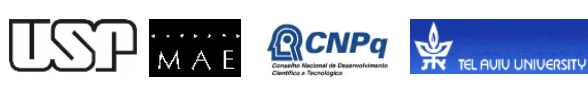 \\
\hline
\end{tabular}




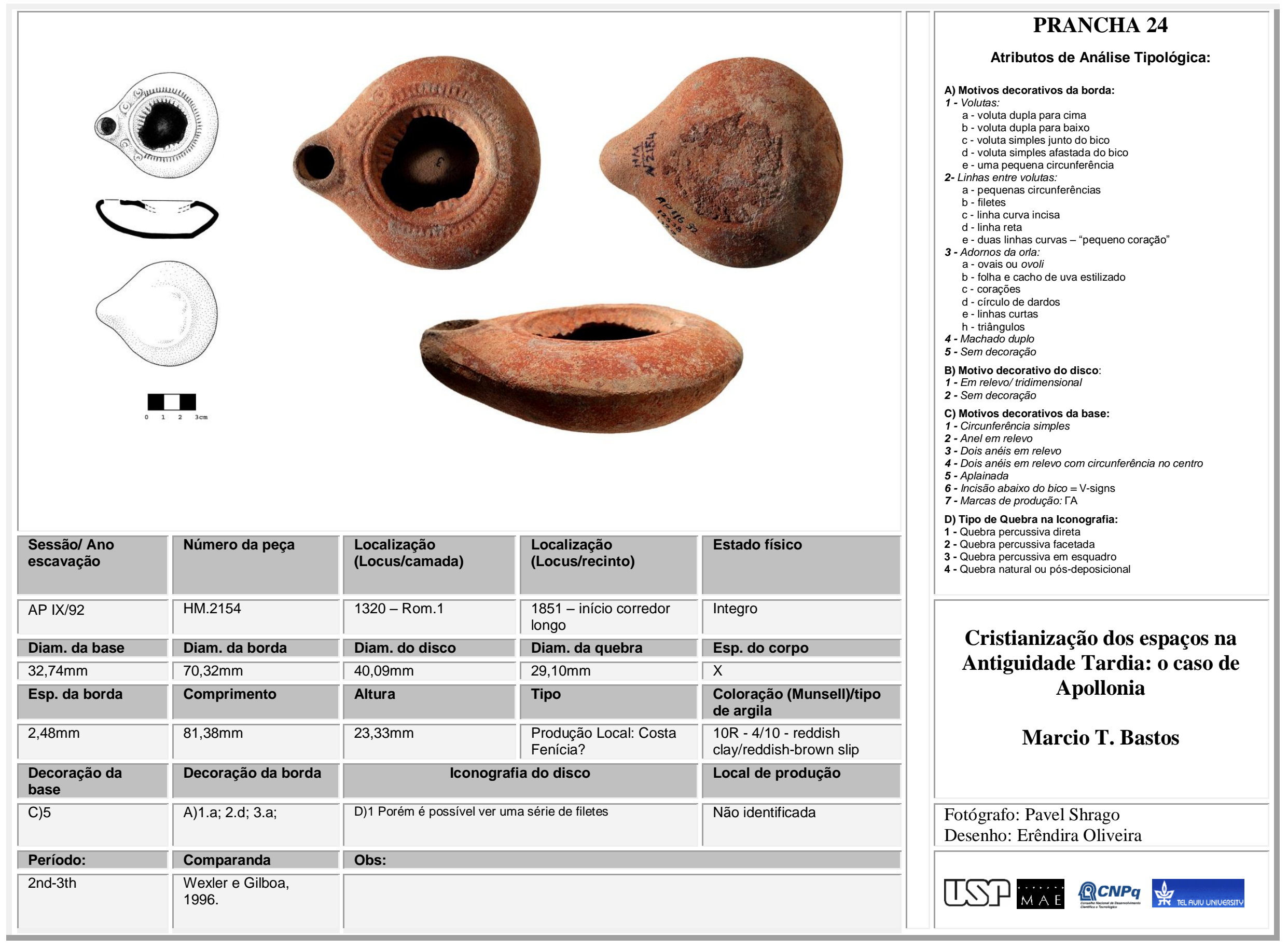




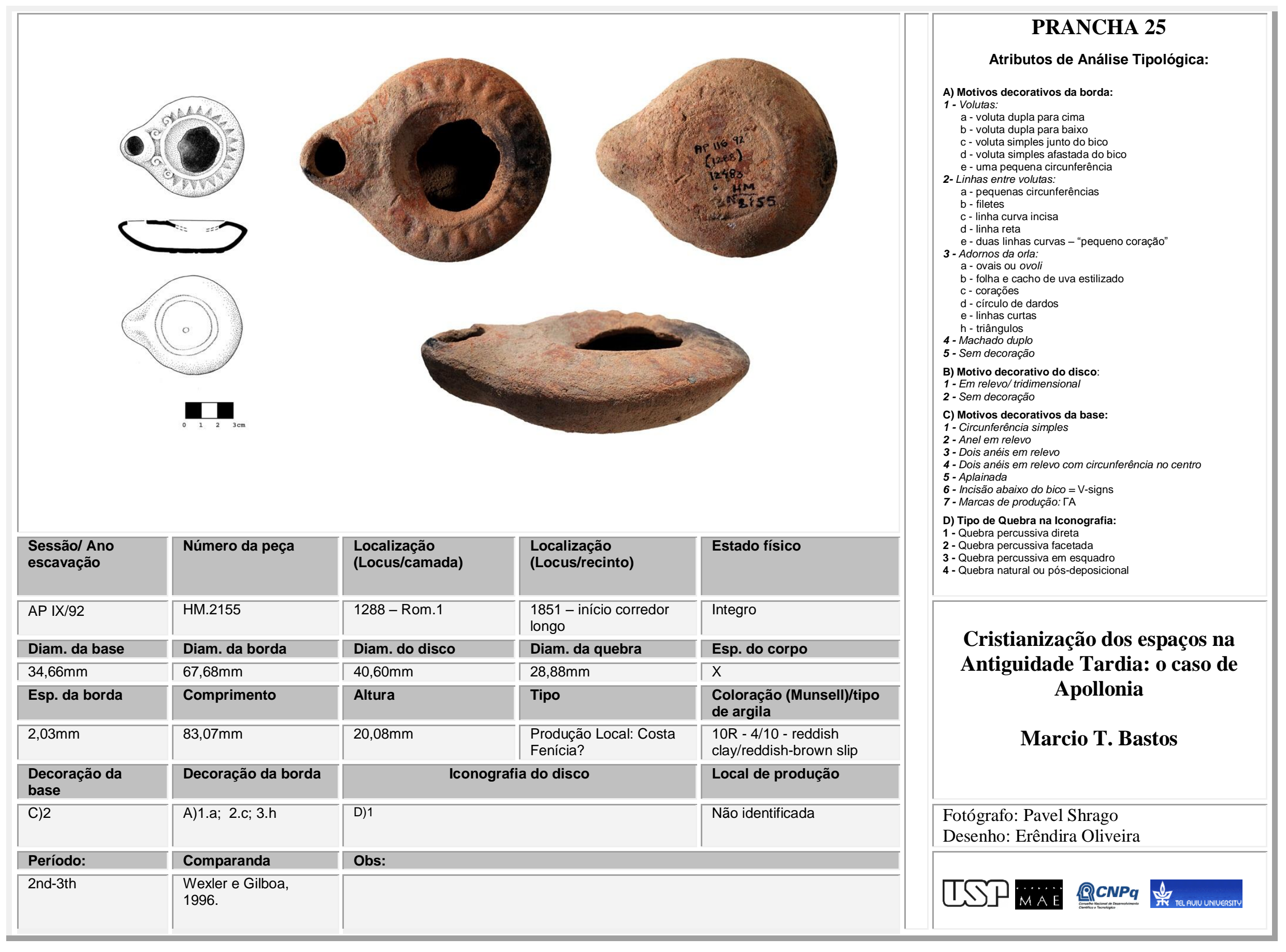




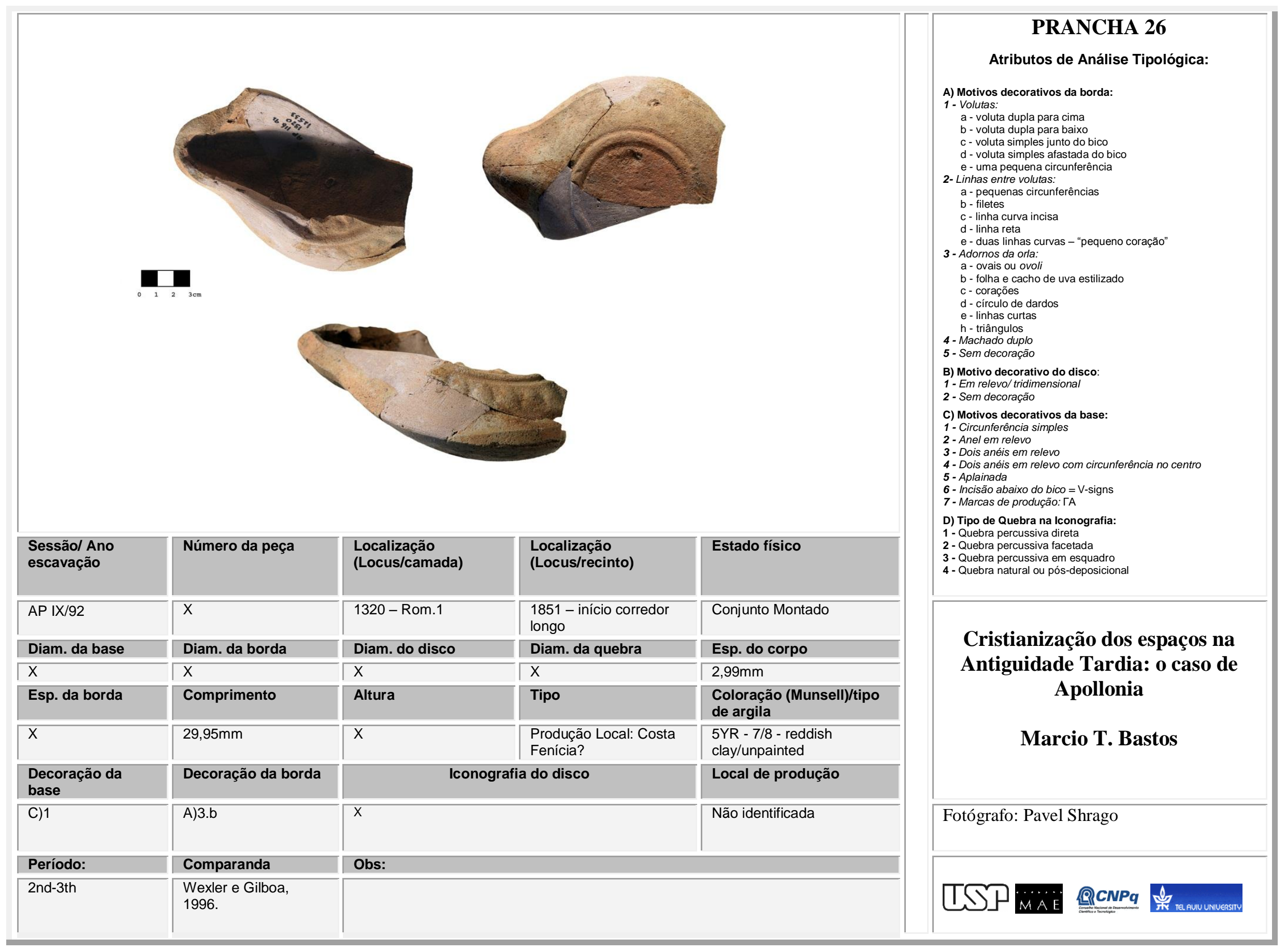




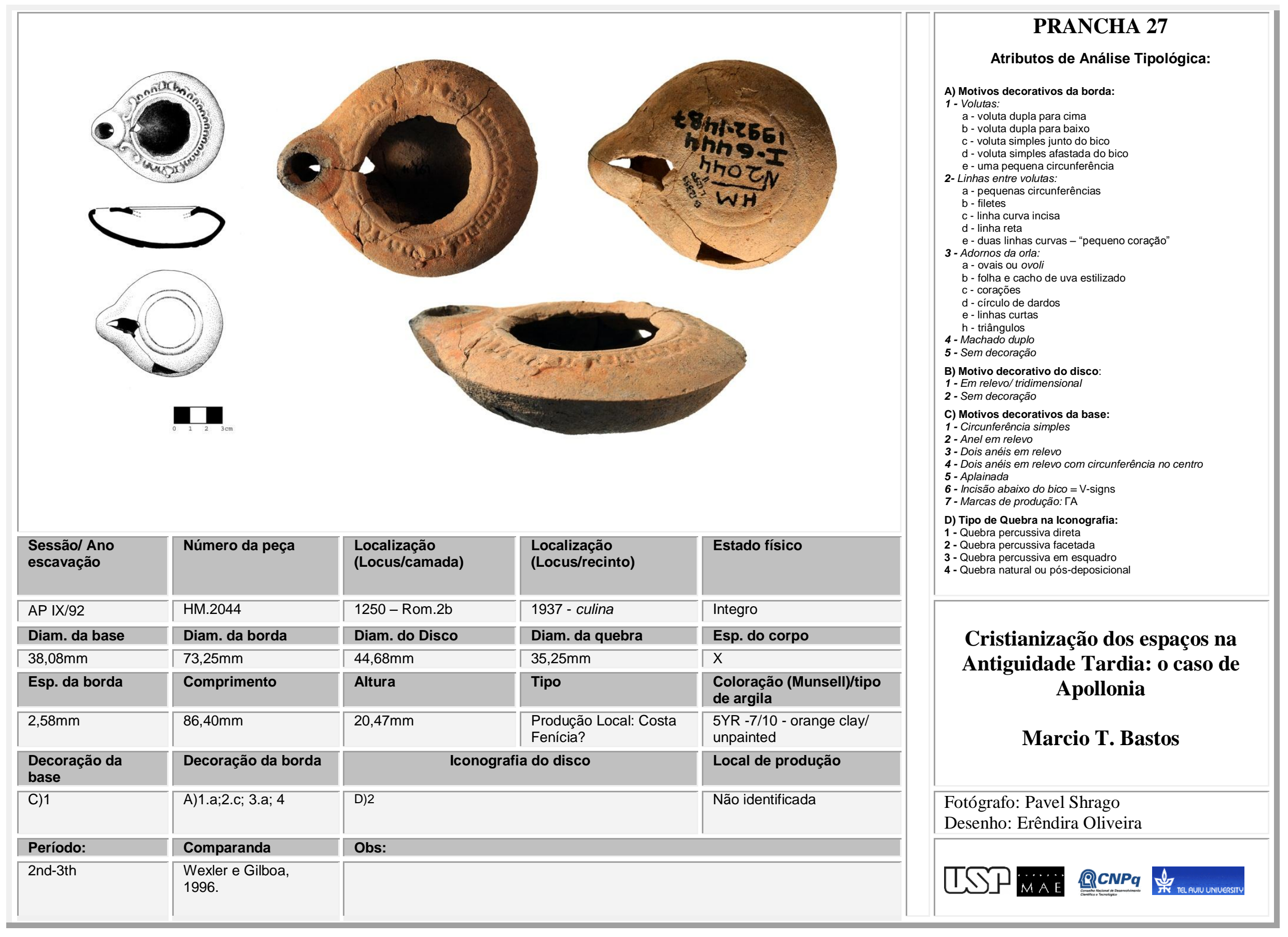




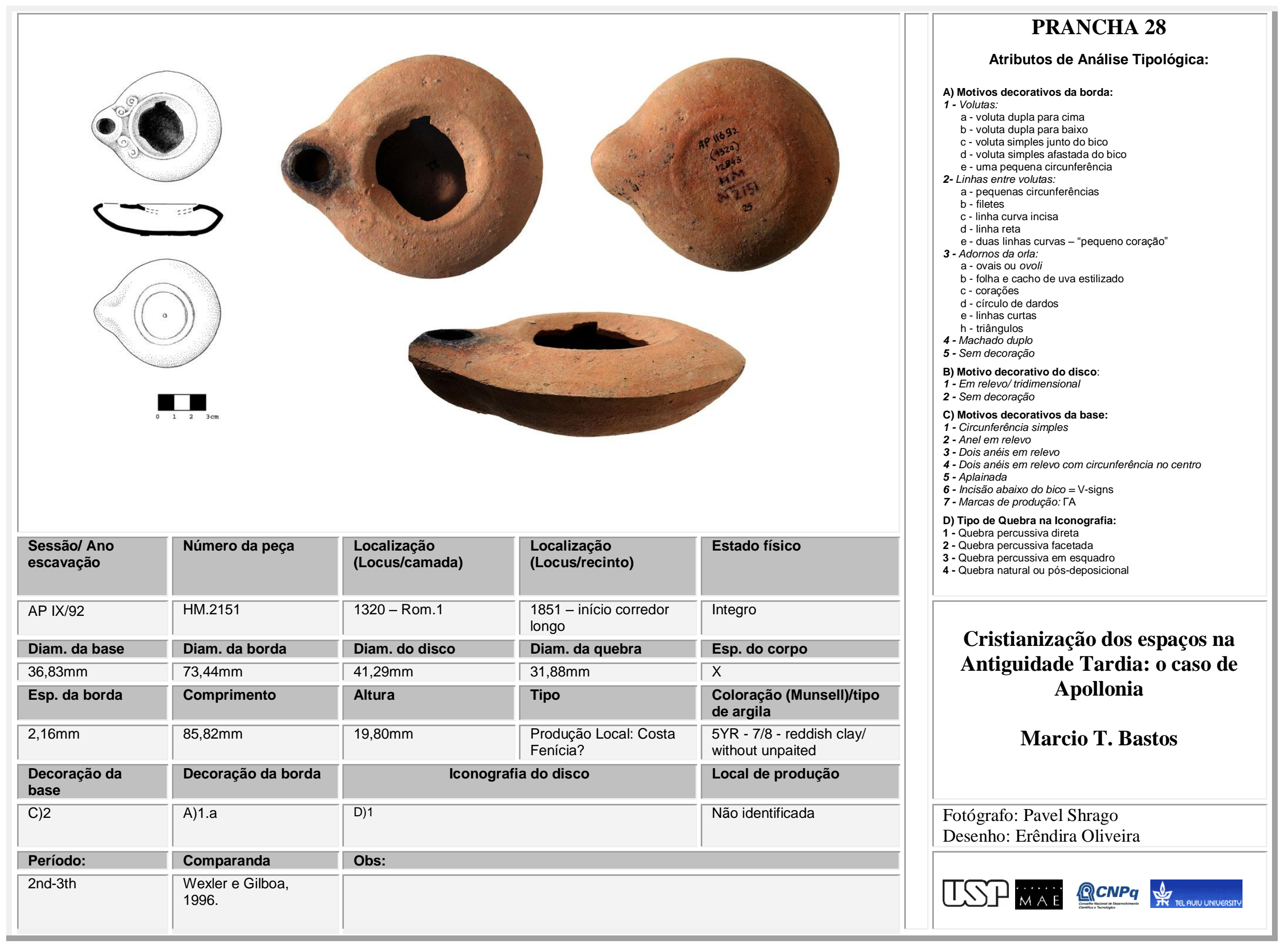




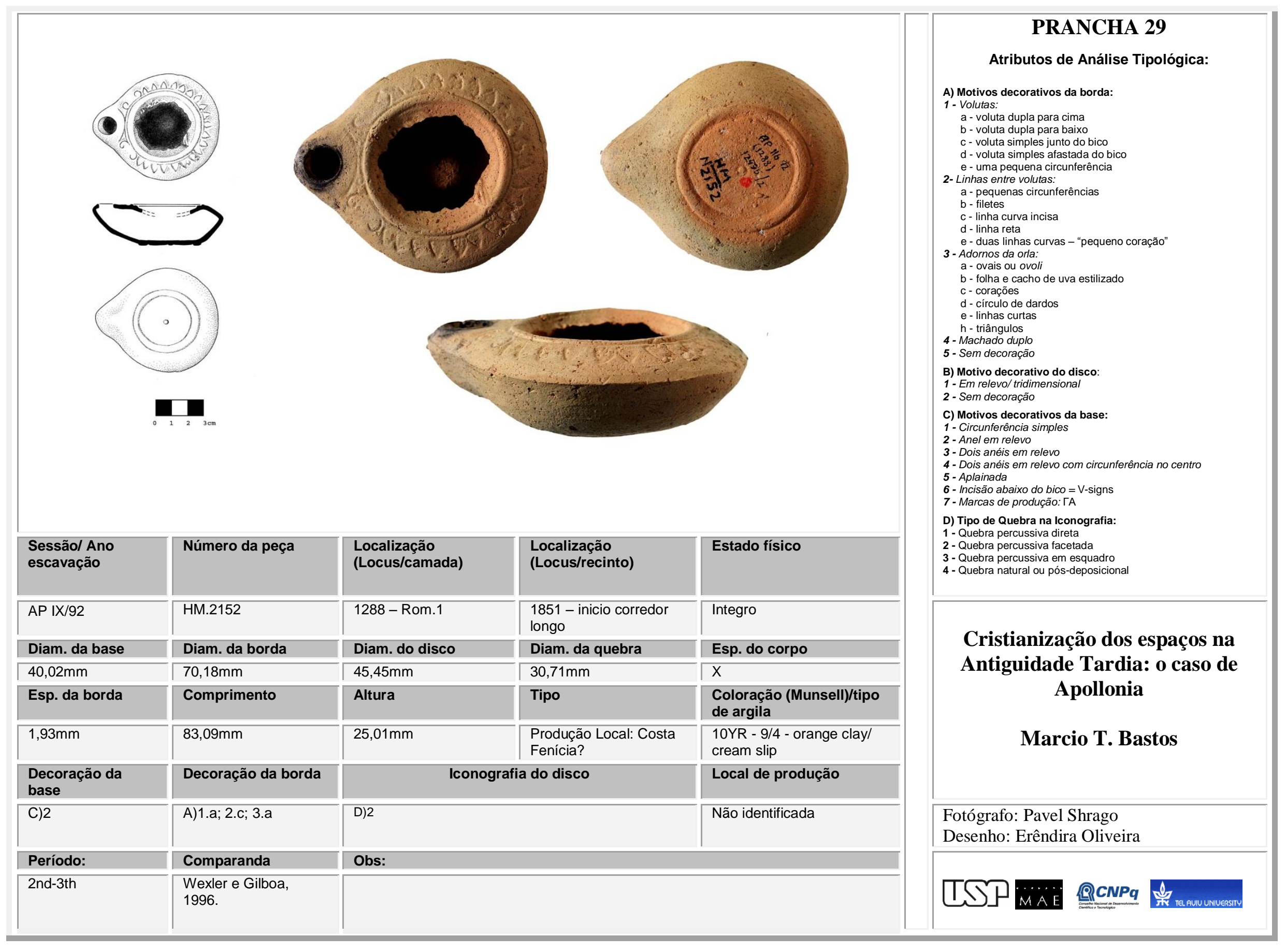




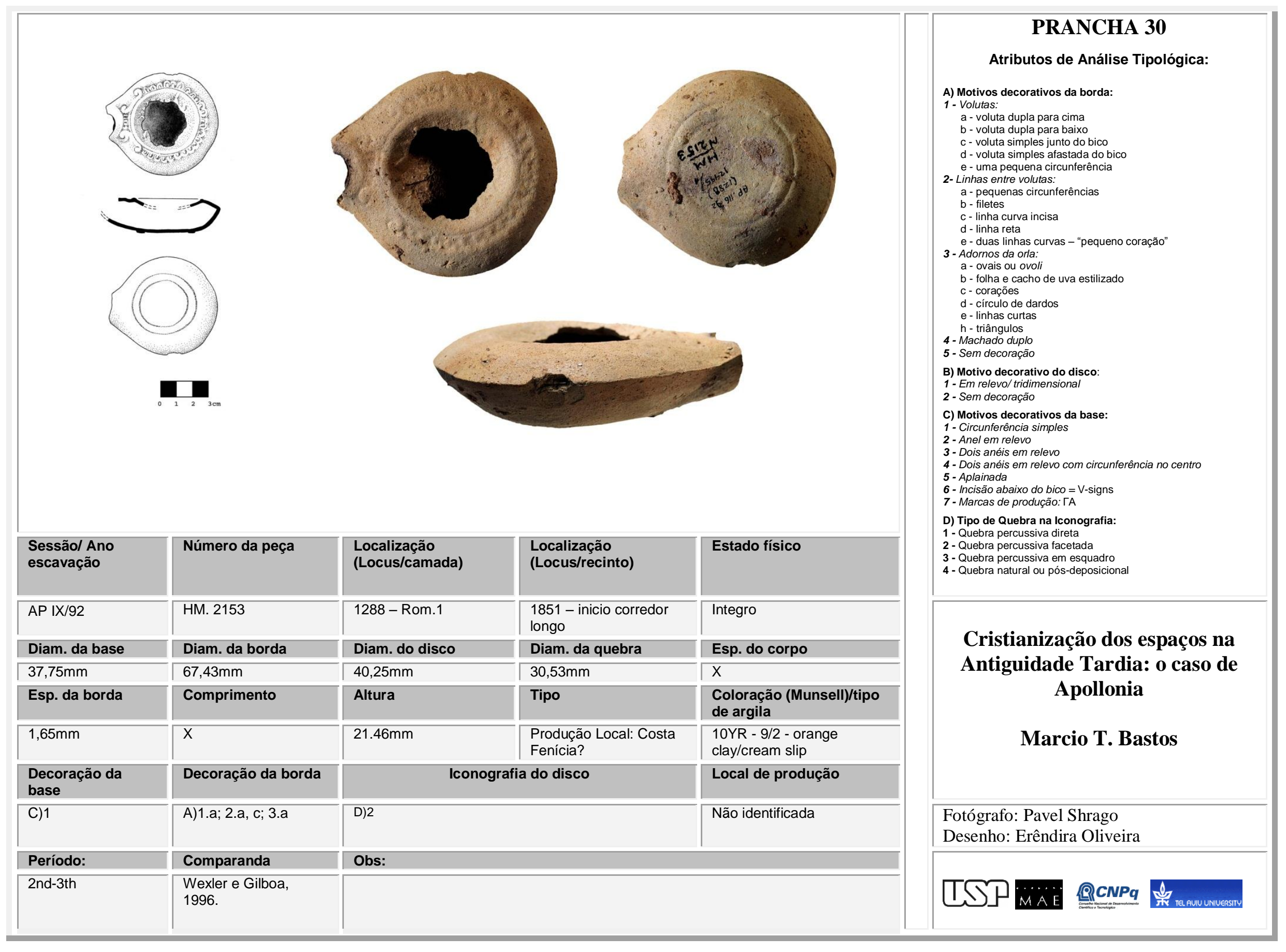




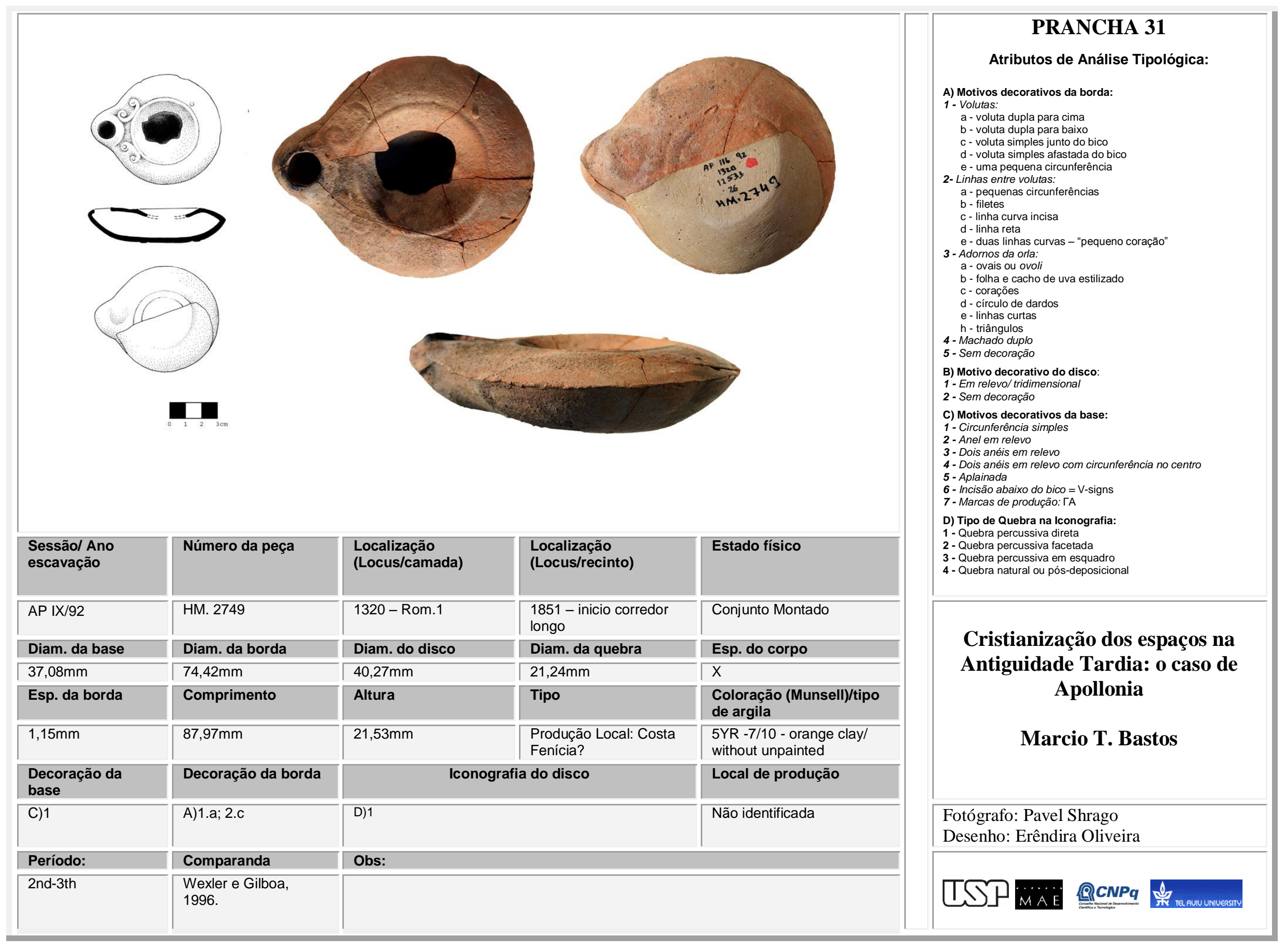




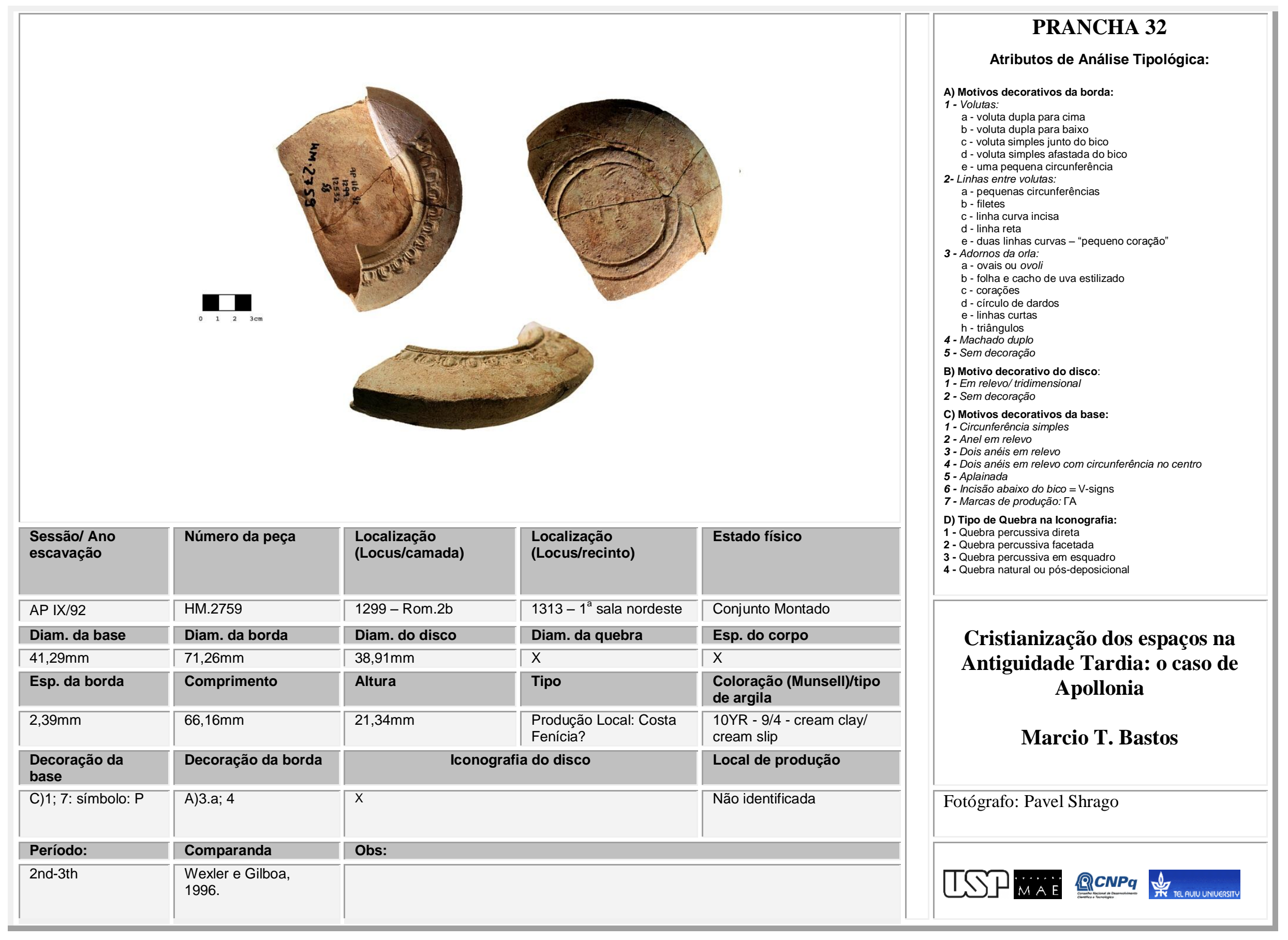




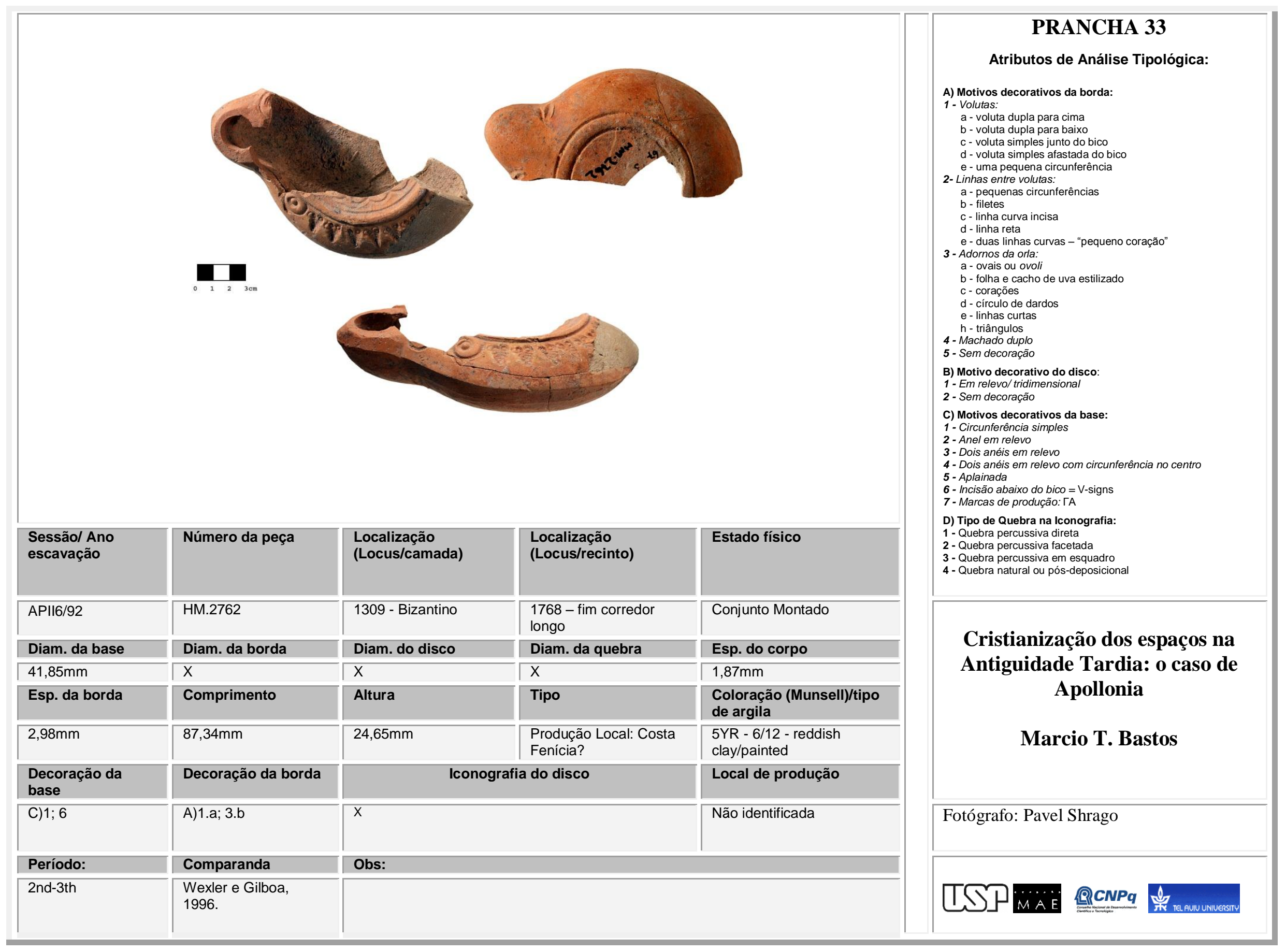




\begin{tabular}{|c|c|c|c|c|c|}
\hline $\begin{array}{l}\text { Sessão/ Ano } \\
\text { escavação }\end{array}$ & Número da peça & $\begin{array}{l}\text { Localização } \\
\text { (Locus/camada) }\end{array}$ & $\begin{array}{l}\text { Localização } \\
\text { (Locus/recinto) }\end{array}$ & Estado físico & 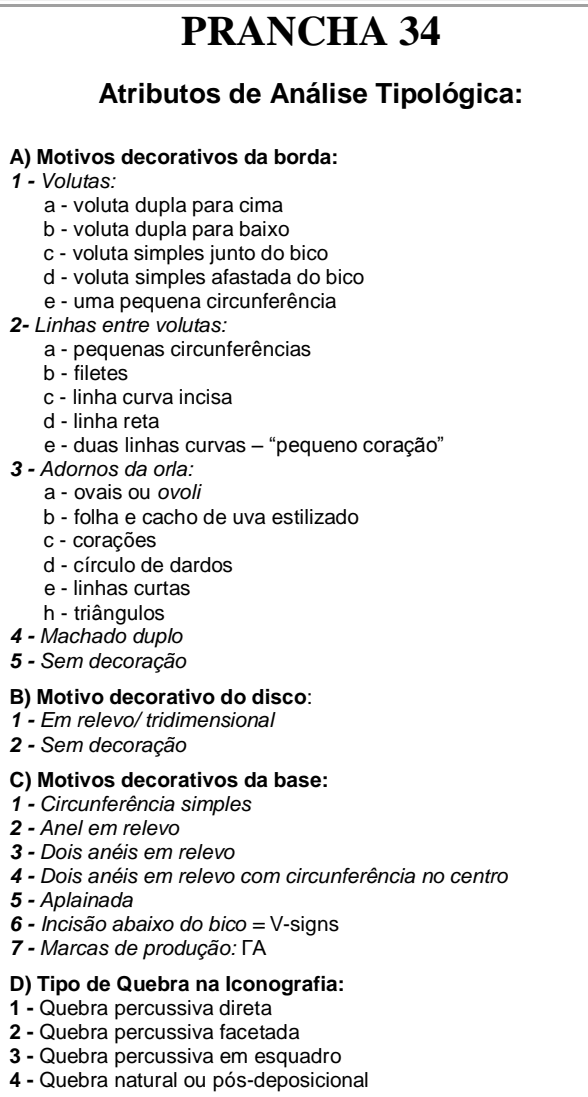 \\
\hline APII6/92 & HM. 2774 & 1309 - Bizantino & $\begin{array}{l}1768 \text { - fim corredor } \\
\text { longo }\end{array}$ & Conjunto Montado & \multirow{6}{*}{$\begin{array}{c}\text { Cristianização dos espaços na } \\
\text { Antiguidade Tardia: o caso de } \\
\text { Apollonia }\end{array}$} \\
\hline Diam. da base & Diam. da borda & Diam. do disco & Diam. da quebra & Esp. do corpo & \\
\hline $39,60 \mathrm{~mm}$ & $76,92 \mathrm{~mm}$ & $42,79 \mathrm{~mm}$ & $25,57 \mathrm{~mm}$ & $\mathrm{X}$ & \\
\hline Esp. da borda & Comprimento & Altura & Tipo & $\begin{array}{l}\text { Coloração (Munsell)/tipo } \\
\text { de argila }\end{array}$ & \\
\hline $2,25 \mathrm{~mm}$ & $87,62 \mathrm{~mm}$ & $20,74 \mathrm{~mm}$ & $\begin{array}{l}\text { Produção Local: Costa } \\
\text { Fenícia? }\end{array}$ & $\begin{array}{l}5 Y-9 / 2 \text { - orange clay/ } \\
\text { cream slip }\end{array}$ & \\
\hline $\begin{array}{l}\text { Decoração da } \\
\text { base }\end{array}$ & Decoração da borda & \multicolumn{2}{|c|}{ Iconografia do disco } & Local de produção & \\
\hline C)2; 6 & A)1.a;2.a, c; 4 & \multicolumn{2}{|c|}{ D)2 - Porém é possivel ver uma flor ou folha estilizada } & Não identificada & $\begin{array}{l}\text { Fotógrafo: Pavel Shrago } \\
\text { Desenho: Erêndira Oliveira }\end{array}$ \\
\hline Período: & Comparanda & \multicolumn{3}{|l|}{ Obs: } & \\
\hline 2nd-3th & $\begin{array}{l}\text { Wexler e Gilboa, } \\
1996 .\end{array}$ & & & & 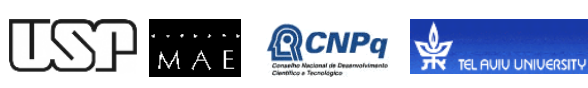 \\
\hline
\end{tabular}




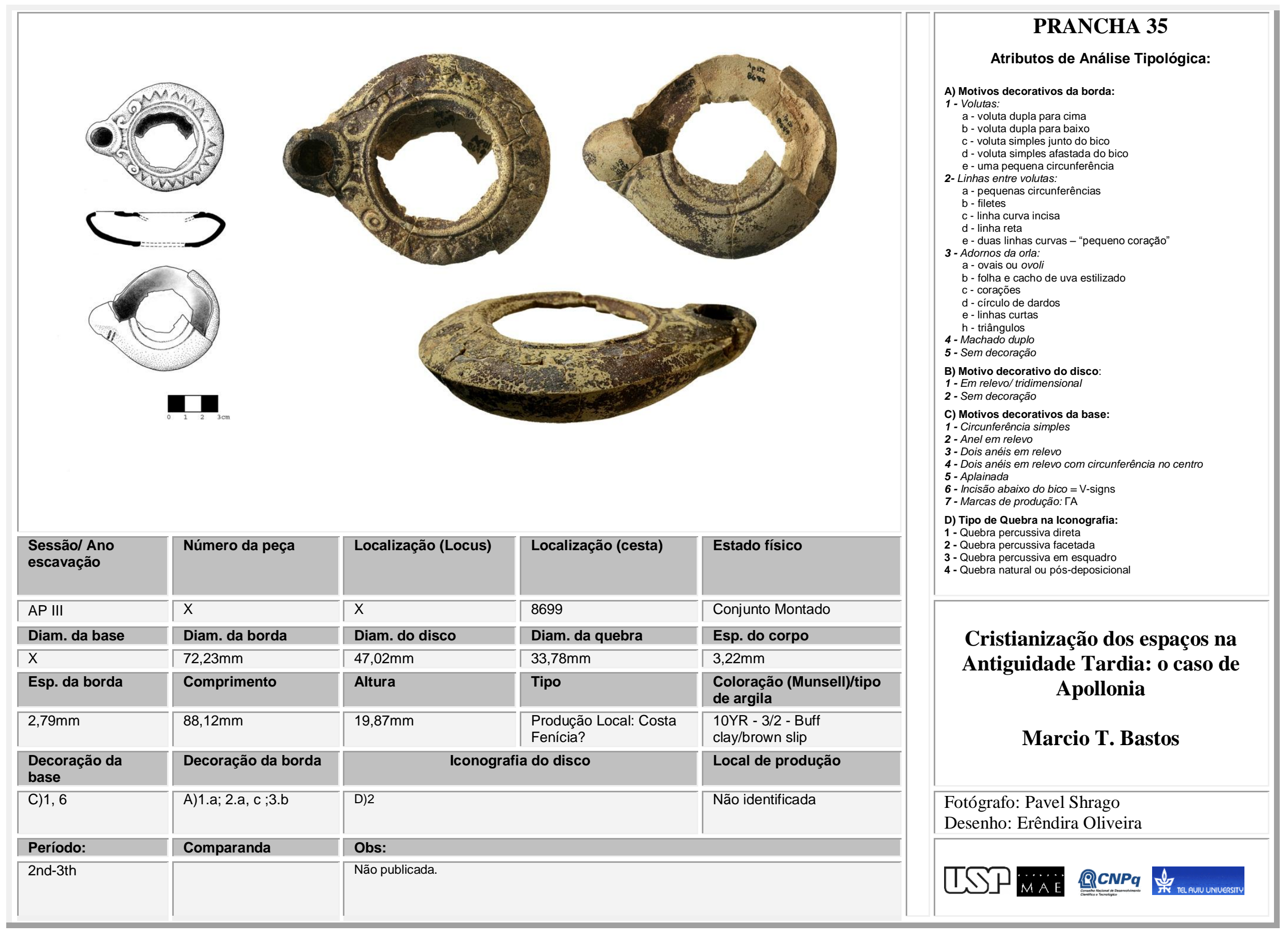




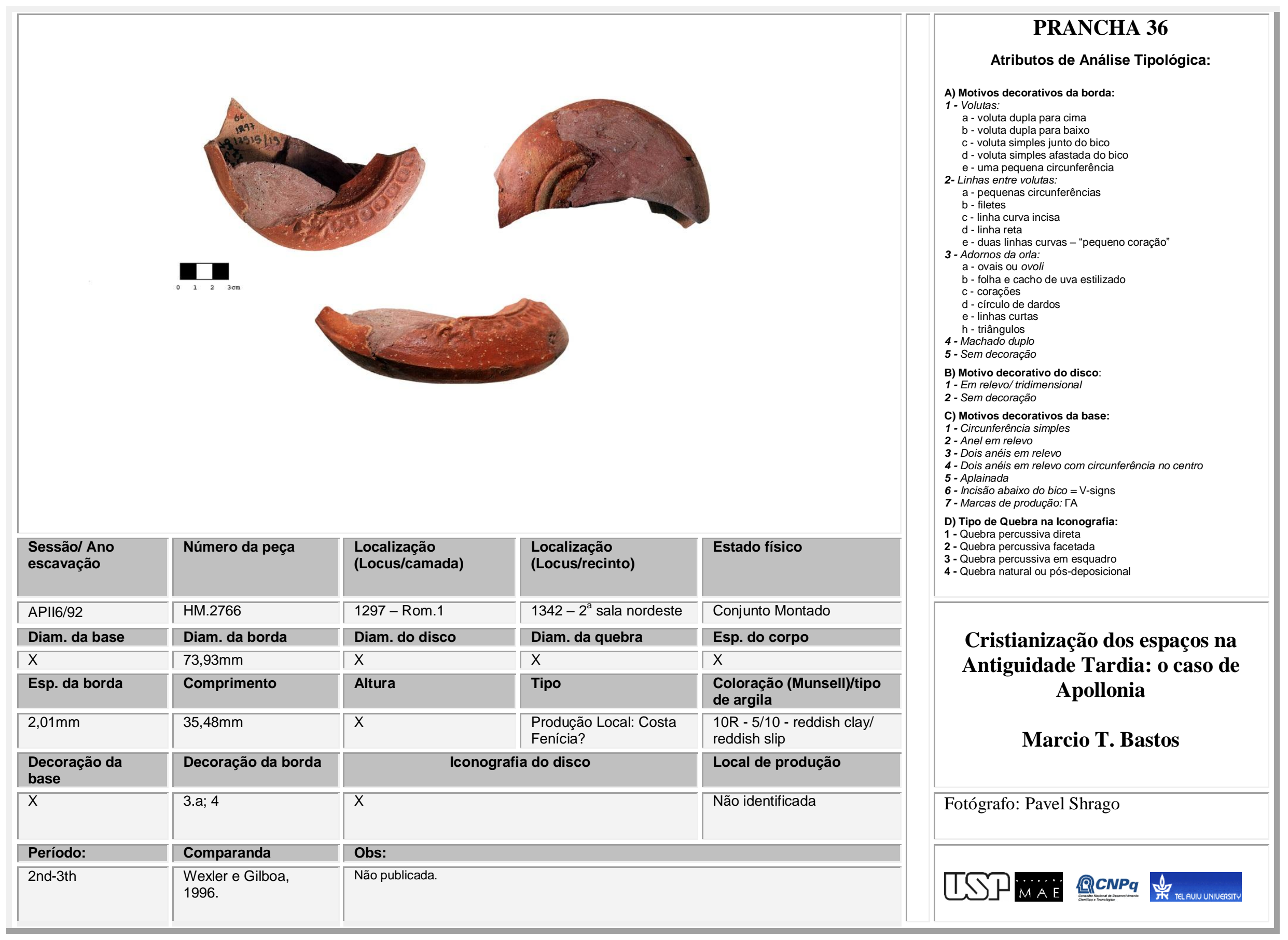




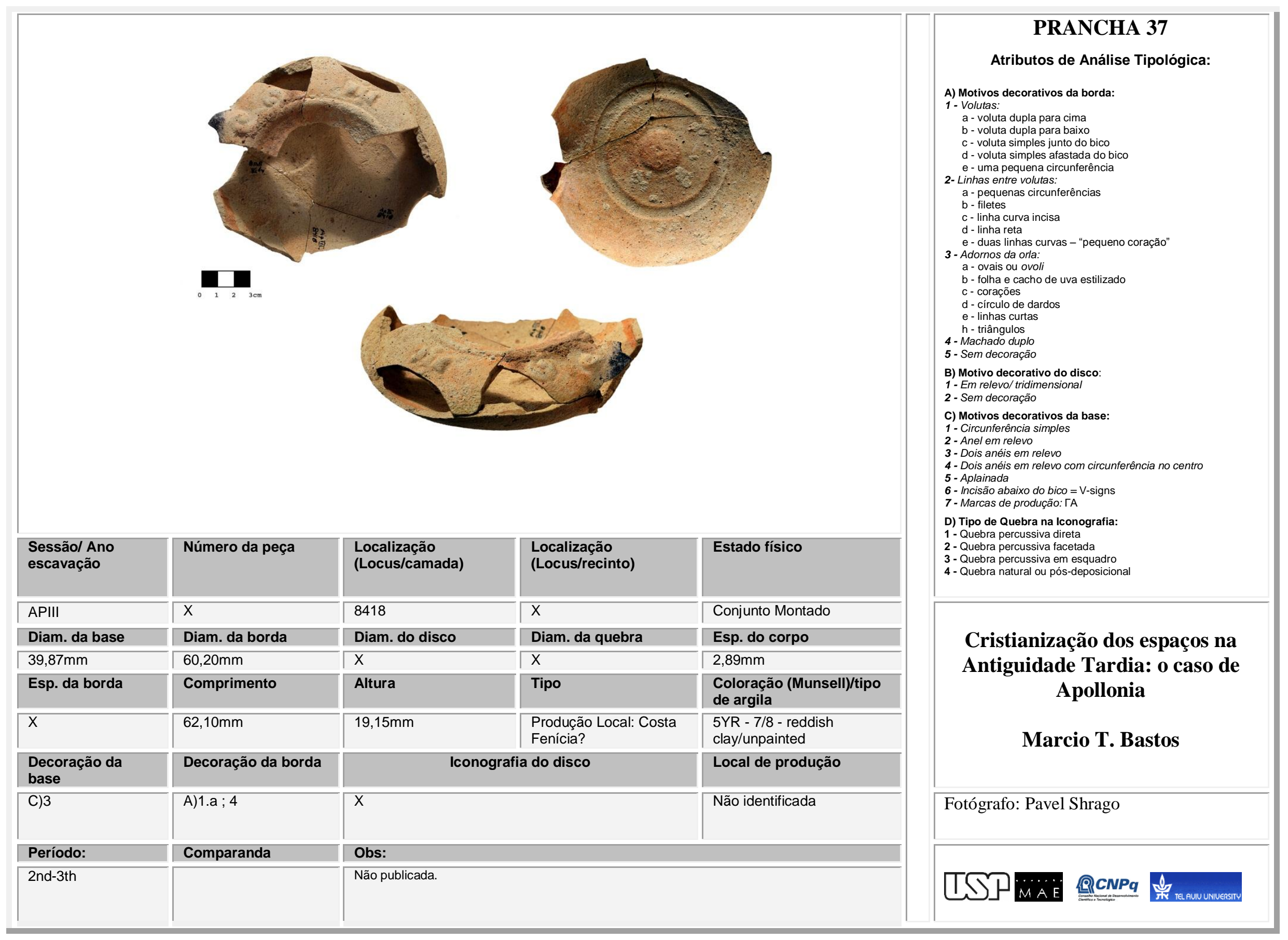




\begin{tabular}{|c|c|c|c|c|c|}
\hline $\begin{array}{l}\text { Sessão/ Ano } \\
\text { escavação }\end{array}$ & Número da peça & $\begin{array}{l}\text { Localização } \\
\text { (Locus/camada) }\end{array}$ & $\begin{array}{l}\text { Localização } \\
\text { (Locus/recinto) }\end{array}$ & Estado físico & 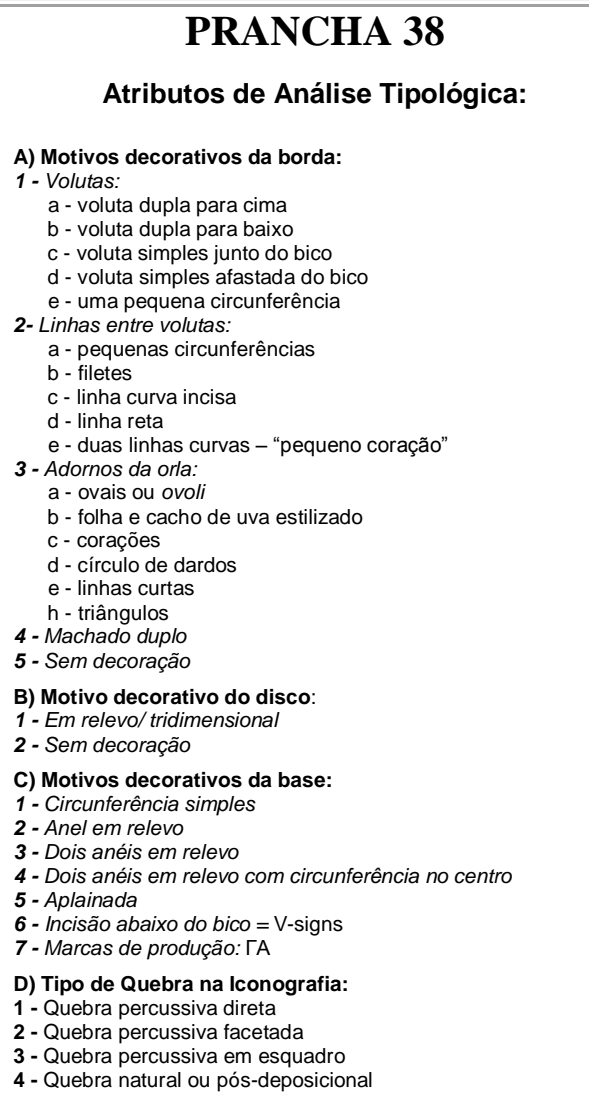 \\
\hline APII6/92 & HM.2771 & $1297-$ Rom. 1 & $1342-2^{a}$ sala nordeste & Conjunto Montado & \multirow{6}{*}{$\begin{array}{c}\text { Cristianização dos espaços na } \\
\text { Antiguidade Tardia: o caso de } \\
\text { Apollonia }\end{array}$} \\
\hline Diam. da base & Diam. da borda & Diam. do disco & Diam. da quebra & Esp. do corpo & \\
\hline $37,95 \mathrm{~mm}$ & $70,29 \mathrm{~mm}$ & $\mathrm{X}$ & $\mathrm{x}$ & $3,10 \mathrm{~mm}$ & \\
\hline Esp. da borda & Comprimento & Altura & Tipo & $\begin{array}{l}\text { Coloração (Munsell)/tipo } \\
\text { de argila }\end{array}$ & \\
\hline $2,45 \mathrm{~mm}$ & $83,42 \mathrm{~mm}$ & $19,58 \mathrm{~mm}$ & $\begin{array}{l}\text { Produção Local: Costa } \\
\text { Fenícia? }\end{array}$ & $\begin{array}{l}\text { 10R - 4/10 - reddish } \\
\text { clay/reddish-brown slip }\end{array}$ & \\
\hline $\begin{array}{l}\text { Decoração da } \\
\text { base }\end{array}$ & Decoração da borda & \multicolumn{2}{|c|}{ Iconografia do disco } & Local de produção & \\
\hline C) 1 & A) $1 . a ; 2 . a$ & \multicolumn{2}{|l|}{$x$} & Não identificada & Fotógrafo: Pavel Shrago \\
\hline Período: & Comparanda & \multicolumn{3}{|l|}{ Obs: } & \\
\hline 2nd-3th & $\begin{array}{l}\text { Wexler e Gilboa, } \\
1996 .\end{array}$ & & & & 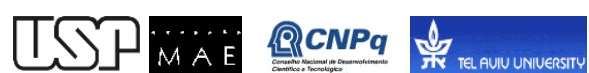 \\
\hline
\end{tabular}




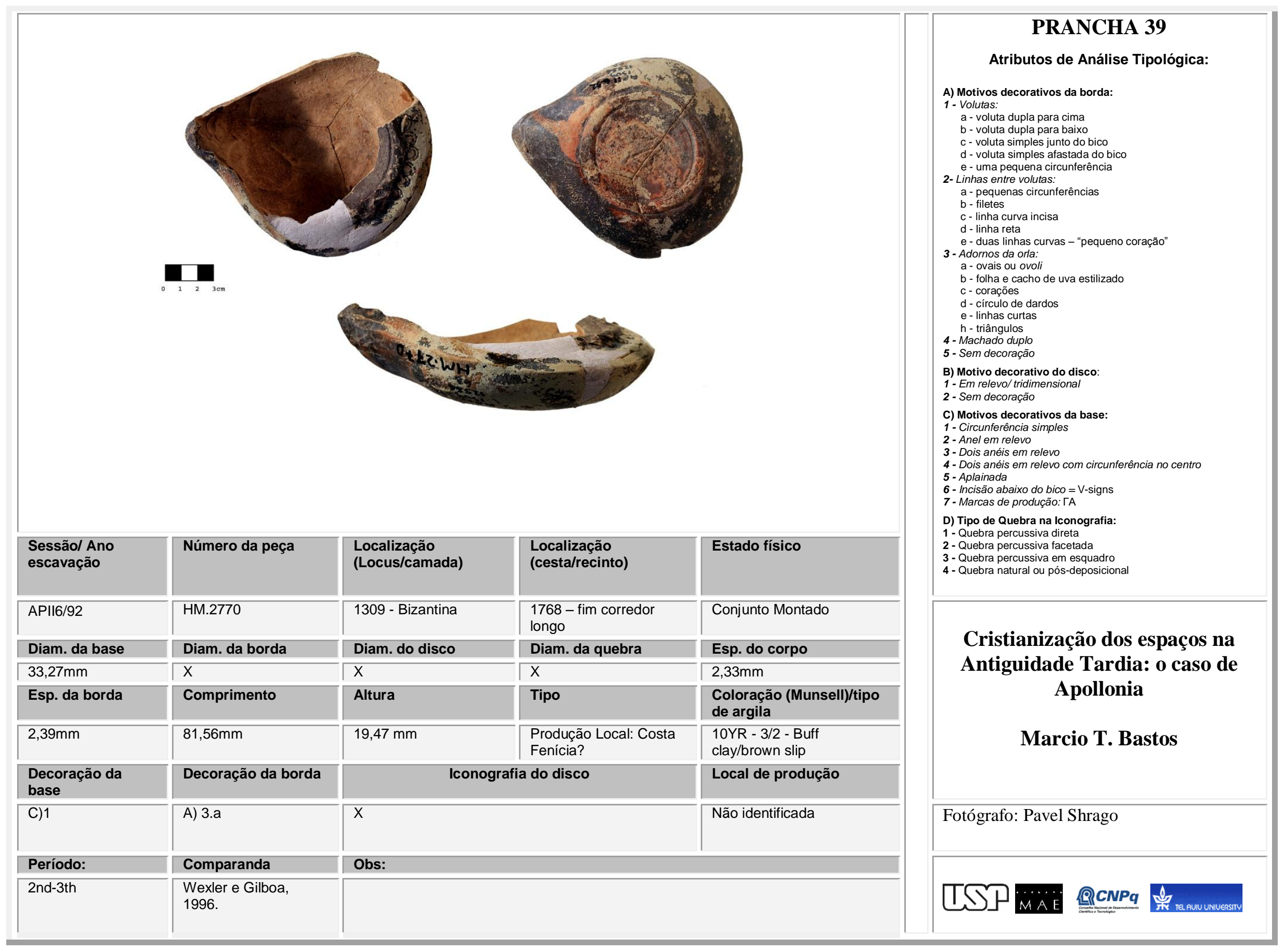




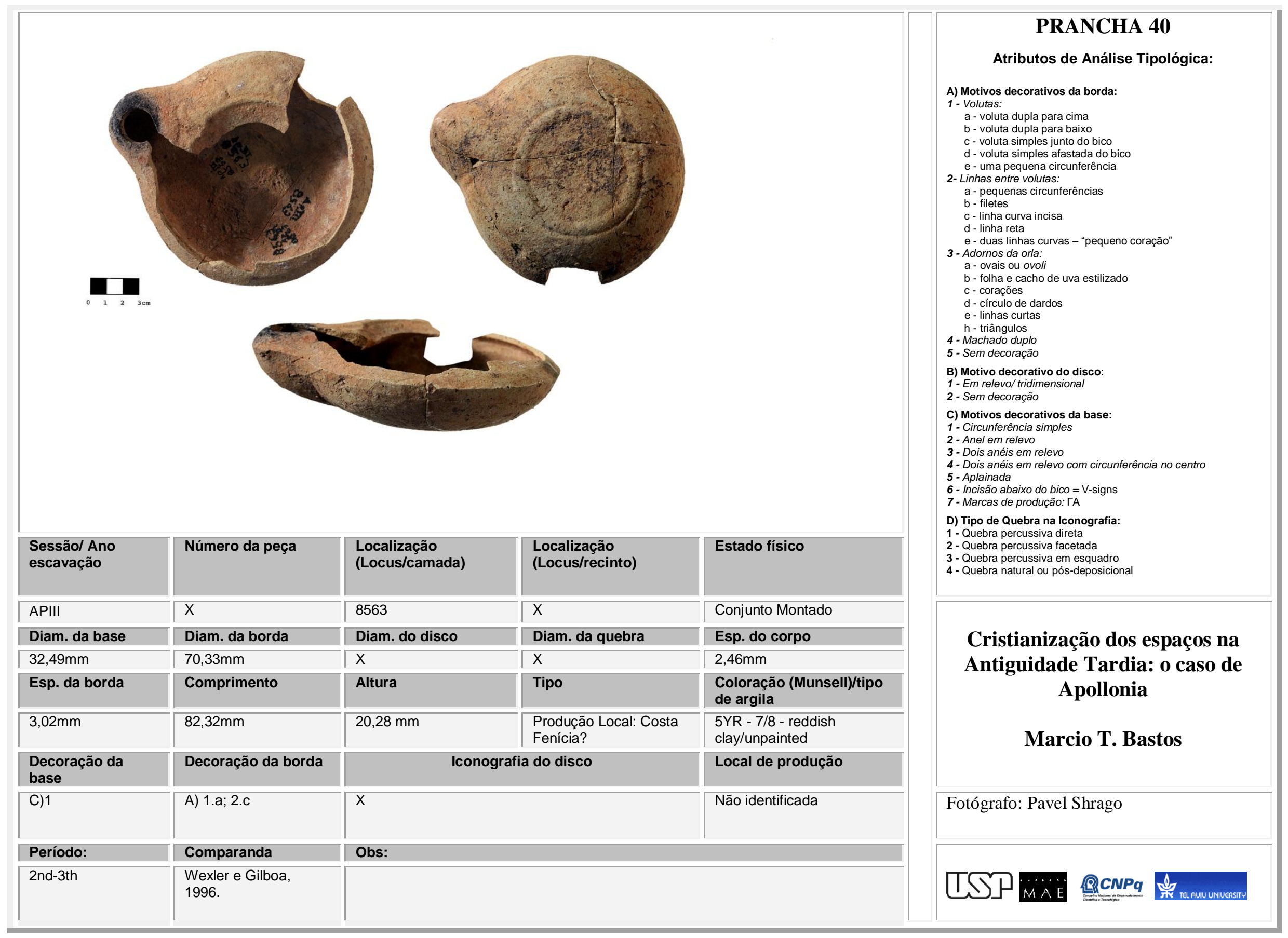




\begin{tabular}{|c|c|c|c|c|c|}
\hline $\begin{array}{l}\text { Sessão/Ano } \\
\text { escavação }\end{array}$ & Número da peça & $\begin{array}{l}\text { Localização } \\
\text { (Locus/camada) }\end{array}$ & $\begin{array}{l}\text { Localização } \\
\text { (Locus/recinto) }\end{array}$ & Estado físico & 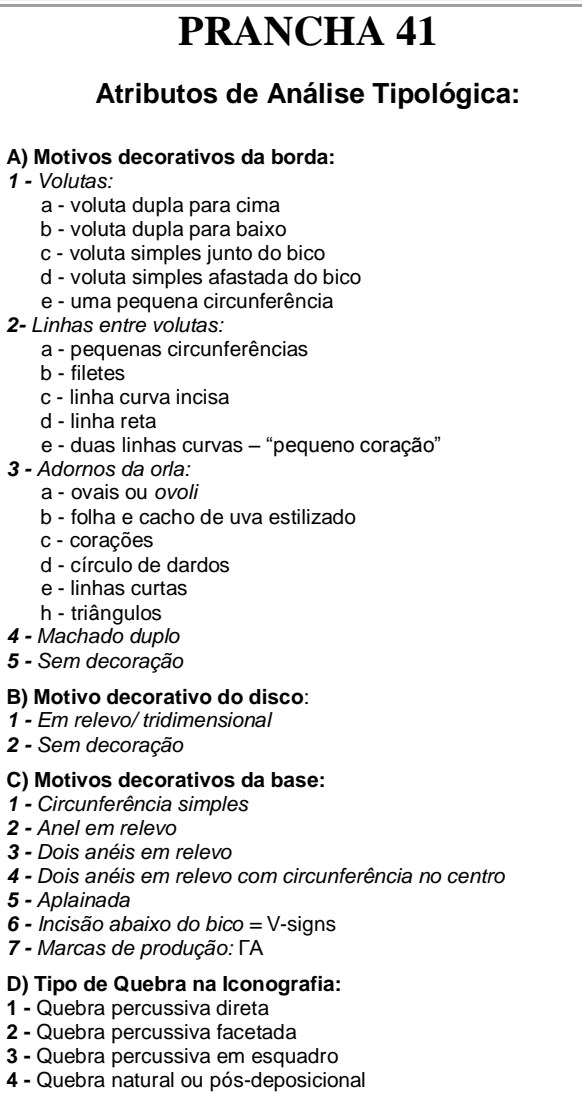 \\
\hline APVIII/91 & $\mathrm{x}$ & 1225 - Rom.1 & 1937 - culina & Parte do objeto & \multirow{6}{*}{$\begin{array}{c}\text { Cristianização dos espaços na } \\
\text { Antiguidade Tardia: o caso de } \\
\text { Apollonia }\end{array}$} \\
\hline Diam. da base & Diam. da borda & Diam. do disco & Diam. da quebra & Esp. do corpo & \\
\hline $38,56 \mathrm{~mm}$ & $71,79 \mathrm{~mm}$ & $\mathrm{X}$ & $\mathrm{X}$ & $2,32 \mathrm{~mm}$ & \\
\hline Esp. da borda & Comprimento & Altura & Tipo & $\begin{array}{l}\text { Coloração (Munsell)/tipo } \\
\text { de argila }\end{array}$ & \\
\hline $2,76 \mathrm{~mm}$ & $66,42 \mathrm{~mm}$ & $19,77 \mathrm{~mm}$ & $\begin{array}{l}\text { Produção Local: Costa } \\
\text { Fenícia? }\end{array}$ & $\begin{array}{l}\text { 10YR - 3/2 - Buff clay/ } \\
\text { brown slip }\end{array}$ & \\
\hline $\begin{array}{l}\text { Decoração da } \\
\text { base }\end{array}$ & Decoração da borda & \multicolumn{2}{|c|}{ Iconografia do disco } & Local de produção & \\
\hline C) 5 & $\mathrm{X}$ & \multicolumn{2}{|c|}{$\mathrm{x}$} & Não identificada & Fotógrafo: Pavel Shrago \\
\hline Período: & Comparanda & \multicolumn{3}{|l|}{ Obs: } & \\
\hline 2nd-3th & & & & & \\
\hline
\end{tabular}




\begin{tabular}{|c|c|c|c|c|c|}
\hline $\begin{array}{l}\text { Sessão/ Ano } \\
\text { escavação }\end{array}$ & Número da peça & Localização (Locus) & Localização (cesta) & Estado físico & 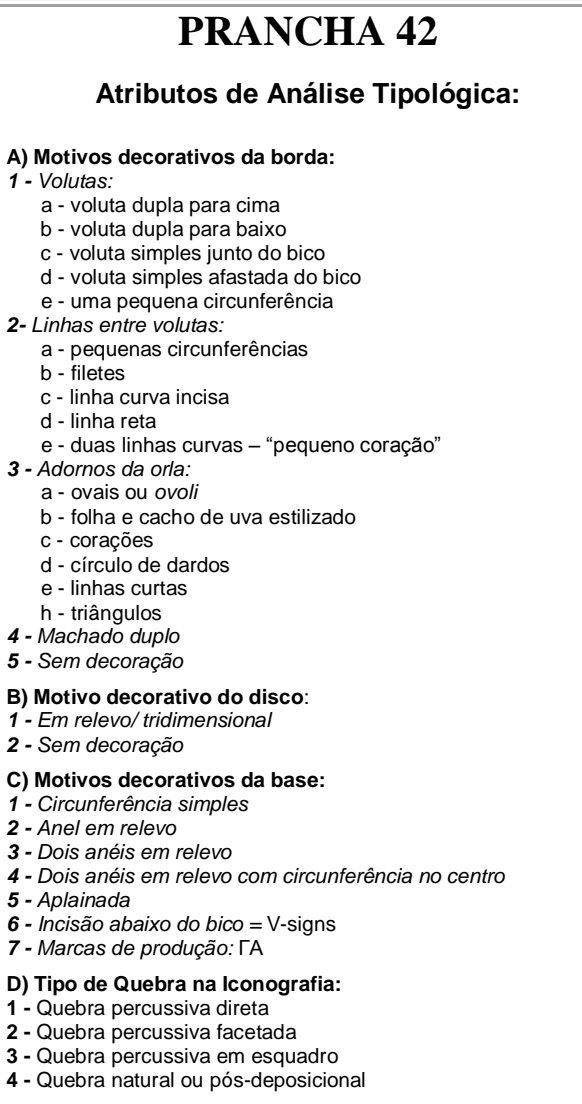 \\
\hline APIII & $\mathrm{x}$ & 8349 & $\mathrm{X}$ & Conjunto Montado & \multirow{6}{*}{$\begin{array}{c}\text { Cristianização dos espaços na } \\
\text { Antiguidade Tardia: o caso de } \\
\text { Apollonia }\end{array}$} \\
\hline Diam. da base & Diam. da borda & Diam. do disco & Diam. da quebra & Esp. do corpo & \\
\hline $40,12 \mathrm{~mm}$ & $65,76 \mathrm{~mm}$ & $\mathrm{X}$ & $\mathrm{X}$ & $2,89 \mathrm{~mm}$ & \\
\hline Esp. da borda & Comprimento & Altura & Tipo & $\begin{array}{l}\text { Coloração (Munsell)/tipo } \\
\text { de argila }\end{array}$ & \\
\hline $3,53 \mathrm{~mm}$ & $79,44 \mathrm{~mm}$ & $20,06 \mathrm{~mm}$ & $\begin{array}{l}\text { Produção Local: Costa } \\
\text { Fenícia? }\end{array}$ & $\begin{array}{l}\text { 10YR - 4/2 - reddish } \\
\text { clay/dark brown slip }\end{array}$ & \\
\hline $\begin{array}{l}\text { Decoração da } \\
\text { base }\end{array}$ & Decoração da borda & \multicolumn{2}{|c|}{ Iconografia do disco } & Local de produção & \\
\hline C) 1 & $\mathrm{X}$ & \multicolumn{2}{|c|}{$\mathrm{x}$} & Não identificada & Fotógrafo: Pavel Shrago \\
\hline Período: & Comparanda & \multicolumn{3}{|l|}{ Obs: } & \\
\hline 2nd-3th & & & & & NNF \\
\hline
\end{tabular}




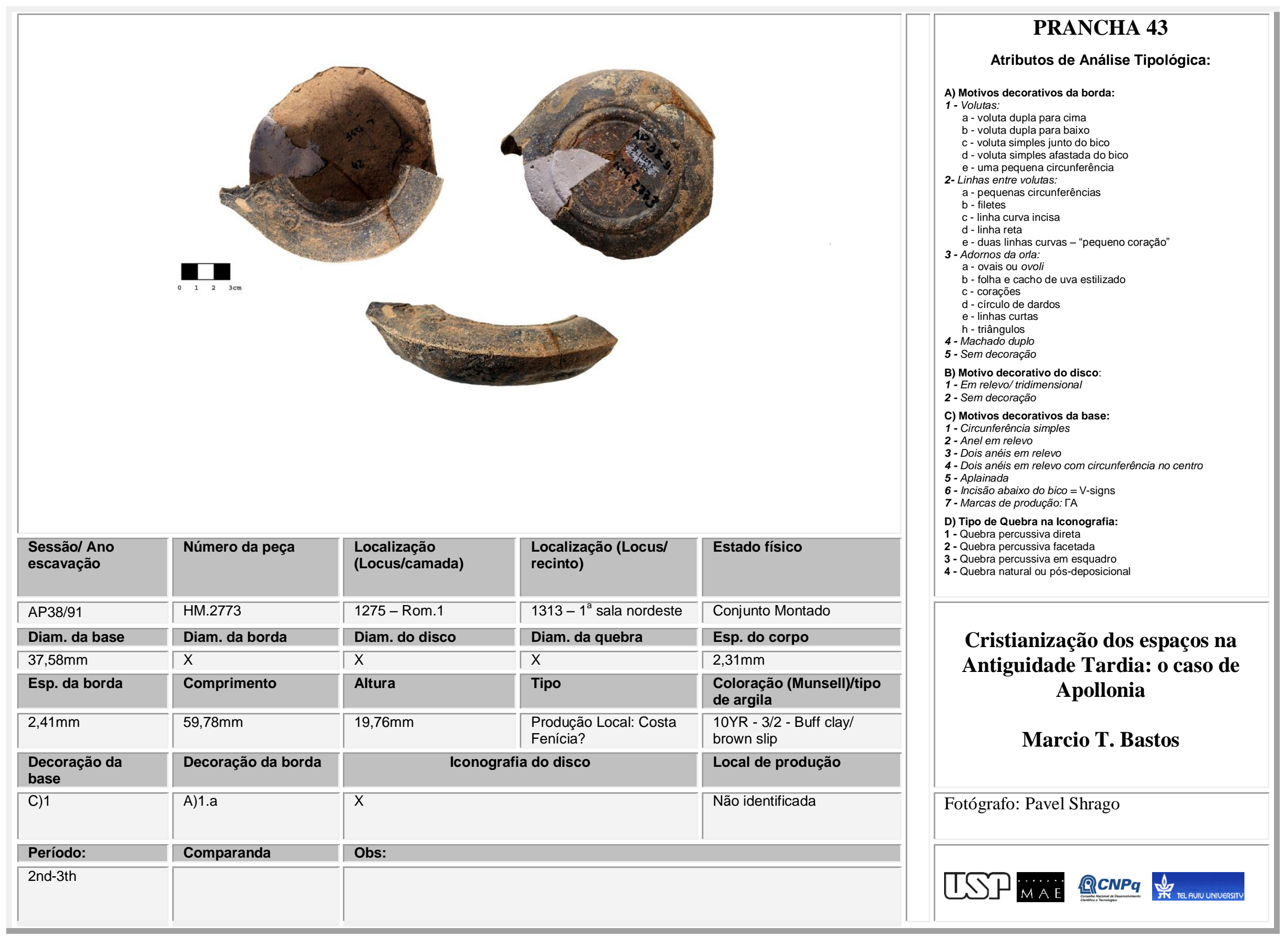




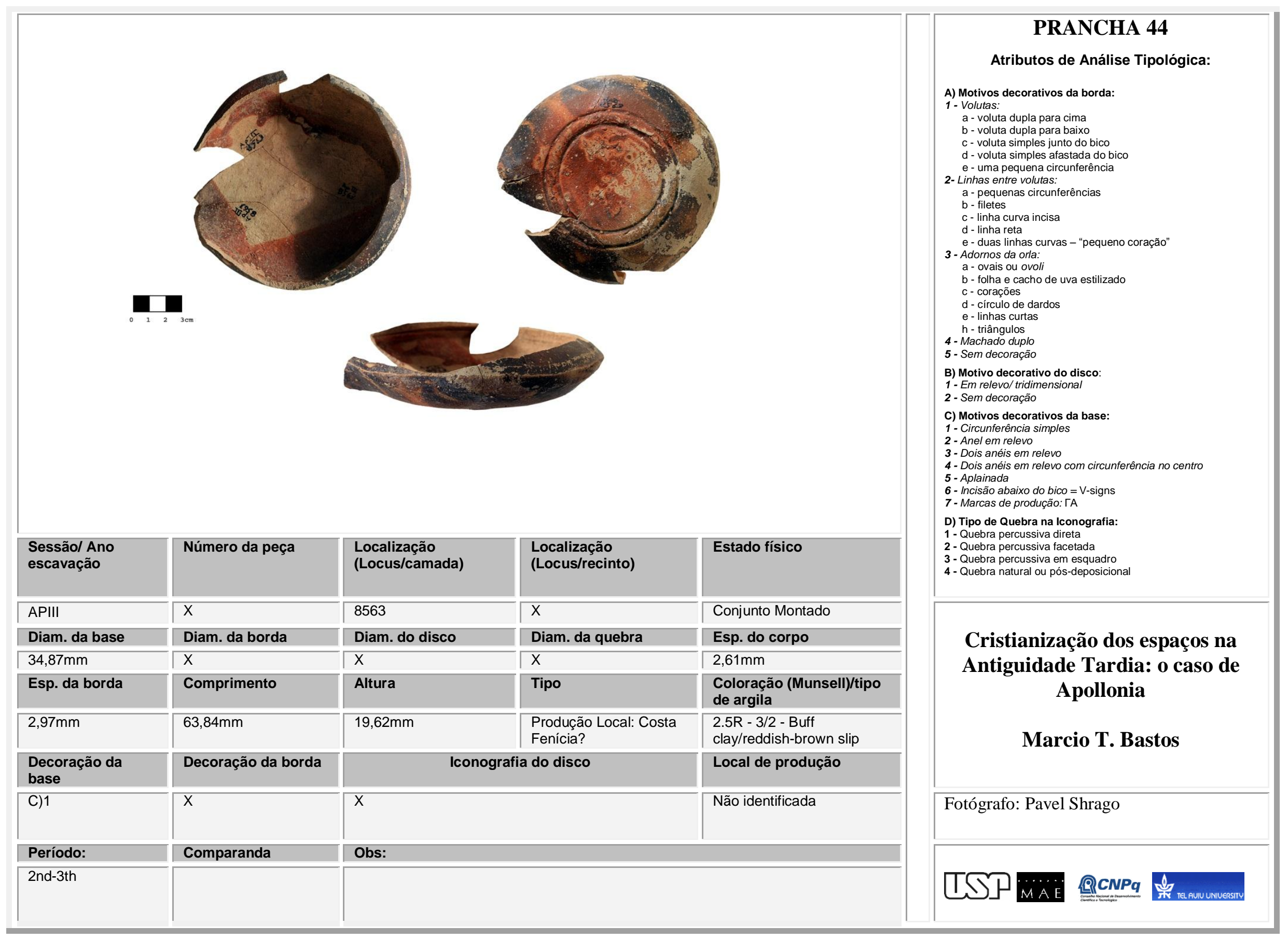




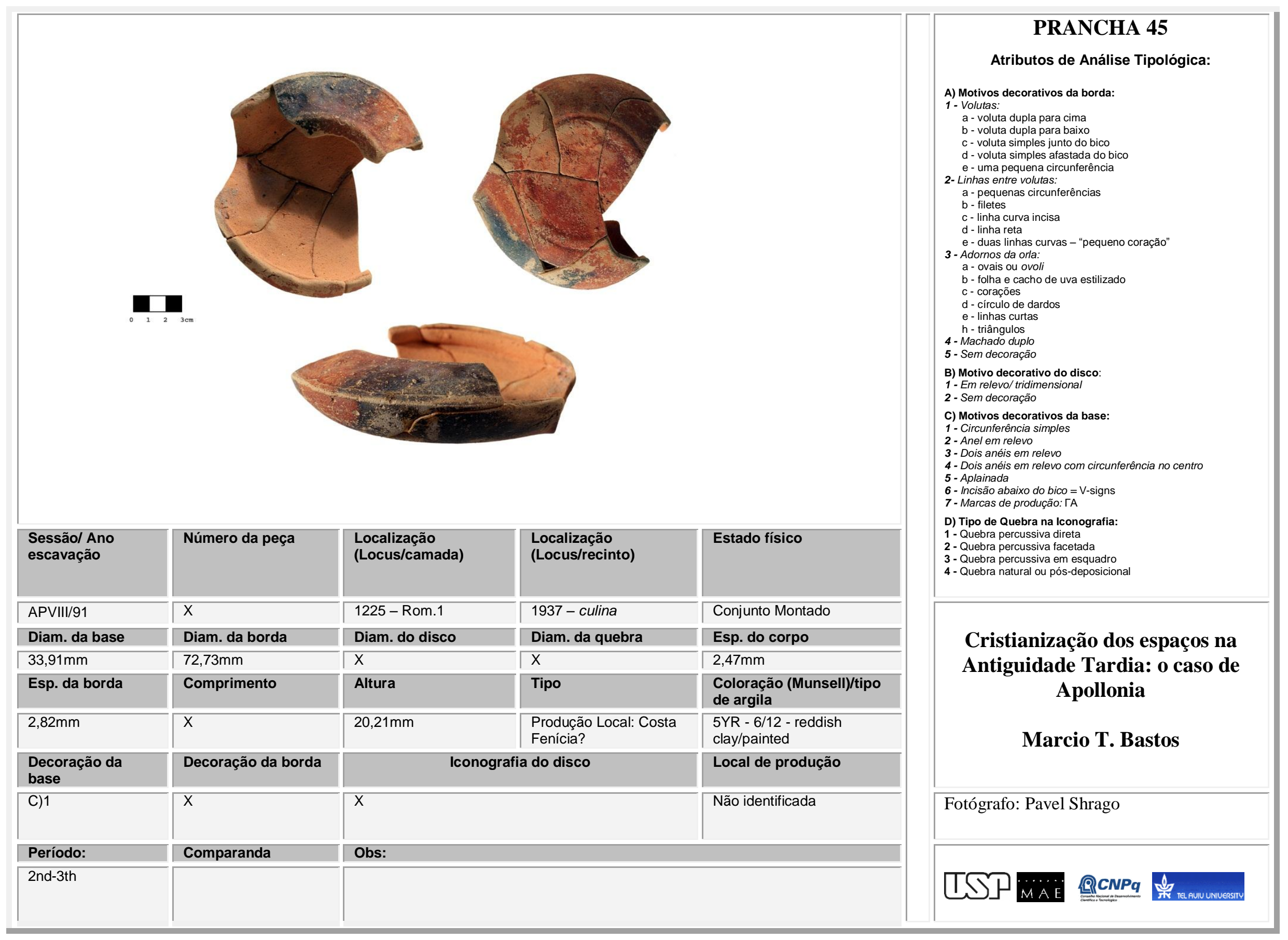




\begin{tabular}{|c|c|c|c|c|c|}
\hline $\begin{array}{l}\text { Sessão/ Ano } \\
\text { escavação }\end{array}$ & Número da peça & $\begin{array}{l}\text { Localização } \\
\text { (Locus/camada) }\end{array}$ & $\begin{array}{l}\text { Localização } \\
\text { (Locus/recinto) }\end{array}$ & Estado físico & 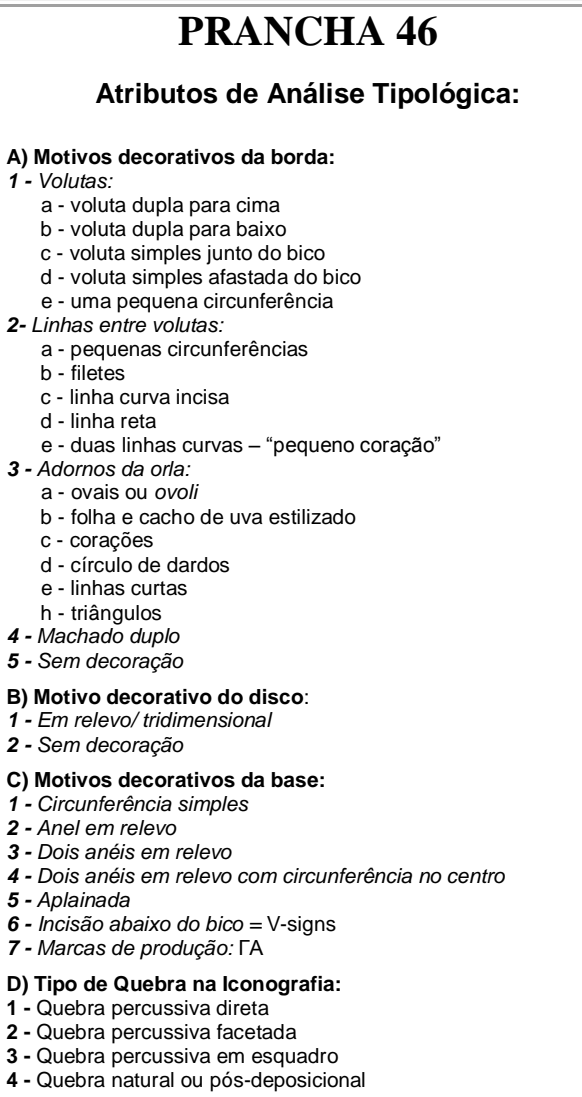 \\
\hline APVIII/91 & $\mathrm{x}$ & 1225 - Rom.1 & 1937 - culina & Conjunto Montado & \multirow{6}{*}{$\begin{array}{c}\text { Cristianização dos espaços na } \\
\text { Antiguidade Tardia: o caso de } \\
\text { Apollonia }\end{array}$} \\
\hline Diam. da base & Diam. da borda & Diam. do disco & Diam. da quebra & Esp. do corpo & \\
\hline $40,15 \mathrm{~mm}$ & $\mathrm{x}$ & $\mathrm{X}$ & $\mathrm{X}$ & $2,53 \mathrm{~mm}$ & \\
\hline Esp. da borda & Comprimento & Altura & Tipo & $\begin{array}{l}\text { Coloração (Munsell)/tipo } \\
\text { de argila }\end{array}$ & \\
\hline $2,91 \mathrm{~mm}$ & $x$ & $20,10 \mathrm{~mm}$ & $\begin{array}{l}\text { Produção Local: Costa } \\
\text { Fenícia? }\end{array}$ & $\begin{array}{l}\text { 5YR - 4/6 - Buff clay/ brown } \\
\text { slip }\end{array}$ & \\
\hline $\begin{array}{l}\text { Decoração da } \\
\text { base }\end{array}$ & Decoração da borda & \multicolumn{2}{|c|}{ Iconografia do disco } & Local de produção & \\
\hline C) 1 & $\mathrm{x}$ & \multicolumn{2}{|c|}{$\mathrm{x}$} & Não identificada & Fotógrafo: Pavel Shrago \\
\hline Período: & Comparanda & \multicolumn{3}{|l|}{ Obs: } & \\
\hline 2nd-3th & & & & & NNF \\
\hline
\end{tabular}




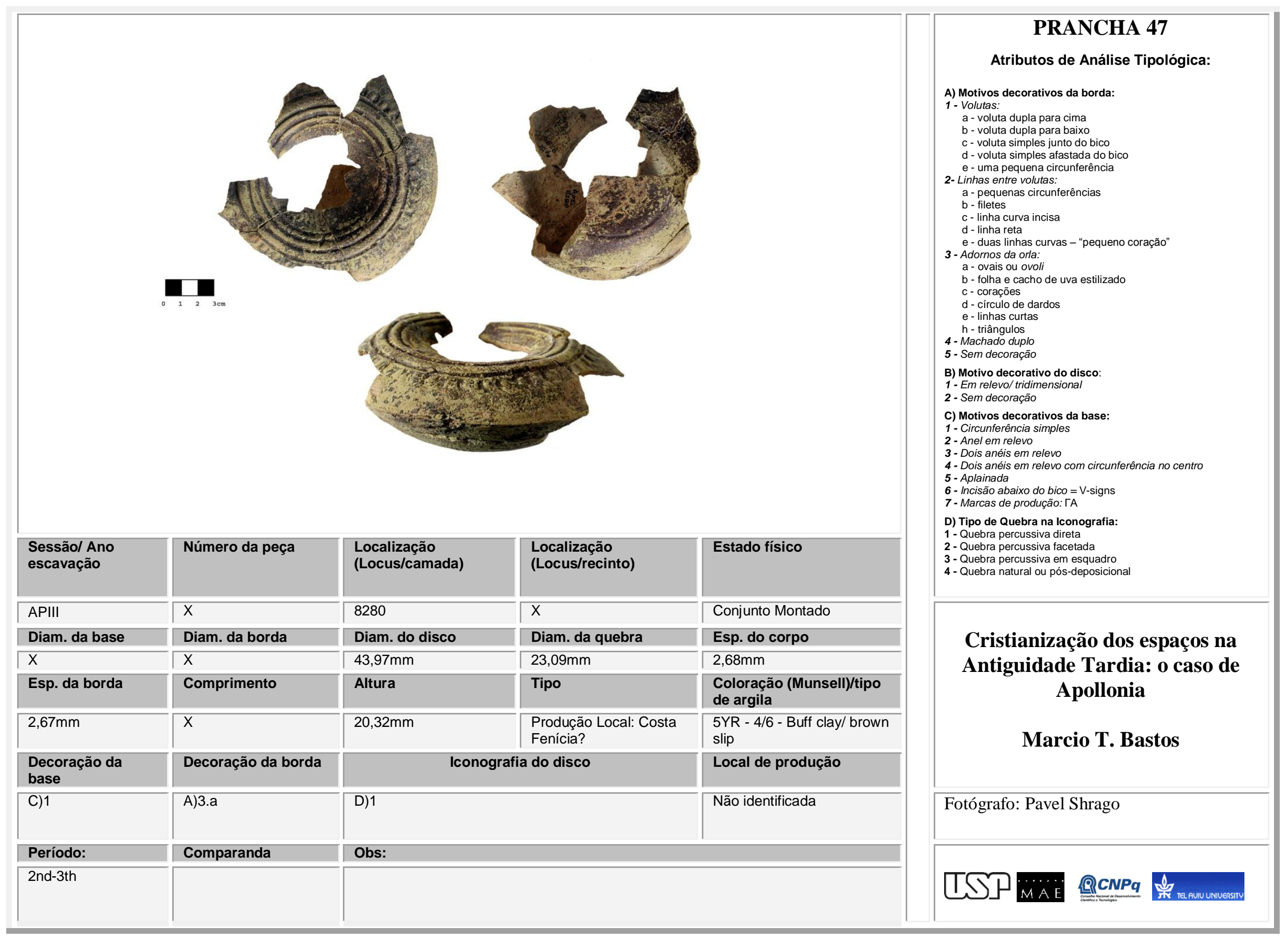




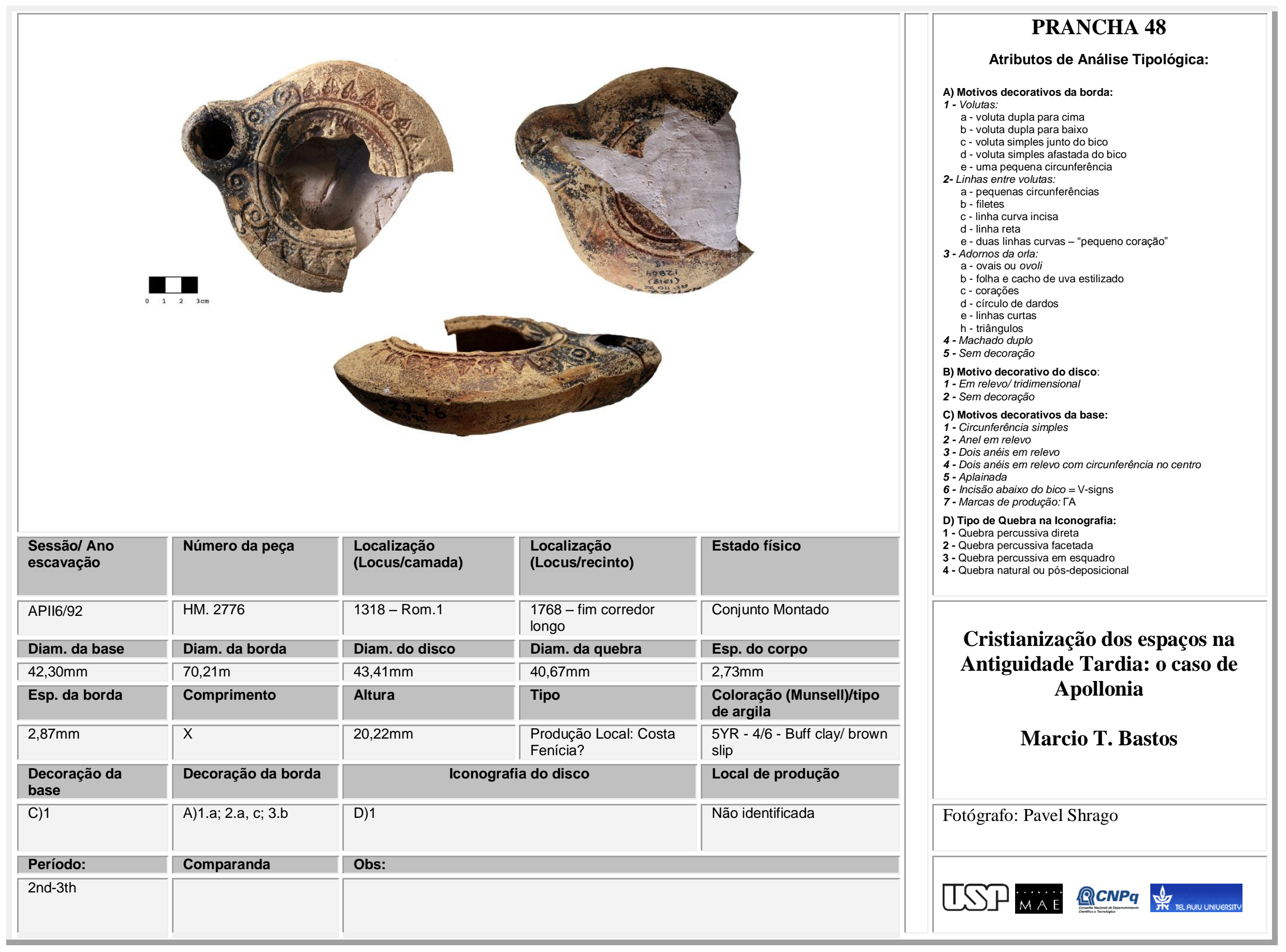




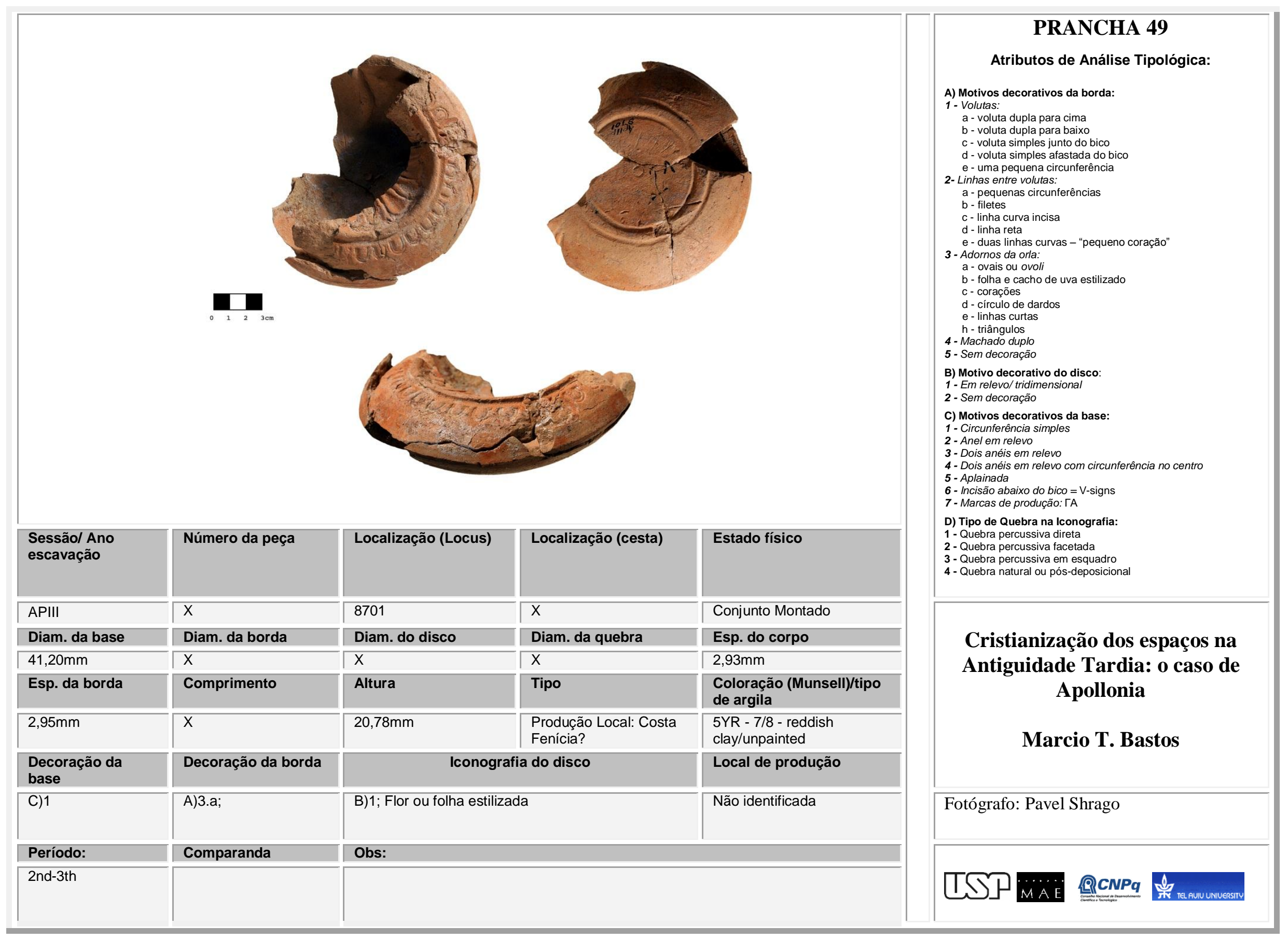




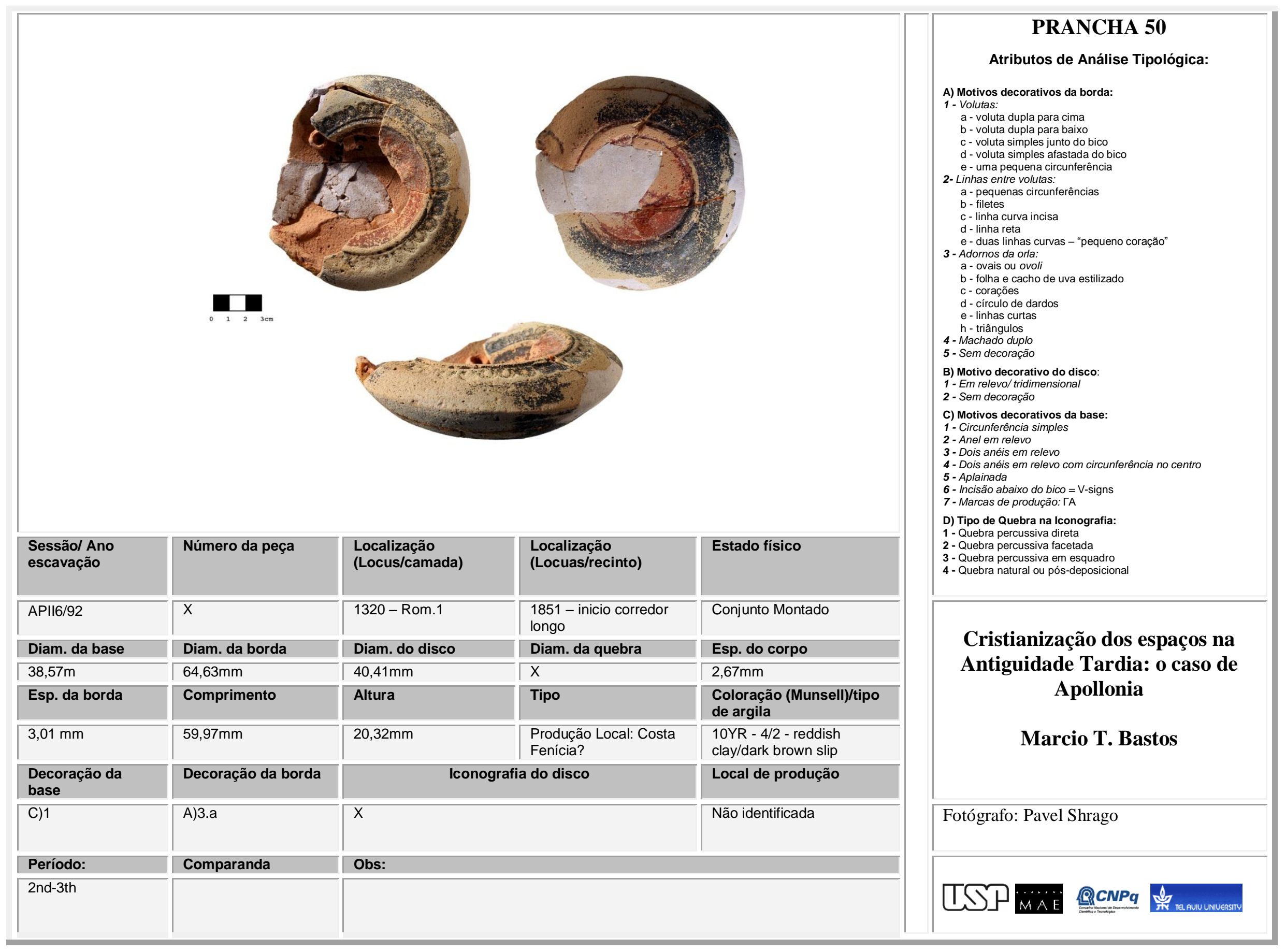




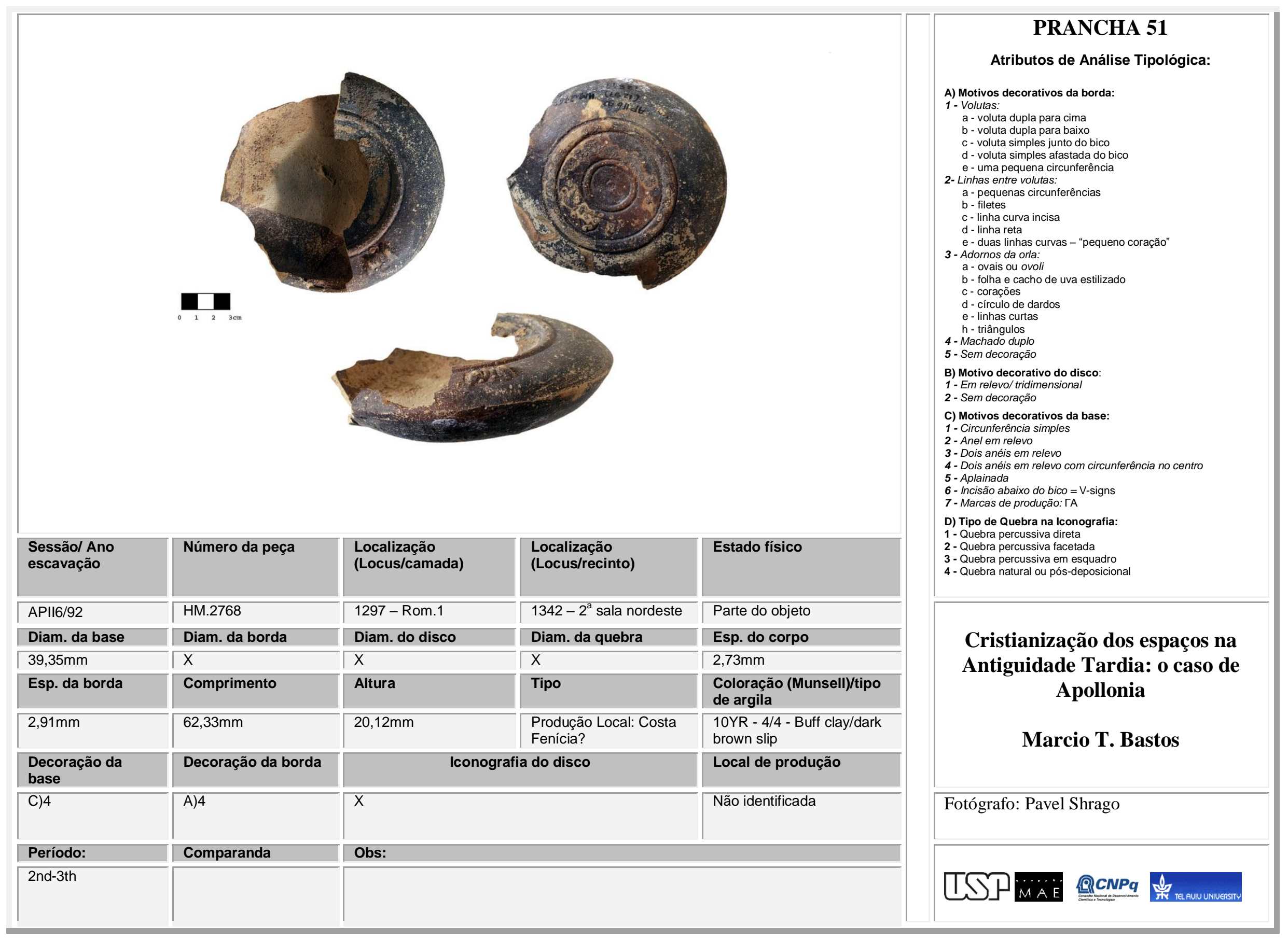




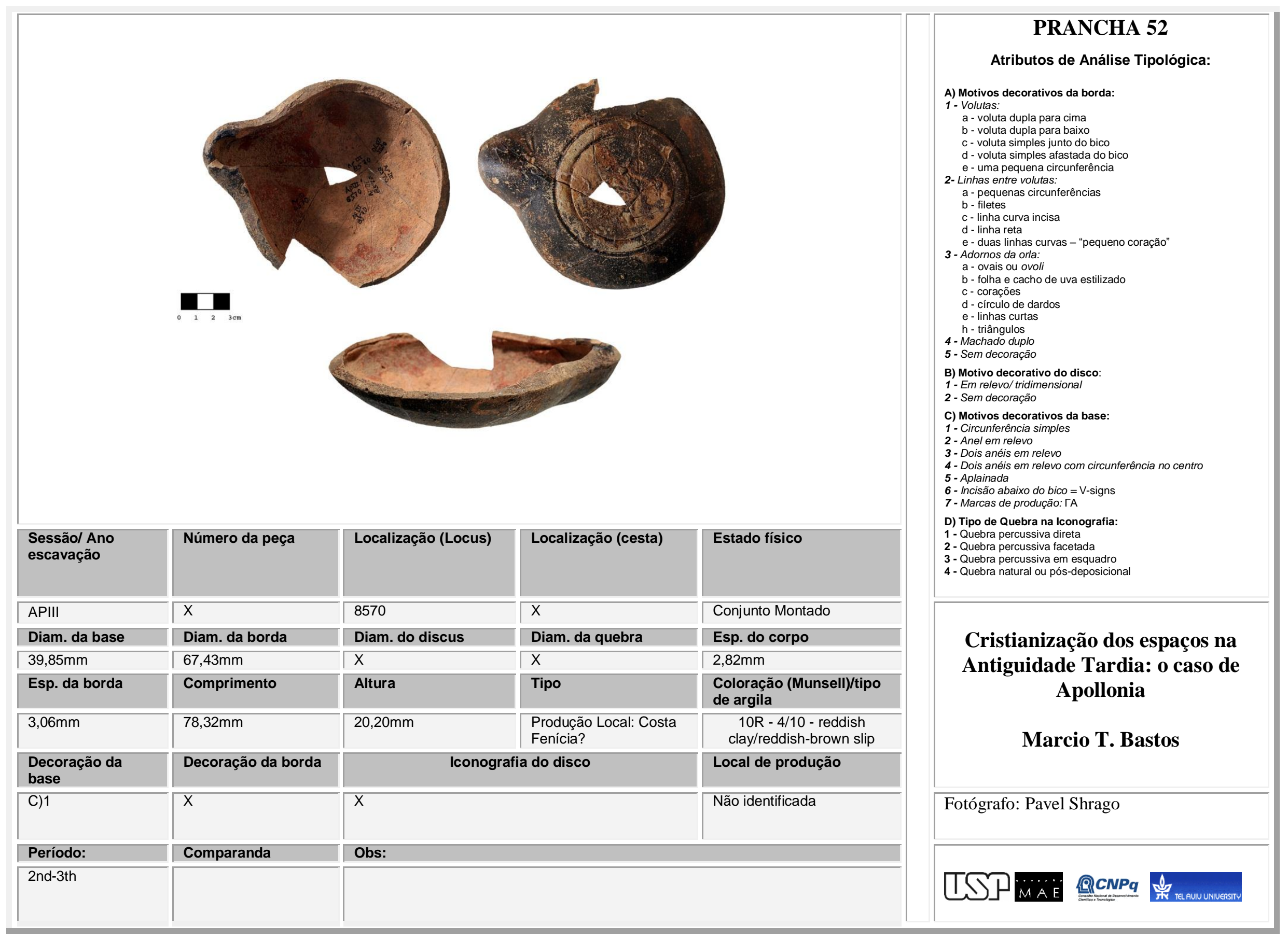




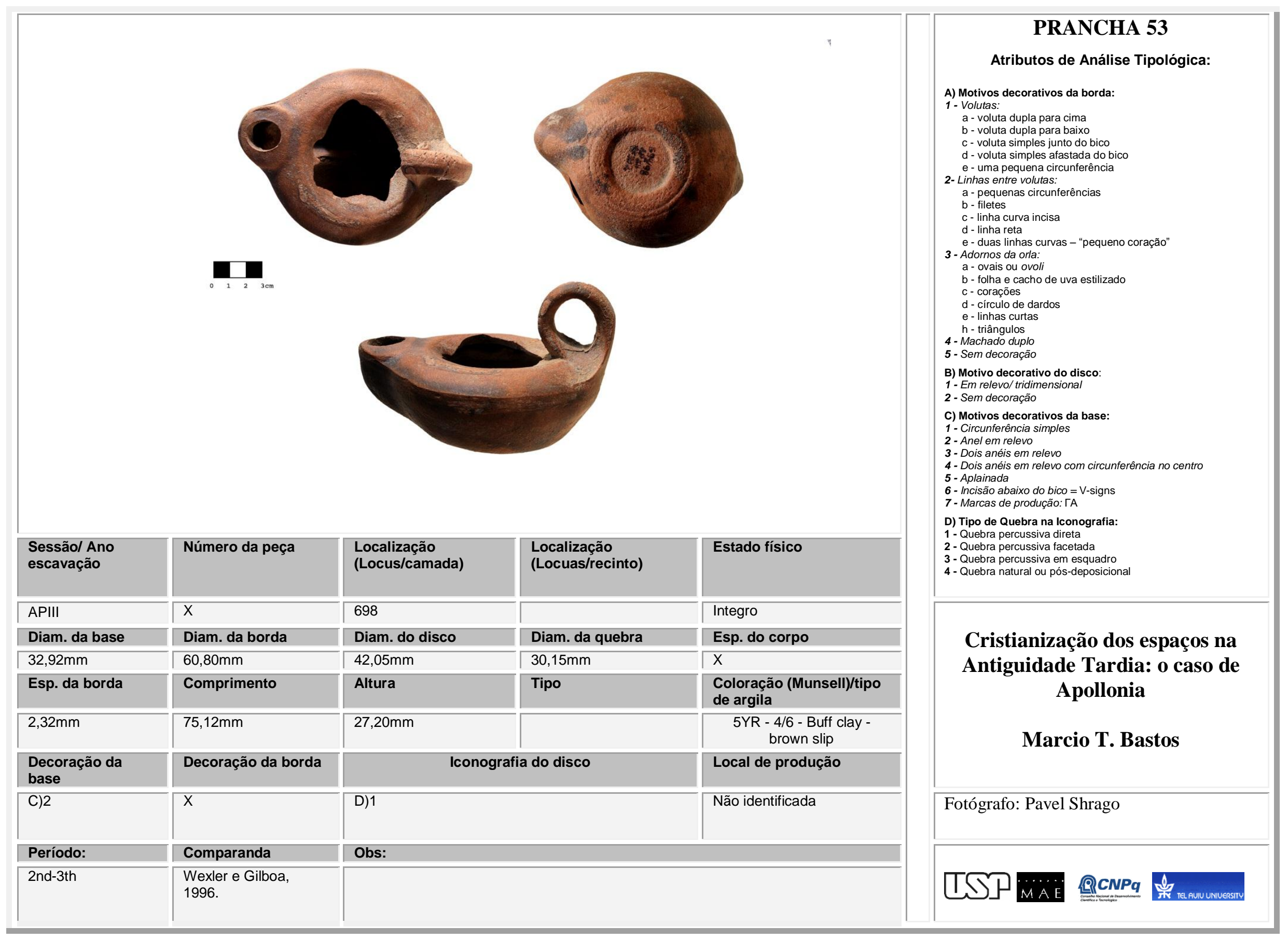




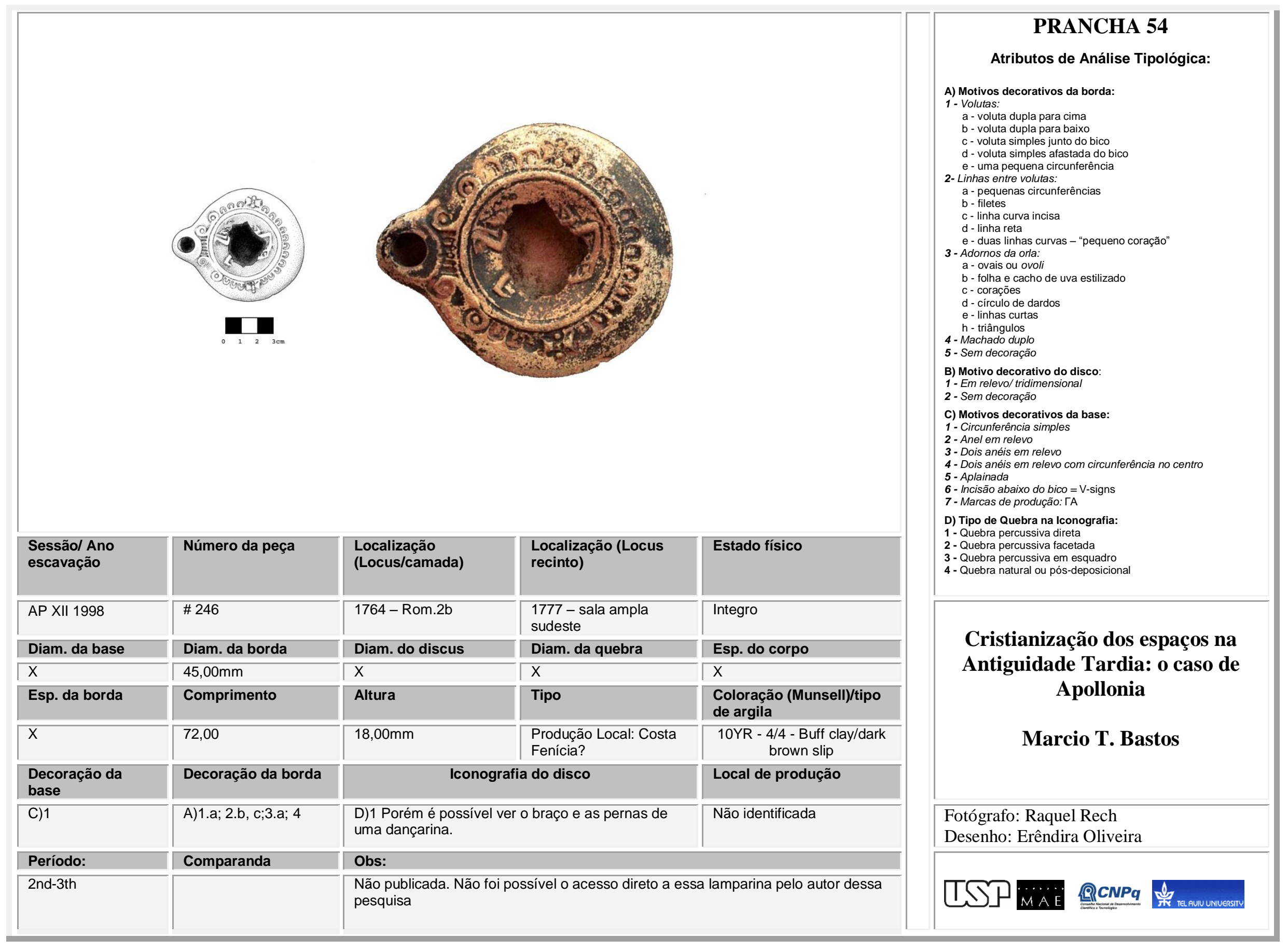




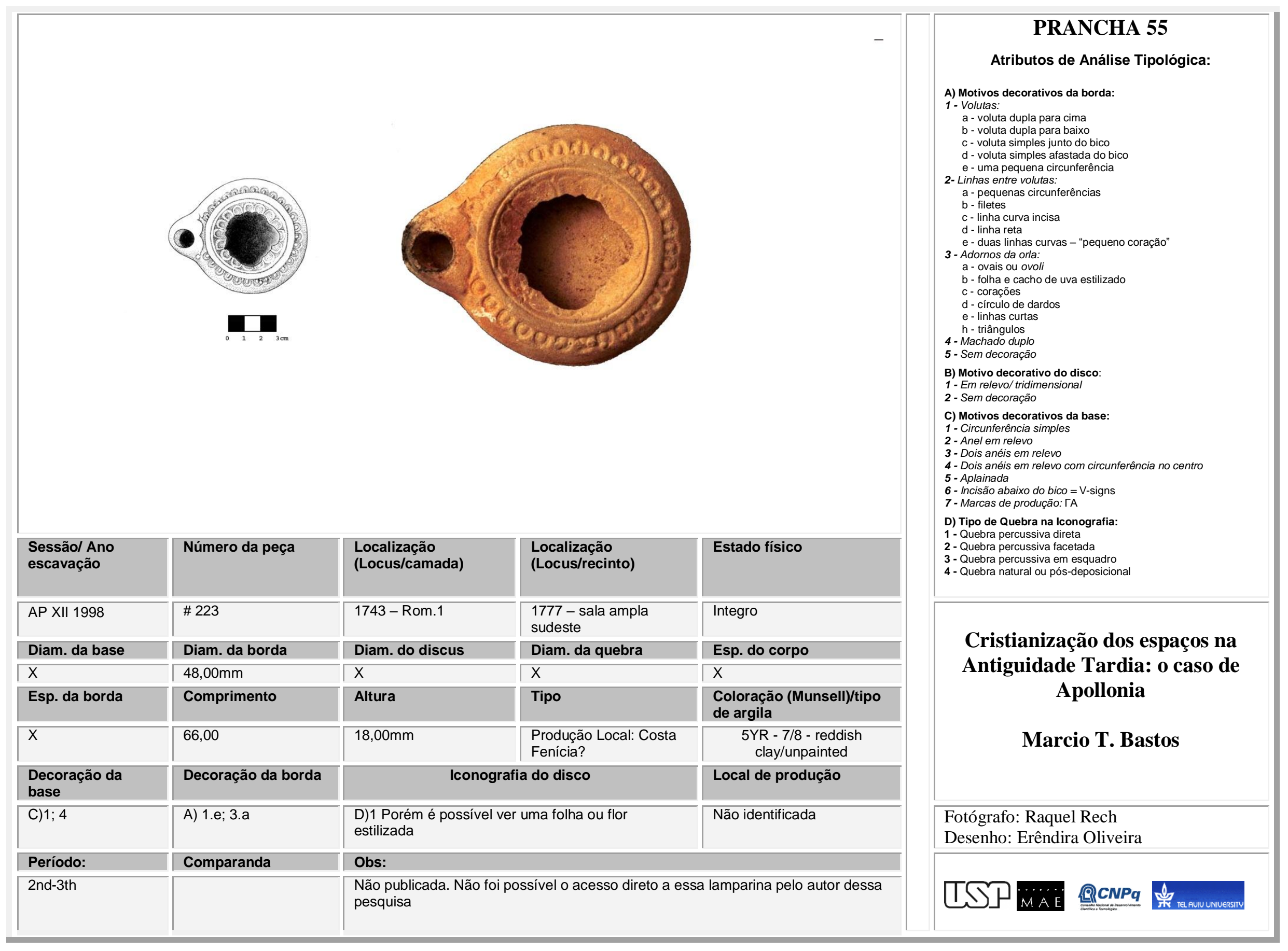




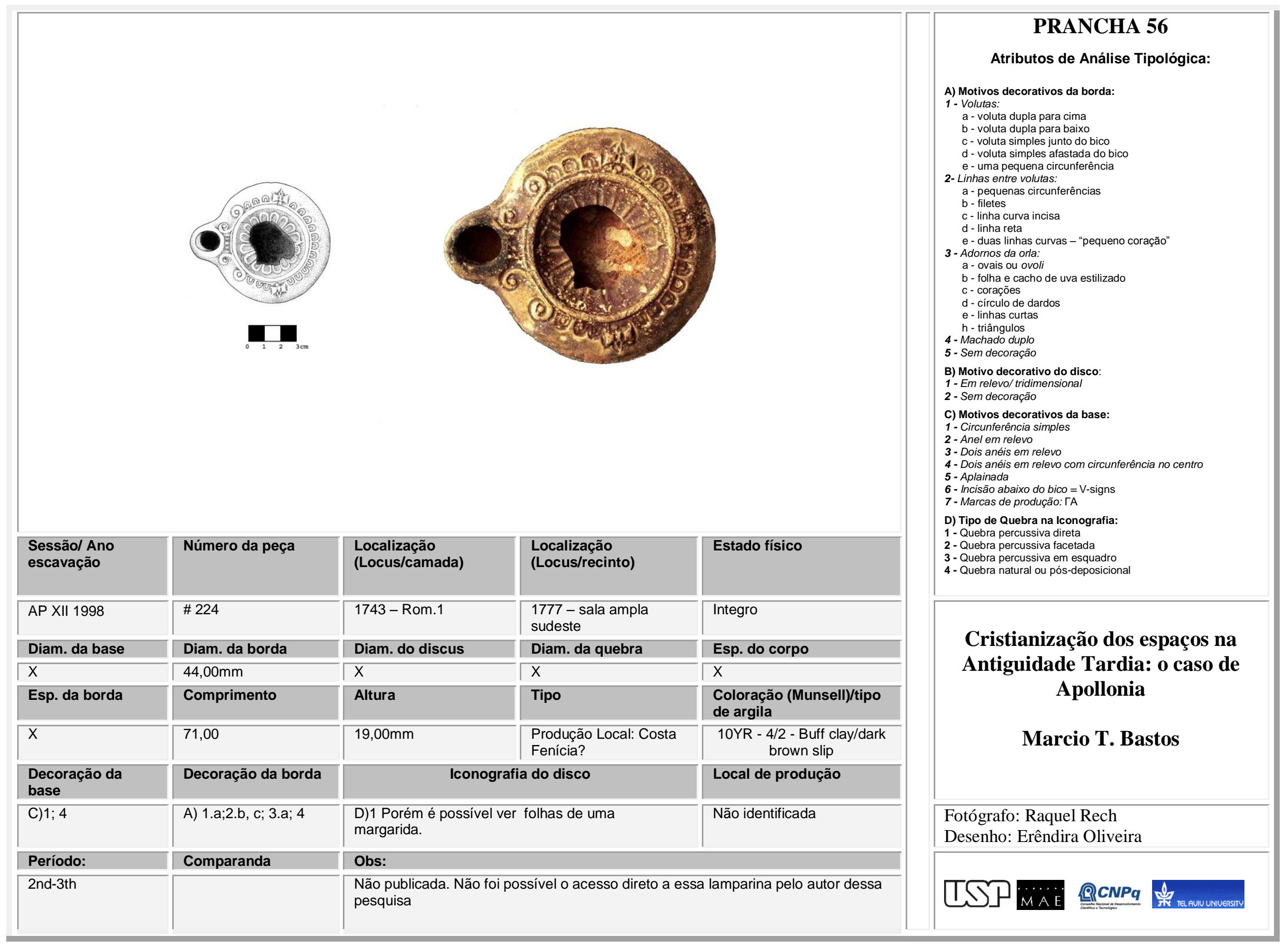




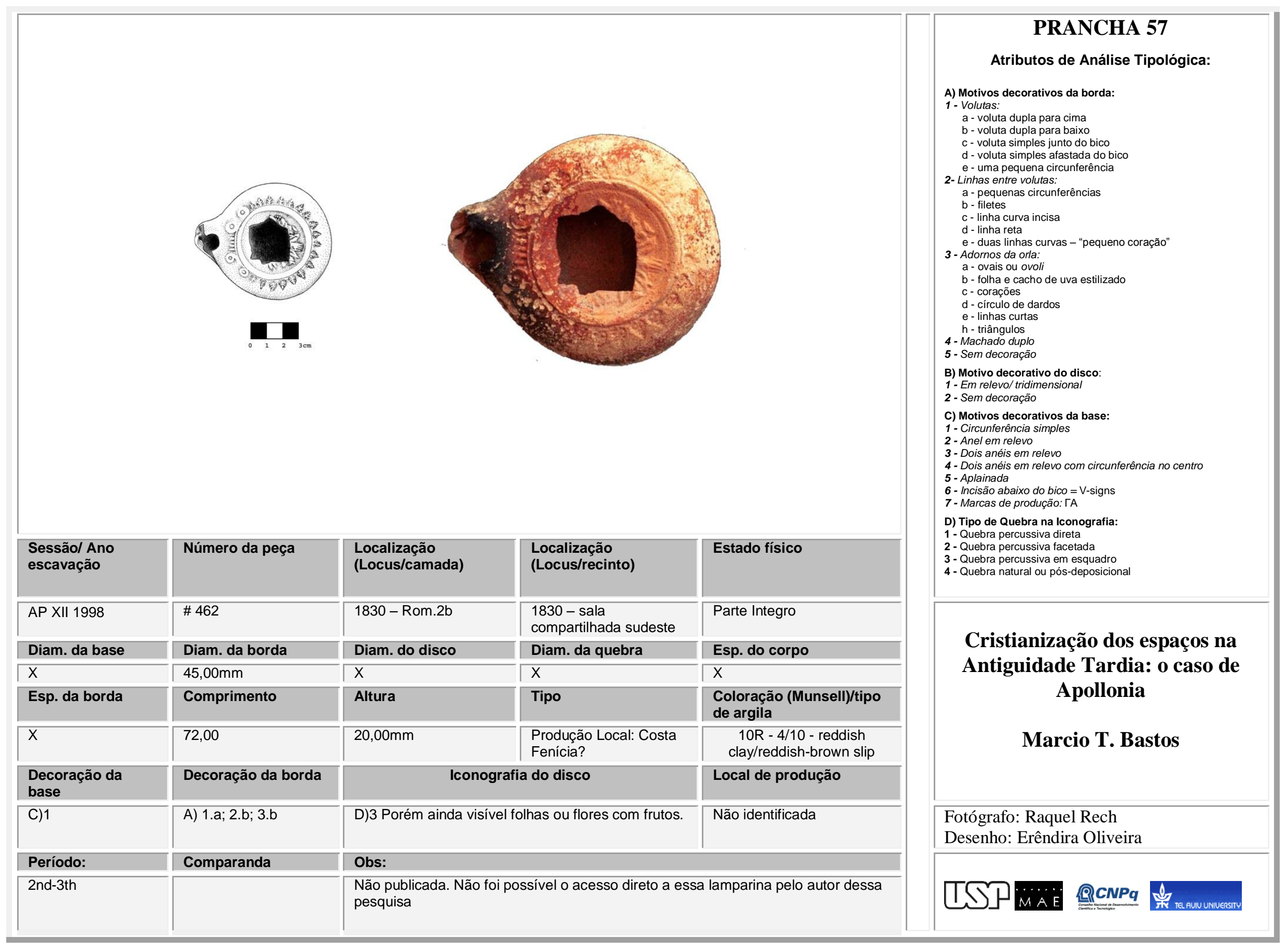




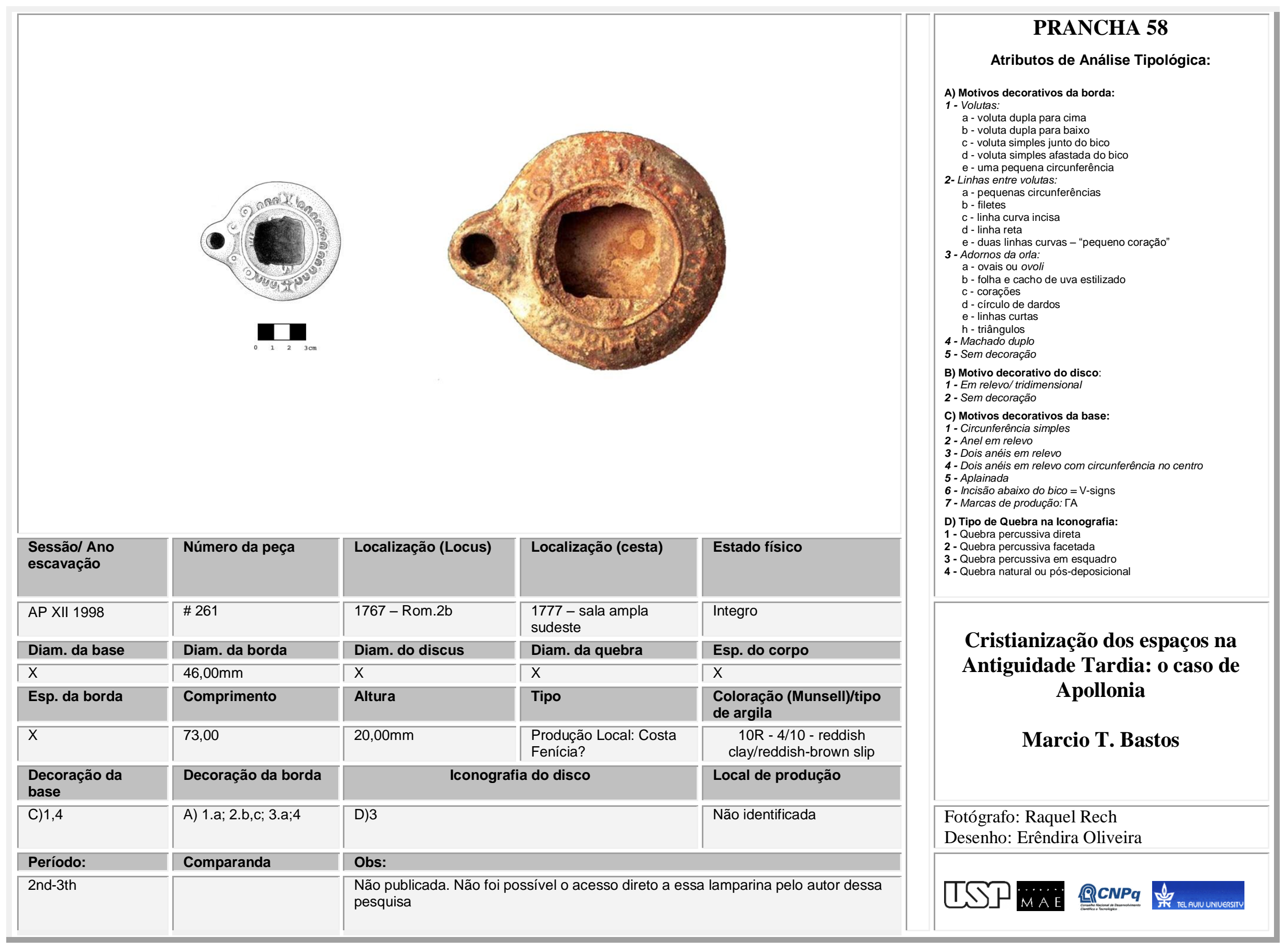




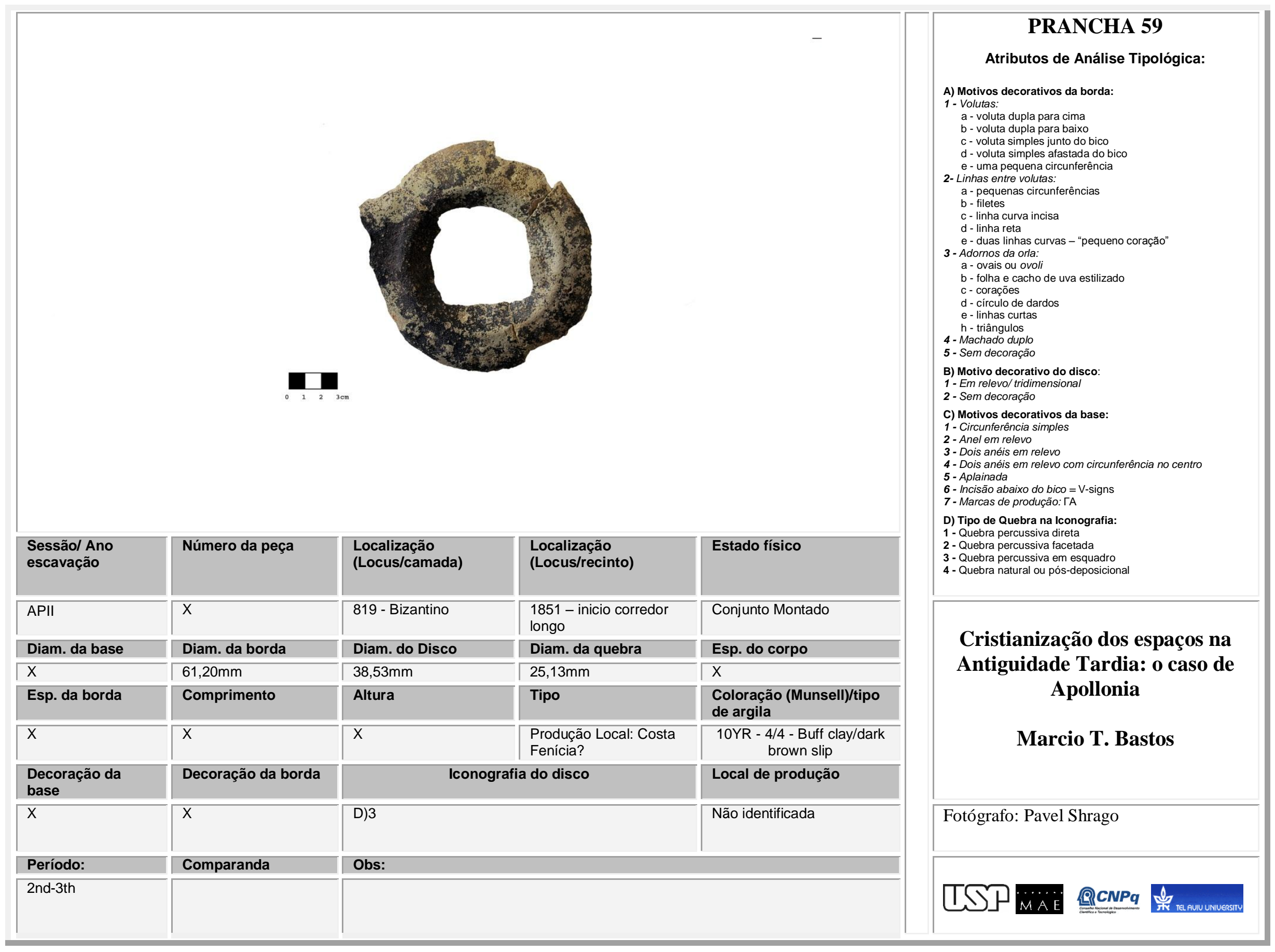




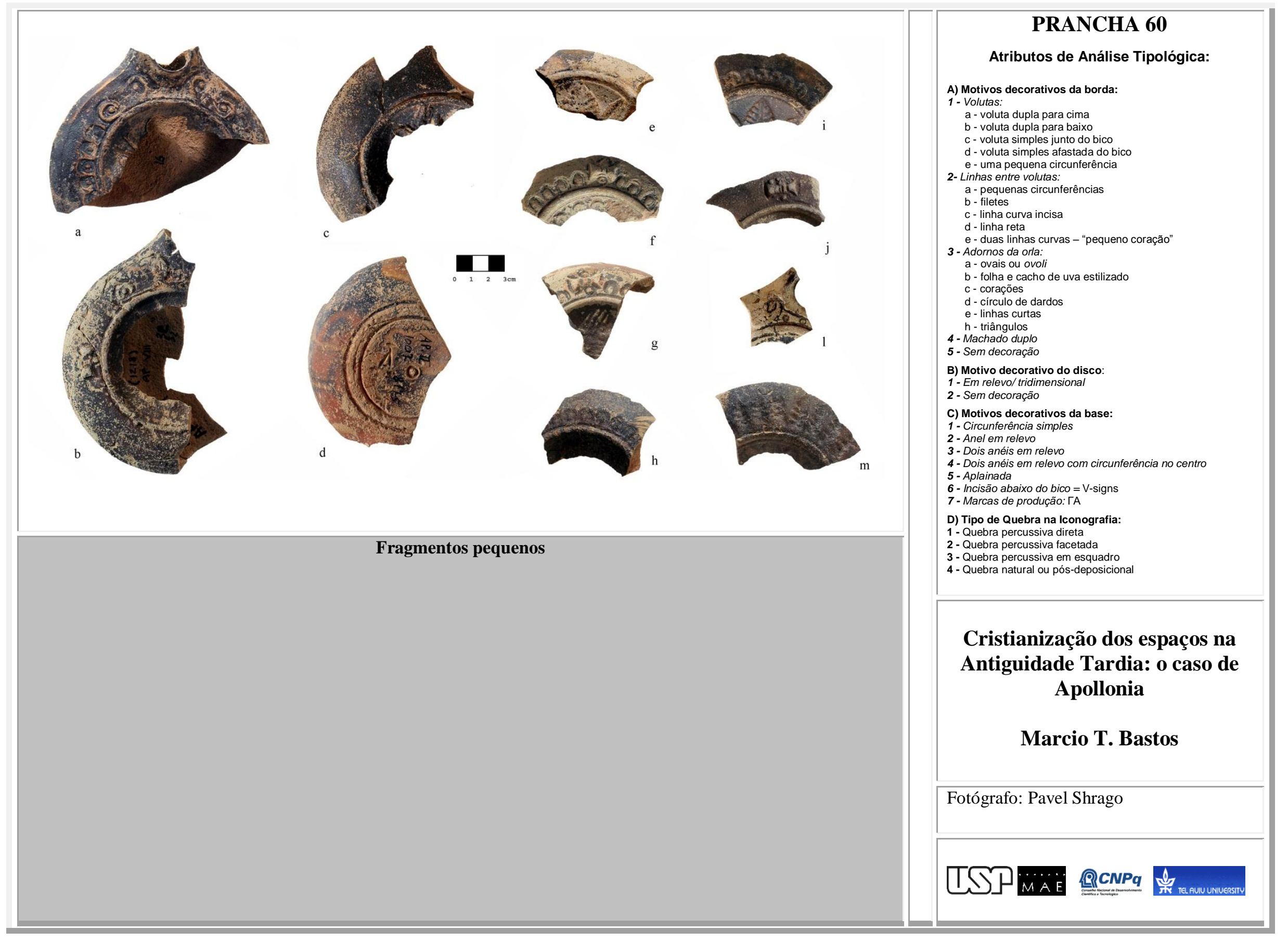




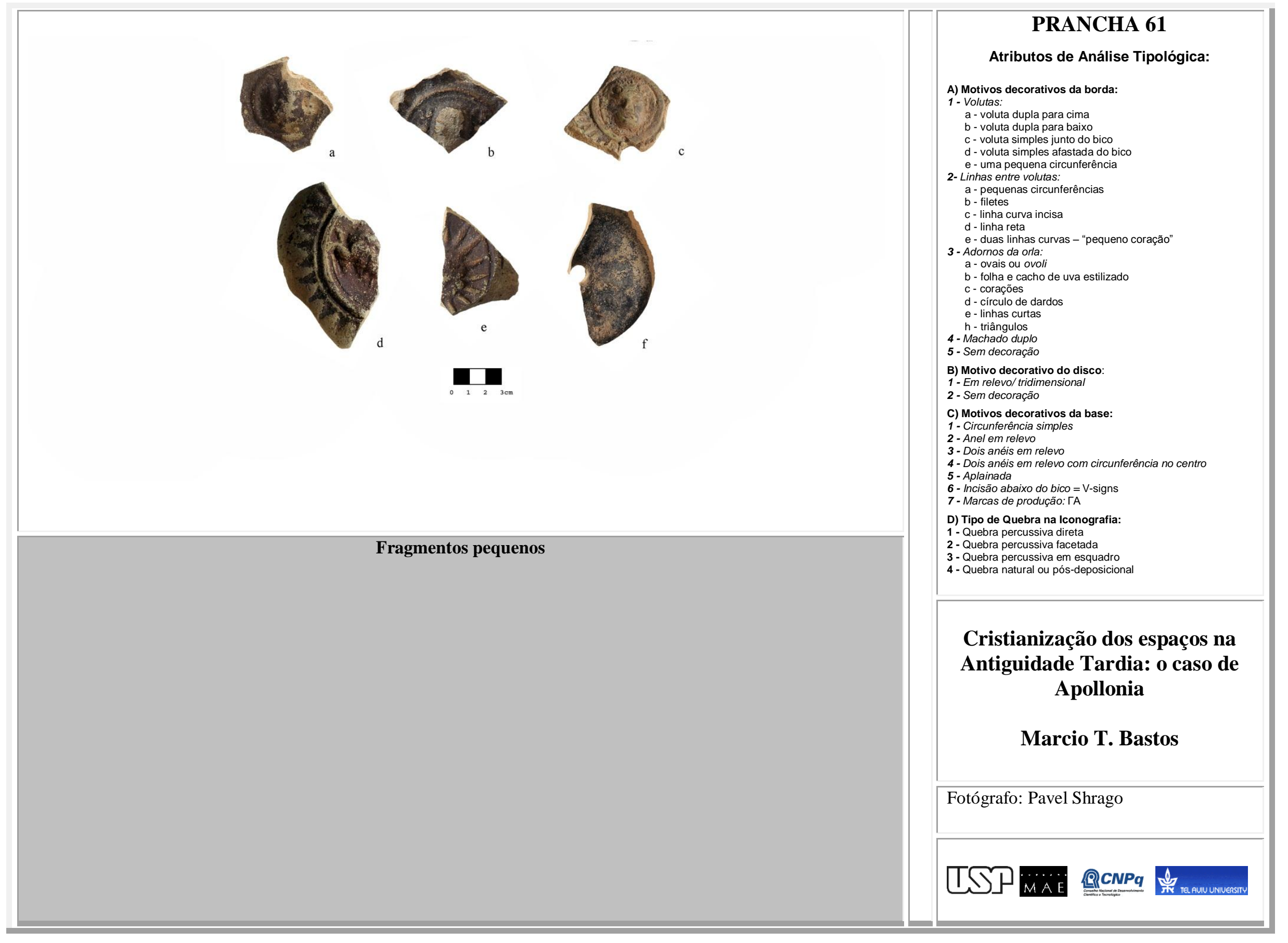




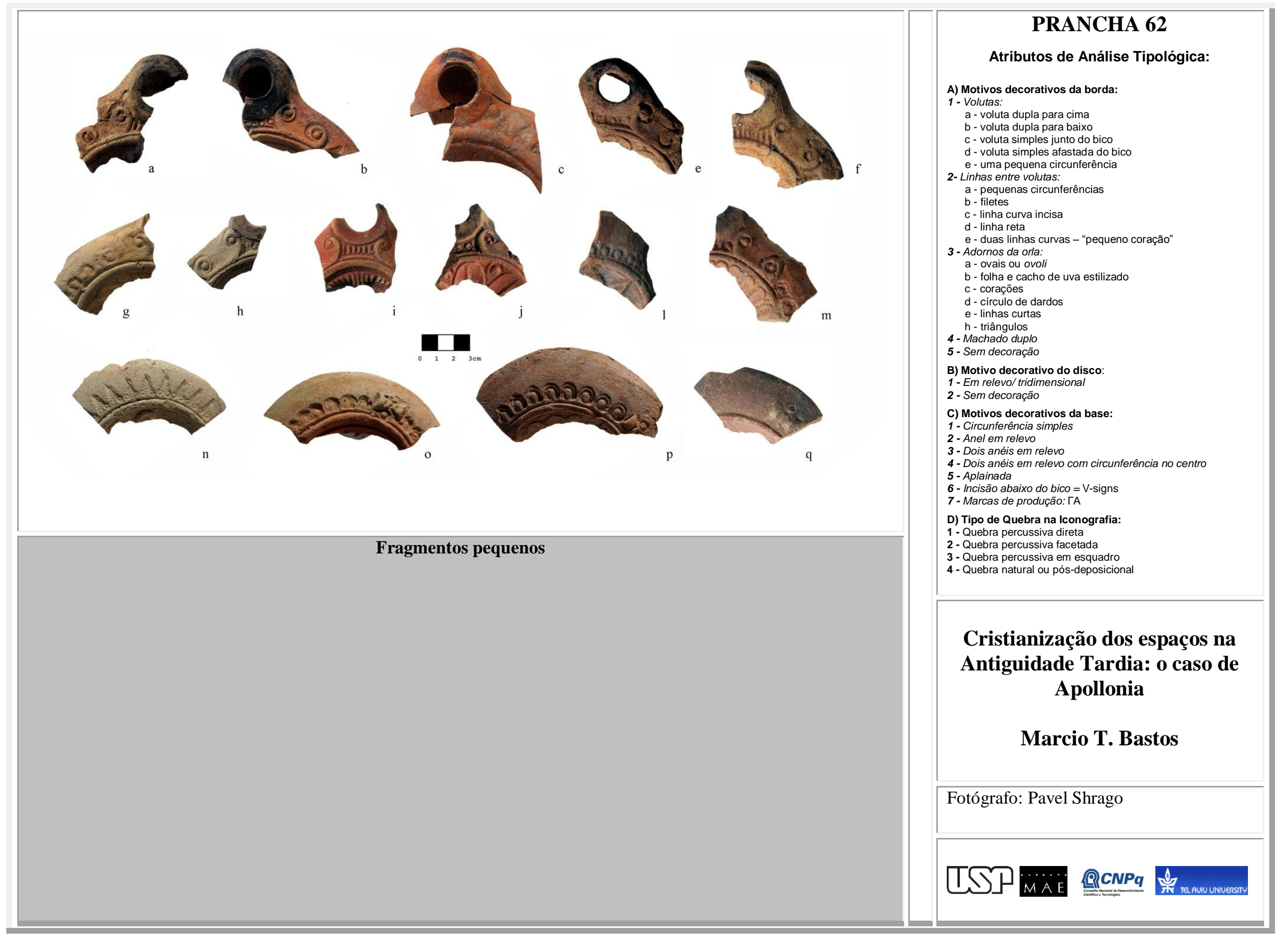




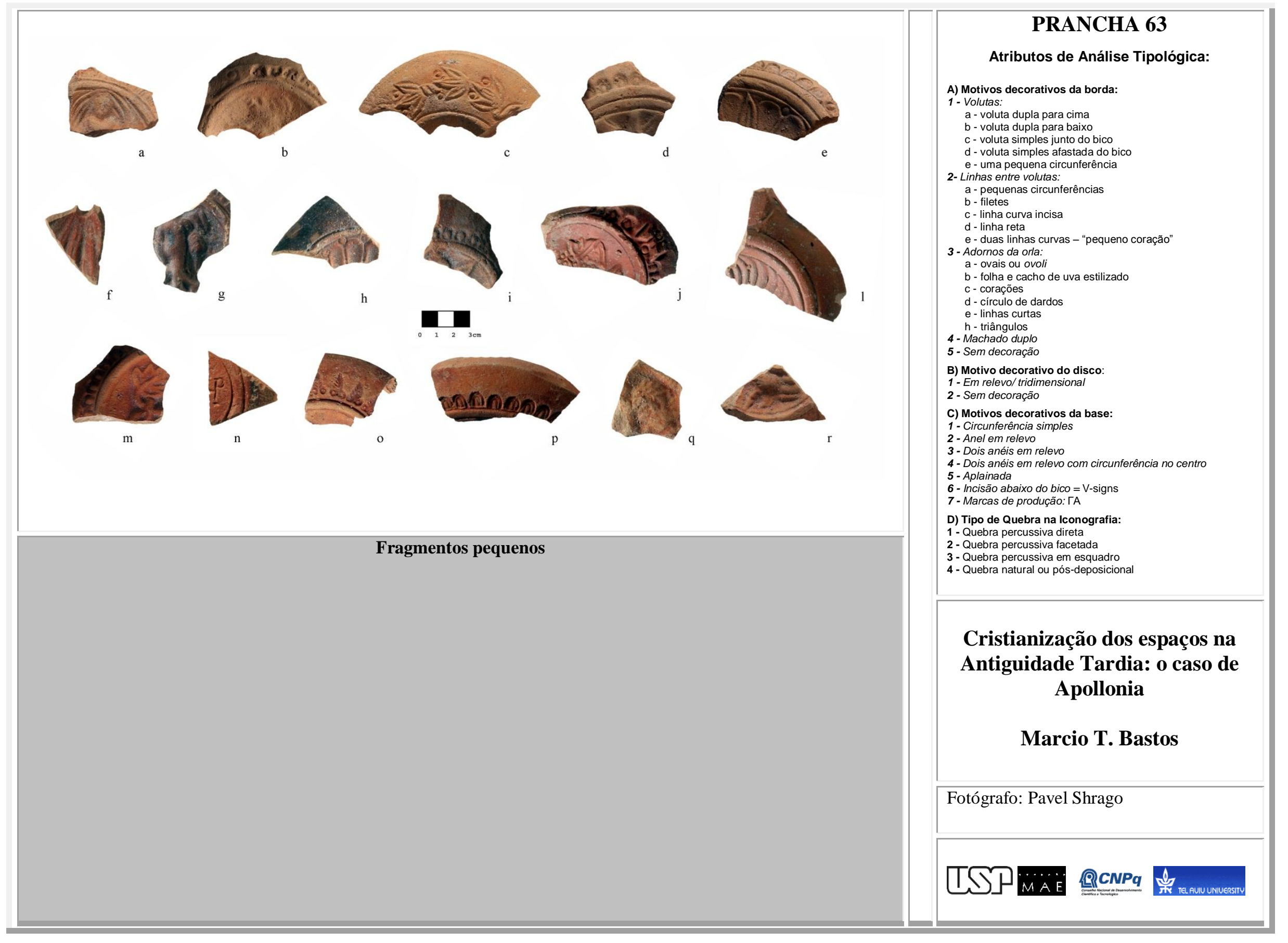




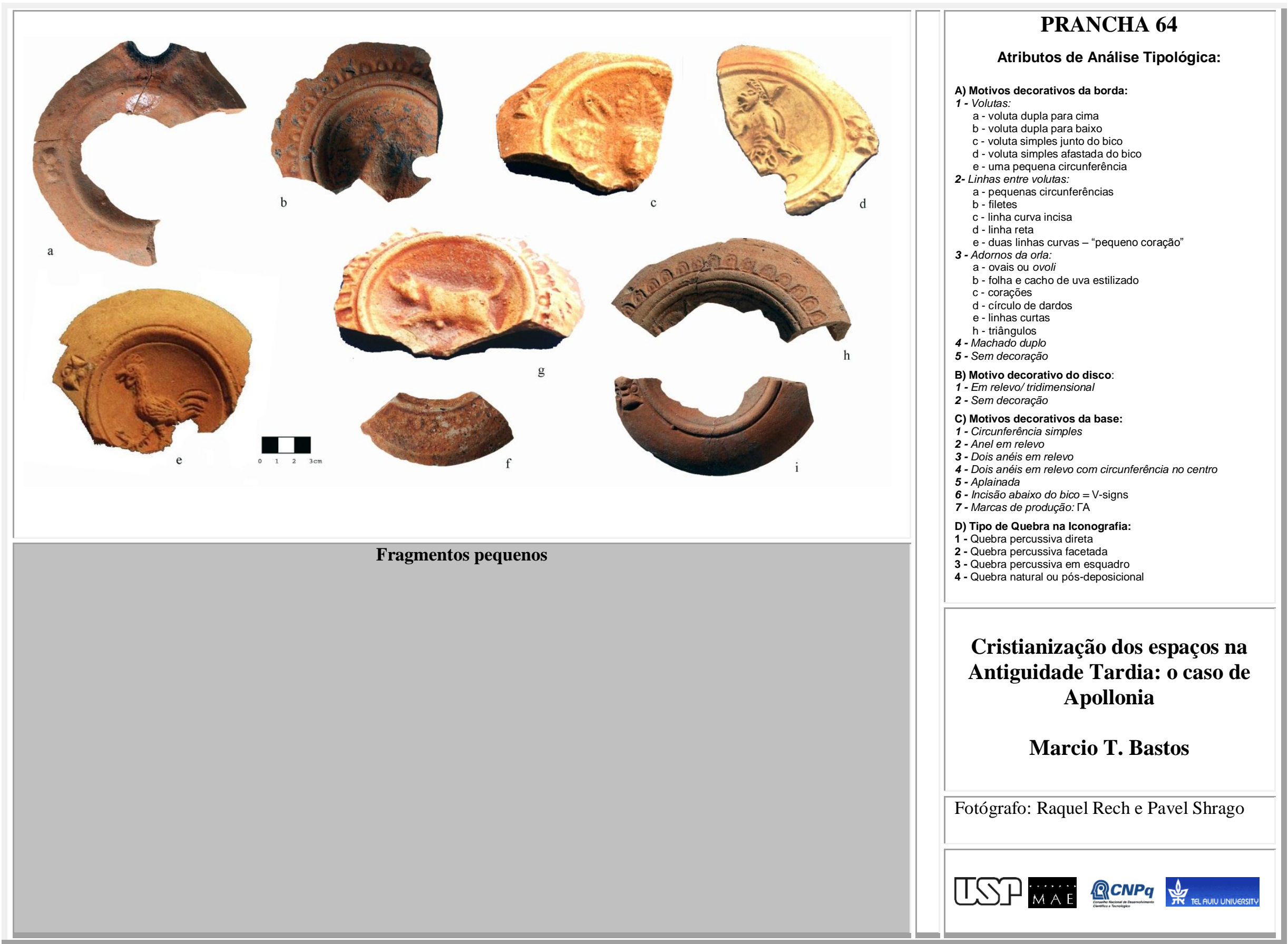




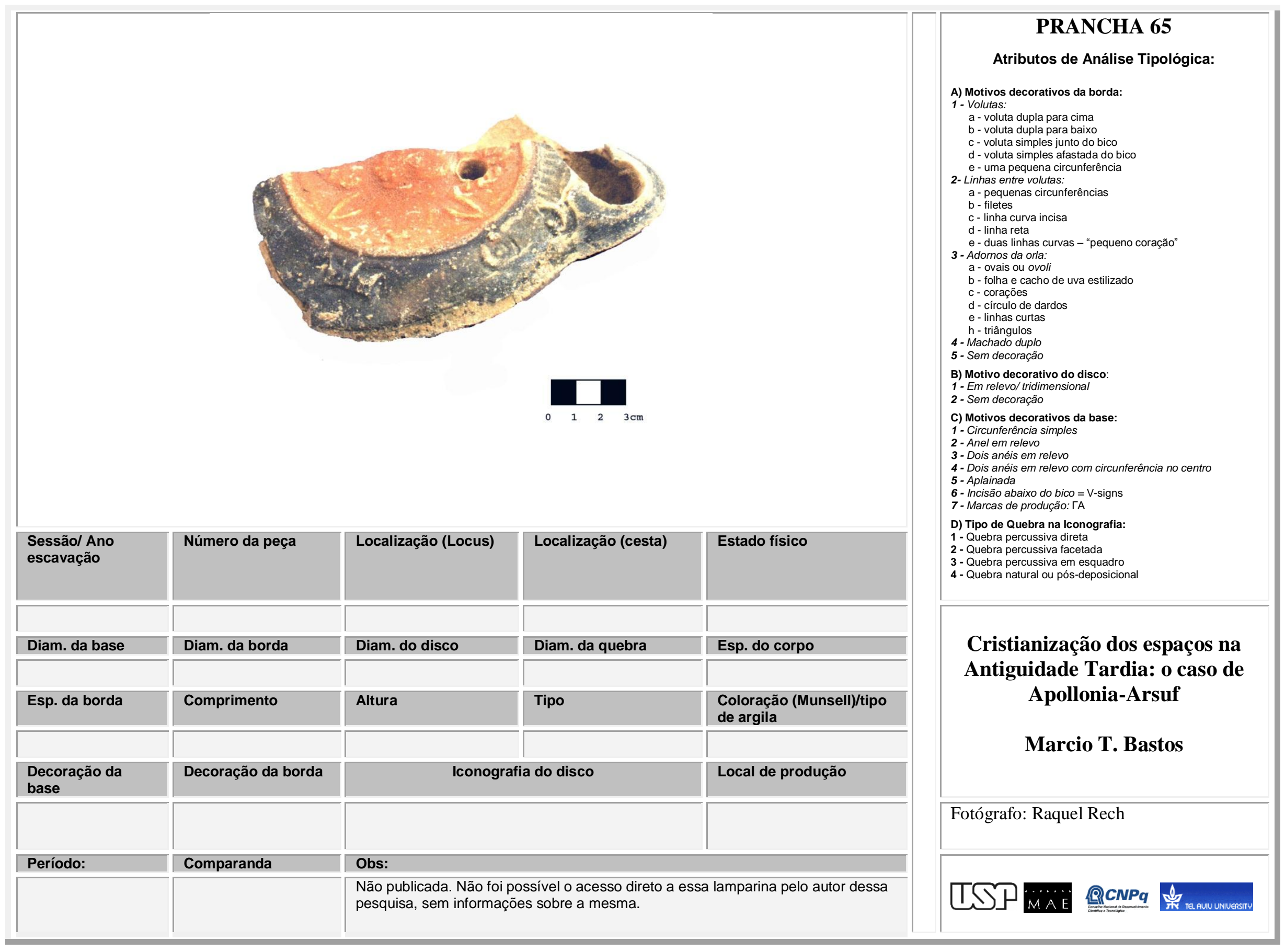




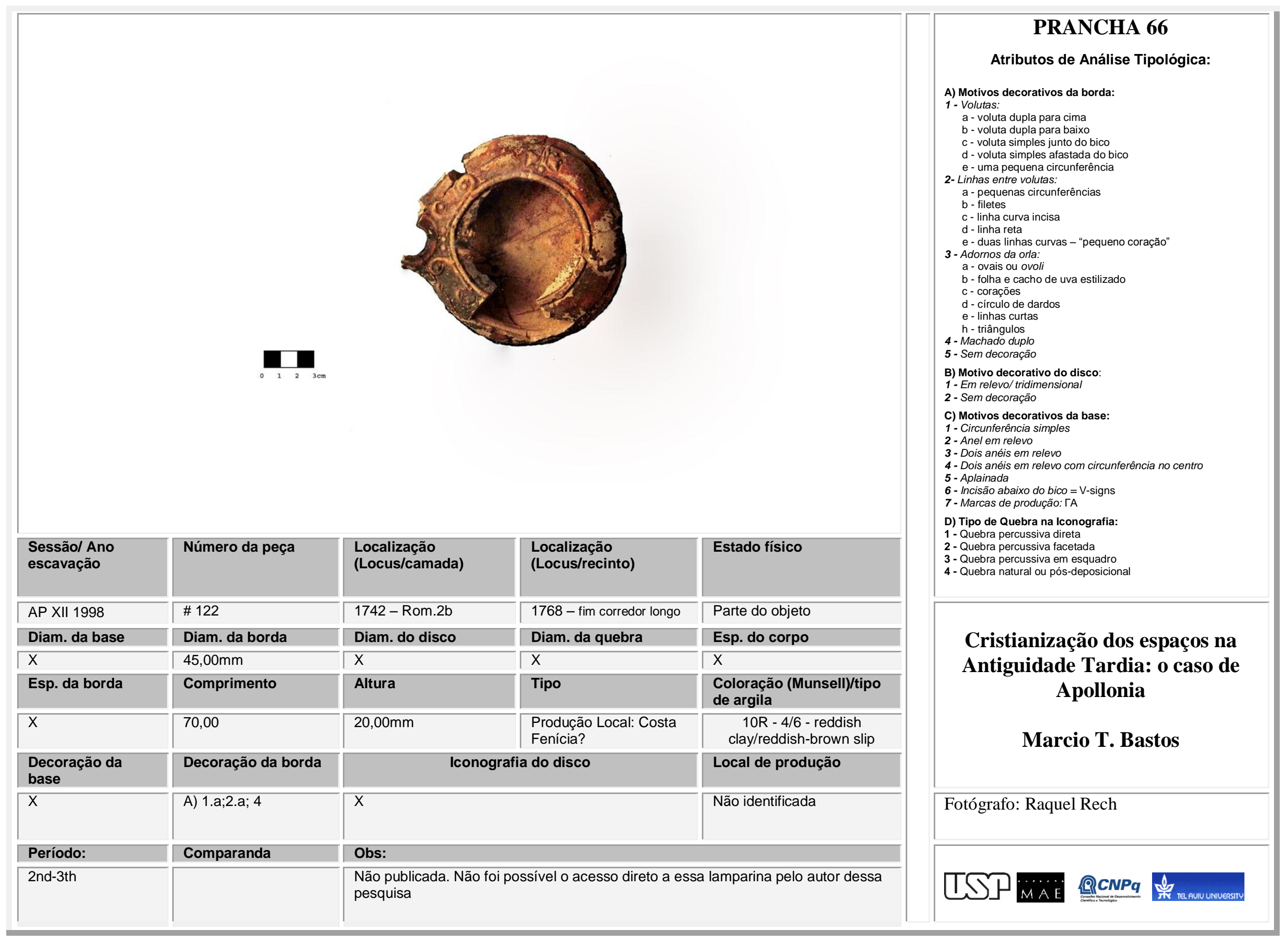




\section{CAPÍTULO 5}

"A inclusione unius ad exclusionem alterius": movimento, paisagem, espaço e identidade

"As verdades únicas não existem: as verdades são múltiplas, só a mentira é global" José Saramago

"A vida é a arte do encontro, embora haja tantos desencontros pela vida" Vínicius de Moraes

Todo dia ele acorda no mesmo horário, pontualmente às 6:00 h da manhã, espreguiça-se e dirige-se até o banheiro. Ainda sonolento abre o chuveiro, a água em seus instantes iniciais é gelada, causando desconforto. Logo em seguida, quando começa a usufruir o calor da água, lembra-se que é momento de sair. Após tomar café, sai de sua casa, e caminha até a parada de ônibus. Chegando ali, percebe que deixou o cachorro sem comida e vê alguns rostos conhecidos da rotina de todas as manhãs; levemente ele acena movimentando a cabeça cumprimentando-os. Já dentro do ônibus mais alguns contatos sem palavras. Uma senhora chega ao seu lado e puxa assunto, provavelmente fala sobre o dia, pensa ele, vendo suas expressões, já que não entende uma palavra do que ela diz. Trata-se de um brasileiro em Israel e como o hebraico não deriva do latim, nem consegue fazer as habituais associações fonéticas que faria em relação ao italiano, espanhol e até mesmo o romeno. Nos primeiros dias naquele lugar constantemente ele era abordado para uma conversa trivial ou um pedido de informação e logo se justificava em inglês, dizendo não ser dali. Com o passar dos dias e as situações se repetindo, resolveu simplesmente concordar quando alguém o abordasse para aquelas poucas palavras trocadas num ônibus. Assim, mesmo sem entender uma palavra do que a doce senhora lhe falava, faz um sinal de concordância e ela, sorrindo, o 
deixa, como se naquele momento ambos tivessem se entendido. De fato se entenderam, porém não sob os mesmos parâmetros. Toda viagem gera expectativa, seja ela para onde for, afinal de contas, somos em grande parte formados exatamente disto: das nossas expectativas. Em certo sentido, por mais rotineiro que seja nosso translado, constantemente somos surpreendidos por situações que nos chamam a atenção, seja por serem "exatamente o que sempre são" nesse conjunto de cenário, seja por conterem algum tipo de diferencial captado por nós em dado momento e que imediatamente é associado a outra série de conexões de nossa experiência. Enquanto não chega a seu destino, ele observa as pessoas que passam na rua apressadas diante do seu olhar, nota que o céu está nublado e que poderia ter saído com um guarda-chuva para mais tarde não ser surpreendido pela eventual chuva; vê um pequeno cachorro a passear com seu dono e outro revirando o lixo, provavelmente em busca de comida. Nesse momento lhe ocorre que até entre os cachorros existem aqueles que recebem algo "de mão beijada" e aqueles que têm que correr atrás de seu sustento. A vida não é coisa fácil, pensa. Ele ouve as pessoas próximas conversarem, algumas falando em inglês sobre a noite passada, outras sobre acontecimentos recentes, provavelmente, e outras ainda sobre o calamitoso "fim dos tempos". Isto lhe chama atenção, pois mesmo não compreendo a língua, ele sabia do que falavam, os gestos lhe diziam isso. A situação o faz recordar da primeira vez que ouviu sobre esse assunto, ainda criança. No mesmo instante pensa que, na época, isso era assunto de adultos, sua preocupação era brincar e jogar bola e se esse tal de mundo fosse acabar não era certamente a sua casa e a vizinhança que sofreriam tal dano. Logo sua atenção é interrompida novamente: está quase no momento de descer do ônibus. Ele tem uma parada a fazer antes de seguir a seu destino último-momentâneo. Dando um sinal, chega e desce do ônibus. Passa num pequeno comércio e procura um livro para sua instrução na língua, afinal ali passaria algum tempo e já que era tido como um comum, melhor seria se comunicar com palavras e não breves gestos. Feita a compra, ele se dirige a outra parada de ônibus; ele está na parte central da cidade, de onde sai o trem para Jerusalém, outras localidades, e onde existe uma ampla estação de ônibus. Procura lugar entre aqueles que vão tomar o ônibus em direção a seu trabalho, praticamente do outro lado da cidade. Espera o desembarque de alguns que acabam de 
chegar e embarca, juntamente com os que ali esperavam. Ao entrar, recorda-se de uma canção popular brasileira que diz: "todos os dias é um vai-e-vem, a vida se repete na estaca; tem gente que chega pra ficar, tem gente que vai pra nunca mais, tem gente que vem e quer voltar, tem gente que vai e quer ficar, tem gente que veio só olhar, tem gente a sorrir e a chorar, e assim chegar e partir são só dois lados da mesma viagem, o trem que chega é o mesmo trem da partida, a hora do encontro é também despedida... a plataforma dessa estação é a vida desse meu lugar..."

Ao olhar para as estações que faltam para sua chegada final, percebe espantado que havia se enganado e estava indo para o sentido contrário. "Maldita desatenção!", exclama! Imediatamente salta do ônibus e toma o reverso. Ao chegar enfim para seu compromisso, logo é interpelado: você viu o que aconteceu? Respondendo brevemente, diz: não o que houve? Acabaram de escalar a equipe que vai trabalhar todos os finais de semana nesse próximo mês e por você não estar aqui, ficou de fora, pensaram que você estava em outro setor. Então pensa: Que feliz acaso!

O espaço foi comumente entendido na modernidade como dividido em lugares estipulados, como um sistema de diferenciação que organizado de maneira particular fez com que a diferença social e espacial fosse concebida nos termos da sequência temporal. Os mais distintos "lugares" foram interpretados como estágios diferentes em um mesmo e único desenvolvimento temporal, assim estórias de progresso unilinear, modernização e desenvolvimento foram francamente explicitadas em sequência de modos de produção que procuraram representar essa forma de viver e operação lógica como auto-evidente e única trajetória global.

O entendimento de que espaço e lugar, sociedade e cultura têm a mesma forma é o que denota o entendimento de que espaço e sociedade formam o mapa um do outro até hoje e que assim estariam divididos assim desde sempre. Foi dessa maneira que "culturas", "sociedades" e "nações" passaram a ser imaginadas todas numa relação integrante de espaços internos coerentemente delimitados uns para com os outros, e dessa forma, diferenciados e separados num conjunto coeso e unitário. Lugares passaram a ser diferenciados em relação a outros que estariam fora das "fronteiras", 
como se estes tivessem autenticidades próprias, internamente geradas, incorrendo na imaginação daquilo que poderia se chamar de um projeto para organizar o espaço global. Nessa acepção se refletia uma cosmologia, uma maneira particular de ordenar e organizar o espaço que se recusava - e ainda se recusa - a reconhecer as multiplicidades, fraturas e dinamismos presentes nele (Massey 2009: 102). É a tentativa ilusória de tratar as instabilidades e criatividades inerentes do espaço como estabilização, coerência e autenticidade, algo que não raro se encontra em discursos nacionalistas e impositivos. A questão aqui é justamente pensar o contrário: a diferença através da conexão.

Para que isso seja plausível, o primordial entendimento que se deve ter a princípio é que espaço só acontece enquanto produto das relações sociais. Se atentarmos momentaneamente a narrativa exposta linhas acima é possível perceber essa relação com alguma clareza. $\mathrm{O}$ ator em questão poderia facilmente se tratar de qualquer um de nós e, portanto, uma constatação se impõe de imediato: mesmo que sutilmente, você está ajudando a alterar o espaço! $\mathrm{Na}$ medida em que estamos constantemente num processo de estabelecer e quebrar elos - elemento que não só constitui o próprio espaço como você mesmo - estamos modificando esse espaço um pouco. Tal qual nosso "ilustre viajante", não estamos somente cruzando o espaço do ponto de nossa origem - a casa na narrativa - para outro(s) ponto(s) que seriam nosso destino último-momentâneo, pois o bairro que momentos antes foi deixado para trás, em direção à parte central da cidade, já não é mais o mesmo, se alterou. Coisas aconteceram, pessoas sem moveram, pássaros cruzaram a janela, o cachorro fez cocô na sala, o carteiro deixou suas correspondências, a vizinha varreu a calçada e você está em outra parte da cidade. Portanto, uma sucessão de outras coisas esteve em movimento, justamente, enquanto você também estava em movimento. Ao chegar a seu último-momentâneo destino, você, tal qual nosso amigo, associa-se ao sempre "novo" lugar, pois se liga à coleção de estórias entrelaçadas das quais esse lugar é feito, junta os fios de discussões anteriores e atuais, se atualiza dos eventos que aconteceram até sua chegada e também das eventualidades quando não estava ali, estabelece correspondências, e, dessa maneira, tece um sentimento mais ou menos coerente do estar "aqui" e "agora" naquele lugar. 
Em outros termos, você se une às trajetórias que encontrou, tanto as passadas quanto as atuais, e, nesse mesmo processo, se desprende de outras. Assim, mais do que cruzar de um ponto a outro, numa visão linear de espaço, que implica na conceituação tradicional de paisagem, você está se movimentando em termos espaciais e temporais, ou seja, você está viajando através de trajetórias! (Massey 2009: 176). É assim que esse mesmo espaço e lugar que estou me referindo, emergem como portadores de práticas materiais ativas, sendo que o movimento e a construção dessas relações, como diria Massey, toma/leva tempo. O espaço mais do que distância entre pontos é a esfera das configurações imprevisíveis dentro das multiplicidades.

As estórias é que compõem esse "aqui e agora" para os indivíduos envolvidos no processo, algumas vezes traçando limites dentro de sistemas seletivos de filtragem dos significados e efeitos, numa constante renegociação. Essas estórias também são constantemente transgredidas e dessa maneira é que a concepção de "lugar" não pode ser entendida como pontos ou áreas num mapa, mas como o lugar onde acontece a constante emergência da unicidade - o estado único de cada contato -; onde a conjugação de espaço e tempo abrange suas eventualidades - sua propriedade de acontecimento e evento - tornam esse mesmo lugar como aberto. Como um tecer de estórias em processo, um momento dentro das geometrias de poder, uma constelação particular de topografias mais amplas de espaço, um constante processo de fazer-se. $\mathrm{O}$ “aqui", portanto, é onde as narrativas espaciais se encontram ou são configuradas, onde conjunturas de trajetórias que têm suas autênticas temporalidades se imbricam em sucessões de encontros, acumulações e tramas, na mesma medida que desencontros, desconexões e quebras se estabelecem. Todas essas variantes formam uma trajetória. São esses encontros e os retornos que deles acontecem, em diferentes temporalidades, que proporcionam as dadas continuidades num dado lugar. Os retornos, que estão constantemente acontecendo, afinal estamos nos movendo, são sempre para o lugar que se transformou, o sempre "novo", na medida em que variadas encontros são interceptados e afetados reciprocamente nessa tessitura de espaço-tempo, "obrigandonos" a "atualização" do que ora aconteceu. 
Perceber o espaço dessa forma é pensar tempo e espaço como mutuamente imbricados, ambos como produtos de inter-relações, tendo inerentes a questão do movimento em si e a visão de que os lugares mudam e prosseguem sem que você esteja neles. A primeira questão de entendimento, então, é que tanto espaço quanto tempo têm conexões e desconexões, bem como efeitos combinatórios decorrentes disso. Foge-se, assim, da ideia de sociedades e lugares como portadores de autenticidade atemporal, o que implicaria na tradicional concepção de espaço como dividido em uma superfície contínua, lisa e branca, em que um agente ativo encontra os demais lugares simplesmente "lá" e "escreve" sua(s) história(s) a partir disso. É a discordância do aclamado ponto de partida, que se fundamenta na premissa de espaço como um vazio, tendo o "Um" - e somente 1 mesmo - como agente ativo nesse processo que capitaneia o restante a ser construído. Esse é justamente o tipo de concepção científica que implica nas ideias estapafúrdias de que a Europa Ocidental e os Estados Unidos são “avançados”, as outras partes do mundo estão "um pouco atrás" e ainda existem aquelas partes do planeta que "definitivamente são atrasadas". E a lógica de que "eles" estão seguindo o mesmo caminho "nosso", e necessariamente têm de fazê-lo sob os mesmos mecanismos para chegar ao mesmo patamar, e, por consequência, ao mesmo fim. Esse entendimento é exatamente o que refreia a abertura do futuro e a multiplicidade espacial, tendo nessa trajetória única um efeito altamente político, ou seja, o estabelecendo de lideranças nas relações de discurso e disputas de poder. Afirmo ser político, pois é a criação de espaço(s) enquanto uma reconfiguração ativa de encontros e desencontros, através de práticas em relação à enorme quantidade de trajetórias que implica em movimentações nos termos sociais e influenciam as relações de poder. Esse tipo de modelo totalizante é na verdade um projeto que se pretende global, em que necessariamente todas as culturas deveriam se desenvolver para o mesmo fim e isso é científica e culturalmente absurdo! O espaço sempre foi e sempre será interconectado, dinâmico e múltiplo: não há um ponto de partida, muito menos um de chegada!

Não existe um momento sequer na história da humanidade que naturalmente tenha sido único, global e integrado. Apesar de os meios midiáticos atualmente procurarem passar essa ideia, em realidade isso não existe e nem nunca existiu. Mesmo 
as chamadas "Guerras Mundiais" não o foram de fato, pois no momento em que determinados grupos de pessoas e até mesmo países se abstiveram dela, em realidade ela nunca foi global e, sim, setorizada, sendo seus efeitos espalhados a algumas partes da crosta, na mesma medida não afetando outras partes dela. A natureza do mundo, por excelência, é heterogenia, em articulação com constelações temporárias de tempoespaço, sinapses de diversas forças que seguem distintas trajetórias em diferentes velocidades. Isso é o que salienta a multiplicidade inerente ao espaço, não sua eliminação, como haveria de se supor.

Seguindo alguns pressupostos enunciados por Doreen Massey (2009), as "trajetórias" e "estórias" a que me referi simplesmente enfatizam o processo de mudança em um fenômeno. Portanto, os conceitos são temporais em sua ênfase, mas também necessariamente espaciais, pois o posicionamento em relação a outras trajetórias está inseparável e intrínseco a seu caráter. O referido fenômeno pode ser uma coletividade, uma convenção social, uma formação geológica, uma atitude científica. Assim, ambos os conceitos estão fundamentados nas mudanças e nos movimentos inerentes e presentes nos próprios objetos de análise (Massey 2009: 33).

Nesse momento é necessário mais uma observação. Se antes o espaço foi tratado como lugares pré-estabelecidos e "desde sempre" delimitados, atualmente somos apresentados a um "mundo de fluxos". O fato é que não se trata nem de um espaço hermeticamente fechado em territórios fixos, tampouco um espaço composto somente de fluxos, tal qual vejo em alguns trabalhos recentemente. Antes, é na tensão do contato com que cada situação específica é negociada e as diretrizes são estabelecidas. Isso implica dizer que é na questão da negociação que residem os direitos de movimento e direitos de retenção. A delimitação pura ou o fluxo contínuo como fundamento autoevidente não passa de falácia, pois é a multiplicidade do espaço a precondição para o temporal, e as multiplicidades dos dois juntos a condição de abertura do devir (Massey 2009: 132). Em ambos os casos, o de um espaço imaginativo dividido e delimitado e/ou o de um espaço de fluxos sem fronteiras, a questão que se supõe não é tanto a descrição do espaço tal qual ele é, mas sim uma imagem através da qual o mundo está sendo feito e tratado, atendendo às necessidades de sua produção tal qual se apresenta. 
Portanto, o espaço global, como um espaço de maneira mais geral, é em essência produto de práticas de poder material. O que se impõe são as constantes e mutantes geometrias do poder que em todo o momento estão sendo produzidas e negociadas nessa cartografia. Assim, não se trata apenas da abertura e o fechamento, ou mesmo a extensão disso, ou ainda somente as conexões que se estabelecem na formação desse espaço, mas em primeira instância como elas se estabelecem (Massey 2009: 130-131). Espaço é um produto emergente de relações, incluindo essencialmente as que estabelecem limites.

Esse reconhecimento de espacialidade passa, necessariamente, por aquilo que Fabian (1983: 154-155) anunciou como sendo a coetaneidade. Tal qual a concepção do próprio autor, e as premissas de Massey (2009: 109), a existência da coetaneidade implica no entendimento da contemporaneidade como condição para o verdadeiro confronto através do contato, oposição não no sentido de mesmas sociedades em diferentes estágios de desenvolvimento, mas de distintas sociedades e grupos, que se confrontam um com o outro ao mesmo Tempo. Em outros termos, é o reconhecimento que espacialidade envolve a existência de trajetórias que têm algum grau de autonomia em relação a outra(s). O espacial é onde as configurações narrativas potencialmente dissonantes ou concordantes se encontram; os lugares, como focos de encontros e desencontros, ao invés de serem localizações de coerência, são onde o previamente nãorelacionado se relaciona e, assim, essencialmente gera o novo. Em seu papel o espacial traz distintas temporalidades a novas configurações, desencadeia sempre novos processos sociais e enfatiza a natureza das narrativas. Nesse sentido, de interação e processo, atinge a constituição das identidades. Em vez de identidades isoladas, um entendimento do espacial como relacional em conexões nessas identidades.

O espaço, então, implica no acaso, no inesperado. O especificamente espacial é tanto produto desse acaso circunstancial como dos arranjos em relação um ao outro, resultante da existência de uma multiplicidade de trajetórias. As configurações espaciais são um fraturado de contingências em narrativas que de outra forma não conectadas podem ser conduzidas a entrar em contato, e ainda, outras tantas narrativas, previamente conectadas podem ser descartadas. Sem dúvida alguma há um elemento de "caos" nesse 
sentido de entendimento, enquanto da abertura e imprevisibilidade das relações. Entretanto, aquilo que a uns pode parecer caótico e aleatório, a outros pode ser o estabelecimento da ordem.

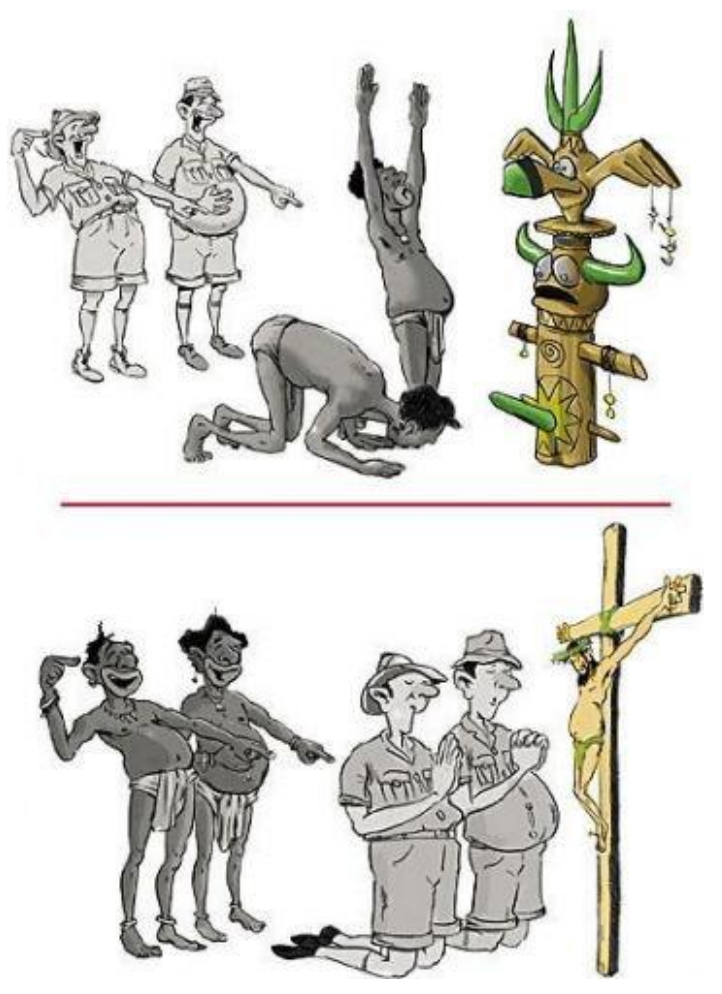

Fig. 31 Charge sobre o estabelecimento de relações.

Porém, é preciso nuançar que tipo de acaso se está evidenciando e nesse sentido ele pode ser tratado como uma "miríade de minúsculas causas que pode contribuir para qualquer acontecimento" (Massey 2009: 171). A relação entre ordem e acaso é parte integrante do processo aberto que caracteriza o espacial; a justaposição no encontro e imbricação e seus, nem sempre previsíveis, efeitos remete ao configuracional. Na ideia de Derrida (1996: 84) esse caos-e-instabilidade é fundamental e irredutível, ao mesmo tempo em que é aquilo que lutamos contra com leis, regras, convenções, políticas e hegemonias provisórias. Nesse sentido, segundo ele, é tanto um risco como uma oportunidade de mudar, de desestabilizar. Se houvesse uma estabilidade contínua, por 
consequência não haveria necessidade de negociação, e estas se mantêm até mesmo porque a estabilidade não é essencial, natural ou substancial.

De fato, se atentarmos brevemente para a aleatoriedade dos movimentos no espaço é possível perceber interessantes analogias ilustrativas para essa ideia. Se tomarmos um conjunto estatístico de pessoas atuando aleatoriamente, frequentemente se apresenta um comportamento tão consistente e em certo sentido presumível, quanto um grupo de pessoas que tenha intenção de atingir objetivos conscientemente. Nesse sentido, Brent Shaw afirma que a "comunicação envolve movimento e conhecimento; conhecimento então provoca e sustenta novo movimento que resulta de novas ideias sobre mais formas em que o ambiente pode ser conectado. Esta mobilidade conectiva é característica de um mundo às vezes surpreendente fixo e imóvel" (Shaw 2001: 424). ${ }^{1}$ $\mathrm{O}$ autor ainda pontua que assim como ocorreu em todo o Mediterrâneo, as microrregiões em si são resultado da interação de longo alcance das forças externas e das forças localizadas internamente que a definiram. As microrregiões seriam também formadas pelas interações cumulativas entre os seres humanos e a maneira com que eles exploraram cada ambiente e local em que viveram.

Einstein em 1905 analisando, sob a ótica da física estatística, um fenômeno chamado movimento browniano, ou como o emprego aqui, movimento randômico, procurou a explicação para esse movimento que acontecia no espaço. A ideia primordial amparava-se nas concepções de Robert Brown, um botânico, que foi o primeiro a fazer uma descrição clara do núcleo celular. Brown observando os grânulos dentro dos grãos de pólen notou que eles pareciam se mover. Numa série de experimentos ele observou que o mesmo tipo de movimento acontecia se ele suspendesse em água - e às vezes em gim - uma enorme variedade de partículas orgânicas, tais como fibras de vitela em decomposição, teias de aranha e até muco. O mesmo pode ser observado em partículas inorgânicas - asbesto, cobre, bismuto, antimônio e manganês. Até notar que o mesmo movimento se estendia também às partículas inorgânicas, Brown achava ter descoberto

\footnotetext{
1 "Communication involves movement and knowledge; knowledge then provokes and sustains new movement that results from novel ideas about more ways in which the environment can be connected. This connective mobility is characteristic of a world that is sometimes still amazingly fixed and immobile".
} 
o movimento da vida, porém, suas expectativas foram frustradas na sequência dos experimentos. Einstein (Brian 1992; Brush 1968) então retomando a premissa de Brown aplicou-se ao estudo do movimento nas moléculas e átomos.

Assim, segundo a Teoria Atômica as moléculas voam pra cá, depois pra lá, seguindo até serem defletidas pelo encontro com outra(s) molécula(s). Esse tipo de trajeto em que a direção se altera aleatoriamente em diversos pontos foi associado ao andar de um bêbado em Mlodinow (2009) e a trajetória do flâneur ${ }^{2}$ em Massey (2009). Em ambos os casos a associação é praticamente a mesma: uma trajetória sem coordenadas espaciais fixas em que não é possível determinar o devir. Embora haja - e de fato há - certa previsibilidade nos comportamentos humanos, eles nunca são prédeterminados, e é nesse o sentido que as figuras aludidas foram usadas, enquanto entidades sem passado ou futuro, sem identidade, somente contingência e indeterminação. Além da questão da identidade que abordo mais abaixo, a imagem do movimento randômico poderia ser questionada em dois pontos. $\mathrm{O}$ primeiro é que as moléculas são leves demais para movimentarem as partículas em suspensão; o segundo é que as colisões moleculares ocorrem com muito mais frequência que as mudanças de direção observadas. Einsten felizmente resolveu a questão e percebeu que esses dois problemas se anulam e embora as colisões ocorram com muita frequência, particularmente em moléculas muito leves, as colisões isoladas não têm efeito visível. Talvez essa tenha sido sua grande descoberta a esse respeito, pois implica compreender que as mudanças de direção que são observáveis só ocorrem quando por acaso, as colisões numa direção particular forem preponderantes. Isso nos leva ao princípio que boa parte da ordem que observamos na natureza esconde uma desordem subjacente invisível que só pode ser nuançada através do olhar sobre a aleatoriedade.

\footnotetext{
${ }^{2} \mathrm{O}$ flâneur seria o que chamaríamos de morador de rua.
} 


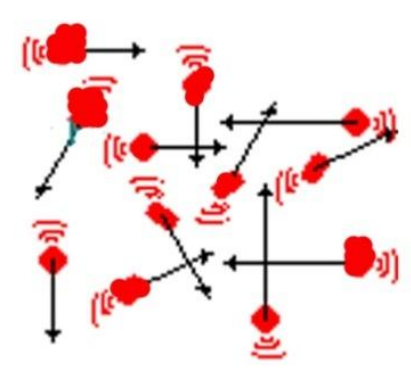

Fig.32 Demonstração do contato de partículas no movimento randômico.

Assim, o movimento randômico tem algumas características particulares que podem servir como figura ilustrativa e não como mero transporte de conceitos da física ao campo social, numa tentativa de buscar "mais cientificidade" ao trabalho. Em realidade a física não detém essa primazia e tampouco é mais científica que outros campos de pesquisa e conhecimento. Deste modo, dentre as características do movimento randômico estão: a) os contatos entre os objetos - sejam moléculas/vidrilhos ou, se o leitor preferir, indivíduos - não têm movimento regular e reproduzível; b) os contatos entre os objetos/indivíduos não têm todos a mesma velocidade; c) os objetos/indivíduos, em seus movimentos, não estão sempre uns junto aos outros; d) os objetos/indivíduos não têm todos a mesma massa; e) para uma possível leitura do movimento, em termos gerais, os contatos entre os objetos/indivíduos têm de ser analisados quanto a suas massas - entenda o leitor como a abrangência do contato - e velocidade. 

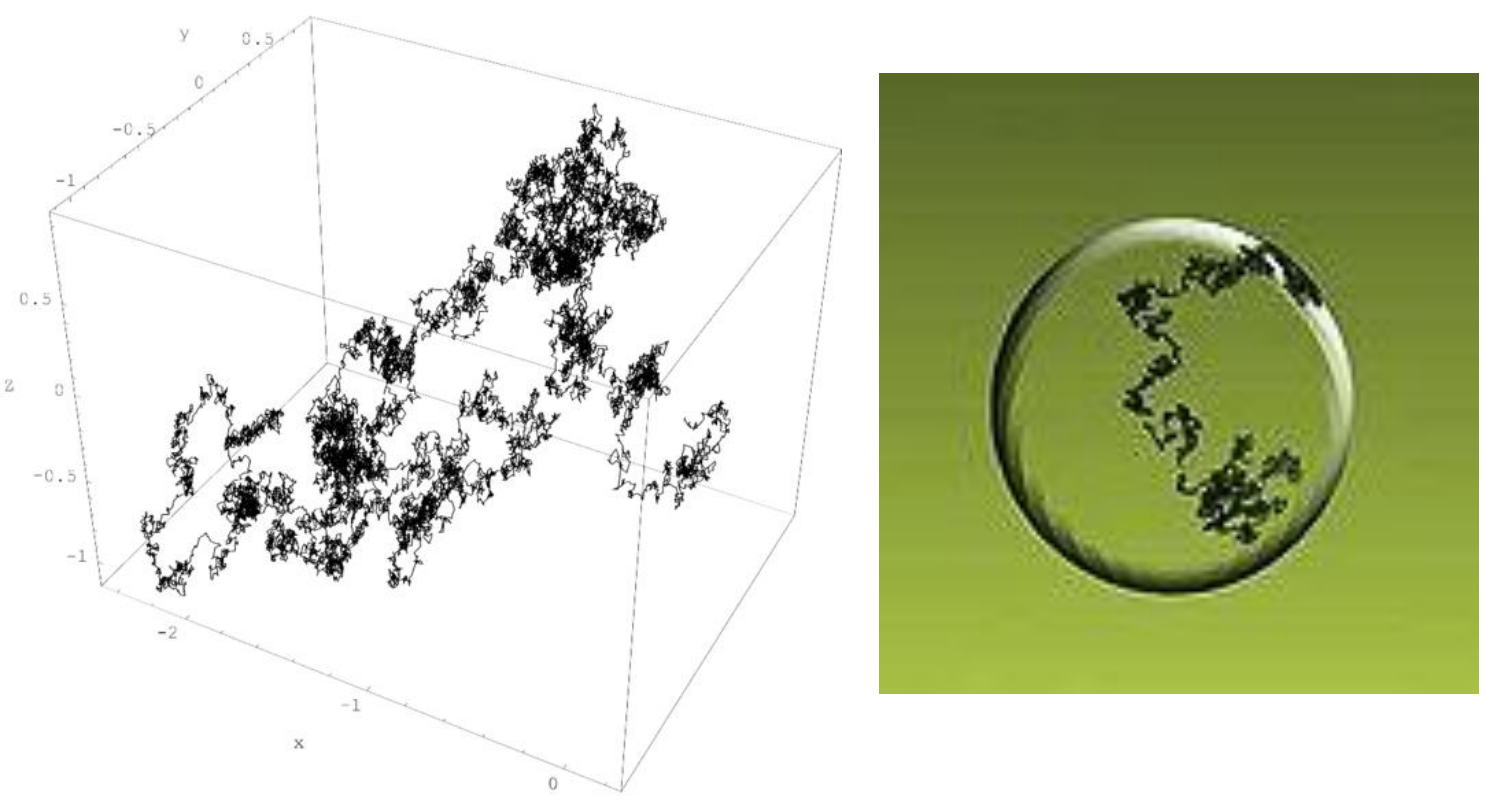

Fig. 33 Modelos computacionais de representação do movimento randômico em que a partir do contato de moléculas o movimento acontece.

Assim, entender o espaço como a esfera da simultaneidade, em que constantemente conexões e desconexões acontecem por novas chegadas, e constantemente há espera pela determinação seguinte, na indeterminação pela construção de novas relações, nos conduz à ideia de que o espaço está sempre sendo feito através desses contatos variados e em velocidades distintas. Esse "sempre" significa que sempre há conexões por serem feitas, justaposições a florescer em interação ou não, elos que se estabelecem ou nunca serão, desconexões, contatos provisórios e malformados que talvez nunca se efetivem. A relação dos contatos pode levar muito tempo ou acontecer em tempos diminutos, sendo contextual por excelência. Igualmente, já que posição/localização é a ordem mínima de diferenciação de elementos na multiplicidade, que é co-formadora do espaço, então, poderíamos fazer a leitura de que as áreas do gráfico em que estão mais agrupados os pontos, por consequência áreas mais escuras - como que borrões -, representariam lugares de maior contato entre os indivíduos. As inumeráveis trajetórias temporárias, nas eventualidades que são os lugares, requerem a negociação que fomenta espaços. 
A negociação e contestação cotidianas de um lugar não implicam necessariamente na contestação coletiva e consciente das identidades. Porém, na medida em que funcionam em distintos lugares, não são de forma alguma insignificantes. É na formação de diferenciadas práticas de negociação e contestação cotidiana dessas práticas que também as identidades estão sendo constituídas e continuadamente moldadas. Determinado lugar nos modifica, não por um pertencimento visceral, mas através da prática do lugar, da negociação das trajetórias que ali se intersectam, tendo inerente às relações da alteridade assimiladas ou não.

À medida que cada indivíduo é um único ser e está constantemente produzindo algo novo, as negociações são sempre invenções que passam por julgamentos, aprendizagem, improvisações, e dessa maneira, estamos sempre construindo espaços e lugares, consequentemente. As coerções temporárias das articulações de relação, os fechamentos parciais e provisórios, as práticas repetidas que indicam caminhos, tornamse impregnadas de noções de discurso e identidade (Massey 2009: 248). O espaço é a condição tanto da existência da diferença quanto do próprio encontro delas.

Assim, o entendimento de espaço, que implica em movimento, que procurei delinear até aqui passa por três entendimentos básicos, ora sumarizados ao leitor: o primeiro é o reconhecimento de que o espaço é produto das inter-relações, constituído através de contato e interação, desde a imensidão do global até o intimamente pequeno; o segundo é que se trata da esfera da possibilidade, da existência da multiplicidade, em uma pluralidade contemporânea, onde distintas trajetórias coexistem, assim, é por excelência, a instância de coexistência da heterogeneidade; e terceiro, o espaço está num constante tornar-se, exatamente porque é produto de relações-entre, imbuídas em práticas materiais que devem ser efetivadas, nunca fechadas, nunca lineares, nunca em branco. O espaço, portanto, é uma simultaneidade de estórias-até-agora (Massey 2009).

Se espaço é uma simultaneidade de estórias-até-agora, então os lugares são coleções dessas estórias, articulações dentro das mais gerais geometrias de poder, tendo em seu caráter as sinapses de cada cenário e aquilo que deles é feito. Desta feita, o espaço não existe antes das identidades/entidades, que aqui poderiam ser vistas como 
cada ponto/molécula/indivíduo, em constante contato, tal qual ilustrei a respeito de movimento randômico poucas linhas acima. O presente - seja ele em que tempo for não é uma espécie de fim acabado, portanto, e tudo está num constante movimento (de maior ou menor densidade), até os continentes naturalmente deslizam alguns centímetros por ano. É assim que de maneira geral, as identidades/entidades e a relação delas com a espacialidade são elementos co-constitutivos entre si e nunca dados prontos e monolíticos.

Diante do exposto, emerge a necessidade de pensar em termos de conjuntura. Pensar conjunturalmente sugere um ir-e-vir entre diferentes molduras temporais e distintos processos que parecem habitar o mesmo momento no tempo. Trata-se, tal qual Massey (2009: 128) sugere, de focar “um lócus de geração de novas trajetórias e novas configurações". Nesse sentido, Apollonia foi o objeto deste estudo e tem muito a contribuir além deste trabalho nos termos ora anunciados. É dessa forma, como propus no capitulo anterior, que a conjuntura/contexto de Apollonia sugere outro tipo de explicação a respeito do fenômeno específico de quebras de lamparinas romanas discus. Como o leitor deve ter notado no catálogo apresentado nessa dissertação, três são as formas intencionais identificadas para execução dessa fissura: a quebra percussiva direta; a quebra percussiva facetada e a quebra percussiva em esquadro. É conveniente salientar que para as duas últimas quebras algum tipo de instrumento provavelmente foi usado.

Através da publicação de Mordechai Avian (2004) nota-se o mapeamento dos lugares que seriam judeus, cristãos e pagãos na Galiléia. Como boa parte dos vinte e três sítios comparativos arrolados nesse trabalho está disperso por essa região, é interessante fazer alguns apontamentos. Entretanto, antes de prosseguir com as observações comparativas nos mapas de Avian e dos apresentados por este trabalho, se faz necessário alguns esclarecimentos, de acordo com o que até o momento procurei apresentar ao leitor como modelo teórico-interpretativo.

Um mapa, assim como uma representação, é elemento seletivo. Na medida em que representação sempre forma ícones, muitas vezes é compreendida como pura espacialização. Através de códigos, convenções, procedimentos organizativos e 
taxonômicos, os mapas constantemente são usados como uma ferramenta para o exercício do poder. Mapas dão a impressão de que o espaço é uma superfície completamente horizontal onde todos os pontos já estão previamente interligados "desde sempre", algo que procurei descontruir junto com o leitor linhas acima. Portanto, apesar de apresentar mapas aqui, o mapa em si, como toda certeza não é um espaço! Assim, não é minha intenção apresentar sincronias coerentes. Contudo recorro a esses para dar uma imagem a respeito do que venho falando, sem ter em mente qualquer representação pura e simples. Da mesma forma que espaço, os mapas são uma tentativa de construir uma sociedade e não declarar o que ela é (Laclau 1990: 82). Laclau apresenta a crítica de que se os mapas e o espaço forem tratados dessa forma, como pura representação, então estes são meramente miméticos e não constitutivos. Visto dessa forma, o espaço passa a ser irrepresentável em si, definido como sem temporalidade, parado no tempo, e não atenderia ao uso que o próprio conceito de representação se propõe. Portanto, o que chamaria de representação aqui, a princípio, trata-se de um elemento em produção contínua, um constante devir. Essa concepção inicial agrega texto e mundo, entendendo-os apenas como uma prática, um engajamento inserido no contexto do qual faz parte, não simplesmente o "representando", mas também experenciando-o (Massey 2009: 54). 


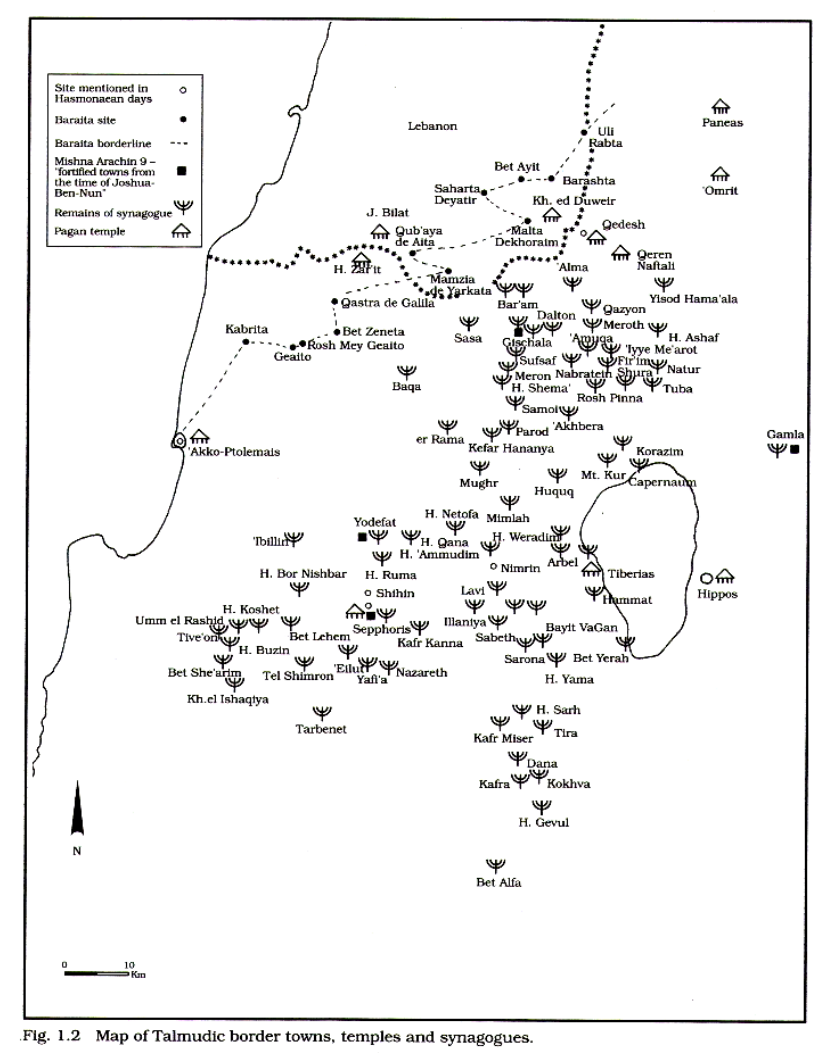

Fig. 34 Mapa dispersão vestígios sítios judaicos na Galileia.

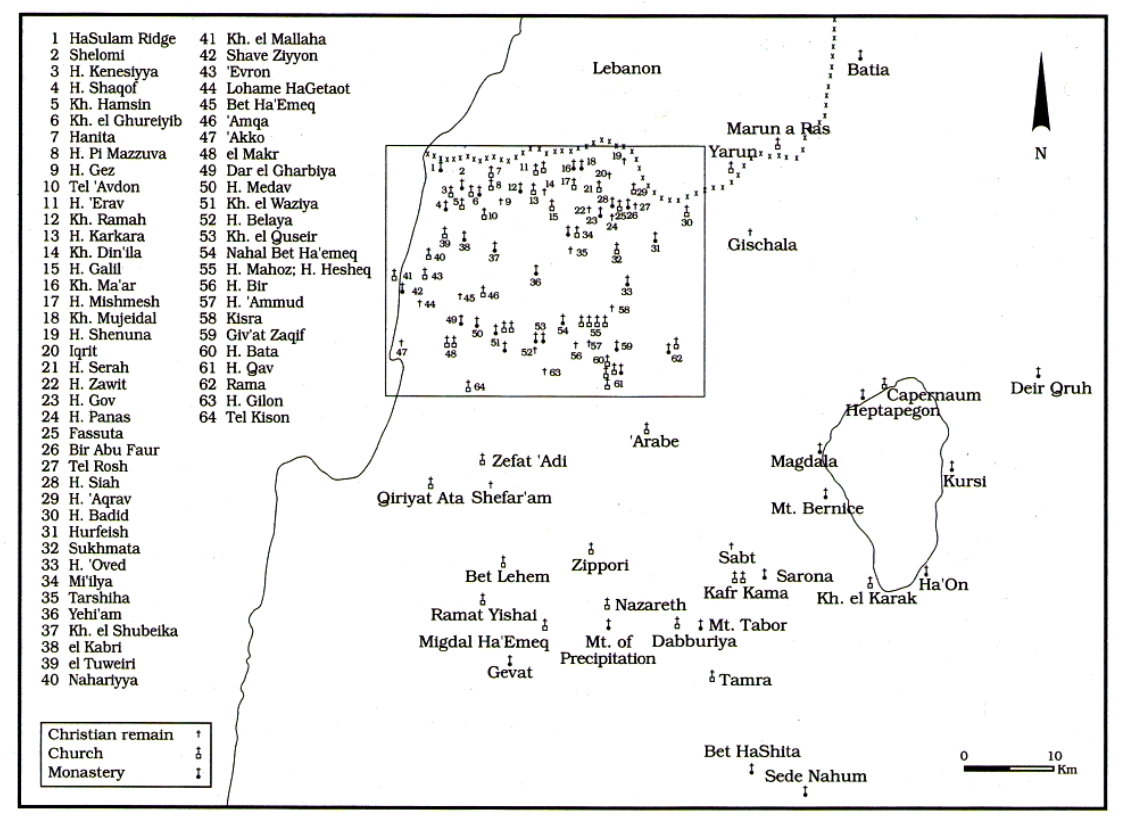

Fig. 1.10 Map of Christian sites.

Fig. 35 Mapa vestígios cristãos na Galileia. 


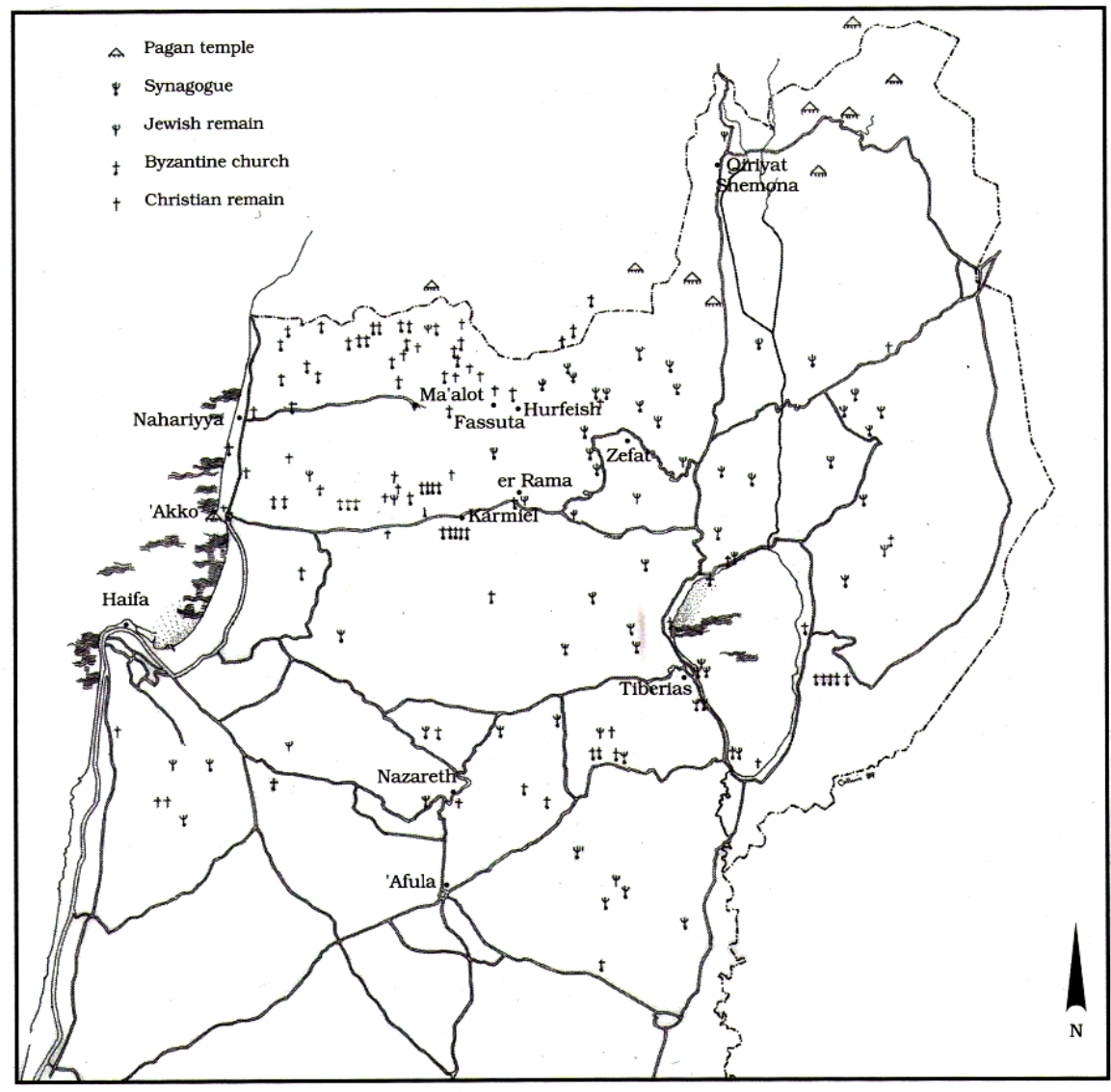

Fig 17.25 Distribution map of Christian and Jewish sites in the Galilee.

Fig.36 Mapa distribuição vestígios cristãos e judeus na Galileia.

Voltando nossa atenção para os mapas acima expostos é possível notar que praticamente não existe uma sobreposição de lugares para as lamparinas romanas discus quebradas, as lamparinas herodianas e as lamparinas samaritanas, salvo algumas exceções. As áreas onde aparecem as lamparinas herodianas correspondem às áreas onde se evidenciam as comunidades judaicas nos mapas de Avian e a incidência das comunidades cristãs do mapa de Avian são condizentes com os sítios que apresentam lamparinas romanas quebradas (compare os mapas com os do fim desse capítulo). Essa alusão conjugada ao contexto de Apollonia apresentado no capítulo anterior conduz à possibilidade interpretativa de que seriam cristãos e/ou judeus-cristãos que estariam praticando esse tipo de quebra, não outros grupos como fora sugerido por outros autores já mencionados anteriormente (cáp.4). 
A quebra também não pode ser atribuída aos samaritanos, pois conforme observa Sussman (1983), os samaritanos tinham esse costume para lamparinas que não possuíam qualquer tipo de iconografia e vinham "seladas". A produção também lhes é característica, peculiar, e a área de dispersão das lamparinas samaritanas não é a mesma que a das romanas provinciais discus (vide mapas no fim deste capítulo).

O fato de quebrarem lamparinas com iconografia alusiva à religião tradicional romana não passou sem significado, pois aquilo que foi, eventualmente, reprimido não permanece no inconsciente, antes, precisa ser expandido, reaparecendo então sob forma de sintomas, ou representações do reprimido, enquanto substituições para a gratificação instintiva não atingida. Os sintomas que são decifrados em sua linguagem simbólica, implicam na prática de conflito ou desejos inconscientes.

O mundo tal qual se apresenta a nós é apreendido, ao contrário do que poderíamos cogitar, não por categorias de adição, ou seja, somando os dados da percepção segundo as semelhanças, mas o é pela submissão dos dados da experiência às categorias mais gerais do entendimento. Procedemos, agrupamos e adicionamos tais dados porque somos orientados por operadores lógicos tanto universais como de contingentes. Todos os nossos pensamentos, experiências e imaginação estão orientados por esses conceitos fundamentais, são esses que delimitam nosso campo de ação. Quando tentamos fugir desses, tornamo-nos estranhos aos outros e a nós mesmos, pois perdemos a competência do nos reconhecer e nos comunicar. Pensamos por conceitos, por modelo de representações, e assim agimos.

O símbolo desempenha um papel importante em toda sociedade, sua função essencialmente é "transformar um objeto ou ato em algo diferente daquilo por que este objeto ou ato são tidos na experiência profana". Na experiência cotidiana, seja para a construção de identidade, reforço da delimitação de semelhanças e diferenças dos grupos sociais, ou consolidação de ideias pretendidas, a existência e/ou supressão de ícones é conditio sine qua non da alteridade.

Para Cuche (2002: 176), a cultura em grande parte depende de processos inconscientes, enquanto a identidade remete a uma norma de vinculação, 
necessariamente consciente, baseada em oposições simbólicas. A cultura é um sistema partilhado de representações, que fornece categorias básicas que organizam ideais e valores (Woodward 2003: 41-42). Portanto, a identidade social de um indivíduo se caracteriza pelo conjunto de suas vinculações em um contexto social, que permite que esse indivíduo se localize e seja localizado socialmente. A identidade social, ao mesmo tempo, inclui e exclui, identifica um grupo e o distingue de outros (Cuche 2002: 177).

Assim, a identidade como uma construção social, e não um dado acontece no interior de contextos que delimitam a posição de seus atores, orientando representações e escolhas. Esses fenômenos têm eficácia social e produzem situações sociais (Cuche 2002: 182). Exatamente por isso que o espaço, bem como o lugar, sendo entendidos como relacionais, são o estabelecimento do real e a multiplicidade "interna" de uma identidade social reflete a multiplicidade "externa" das relações entre corpos dos atores. Em outros termos, a construção da identidade é tanto simbólica quanto social, e as lutas para afirmar as diferentes identidades têm causas e consequências materiais, como diria Woodward (2003: 10). Ainda conforme esse autor, as identidades tomam sentido a partir dos sistemas simbólicos e linguagem em que elas são apresentadas. Entretanto, como observa Chuce (2002), nem todos os grupos têm o mesmo poder de se nomear e nomear os outros. Até mesmo por este fato que nenhum grupo ou indivíduo está preso a uma identidade unidimensional, tendo a possibilidade da pluralidade de referências identitárias (Chuce 2002: 185-186). Nesse sentido, não passa despercebido todo o esforço que o cristianismo em seu momento inicial procurou empreender na consolidação de sua identidade face os grupos de contato. A respeito disso discorri no capítulo 2.

A identidade não existe sem as estratégias de afirmação dos atores, num constante processo de construção, desconstrução, sinapses e simbioses em um movimento randômico de contato que conduz a constantes reformulações e busca de novos posicionamentos. Junto de uma relação de identidade está uma série de restrições sobre os papéis que devem ser assumidos, além de parceiros e negócios a escolher. Essa questão envolve a aceitação no interior de um grupo mediante a submissão às regras e disposições que estipula o dado grupo em si (Barth 1998: 198-199). Trata-se, assim, de nuançar os limites entre "eles" e "nós", demarcar e manejar as fronteiras simbólicas 
entre o que um grupo pretende distinguir e o que os "outros" intentam designar sobre o grupo, que depende da força desses conjugados em negociação.

As identidades cambiantes e diversas contidas nos sistemas simbólicos e contextos sociais em que são vividas seriam os instrumentos com os quais os atores recebem sentido de suas próprias posições (Woodward 2003: 33). Essas posições e câmbios dependem do lugar em que cada ator social está localizado e os contextos específicos que podem orientar, justamente, a tomada dessas posições. Portanto, são as situações relacionais, que quase nunca são estáveis, que também estão sujeitas à mudança. Assim, mesmo tratando de cristianização dos espaços, isso não implica que não houvesse judeus não ortodoxos e samaritanos também praticando o mesmo ato simbólico, compartilhando, assim, identidades cambiantes.

Ambos os processos, o simbólico e o social, são necessários e a marcação simbólica é o meio no qual as práticas e as relações de contato recebem determinados sentidos sociais, onde também se define quem é excluído e quem é incluído. Nesse sentido os discursos e práticas são, por um lado, os indivíduos e grupos assumirem lugares como sujeitos de discurso, e por outro, contribui ativamente para a constituição de suas próprias subjetividades (Hall 2003: 111-112). Como bem observa Gilvan V. da Silva, essa relação com a identidade não escapa da ampla disputa pelos recursos simbólicos e materiais da sociedade (Silva 2003: 81).

Portanto, a supressão do repertório iconográfico das lamparinas romanas de Apollonia aponta para o que denominei de processo de "cristianização dos espaços", sendo definido como um tipo específico de representação, no sentido de uma matriz de discursos e práticas diferenciadas que tem por objetivo a construção do mundo social e a definição contraditória de identidades. A representação como experiência traz a si a capacidade de produzir significados, sendo a adequação entre aquilo que se pretende exprimir e o contexto cultural inserido. Uma representação, tal como está apresentada em Geertz (1989) sempre será mais eficaz na medida em que sua competência em eleger símbolos for maior, conseguindo decodificar os acontecimentos sociais ou ideias pretendidas de uma forma aceitável e inteligível para os indivíduos envolvidos nesse 
processo. Nesse caso o símbolo pode ser "qualquer objeto, ato, acontecimento, qualidade ou relação que serve como vínculo a uma concepção", sendo a concepção o "significado" do símbolo (Geertz 1989: 105).

Segundo Mircea Eliade, ao manifestar o sagrado um objeto qualquer se torna outra coisa, ao mesmo tempo que continua a ser ele mesmo, pois segue participando do meio cósmico envolvente (Eliade 2001: 18). René Girad (1998) pertinentemente lembra que o sagrado é em grande medida sacrifical, pois é a morte real ou simbólica que sacraliza o objeto expiatório, distanciando-o do mundo cotidiano. O autor argumenta que a articulação de diversos fenômenos sociais opera através da íntima relação do sagrado com a violência. Nas suas palavras: "a violência que constitui o verdadeiro coração e alma secreta do sagrado" (Girad 1998: 46). Assim, violência e o sagrado são inseparáveis. O sagrado seria a ferramenta reguladora da qual os grupos lançam mão para evitar a violência generalizada. É sem dúvida alguma um tipo de controvérsia, pois é a violência do sacrifício que - o leitor entenda também a quebra das lamparinas nesse caso - além de produzir o sagrado, também sacraliza a própria ação violenta que passa a ser considerada purificadora (Girad 1998: 384). Girard argumenta que nos rituais a violência do sacrifício produz o sagrado e sacraliza a violência, transformando-a em elemento purificador e expulsando a impureza profana. Isso, portanto, tal qual uma falácia, diferencia a violência legítima da ilegítima, impedindo a contestação que poderia incorrer num ciclo vicioso de vingança. Diante de uma crise de perigo que ameaça destruir a comunidade, argumenta o autor, aparece o ritual com a função de purificar a violência, enganá-la, dissipá-la sobre vítimas que não possam ser vingadas (Girad 1998: 52). Não foi o objetivo deste trabalho tratar especificamente das ondas de perseguição aos cristão, mas lembre o leitor que entre o século II e III os cristãos sofreram violentas ondas de perseguição pelo Império Romano.

Aldo Natele Terrin (2004) salienta que o rito cumpre uma diversidade de âmbitos: psicológico, sociológico, linguístico, antropológico, histórico religioso, fenomenológico, teológico, etnológico e biológico. O rito, então, coloca ordem, classifica, estabelece as prioridades, emprega sentido do que deve ser importante e do que é secundário. É ele o responsável pela proporção de "mundo organizado" para 
aqueles que dele participam, fugindo do caótico, permitindo "sentir-se em casa", num mundo, que é justamente o oposto dessa suposta estabilidade (Terrin 2004: 19).

Além da questão ritualística do sagrado, a prática da quebra das lamparinas discus também está inserida nas relações de lembranças e esquecimentos que Andrew Jones (2007) discorreu afirmando que mais “(...) do que a simples construção ou destruição de artefatos pode-se criar ou destruir memórias, por outro lado, fazer um artefato ou monumento pode excluir memórias, são brechas na lembrança. Igualmente a destruição de um artefato ou monumento deixa marcas, levando consigo memórias de eventos passados. Essa perspectiva é encorajadora, pois traz consigo um grande problema porque encaminha para a questão mais ampla de como nós investigamos as relações entre cultura material e memória" (Jones 2007: 40). ${ }^{3}$ Corroborando essa assertiva, Hodder (1985) afirma que: “o sentido prático de um item da cultura material varia de acordo com o contexto em que ele é usado, embora (...) o uso de um item em um contexto não é seja independente de sua utilização em outros. (...) O efeito evocativo de um símbolo material depende do contexto e do modo que esse mesmo item pode ser visto a partir de contextos diferentes, ao mesmo tempo. Cada pessoa traz uma compreensão individual, um sistema específico de enfrentamento para a percepção e utilização de cada artefato. (...) A ambiguidade é, portanto, uma parte necessária e central do processo simbólico. Sem ela, os indivíduos não poderiam, de seus diferentes pontos de vistas, concordar ou discordar, eles não poderiam ser competentes (ou incompetentes) atores sociais, e não poderiam mudar o mundo social, alterando o mundo material" (Hodder 1985: $14-15)^{4}$

\footnotetext{
3 “ (...) the simple construction or destruction of artifacts can create or destroy memory, on the other hand, making an artefact or monument can leave out memories, there are gaps in remembrance. Similarly, the destruction of an artefact or monument leaves residue, carrying with it memories of past events. This perspective is encouraging because it addresses the wider problem of how we investigate the relationship between material culture and memory."

4 "The practical meaning of an item of material culture varies according to the context in which it is used although (...) the use of an item in one context is not independent of its use in others. (...) The evocative effect of a material symbol depends on context and the same item may be viewed from different contexts at the same time. Each person brings an individual understanding, a particular coping system to the perception and use of each artefact. (...) Ambiguity is thus a necessary and central part of symbolic process. Without it, individuals could not, from their different standpoints, agree to differ, they could not
} 
Assim, para o cristianismo a quebra da iconografia contida nas lamparinas discus poderia ser vista como uma sacralização, uma "conversão" da peça, pois conversão no cristianismo agrega apropriar, mudar o sentido, o caminho. Diferentemente das orientações das Mishnás como vimos. Ao refutar o ídolo, ele podería estar perto da área de descarte, afinal de contas "ele foi vencido", a idolatria foi banida e a peça agora serve a novo propósito. Desta maneira, se explicaria encontrar em Apollonia os fragmentos da parte central do discus no sítio, indicando que a prática foi realizada ali mesmo. Mais interessante é notar a peça "b" da prancha 62. Uma pequena parte central de uma lamparina romana que foi facetada intencionalmente, "apagando" as feições humanas que ali estavam.

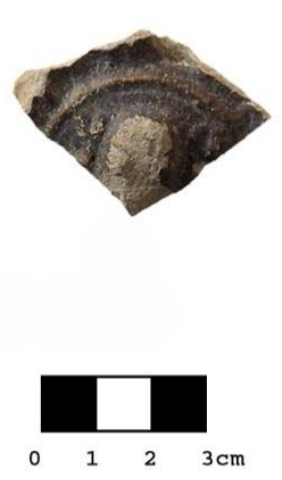

Fig. 37 Imagem "b" da prancha 61.

Esse fenômeno iconofóbico esteve presente em quase todas as manifestações de um cristianismo emergente que buscava espaço. As 293 menções ${ }^{5}$ a essa temática nos escritos dos séculos II e III não deixam dúvidas a esse respeito. Convém lembrar ao leitor outra vez, a título de exemplificação, a admoestação do ensino dos doze apóstolos que diz: "Cuida da segurança de tua vida. Não deixes tuas lamparinas serem apagadas, nem teus lombos frouxos; mas está pronto, pois não sabes a hora em que

be competent (or incompetent) social actors, and they could not change the social world by changing the material world."

${ }^{5}$ Vide tabela de referências em anexo. 
nosso Senhor virá. 2. Mas, frequentemente, vós deveis unir-vos, tu deves unir-te, buscando as coisas que são condizentes com vossas almas: para que pois todo o tempo, todo de tua fé, não te será de proveito seja aproveitado em vão (...)." (The Teaching of the Twelve Apostles, vol. 7, cap. XVI: 570) ${ }^{6}$. Longe de ser entendida como algo meramente espiritual a advertência para ter "lamparinas acesas" era algo real, físico e material, pois o messias poderia chegar a qualquer momento. A lamparina no cristianismo inicial é, portanto, um elemento extremamente importante, participando ativamente das relações votivas e da compreensão affidavit veritas a que o cristianismo se propunha. Trata-se de um elemento ativo da cosmovisão cristã e a parábola das dez virgens - em que cinco loucas não preparam suas lamparinas - é a égide de cinco virgens prudentes e preparadas para seu encontro com o “senhor” (Mt 25:1-13).

Digna ainda é a menção à “oração da lamparina" presente nas "Elucidações” de Clemente de Alexandria. O antigo cântico, segundo o autor, não era litúrgico, e o mesmo se referia a ele como "o cântico noturno dos cristãos gregos", , porém, não era destinado somente aos gregos - como o próprio autor referencia -, mas a todos os crentes e credos. O nome mais popular do hino era "O cântico do entardecer" cântico da lamparina acesa"" . O mesmo cântico também seria utilizado no âmbito das refeições noturnas, quando se rendiam graças antes das ceias, e assim entoavam:

"Luz serena da Santa Glória
Do Pai Eterno, Jesus Cristo:
Venha para ver o pôr do sol,
e vendo a luz da noite,
nós louvamos o Pai e o Filho,
e o Santo Espírito de Deus.
A Vós é dado o louvor,
Sempre com cânticos sagrados,
Filho de Deus que deu Sua vida,
Assim, o mundo Te glorifica."

\footnotetext{
6 "1. Watch for your life's sake. Let not your lamps be quenched, nor your loins unloosed; but be ye ready, for ye know not the hour in which our Lord cometh.2. But often shall ye come together, seeking the things which are befitting to your souls: for the whole time of your faith will not profit you (...).”

7 "The Evening Hymn of the Greek Christians".

8 "The Eventide Hymn".

9 "The Hymn for the Lighting of the Lamps".
} 
(Clement of Alexandria, Elucidations, vol.2, III: 483-84) ${ }^{10}$

Conforme pontuei no capítulo anterior, Apollonia parece ter sido um importante centro cristão durante o século III d.C., tendo um bispo contado entre os primeiros líderes da igreja. Talvez o início do processo de cristianização e, por consequência, o estabelecimento de Marcos, primo de Barnabé, como o responsável da congregação ali presente, tenha relação com a passagem de Atos dos Apóstolos 10:1-30. Nesse relato, Pedro, o apóstolo, é procurado por dois empregados e um soldado, que serviam a Cornélio, um centurião romano, e sua família. Cornélio residia em Cesareia e enviou seus mensageiros a Jope, à casa de Simão, o curtidor, "que vive perto do mar" (v. 6). O proselitismo relatado demora cerca de quatro dias, sendo que depois da conversão de Cornélio, Pedro é convidado a permanecer alguns dias com eles. Interessante é que Cornélio dá ordens de partida aos mensageiros às três horas da tarde e o texto na sequência afirma que: "no dia seguinte, enquanto eles estavam a caminho e se aproximavam da cidade, ao meio dia Pedro subiu ao terraço para orar; (...) neste momento os homens enviados por Cornélio perguntaram pela casa de Simão e se apresentaram à porta (...)” (v. 10-17). O trajeto foi percorrido em 19 horas, sendo que a distância entre as duas cidades é de $51 \mathrm{~km}$. Assim, fica subentendido que os emissários pernoitaram em algum lugar: Apollonia que está a $17 \mathrm{~km}$ de Jope e $34 \mathrm{Km}$ de Cesareia.

Encontrando Pedro em Jope o texto afirma: "No dia seguinte, Pedro partiu com ele e alguns irmãos de Jope o acompanharam. E no outro dia chegou a Cesareia”" (v. 2324). Note o leitor que esse eventualmente pode ter sido o ensejo em que Pedro, junto com

\footnotetext{
${ }^{10}$ HYMN.

Serene light of the Holy Glory

Of the Father Everlasting,

Jesus Christ:

Having come to the setting of the sun,

And seeing the evening light,

We praise the Father and the Son,

And the Holy Spirit of God.

It behooveth to praise Thee,

At all times with holy songs,

Son of God, who hast given life;

Therefore the world glorifieth Thee.
} 
alguns congregados, tenha iniciado os contatos de cristianização em Apollonia, pernoitando no lugar. $\mathrm{O}$ relato ainda desperta outra interessante correlação a respeito da identidade e relação entre judeus e cristãos. O texto diz que Pedro afirmou "Vocês sabem que é proibido para um judeu relacionar-se com um estrangeiro ou entrar na casa dele. Deus, porém, mostrou-me que não se deve dizer que um homem é profano ou impuro. Por isso, sem hesitar, eu vim logo que vocês mandaram chamar (...)” (v .28-29). A distinção de puro e impuro no judaísmo ortodoxo não se restringia somente aos objetos, mas também às pessoas. Contudo, essa relação indica ter sofrido mudança no desenvolvimento do cristianismo, sendo que Pedro considerava-se um judeu cumpridor das ordenanças, chegando a afirmar antes do encontro com Cornélio: "De modo nenhum, Senhor! Porque eu jamais comi coisa profana e impura! A voz lhe disse pela segunda vez: 'Não chame de impuro o que Deus purificou,'” (v. 14-16). Veja, então, que acima da relação de puro ou impuro - que continuará firmemente presente no ideário cristão - a questão da “conversão" se sobrepõe às demais. Portanto, é impreterível a conversão, tanto de pessoas, como no caso de Cornélio, quanto de objetos, como no caso das lamparinas. A questão de "converter", como ora expus anteriormente, atende não somente à restrição de puro/impuro, mas ao imperativo da mudança de modalidade e estado. "Converter" é, portanto, no cristianismo a ação de mudar de direção, mudar de sentido, no caminho oposto ao que antes era comum. Através desse entendimento, é possível explicar a presença de inúmeras lamparinas romanas em sepultamentos.

$\mathrm{Na}$ caracterização dos sepultamentos em cavernas onde as lamparinas aparecem, estas, em linhas gerais, são atribuídas como judaicas, e possivelmente o são mesmo, contudo, note o leitor que o processo de cristianização do qual estou tratando, para o período em questão, não atribui distinção completa do "ser judeu". Basta apontar que Pedro na passagem acima se identifica como um, assim como Paulo e, certamente, muitos outros nesse período do movimento. Como observei no capítulo dois não é possível tratar do cristianismo como se fosse uma coisa só nesse momento, mas como muitos movimentos e contatos que no desenvolver dos séculos foi sendo "lapidado" pelas disputas internas de grupos e correntes de pensamento. É justamente por este fato que quando trato de cristianismo o associo como uma matriz representativa que tem 
suas lógicas internas de disputa de poder, discursos e práticas diferenciadas que objetivam a ordenação do mundo social e a definição contraditória das identidades.

Assim, não seria estranho que os sepultamentos em caverna tivessem todos os elementos de um sepultamento eminentemente judaico. Entretanto, estou inclinado ao pensamento de que lamparinas romanas discus possam ser um dos diferenciais que distinguiam exatamente judeus ortodoxos de judeus helenizados, judeus-cristãos ou simplesmente cristãos sem origem judaica. A presença de sinos em alguns desses sepultamentos poderia ser indicativo colaborativo dessa questão, sendo que esse elemento não é associativo, usualmente, dos contextos de sepultamento de judeus ortodoxos.

Na caverna de Sajur a presença de um sino, lamparinas discus quebradas e um anel com símbolo de um leão pode indicar um contexto elucidativo nessa questão. $\mathrm{Na}$ localidade, a existência de pagãos, judeus e cristãos, é indicada pelo autor (Braun et al. 1994: 111). O leão foi associado à figura de Jesus como sendo ele próprio "o leão da tribo de Judá”.

Em Ginnegar ou Ginosar, na região da Alta Galileia, mais uma vez a associação de lamparina quebrada e sino é constatada (Oshri, Najjar 1997: 51-52). Shoham e Horbat Zikhrim são outros dois exemplos que podem ser referidos. Em Shoham dois sinos de bronze do período Bizantino (século V e VI d.C.) estão associados a lamparinas discus quebradas. Já em Horbat Zikhrim o sino tem datação do século III d.C.

Ainda os sítios de 'Ein Ez-Zeituna, Ha-Horesh e Ha-Emeq poderiam contribuir para a ideia de que nessas outras localidades são judeus-cristãos ou simplesmente cristãos que estão praticando a "conversão" das peças. O sítio de 'Ein Ez-Zeituna está relacionado muito mais em relação a sua cronologia e por ser um sítio com contexto doméstico não associado a judeus ortodoxos e ocupado somente durante o período do século II d.C. Assim, é possível afirmar com certo grau de segurança, como acima já o fiz, que as lamparinas romanas discus passam a circular a partir de 135 d.C., sendo um fenômeno característico provavelmente da segunda metade do século II d.C., que se estende durante todo o século III d.C. Já os sítios de Ha-Horesh e Ha-Emeq relacionamse por serem dois cemitérios de população mista. Nas proximidades de Ha-'Emeq, 
extremo oeste de Nazaré, foram encontrados vestígios de igrejas cristãs em Ramat Yishai e Belém; já em Ha-Horesh a ocupação teria um lapso temporal entre meados do século II d.C. e sua reutilização em século III d.C., que foi explicada por uma primeira ocupação de judeus e, posteriormente, outras ocupações. A evidência de outras ocupações é dada por uma lamparina que contém praticamente as mesmas características estilísticas das romanas provinciais discus, contudo, seu orifício de alimentação é amplo, como "se já estive quebrada" (vide figura abaixo).

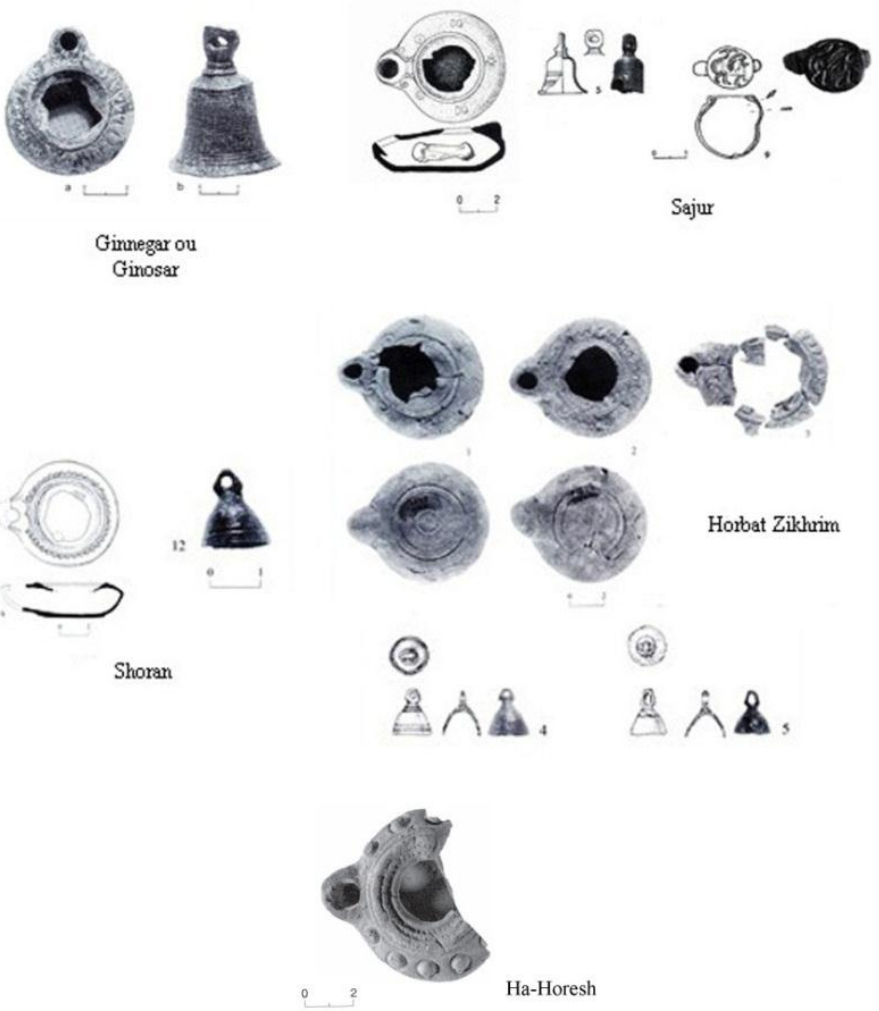

Fig. 38 Lamparinas e Sinos de Ginnegar/Ginosar; Sajur, Shoran e Horbat Zikhrim.

A guisa de conclusão, dois pontos merecem atenção especial. O primeiro é em relação à ocupação e abandono de Apollonia em período romano e o segundo diz respeito à memória do sítio.

O desabamento particularmente grave da metade sul da edificação, causado possivelmente pelos abalos sísmicos de 115 d.C. ou 127 d.C., segundo a concepção de 
Roll (2003: 167) teria levado ao abandono do prédio e o autor atribui a formação das camadas romana 1 (Rom.1) e bizantina ao descarte das edificações que estariam na parte superior do platô de kurkar, correspondente à área $\mathrm{P}$. Ainda segundo a ideia de Roll o descarte aconteceria pelo arremesso de numerosas cerâmicas da parte mais alta para a mais baixa do sítio (área $\mathrm{E}$ - Villa marittima).

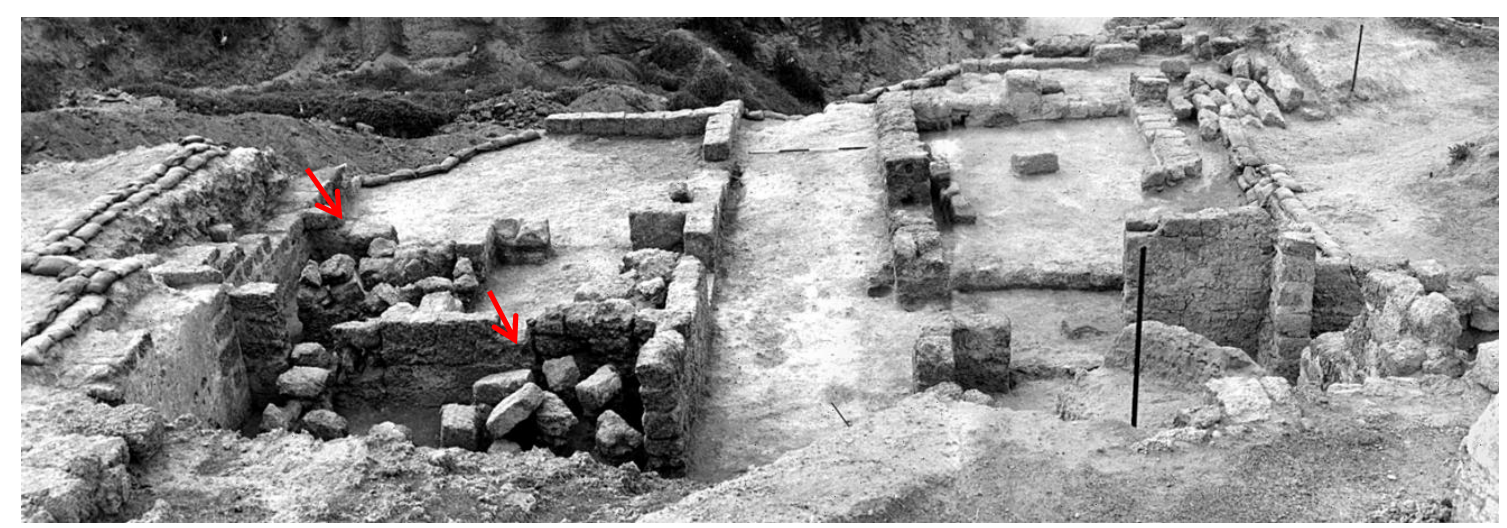

Fig. 39 Indicação do desabamento causado pelo terremoto na ala sul da edificação.

Analisando a ideia com mais cuidado e observando os dados levantados pela pesquisa das lamparinas romanas discus no sítio, a tendência é discordar dessa afirmação. Isto porque na sequência estratigráfica em pelo menos cinco Locus (1250, $1764,1767,1768,1830)$ da camada romana 2 b cinco lamparinas com quebra no disco (pranchas 07, 27, 54, 57, 58) estão íntegras no restante e uma intacta no disco (prancha 15). Na camada romana 1 , mais cinco Locus $(1225,1297,1743,1320,1288)$ apresentam dez (10) lamparinas com quebra no disco e intactas no restante (pranchas $11,12,13,24,25,28,29,30,55,56)$ e uma sem quebra no discus (prancha 22). Já na camada bizantina onze lamparinas com quebra no disco e intactas no restante aparecem (Locus 806, 815, 816, 824, 838, 1218, 1309 - pranchas 1, 2, 3, 4, 5, 8, 10, 17, 18, 23, 34). A diferença de localização do Locus 1250, na camada Rom.2b, o mais profundo em que uma lamparina intacta foi escavada, para o Locus 1218 na camada bizantina, o mais superficial na estratigrafia, é de 20,65 cm. Assim, em primeiro lugar, se as lamparinas 
dos Locus mais baixos fossem arremessadas da parte mais alta do sítio para a mais baixa, com o desnível que beira a $3 \mathrm{~m}$, as peças não resistiriam ao impacto, o mesmo ocorrendo pelo menos para a camada Rom.1; em segundo lugar, não se encontrariam as mesmas lamparinas romanas provinciais com quebra em lugares específicos da disposição espacial dos recintos da Villa.

Portanto, é bem possível que o abandono causado pelo terremoto tenha sido temporário ou tenha inutilizado somente alguns recintos da edificação, provavelmente aqueles da ala sul. Contudo, não resta dúvida de que a camada romana 1 corresponde a um período de ocupação do prédio, dada a disposição das lamparinas, caso contrário o arremesso dos objetos seria menos sistemático e seriam encontrados pelo menos alguns fragmentos de lamparinas pelos cômodos restantes da edificação (ex. Locus 1817, 1844, 1761, 1902, que correspondem à primeira sala sul, peristilo central, corredor curto norte, corredor curto oeste). Nesse sentido, penso que na camada romana $2 b$, em que os recintos foram divididos e isolados, com cada recinto possivelmente tendo um proprietário, alguns desses cômodos foi ocupado por cristãos, que após o abalo sísmico permaneceram no local e desta maneira se explicaria a maior quantidade de lamparinas quebras no sítio nas camadas Rom.1 e bizantina (veja a disposição dos Locus nas camadas na representação abaixo). 
Tabela numérica de disposição espacial dos Locus ${ }^{11}$

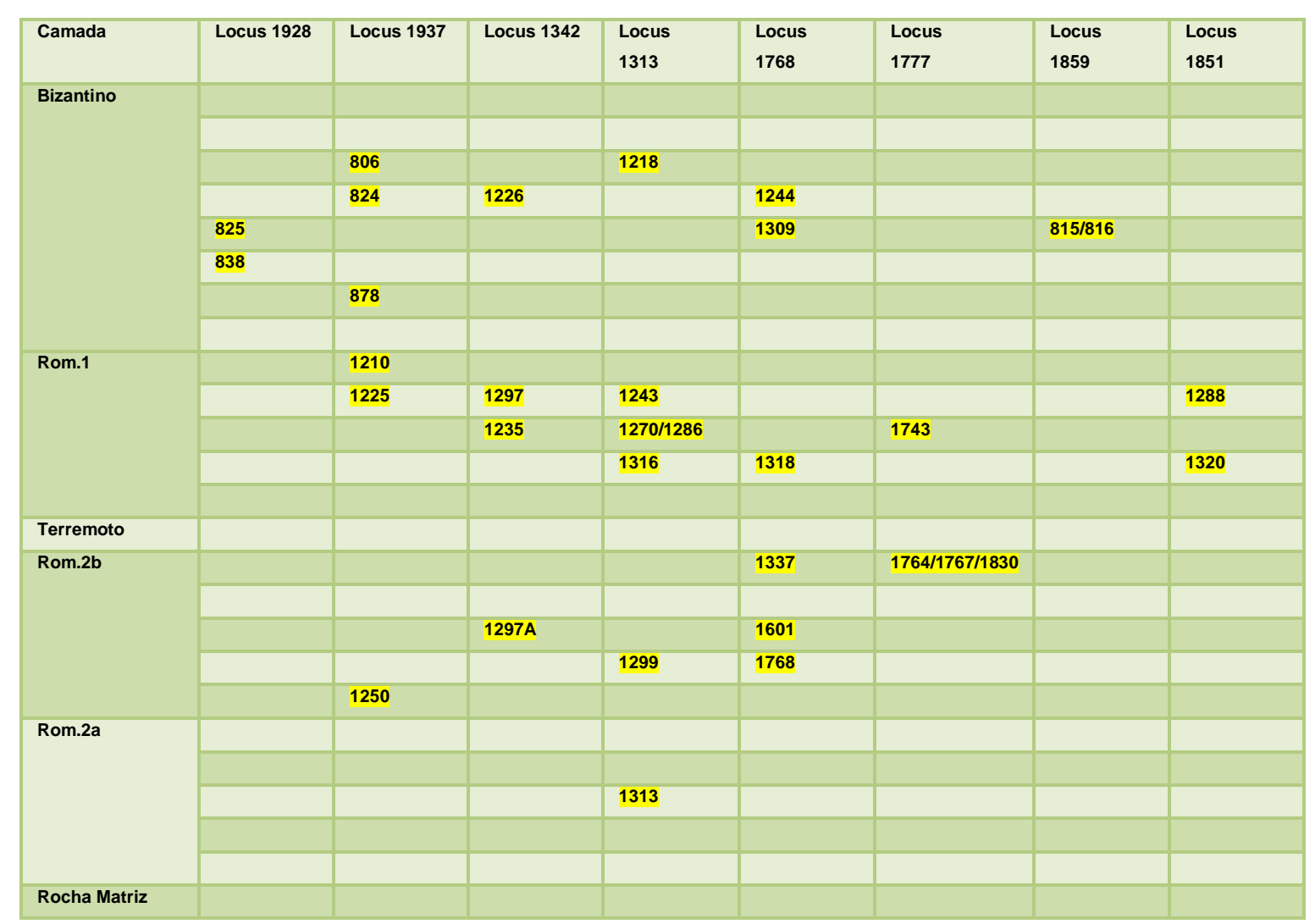

As lamparinas romanas discus estão distribuídas intra-sítio majoritariamente na parte leste do sítio e a culina apresenta 40,9\% do total de fragmentos, seguido do Locus 1313 com 6,5\%, Locus 1342 com 5,83\%, Locus 1851 com 5,4\% e Lararium (Locus 1768) com 5,30\%. Já o Locus 1777 e 1928 apresentam 0,7 e 0,3\% do número total de peças, respectivamente.

O segundo ponto, referente à memória do sítio, corresponde à indicação que apresentei ainda no capítulo quatro de um bispo chamado Marcos, que seria primo de Barnabé e conforme Hipólito de Roma na obra "Espúria" Apollonia. A lista que apresentei no capítulo anterior é um texto conhecido como Sinaxe dos 70 Apóstolos, é na verdade uma festa litúrgica que foi estabelecida pela

\footnotetext{
${ }^{11}$ Cada linha na tabela corresponde aproximadamente a $10 \mathrm{~cm}$.

${ }^{12}$ Usei a versão em inglês do texto de Philip Schaff (1819-1893), conforme expliquei no capítulo 2.
} 
Igreja Ortodoxa para indicar os primeiros setenta apóstolos e qualificá-los como iguais em importância, dessa forma, rendendo-lhes homenagem. Refere-se, portanto, em primeira instância ao texto de Lucas 10: 1, em que Jesus instrui alguns de seus discípulos à peregrinação e proselitismo "por toda terra". A celebração da "Sinaxe dos Santos Discípulos”, como é conhecida, comemora a memória de cada um dos setenta nomeados em um período do ano.

Apesar de a menção inicial dos setenta apóstolos ter sido feito ainda no século III d.C. por Hipólito, ela só foi canonizada no século IX por José, o Hinógrafo, que dirimiu as questões da presença e ausência de alguns nomes na lista. Entretanto, essa indecisão não parece ter chegado ao nome do bispo de Apollonia. O Marcos de quem estou me referindo recebe uma série extensa de menções nos escritos cristãos, vejamos rapidamente algumas delas:

Em Colossenses 4:10 encontra-se: "Aristarco, meu companheiro de prisão, e Marcos, primo de Barnabé, mandam saudações. Sobre Marcos já mandei recomendações; se for visitá-los o acolham bem. (...) Estes são os únicos judeus que trabalham comigo pelo Reino de Deus, e eles são grande consolação para mim."

"Pedro então refletiu e foi para casa de Maria, mãe de João, também chamado Marcos, onde muitos se haviam reunido para orar (...)" (At 12:12).

"Barnabé e Paulo terminaram seu serviço em favor de Jerusalém, e voltaram, levando consigo João, também chamado Marcos" (At 12:25).

"Enviados pelo Espírito Santo, Barnabé e Saulo desceram a Selêucida e daí navegaram para Chipre. Quando chegaram a Salamina, começaram a anunciar a Palavra de Deus nas sinagogas dos judeus, tendo João como ajudante"(At 13:5).

"Paulo e seus companheiros embarcaram em Pafos e chegaram a Perge da Panfília. João, porém, separou-se do grupo e voltou a Jerusalém" (At 13:13). 
"Depois de alguns dias, Paulo disse a Barnabé: 'Vamos voltar para fazer visita a todas as cidades onde anunciamos a Palavra do Senhor, para ver como estão passando'. Barnabé queria levar junto também João, chamado Marcos. Paulo, porém, era de opinião que não deveria levar consigo uma pessoa que havia se separado deles na Panfília e não os acompanhara no trabalho. Houve desacordo entre eles, a tal ponto que tiveram de separa-se um do outro. Barnabé levou Marcos consigo e embarcou para Chipre. Paulo, por sua vez, escolheu Silas, e partiu, recomendado pelos irmãos às graças do Senhor. Atravessaram a Síria e a Cilícia, dando nova força às igrejas" "At 15:36-41).

"Saudações de Epafras, meu companheiro de prisão em Jesus Cristo, como também Marcos, Aristarco, Demas e Lucas, meus colaboradores" (Filemon 23).

"Procure vir logo ao meu encontro, pois Demas me abandonou, preferindo o mundo presente. Ele partiu para Tessalônica, Crescente para Galácia, Tito para a Dalmácia. Somente Lucas está comigo. Procure Marcos e traga-o com você, porque ele pode ajudar no ministério" (2 Tm 4:10-11).

"A comunidade que vive em Babilônia [provavelmente estava se referindo a Roma $]^{13}$, escolhida como vocês, manda saudações. Marcos, meu filho, também manda saudações" (1 Pedro 5:13).

Como o leitor deve ter observado, o "Marcos" em questão provavelmente é o mesmo que hipoteticamente teria escrito o evangelho com o mesmo nome. A figura de Marcos, como é possível extrair dos textos acima, é a de um jovem judeu que acompanhou os apóstolos Paulo e Pedro. Pode então ser colocado como um líder de segunda geração, assim como Lucas, que também parece ter sido seu companheiro em dados momentos. Conhecido como João Marcos, encontra-se no evangelho que lhe é atribuído um paralelo aproximado de $90 \%$ de similaridade com os livros de Mateus e do próprio Lucas, sendo classificado como sinótico. Nesse evangelho 19 vezes aparece a palavra "logo" e 17 vezes a palavra "imediatamente", assim, seu caráter é o da eminente vinda messiânica, e do mesmo modo deveriam ser sua pregações, subentende-se.

\footnotetext{
${ }^{13}$ Observação do autor.
} 
Tradicionalmente atribui-se às primeiras igrejas em Alexandria a sua imagem e especula-se que ele fosse mais novo que todos os Apóstolos, por volta de 15 anos, daí o motivo de Pedro também lhe chamar "filho".

Assim, além de o próprio Pedro provavelmente ter pernoitado em Apollonia, Marcos, primo de Barnabé, autor hipotético do evangelho de Marcos, foi o bispo na localidade. Conforme se depreende das citações acima, o líder cristão participava ativamente das viagens de proselitismo e tinha laços familiares em Jerusalém. Poder ser que não tenha estado à frente da igreja de Apollonia por um longo tempo, entretanto, no momento da menção de Hipólito, esse apologista, o identificou como tal.

Portanto, diante dessas questões, o processo de espacializar, assim como foi preconizado por Derrida (1997: 107) é o movimento de "colocar de lado". Ele assinala o que é colocado de lado em relação a si mesmo, que interrompe toda auto-identidade, toda agência do "eu", toda auto-homogeneidade, auto-interioridade, e se caracteriza como um ato-tentativa de separação para a construção da auto-identidade homogênea que, amparada sob as mesmas categorias anteriores, tem o diferencial de direcioná-las justamente para a homogeneidade almejada. O foco se desloca e atenta para a ruptura, a desarticulação, a fragmentação e co-constituição da identidade/diferença no contato com o grupo que está inserido e os demais presentes no espaço. Assim, é o balizamento do espaço como um repertório de sequência de ações através do tempo e repleção que repercutem na memória de um grupo. Concebe-se a heterogeneidade, a ruptura interna e incoerência, em vez de multiplicidade positiva, como a coexistência de "outros" e a especificação de sua "diferença" em relação ao processo de "colocar de lado", a parte. As ações podem ser evidenciadas nos tipos de artefatos com características associadas a múltiplas ocupações de uma dada localidade, como em Apollonia, e em práticas de uso visivelmente consistentes que modificam um lugar e seu entorno, conforme as contingências dos indivíduos e do grupo. Como Zedeño (2000: 107; Zedeño e Bowser 2009: 8) preconizou, na medida em que ao longo do tempo um lugar continua a ser ocupado, os artefatos, recursos, modificações e contatos, podem se tornar os marcos de memórias individuais e de grupo, necessários à coesão social, e, eu diria, 
imprescindíveis à formação e consolidação das identidades, tanto individual como coletivas.

O cristianismo, assim como outras matrizes de representação, alcança também essas relações de identidade/alteridade, atuando na co-constituição tanto de uma nova identidade a seus prosélitos, marcada por um forte discurso de alteridade, como procurando dar conta da aleatoriedade e incerteza do devir, proporcionando a ordem e o fomento de memória coletiva em consonância com práticas que objetivam a consolidação do seu ideário e a constituição dos espaços. 
SÍTIOS COM LAMPARINAS ROMANAS DISCUS QUEBRADAS

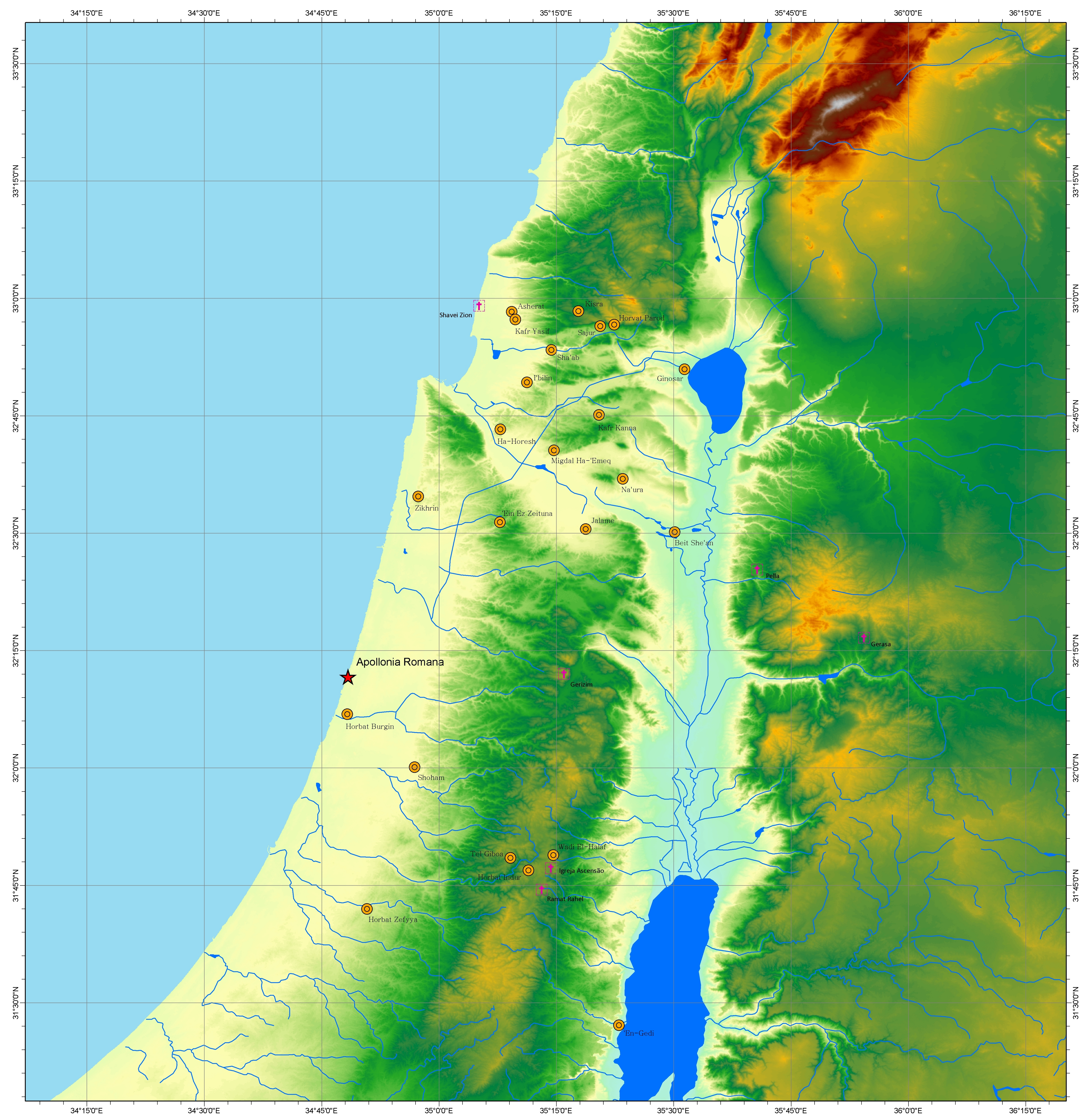

\section{Legenda}

卖 Apollonia

(2) Sítios com lamparinas romanas discus quebradas

[†] Igrejas do II e III séculos d.C.

Modelo Digital de Elevação - DEM

Value

High : 3084

Low : -428

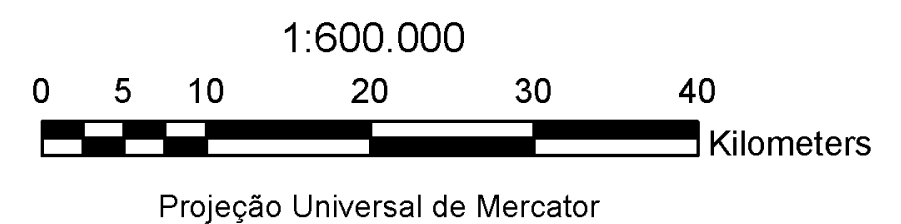

Projeção Universal de Mercator

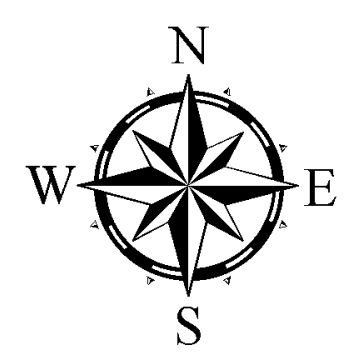

Projeto Cristianização dos espaços na Antiguidade Tardia: o caso de Apollonia-Arsuf. Marcio Teixeira Bastos

Bolsista CNPq

Universidade de São Paulo - Museu de Arqueologia e Etnologia

University of Tel Aviv

Mapa desenvolvido por Rafael Corteletti, 2011.

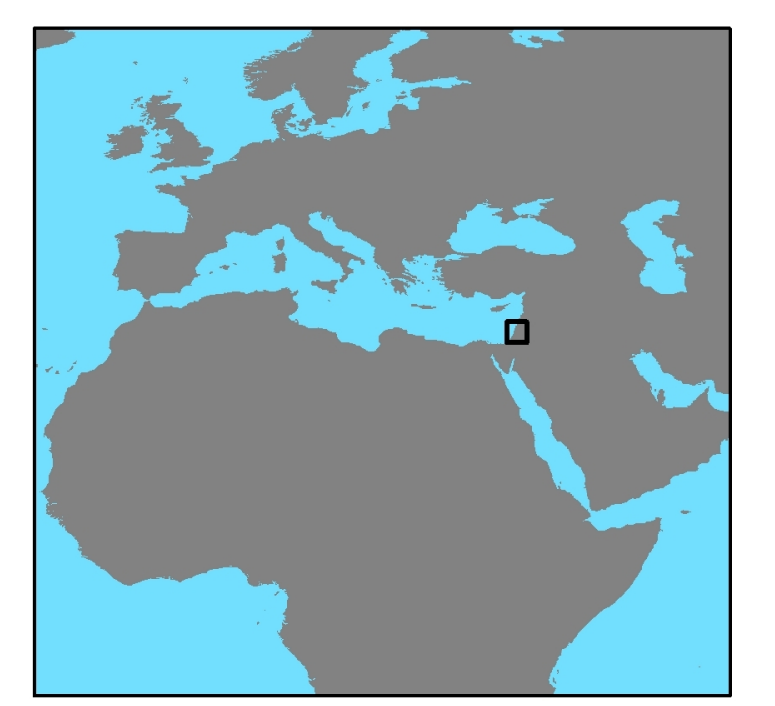


DISTRIBUIÇÃO ESPACIAL DE SÍTIOS COM LAMPARINAS HERODIANAS, SAMARITANAS E ROMANAS DISCUS COM QUEBRA.

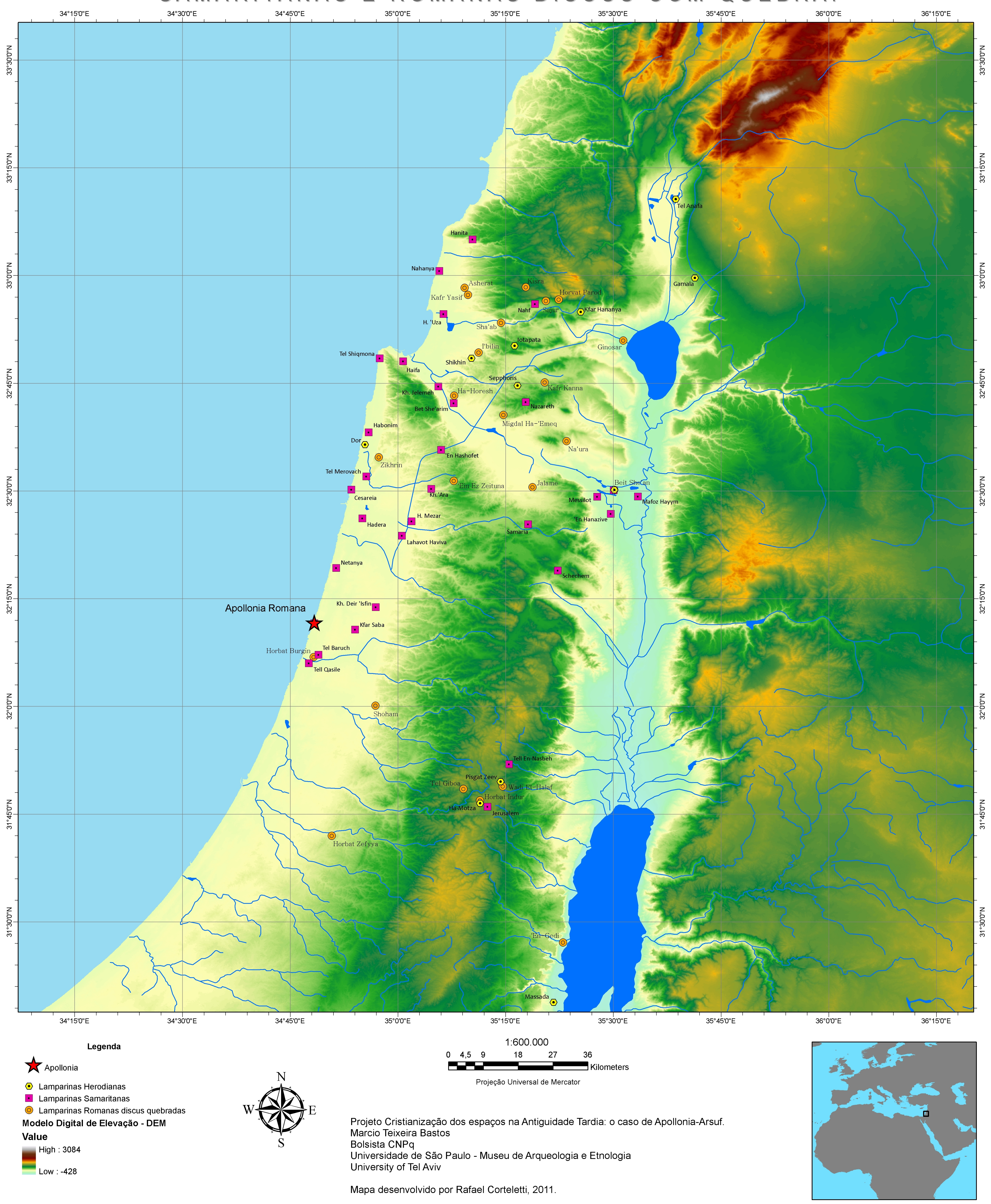


DISTRIBUIÇÃO ESPACIAL DOS SÍTIOS

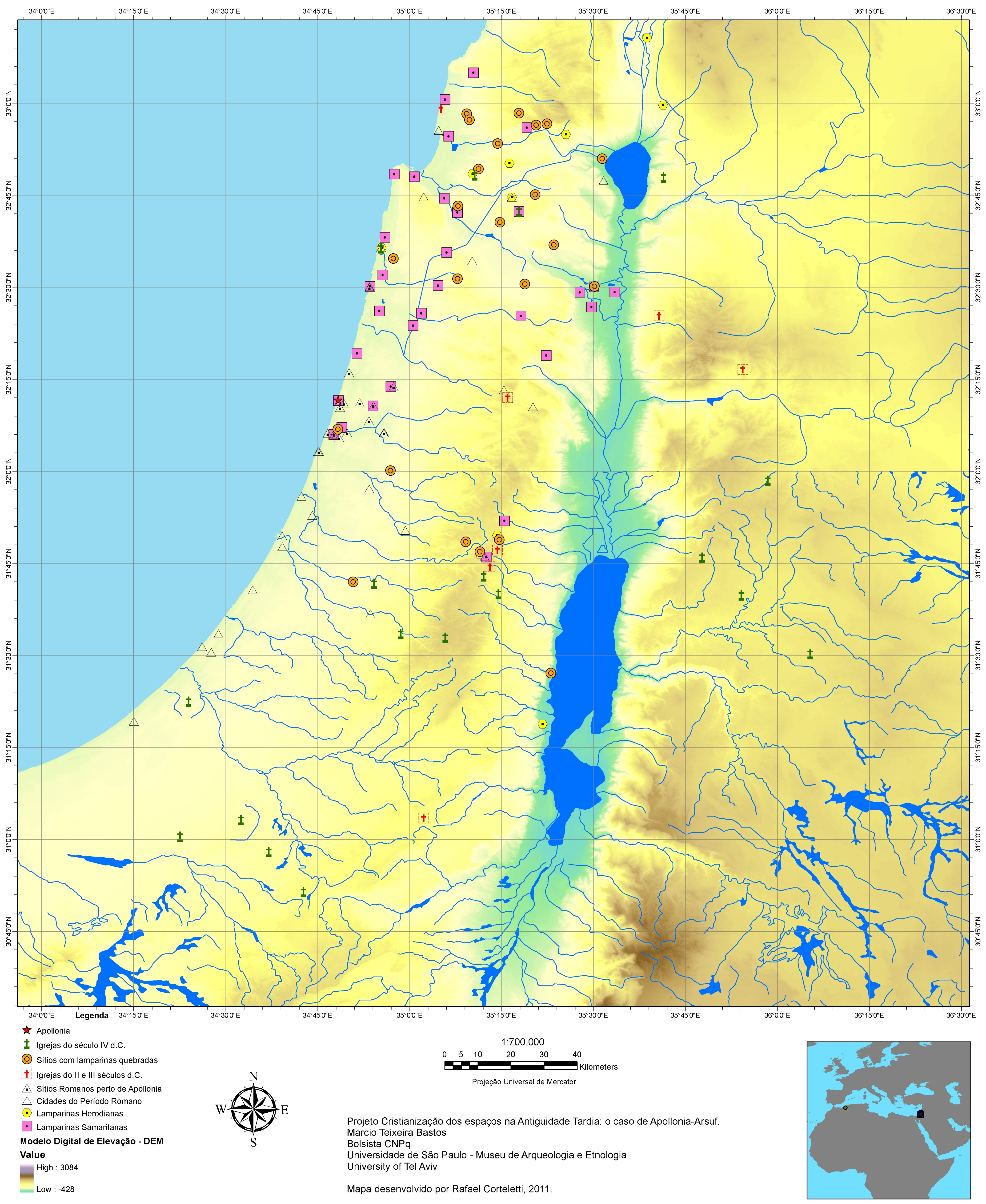




\section{Referências Bibliográficas:}

ABEL, F.-M. (1938). Geographie de la Palestine. Paris: J. Gabalda.

ADAN-BAYEWITZ, D. Comon Pottery in Roman Galillee: A study of Local Trade, RamatGan: Bar-Ilan Univeristy.

ADAN-BAYEWITZ, D.; et al. ASARO; WIEDER; GIAUQUE (2008). Preferential Distribution of Lamps from Jerusalem Area in the Late Second Temple Period (Late First Centruy B.C.E. - 70 C.E.). Boston: BASOR.

ALARCÃO, A. M. \& DE PONTE, S. (1976). Les lampes en "Céramiques diverses et verres". Fouilles de Conimbriga, VI, Paris : 93-114, lâms. XXIII-XXX.

ALCOCK, S. E. (1989). Archaeology and Imperialism: Roman Expansion and the Greek City. Cambridge: Cambridge University Press.

ALCOOK, S. E. (ed.) (1997). The early Roman empire in the East. Oxford: Oxbow (Oxbow Monograph; 95).

ALMEIDA, J. M. F. (1952). Introdução ao estudo das lucernas romanas em Portugal. $O$ Arqueólogo Português, série 2. Lisboa:

ALVAREZ-OSSORIO, F. (1942). Lucernas o lámparas antiguas de barro cocido del Museo Arqueológico Nacional. A. E. A., XV: 271 -287.

AMARE TAFALLA, M. T. (1987). Lucernas romanas: generalidades e bibliografia. Zaragoza: Zaragoza.

AMARE TAFALLA, M. T. (1988). Lucernas romanas en Aragón. Zaragoza: Zaragoza.

AMORES, F. \& KEAY, S. J. (1999). Las sigillatas de imitación tipo Peñaflor. Una série de hispánicas precoces. In: ROCA ROUMENS, M. \& FERNÁNDEZ GARCÍA, M. I. (coords.). Terra sigillata hispánica. Centros de fabricación y producciones altoimperiales. Universidad de Jaén; Universidad de Málaga: 235-52.

APPLEBAUM, S. (1986). The Settlement Pattern of Western Samaria from Hellenistic to Byzantine Times: a Historical Commentary. In: S. DAR (ed.). Landscape and Pattern. An Archaeological Survey of Samaria. 800 BCE - 636 CE. Oxford: BAR International Series, 308: 257-269.

AVIAN, M. (1997). A Rock-cut Tomb at Sha 'Ab. ATIQOT, XXXIII: Burial caves of the Roman and Byzantine Periods in Western Galilee. Jerusalem: The Israel Antiquities Authority: 79-80, 1997. Israel Antiquities Authority: 103-116.(Hebrew)

AVIAN, M. (1997). A burial cave at Kafr Yasif. ATIQOT, XXXIII: Burial caves of the Roman and Byzantine Periods in Western Galilee. Jerusalem: The Israel Antiquities Authority: 71-77 (Hebrew).

AVIAN, M. (2004). Jews, Pagans and Christians in the Galilee: 25 years of archaeological excavations and surveys. Hellenistic to Byzantine periods. New York: University of Rochester Press.

AVIAN, M. \& ROSEN-GORIN, Y. (1997). Three burial caves from the Roman Period at Hurfeish. ATIQOT, XXXIII: Burial caves of the Roman and Byzantine Periods in Western Galilee. Jerusalem: The Israel Antiquities Authority: 25-37 (Hebrew). 
AVI-YONAH, M. (1936). Map of Roman Palestine. Quarterly of the Department of Antiquities of Palestine, 5: 139-93.

AVI-YONAH, M. (1977). The Holy Land. Grand Rapids.

AYLON, E. (1994). A Roman-Byzantine Mausoleum at KH. Sabiya, Kefar Sava. In:

'ATIQOT. Vol. XXV. Jerusalem: The Israel Antiquities Authority:27-39 (Hebrew).

BADDELEY, A. (1990). Human Memory: Theory and Practice. Boston: Allyn and Bacon.

BAILEY, D. M. B. (1975). Greek, Helenistic and Early Roman Pottery Lamps. London: British Museum (A Catalogue of the Lamps in the British Museum; I).

BAILEY, D. M. B. (1980). Roman Lamps made in Italy. London: British Museum (A Catalogue of the Lamps in the British Museum; II).

BALIL, A. (1982). Revisión de la cronología de algunas lucernas romanas de Ampurias. IV Colloqui Internacional d'Arqueologia de Puigcerdá: Estat actual de la recerca arqueológica a l'Istme Pirinenc. Homenatge al Dr. Oliva Prat. Puigcerdá: 247-249.

BANDINELLI, R. B. \& BECATTI, G. (eds.) (1965). Roma Antica e Paleocristiana. Roma: Istituto Poligrafico dello Stato (Articolo "ROMA", pubblicato nel vol. VI, pp. 764-936 e in Appendice, p. 179 e ss., gli articoli referentesi ai monumenti della città di Roma pubblicati nei voll. I-V). Estratto dalla Enciclopedia dell"Arte Antica Classica e Orientale.

BARAG, D. \& HERSHKOVITZ, M. (1994). Lamps from Masada. In: FOERSTER, G. \& NETZER, E. Masada, vol. 4: The Yigael Yadin Excavations, 1963-1965. Final Reports. Jerusalem: Israel Exploration Society:

BAR-NATHAN, R. (2002). Hasmonean and Herodian Palaces at Jericho: Final Reports of the 1973-1987 Excavations. Vol. 3: The Pottery. Jerusalem: Israel Exploration Society.

BARSHAD, D. (2004). A burial cave at Horbat Indur, on the Slopes of Giv 'At Ha-Moré. ATIQOT, 46. Jerusalem: The Israel Antiquities Authority: 15-25. (Hebrew)

BARTH, F. (1969). Models of social organization. London: Royal Anthropological Institute (Ocasional Papers; 23).

BARTH, F. (1969/1998). Introdution. In: BARTH, F. (org.). Ethnic Groups and Boundaries: the social organization of cultural difference. London: George Allen \& Unwin:

BARTH, F. (2000). Os grupos étnicos e suas fronteiras. In: O guru, o iniciador e outras variações antropológicas. Rio de Janeiro: Contracapa [1969]: 25-67.

BARUCH, Y. (1997). A burial cave of the Roman Period on the outskirts of El-Kirmil. ATIQOT, XXXII: Reports and Studies of Excavations in Judea and Samaria. Jerusalem: The Israel Antiquities Authority: 91-94 (Hebrew).

BEAUDRY, M. C.; COOK, L. J.; MROZOWSKI, S.A. (2007). Artefatos e Vozes Ativas: cultura material como discurso social. Vestígios: Revista Latino-Americana de Arqueologia Histórica, 1 (2):

BELLEZA, F. S. (1996). Mnemonic methods to enhance storage and retrieval. In: BJORK, E. Ligon \& BJORK, R. A. (eds.). Memory. San Diego: Academic Press: 345-80. 
BENNETT, T. et al. (1986). Introduction: Popular Culture and the Turn to Gramisci. In: Popular Culture and Social relations. Open University Press, Milton Keynes:

BESNIER, M. \& BLANCHET, P. (1900). Collection Farges. Musées et Collections archéologiques del`Algérie et de la Tunisie, IX, París.

BET, Ph. \& VERTET, H. (1986). Centre de production de Lezoux. In: La terre sigillée galloromaine. Lieux de production du haut empire: implantation, produits, relations. Paris: Editions de la Maison des Sciences de 1'Homme (Documents d'Archéologie Française; 6): 138- 144.

BÍBLIA SAGRADA (1996). $3^{\mathrm{a}}$ ed. Trad. das línguas originais: João Ferreira de Almeida. São Paulo: Vida.

BIRNBAUM, R.; OVADIAH, A. (1990) A Greek Inscription from the Early Byzantine Church at Apollonia. Israel Exploration Journal 40: 182-91

BISl INGRASSIA, A. M. (1977). Le luceme fittili dei nuovi scavi di Ercolano. L'Instrumentum Domesticum di Ercolano e Pompei nella prima etá imperiale. Quademi di Cultura Materiale, 1: 73-104.

BONIFAY, M. (2004). Études sur la céramiques romaine tardive d'Afrique. Oxford: BAR International Series; 1301.

BONIFAY, M.; CRIDI, F.; JACQUEST, H. (2004). Un ensemble de céramiques du IV ${ }^{\mathrm{e}}$ s. dans une citerne du capitole. In : BEN HASSEN, H. \& MAURIN, L. (dir.). Oudhne (Uthina), colonie de vétérans de la XIII légion. Histoire, urbanisme, fouilles et mise en valeur des monuments. Bordeaux-Paris-Tunis: Ausonius Publications: 219-235 (Mémoires; 13).

BOOGS, C. (1976). Gramisci’s Marxism. London: Pluto Press.

BOURDIEU, P. (1990). Coisas Ditas. São Paulo, Brasiliense.

BOURDIEU, P. (1991). Estruturas sociais e estruturas mentais. Teoria \& Educação, 3. Porto Alegre: 113-119.

BOURDIEU, P. (1994) Razões Práticas: sobre a teoria da ação. Campinas, Papirus Editora.

BOURDIEU, P. (2002). A economia das trocas simbólicas. São Paulo: Perspectiva.

BOWSER, B. (2004). Prologue: Toward an Archaeology of Place. Journal of Archaeological Method and Theory, 11 (1): 1-3.

BRADLEY, R. (2000). Archaeology of Natural Places. London: Routledge.

BRAND, J. (1953). Ceramics in Talmudic Literature. Jerusalem: (Hebrew).

BRAND, J. (1969-70). Jewish vessels during the Mishnah time. Eretz Israel, 9: 40-41 (Hebrew).

BRIAN, J.F. (1992). Brownian movement in clarkia pollen: A reprise of the first observations. Microscope, 40, n.4.

BRAUN, E.; DAUPHIN, C.; HADAS, G. (1994). A Rock-cut Tomb at Sajur. ATIQOT,XXV. Jerusalem: The Israel Antiquities Authority: 103-116.

BRONEER, O. (1930). Terracotta Lamps. Corinth, II. Cambrigde: 
BROSHI, M. (1979-80). The Population of Western Palestine in the Roman-Byzantine Period. Bulletin of the American Schools of Oriental Research, 233, Michigan.

BROWN, P. R. L. (1999). A ascensão do Cristianismo no Ocidente. Tradução de Eduardo Nogueira. Lisboa: Editorial Presença (Coleção Construir a Europa).

BRUSH, S. (1968). A history of random processes. I. Brownian movement from Brown to Perrin. Archive for History of Exact Sciences, 5, n.34.

BYATT, Anthony (1973). Josephus and population numbers in first century Palestine. Palestine Exploration Quarterly: 51-60

CAETANO, J. C. (2001). Lucernas romanas de Conímbriga. Escavações de 1963 - 1970. Dissertação de Mestrado em Arqueologia, área de especialização em Arqueologia Romana, apresentada à Faculdade de Letras da Universidade de Coimbra.

CAMBERLIN, M. (2006). Symbolic Conflict and the Spatiality of Traditions in Small-scale Societies. Archaeological, 16 (1), Cambridge.

CARANDINI, A. et al. (1981). Ceramica Africana. In: Atlante delle forme ceramiche I. Roma: Enciclopedia dell'Arte antica e orientale:

CARANDINI, A. \& PANELLA, C. (eds.) (1977). Ostia IV (Le terme del nuotatore. Scavo dell 'ambiente XVI e dell 'area XXV). Roma: De Luca Editore (Studi Miscellanei; 23).

CÉRDAN, M. A. (1999). Lucernas romanas en la región septentrional de la Península Ibérica. Montagnae: Éditions Monique Mergoil (Monographies Instrumentum 8/2).

CÉRDAN, M. A. (1990). En Torno a la Tipologia de lucernas romanas: problemas de nomenclatura. CuPAUAM, 17: 143-167.

CLARK, A. (1997). Being there: putting brain, body and world together again. Cambridge, MA: MIT Press.

CLAVAL, Paul (1997). A geografia cultural. Florianópolis: Editora UFCS.

COHEN, A. (1994). Self Consciousness: an Alternative Anthropology of Identity. London: Routledge.

CUCHE, D. (2002). A noção de cultura nas ciências sociais. Trad. Viviane Ribeiro. 2 ed. Bauru, SP: EDUSC. [1 ed., 1999. La notion de culture dans les sciences sociales. Paris : La Découverte, 1996]

DAY, F. (1942) Early Islamic and Christian Lamps. Berytus 7: 64-79.

DE BRUN, P. \& CAGNIERE, S. (1937). Les Lampes antiques du Musée Calvet d'Avignon, Carpentras.

DEJOIE, C.; RELAIS, S.; SCIOU, Ph. (2005). Les sigillées des ateliers de la Graufsenque et de Montans. Étude comparative des pâtes et engobes. In: NIETO, X. et al. (eds.). La difusió de la terra sigillata sudgàl.lica al nord d'Hispania. Barcelona: Museu d'Arqueologia de Catalunya: 9-18 (Monografies; 6).

DENEAUVE, J. (1969). Lampes de Carthage. Paris.

DERFLER, S. (1989). Roman fortress (Stratum II). In: HERZOG, Z. et al. (eds). Excavations at Tel Michal, Israel. Tel Aviv University: 188-194 (Publications of the Institute of Archaeology; 8). 
DERRIDA, J. (1996). Remarks on deconstruction and pragmatism. In: MOUFFE, C. (org). Deconstruction and pragmatism. London: Routledge: 77-88.

DIAS, A. S. \& SILVA, F. A. (2001). Sistema tecnológico e estilo: as implicações desta interrelação no estudo das indústrias líticas do Sul do Brasil. Rev. do Museu de Arqueologia e Etnologia, São Paulo, 11: 95-108.

DOBRES, Marcia-Anne (2000). Technology and social agency. Oxford: Blackwell.

DORNAN, J. (2004). Beyond Belief: Religious Experience, Ritual, and Cultural Neurophenomenology in the Interpretation of Past Religious Systems. Cambridge: Archaeological, 14 (1) .

DOUMERGUE, F. (1932). Lampes antiques en terre cuite en "Catalogue raisonné des objects archéologiques contenus dans le Musée Municipal d'Oran". Bulletin de la Société de Géographie et Archéologie d'Oran, 53: 362-380.

DRAGENDORFF, H. \& WATZINGER, C. (1985). Arretinische Reliefkeramik mit Beschreibung der Sammlung in Tübingen. 2 vols. Gryphius; Reutlingen.

DRESSEL, H. (1899). Lucemae Formae, C /. L. (Inscriptiones Urbis Romae Latinae. Instrumentum Domesticum) XV, II, 1, lam. III.

ELIADE, M. (1998). Tratado de história das religiões. 2 ed. Trad. Fernando Tomaz; Natália Nunes. São Paulo: Martins Fontes.

ELIADE, M. (2001). O Sagrado e o Profano: A essência das religiões. São Paulo, Martins Fontes.

EUSÉBIO DE CESARÉIA (2002). História Eclesiástica. Trad. Wolfgang Fischer. São Paulo: Novo Século.

FABIAN, J. (1983). Time and Other: how anthropology makes its object. Nova York: Columbia University Press.

FEIG, N. (1999). A Roman burial cave at I 'Billin. ATIQOT, XXXVIII. Jerusalem: The Israel Antiquities Authority: 49-53 (Hebrew).

FERNÁNDEZ CHICARRO C. (1952-3). La colección de lucernas antiguas del Museo Arqueológico de Sevilla. Memorias Museos Arqueológicos Provinciales yaW-yjy: 61124.

FERNÁNDEZ GARCÍA, M. I. et al. (1999). El centro de producción de terra sigillata hispánica de Los Villares de Andújar (Jaén). Síntesis de los resultados obtenidos en la campaña de 1999. Anuario Arqueológico de Andalucía, série II/Actividades Sistemáticas y Pontuales: 41-6.

FINK, J. (1901). Formen und Stempel romischer Thonlampen. Sitzüngsberichte München, 1900: 685-703.

FISCHER, M. \& TAL, O. (1996). Two ceramic assemblages from Hellenistic Apollonia. Journal of Tel Aviv University, 23: 213-234.

FLAVIUS JOSEPHUS. Antiquitates Judaicae.

FLAVIUS JOSEPHUS. Bellum Judaicum. 
FLEMING, M. I. D’A. (1978). As Lamparinas na Antiguidade Clássica. Problemas sociais, econômicos e tecnológicos. Dissertação de Mestrado, Universidade de São Paulo.

FLEMING, M. I. D’A. (1989). As lamparinas de Terracota greco-romanas como veículos de iconografia religiosa. Dédalo, São Paulo, 27: 173-187.

FLORENZANO, M. B. B. \& GALVÃO SOBRINHO, C. R. (2001). Apolônia e seu território: paisagem rural e mudança social na Palestina romana. Universidade de São Paulo: Relatório de Pesquisa, 2000-2001.

FOUCAULT, M. (1971). L'Ordre du discours. Paris: Gallimard.

FOUCAULT, M. (2007). Microfísica do poder. São Paulo: Graal, Ed 23.

FULFORD, M. G. \& PEACOCK, D. P. S. (eds.) (1984). Excavations at Carthage: the British mission, I. 2. The Avenue President Habib Bourguiba, Salammbo. The pottery and other ceramic objects from the site). The British Academy.

FULLE, G. (1997). The internal organization of Arretine terra sigillata industry: problems of evidence and interpretation. Journal of Roman Studies, 87: 111-155.

FUNARI, P. P. A.; HALL, M.; JONES, S. (eds.) (1999). Historical Archaeology: Back from the Edge. London: Routledge.

GALOR, K.; ROLL, I.; TAL, O. (2009). Apollonia-Arsuf between Past and Future. Near Eastern Archaeology, 72: 1.

GEERTZ, C. (1989). A interpretação das culturas. Rio de Janeiro: LTC.

GELLNER, E. (1983). Nations and Nationalism. Oxford: Basil Blackwell.

GELLNER, E. (1987). Culture, Identity and Politics. Cambridge: Cambridge University Press.

GIRARD, R. (1998). A Violência e o Sagrado. Rio de Janeiro: Paz e Terra.

GLICK, D. (2006). A Salvage Excavation at "Ein Ez-Zeituna in Nahal" Iron. ATIQOT, 51. Jerusalem: The Israel Antiquities Authority: 31-70.

GOLDMAN, H. (1950). Excavations at Gozlü Kule, Tarsus. I. The Hellenistic and Roman Period. Princeton: 84-134, lams. 93-113.

GOODENOUGH, E. R. (1953). Jewish Symbols in the Greco-Roman Period. New York: Pantheon Books, vol. I-VII.

GOODMAN, M. (1983). State and Society in Roman Galilee, A.D. 132-212. Totowa, NJ: Rowman and Allanheld.

GOODMAN, M. (1999). The Pilgrimage Economy of Jerusalem in the Second Temple Period. In: LEVINE, L. I. (ed.). Jerusalem: Its Sanctity and Centrality to Judaism, Christianity, and Islam. New York: Continuum.

GOPHNA, R. \& AYALON, E. (1998). Archaeological Survey of Israel. Map of Herzliyya (69). Jerusalem: Israel Antiquities Authority.

GOPHNA, R.; SUSSMAN, V. (1974) A Jewish burial cave of the Roman Period at the foot of Tel Halif. In: 'ATIQOT. Vol.VII. Jerusalem: The Israel Antiquities Authority:69-76.

GORING-MORRIS, N.; LEVINE, L. I.; MAZAR, A. (2002). Bet Shean - Scythopolis. Qedem Reports, 4: 13-25. 
GOSDEN, C. (1994). Social being and time. Oxford: Blackwell.

GOSDEN, C. (2005). What Do ObjectsWant? Journal of Archaeological Method and Theory, 12, (3) September.

GORING-MORRIS, N.; LEVINE, L.I.; MAZAR, A. (2002) Bet Shean. Qedem Reports 4. Jerusalem: The Israel Exploration Society.

GORNI-AVSHALON, D. (2000) A burial cave of the Byzantine period at Bet She' An. In : 'ATIQOT.Vol. XXXIX. Jerusalem: The Israel Antiquities Authority:.49-60 (Hebrew).

GOULD, R. A. (1980). Living archaeology. New York: Cambridge University Press.

GREENBERG, J. (2003). Plagued by doubt: reconsidering the impact of a mortality crisis in the 2nd c. A.D. Journal of Roman Archaeology, 16.

GREENE, K. (2005). Roman pottery: models, proxies and economic interpretation. Journal of Roman Archaeology, 18.

GUARINELLO, N. L. (2005). Archaeology and the Meanings of Material Culture. In: FUNARI, P. P. A. et al. 19-27.

HADAD, S. (2002). The Oil Lamps from the Hebrew University Excavations at Bet Shean (Qedem

Reports 4). Jerusalem.

HADDAD, E. (2007). A burial cave from the First-Second Centuries and Double-Arcosolia tombs from the Fourth-Fifth Centuries C.E. on the fringes of Horbat Zikhrin. ATIQOT, 56. Jerusalem: The Israel Antiquities Authority: 45-57 (Hebrew).

HAKEN, R. (1958). Roman Lamps in the Prague National Museum and in other Czechoslovak Collections. Praga (Acta Musei Nationalis Pragae, Serie A: Historia, XII, 1).

HALL, S. (org.) (1997). Representation. Cultural representation and cultural signifying practices. London: Thousand Oaks; New Delhi: Sage/Open University.

HALL, S. (2003). A identidade cultural na pós-modernidade. Tradução Tomás Tadeu da Silva, Guaracira Lopes Louro. 6 ed. Rio de Janeiro: DP\&A.

HAYES, J. W. (1972). Late Roman Pottery. London: The British School at Rome.

HAYES, J. W. (1978a) - Appendix 1. Selected deposits. In:HUMPHREY, J. H., ed. Excavations at Carthage 1975 conducted by the University of Michigan. II. Tunis: Cérès Productions:113-18.

HAYES, J. W. (1978b) - Pottery report - 1976. In: HUMPHREY, J. H., ed. - Excavations at Carthage 1976 conducted by the University of Michigan. I. Tunis: Cérès Productions, p.23-98.

HAYES, J. W. (1980). A supplement to late Roman pottery. London: The British School at Rome.

HAYES, J. W. (1985) - Sigillate orientali, In Atlante delle forme ceramiche II, ceramica fina romana nel Bacino del Mediterraneo.(Tardo elenismo e Primo Impero). Enciclopedia dell'Arte Antica. Roma: 1-96.

HARRISON, S. (2001). Four types of symbolic conflict. Journal of the Royal Anthropological Institute 1: 255-72. 
HERES, G. (1972). Die romischen Bildlampen der Berliner AntUcen-Sammlimg. Schrifien zur Geschichte und Kultur der Antike, 3.

HERZOG, Z. et al. (eds) (1989). Excavations at Tel Michal, Israel. Tel Aviv: Tel Aviv University (Publications of the Institute of Archaeology, 8).

HIRSCHFELD, Y. et al. (1995). The Palestian Dwelling in the Roman-Byzantine Period. Jerusalem: Franciscan Printing Press; Israel Exploration Society.

HIRSCHFELD, Y. (1997b). Jewish rural settlement in Judea in the early Roman period. In: Farms and villages in Byzantine Palestine. DOP51: 33-71.

HIZMI, H. (1997). Burial Caves at Itamar. ATIQOT, XXXII: Reports and Studies of Excavations in Judea and Samaria. Jerusalem: The Israel Antiquities Authority: 63-67 (Hebrew).

HIZMI, H. (1997). Two burial caves in Rafidya (Shechem). ATIQOT, XXXII: Reports and Studies of Excavations in Judea and Samaria. Jerusalem: The Israel Antiquities Authority: 125-130 (Hebrew).

HODDER, I. (1985). Postprocessual archaeology. In: SCHIFFER, M. B. (ed.). Advances in archaeological method and theory. New York: Academic Press: .

HODDER, I. (2005). Symbolic and Structuralist Archaeology. In: RENFREW, C. \& BAHN, P. (eds.). Archaeology: the Key Concepts. Oxon: Routledge: 254-9.

HODDER, I. (ed.) (1991). The Meanings of Things: material culture and symbolic expression. One Word Archaeology. Cambridge: Cambridge

HORDEN, P. \& PURCEL, N. (2000). The Corrupting Sea: a study of Mediterranean history. Oxford: Blackwell Publishers.

HUMPHREY, J. H. (1999). The Roman and Byzantine Near East. Some Recent Archaeological Research. Journal of Roman Archaeology, 2: 77-106.

ILIFRE, J. H. (1934). A tomb at El Bassa of c. A.D. 396. The Quarterly of the Department of Antiquities in Palestine, III. London: Oxford University Press.

INGOLD, T. (1993). The temporality of the landscape. World Archaeology, 25 (2): 152-174.

INSOLL, T. (ed.) (2007). Archaeology of identities: a reader. London: Routledge.

ISRAELI, Y.; AVIDA, U. (1988). Oil Lamps from Eretz Israel. Jerusalem: 37-45.

ISAAC, B. (1992). The Limits of Empire. In: The Roman Army in the East. Oxford: 333-371.

IVANYl, D. (1935). Die pannonischen Lampen. Eine typologisch-chronologische Übersicht. Dissertationes Pannonicae, 2, 2.

JENKINS, D. (1994). Object Lessons and Ethnographic Displays: Museum Exhibitions and the Making of American Anthropology. Comparative Studies in Society and History, 36 (2): 242-270.

JONES, A. (2007). Memory and Material Culture. Cambridge: Cambridge University Press.

JONES, A. H. (1971). The Cities of the Eastern Roman Provinces. Oxford.

JONES, S. (1999). Historical categories and the praxis of identity: the interpretation of ethnicity in historical archaeology. In: FUNARI, P. P. A.; HALL, M.; JONES, S. (eds.). Historical Archaeology: Back from the Edge. London: Routledge: 219-32. 
JOYCE, R. A. (2003). Concrete Memories: Fragments of the Past in the Classic Maya Present (500- 1000 AD). In: VAN DYKE, R. M. \& ALCOCK, S. (eds.). Archaeologies of Memory. Oxford: Blackwell: 104-125.

KAHANE, P. P. (1952). Pottery Types from the Jewish Ossuary-Tombs around Jerusalem II. IEJ, 2: 176-182.

KAHANE, P. P. (1961). Tombs at Huqoq. Notes on the Finds. ATIQOT (ES), 3: 128-147.

KEAY, S.; CREIGHTON, J.; REMESAL RODRÍGUEZ, J. (2001). Celti (Peñaflor). La arqueología de una ciudad hispanorromana en la Baetica: prospecciones y excavaciones. 19871992. Junta de Andalucia/Consejeria de Cultura.

KELLEY, C. \& LINDSAY, D. S. (1996). Conscious and unconscious forms of memory. In: BJORK, E. Ligon \& BJOK, R. A. (eds.). Memory. San Diego: Academic Press: 31-63.

KELLEY, C. P. (1994). Who did the Iconoclasm in the Dura Synagogue. Boston: BASOR.

KENNEDY, C. A. (1963). The Development of the Lamp in Palestine. Berytus, 14: 67-115.

KENNEDY, D. (1999). Greek, Roman and Native Cultures in the Roman Near East. In: HUMPHREY, J. H. (ed.). The Roman and Byzantine Near East. Some Recent Archaeological Research. Journal of Roman Archaeology: Suppl. Series, 2.

KINDLER, A. (1958). A Seventh Century Lamp with Coin Decoration. IEJ 8: 106-109.

KLETTER, R. \& RAPAUANO, Y. (1998). A Roman well at Khirbet Ibreiktas. ATIQOT, XXXV. Jerusalem: The Israel Antiquities Authority: 43-59.

KNAPP, A. B. \& DOMMELEN, P. V. (2008). Past Practices: Rethinking Individuals and Agents in Archaeology. Cambridge: Archaeological, 18 (1).

KNAPP, A. B. (1999). Ideational and industrial landscape on prehistoric Cyprus. In: ASHMORE, W. \& KNAPP, A. B. Archaeological of Landscape: contemporary perspectives. Oxford: Blackwell: 229-252.

KUHN, T. (1996). A estrutura das revoluções científicas. Trad. B. V. Boeira e N. Boeira. São Paulo: Perspectiva.

LACLAU, E. (1990). New reflections on the revolution of our time. London: Verso.

LAMBOGLIA, N. \& BELTRAN, A. (1952). Apuntes sobre cronología cerâmica. Caesaraugusta, 3: 87-89, lams.X-XIII.

LAMBOGLIA, N. (1958). Nuove osservazioni sulla "terra sigillata chiara" (tipi A e B). Rivista di Studi Liguri, XXIV; 3-4. Bordighera: Instituto Internazionale di Studi Liguri: 257330.

LAZREG, N. B. (2003). Roman and Early Christian burial-complex at Leptiminus: first notice. Journal Roman Archaeology, 16.

LEIBNER, U. (2004). History of Settlement in the Eastern Galilee during the Hellenistic, Roman and Byzantine Periods in Light of an Archaeological Survey. Ph.D. dissertation. Bar-Ilan Univeristy (Hebrew).

LEIBUNDGUT, A. (1977). Die romischen Lampen in der Schweii. Berna .

LERAT, L. (1954). Les Lampes antiques en "Catalogue des Collections Archéologiques de Besangon". Annales Litteraires de l'Université de Besan, 2, 1, 1: 
LESFARGUES, A. \& VERTET, H. (1976). Les estampilles sur sigillée lisse de l'atelier augustéen de la Muette à Lyon. Figlina. Lyon, 1: 39-87.

LEVINE, L. I. (1975). A History of Caesarea under Roman Rule. Leiden: Brill.

LEVINE, L. I. (2002). Jerusalem: Portrait of the City in the Second Temple Period (538 B.C.E.-70 C.E.). Philadelphia: Jewish Publication Society.

LEVINE, H. (1999) Reconstructing ethnicity. Journal of Royal Anthropological Institute 5: $165-80$.

LOESCHCKE, S. (1909). Keramische Funde in Haltern. Ein Beitrag zur Geschichte der augusteischen Kultur in Deutschland. Bonn.

LOESCHCKE, S. (1919). Lampen aus Vindonissa, Ein Beitrag zur Geschichte von Vindonissa und des antiken Beleuchtungwesens, Zurich.

LOFFREDA, S. (1996). La ceramica di Macheronte e dell'Herodion (90 a.C.-135 d.C.). Jerusalem: Franciscan (Collectio maior, 39).

LOFLAND, L.H. 1973. A World strangers: Order and Action in Public Space.New York: Basic Books.

MACDONELL, A. M.(1988). The Terracotta Lamps. In WEINBERG, G.D. (eds)Excavations at Jalame: site of a glass factory in late Roman Palestine: excavations conducted by a jont expedition of the University of Missouri and the Corning Museum of Glass. Columbia: University of Missouri Press.

MACKENSEN, M. \& SCHNEIDER, G. (2002). Production centres of African Red Slip Ware (3rd-7th) in northern and central Tunisia: archaeological provenance and reference groups based on chemical analysis. Journal of Roman Archaeology, 15.

MACKENSEN, M. \& SCHNEIDER, G. (2006). Production centres of African Red Slip Ware (2nd-3rd) in northern and central Tunisia: archaeological provenance and reference groups based on chemical analysis. Journal of Roman Archaeology, 19.

MACKENSEN, M. (1998). New evidence for Central Tunisian red slip ware with stamped decoration (ARS style D). Journal of Roman Archaeology, 11.

MACKENSEN, M. (2004). Produzione e diffusione della ceramica sigillata africana nella Tunisia centrale e settentrionale dalla metà del III secolo alla metà del V secolo d.C. In: DE VOS, M. (ed.). Archeologia del territorio. Metodi materiali prospective. Medjerda e Adige. Due territori a confronto. Trento: Dipartamento di Scienze Filologiche e Storiche: 131-60.

MAGNESS J. (2005). The Roman Legionary Pottery. In B. Arubas and H. Goldfus eds. Excavations on the Site of the Jerusalem International Convention Center (Binyanei Ha'uma): The Pottery and Small Finds (JRA Supplementary Series 60). Portsmouth, Rhode Island: 69-191.

MAIA, M. G. P. \& MAIA, M. (1997). Lucernas de Santa Bárbara. Castro Verde: Cortiçol.

MARSHALL, F. (org.) (2003). História Antiga e Arqueologia: Dossiê Projeto Apollonia. Revista Anos 90, Porto Alegre: UFRGS, 10: 229-250. 
MARTIN, T. H. (1986a). Le déclain. In: La terre sigillée galloromaine. Lieux de production $d u$ haut empire: implantation, produits, relations. Paris: Editions de la Maison des Siences de 1‘Homme : 3-5 (Documents d’Archéologie Française; 6).

MARTIN, T. H. (1986b). Montans. In: La terre sigillée galloromaine. Lieux de production du haut empire: implantation, produits, relations. Paris: Editions de la Maison des Siences de 1'Homme: 58-71 (Documents d'Archéologie Française; 6).

MARTIN, T. H. (1986c). Centre de Montans: atelier de Crambade. In: La terre sigillée galloromaine. Lieux de production du haut empire: implantation, produits, relations. Paris: Editions de la Maison des Siences de 1'Homme): $72-7$ (Documents d'Archéologie Française; 6).

MARTÍNEZ GONZÁLEZ, M. M. (2005). La producción de Terra Sigillata Hispánica Tardia en el área riojana. Valoración arqueológica de los datos disponibles. Iberia, 8: 113-134.

MARTÍNEZ RODRÍGUEZ, F. (1989). Las cerâmicas béticas de imitación tipo Peñaflor: bases para el estudio de un nuevo grupo de época altoimperial. Boletín de la Associación Española de Amigos de Arqueologia, 26: 60-65.

MARTIN-KILCHER, S. (1999). Karthago 1993. Die Füllung eines Frühkaiserzeitliches Pozzo. In: RAKOB, F. (ed.). Die deutschen Ausgrabungen in Karthago, III. Mainz am Rhein: Philipp von Zabern; Deutsches Archäologisches Institut: 403-434.

MASSEY, D. (2009). Pelo Espaço: uma nova política da espacialidade. Rio de Janeiro: Bertrand Brasil.

MATTINGLY, D. J. (ed.). (1997). Dialogues in Roman Imperialism: Power, discourse, and discrepant experience in the Roman Empire. Journal of Roman Archaeology, Supplementary series, 23. Portsmouth, Rhode Island.

MAZAR, E. (1994). A Burial Ground of the Roman Period at Gesher Haziv. 'Atiqot 25: 7793.

MENZEL, H. (1954) Antike Lampen im Römisch-Germanisches Zentralmuseum zu Mainz. Römisch-Germanisches Zentralmuseum zu Mainz, Katalog 15.

MESKELL, L. (2007). Archaeologies of identity. In: INSOLL, T. (ed). Archaeology of identities: a reader. London: Routledge: pp.

MESQUÍRIZ, M. A. (1985). Terra sigillata Ispanica. In: AA.VV. Enciclopedia dell'Arte Antica Classica e Orientale. Atlante delle Forme Ceramiche, II (Ceramica Fine Romana nel Bacino Mediterraneo. Tardo Ellenismo e Primo Impero): 97-174.

MEYERS, E. M. (1971). Jewish Ossuaries: Reburial and Rebirth. Rome.

MEYERS, E.M.; STRANGE, J.F.; MEYERS, C.L. (1981). Excavations at Ancient Meiron, Upper Galilee, Israel 1971-72, 1974-75, 1977. In: MEYERS, E.M.; STRANGE, J.F.; MEYERS, C.L. Meiron Excavation Project 3. Cambridge, MA: American Schools of Oriental Research.

MIDDLETON, D. \& EWARD, D. (1997). Collective remembering. London: Sage.

MILLAR, F. (1993). The Roman Near East 31 BC-AD 333. Cambridge: Harvard University Press. 
MILLAR, F. (2000). Pagan and Christian voices from late antiquity. Journal of Roman Archaeology, 13.

MILLER, D. (1987). Material culture and mass consumption. Oxford: Blackwell.

MILLER, D. (1994). Artefacts and the meaning of things. In: INGOLD, T. (ed.). Companion encyclopedia of anthropology. London: Routledge: 396-419.

MILLER, D.; ROWLANDS, M.; TILLEY, C. (1995). Domination and Resistance. London: Routledge: 40-62.

MISHNÁ: Essência do Judaísmo Talmudico (1973). Documentário.

MLODINOW, L. (2009). O andar do bêbado: como o acaso determina nossas vidas. Rio de Janeiro: Zahar.

MLYNARCZYK, J. (1995). New Data on the Chronology of Late Roman Lamps in Alexandria. Études et Travaux 17: 134-175.

MLYNARCZYK, J. (1998). Terracota Mould-made Lamps in Alexandria (Hellenistic to Roman Period). BCH Supplement 33: 327-352.

MOSHENSKA, G. (2010). Working with Memory in the Archaeology of Modern Conflict. Cambridge: Archaeological, 20 (1).

NA'URA (1993). Excavations and Surveys in Israel 1993, 13. English Edition of Hadashot Arkheologiyot Archaeological Newsletter of the Israel Departament of Antiquities and Museums, 100. Jerusalem.

NAGORSKI, A. (2007). A tomb from the Second Temple Period at Shoham. ATIQOT, 55. Jerusalem: The Israel Antiquities Authority: 43-50*.

NAHSHONI, P.; ZISSU, B.; SARIG, N.; GANOR, A.; AVGANIM, A. (2002). A Rock-cut burial cave from the Second Temple period at Horbat Zefiyya, Judean Shephelah. ATIQOT, XLIII. Jerusalem: The Israel Antiquities Authority: 49-72.

NAIME, J. S. (1996). Short-term/working memory. In: BJORK, E. Ligon \& BJORK, R. A. (eds.) Memory. San Diego: Academic Press: 101-26.

NAJJAR, N. KAFR KANNA (B) (1997). Excavations and Surveys in Israel 1997, 16. English Edition of Hadashot Arkheologiyot Archaeological Newsletter of the Israel Departament of Antiqities and Museums, 104. Jerusalem.

NEIDINGER, W. (1982). A Typological of oil lamps from the mercantile quarter of Antipatris. Journal of Tel Aviv University, 9 (1).

OFM, B. B. (s/d). Ancient Christian Villages of Samaria. Jerusalem: Franciscan Printing Press.

OFM, S.L. (1989) Lucerne Bizantine in Terra Santa com iscrizioni in Greco. Jerusalem: Franciscan Priting Press.

OLSON, Roger E. (2001). História da teologia cristã: 2000 anos de tradição e reformas. Trad. Gordon. São Paulo: Editora Vida.

ONN. A.(1994) The Ancient Synagogue at Kafr Misr. In: 'ATIQOT. Vol. XXV. Jerusalem: The Israel Antiquities Authority:117-134.

OPPENHEIMER, A. (1991). Galilee in the Mishnaic Period. Jerusalem: Shazar (Hebrew). 
OREN, E.D.; RAPPAPORT, U.(1984). The Necropolis of Maresha - Beit Govrin. IEJ 34: 11453.

OSHRI, A. \& NAJJAR, N. (1997). GINNEGAR. Excavations and Surveys in Israel 1997, 16. English Edition of Hadashot Arkheologiyot Archaeological Newsletter of the Israel Departament of Antiqities and Museums, 104. Jerusalem.

PALOL, P. de (1948-9). La colección de lucernas romanas de cerámica procedentes de Ampurias en el Museo Arqueológico de Barcelona. Memorias Museos Arqueológicos provinciales, IX-X: 233-265.

PASHLER, H. \& CARRIER, M. (1996). Structures, processes, and the flow of information. In: BJORK, E. Ligon \& BJORK, R. A. (eds.). Memory. San Diego: Academic Press: 3-29.

PAVOLINI, C. (1981). Le lúceme nell'ltalia lomans. In: Società romana e produzione schiavistica, II: Merci, mercati e scamhi nel Mediterráneo. Bari: 139-184.

PERATH, I. \& ALMAGOR, G. (2000). The Sharon Escarpment (Mediterranean Coast, Israel): Stability, Dynamics, Risks and Environmental Management. Journal of Coastal Research, 16 (1): 207-224.

PEREIRA, C. S. P. (2008). As lucernas romanas de Scallabis. Dissertação de mestrado. Universidade de Lisboa.

PERLZWEIG, J. (1961). Lamps from the Athenian agora. Picture Book No. 9. Princeton, NJ: American School of Classical Studies at Athens.

PHILIP SCHAFF, Philip (2001). Ante-Nicene Fathers: The Writings of the Fathers Down to $A D$ 325. Vols. 1-10. Grand Rapids, MI: Christian Classics Ethereal Library and Wm. B. Eerdmans Publishing Company.

PONSICH, M. (1961). Les lampes romaines en terre cuite de la Mauretania Tin^tane, Rabat.

PORAT, R.; ESHEL, H.; FRUMKIN, A. (2009). The "caves of the Spear": Refuge Caves from the Bar-Kokhba Revolt North of 'En-Gedi. Jerusalem: Israel Exploration Journal, vol.59, $\mathrm{n}^{\mathrm{o}} 1: 21-46$.

PORATH, Y. (2007). Burials from the Roman and Byzantine Periods at Caesarea. ATIQOT, 55. Jerusalem: The Israel Antiquities Authority: 45-56 (Hebrew).

PROVOOST, A. (1976). Les lampes antiques en terre cuite. Introduction et essai de typologie genérale avec des détaíls concernant les lampes trouvées en Italie. L'Antiquité Classique, yíN, 5-39 y 550-586.

PUCCI, G. (1985). Terra sigillata italica. Atlante delle forme ceramiche II: ceramica fina romana nel Bacino del Mediterraneo (Tardo elenismo e Primo Impero). Enciclopedia dell 'Arte Antica. Roma: 361-404.

QUARESMA, J. C. (2009). Economia antiga a partir de um centro de consumo lusitano. Terra sigillata e cerâmica africana de cozinha em Chãos Salgados (Mirobriga?). Tese de doutorado. Universidade de Lisboa.

RAHMANI, L.Y. (1976) Roman Tombs in Nahal Raqafot, Jerusalém. In: 'ATIQOT. Vol .XI. Jerusalem: The Israel Antiquities Authority: 77-88.

RAHMANI, L.Y. (1994). A Catalogue of Jewish Ossuaries in the Collections of the State of Israel. Jerusalem. 
RAKOB, F. (ed.) (1999). Die deutschen Ausgrabungen in Karthago, III. Mainz am Rhein: Philipp von Zabern; Deutsches Archäologisches Institut.

RAPPAPORT, U. (2006). John of Gischala: From the Mountains of Galilee to the Walls of Jerusalem. Jerusalem: Shazar (Hebrew).

REBORATTI, Carlos E. (1993). La geografia en la escuela secundaria: de inventario intranscedente a herramienta de comprensión. Geographikós, uma revista de geografia, 4: Ano 3.

RECH, R. M. (2003). Apollonia romana e sua villa marítima. In: MARSHALL, F. (org.). História Antiga e Arqueologia: Dossiê Projeto Apollonia. Revista Anos 90, Porto Alegre: UFRGS, 10: 229-250.

RENFREW, C. \& BAHN, P. (eds.) (2005). Archaeology: The Key Concepts. Oxon: Routledge.

RICCI, M. (1974). Per una cronologia delle lúceme tardo-repubblicane. R. S. L., XXXIX, 2-4: 168-234.

ROCA ROUMENS, M. \& FERNÁNDEZ GARCÍA, M. I. (coords.) (1999). Terra sigillata hispánica. Centros de fabricación y producciones altoimperiales. Universidad de Jaén; Universidad de Málaga.

ROCA ROUMENS, M. (1976). Sigillata Hispanica Producida en Andujar (Jaén). Jaén: Instituto de Estudios Giennenses; Exma. Diputación Provincial.

ROLL, I. \& AYALON, E. (1988). Models of Settlements in Southern Sharon in Ancient Times. Ariel, 55-56: 38-43.

ROLL, I. \& AYALON, E. (1990). Economic and Settlement Growth is Southern Sharon in the Roman Period. In: A. DEGANI et al. (ed.) HaSaharon between Yarkon and Karmel. Tel Aviv: Tel Aviv University: 191-200.

ROLL, I. \& TAL, O. (1999). Apollonia-Arsuf. Final Reports of the Excavations. Vol. I: The Persian and Hellenistic periods. Tel Aviv: Tel Aviv University.

ROLL, I. \& TAL, O. (2007). A Peristyle Villa Martima at Apollonia-Arsuf, Israel: A Preliminary Study. In: GALLOR, K. \& WALISZEWSKI, T. (eds.). From Antioch to Alexandria. Recent Studies in Domestic Architecture. Warsaw: 137-150.

ROLL, I. \& TAL, O. (2008). A Villa of the Early Roman Period at Apollonia-Arsuf. Israel. Exploration Journal, 58: 132-49.

ROLL, I. (1983). The Roman Road System in Judea. Jerusalem: The Jerusalem Cathedra, 3: 136- 161

ROLL, I. (1989). Apollonia and Southern Sharon: Model of a coastal city and its Hinterland. Tel Aviv: Tel Aviv University.

ROLL, I. (1996). Roman Roads to Caesarea Maritima. In: RABAN, A. \& HOLUN, K. (eds.). Caesarea Maritima. A Retrospective after two Millennia. Leiden.

ROLL, I. (2003). Apollonia. História do sítio, suas pesquisas e escavações. In: MARSHALL, F. (org.). História Antiga e Arqueologia: Dossiê Projeto Apollonia. Revista Anos 90, 10. Porto Alegre: UFRGS: 229-250.

ROLLER, D. W. \& HOHFELDER, R. L. (1983). The problem of the location of Straton's Tower. Bulletin of the American Schools of Oriental Research, 252: 61-68. 
ROSENTHAL, R. \& SIVAN, R. (1978). Ancient Lamps in the Schloessinger Collection (Qedem 8). Jerusalem.

ROSSIGNOL \& WANDSNIDER (1992). Space, time, and archaeological landscapes. New York; London: Plenum.

ROTROFF, S. (1999). A conference on early Italian terra sigillata. The chronological framework and trade patterns. In: (eds.). Proceedings of the first internacional roctcongress, Leuveun.

ROOVERS, I. (1993). The Lamps. In: WAELKENS, W. (ed) Sagalassos I: First general reporto $\mathrm{n}$ the survey (1986-1989) and excavations (1990-1991) (Acta Archaeologica Lovaniense Monographiae 5). Leuven: 153-162.

SAÉNZ PRECIADO, M. \& SAÉNZ PRECIADO, C. (1999). La terra sigillata hispánica altoimperial. In: ROCA ROUMENS, M. \& FERNÁNDEZ GARCÍA, M. I. (coords.) Terra sigillata hispánica. Centros de fabricación y producciones altoimperiales. Universidad de Jaén; Universidad de Málaga: 61-136.

SAÉNZ PRECIADO, M. (1999). Inicio de la campaña arqueológica en el término de El Quemao (Tricio) afectado por las obras de ensache y mejora de la LR 430 y de la LR 113 a Arenzana de Abajo. Estrato, 10: 20-21.

SAFRAI, S. (1965). Pilgrimage at the Time of the Second Temple. Tel Aviv: Am Hassefer (Hebrew).

SAHLINS, M.,(1981) Historical Metaphors and Mythical Realities. Ann Arbor (MI): University of Michigan Press.

SAFRAI, S. (1974). Relations between the Diaspora and the Land of Israel. In: SAFRAI, S. \& STERN, M. (eds.). The Jewish People in the First Century. Vol. 1. Compendia rerum Judaicarum ad Novum Testamentum, Section 1. Assen: Van Gorcum.

SAFRAI, S. (1976). The Temple. In: SAFRAI, S. \& STERN, M. The Jewish People in the First Century. Vol. 2. Compendia rerum Judaicarum ad Novum Testamentum, Section 1. Assen: Van Gorcum.

SAGIV, N.; ZISSU, B.; AVINI,G. (1998). Tombs of the Second Temple period at Tel Goded, Judean Foothills. ATIQOT, XXXV. Jerusalem: The Israel Antiquities Authority: 7-21 (Hebrew).

SANTOS, Milton (1986). Por uma geografia nova. São Paulo: HUCITEC.

SANTOS, Milton (1992). Espaço e método. São Paulo: Nobel.

SANTOS, Milton (1994). Metamorfoses do espaço habitado. Fundamentos teóricos e metodológicos da geografia. 3 ed. São Paulo: HUCITEC.

SANTOS, Milton (2004). O Espaço Geográfico, um Híbrido. Uma necessidade Epistemológica: a distinção entre a Paisagem e o Espaço. In: A Natureza do Espaço: Técnicas e Tempo, Razão e Emoção. 4 ed. São Paulo: Editora da Universidade de São Paulo (Coleção Milton Santos; 1).

SCHIFFER, M. B. \& MILLER, A. R. (1999). The material life beings: Artifacts, behavior, and communication. London; New York: Routledge. 
SCHIFFER, M. B. (2000). Explorations in Social Theory. Salt Lake City: University of Utah Press.

SCHINDLER-KAUDELKA, E.; SCHNEIDER, G.; ZABEHLICKY-SCHEFFENEGGER, S. (1997). Les sigillées padanes et tardo-padanes. Nouvelles recherches en laboratoire. SFECAG, Actes du congrès du Mans :.481-192.

SCHALANGER, S. (1992). Recognizing persistent places in Anasazi settlement systems. In: ROSSIGNOL \& WANDSNIDER. Space, time, and archaeological landscapes. New York; London, Plenum: 91-112.

SCHELTENS, E. (1993). Some Wheelmade Lamps of Sagalassos: A Preliminay Note. In WAELKENS, M.; POBLOME, J. (eds) Sagalassos II: Report on the third excavation campaign of 1992. Leuven: 191-207.

SCHNEIDER, G. \& DASZKIEWICZ, M. (2006). Chemical analysis of Italian Sigillata from Italy and from the Northern provinces. In: MALFITANA, D.; POBLOME, J.; LUND, J. (eds.). Old pottery in a new century. Innovating perspectives in Roman pottery studies. Atti del convegno internazionale di studi. Catania, 22-24 Aprile 2004. Catania: Consiglio Nazionale delle Riceche (Monografie dell'Instituto per i Beni Archeologici e Monumentali (IBAM); 1): 537-544.

SCHURING, J. M. (1988). Terra sigillata africana fom the San Sisto Vecchio in Rome. Bulletin Antieke Beschaving / Annual Papers on Classical Archaeology. 63: 1-68.

SELLERS, O. R. (1949). Study of finds in the Ain Fashkha cave. The Biblical Archeologist: Archaeological News from Palestine, XII (3).

SERRANO RAMOS, E. (1999a). Producciones hispánicas precoces. In: ROCA ROUMENS, M. \& FERNÁNDEZ GARCÍA, M. I. (eds.). Terra sigillata hispánica. Centros de fabricación y producciones altoimperiales. Universidad de Jaén; Universidad de Málaga: 231-234.

SERRANO RAMOS, E. (1999b). Centros productores de T.S.H. en las provincias de Granada y Málaga. In: ROCA ROUMENS, M. \& FERNÁNDEZ GARCÍA, M. I. (eds.). Terra sigillata hispánica. Centros de fabricación y producciones altoimperiales. Universidad de Jaén; Universidad de Málaga: 137-68.

SHAW, B. D. (2001). Challenging Braudel: A new vision on the Mediterranean. Journal of Roman Archaeology, 14: 419-453.

SHÜRER, E. (1979). History of the Jewish people in the Age of Jesus Christ (156 BC-AD 135). In: VERMES, G. \& MILLAR, F. (eds.). History of the Jewish people in the Age of Jesus Christ. Vol.II, Edinburgh:

SHURKIN, O. (2004). Burial Grounds and an Industrial Area in Wadi El-Halaf (Near Khirbat Ras Abu Ma,Aruf) In Pisgat Ze" Ev, Jerusalem. ATIQOT, 48. Jerusalem: The Israel Antiquities Authority: 27-58. (Hebrew).

SIEGELMANN, A. \& NE`EMAN (1992). A Painted Tomb Near Caesarea. ATIQOT, XXI. Jerusalem: The Israel Antiquities Authority: 57-62 (Hebrew).

SILVA, G. V. da (2004). Representação social, identidade e estigmatização: algumas considerações de caráter teórico. In: FRANCO, Sebastião Pimentel; SILVA, G. V. da; LARANJA, A. L. (orgs.). Exclusão social, violência e identidade. Vitória: Flor\&Cultura, v. 1: 13-29. 
SILVA, G. V. da (2004). Representando a alteridade no Baixo Império: os judeus e a construção de uma identidade romano-cristã. In: SILVA, Gilvan Ventura da; CAMPOS, Adriana Pereira; FRANCO, Sebastião Pimentel (orgs.). História, Violência e Imaginário Político. Vitória: PPGHIS/UFES: 1-9.

SILVA, G. V. da (org.) (2008). Conflito cultural e intolerância religiosa no Império Romano. Vitória: GM Editora, v. 1.

SILVA, Tomás Tadeu (org.) (2003). Identidade e diferença. 2 ed. Petrópolis: Vozes.

SMITH, R. H. (1961). The Herodian Lamp of Palestine: Types and Dates. Berytus, 14: 53-65.

SMITHLINE, H. (1997). Three burial caves from the Roman Period in Asherat. ATIQOT, XXXIII: Burial caves of the Roman and Byzantine Periods in Western Galilee. Jerusalem: The Israel Antiquities Authority: 47-60 (Hebrew).

SOTOMAYOR, M (1988). Fondos de sigillata en Andalucía con marcas interiores de entalles. Anejos de Gerión, I. Madrid: Edit. Universidad Complutense: 253-64.

SOTOMAYOR, M.; ROCA, M.; FERNÁNDEZ GARCÍA, I. (1999) - Centro de producción de Los Villares de Andujar (Jaén). In ROCA ROUMENS, M.; FERNÁNDEZ GARCÍA, M. I., coords. (1999) - Terra sigillata hispánica. Centros de fabricación y producciones altoimperiales. Universidad de Jaén / Universidad de Málaga:19-60.

STERN, E. J. (2000). Dor, ruler of the Seas. Nineteen years of excavations at IsraelitePhoenician Harbor town on the Carmel Coast. Jerusalem: Israel Exploration Society.

STERN, E. J. (1997). Burial caves at Kisra. ATIQOT, XXXIII: Burial caves of the Roman and Byzantine Periods in Western Galilee. Jerusalem: The Israel Antiquities Authority: 103135 (Hebrew).

STERN, E.; GILBOA, A.; SHARON, I. (2000). TEL DOR - 1996. Excavations and Surveys in Israel, 20 [English Edition of Hadashot Arkheologiyot Archaeological Newsletter of the Israel Department of Antiquities and Museums, 108] Jerusalem: *30.

SUSSMAN, V. (1972). Ornamented Jewish Oil Lamps from the Fall of the Second Temple through the Revolt of Bar Kocheba. (Hebrew)

SUSSMAN, V. (1976). A burial Cave at Kefar Ara. ATIQOT, XI. Jerusalem: The Israel Antiquities Authority: 92-101.

SUSSMAN, V. (1980a). Five Christian Lamps. ATIQOT, XIV. Jerusalem: The Israel Antiquities Authority: 80-82.

SUSSMAN, V. (1980b). Mould for Lamps and Figurines from a Caesarea workshop. ATIQOT, XIV. Jerusalem: The Israel Antiquities Authority: 76-79.

SUSSMAN, V. (1982). Ornamented Jewish Oil-Lamps from the Destruction of the Second Temple through the Bar-Kokhba Revolt. Warminster.

SUSSMAN, V. (1983). The Samaritan Oil Lamps from Apollonia-Arsuf. Journal of Tel Aviv University, 10: 71-96.

SUSSMAN, V. (1985/6) Ornamental Figures on "Beit Nattif" Type Oil Lamps form Northern and Southern Workshops. Israel - People and Land 2-3: 63-86 (Hebrew)

SUSSMAN, V. (1989). Northern Stamped Oil Laps and their Typology. Michmanim 4: 23-58. 
SUSSMAN, V. (1996). Caesarea Illuminated by its Lamps. In: RABAN, A.; HOLUM, K.G.(eds). Caesarea Maritima, A Retrospective after Two Millennia. Leiden/New York/ Köln: 346-358.

SUSSMAN, V. (2002). Important and Production of Oil Lamps: Between Eretz-Israel and Egypt. In Y.ESHER (ed). Judea and Samaria Research Studies. Proceedings of the $11^{\text {th }}$ Annual Meeting: $137-150$.

SUSSMAN, V. (2003). The Beth Ha-shitta Mosaic Floor -A New Perspective on the Light of Samaritan Oil Lamps. Liber Annuus: Edizioni Terra Santa: 351-368.

SUSSMAN, V. (2004). Horbat Rimmon: Pottery and Small finds. ATIQOT, 46. Jerusalem: The Israel Antiquities Authority: 99-112.

SUSSMAN, V. (2007). The clay oil lamps from Khirbat El-Ni Ana. ATIQOT, 57. Jerusalem: The Israel Antiquities Authority: 51-72.

SWEELY, T. (ed.) (2001). Manifesting Power: Gender and the interpretation of power in archaeology. London: Routledge.

SYON, D. (1999). A Roman burial cave on MT. Gilboa. ATIQOT, XXXVIII. Jerusalem: The Israel Antiquities Authority: 55-71 (Hebrew).

SHIER, L.A. (1978). Terracota Lamps from Karanis, Egypt. Ann Arbor.

SZENTLELEKY, Th. (1969). Ancient Lamps. Budapest: Editora (Melanges d'Archéologie et d' Histoire; 1).

TATCHER, A. \& GAL, Z. (2008). The ancient Cemetery at Migdal Ha-,Emeq (El-Mujeidil). ATIQOT, 61. Jerusalem: The Israel Antiquities Authority: 1-47* (Hebrew).

TATE, G. (1992). Les campagnes de la Syrie du nord du $l l^{e}$ au VII siècle. Paris.

TATE, G. (1997). The Syrian countryside during the Roman era. In: ALCOOK, S. E. (ed.). The early Roman empire in the East. Oxford: Oxbow: 55-71 (Oxbow Monograph; 95)).

TERRIN, A. N. (2004). O rito: antropologia e fenomenologia da ritualidade. São Paulo: Paulus.

THOMAS, J. (2003). Archaeologies of place and landscape. In: HODDER, I. (org.). Archaeological Theory Today. Cambridge: Polity: 165-186.

TILLEY, C. (1997). Discourse and power: the genre of the Cambridge inaugural lectura. In: $A$ Phenomenology of Landscape: Places, Paths and Monuments. Oxford/Providence: Berg Publishers (Explorations in Anthropology series).

TORTORELLA, S. (1982). La sigillata africana a Cartagine fra il 400 d.C. e la conquista vandala: i dati dello scavo della missione archeologica italiana. In: Actes du colloque sur la céramique antique. Carthage, 23-24 Juin 1980 : 125-39 (CEDAC; dossier 1).

TROCOLLI, R. (2001). Women leaders in native North American societies: invisible women of power. In: SWEELY, T. (ed.). Manifesting Power: Gender and the interpretation of power in archaeology. London: Routledge: 49-61.

TUFI, S. R. (2000). Archeologia delle Province Romane. Roma: Carocci.

TURNER, V. (1974). Dramas, Fields, and Metaphors: Symbolic Action in Human Society. Ithaca, NY: Cornell University Press. 
UQSA, H. A.; NAJJAR, N. KAFR KANNA (B) Excavations and Surveys in Israel 1997 volume 16. English Edition of Hadashot Arkheologiyot Archaeological Newsletter of the Israel Departament of Antiqities and Museums, Numbers 104, Jerusalem, 1997.

VAN DYKE, R. M. \& ALCOCK, S. (2003). Archaeologies of Memory. Oxford: Blackwell.

VERNHET, A. (1986a). L'essor des ateliers entre 30 et 120 ap. J.-C. In: La terre sigillée galloromaine. Lieux de production du haut empire: implantation, produits, relations. Paris: Editions de la Maison des Siences de 1'Homme: 39- 41 (Documents d“Archéologie Française; 6).

VERNHET, A. (1968b). Centre de production de Millau. Atelier de La Graufesenque. In: La terre sigillée galloromaine. Lieux de production du haut empire: implantation, produits, relations. Paris: Editions de la Maison des Sciences de l'Homme: 96-103 (Documents d'Archéologie Française; 6).

VERNHET, A. (1986c). Présentation générale. In: La terre sigillée gallo-romaine. Lieux de production du haut empire: implantation, produits, relations. Paris: Editions de la Maison des Sciences de 1'Homme: 3-4, (Documents d'Archéologie Française; 6).

VIEGAS, C. (2002). A Alcáçova. In: De Scallabis a Santarém. Lisboa: Museu Nacional de Arqueologia/Câmara Municipal de Santarém: 73-81.

VIEGAS, C. (2003). A terra sigillata da Alcáçova de Santarém. Cerâmica, economia e comércio. Lisboa: Instituto Português de Arqueologia (Trabalhos de arqueologia, 26).

VIEGAS, C. (2003). Cerâmica, economia e comércio: a terra sigillata da Alcáçova de Santarém. Lisboa: Instituto Português de Arqueologia (Trabalhos de Arqueologia; 26).

VITTO, F. (2011). A Roman-Period Burial Cave on Ha-Horesh Street, Qiryat Tiv. ATIQOT, 65. Jerusalem: The Israel Antiquities Authority: (Hebrew).

WALDHAUER, O. (1914). Die antiken Tonlampen. San Petersburg: Kaiserliche Ermitage.

WALTERS, H. B. (1914). Catalogue of the Greek and Roman Lamps in the British Museum, London.

WELLER, C.H. (1903) The Cave at Vari, Account of Excavation, and History. American Journal of Archaeology. Vol.7, n $3: 266-288$.

WEINBERG, G. D. (1998). Jalame. Excavations at Jalame. 116-135.

WEXLER, L. \& GILBOA, G. (1996). Oil Lamps of the Roman Period from Apollonia-Arsuf. Journal of Tel Aviv University, 23.

WILLIAMS, R. (1977). Marxism and Literature. Oxford: Oxford University Press.

WOODWARD, K. (2003). Identity and difference. London: Routledge.

WOOLF. G. (1997). The Roman urbanization of the East. In: ALCOOK, S. E. (ed.). The early Roman empire in the East. Oxford: Oxbow: 1-14 (Oxbow Monograph; 95).

ZEDEÑO, M. N. \& BOWSER, B .J. (2009). The Archaeology of Meaningful Places. Salt Lake City: University of Utah Press.

ZEDEÑO, M. N. (2000). On What People Make of Places. A Behavioral Cartography. In: SCHIFFER, M. B. (ed.). Explorations in Social Theory. Salt Lake City: University of Utah Press. 
ZEHAVI-KOGAN, E. (2006). A Burial cave of the Byzantine Period in the Nahalat Ahim Quarter, Jerusalem. ATIQOT, 54. Jerusalem: The Israel Antiquities Authority: 61-86 (Hebrew).

ZIAS, J. (1980). A Roman Tomb at Ar Ara. ATIQOT, XIV. Jerusalem: The Israel Antiquities Authority: 60-65 (Hebrew).

ZISSU, B. \& GANOR, A. (1997). HORVAT BURGIN. Excavations and Surveys in Israel 1997, volume 16. English Edition of Hadashot Arkheologiyot Archaeological Newsletter of the Israel Department of Antiquities and Museums, 104, Jerusalem.

ZISSU, B. \& GANOR, A. (2008). Survey and Excavations at Horbat Brugin in the Judean Shephelah: Burial Caves, Hiding complexes and Installations of the Second Temple and Byzantine Periods. ATIQOT, 58. Jerusalem: The Israel Antiquities Authority: 15-48 (Hebrew). 


\section{Tabela de Referências a Idolatria}

\begin{tabular}{|c|c|c|c|}
\hline Pais Apostólicos & Período d.C. & Referência & $\begin{array}{c}\text { Número total } \\
\text { de } \\
\text { referências }\end{array}$ \\
\hline Clemente de Roma & $30-100$ & Sem menção direta & 0 \\
\hline Inácio de Antioquia & $30-107 / 15$ & (Livro1)p.94;p.100;p.203 & 3 \\
\hline Policarpo de Esmirna & $65-100 / 55$ & (Livro1)p.62; & 1 \\
\hline Barnabé & $30-135$ & (Livro1)p.214;p.222;p.232;p.235; & 4 \\
\hline Pastor de Hermas & $140-145$ & (Livro2)p.43;p.83; & 2 \\
\hline O Didaquê & $70-90$ & (livro7)p.561;p.563;p.564; & 3 \\
\hline \multicolumn{4}{|l|}{ Apologistas } \\
\hline $\begin{array}{l}\text { Mathetes - Epistola a } \\
\text { Diogneto }\end{array}$ & $130-200$ & (Livro1)p.45; & 1 \\
\hline Justino Mártir & $114-165$ & $\begin{array}{l}\text { (Livro1)p.251;p.273;p.278;p.302;p.315;p.322;p.323;p.3 } \\
\text { 25;p.335;p.336;p.347;p.355;p.372;p.378;p.398;p.399;p. } \\
\text { 400;p.417;p.421; p.433;p.435; p.461; p.480; } \\
\text { p.492;p.504; p.506; }\end{array}$ & 26 \\
\hline Ireneu de Esmirna & $120-202$ & $\begin{array}{l}\text { (Livro1)p.530;p.559;p.571;p.575;p.579;p.581;p.587;p.6 } \\
\text { 74;p.693;p.694;p.717;p.719;p.722;p.765;p.778;p.800;p. } \\
\text { 801;p.807;p.828;p.829;p.835;p.837;p.838;p.901;p.902;p } \\
\text {.904;p.930;p.938;p.941;p.963;p.966; }\end{array}$ & 31 \\
\hline Hipólito de Roma & $170-236$ & $\begin{array}{l}\text { (Livro5)p.90;p.211;p.248;p.310;p.312;p.316;p.332;p.33 } \\
\text { 5;p.390;p.392;p.393;p.395;p.426;p.429;p.447; }\end{array}$ & 15 \\
\hline Teófilo de Antioquia & $115-168 / 81$ & (Livro2)p.135;p.140;p.143;p.170; & 4 \\
\hline Atenagoras de Atenas & 177 & (Livro2)p.212;p.215;p.223;p.226;p.227; & 5 \\
\hline Clemente de Alexandria & $153-193 / 217$ & $\begin{array}{l}\text { (Livro2)p.266;p.267;p.270;p.274;p.277;p.278;p.289;p.2 } \\
\text { 90;p.291;p.292;p.297;p.298;p.299;p.303;p.306;p.307;p. } \\
\text { 312;p.314;p.315;p.325;p.326;p.379;p.381;p.384;p.395;p } \\
\text {.402;p.409;p.424;p.433;p.591;p.619;p.702;p.764;p.779; } \\
\text { p.780;p.787;p.819;p.820;p.858;p.863;p.870; }\end{array}$ & 41 \\
\hline Tertuliano & $145-220$ & $\begin{array}{l}\text { (Livro3)p.52;p.59;p.89;p.90;p.91;p.92;p.94;p.95;p.96;p. } \\
\text { 97;p.98;p.100;p.102;p.103;p.105;p.107;p.108;p.109;p.1 } \\
\text { 11;p.116;p.121;p.125;p.126;p.127;p.128;p.147;p.149;p. } \\
\text { 150;p.154;p.155;p.188;p.234;p.240;p.245;p.259;p.266;p } \\
\text {.353;p.375;p.385;p.417;p.418;p.424;p.425;p.445;p.448; } \\
\text { p.450;p.454;p.466;p.503;p.509;p.514;p.515;p.521;p.549 } \\
\text {;p.550;p.562;p.574;p.594;p.598;p.604;p.628;p.644;p.64 } \\
\text { 6;p.685;p.762;p.772;p.983;p.1062;p.1071;p.1072;p.110 } \\
\text { 8;p.1109;p.1110;p.1111;p.1116;p.1128;p.1140;p.1153;p } \\
\text {.1163;p.1165;p.1166;p.1194;p.1208;p.1232;(Livro4)p.2 } \\
\text { 6;p.113;p.195;p.197;p.256;p.287; }\end{array}$ & 90 \\
\hline Commodiano & 240 & (Livro4)p.370;p.377;p.382;p.388;p.391;p.399; & \\
\hline Orígenes & $185-230 / 54$ & $\begin{array}{l}\text { (Livro4)p.604;p.625;p.643;p.682;p.779;p.802;p.814;p.8 } \\
\text { 58;p.888;p.959;p.990;p.1012;p.1018;p.1024;p.1108;p.1 } \\
\text { 111;p.1147;p.1150;p.1153;p.1154; }\end{array}$ & 20 \\
\hline Ciprião & $200-258$ & $\begin{array}{l}\text { (Livro5)p.487;p.498;p.540;p.587;p.591;p.593;p.594;p.6 } \\
\text { 13;p.618;p.645;p.654;p.708;p.739;p.758;p.765;p.768;p. } \\
\text { 772;p.776;p.778;p.779;p.806;p.808;p.868;p.869;p.870;p } \\
\text {.974;p.975;p.976;p.1023;p.1024;1026; }\end{array}$ & 31 \\
\hline Dionísio de Alexandria & $200-265$ & (Livro6)p.150;p.168;p.169;p.184; & 4 \\
\hline Júlio Africano & $200-232 / 45$ & (Livro6)p.242;p.243; & 2 \\
\hline Anatólio de Laudicéia & $230-270 / 80$ & (Livro6)p.273; & 1 \\
\hline Arquelau & 277 & (Livro6)p.350;p.363; & 2 \\
\hline Pedro de Alexandria & $260-300$ & (Livro6)p.444;p.472; & 2 \\
\hline Methodius de Lycia & $260-312$ & (livro6)p.667; & 1 \\
\hline Lactâncio & $260-330$ & (Livro7)p.37;p.351;p.461;p. & 3 \\
\hline Dionísio de Roma & $259 / 69$ & (Livro7)p.563 & 1 \\
\hline Total & & 293 & \\
\hline
\end{tabular}

